
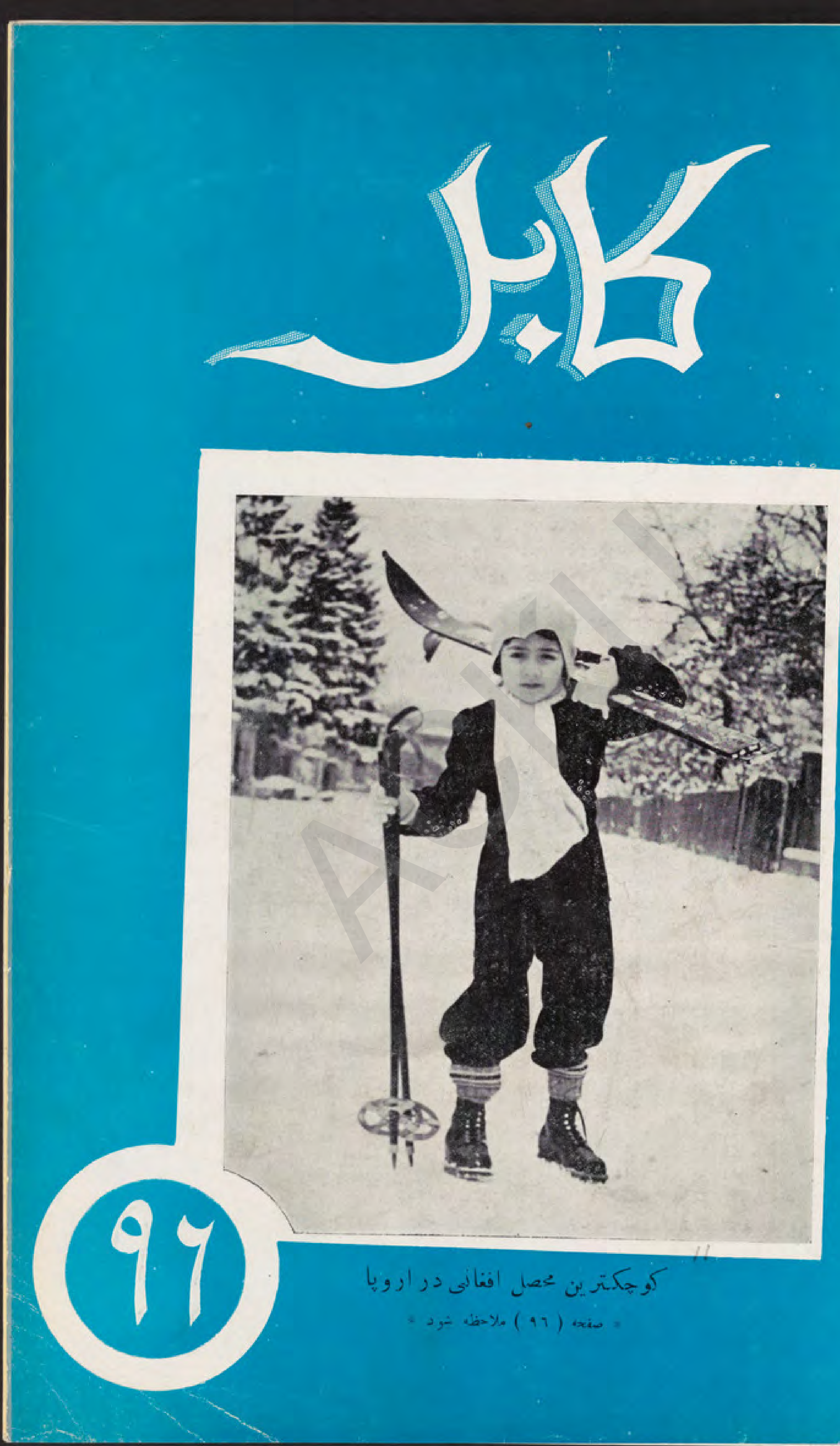

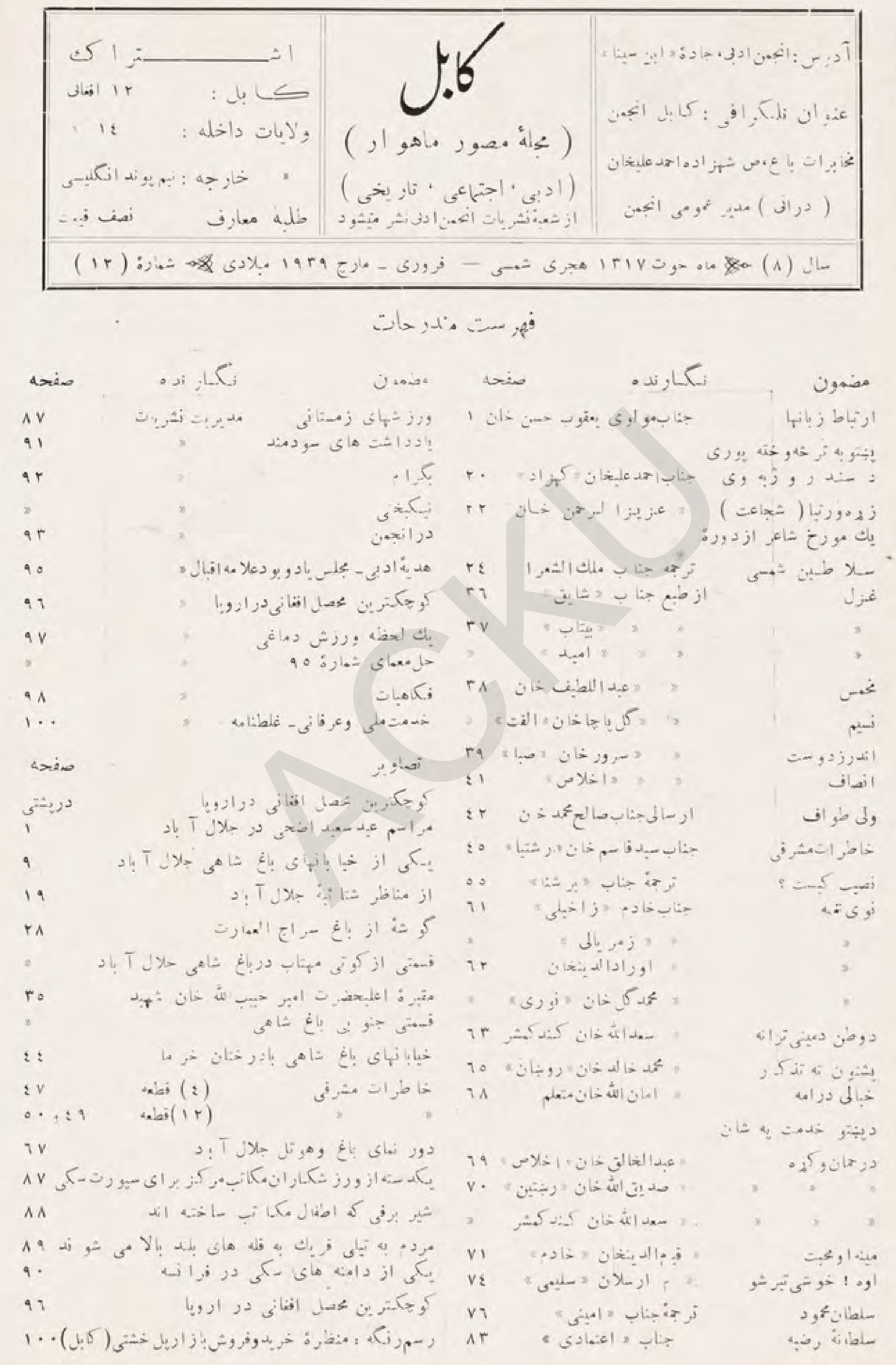



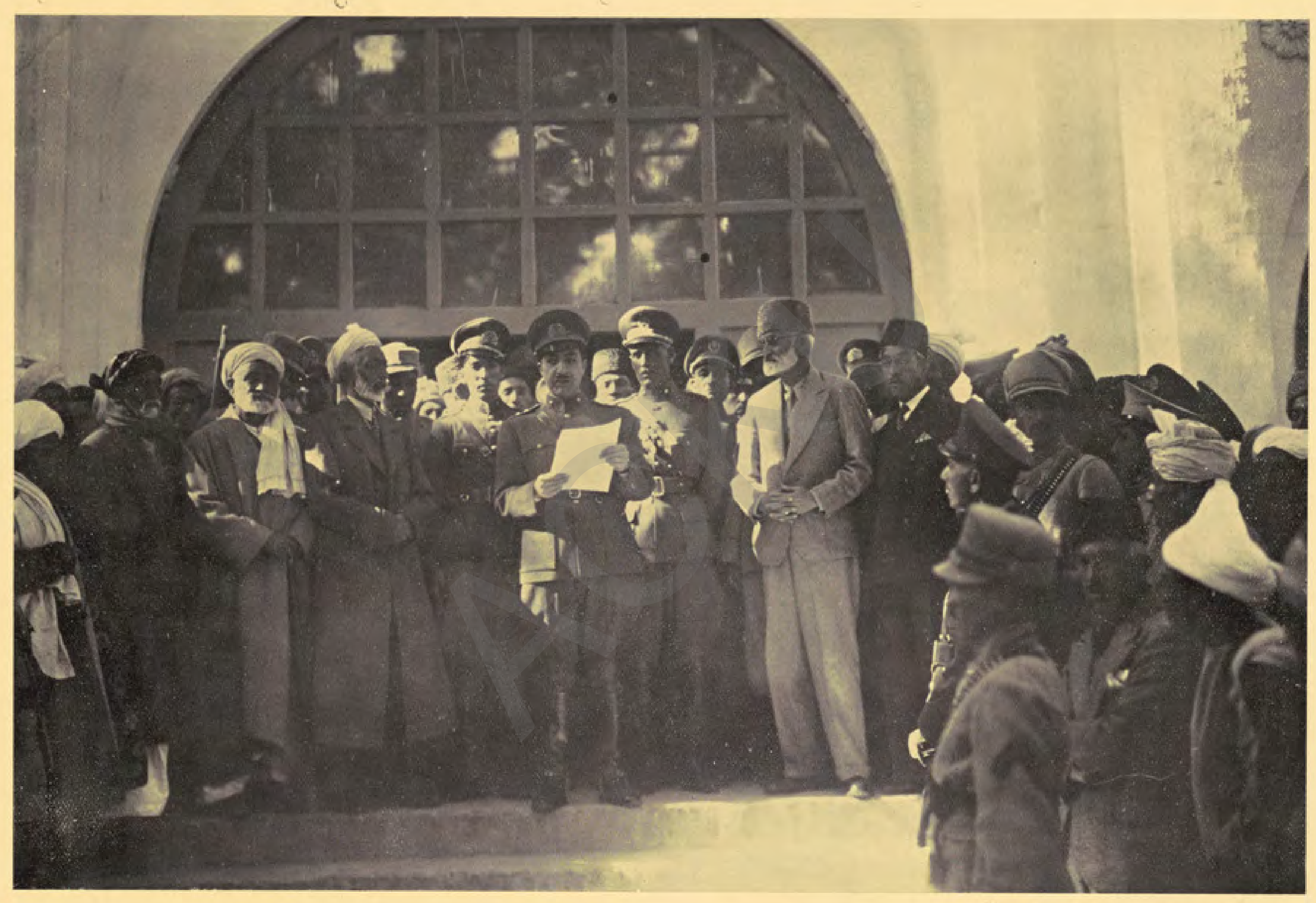

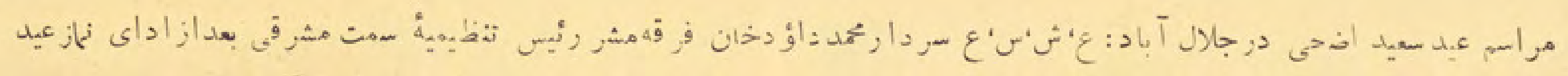

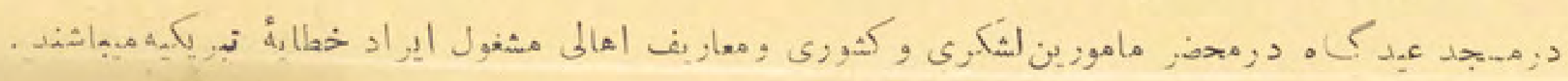




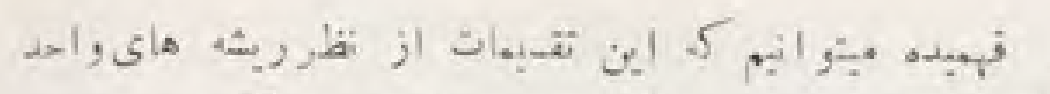
كر

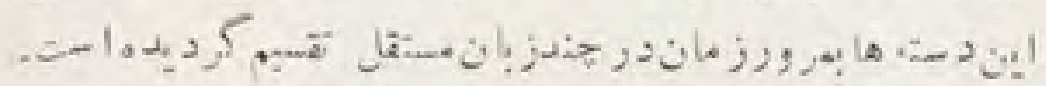

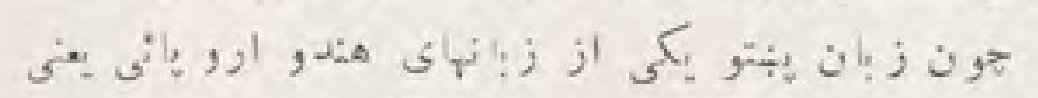

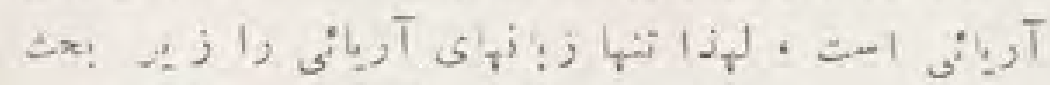

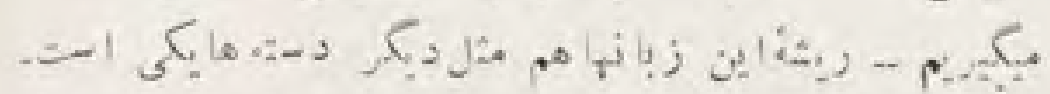

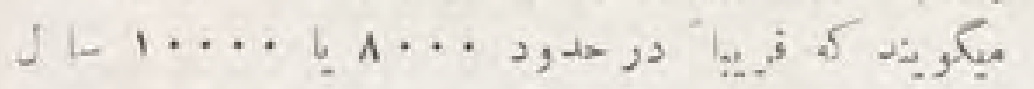

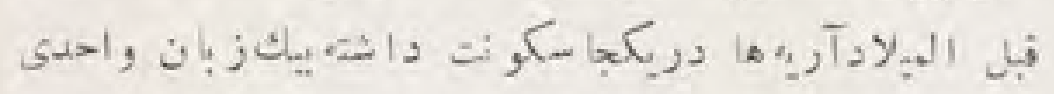

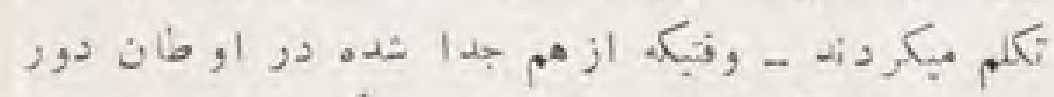

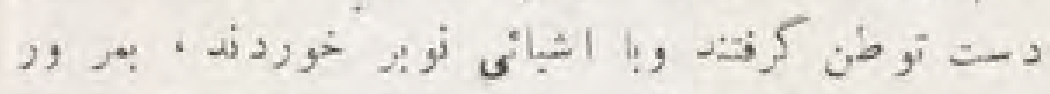

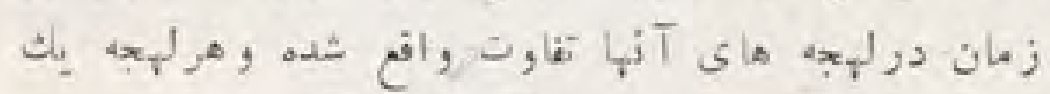

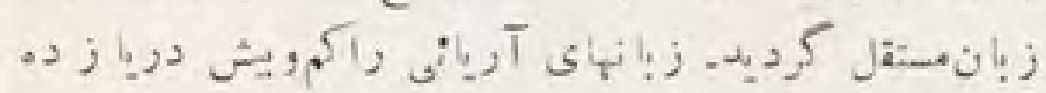

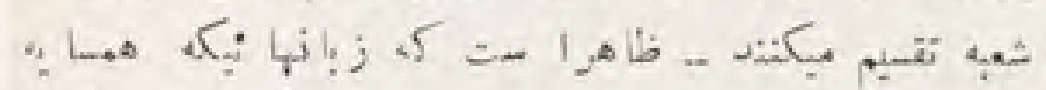

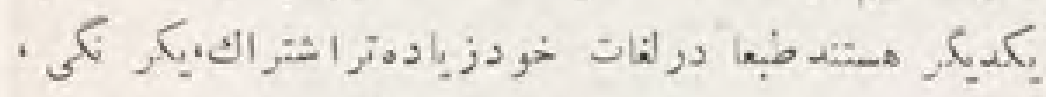

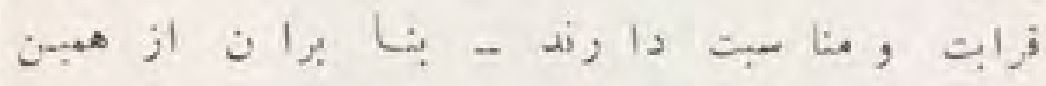

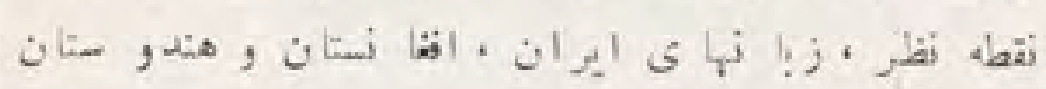

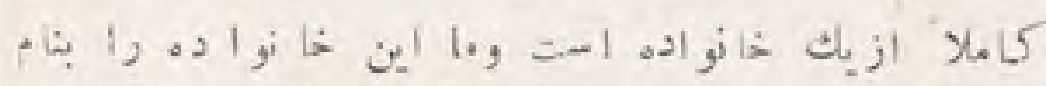

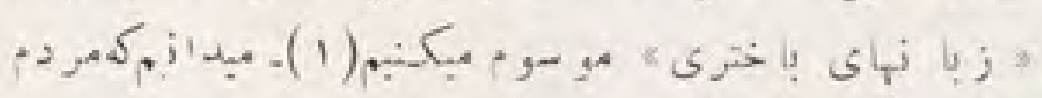

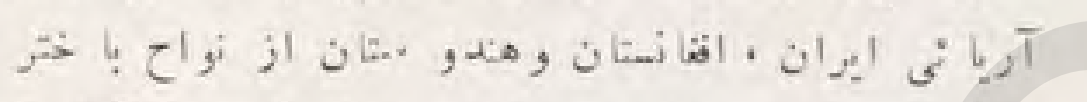

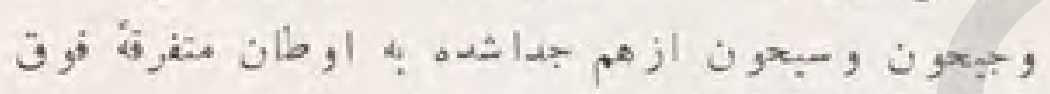

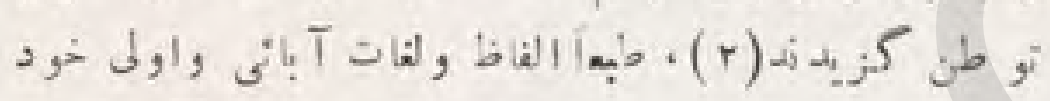

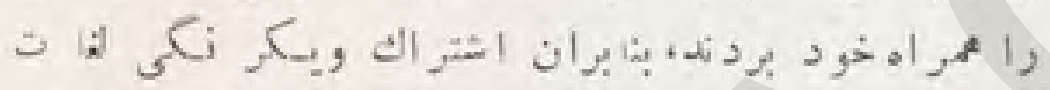

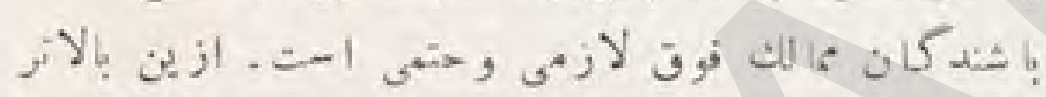

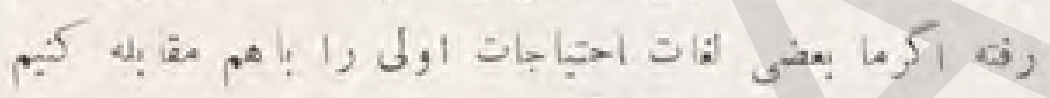

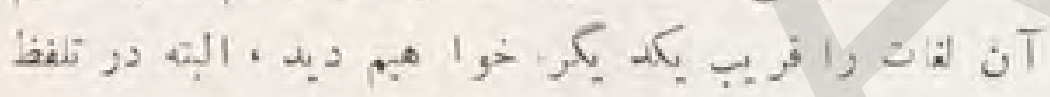

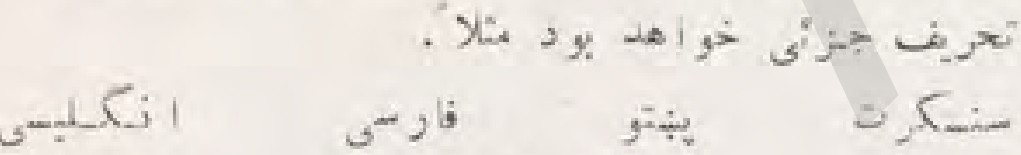

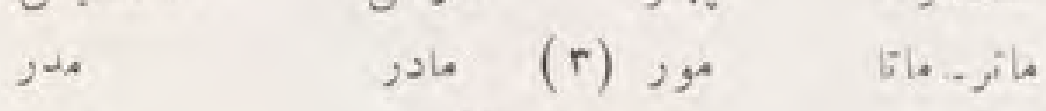

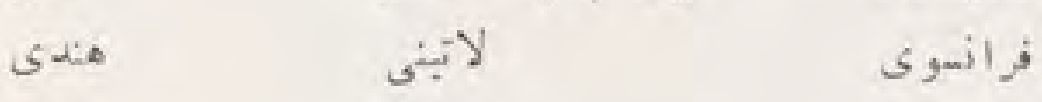

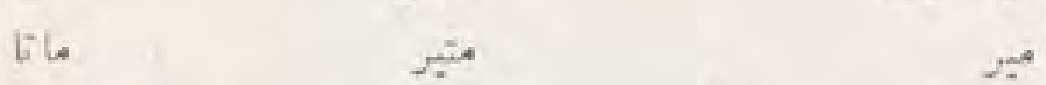

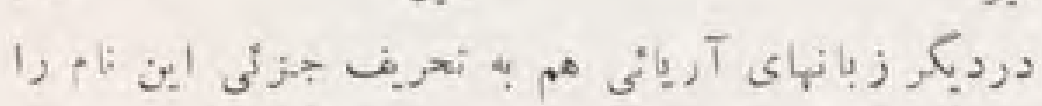

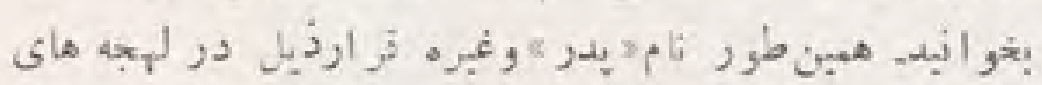

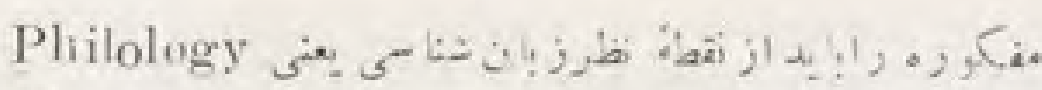

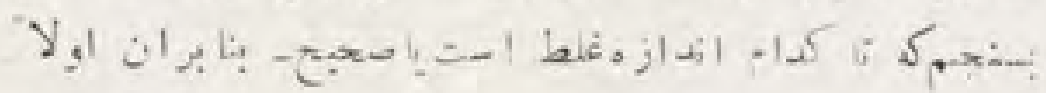

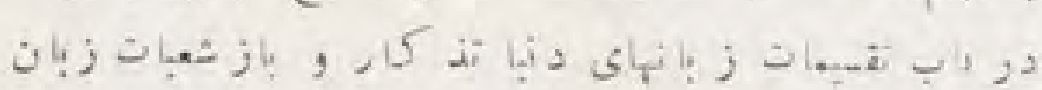

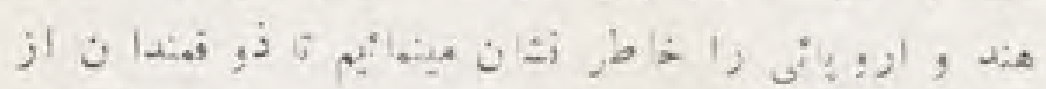

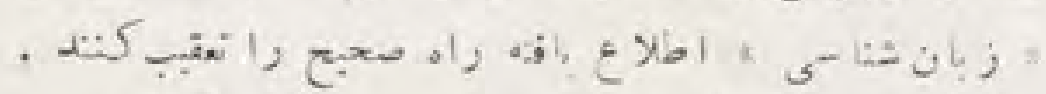

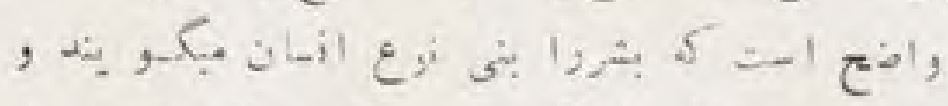
أنى

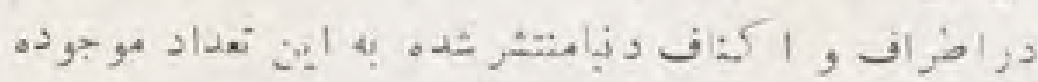

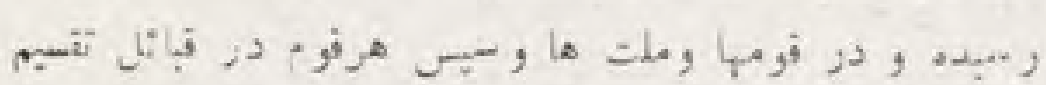

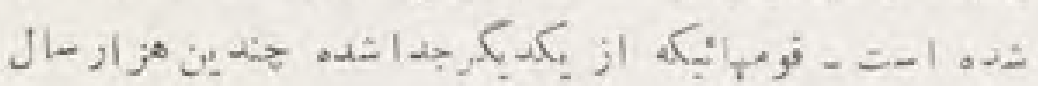

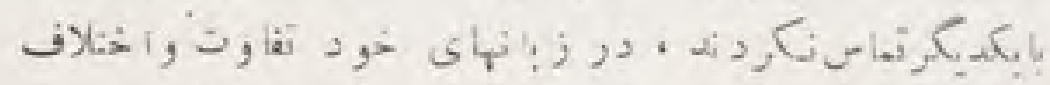

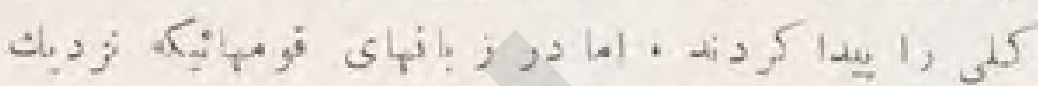

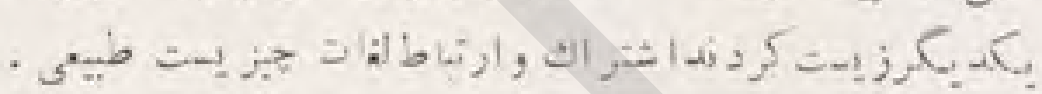

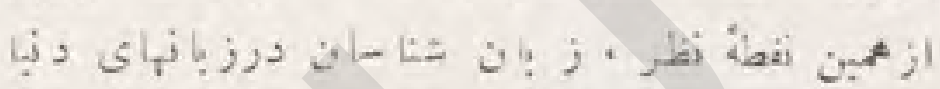

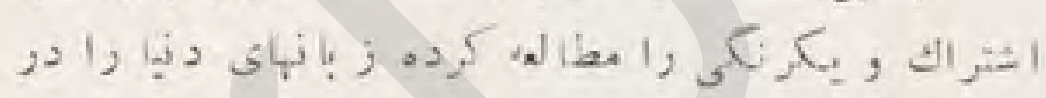

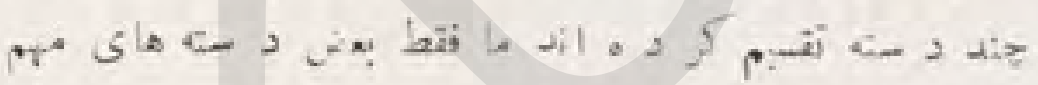
joا

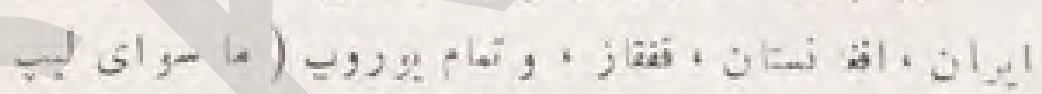

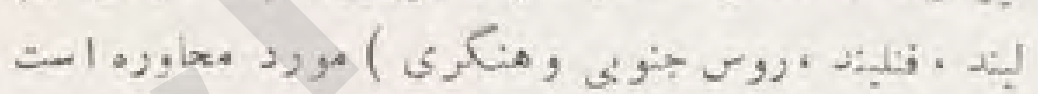

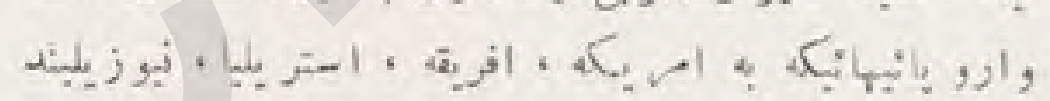

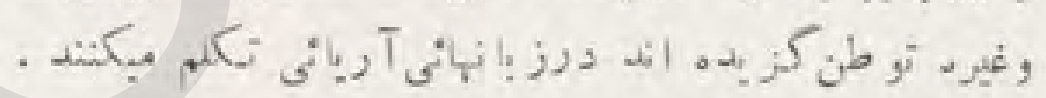

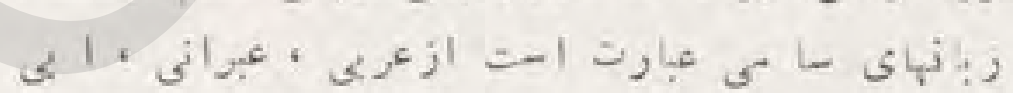
-

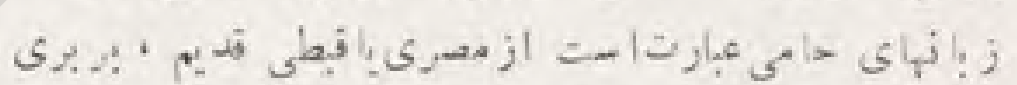

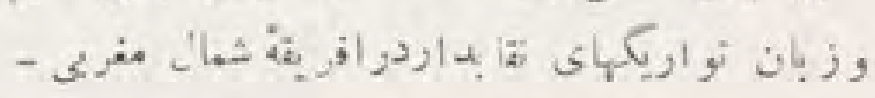

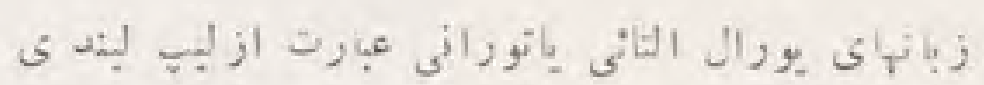

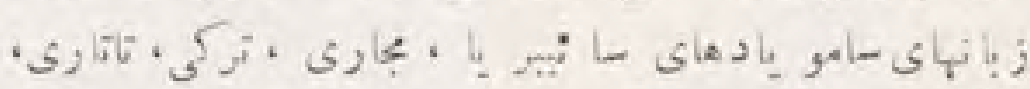

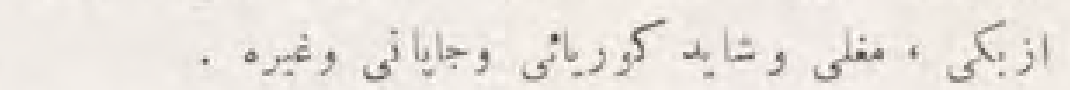

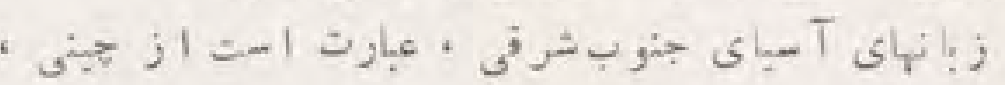

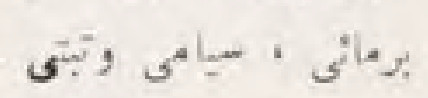

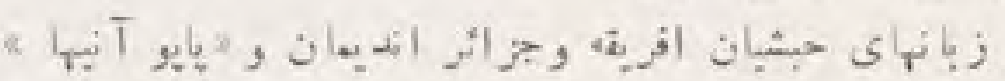

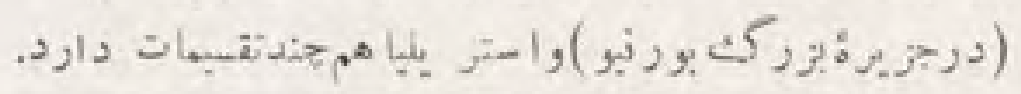

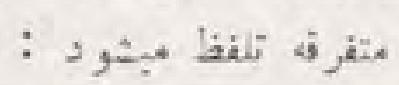

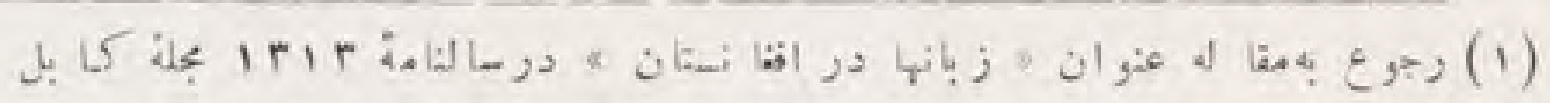

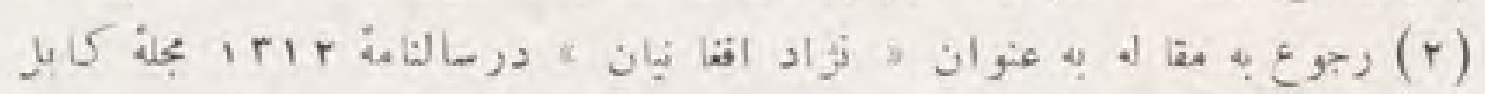

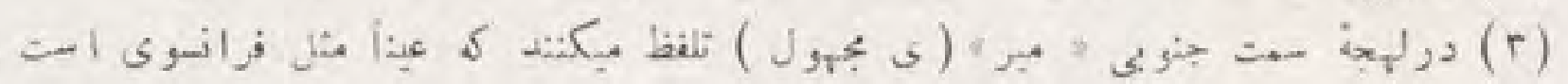




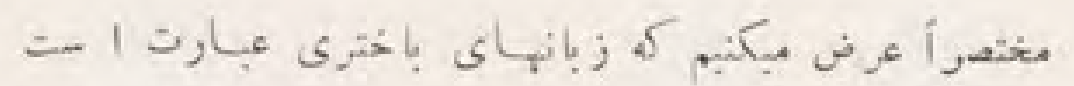

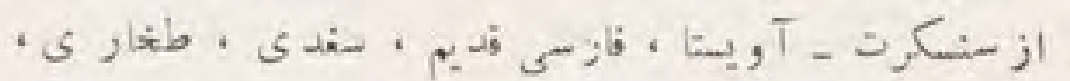

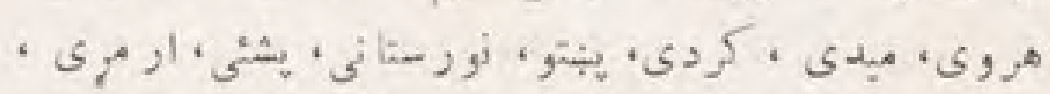

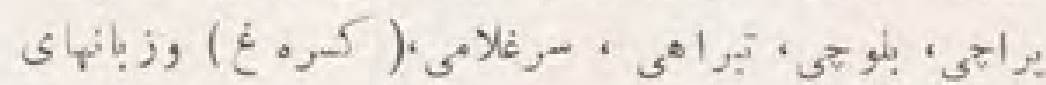

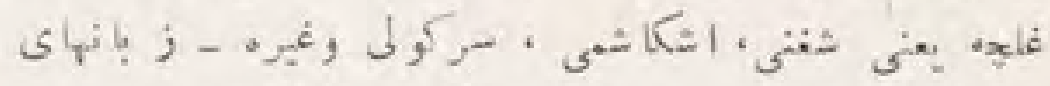

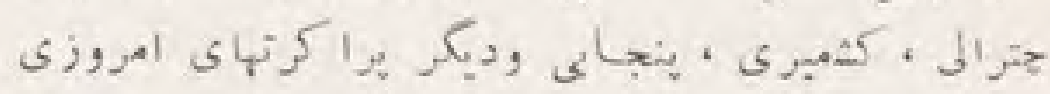

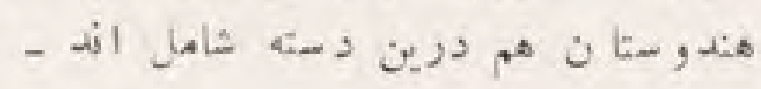

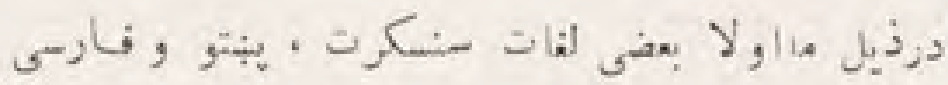

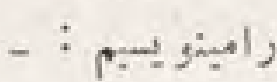

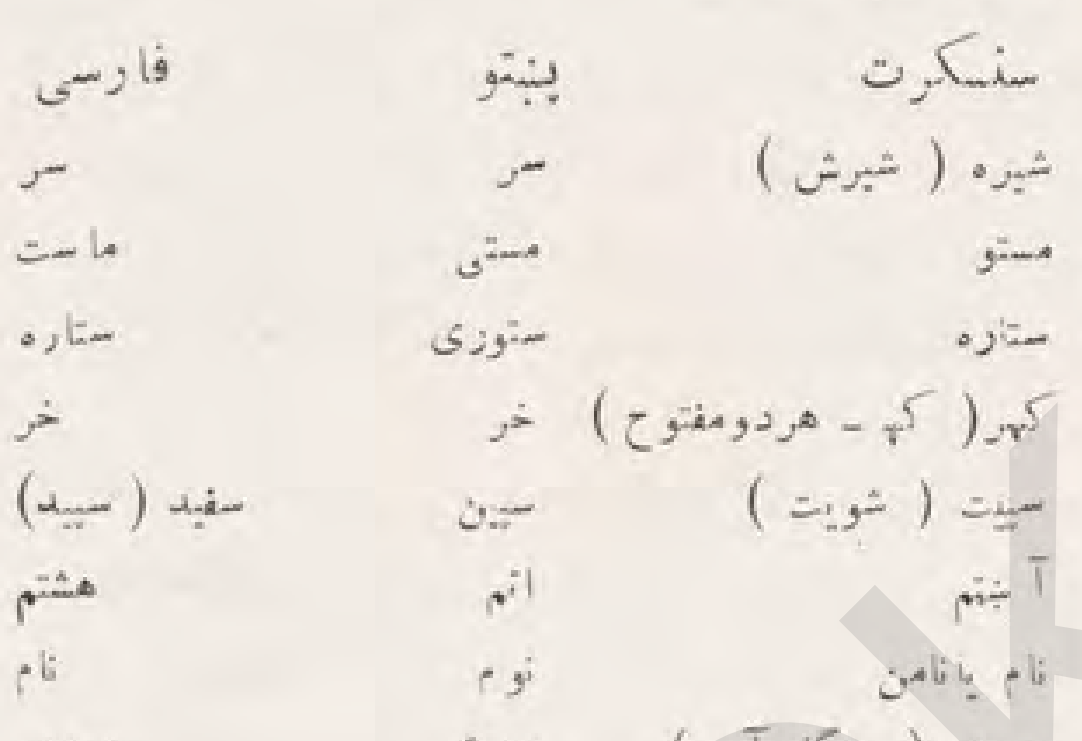

مورى

i

Jis

S $>1$

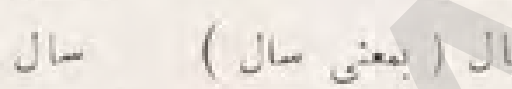

بإب

بار

24

is

إبر أبات

غان

ن 15

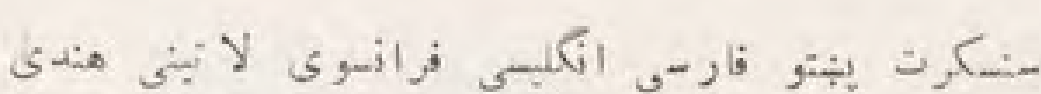

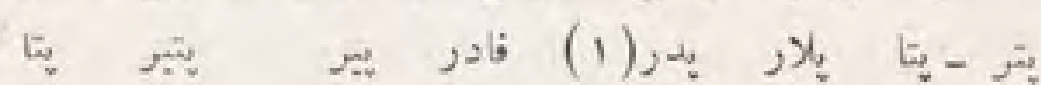

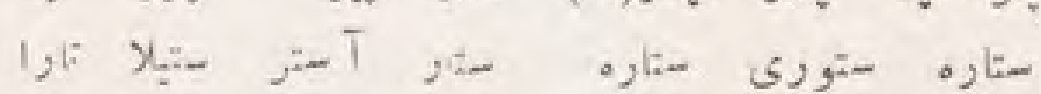
ناهن

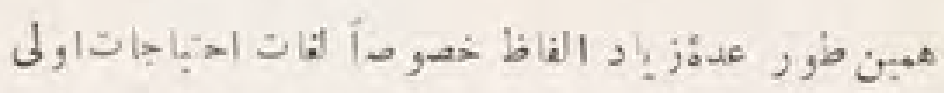

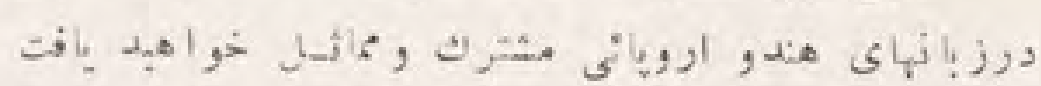

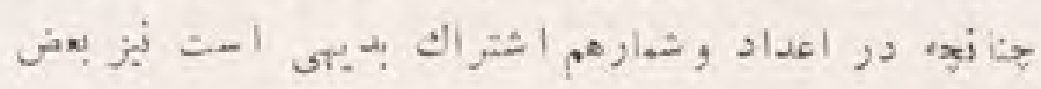

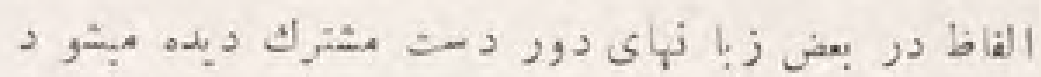

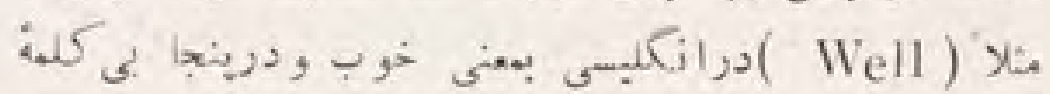

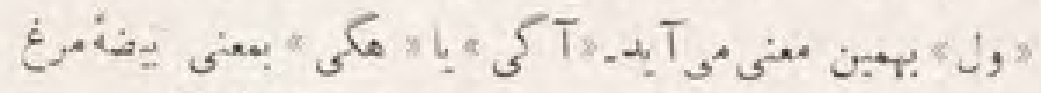

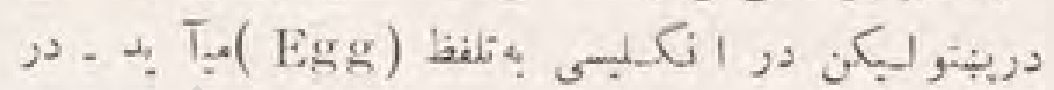

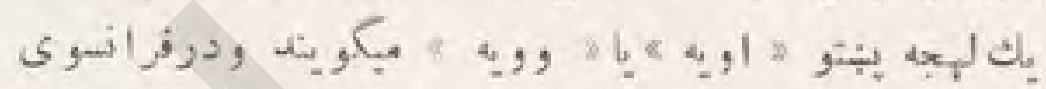

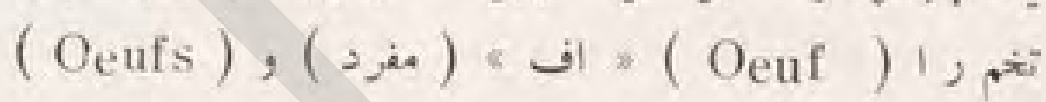

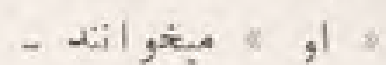

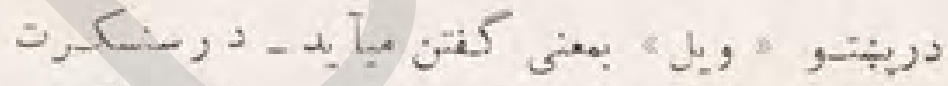

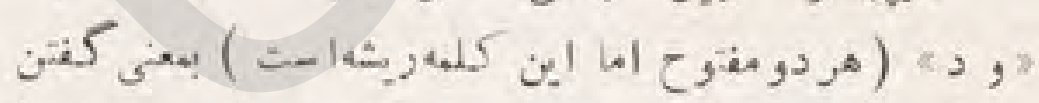

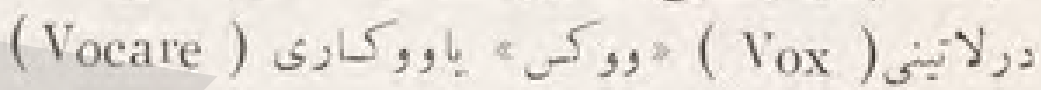

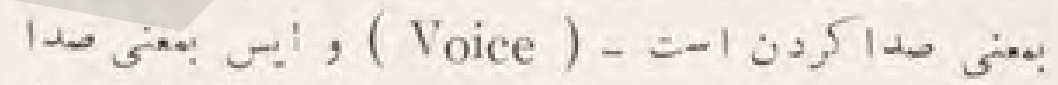

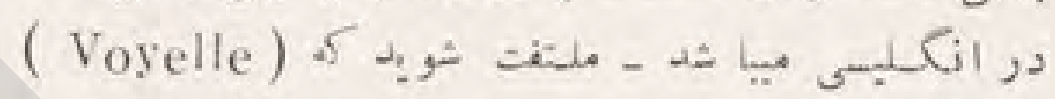

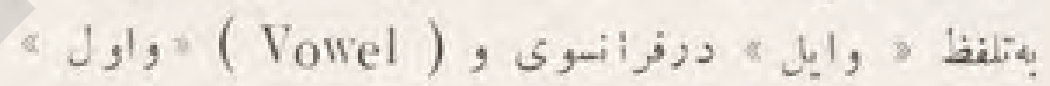

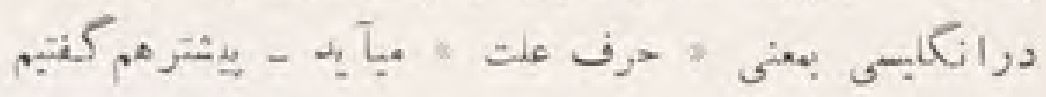

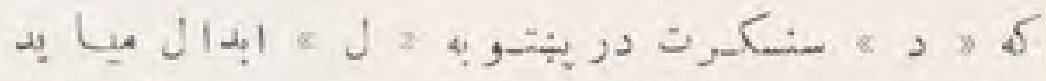

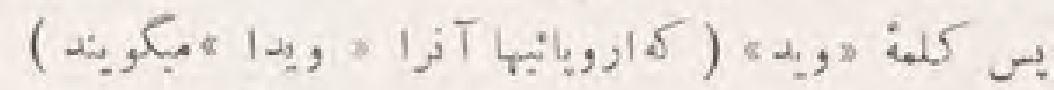

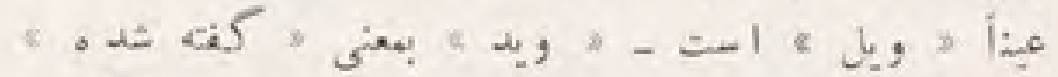

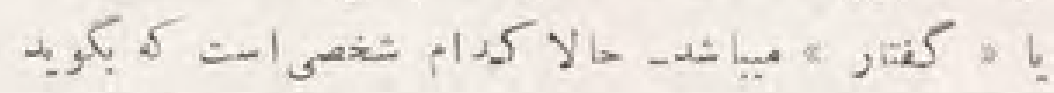

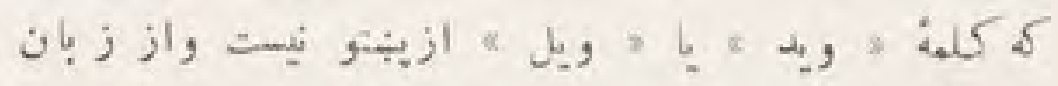

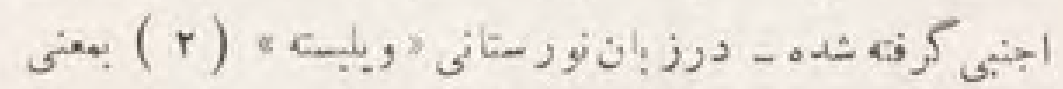

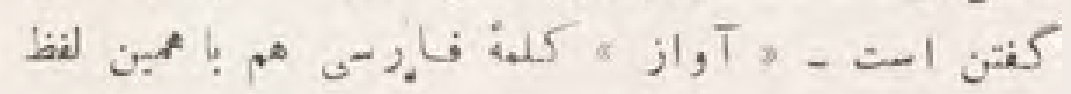

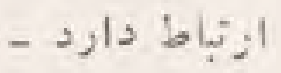

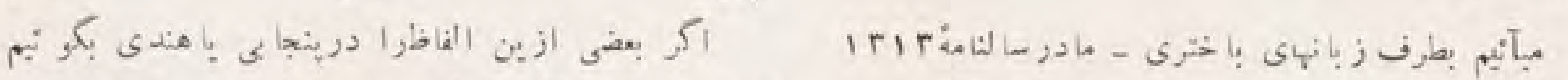

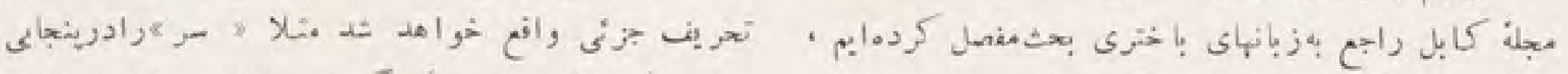

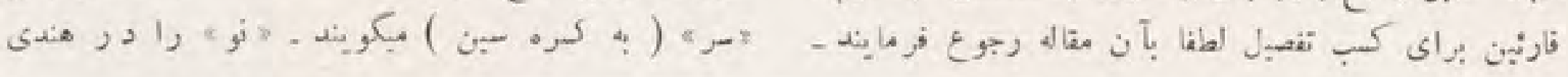

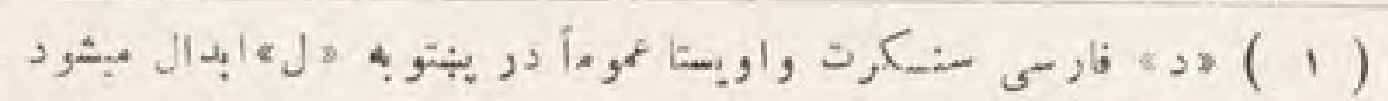

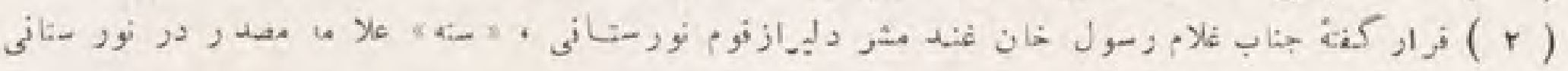

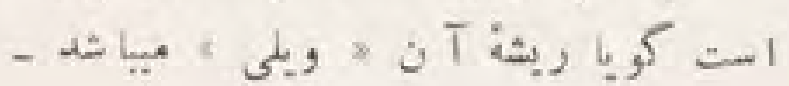




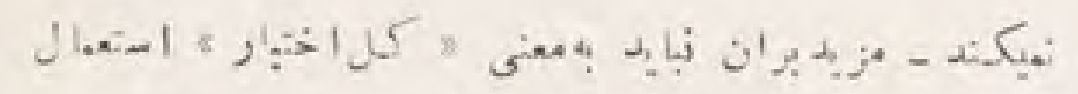

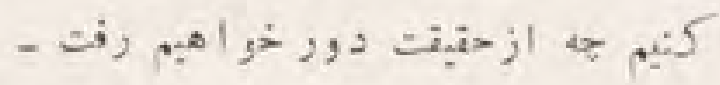

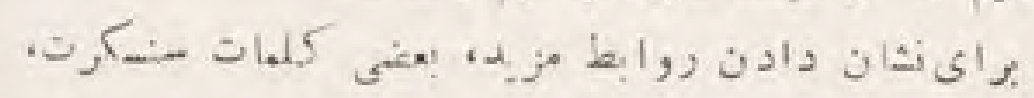

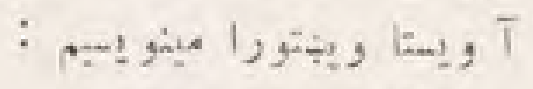

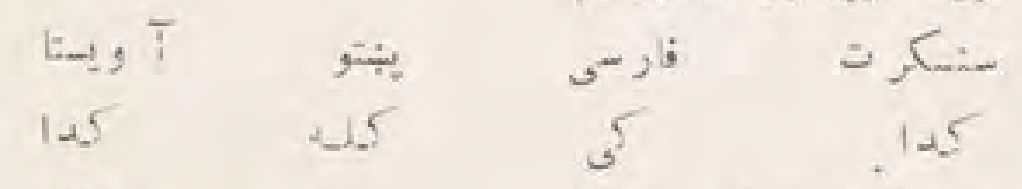

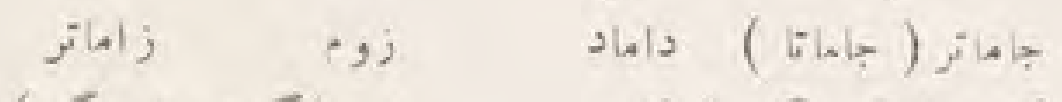

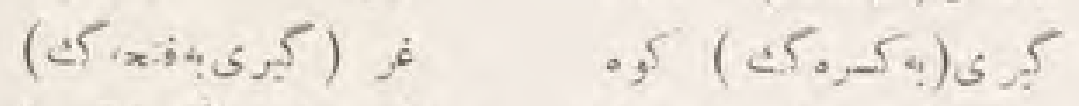

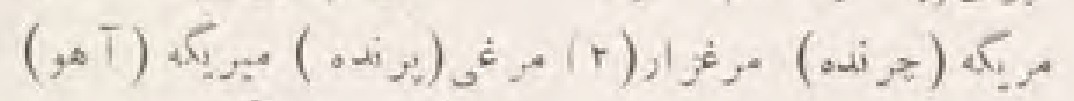

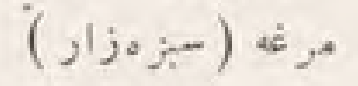

$(0,1,2)$ (

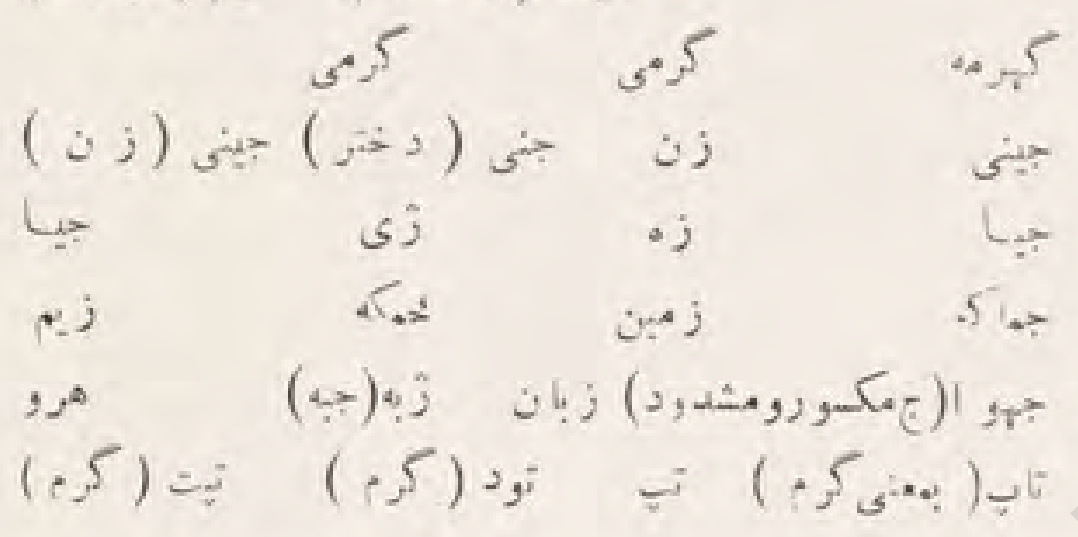

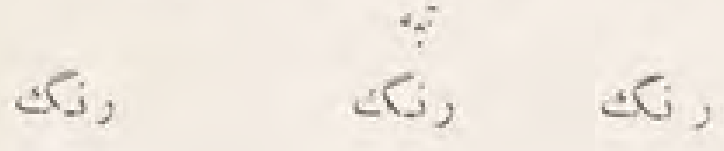

a d a

पم

كميا

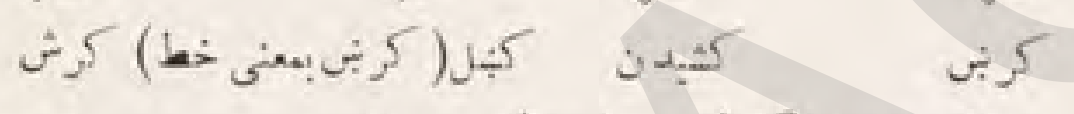

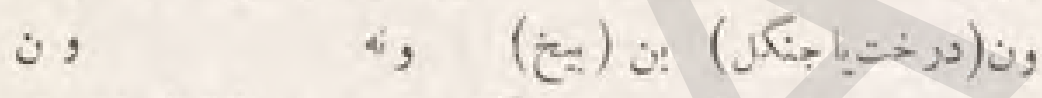

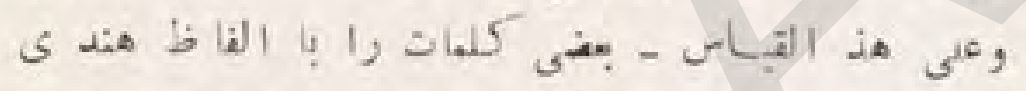

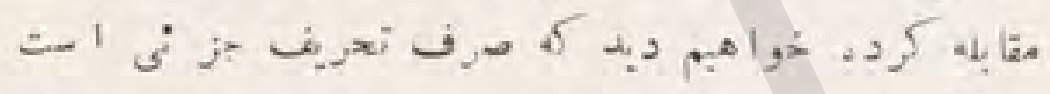

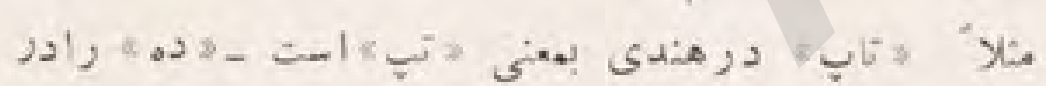

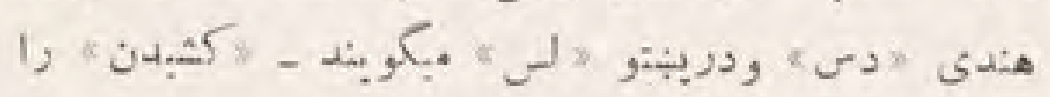

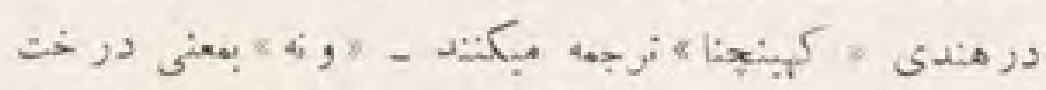

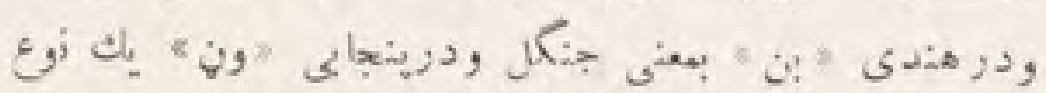

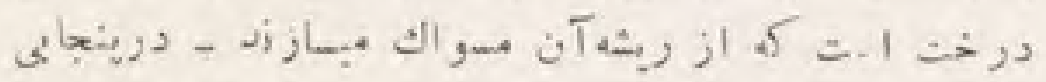

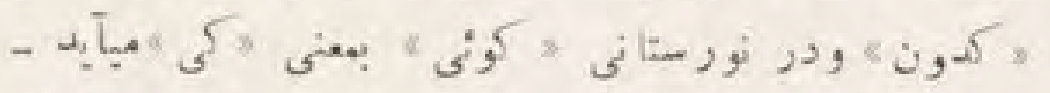

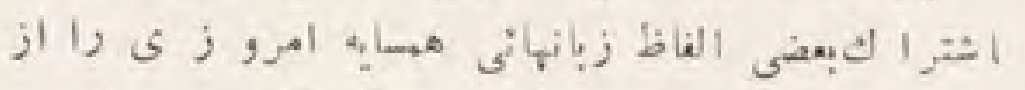

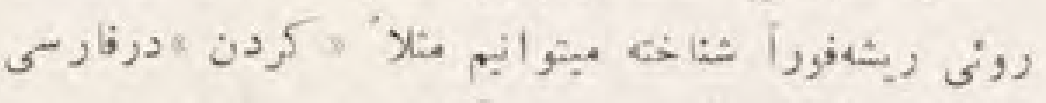

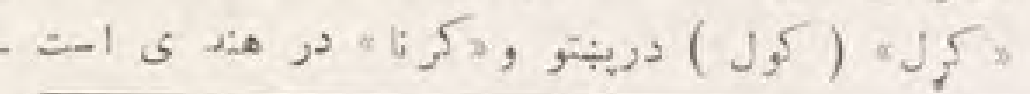

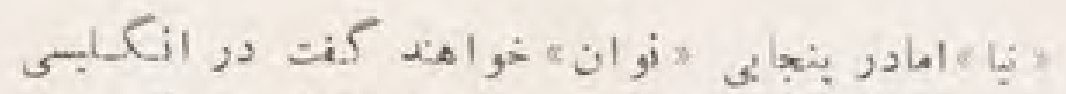
(New)

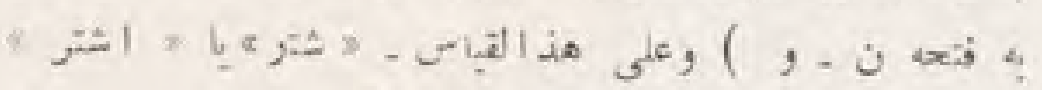

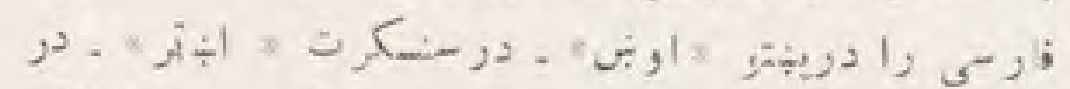

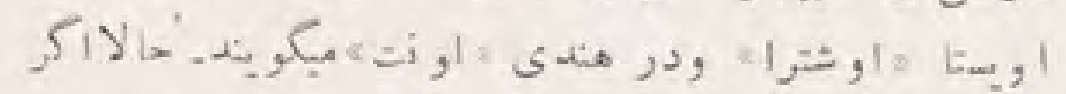

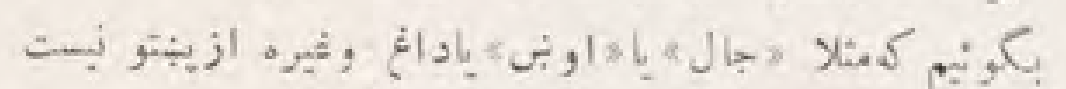

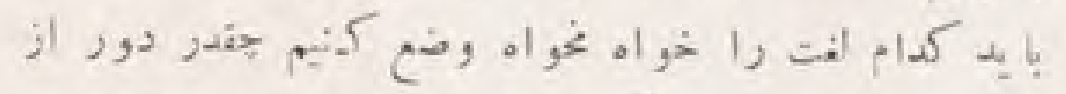

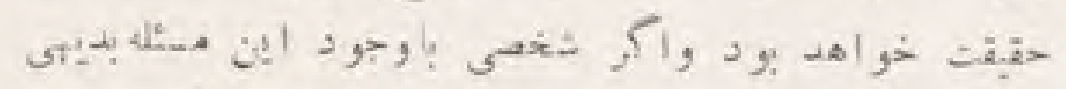

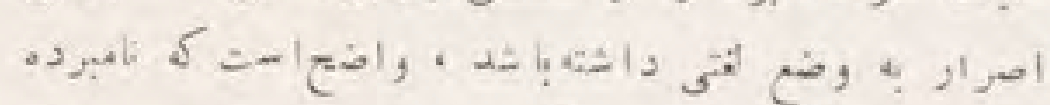

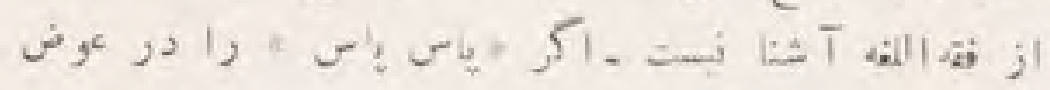

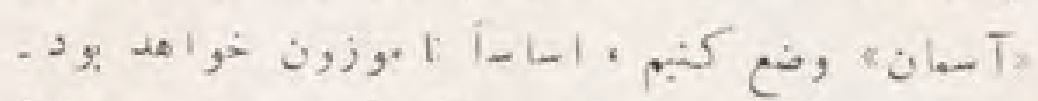

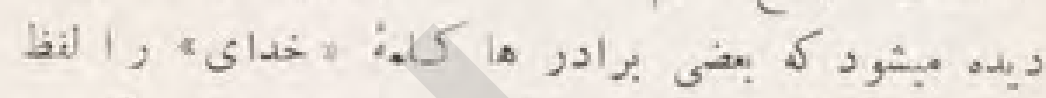

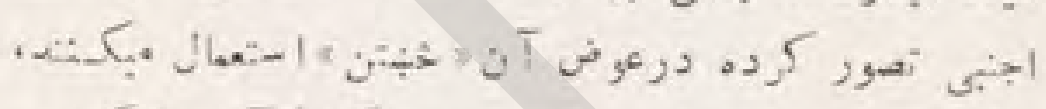

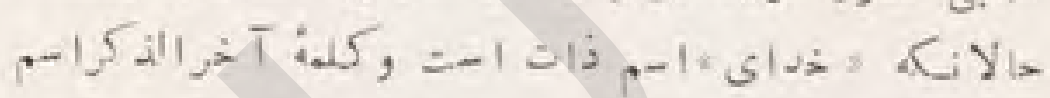

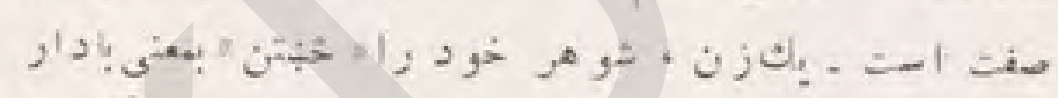

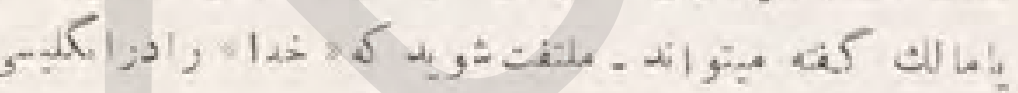

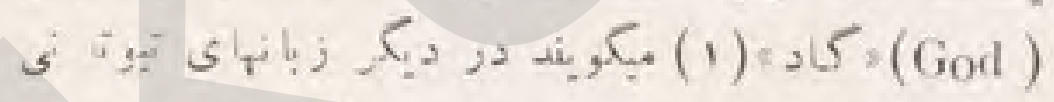

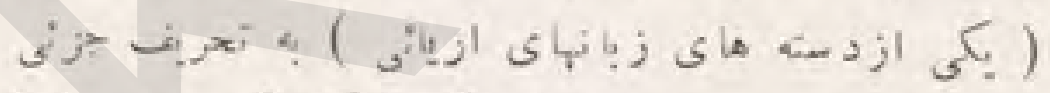

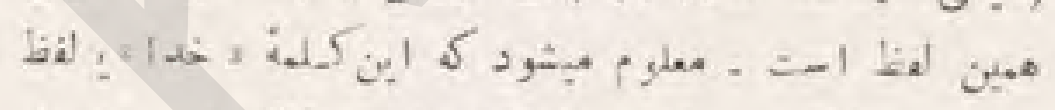

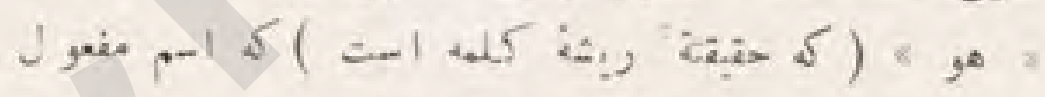

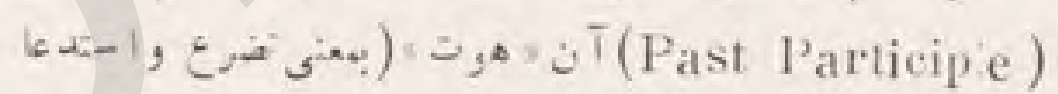

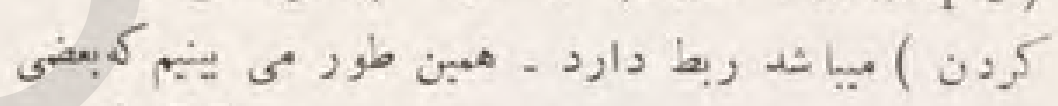

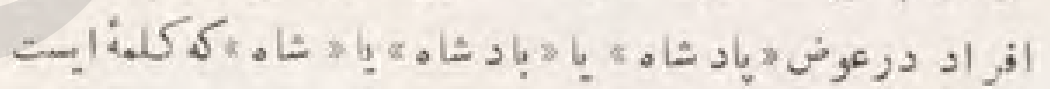

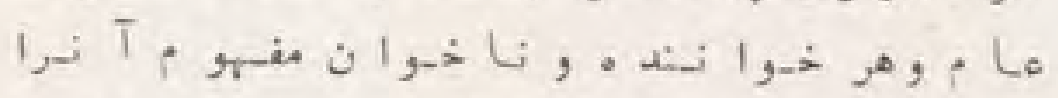

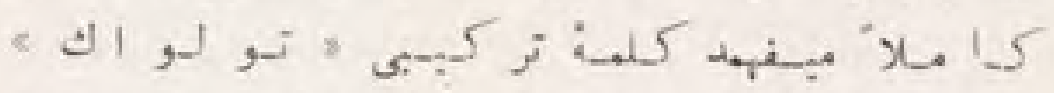

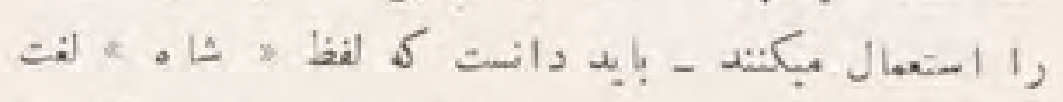

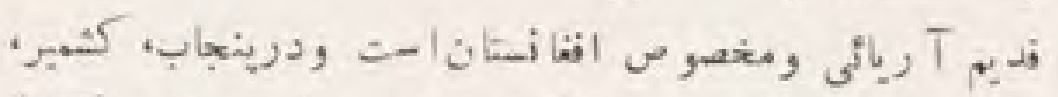

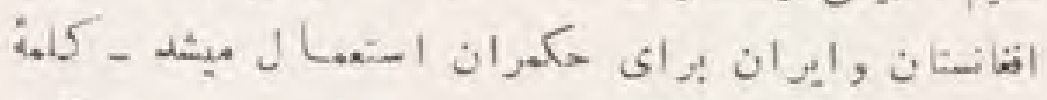

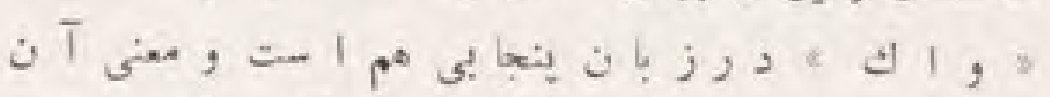

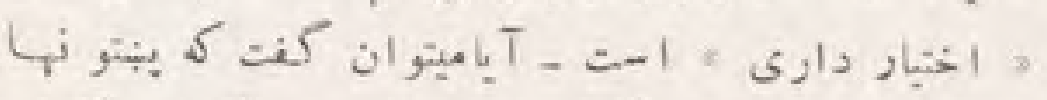

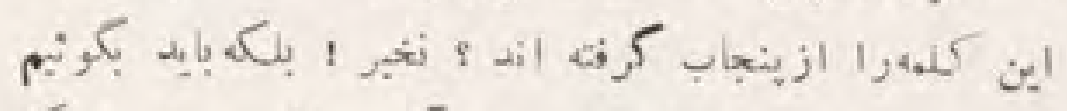

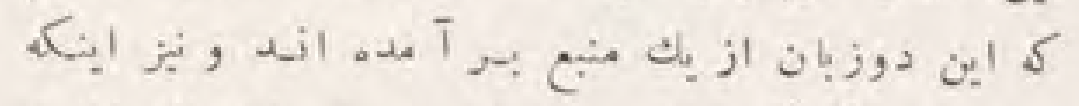

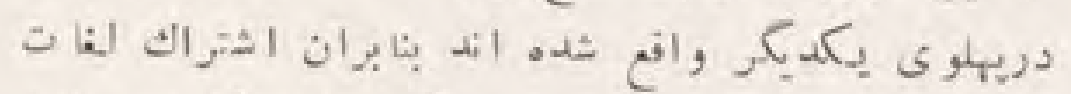

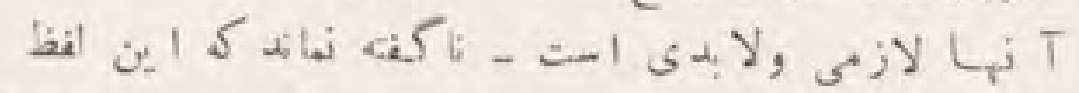

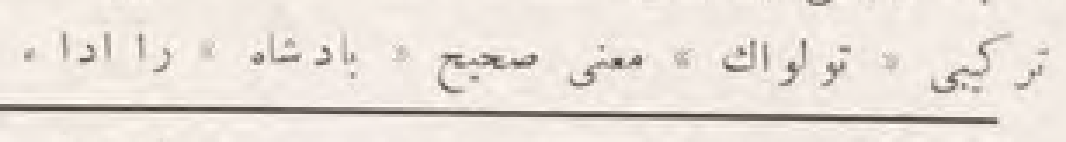




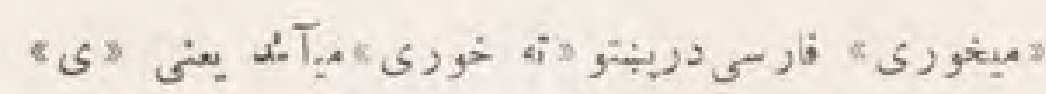

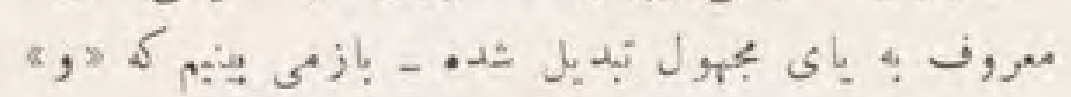

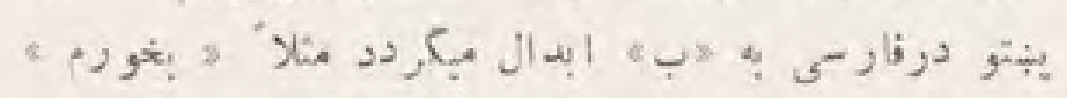

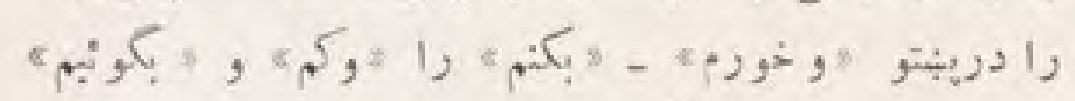

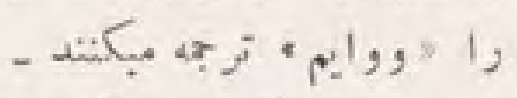

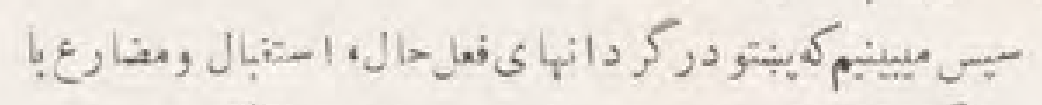

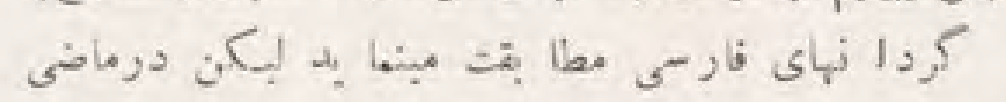

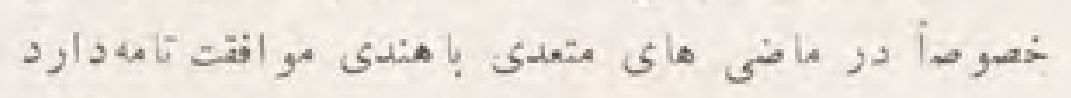

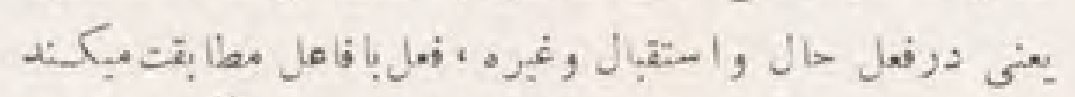

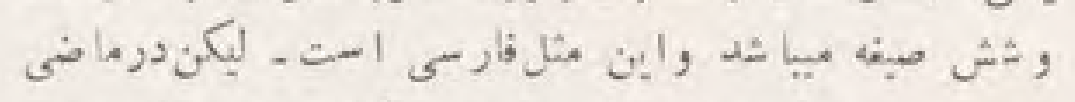

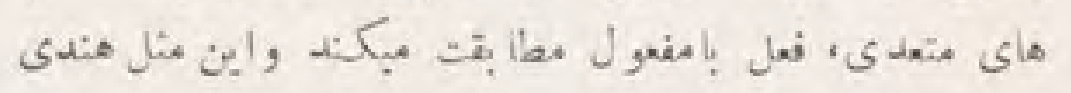

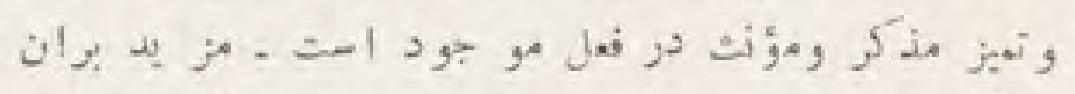

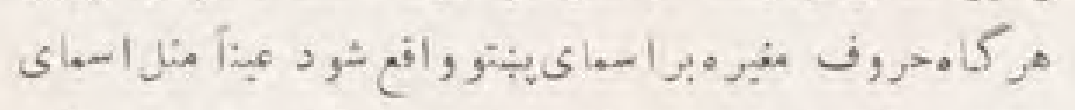

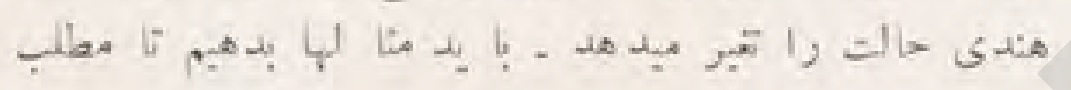

$$
\text { : }
$$

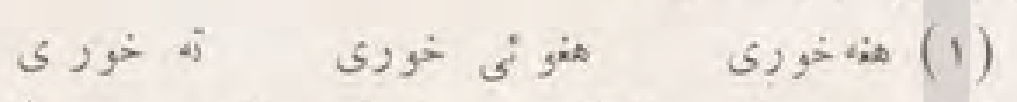

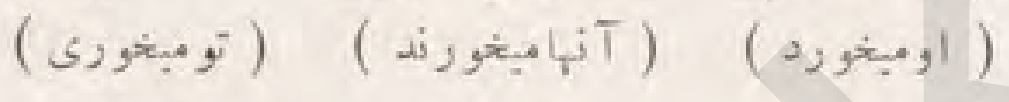

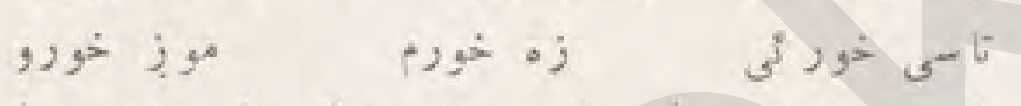

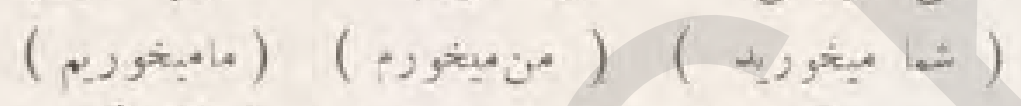

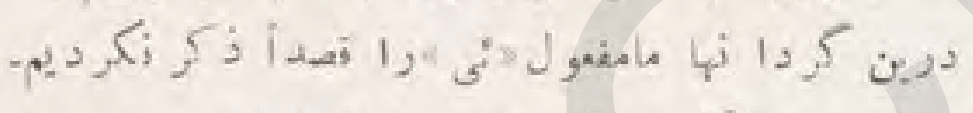

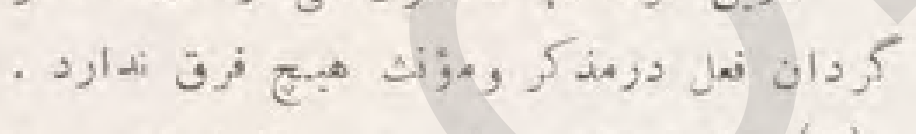

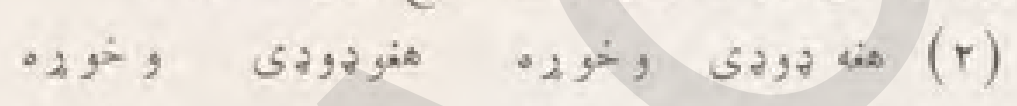

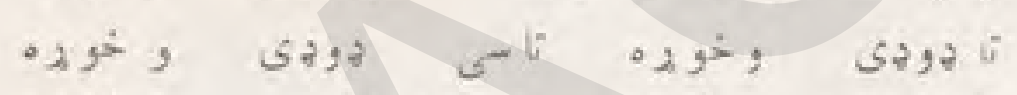

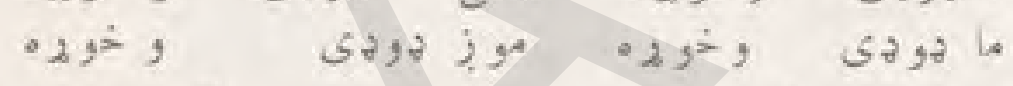

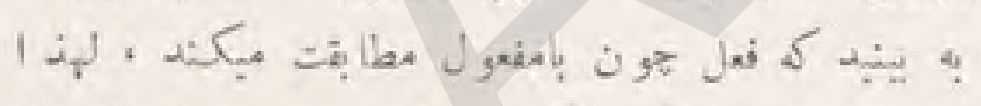

\begin{tabular}{|c|c|c|}
\hline ( بـ ك, & ostip & $s_{2}$ \\
\hline Jis & $s_{i-}$ & دوب \\
\hline a) 27 & $4 \div$ & يوه. \\
\hline$ل_{\lambda^{i}}$ & $\sqrt{2} \div$ & ی, \\
\hline , & $\approx$ & \\
\hline 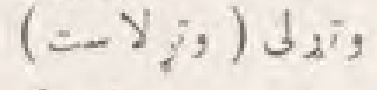 & تا س & \\
\hline$\sqrt{3}$ & •j & \\
\hline I tis & موبز & \\
\hline
\end{tabular}

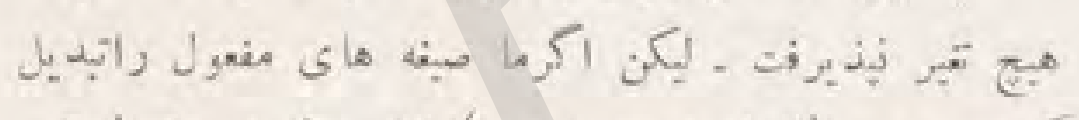

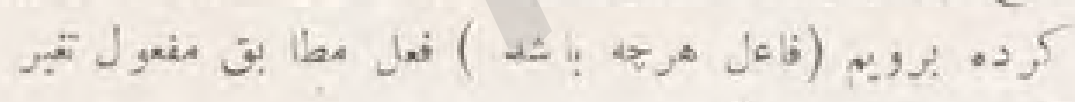

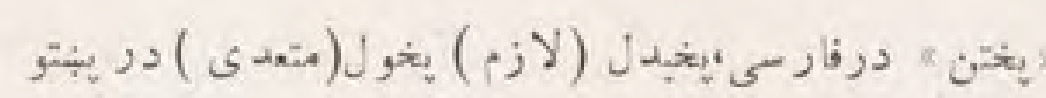

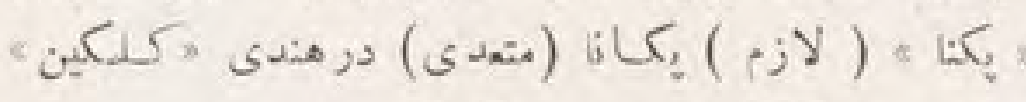

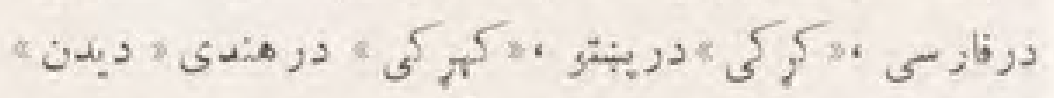

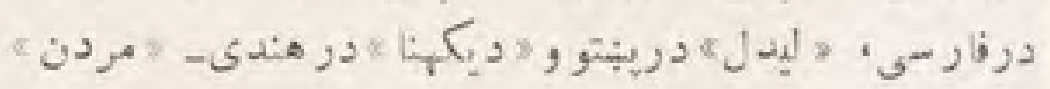

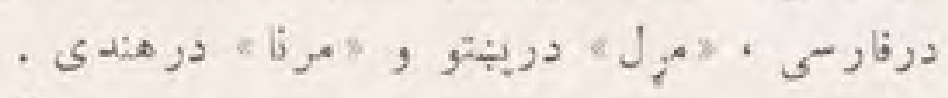

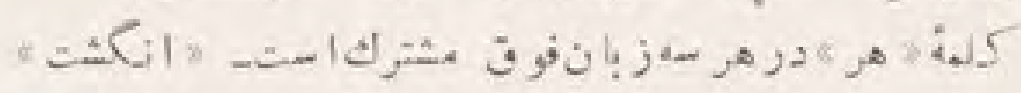

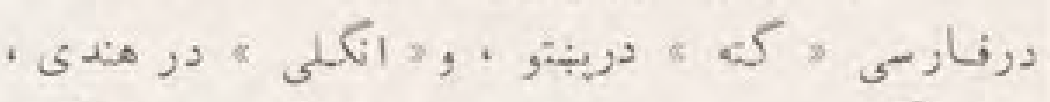

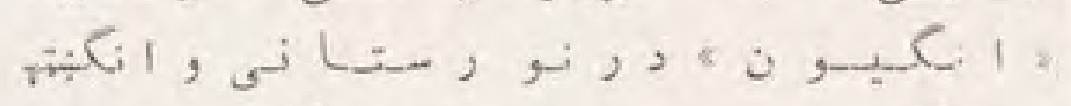

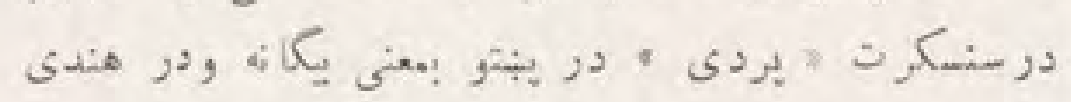

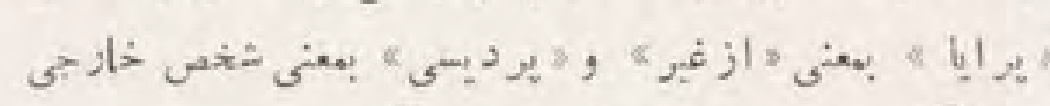

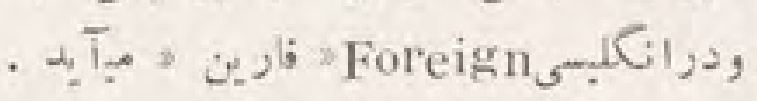

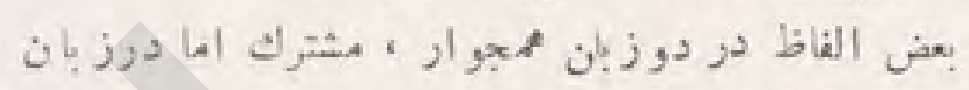

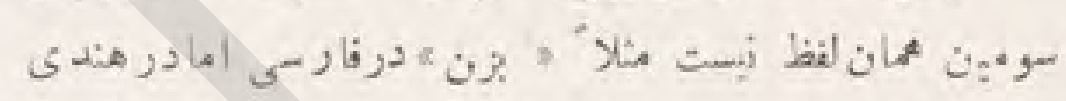

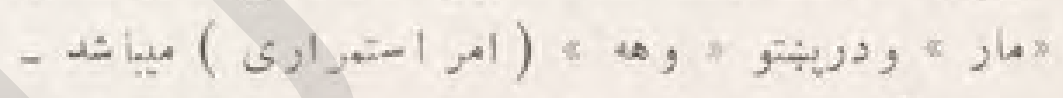

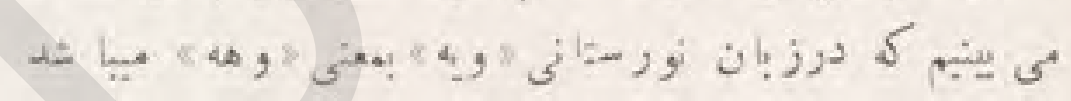

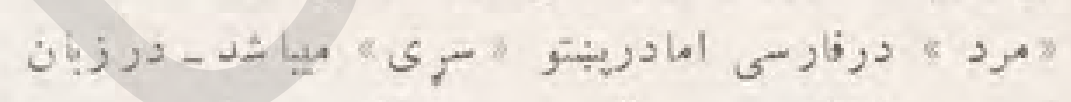

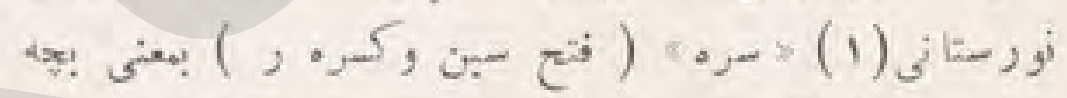

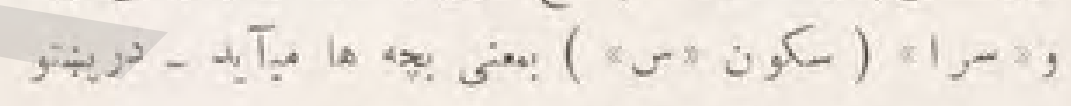

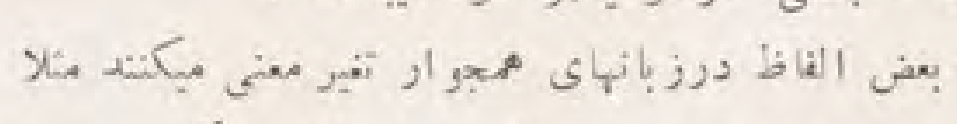

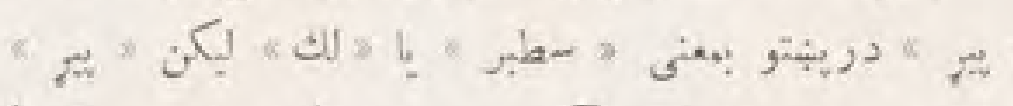

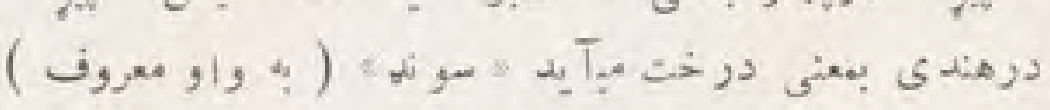

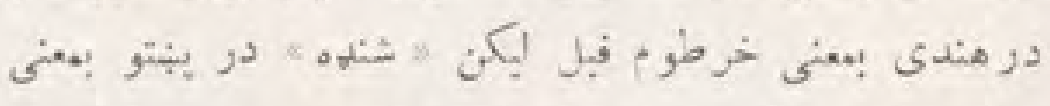

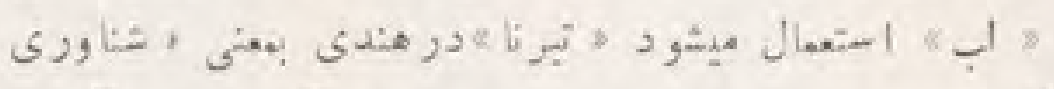

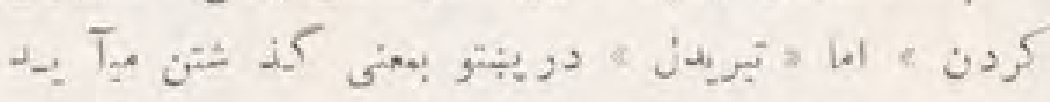

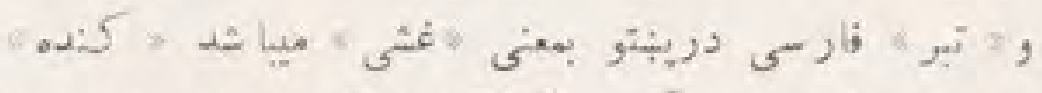

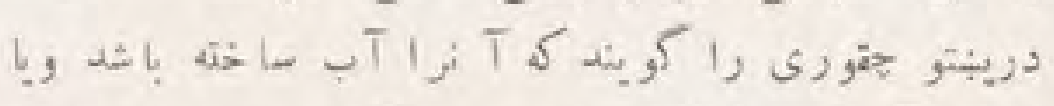

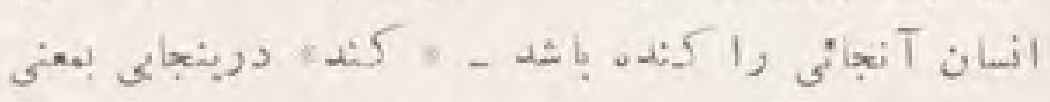

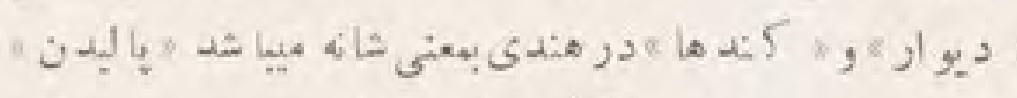

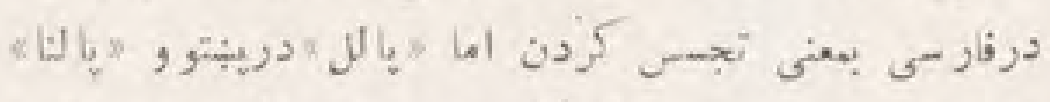

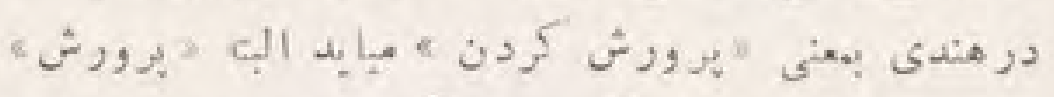

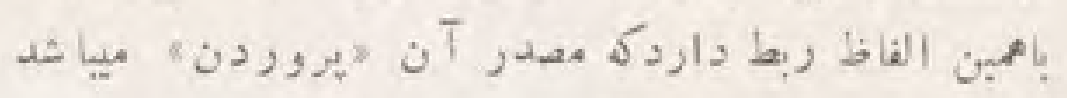

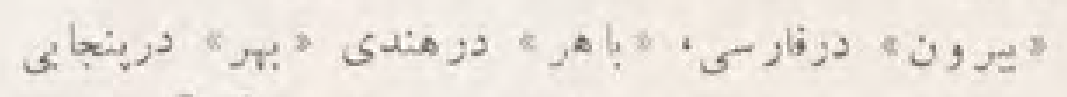

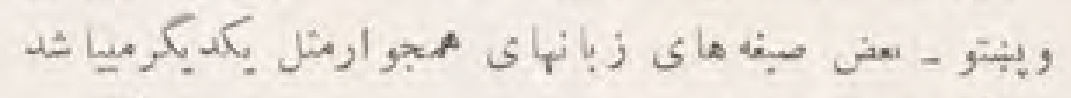

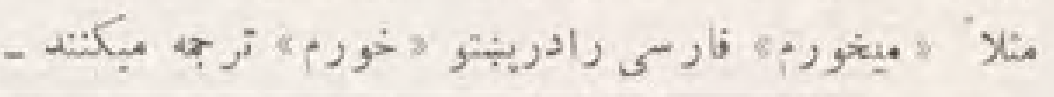

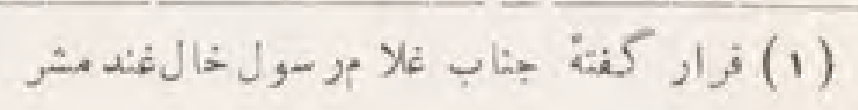




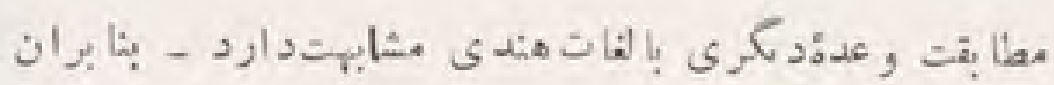

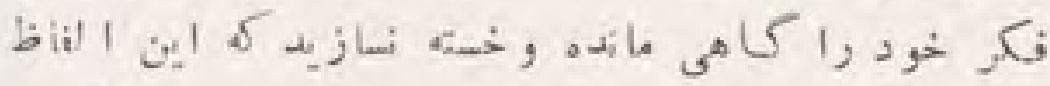

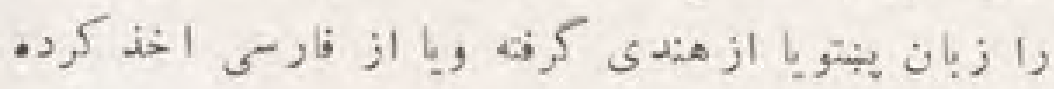

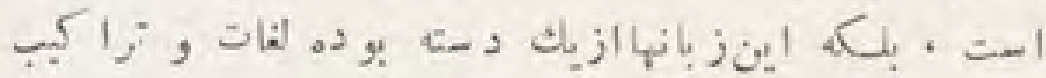

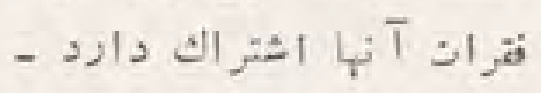

\section{خे دات}

حكوهت و مد نيت , علموسيله ايست براى ادخال لغات :

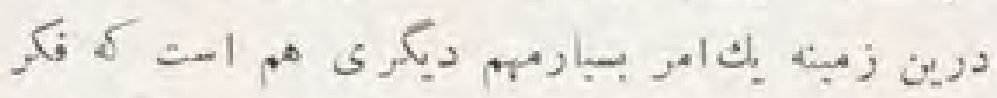

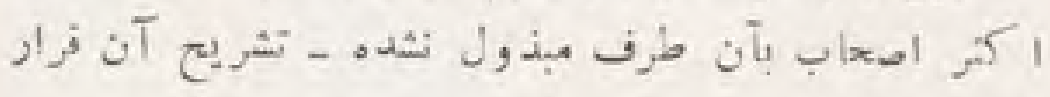

$$
\text { زيل است : أمجات }
$$

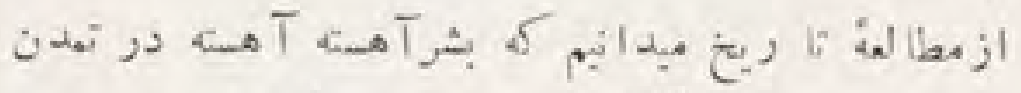

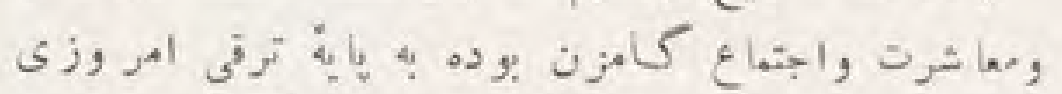

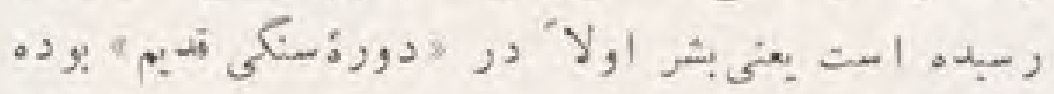

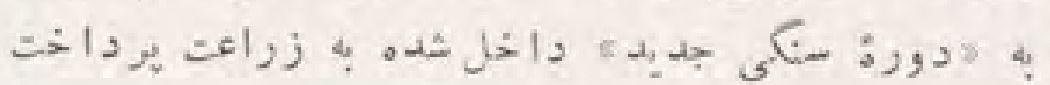

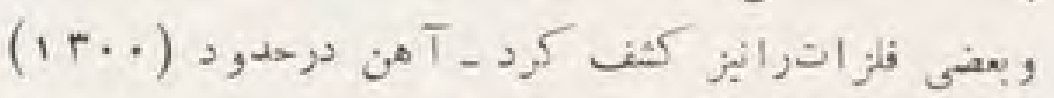

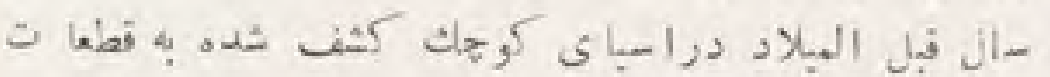

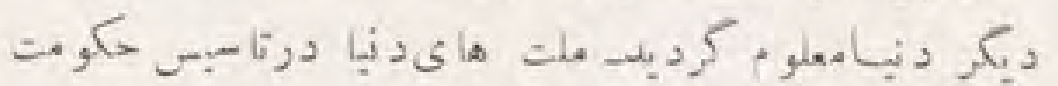

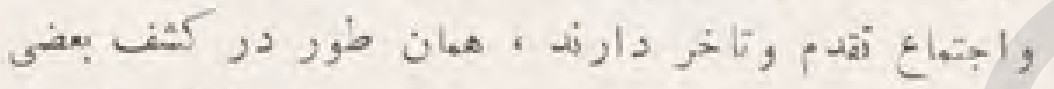

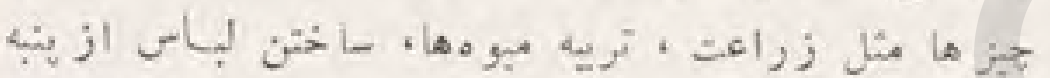

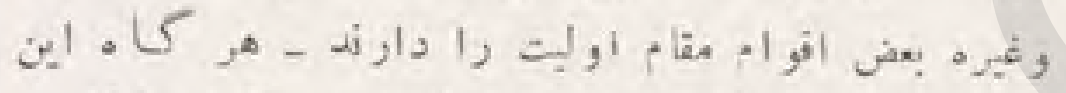

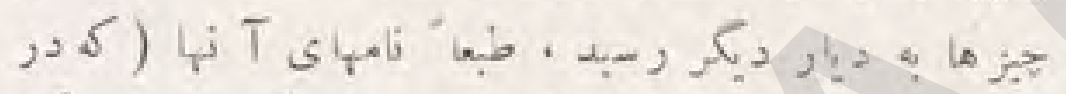

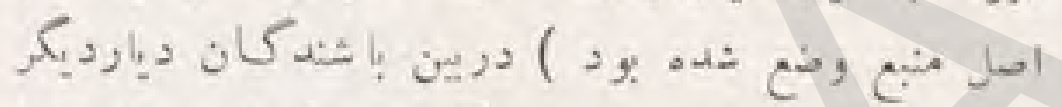

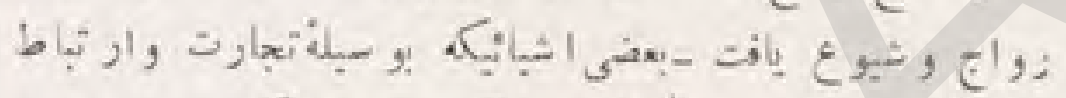

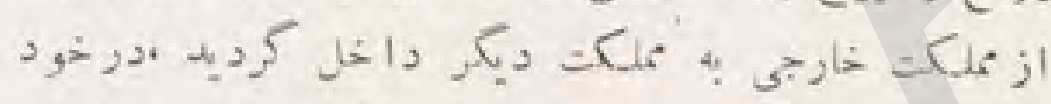

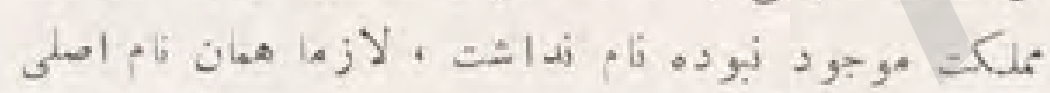

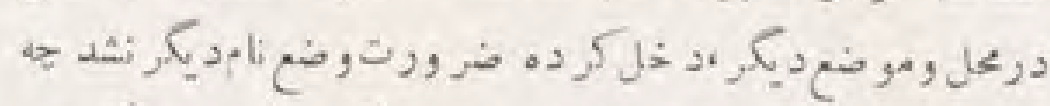

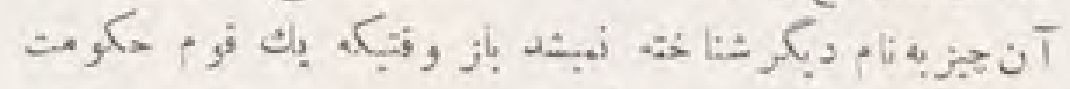

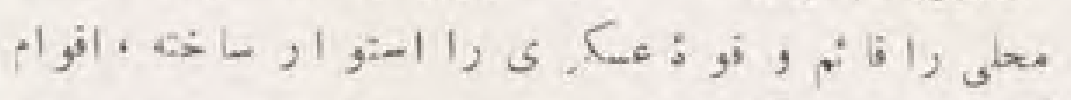

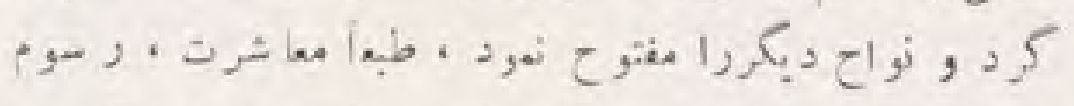

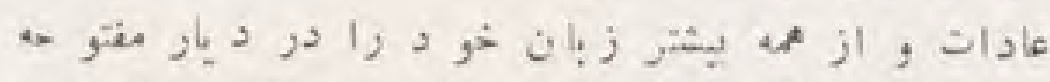

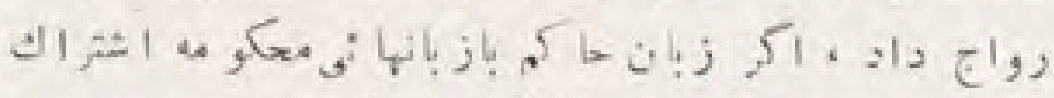

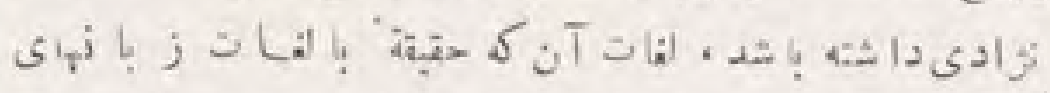

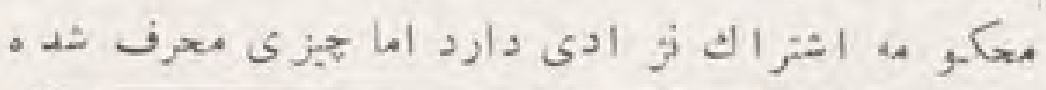

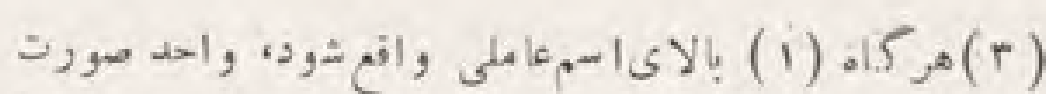

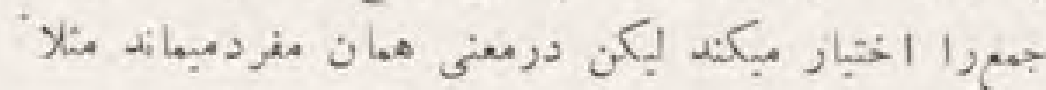

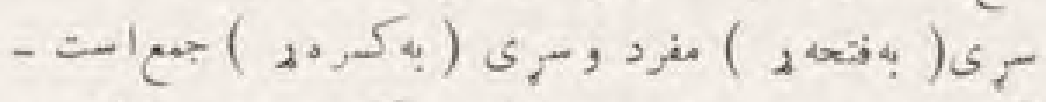

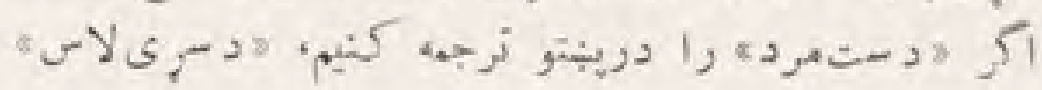

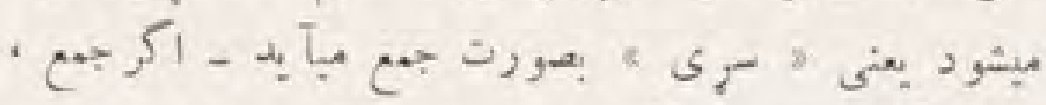

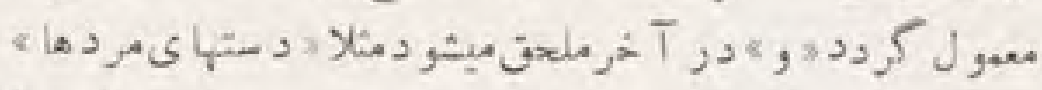

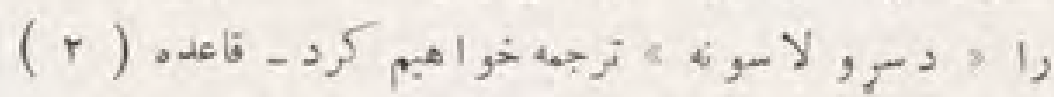

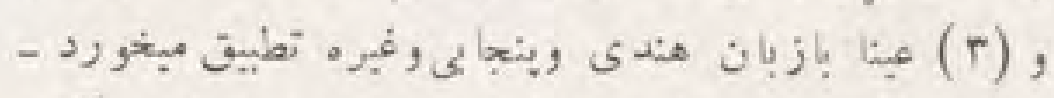

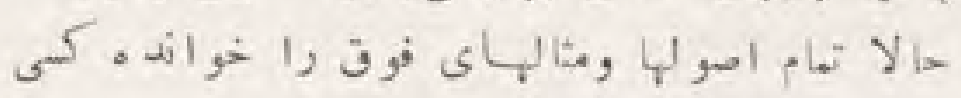

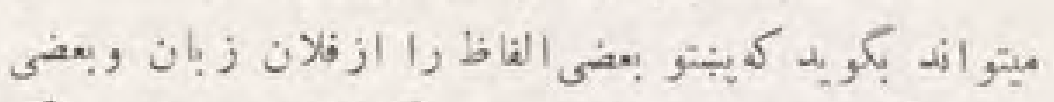

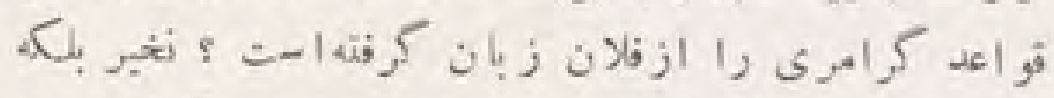

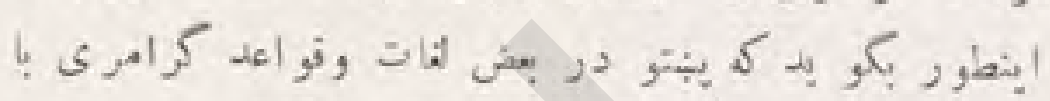

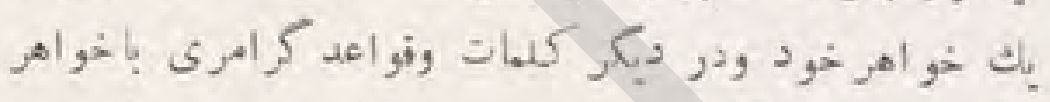

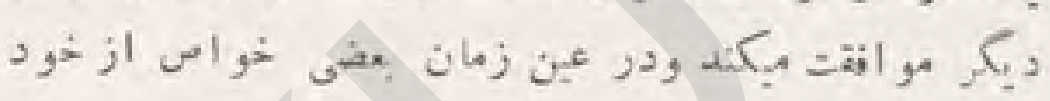

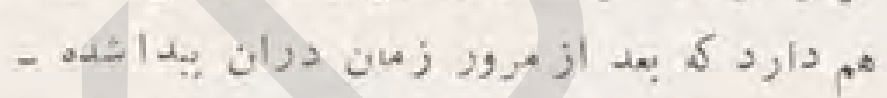

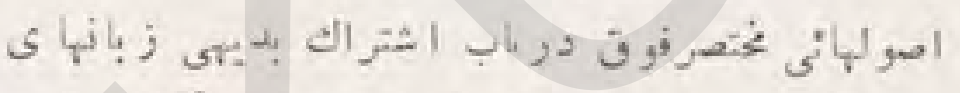

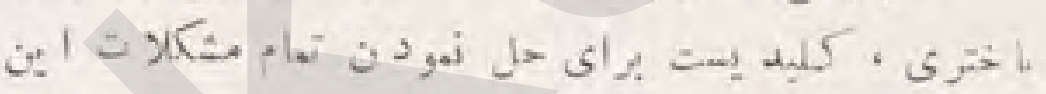

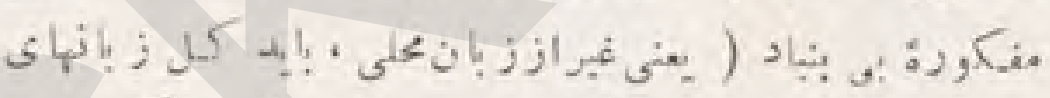

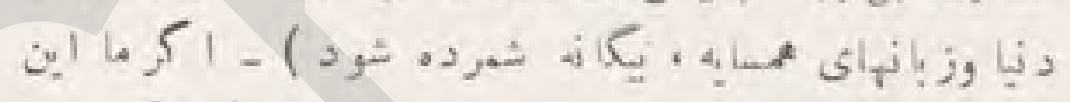

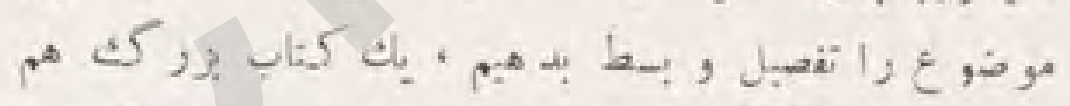

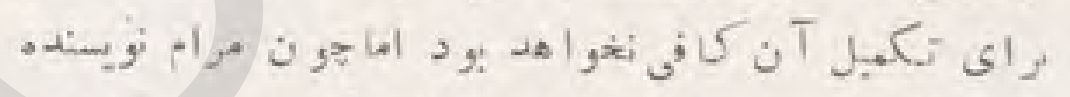

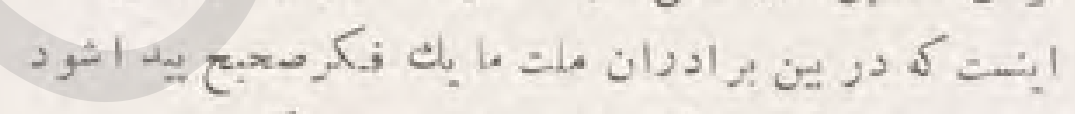

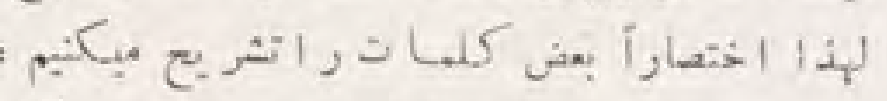

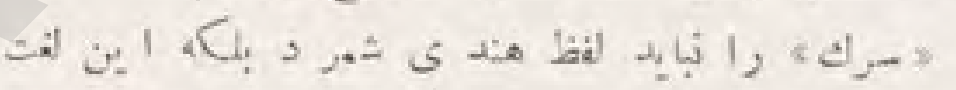

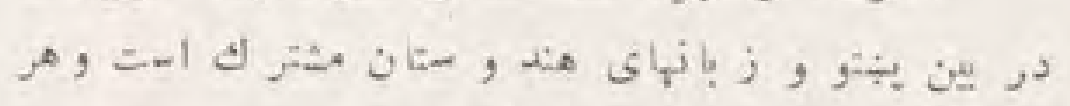
Tا

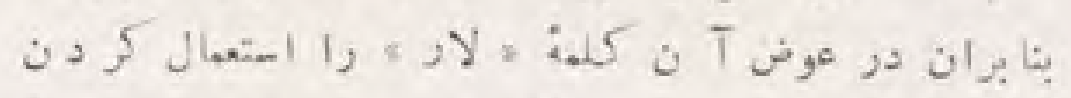

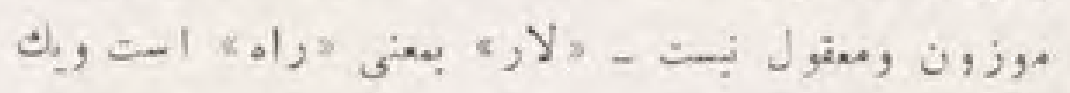

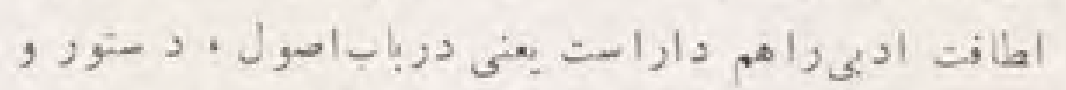

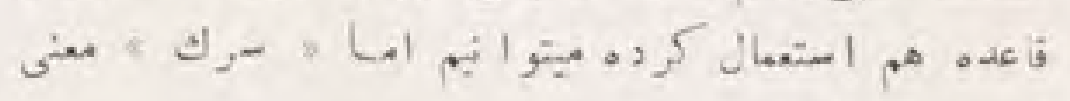

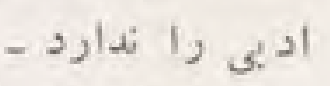

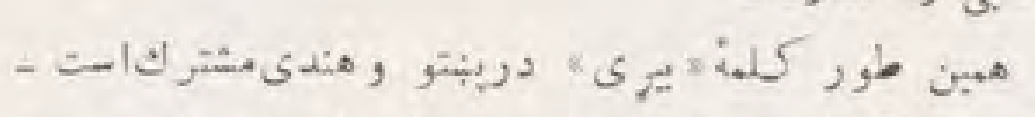

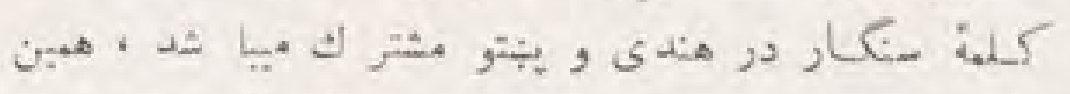

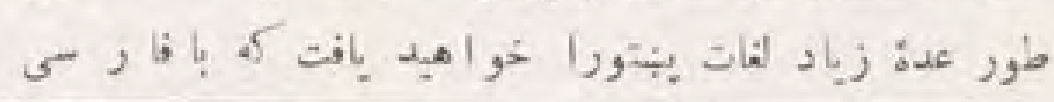

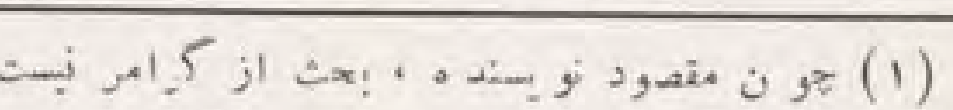

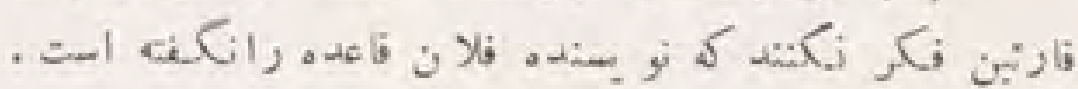




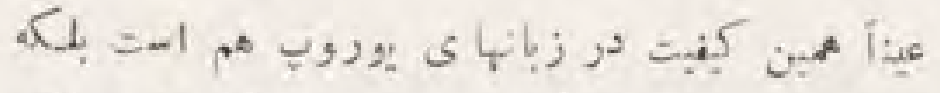

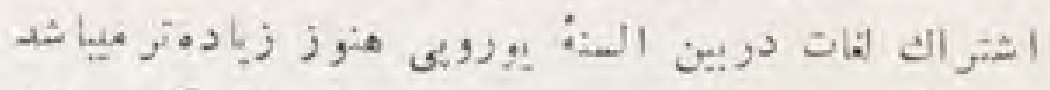

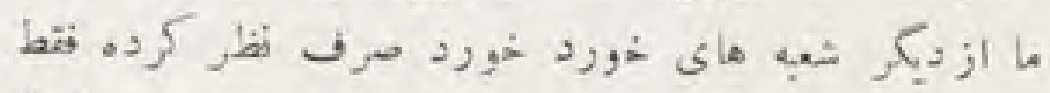

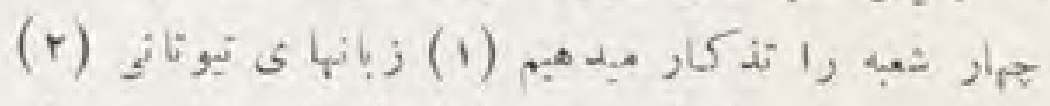

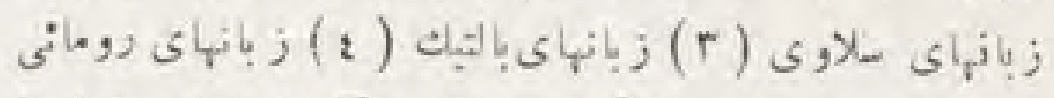

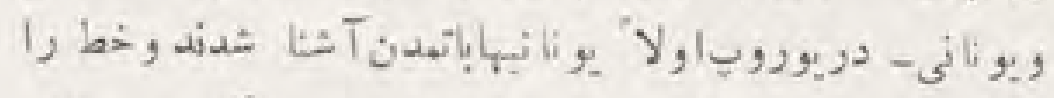

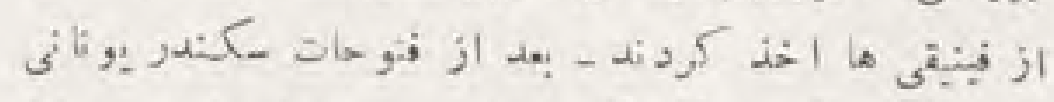

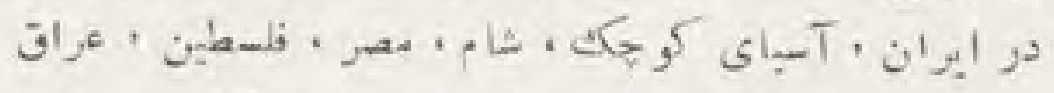

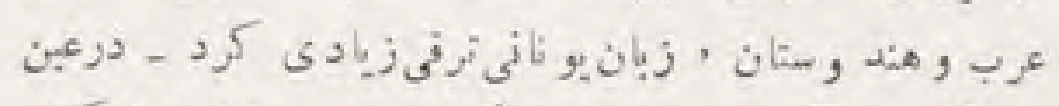

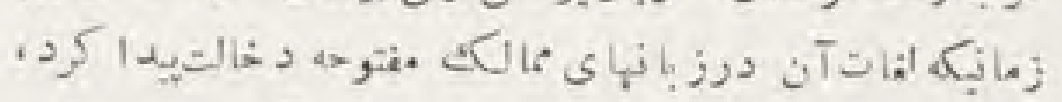

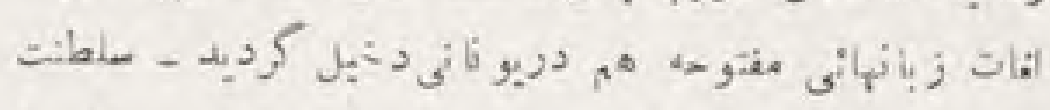

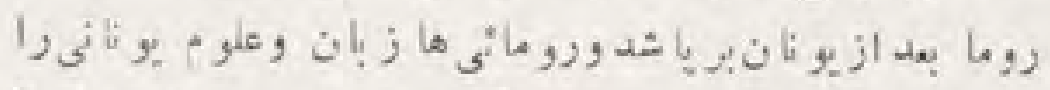

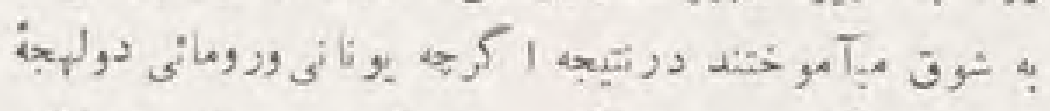

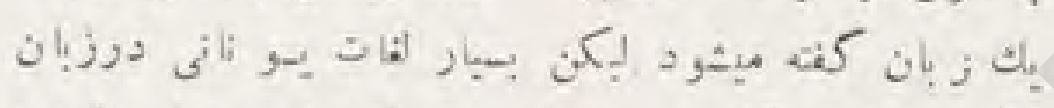

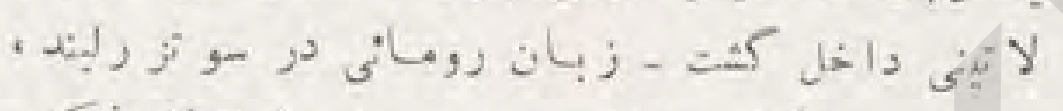

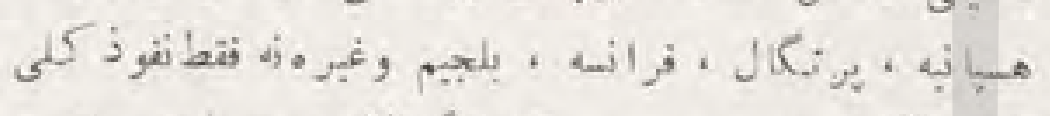

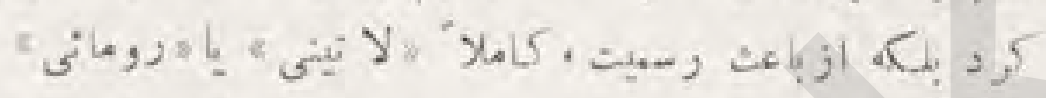

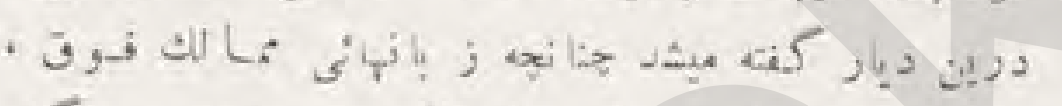

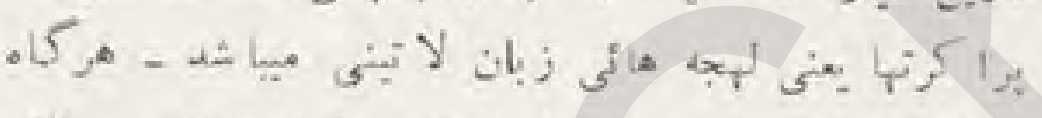

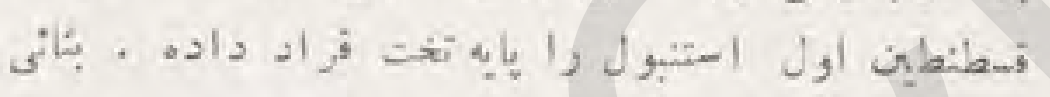

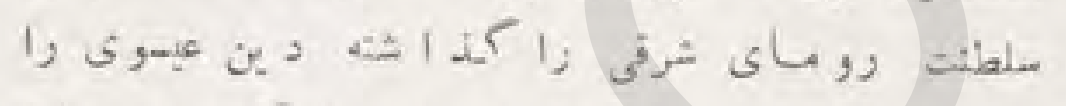

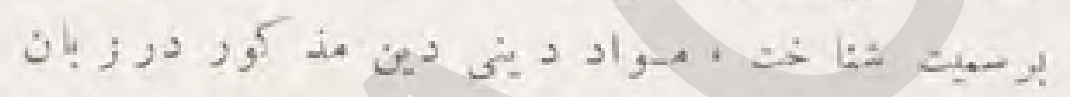

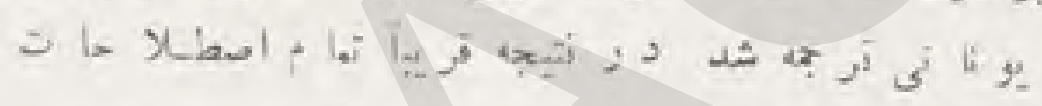

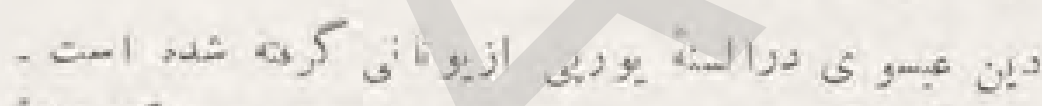

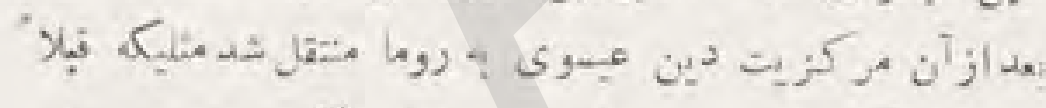

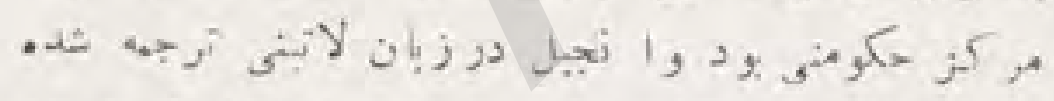

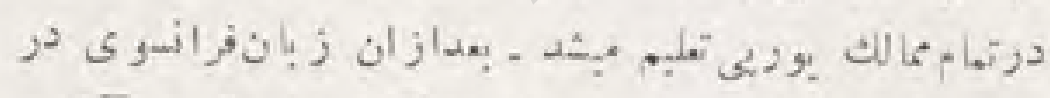

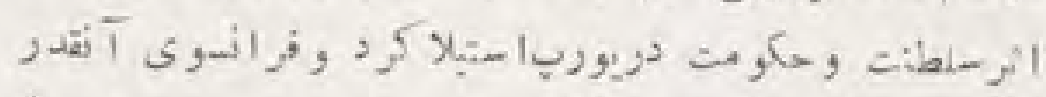

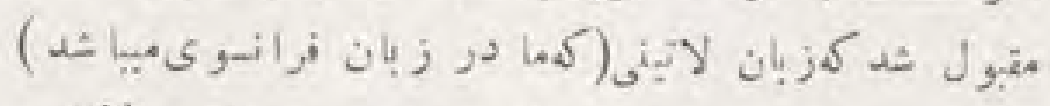

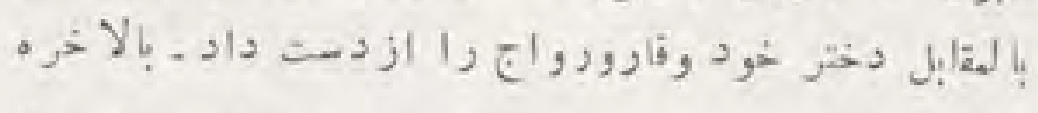

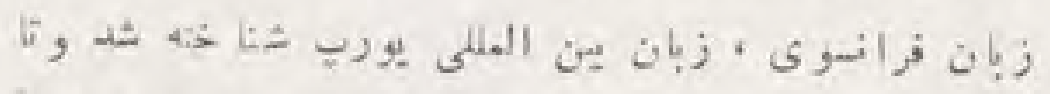

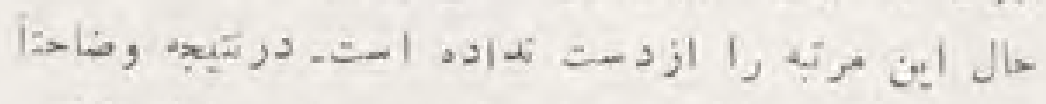

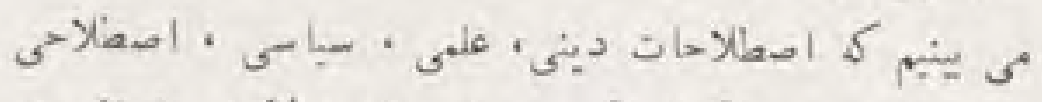

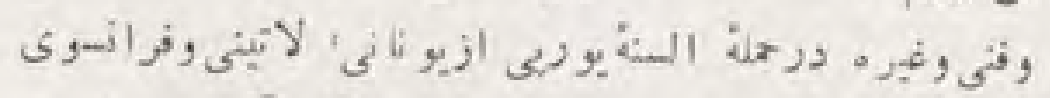

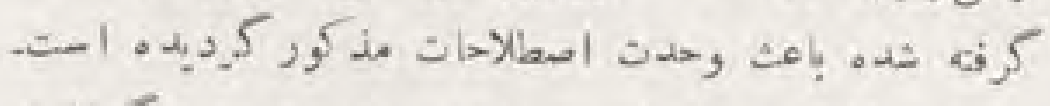

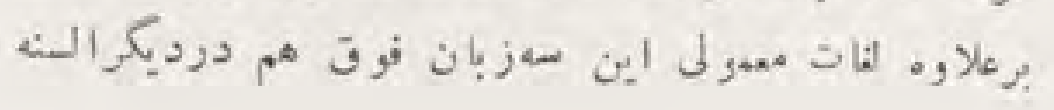

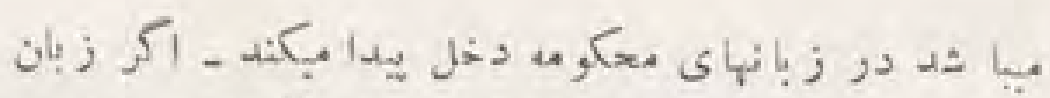

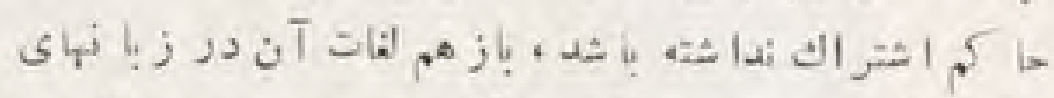

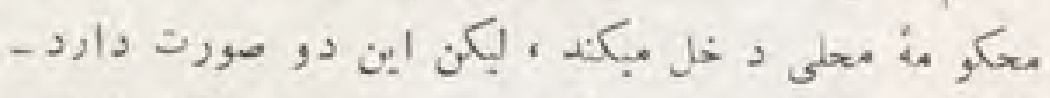

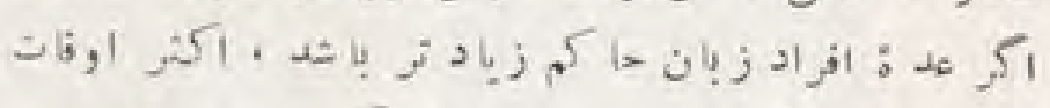

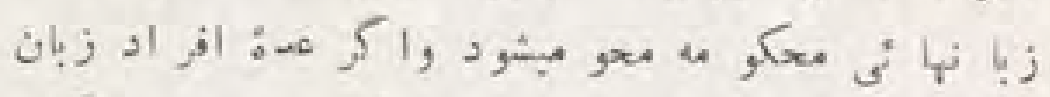

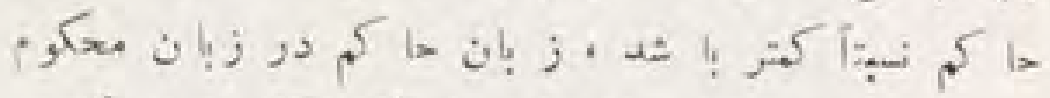

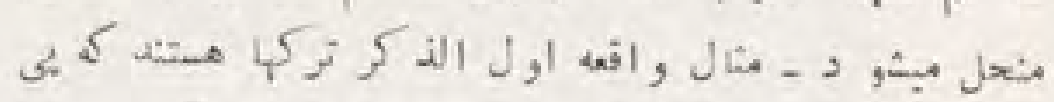

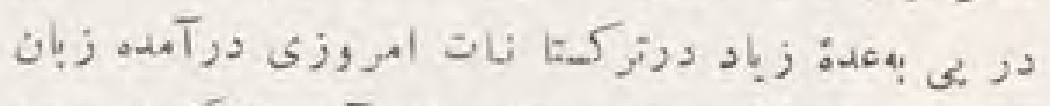

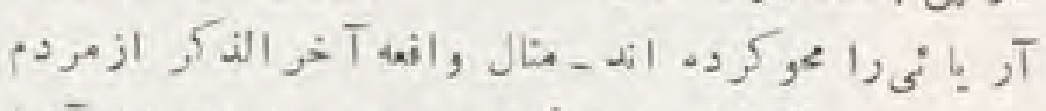

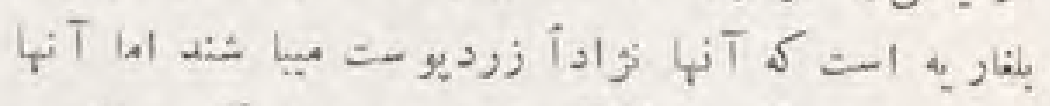

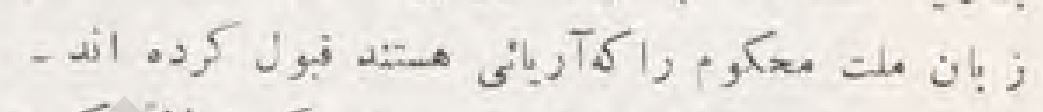

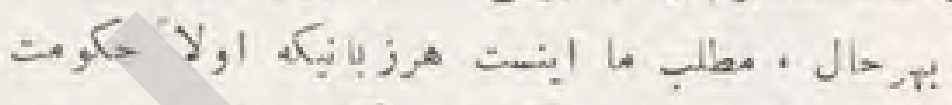

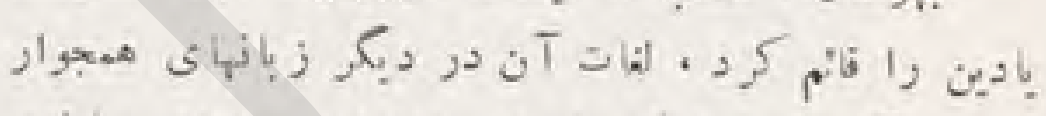

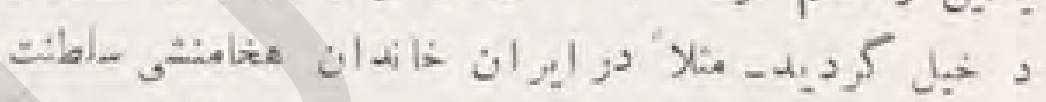

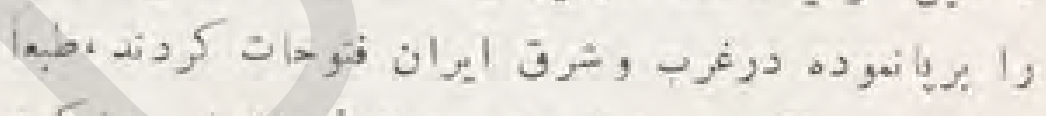

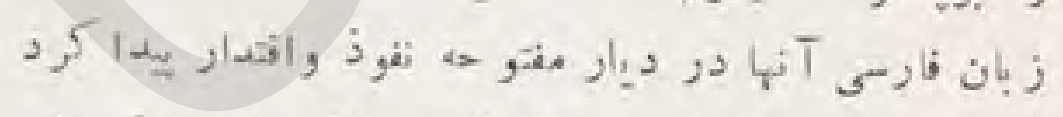

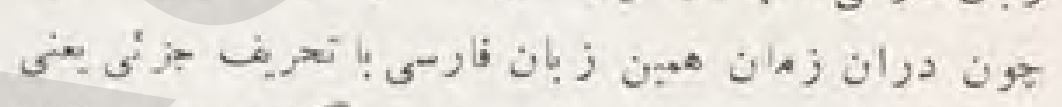

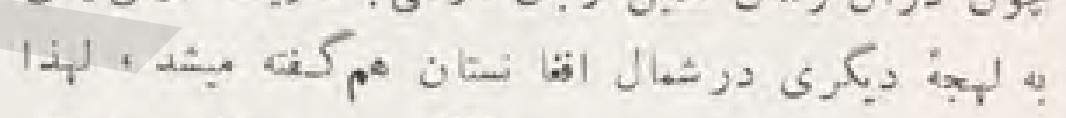

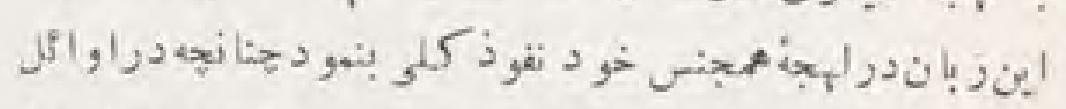

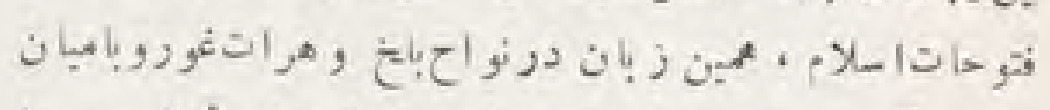

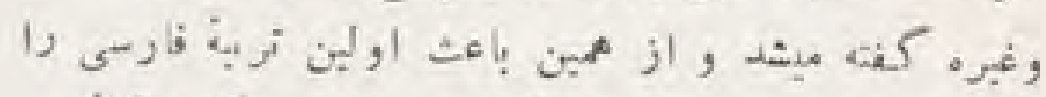

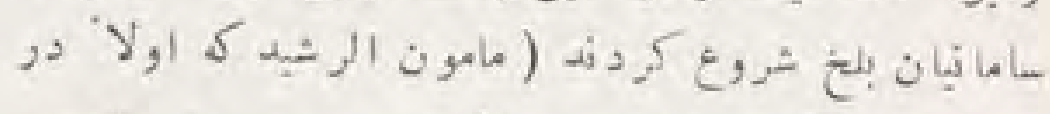

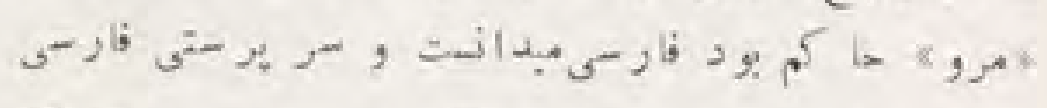

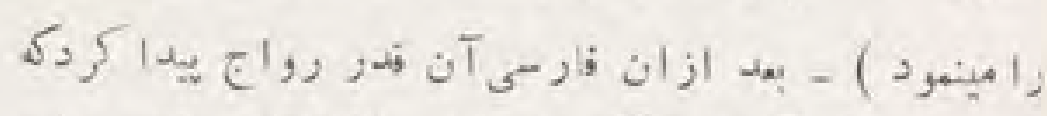

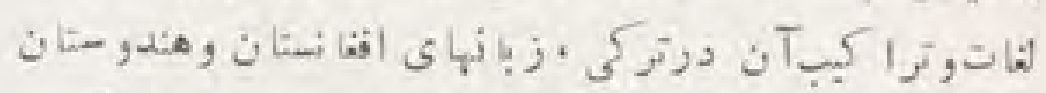

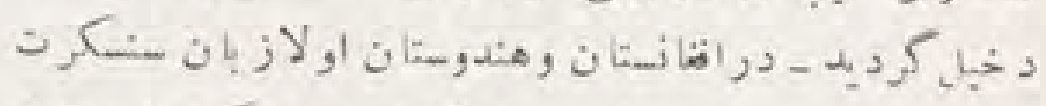

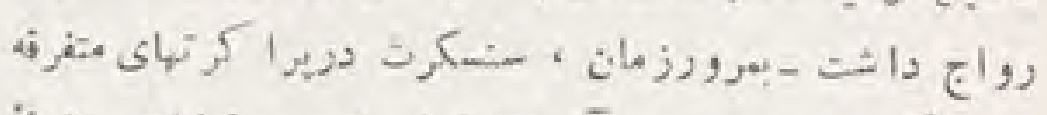

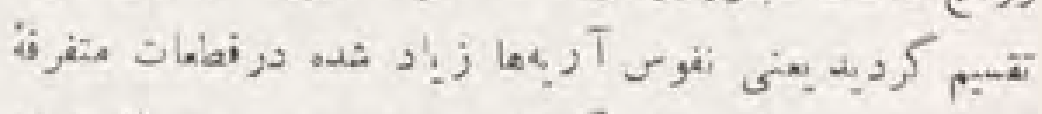

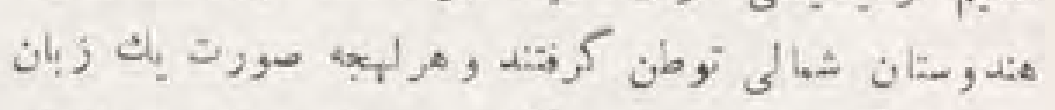

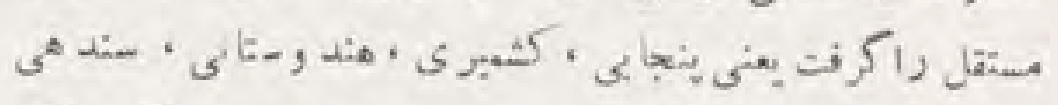

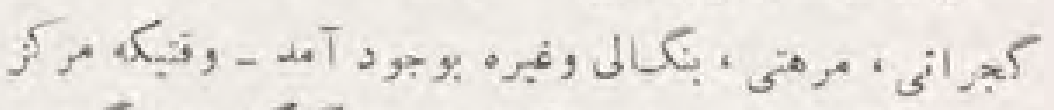

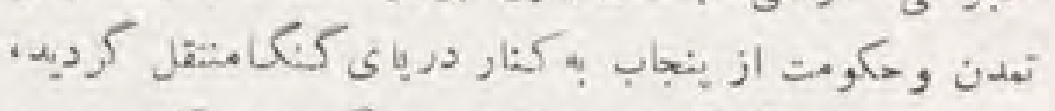

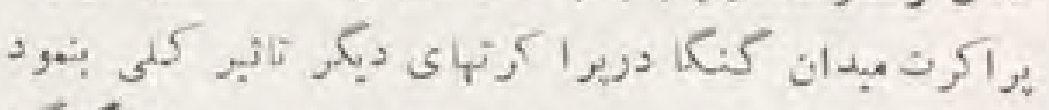

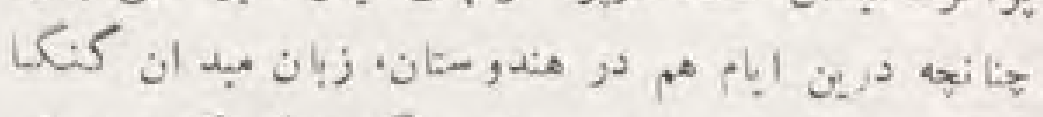

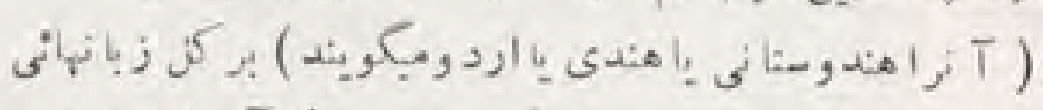

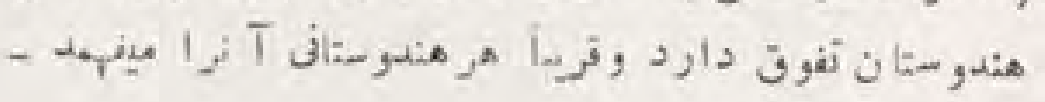




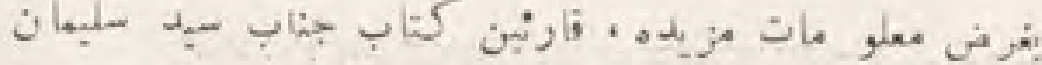

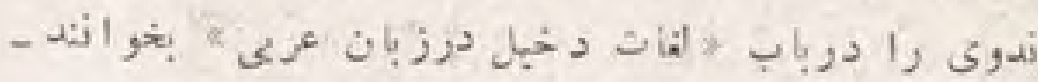

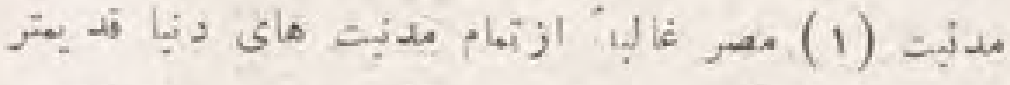

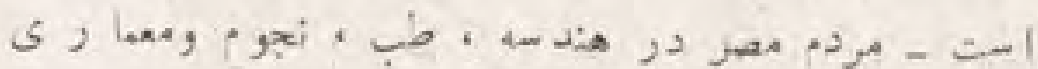

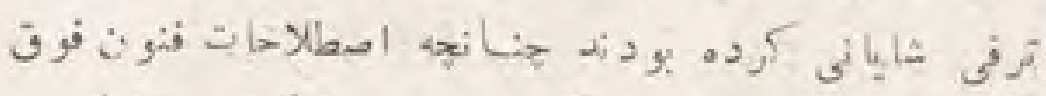

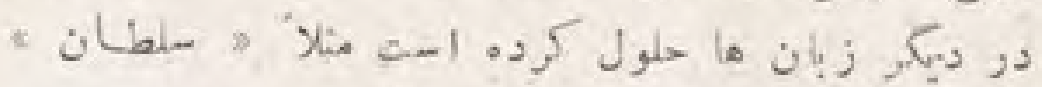

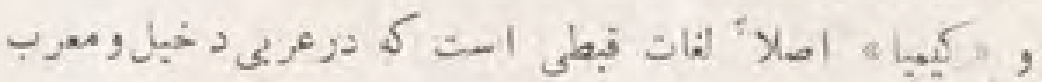
$-=-1 \cdot 1 \cdot 4$

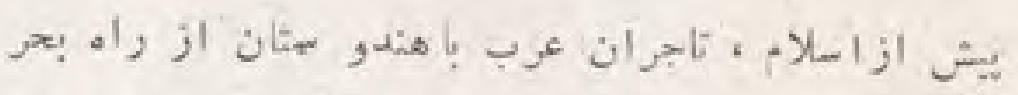

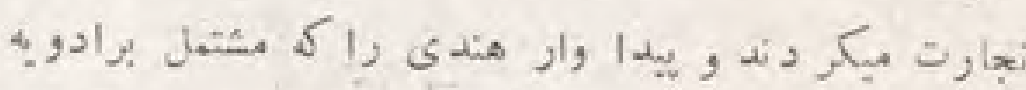

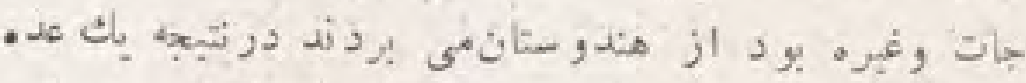

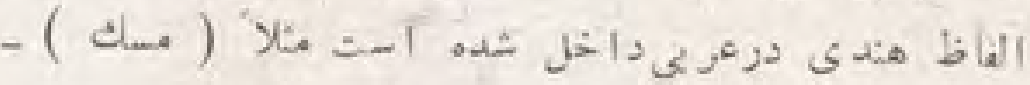

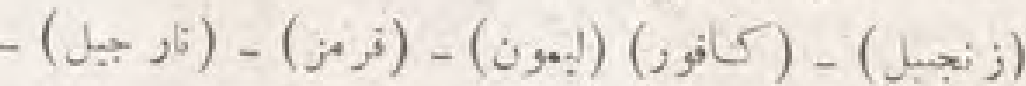

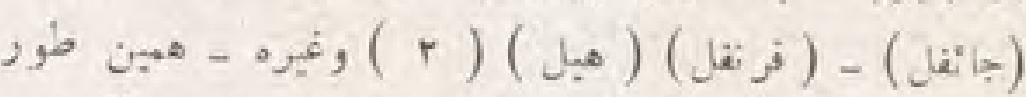

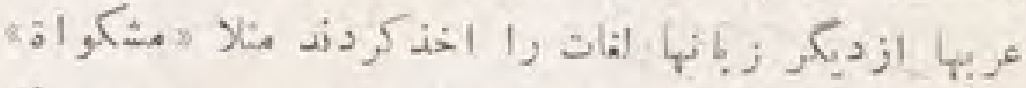

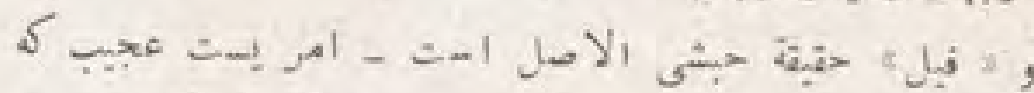

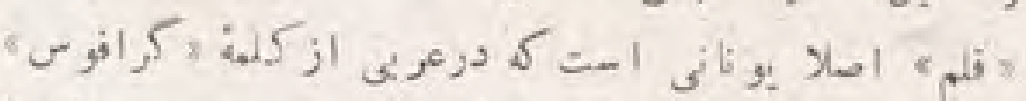

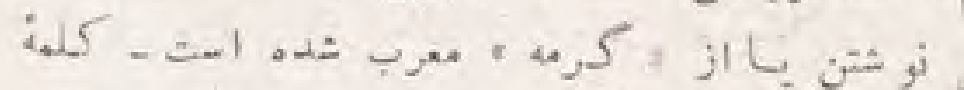

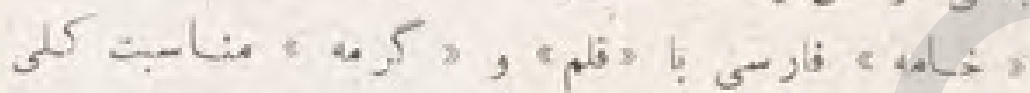

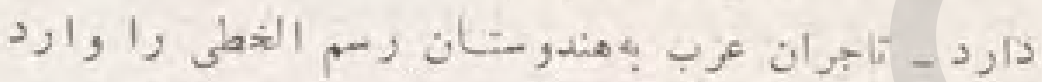

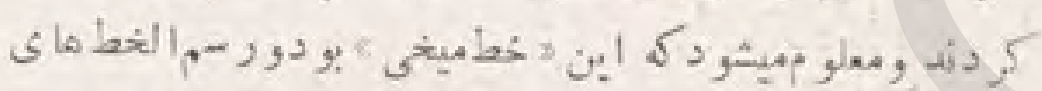

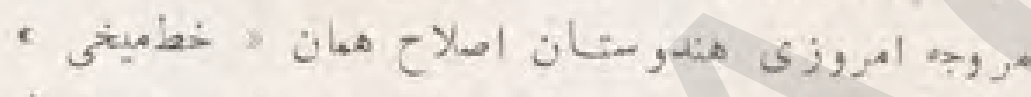

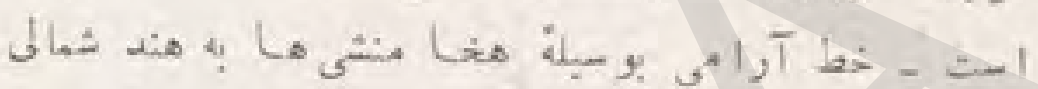

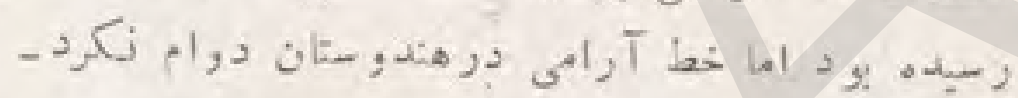

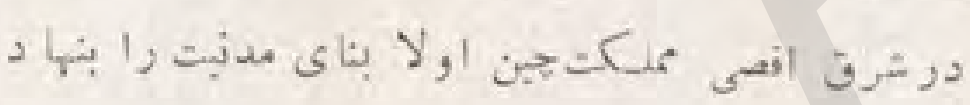

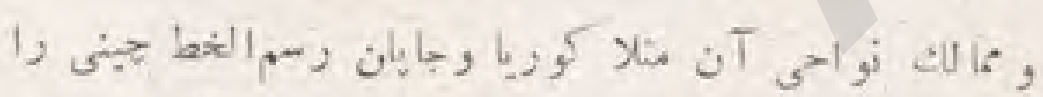

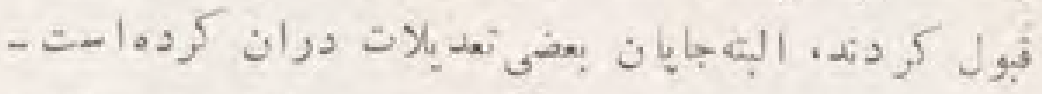

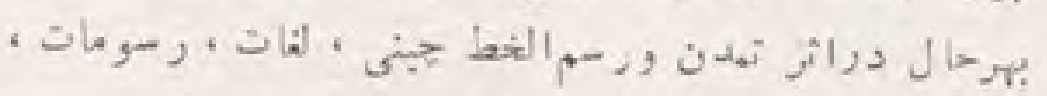

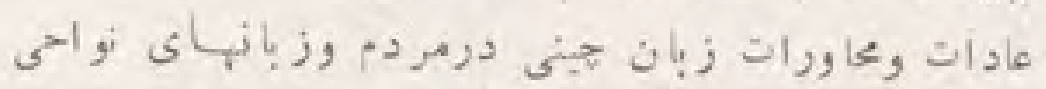

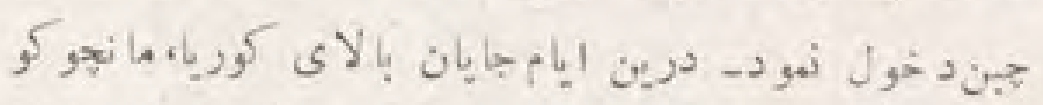

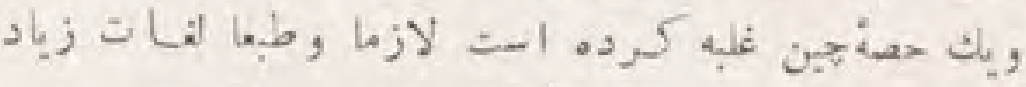

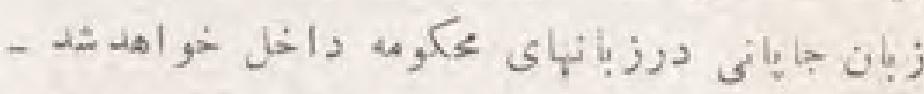

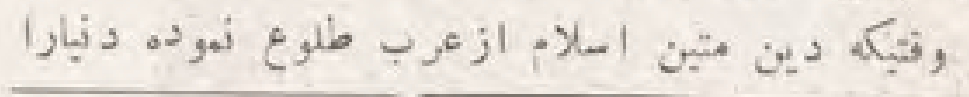

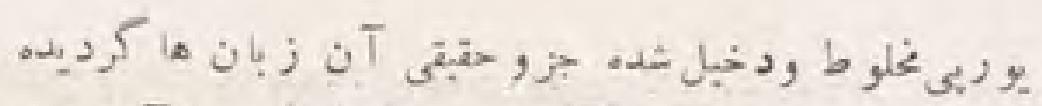

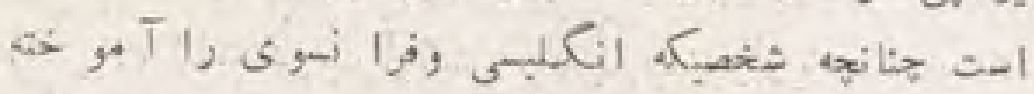

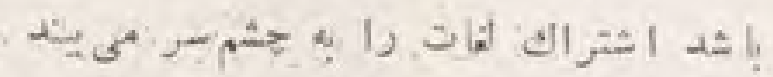

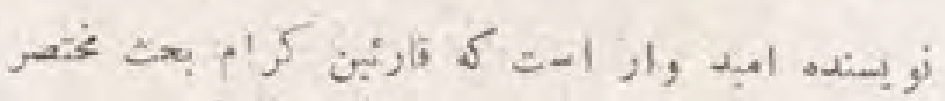

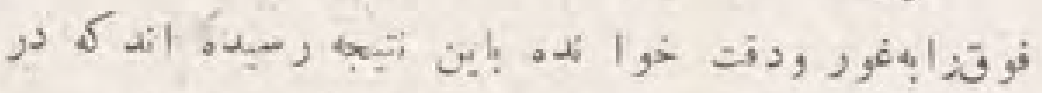

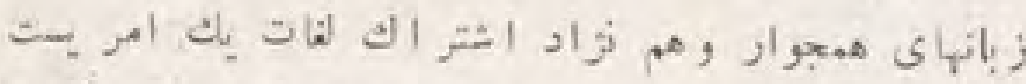

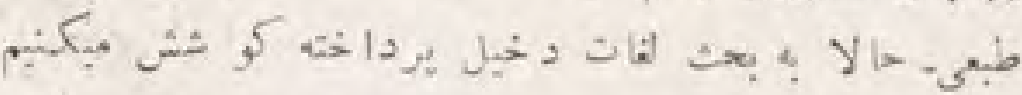

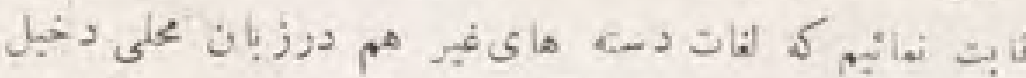

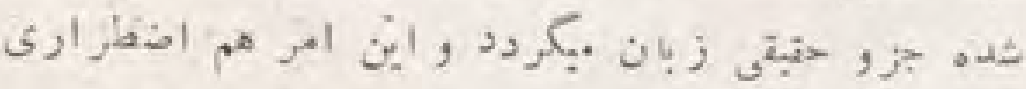

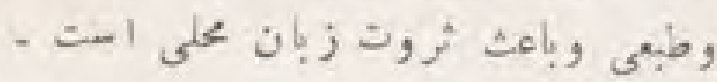

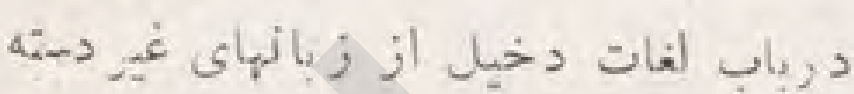

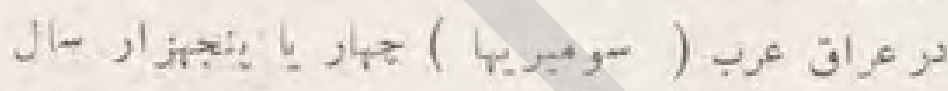

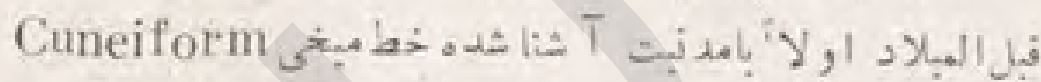

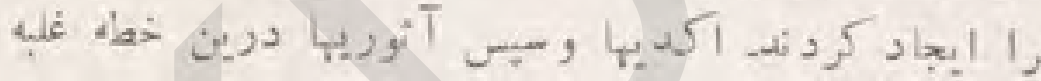

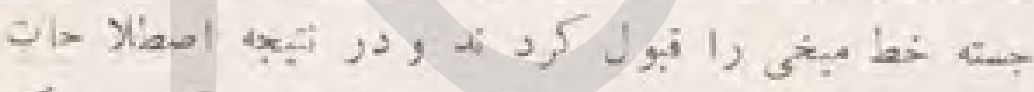

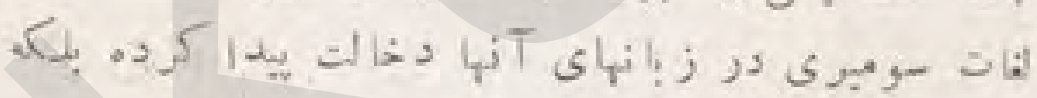

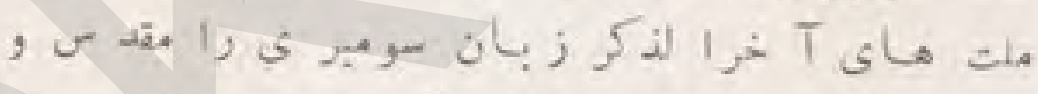

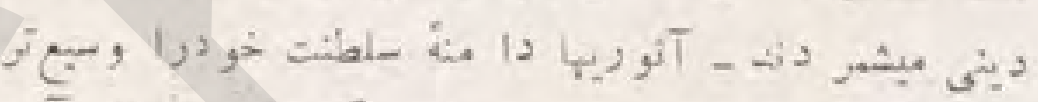

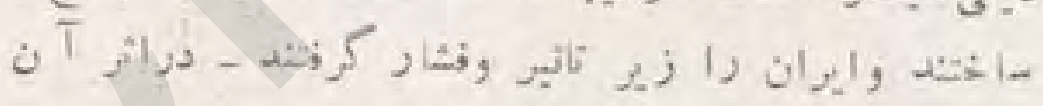

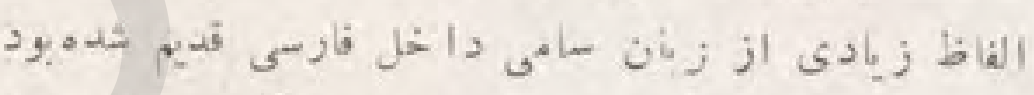

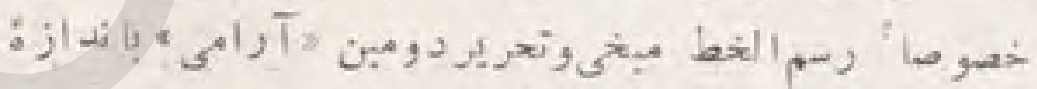

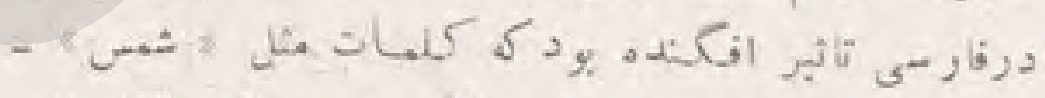

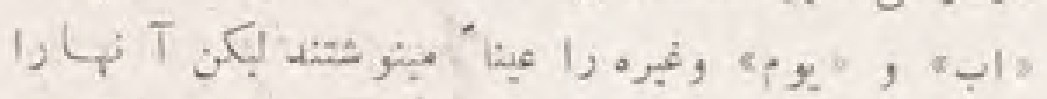

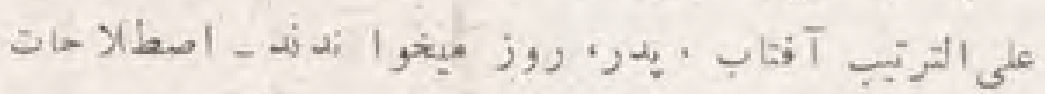

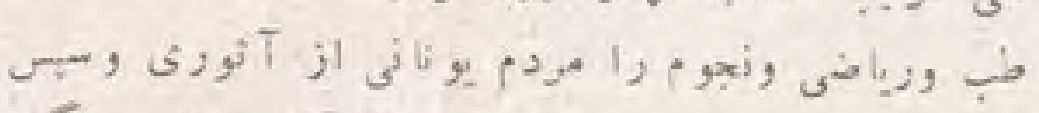

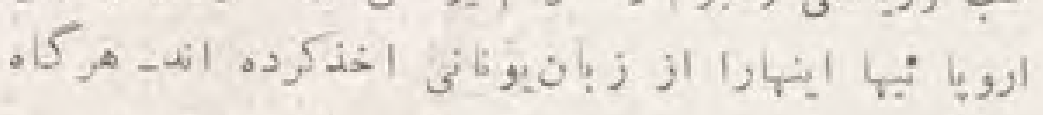

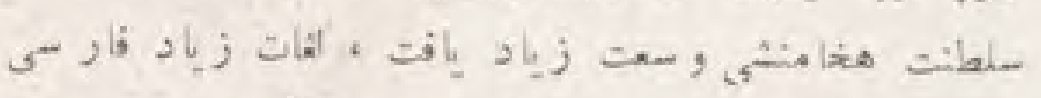

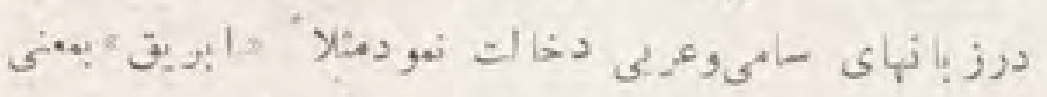

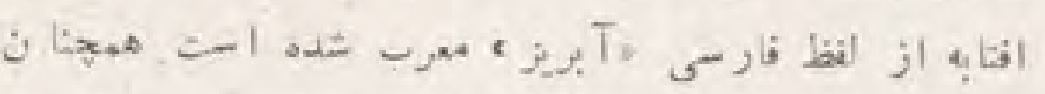

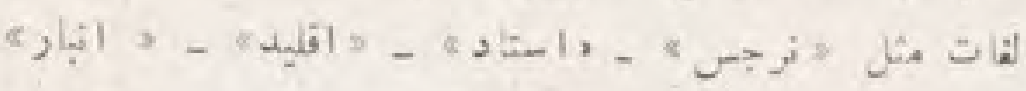

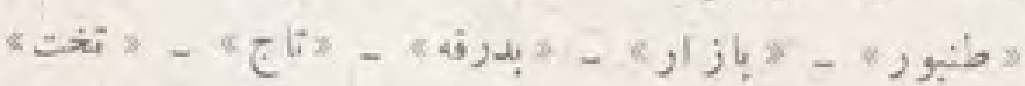

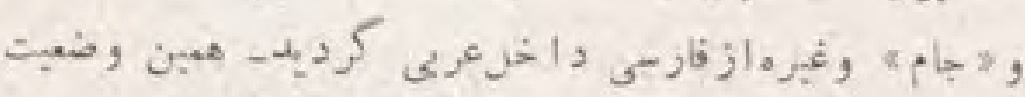

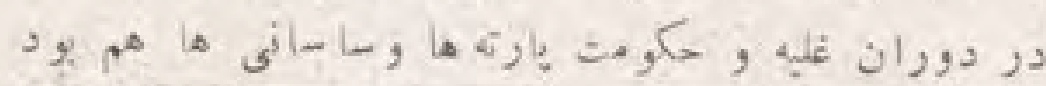

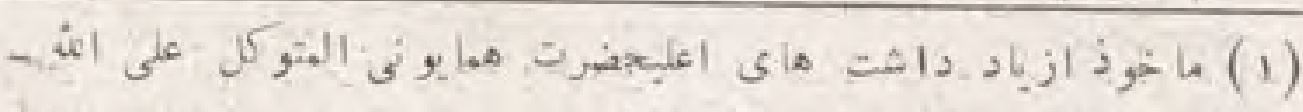

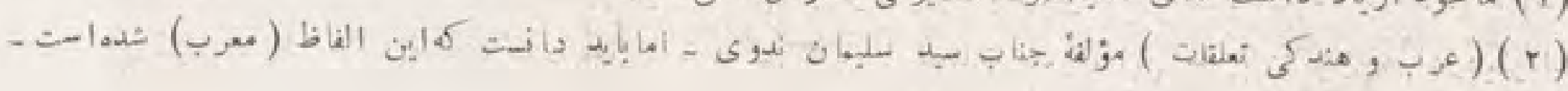




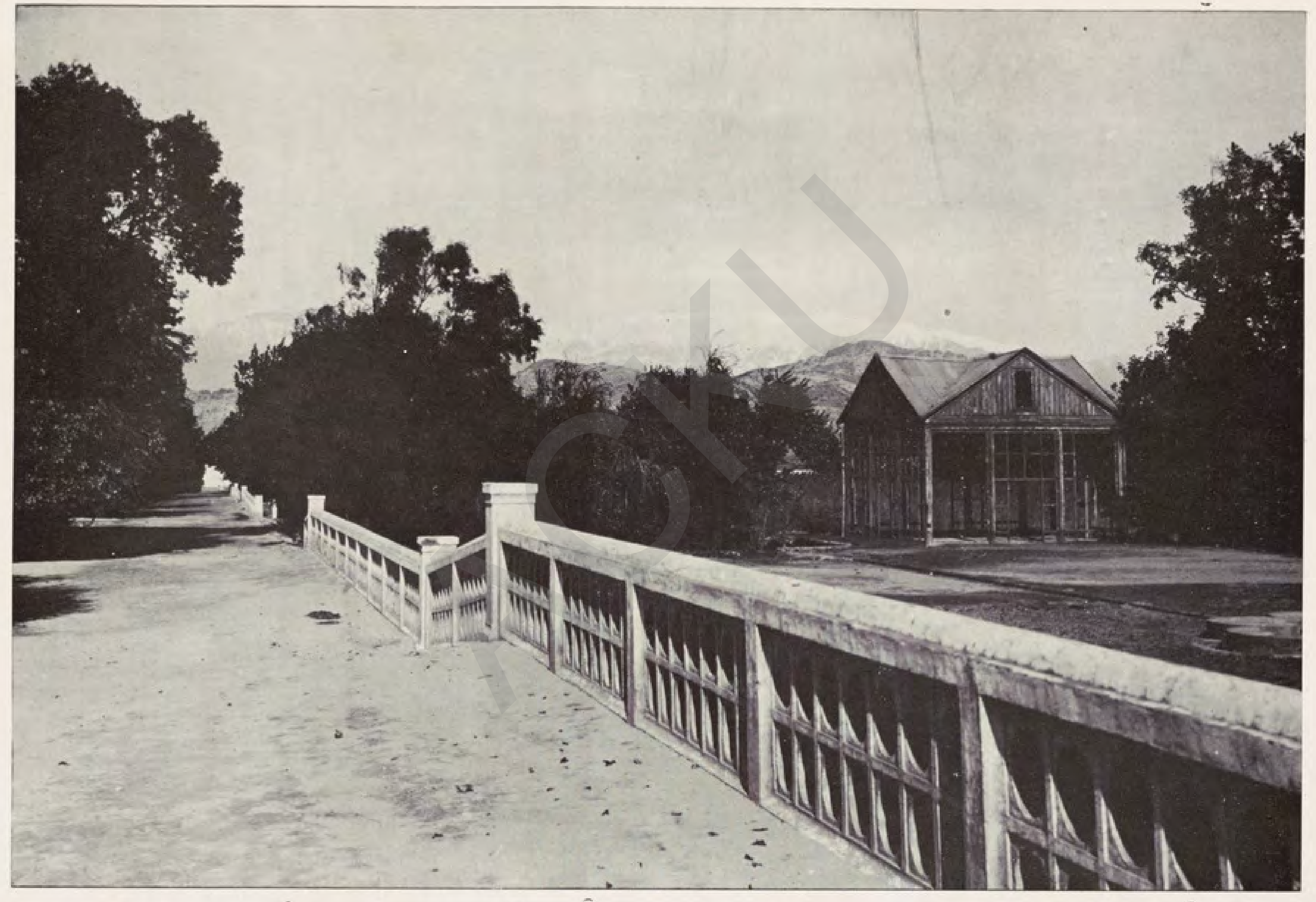

$$
\text { از مناظر سمت مث: قى : - يكى از خيابانهاى باغ ثاهى جلال آ باد }
$$




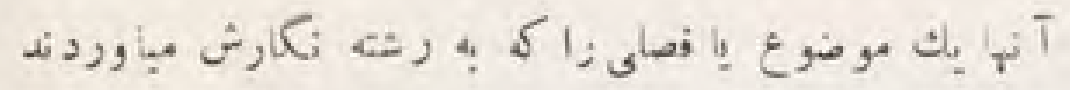

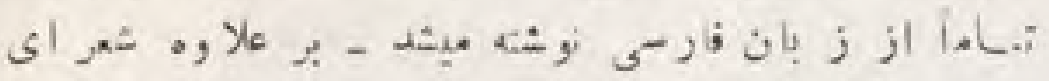

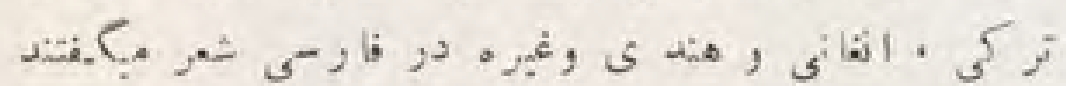

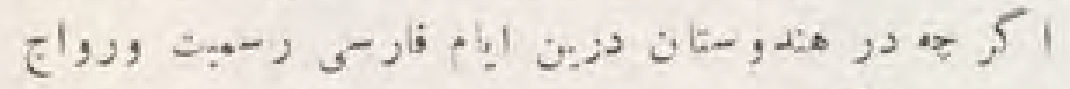

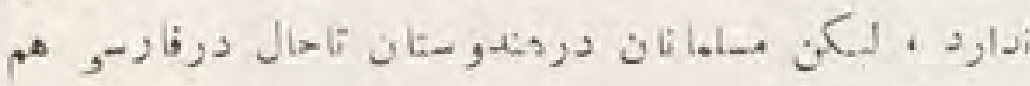

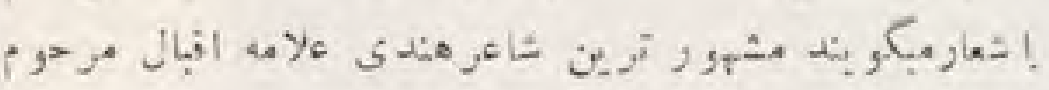

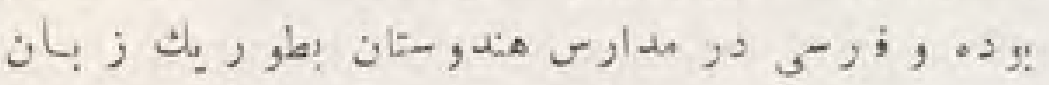

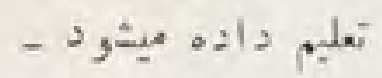

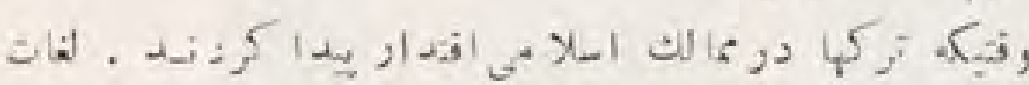

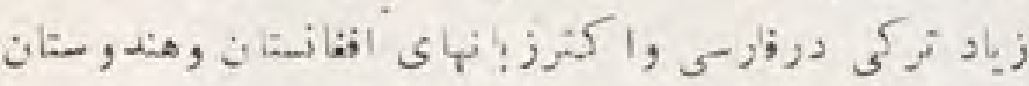

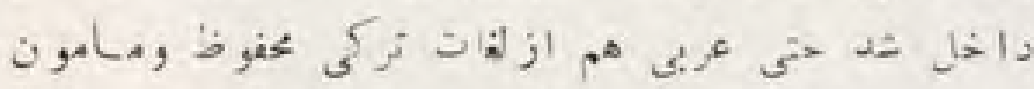

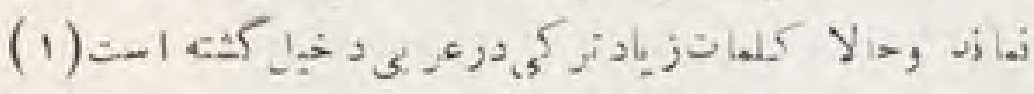

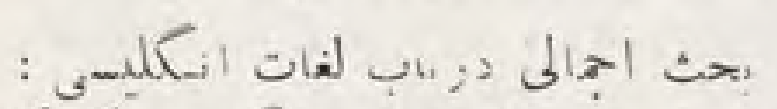

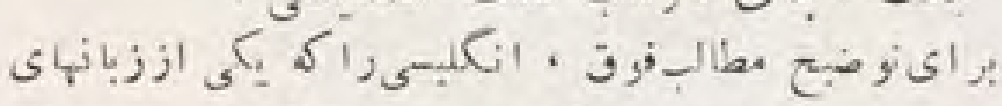

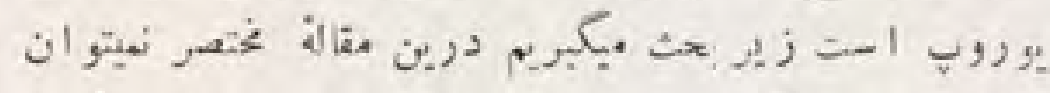

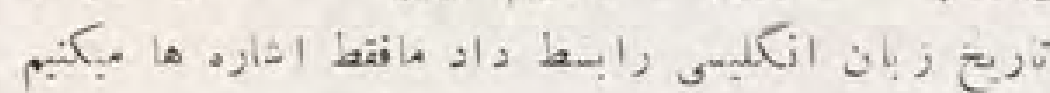

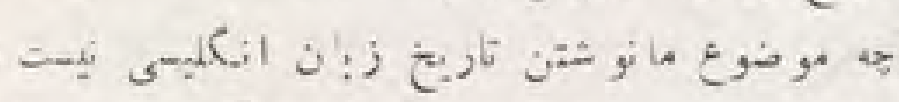

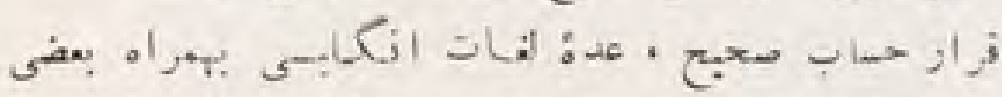

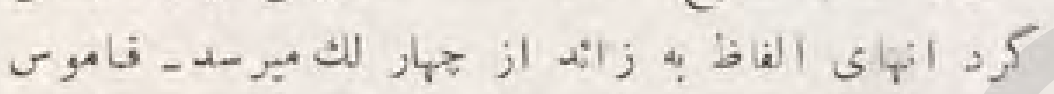

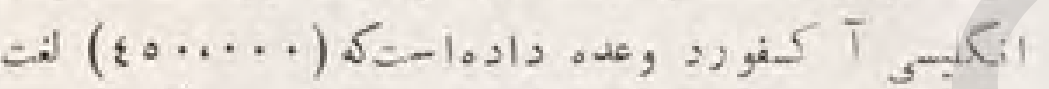

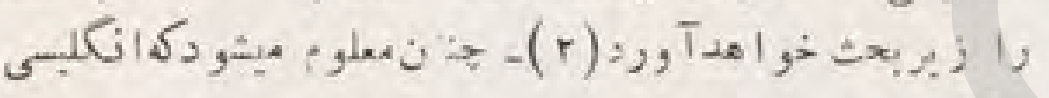

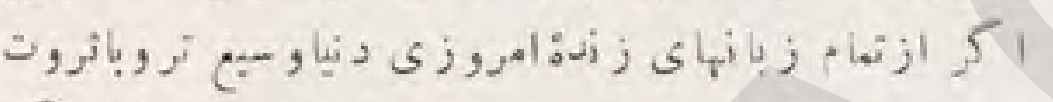

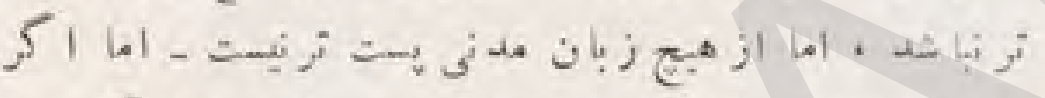

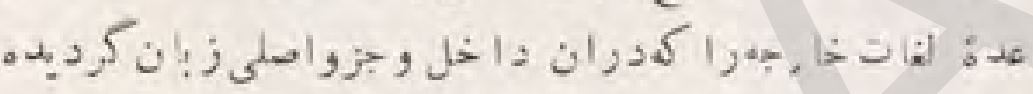

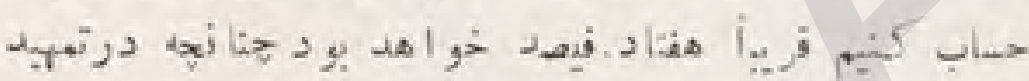

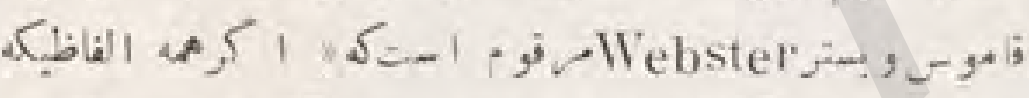

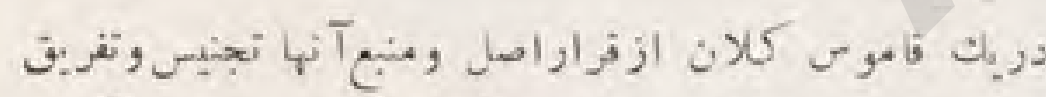

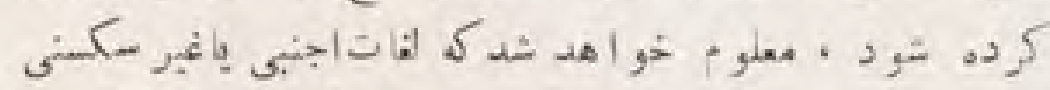
Saxon

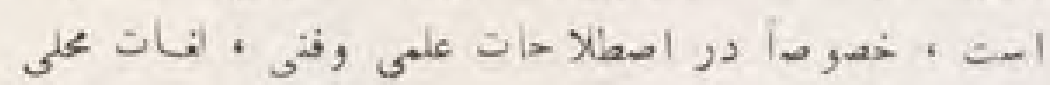

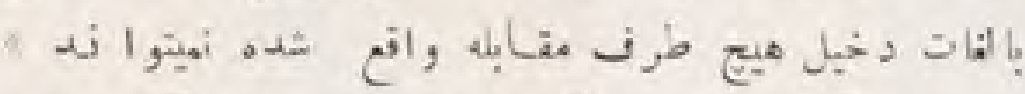

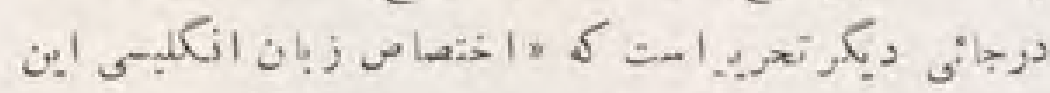

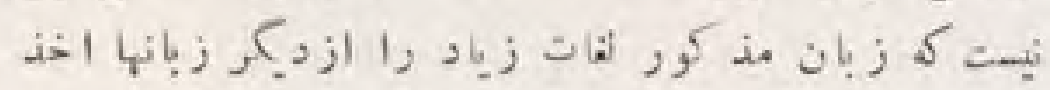

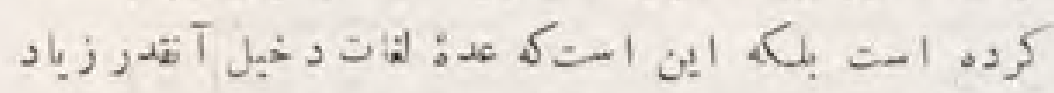
1

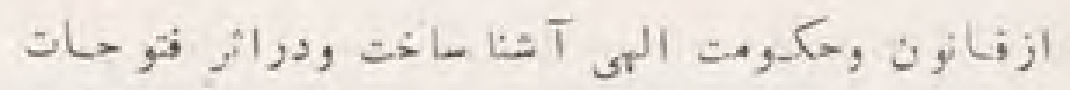

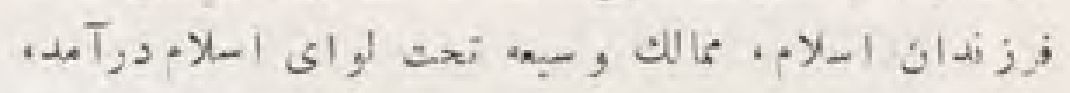

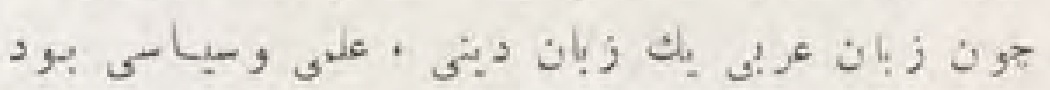

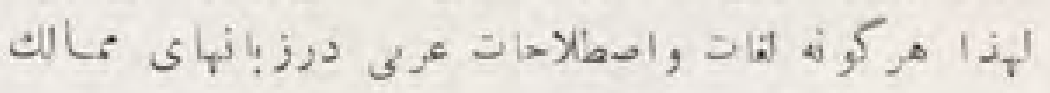

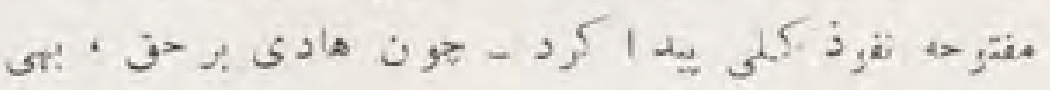

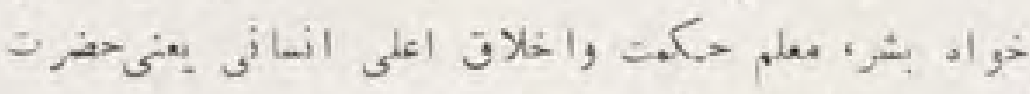

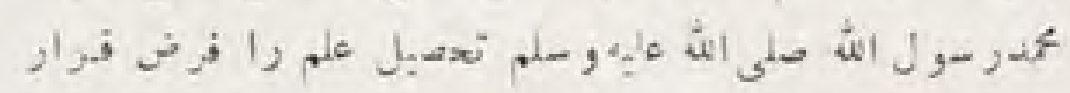

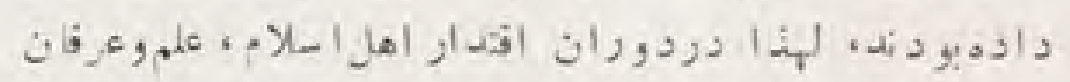

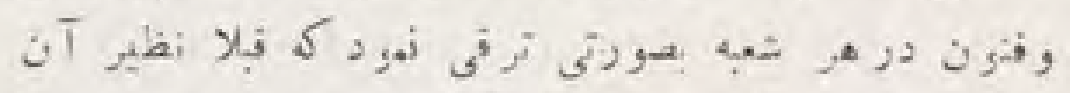

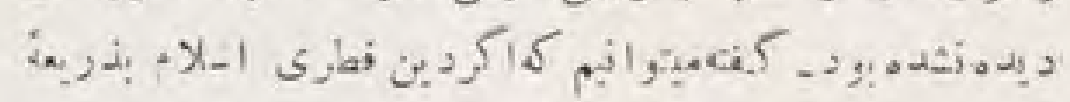

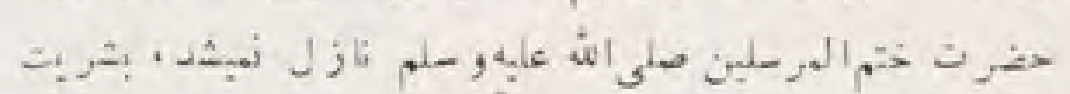

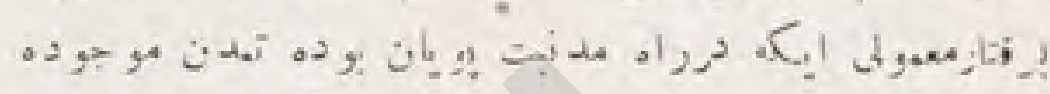

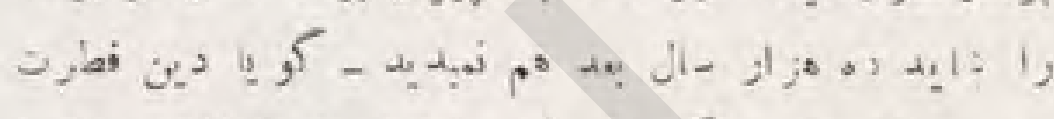

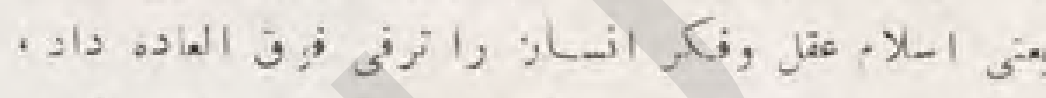

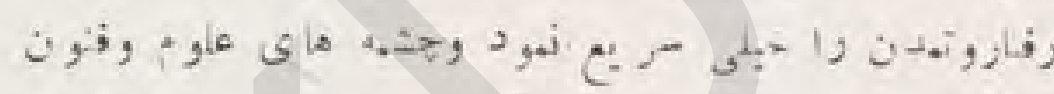

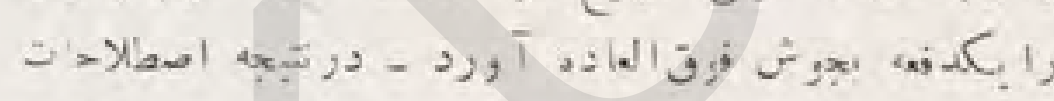

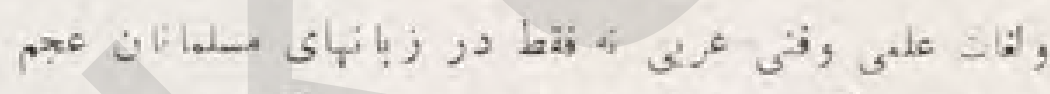

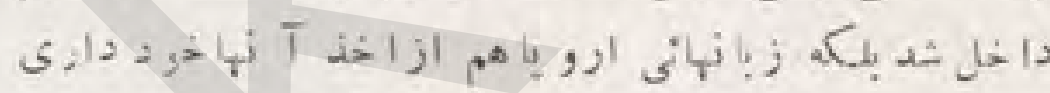

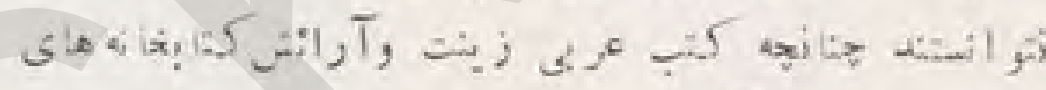

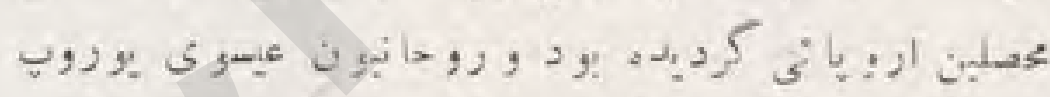

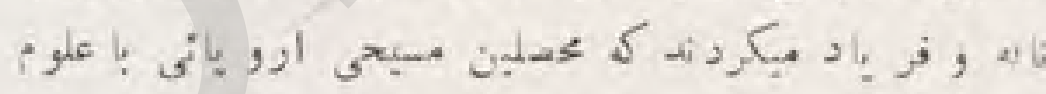

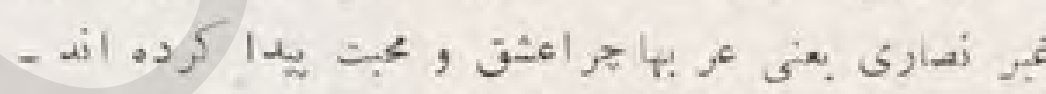

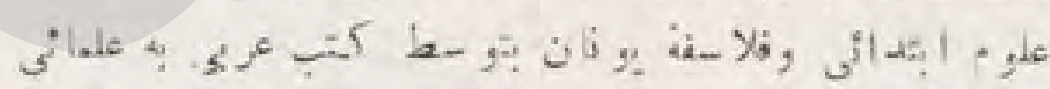

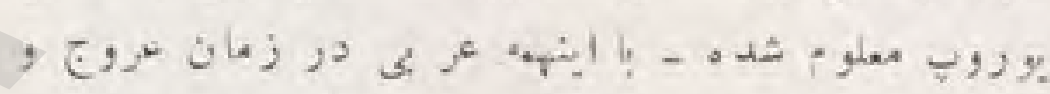

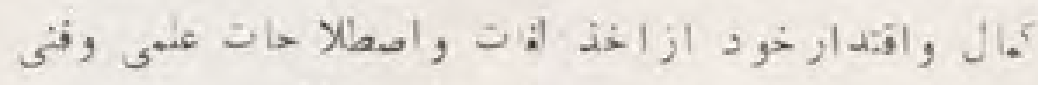

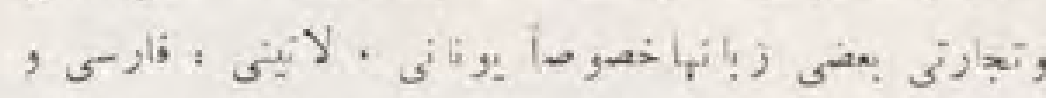

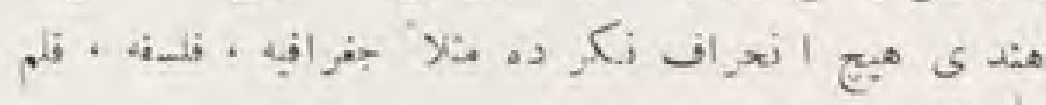

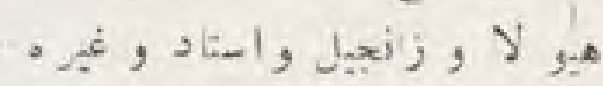

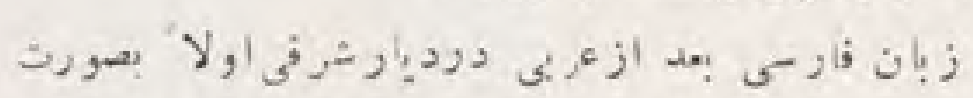

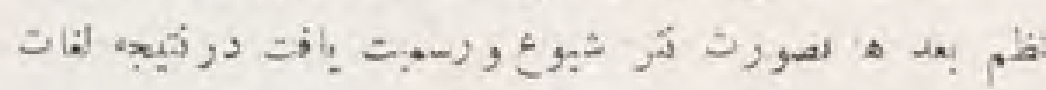
كراك

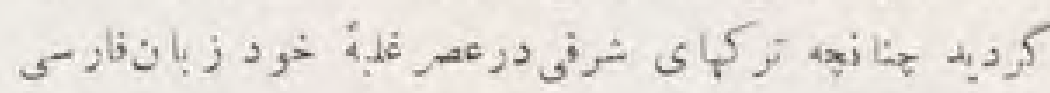

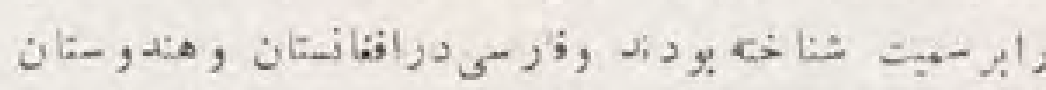

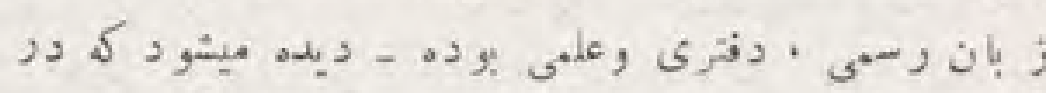

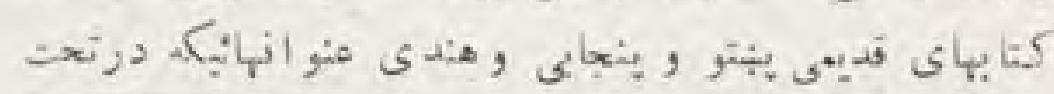

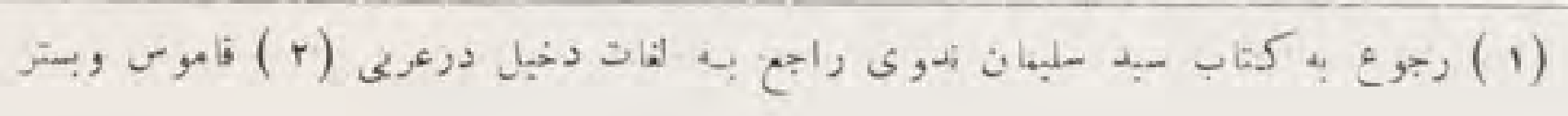




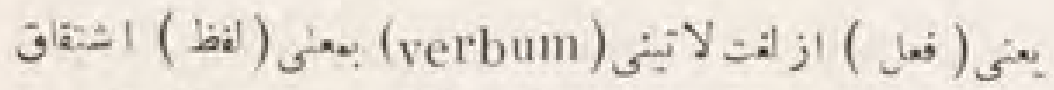

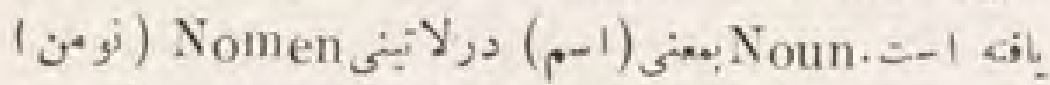

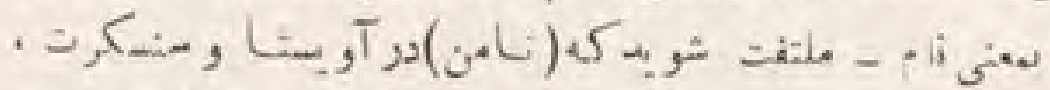

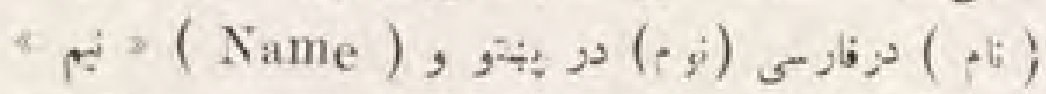

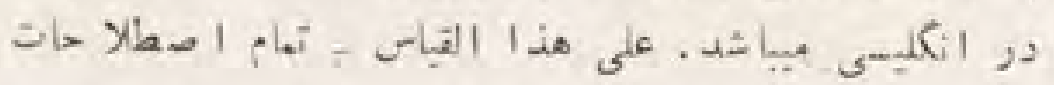

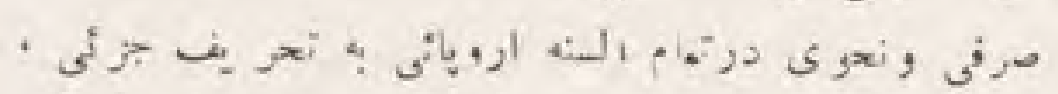

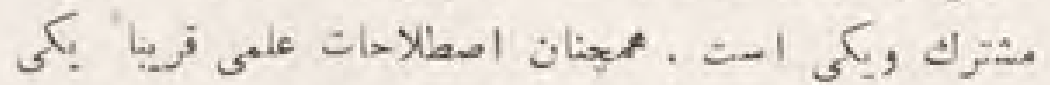
است مثلا 'Philosophy - Asycology _ Zoology Eotany

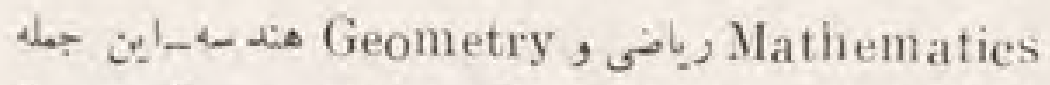

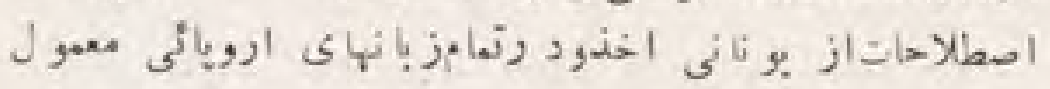

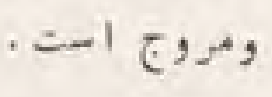

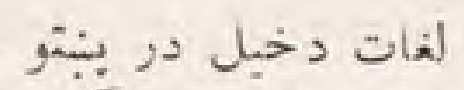

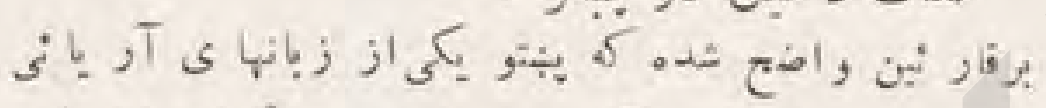

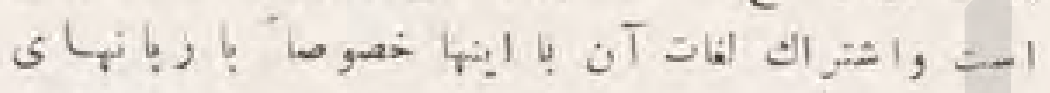

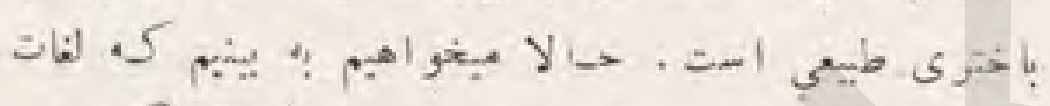

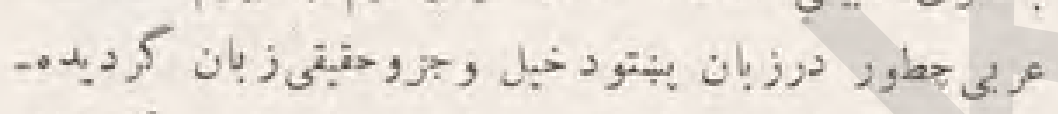

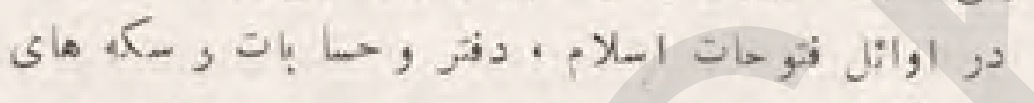

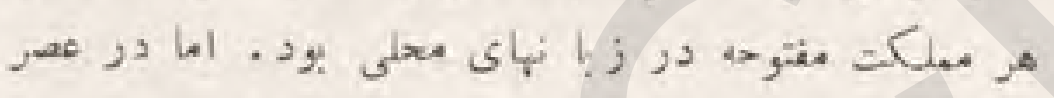

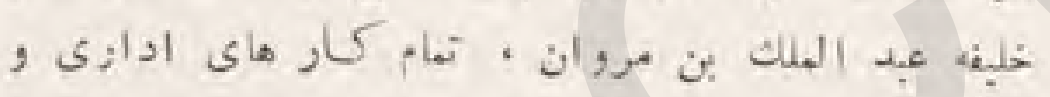

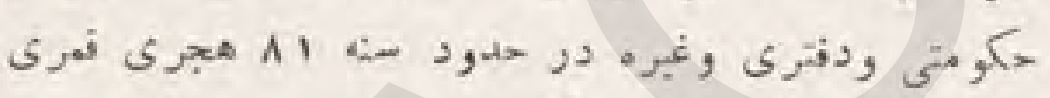

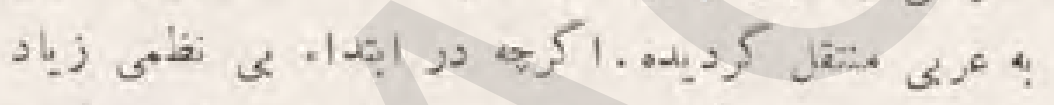

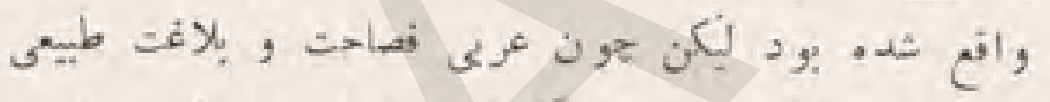

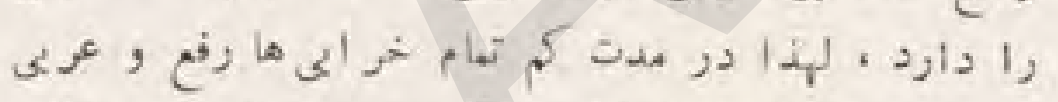

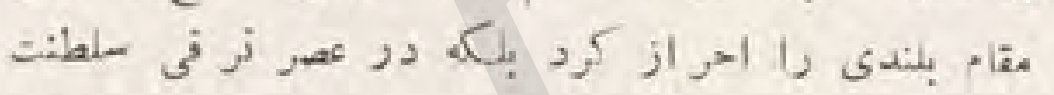

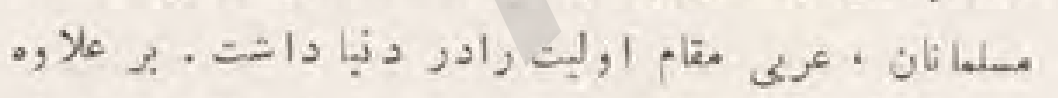

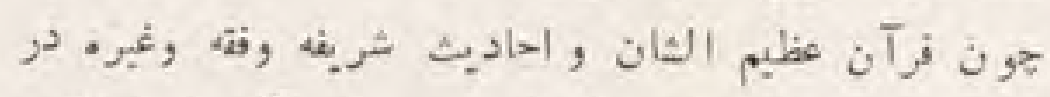

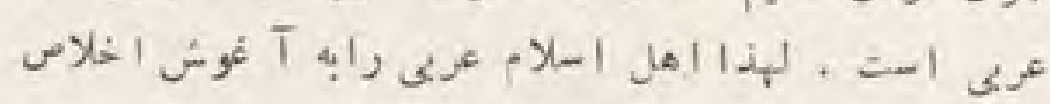

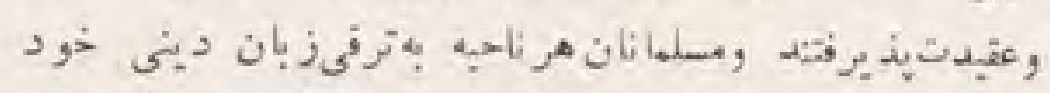

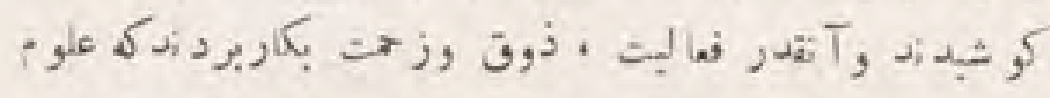

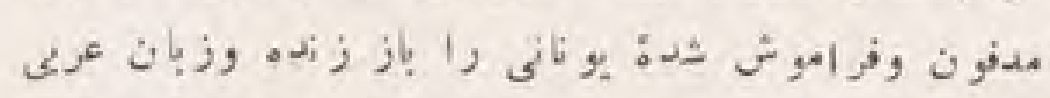

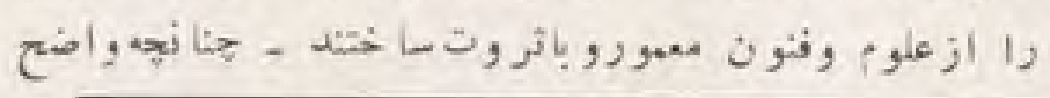

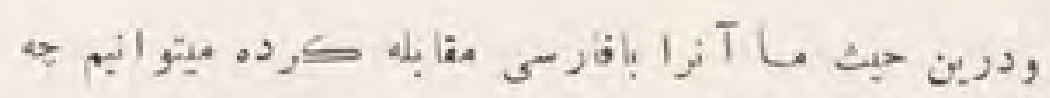

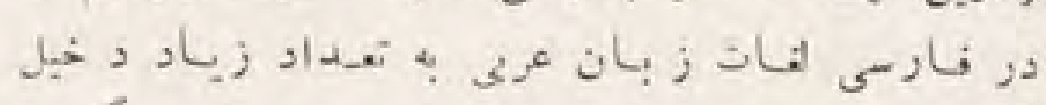

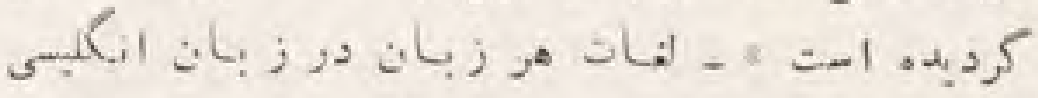

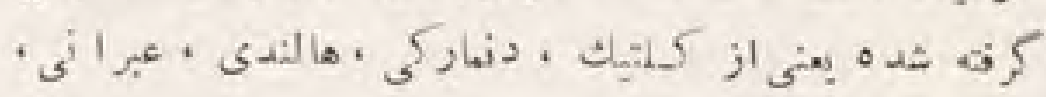

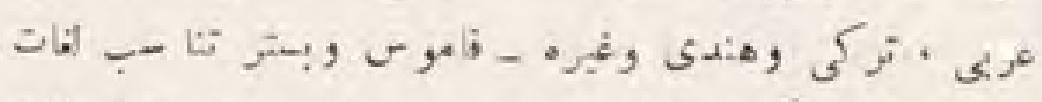

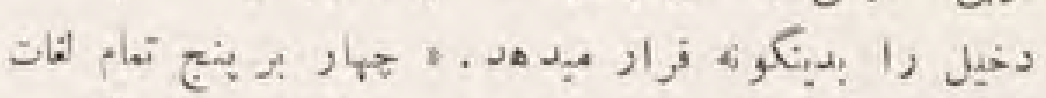

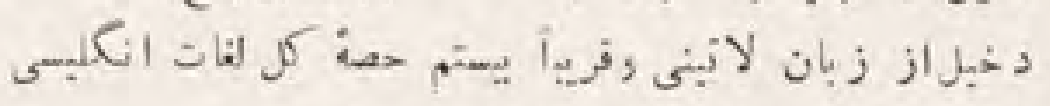

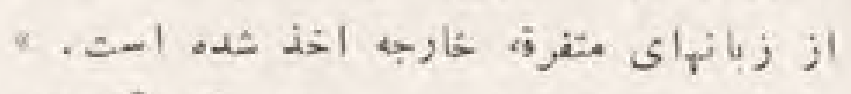

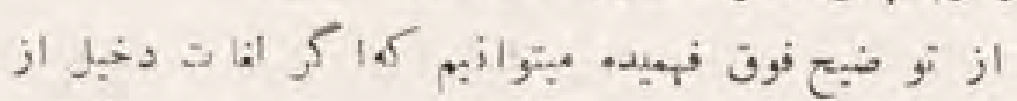

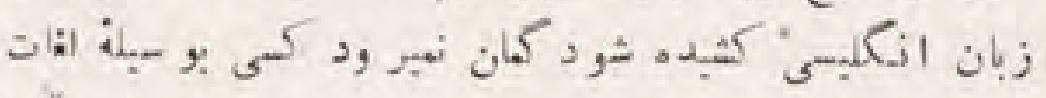

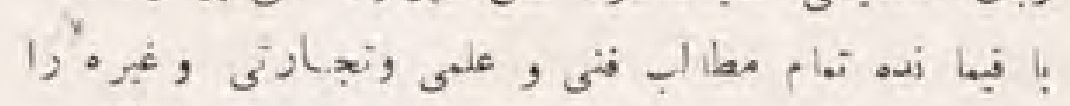

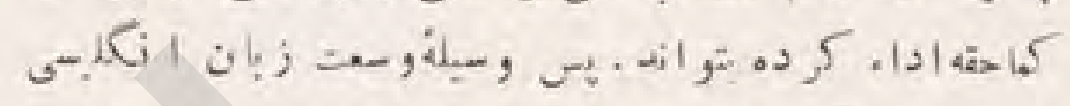

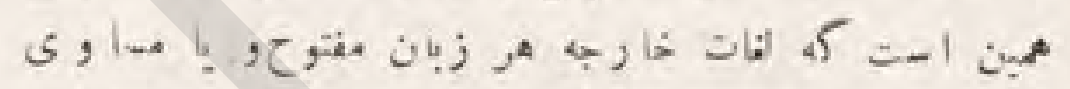

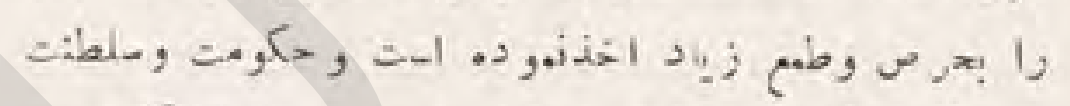

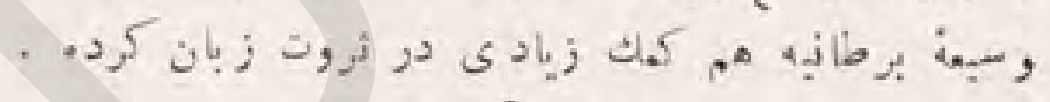

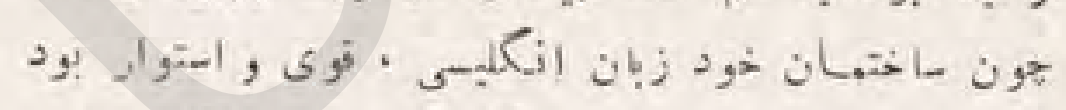

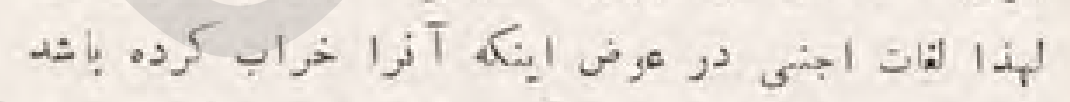

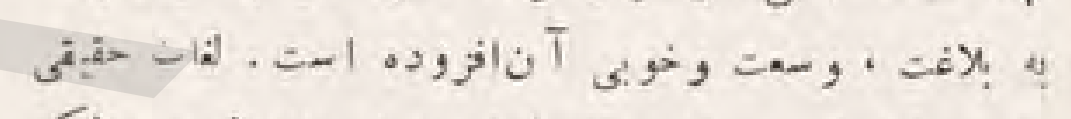

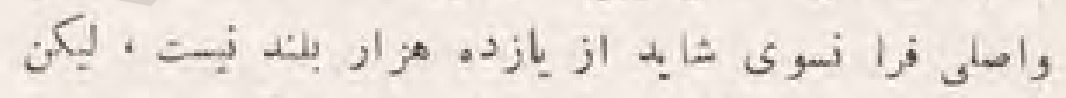

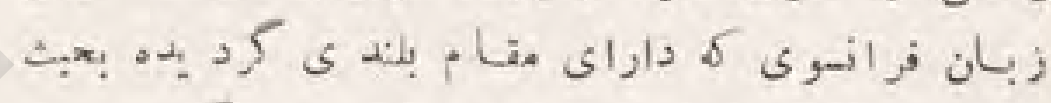

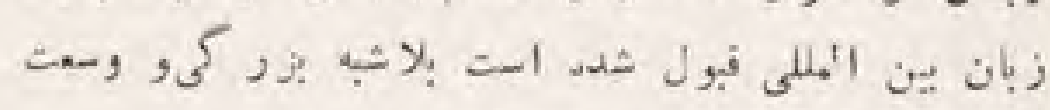

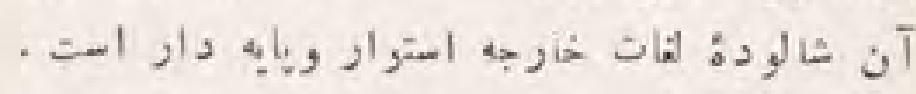

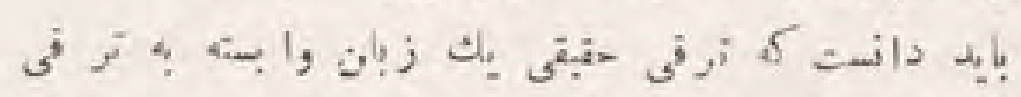

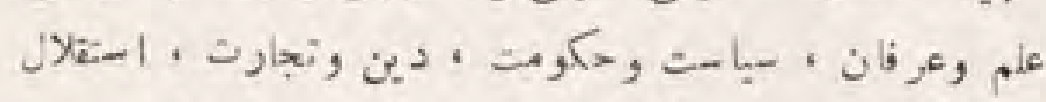

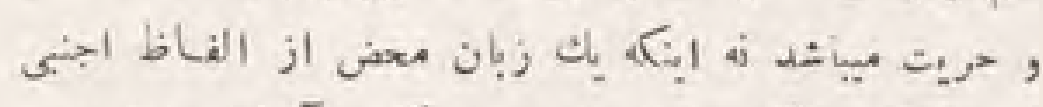

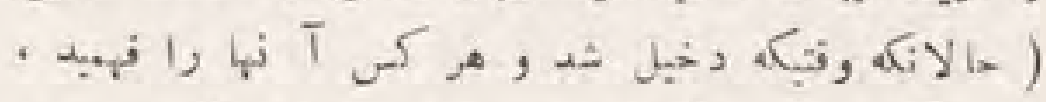

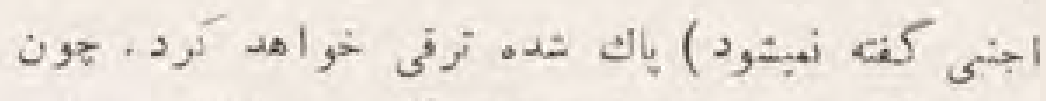

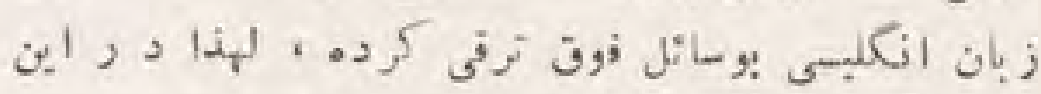

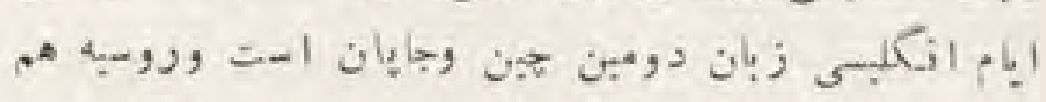

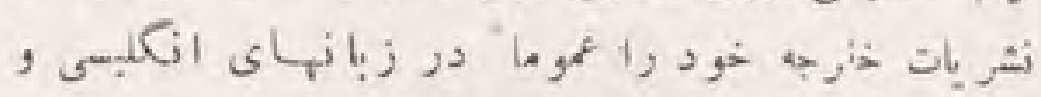

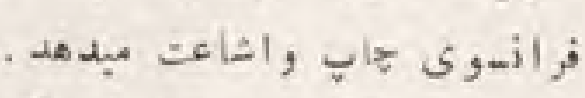

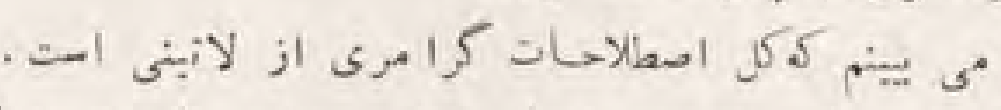
( verb)

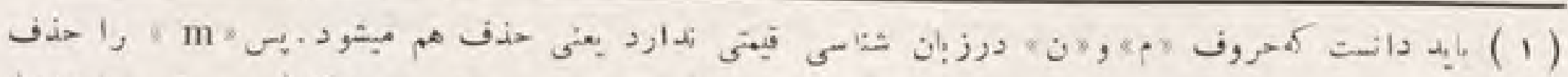

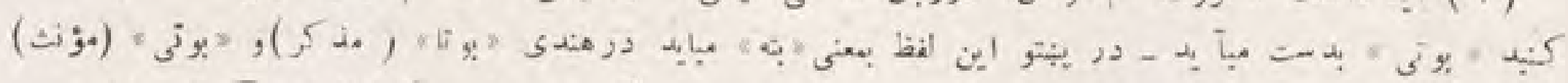

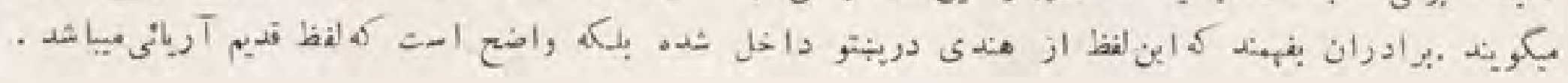


.

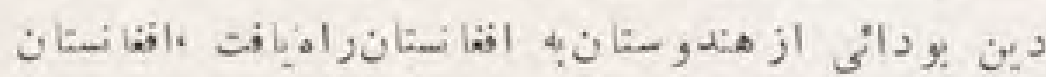

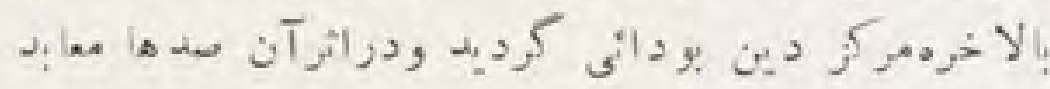

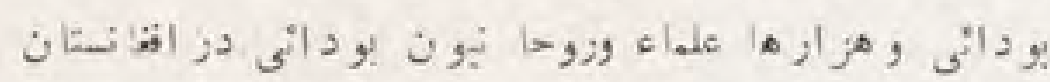

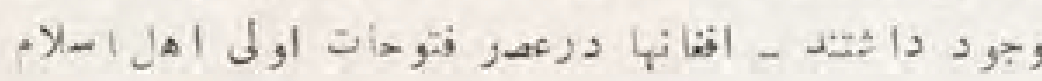

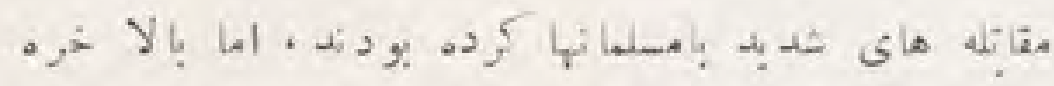

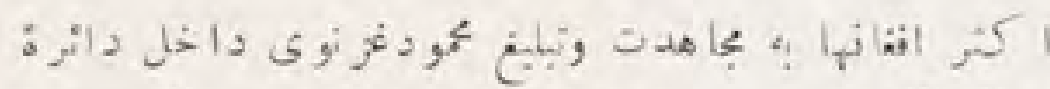

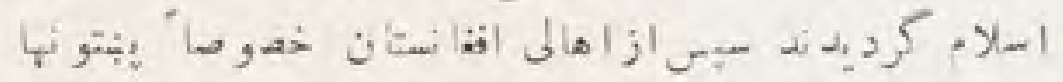

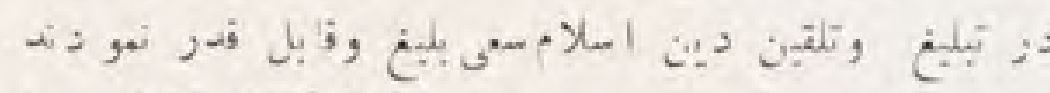

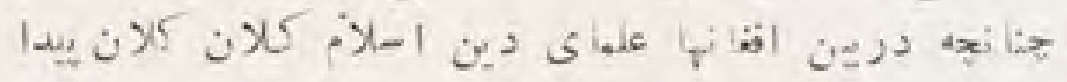

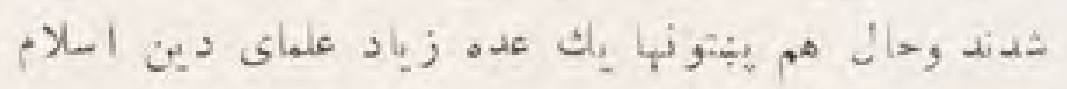

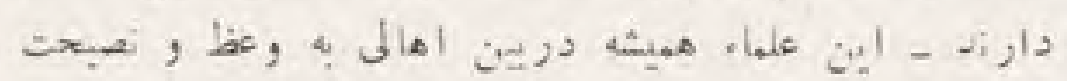

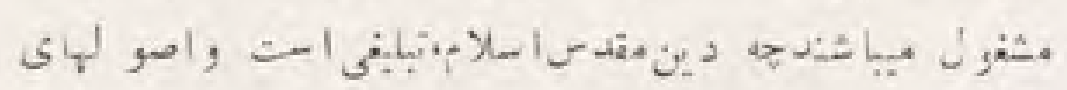

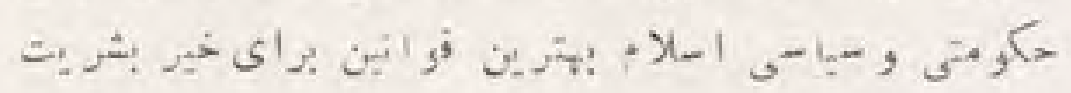

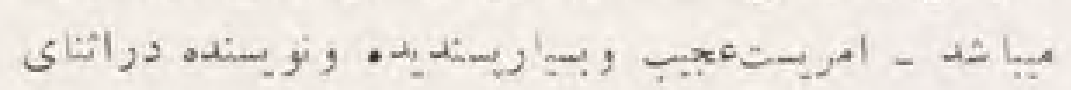

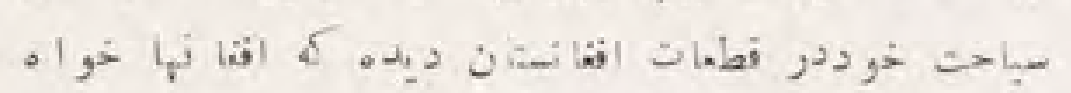

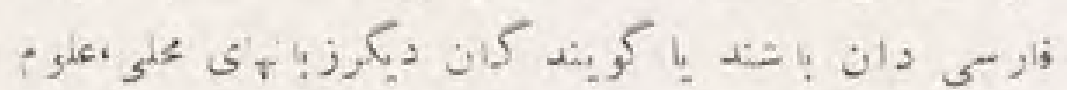

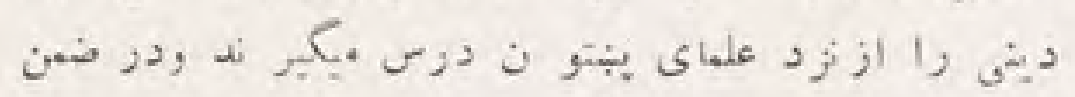

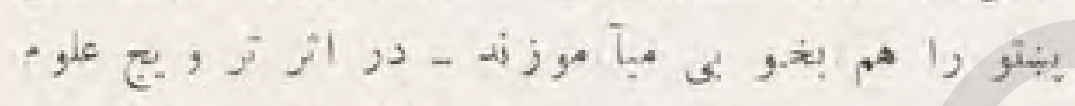

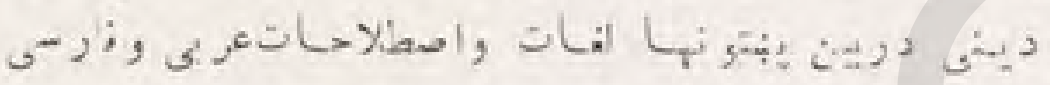

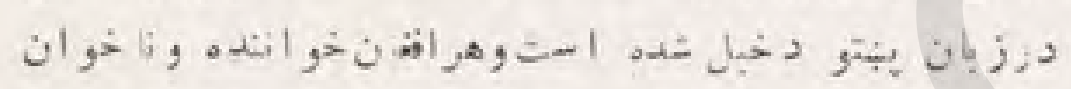

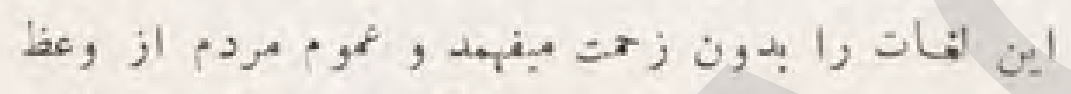

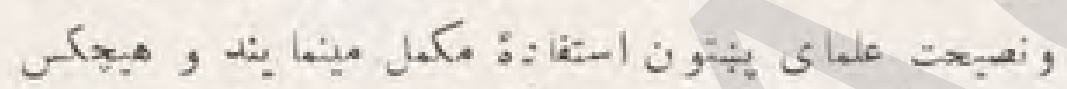

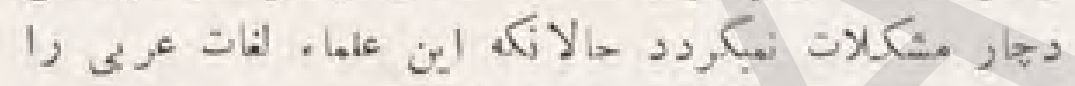

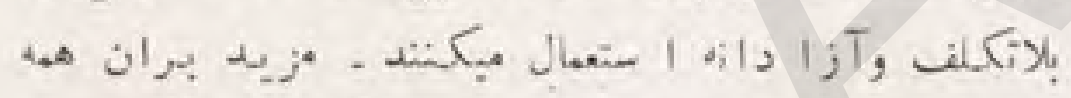

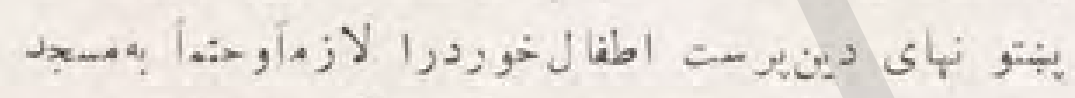

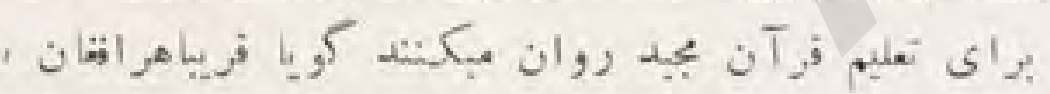

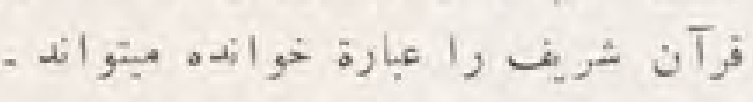

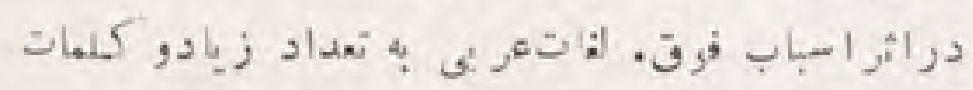

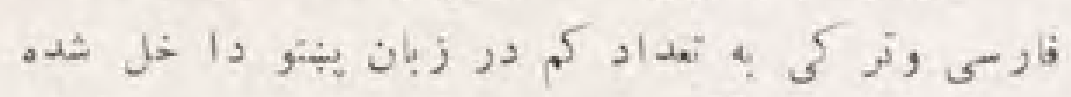

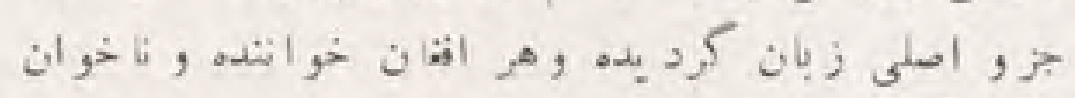

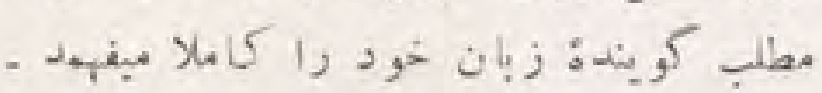

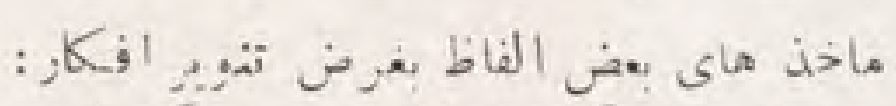

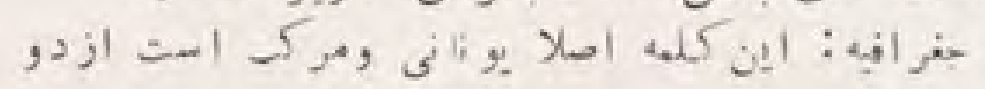

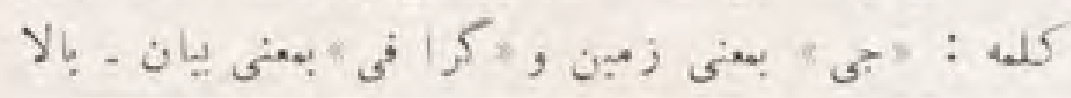

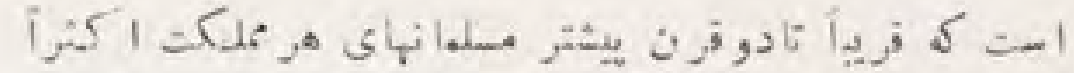

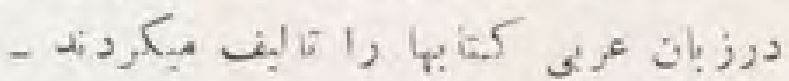

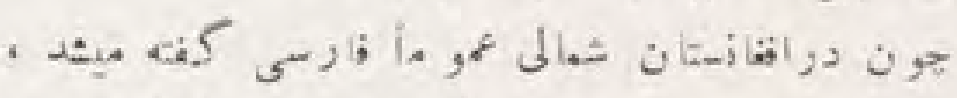

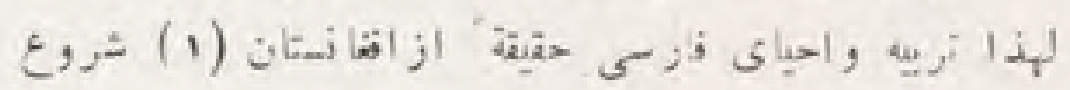

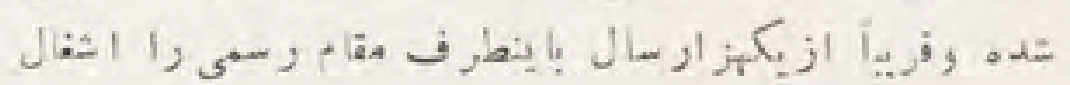

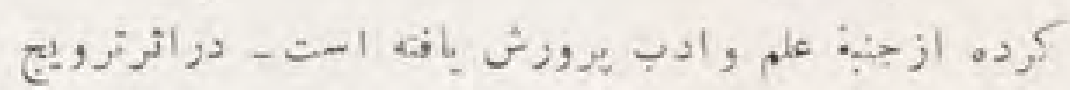

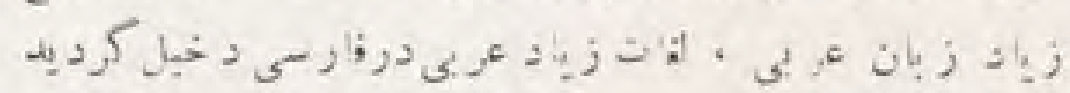

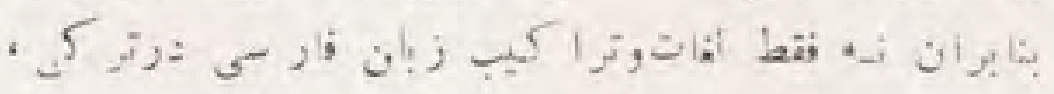

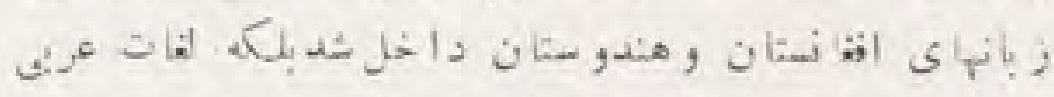

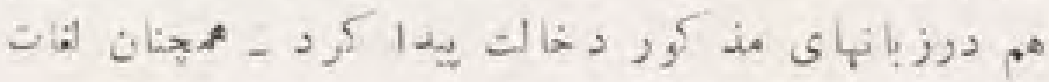

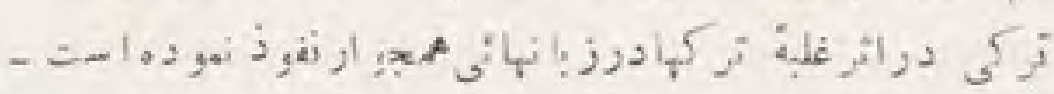

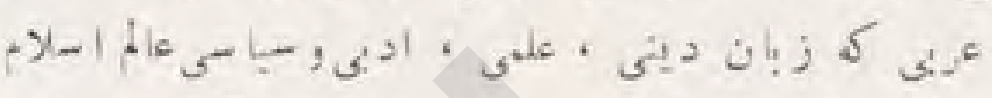

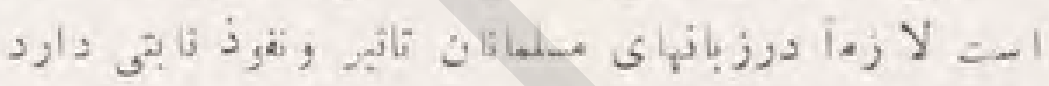

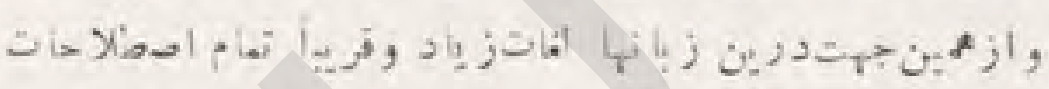

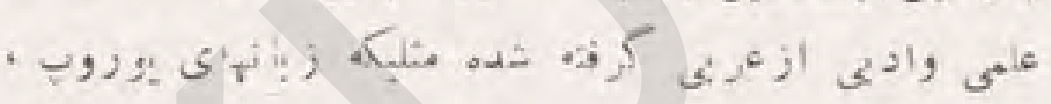

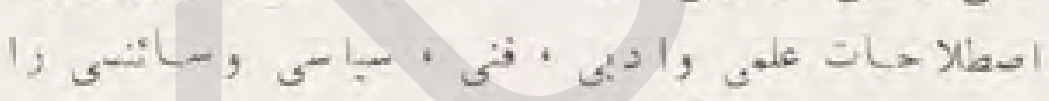

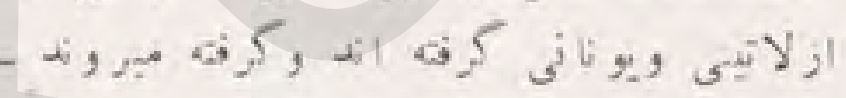
|

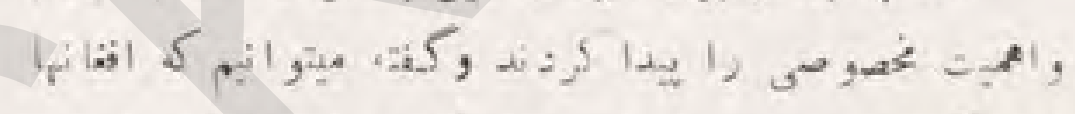

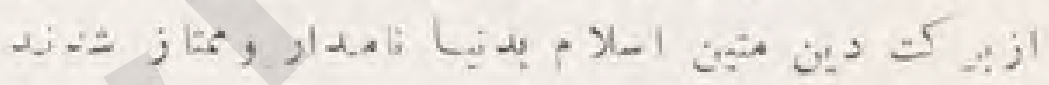

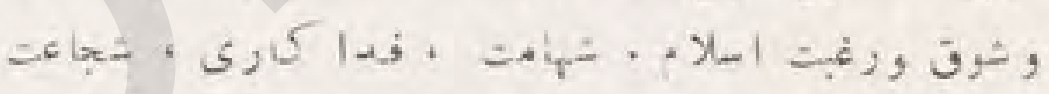

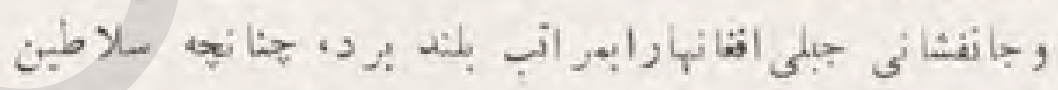

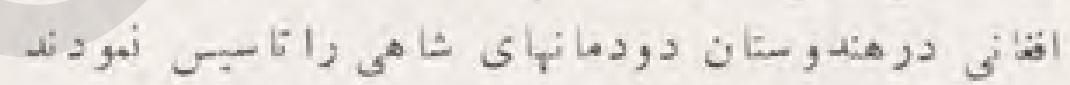

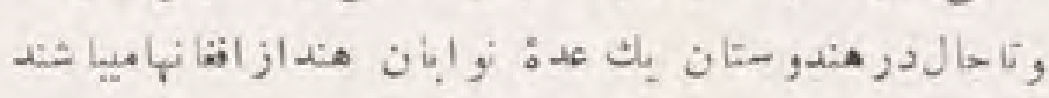

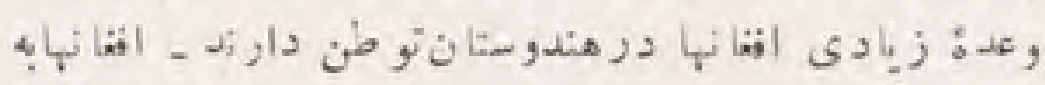

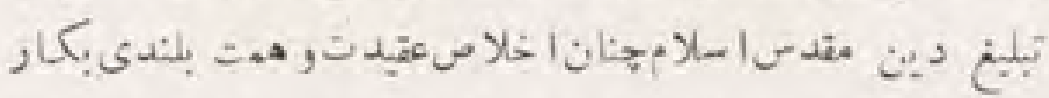

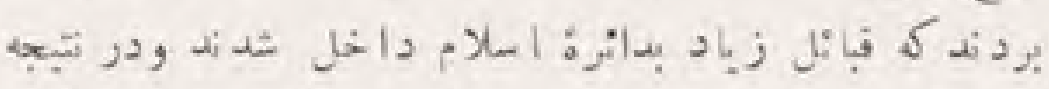

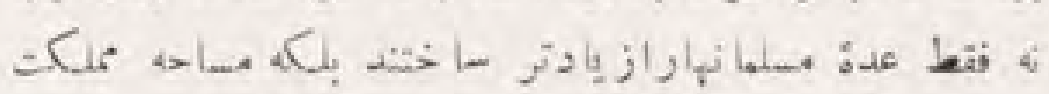

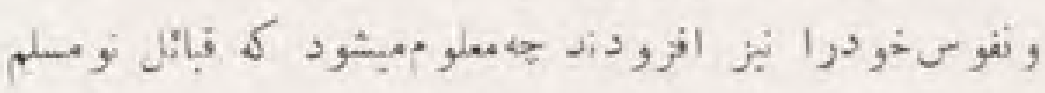

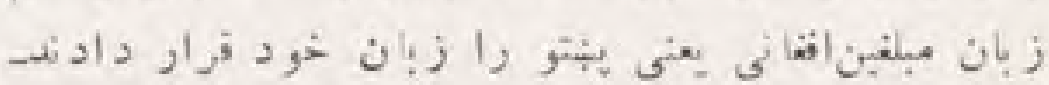

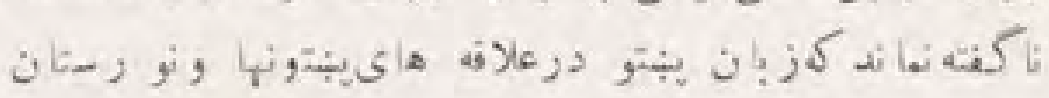

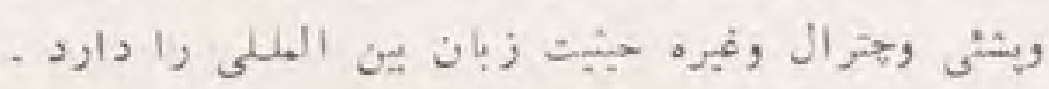

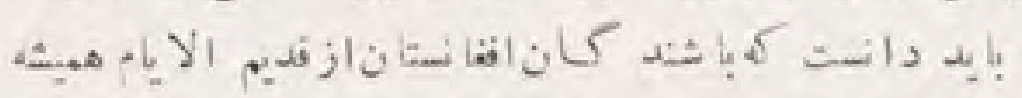

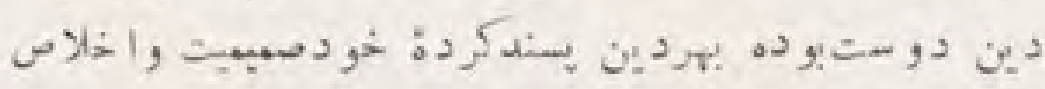

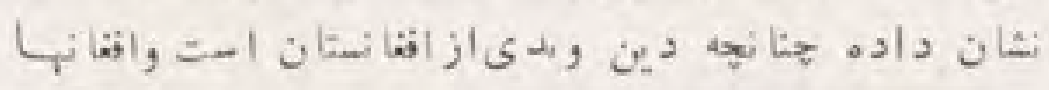

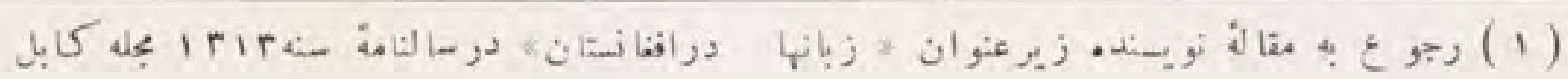




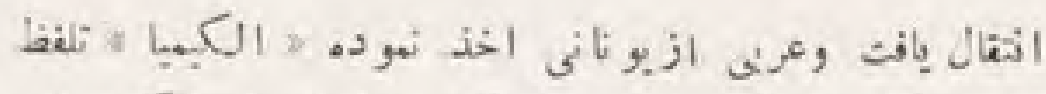

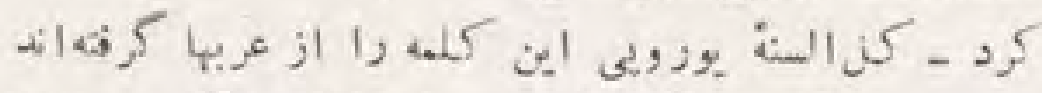

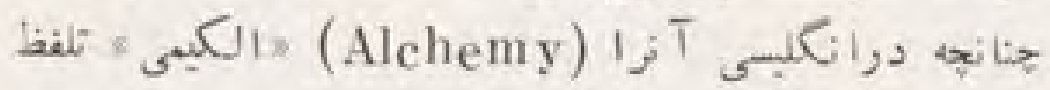

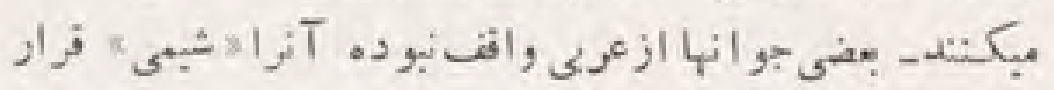

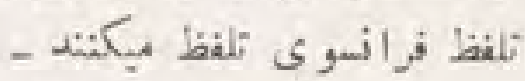

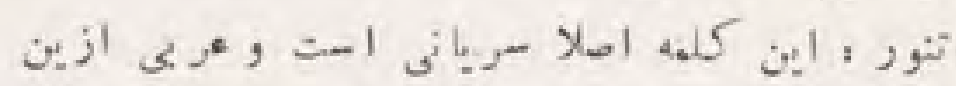

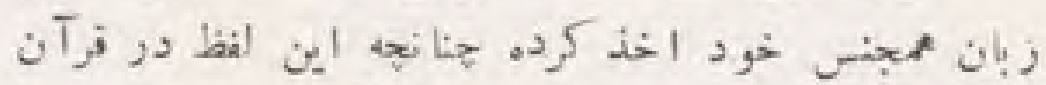

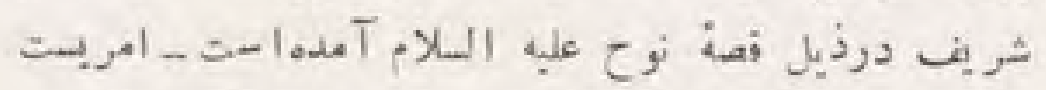

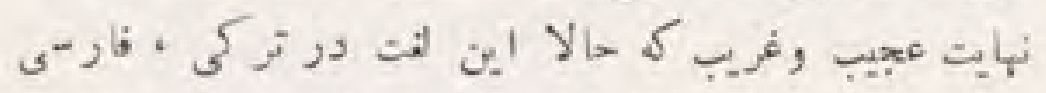

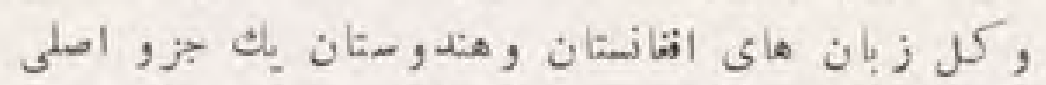

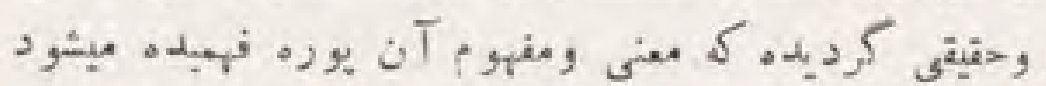

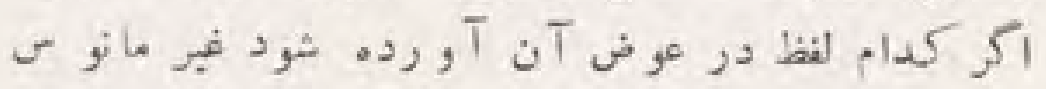

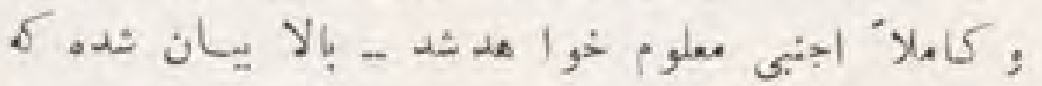

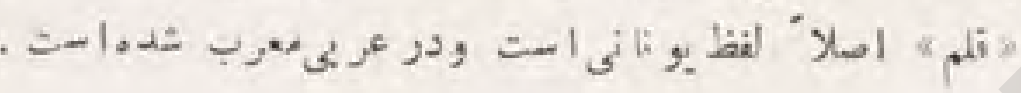

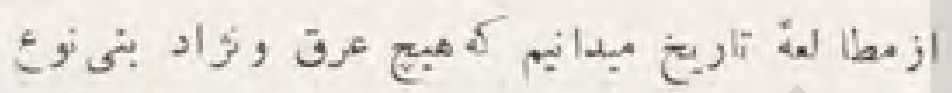

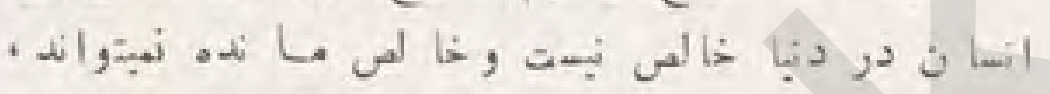

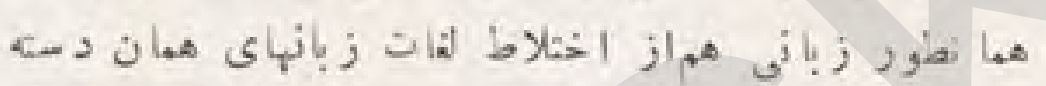

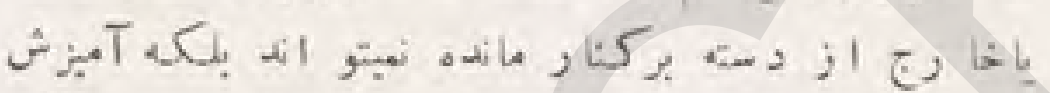

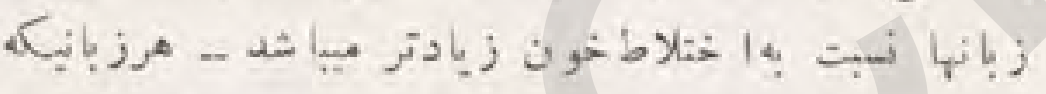

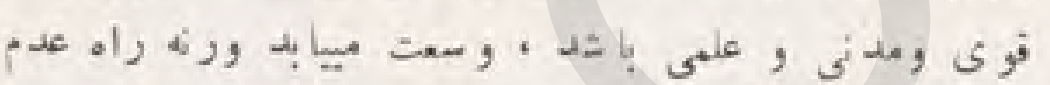

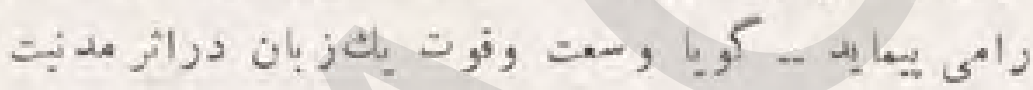

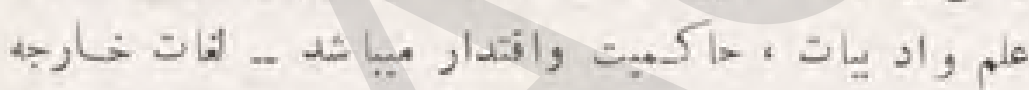

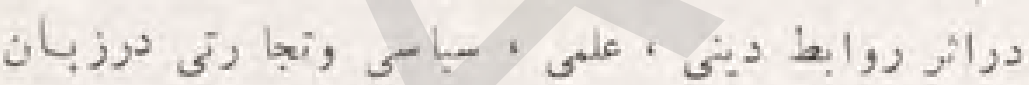

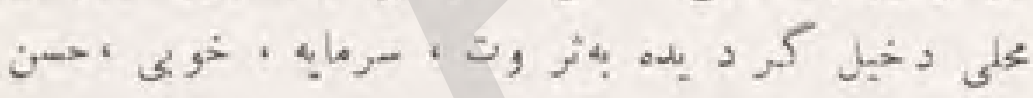

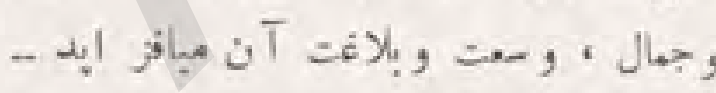

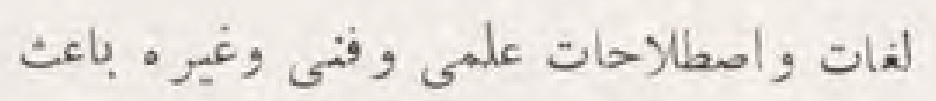

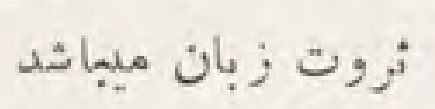

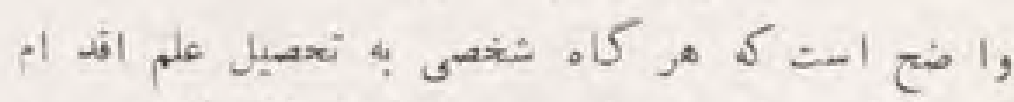

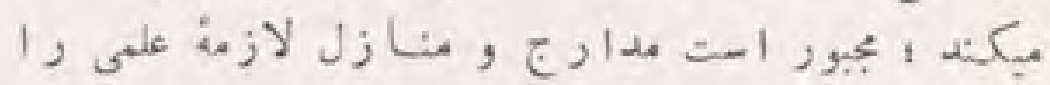

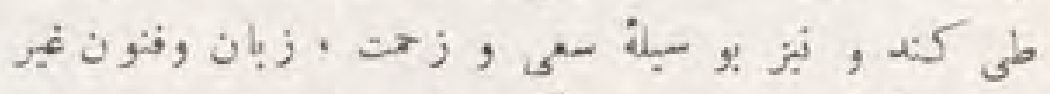

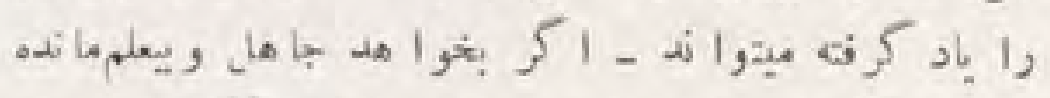

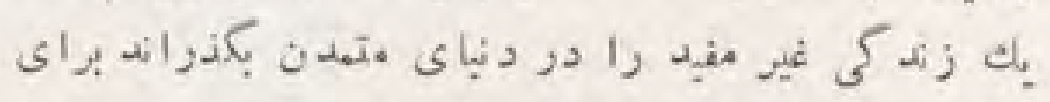

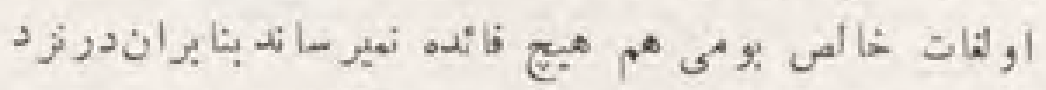

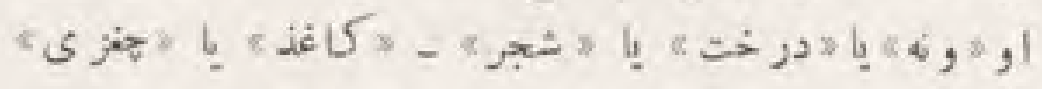

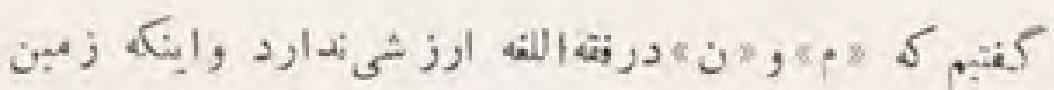

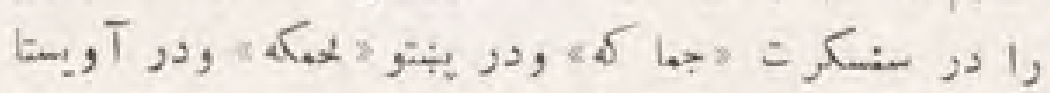

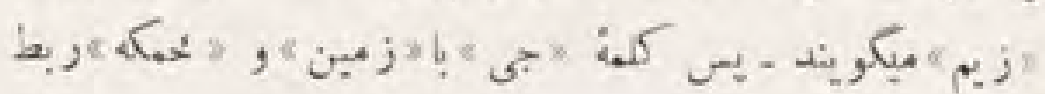

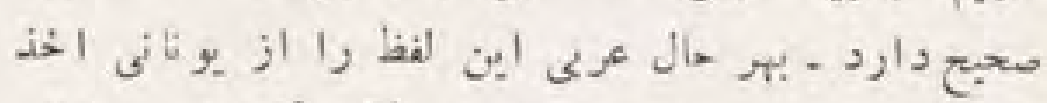

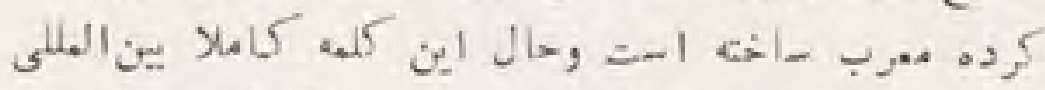

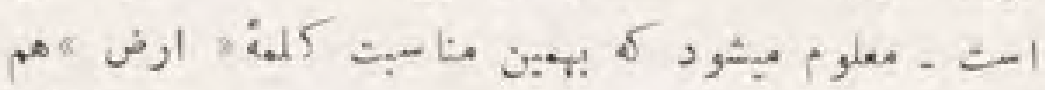

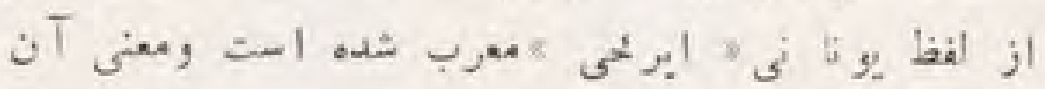

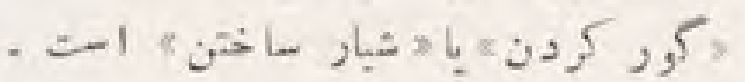

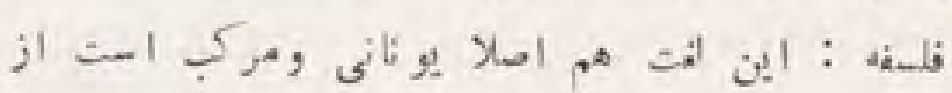

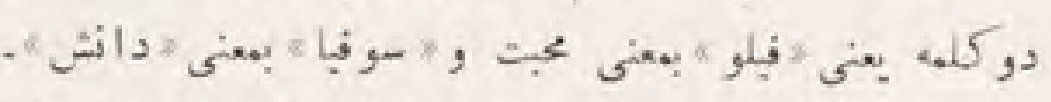

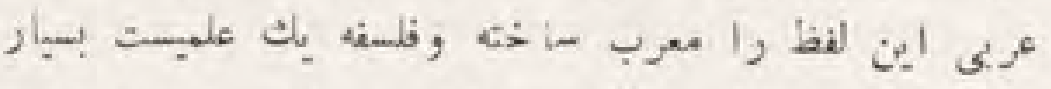

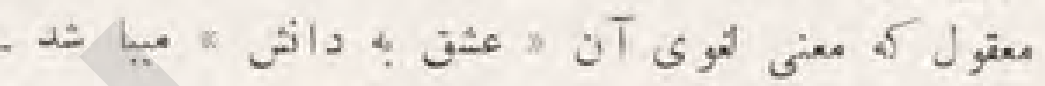

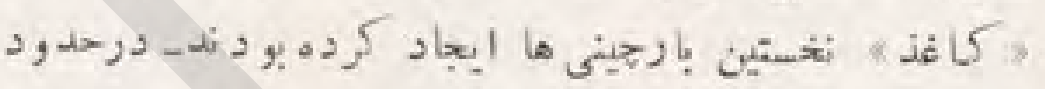

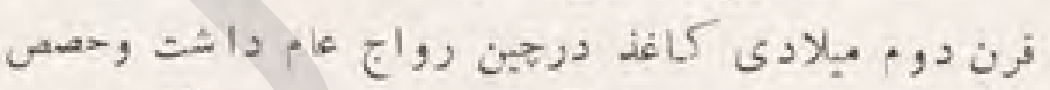

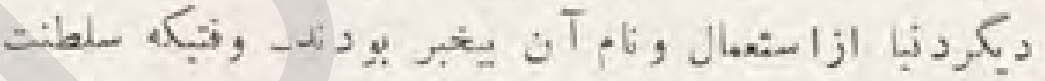

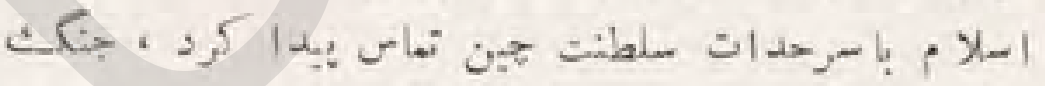

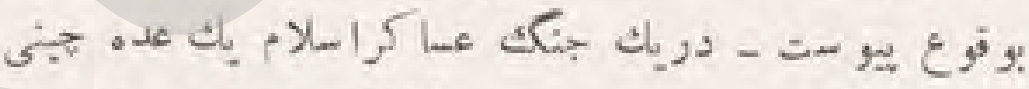

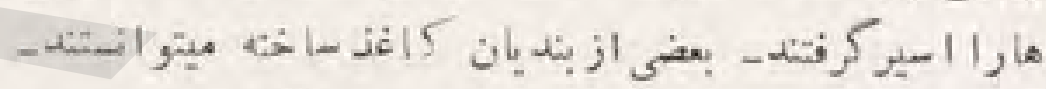

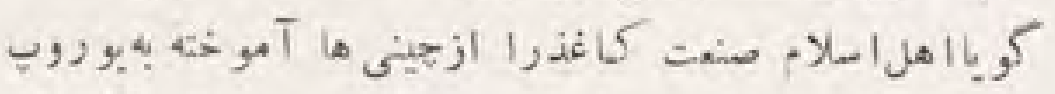

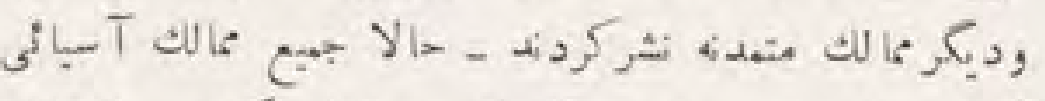

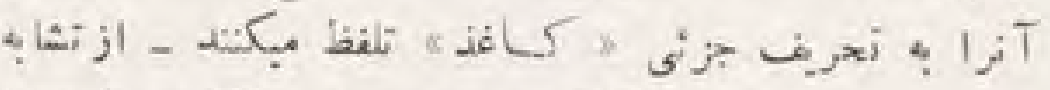

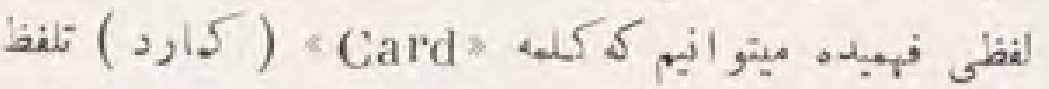

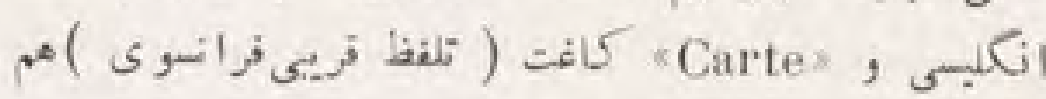

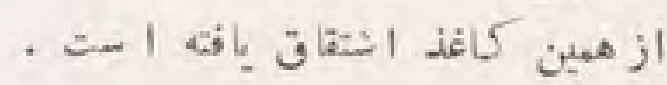

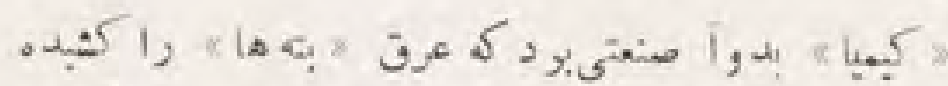

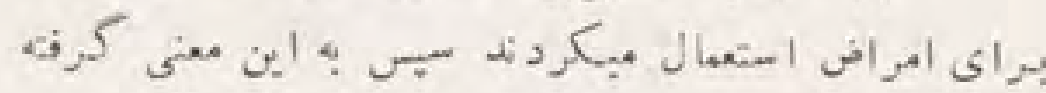

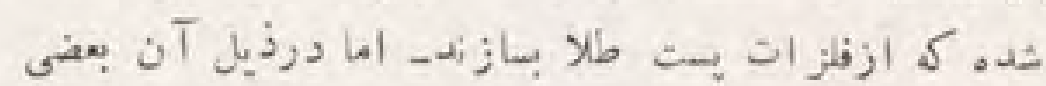

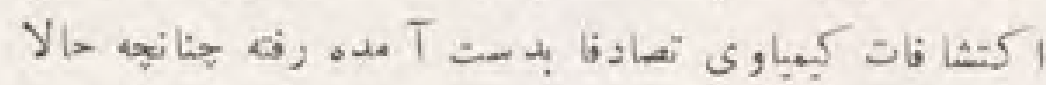

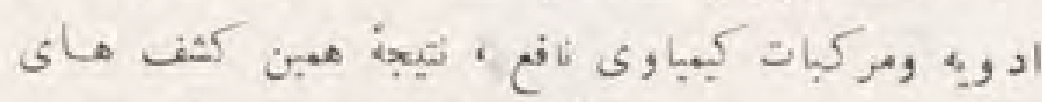

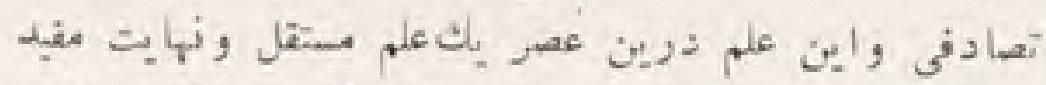

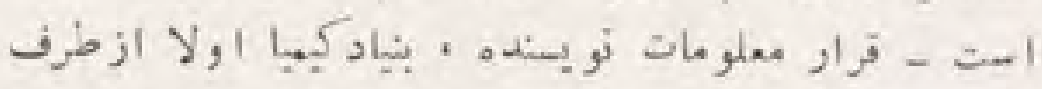

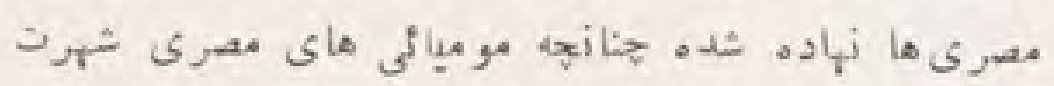

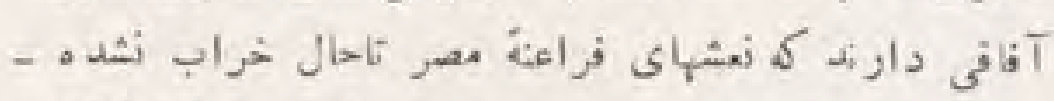

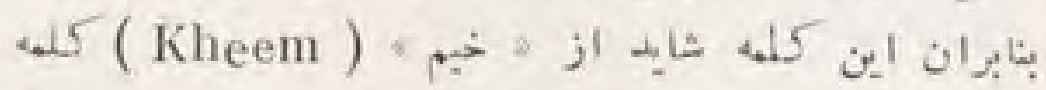

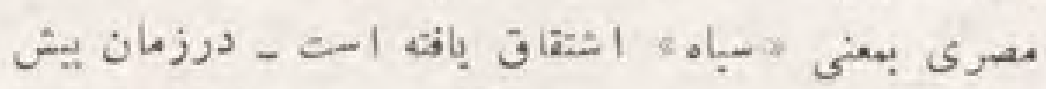

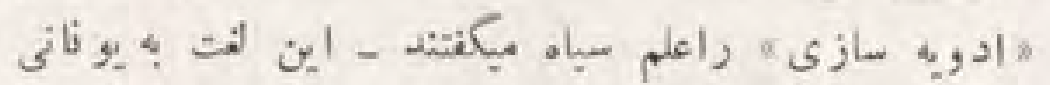




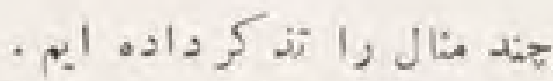

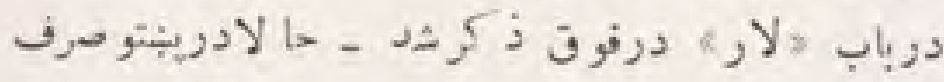

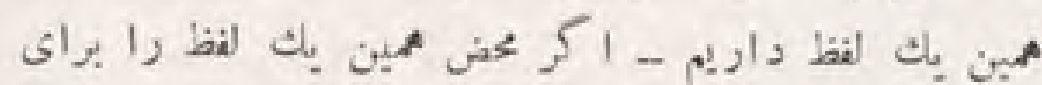

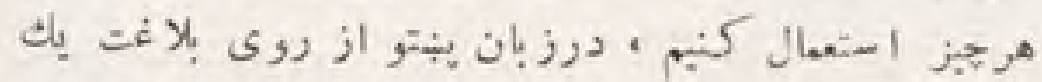

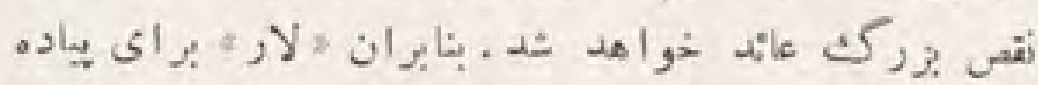

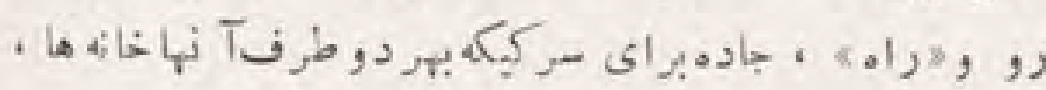

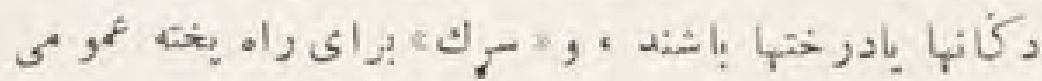

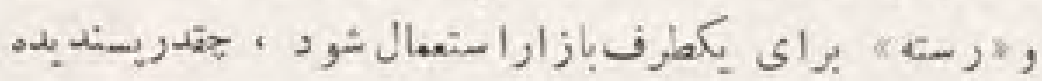

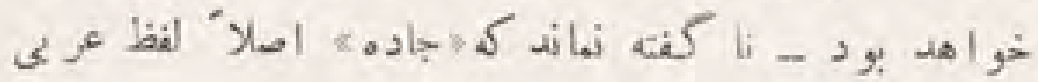

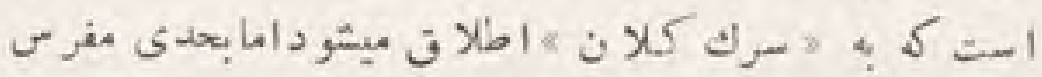

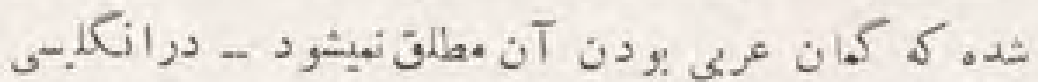

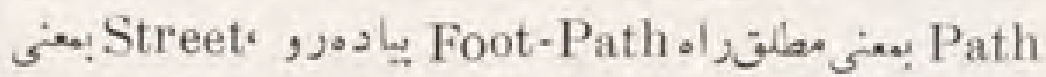

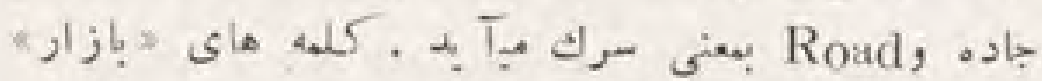

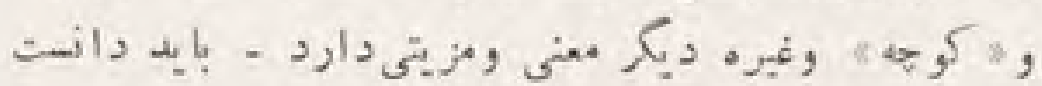

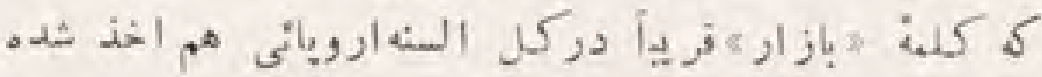

$$
\text { 1, }
$$

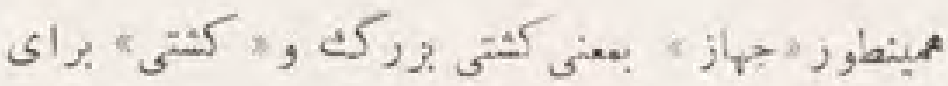

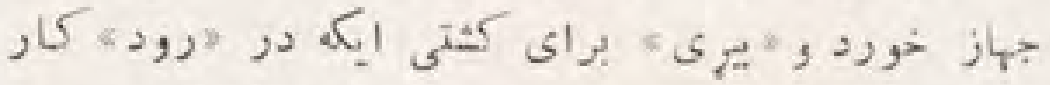

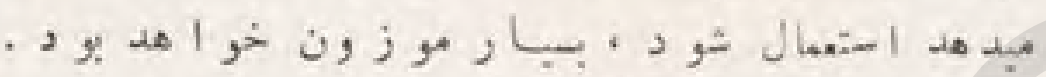

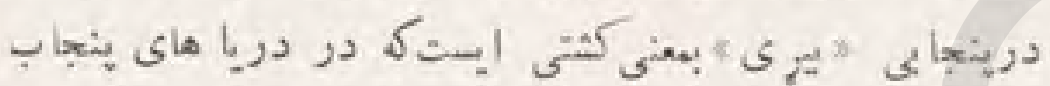

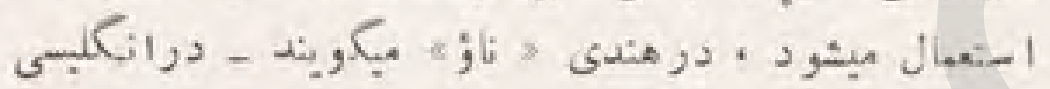

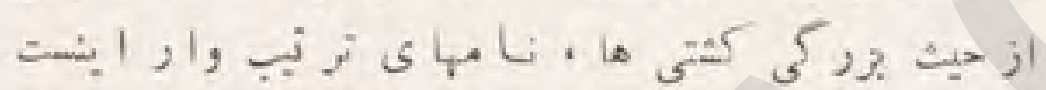
وغبره، نامباى Junk-Canoe-Boat-Vessel-Ship

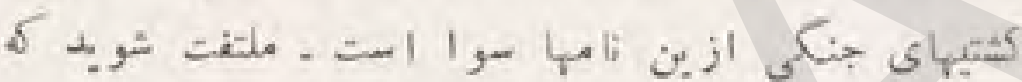

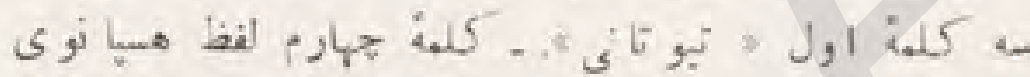

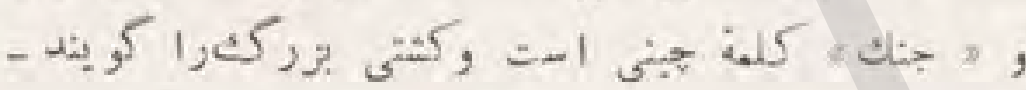

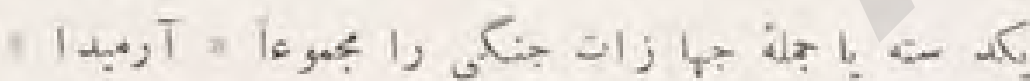
(Armada)

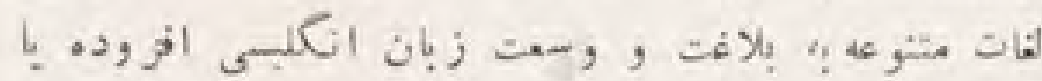

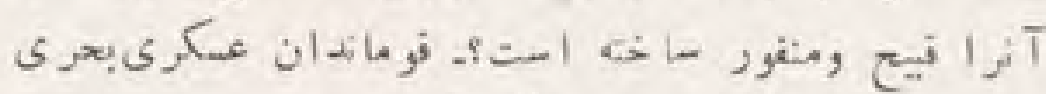

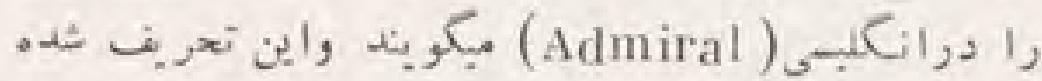

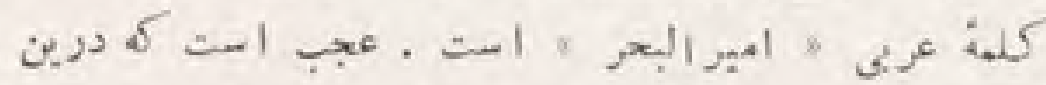

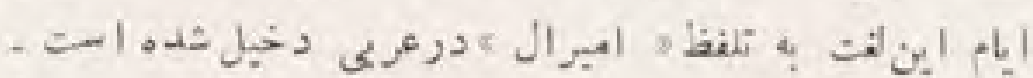

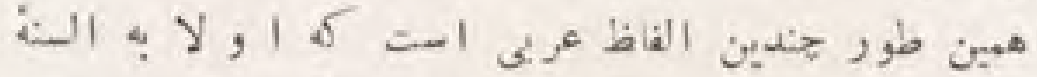

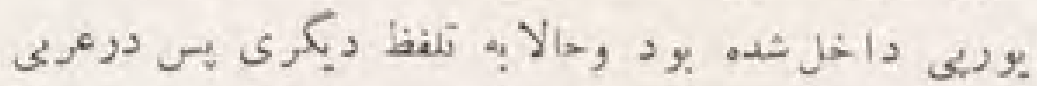

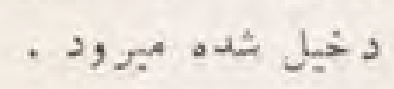

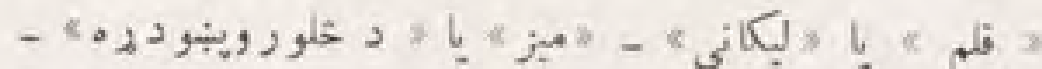

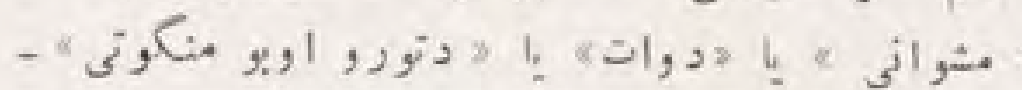

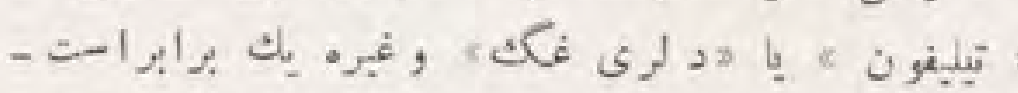

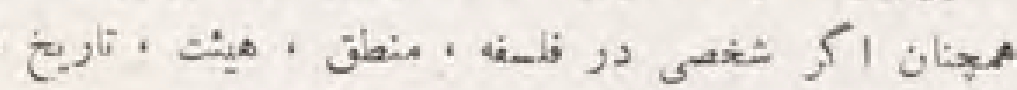

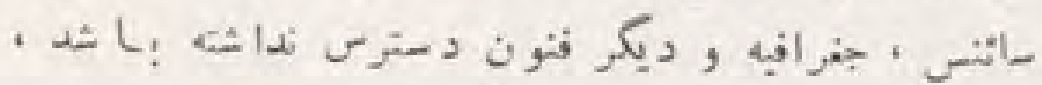

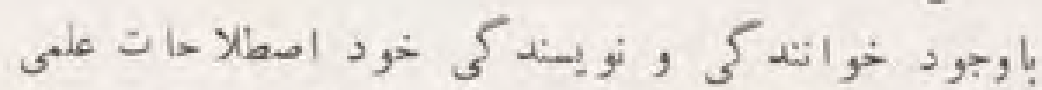

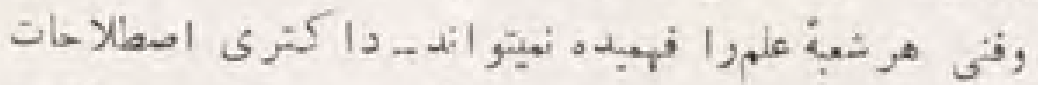

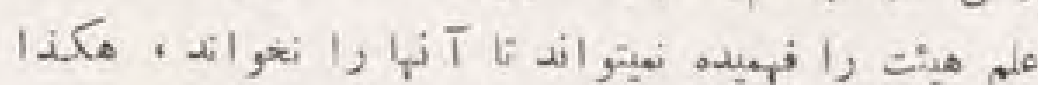

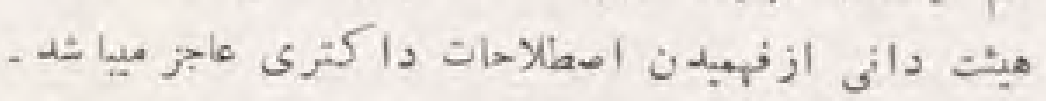

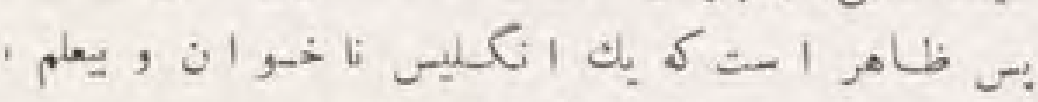

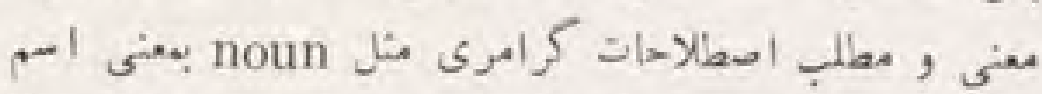

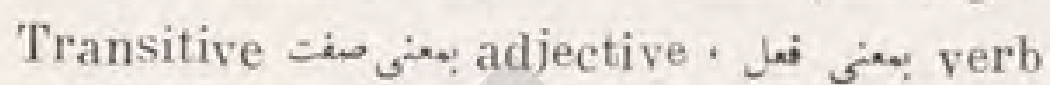

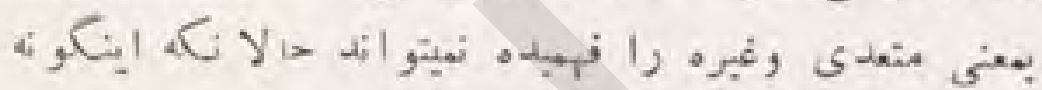

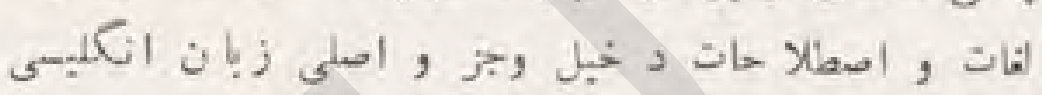

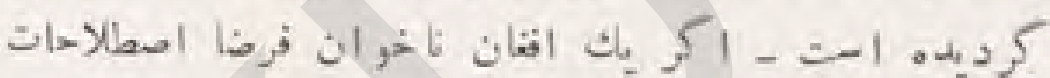

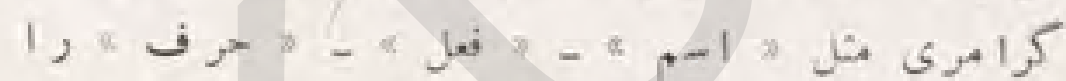

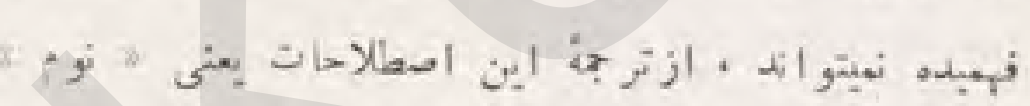

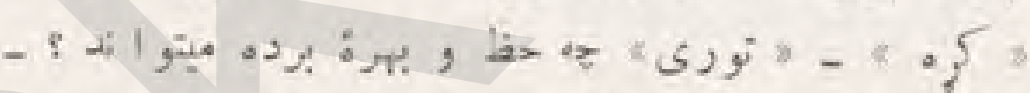

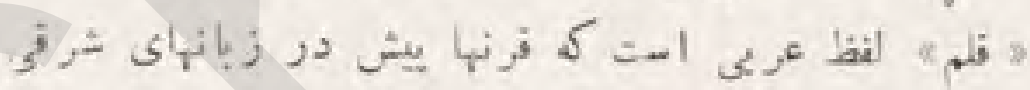

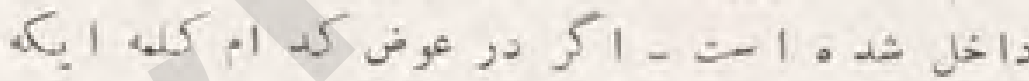

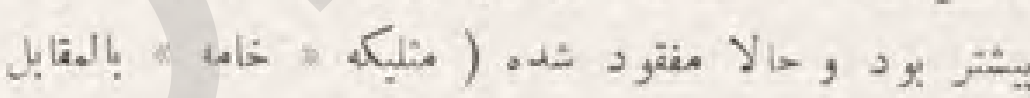

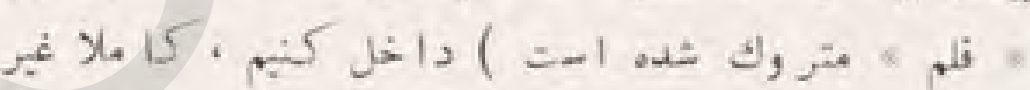

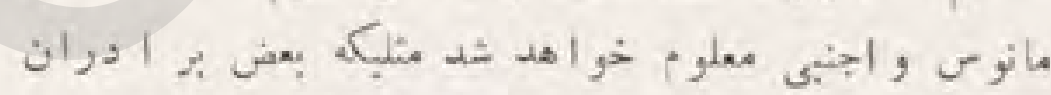

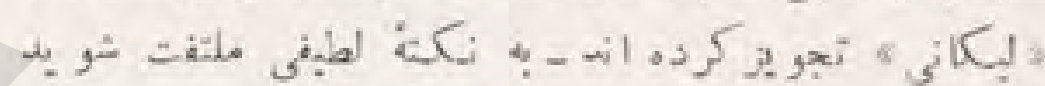

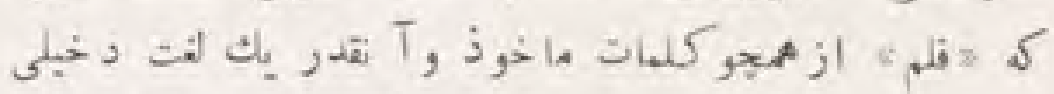

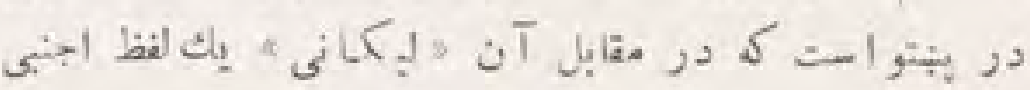

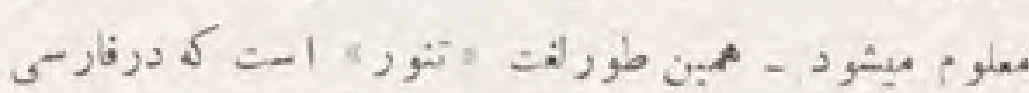

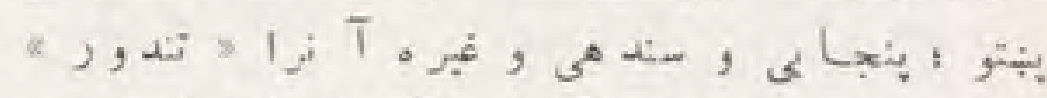

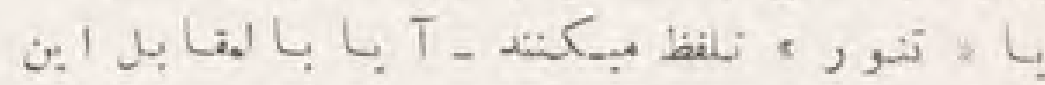

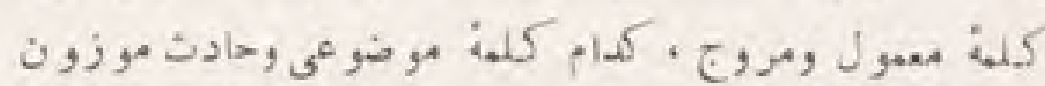

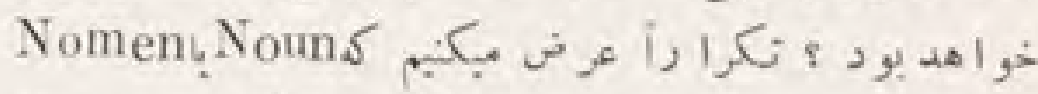

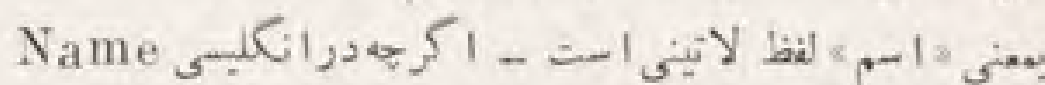

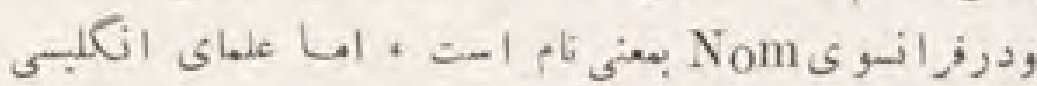

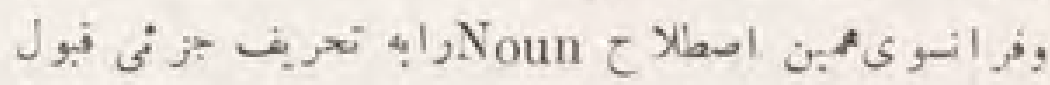

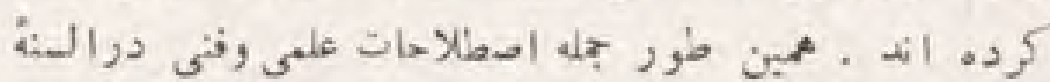

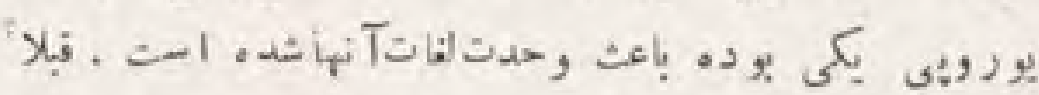




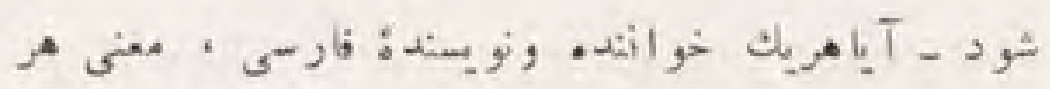

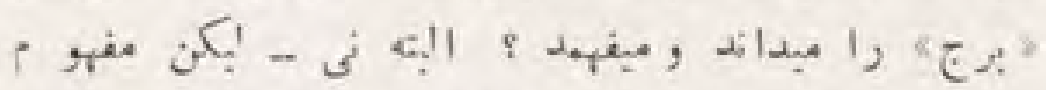

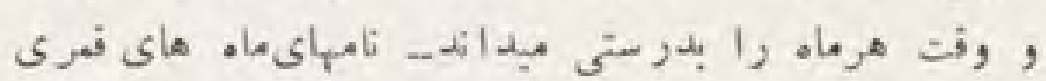

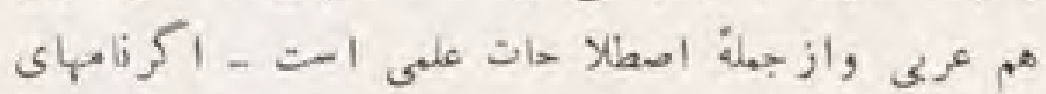

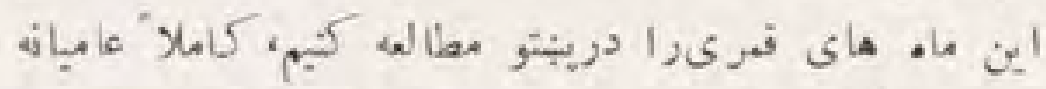

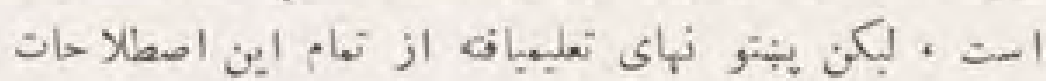

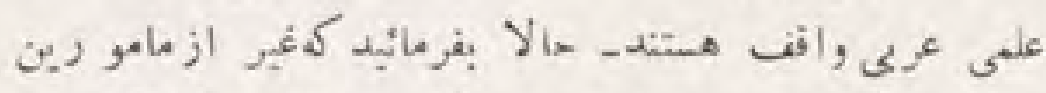
جند نغر ديكر بوجيو

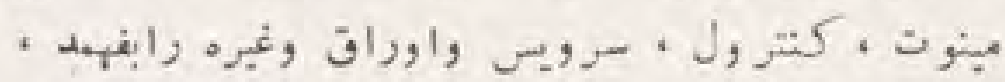

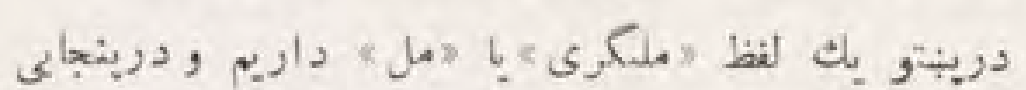

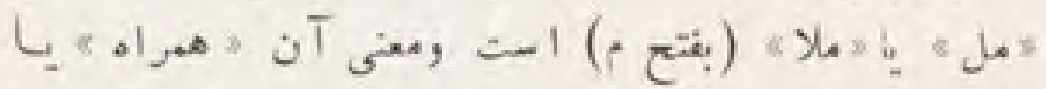

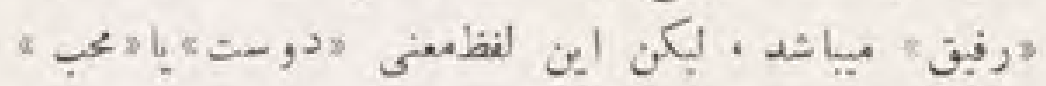

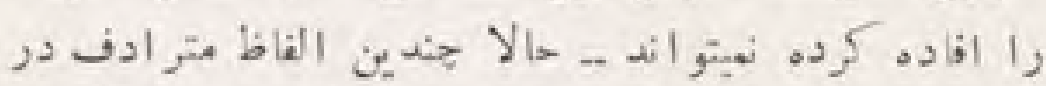

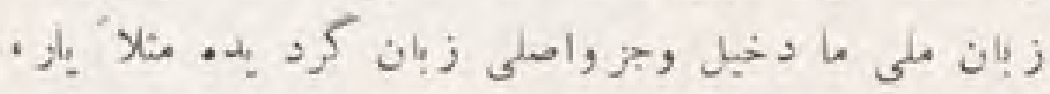

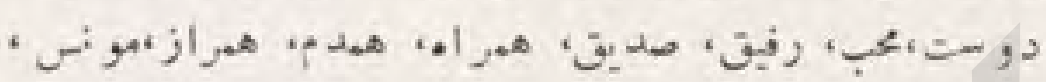

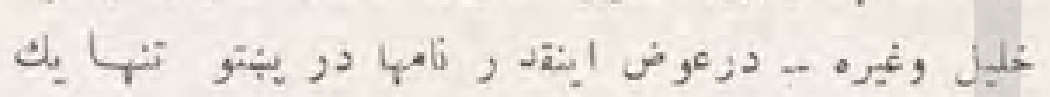

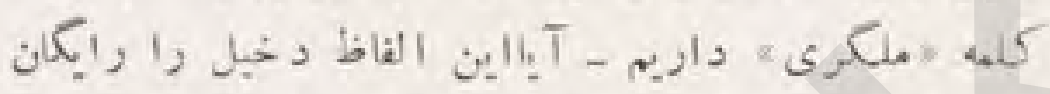

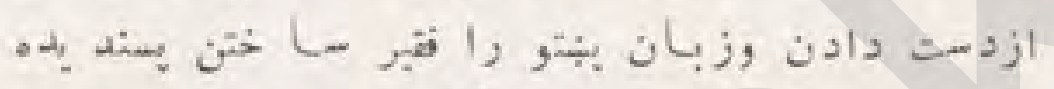

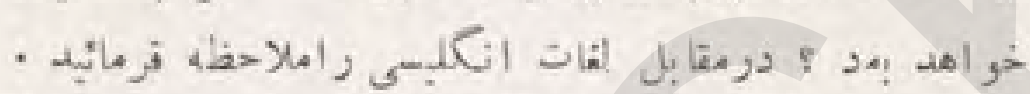
Compeer-Assosiate-Partner-Fellow - Friénd

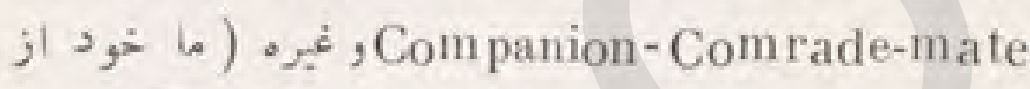

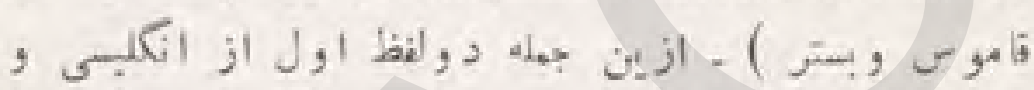

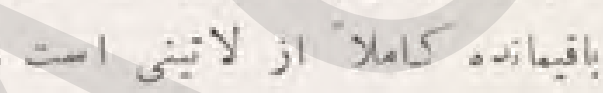

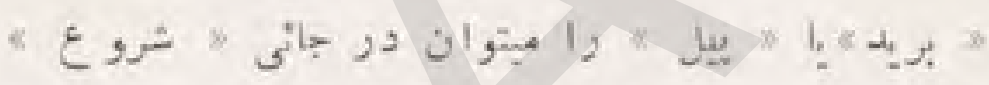

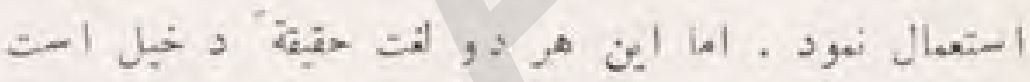

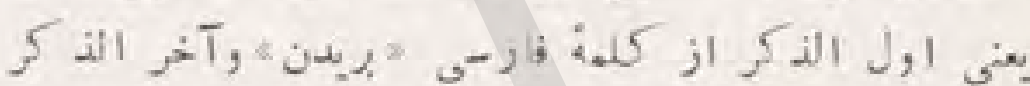

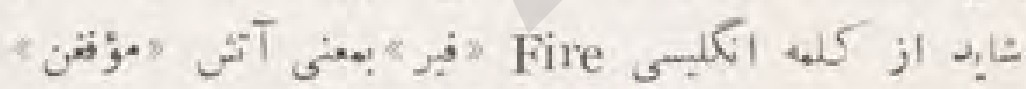

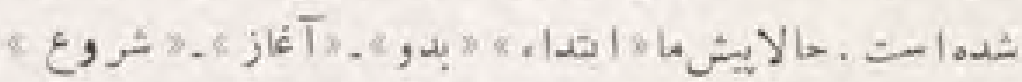

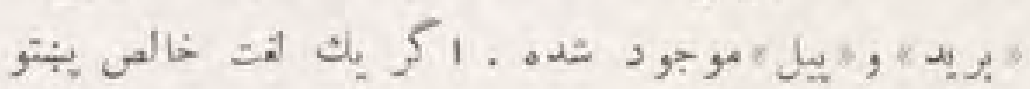

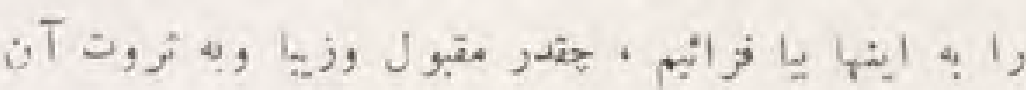

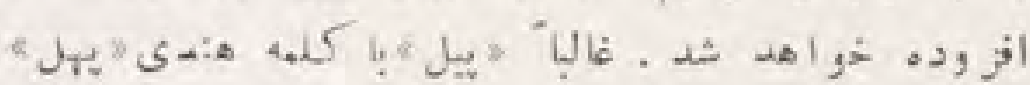

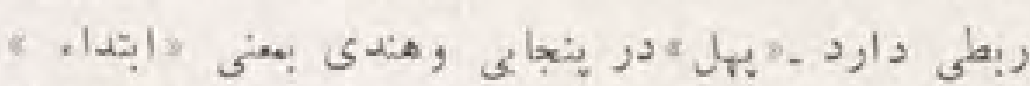

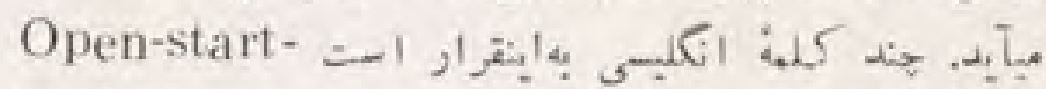
begin-introduce-admit-initiate-Commence

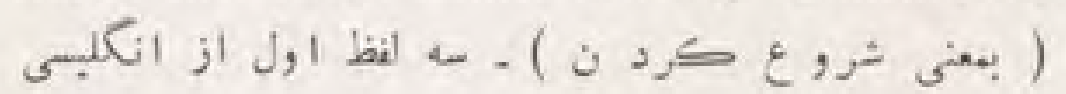

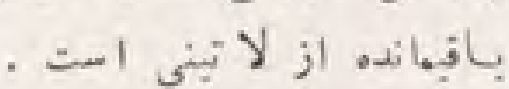

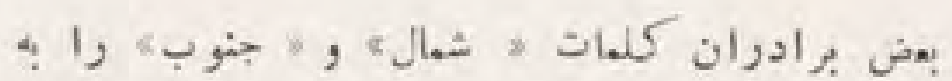

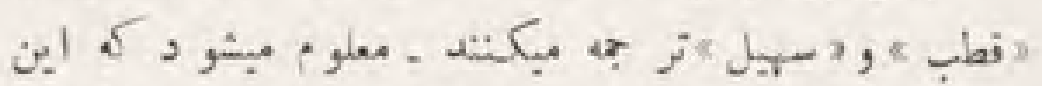

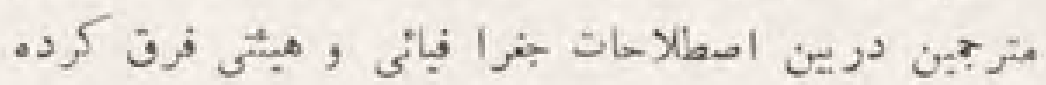

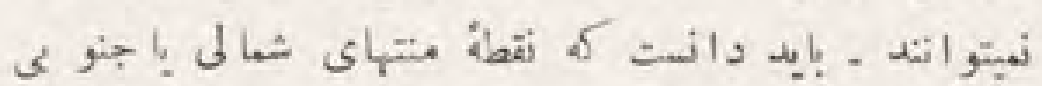

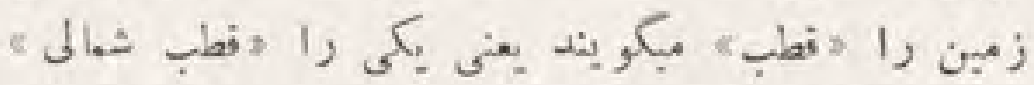

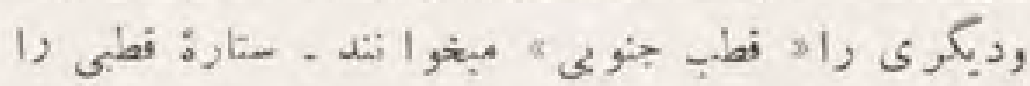

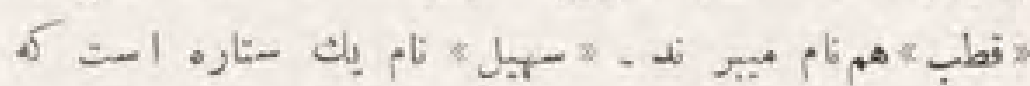

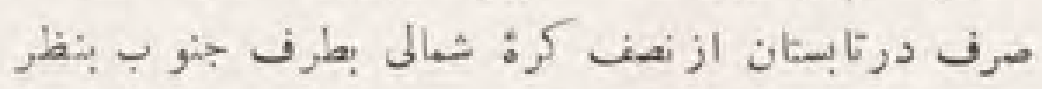

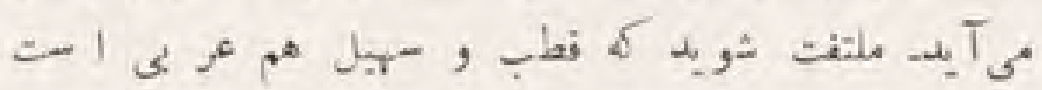
ودر عرى بودن شهال وجنوب هم شاك نيستامارول الذكر

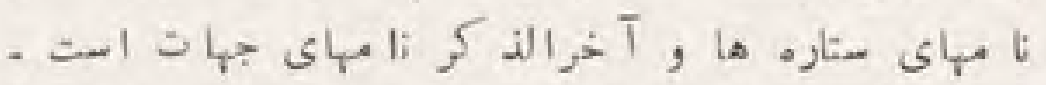

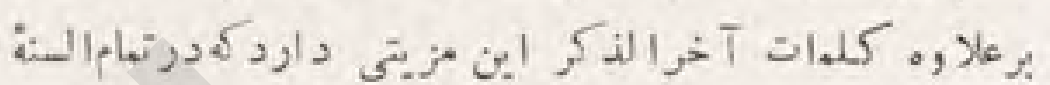

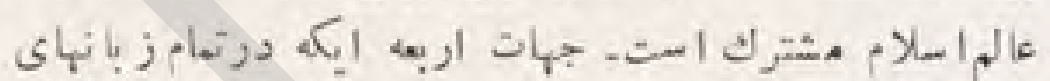

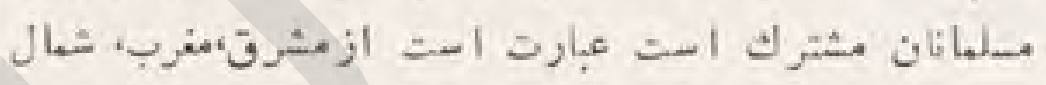

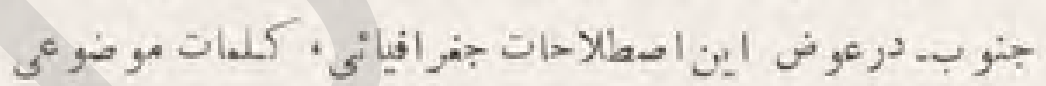

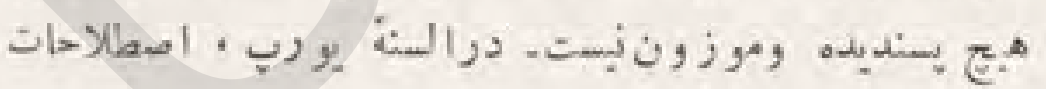
.

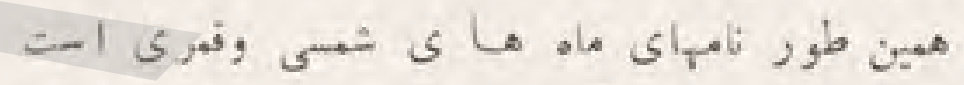

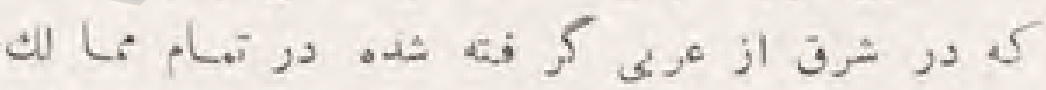

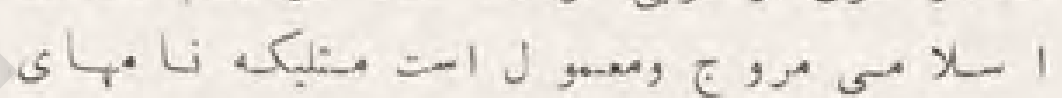

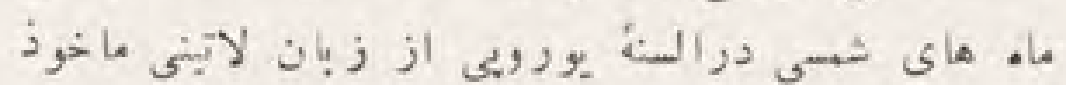

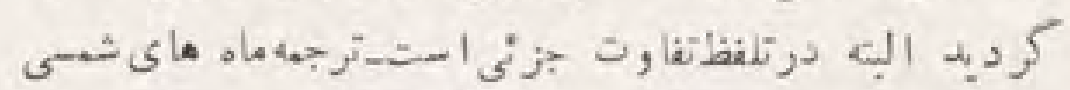

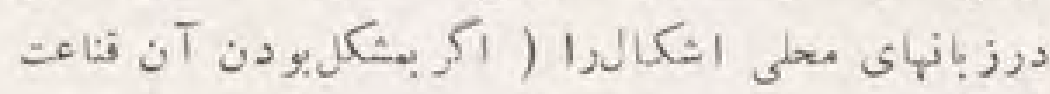

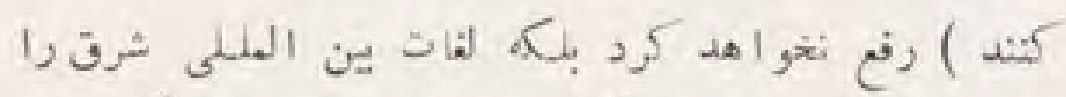

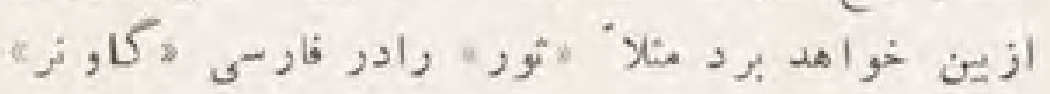

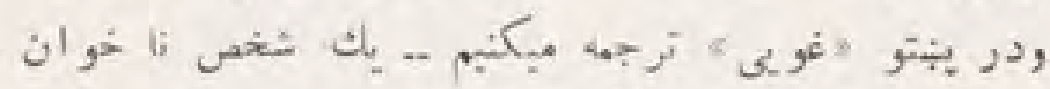

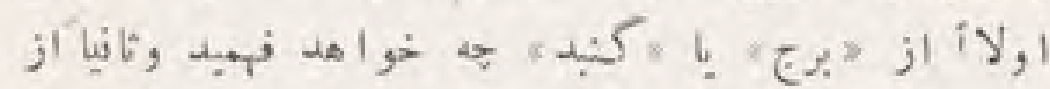

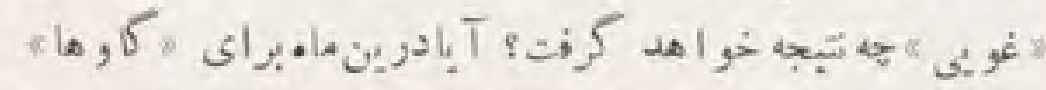

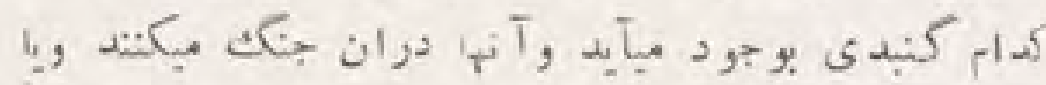

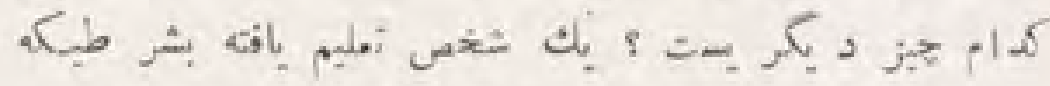

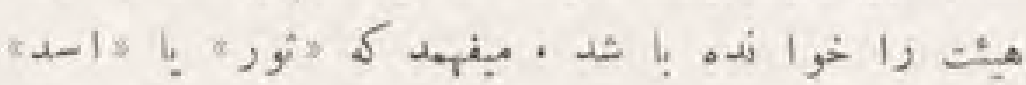

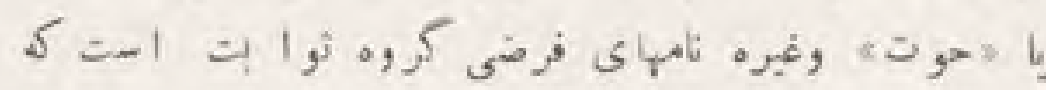

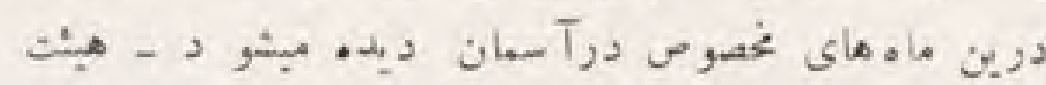

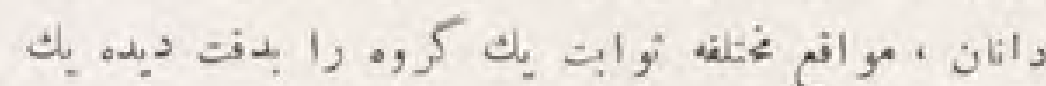

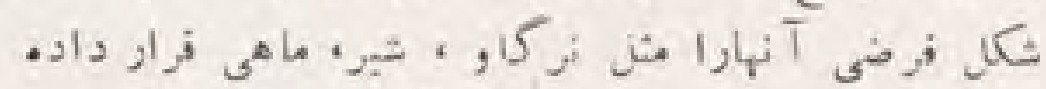

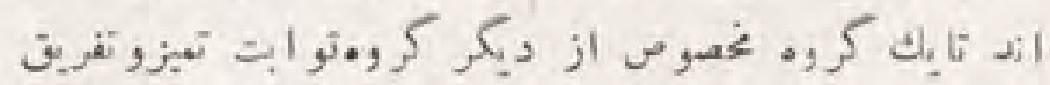


زودتر بادمبكبر ند ونيز بهمن وتيره ميتوان ايرانى هـا.

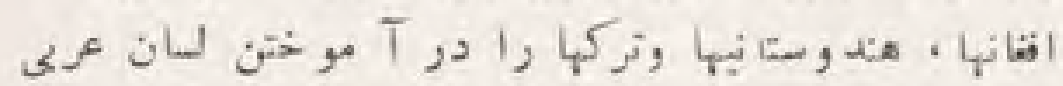

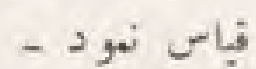

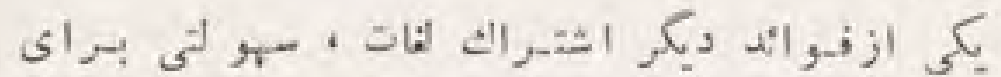

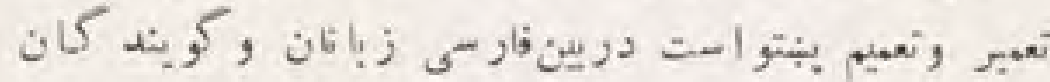

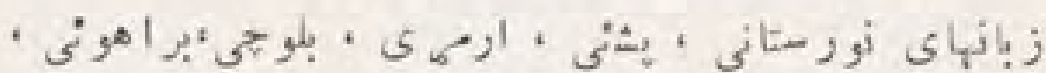

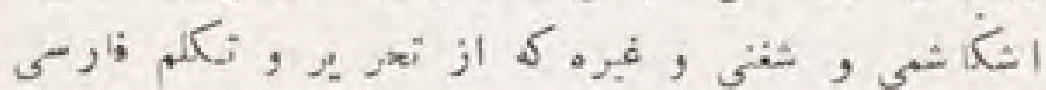

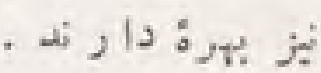

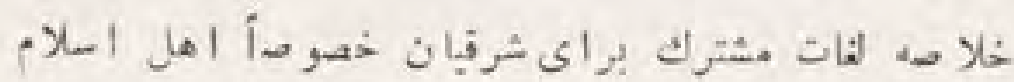

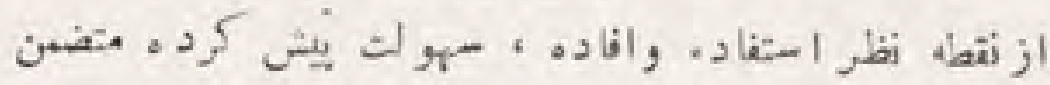

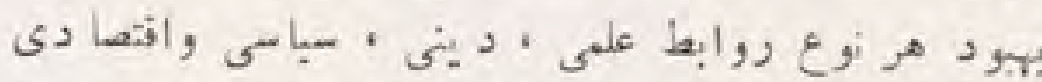
. ب زو نيح هز يد وخسار نهائكه إز اخراج لغنات

$$
\text { دخبل واقع منشود }
$$

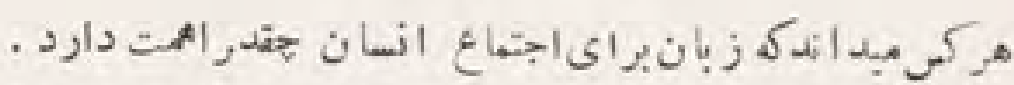

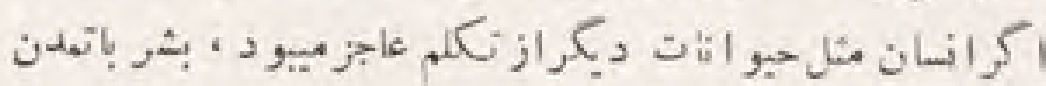

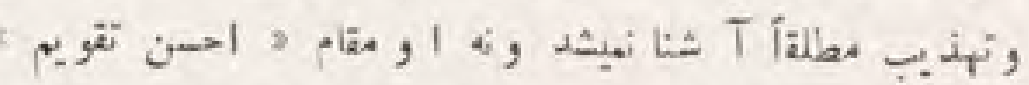

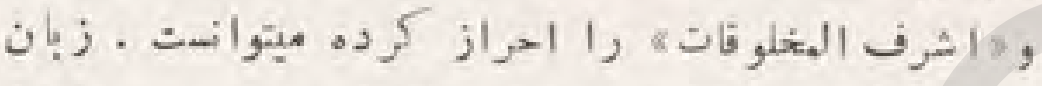

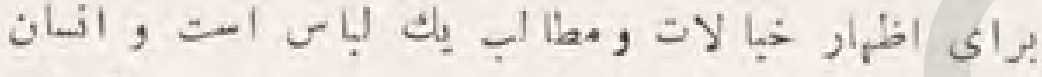

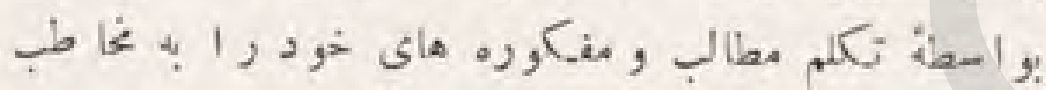

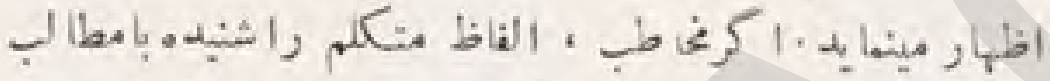

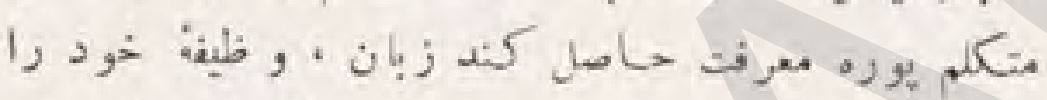

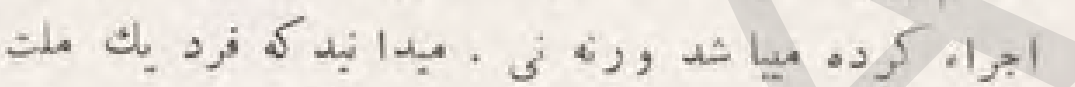

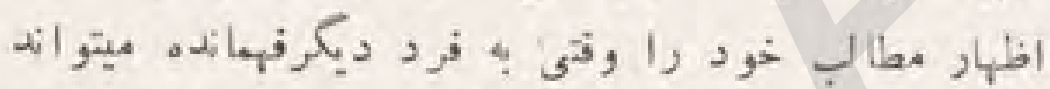

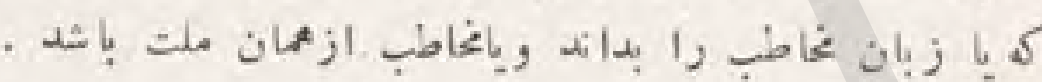

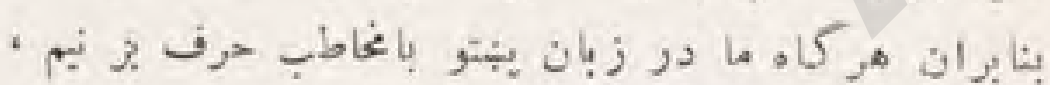

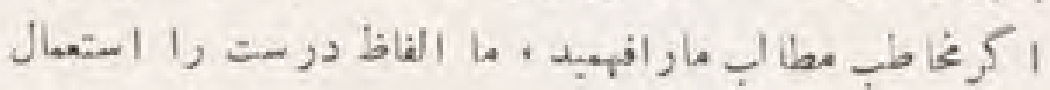

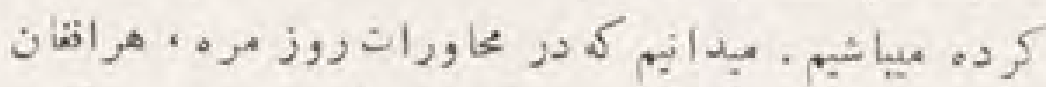

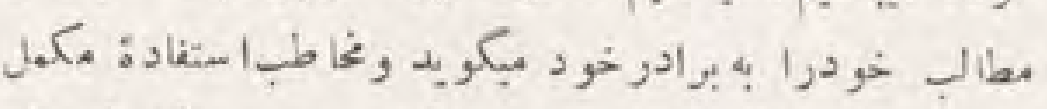

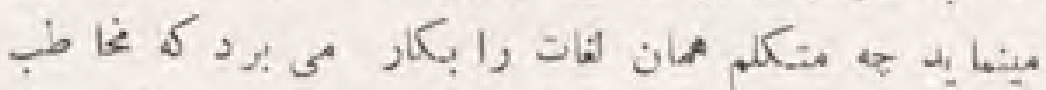

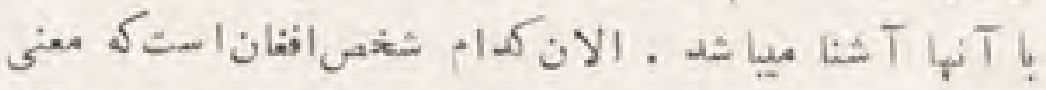

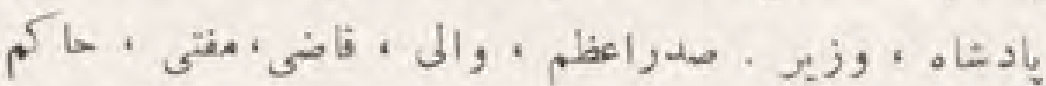

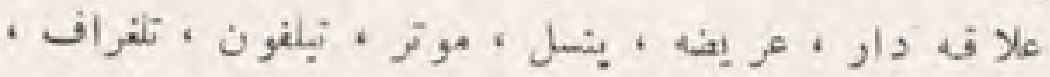

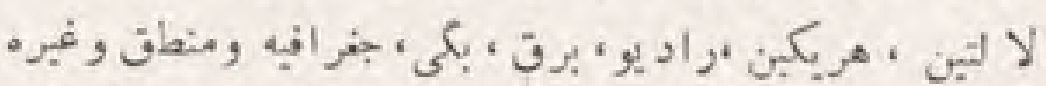

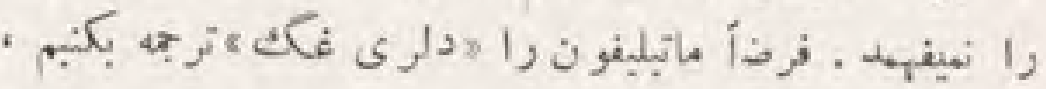

فوائدلغاتراصلاحأت مشتركه درميالك شرقى :

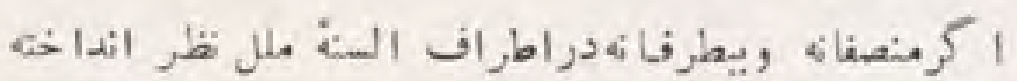

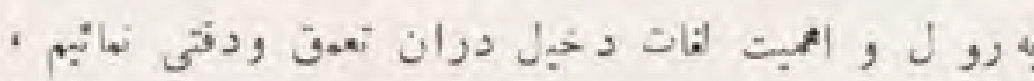

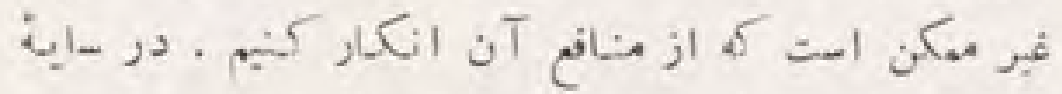

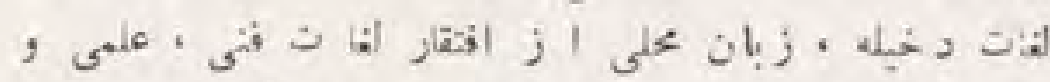

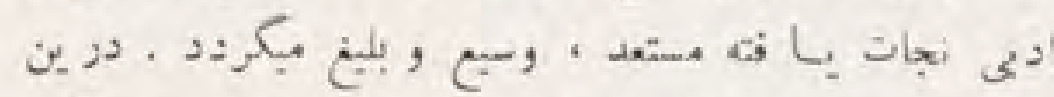

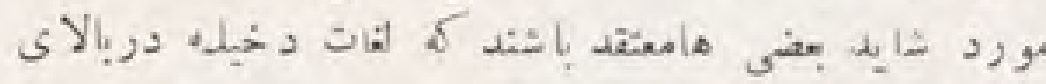

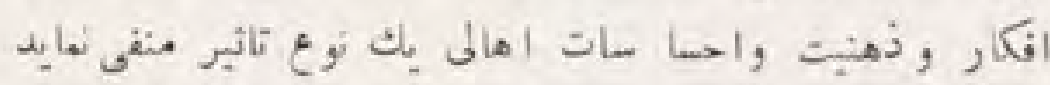

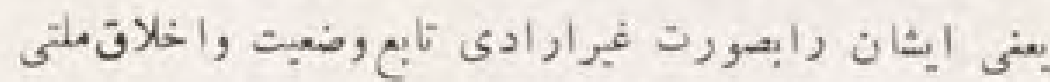

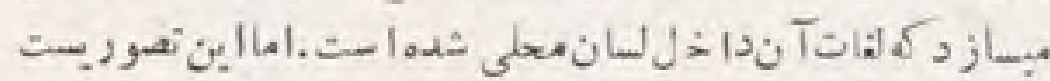

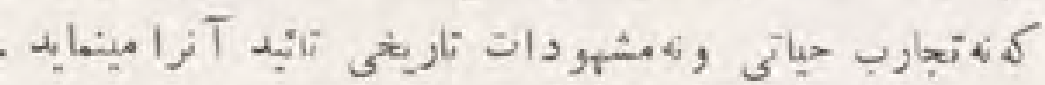

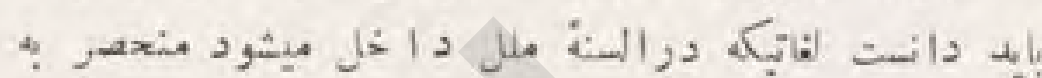

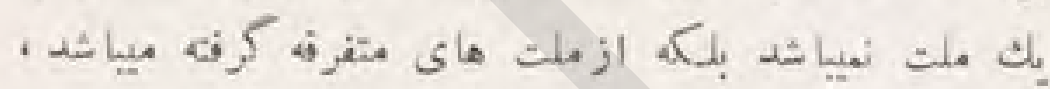

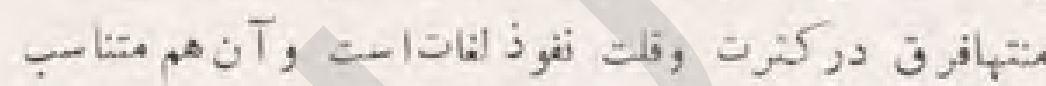

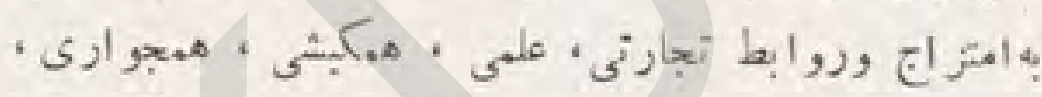

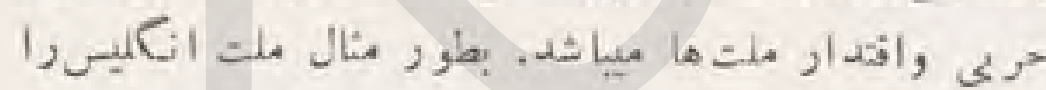

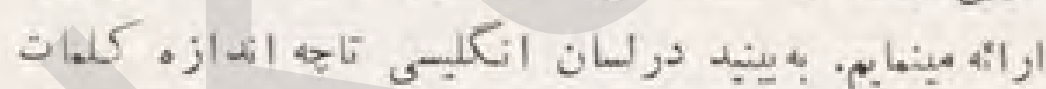

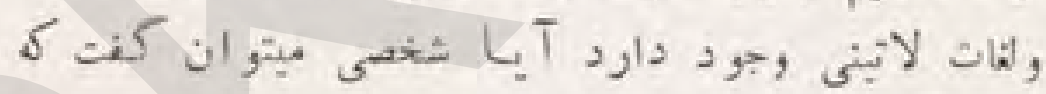

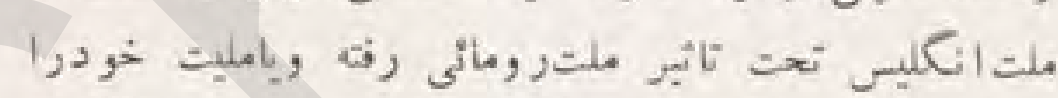

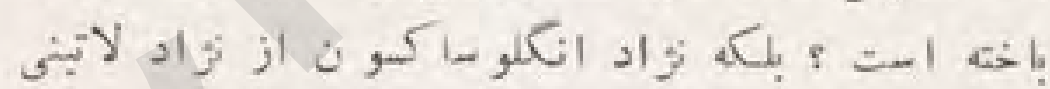

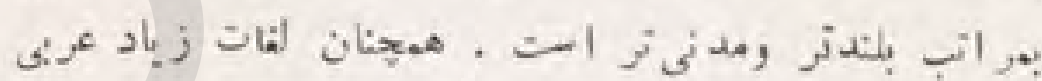

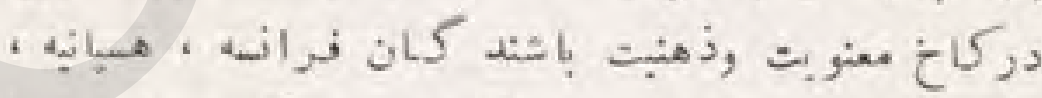

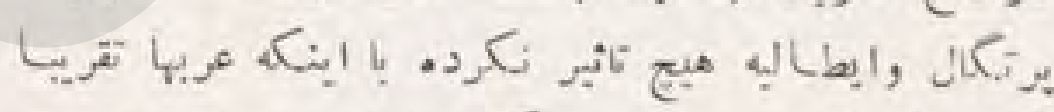
(v. (v)

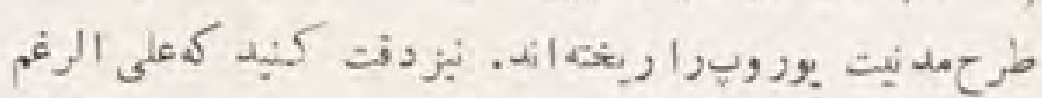

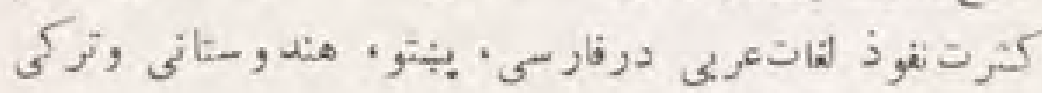

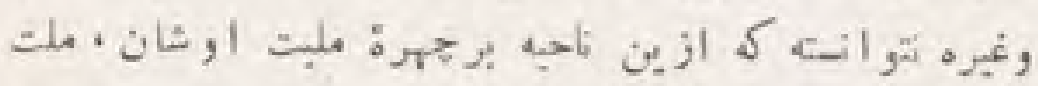

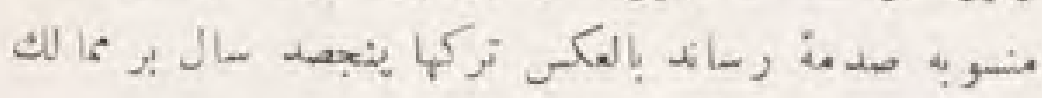

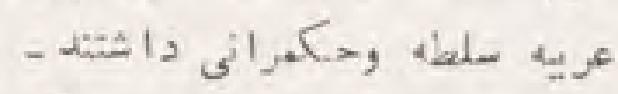

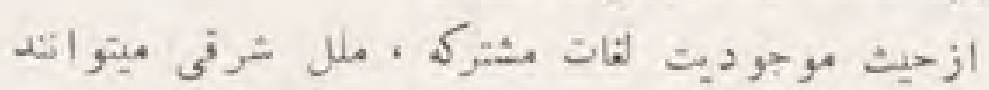

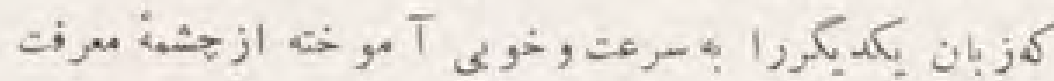

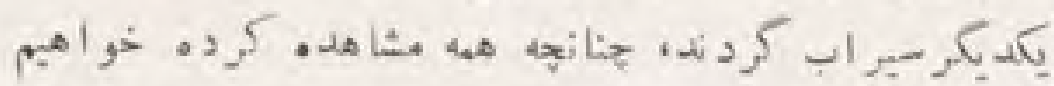

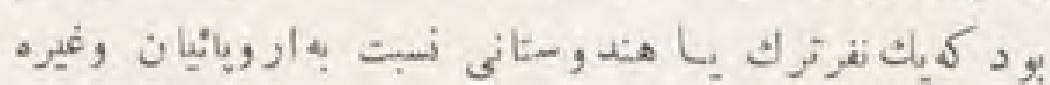

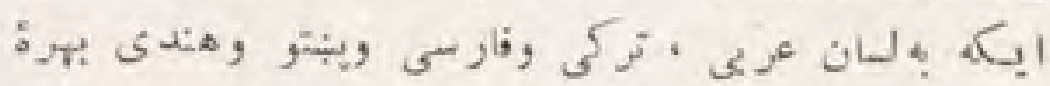

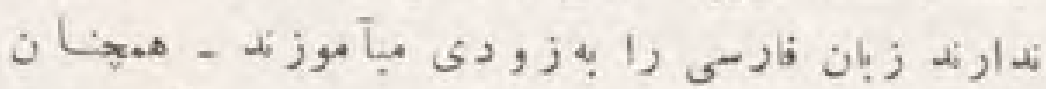

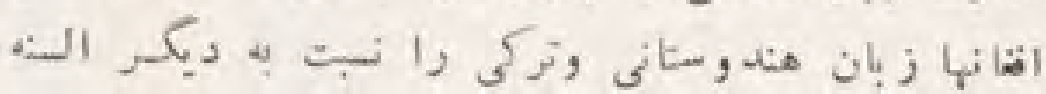




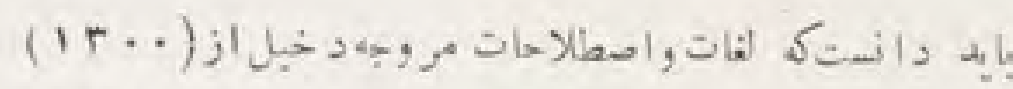

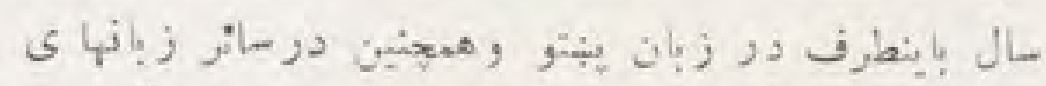

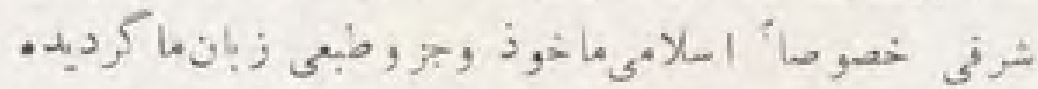

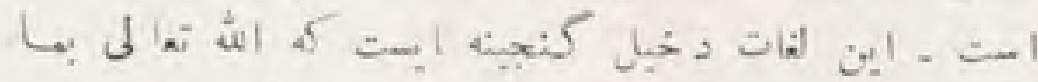

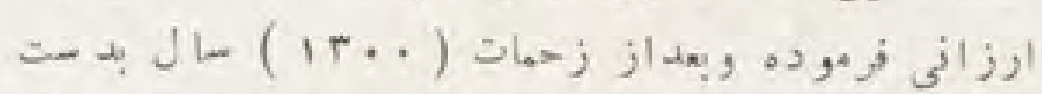

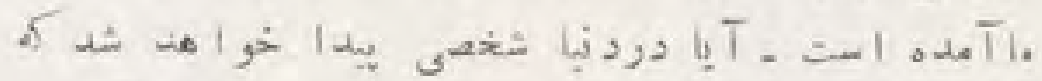

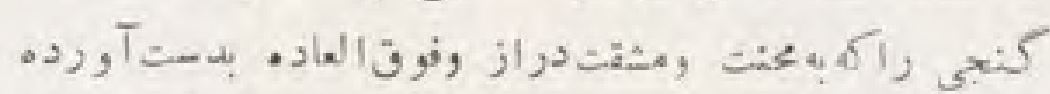

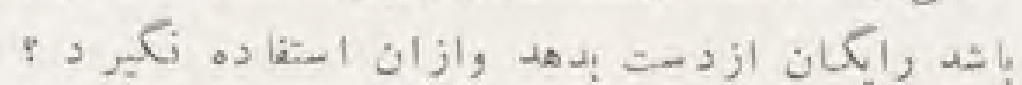

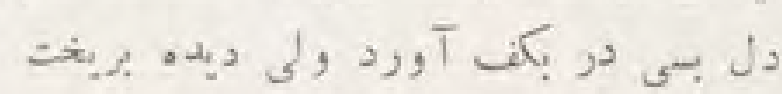

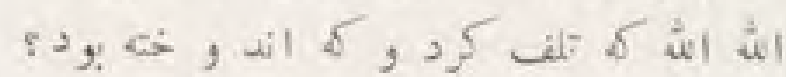

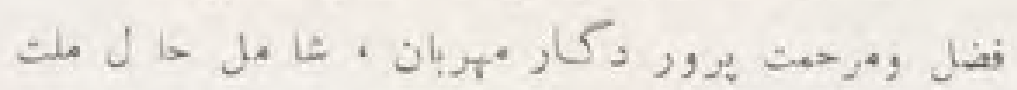

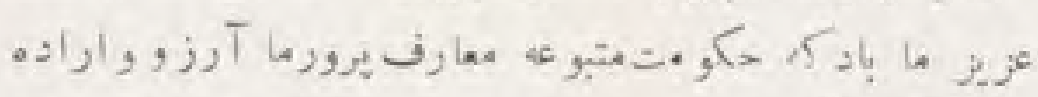

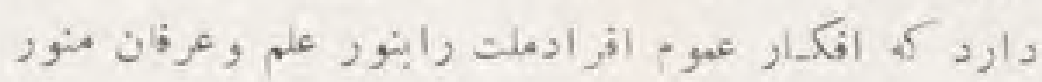

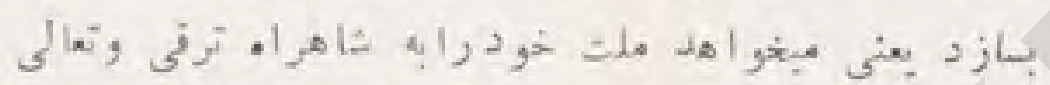

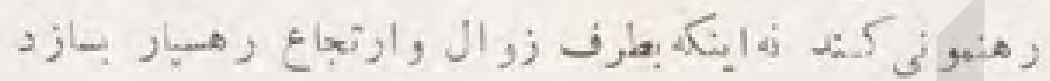

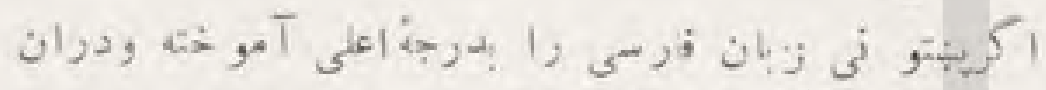

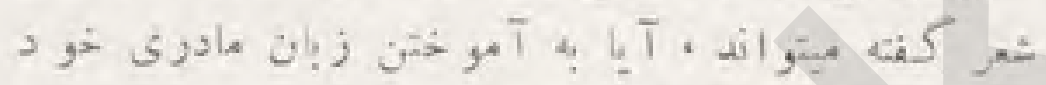

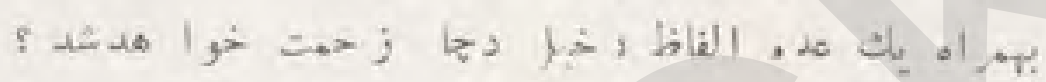

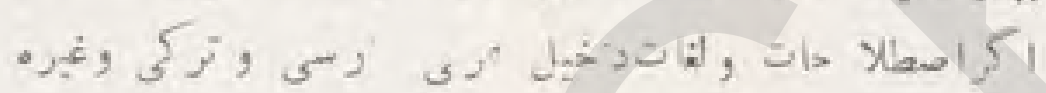

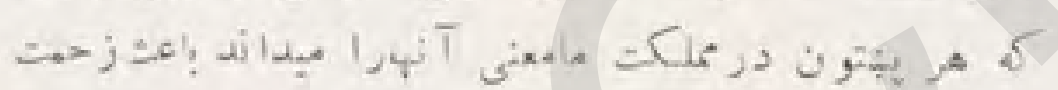

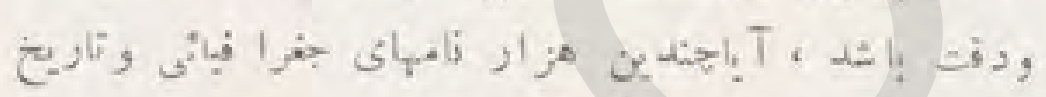

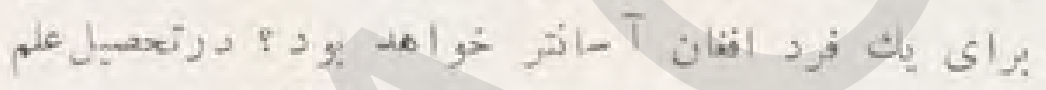

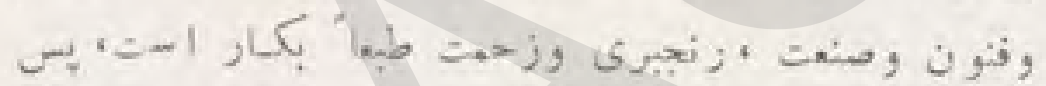

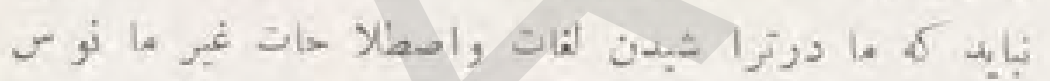

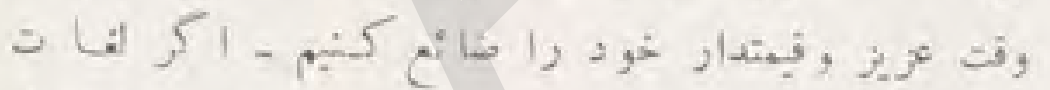

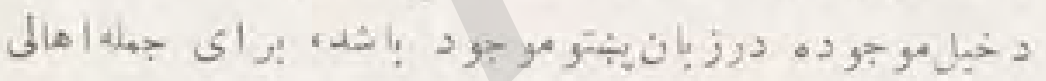

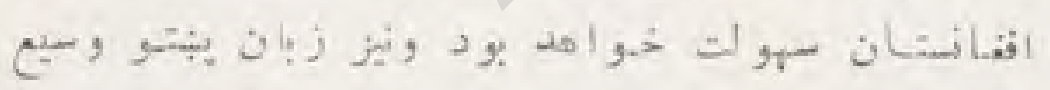

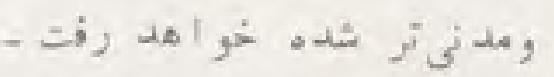

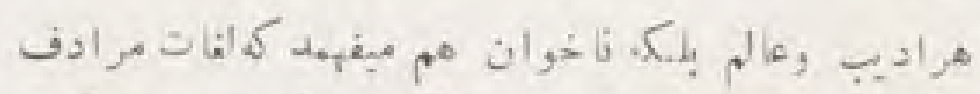

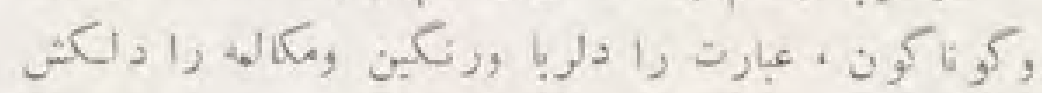

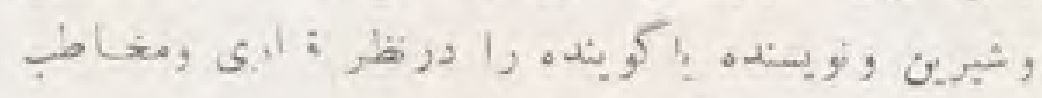

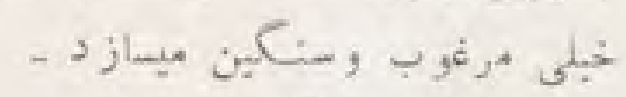

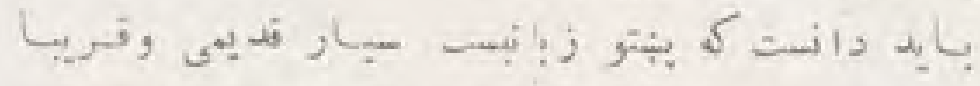

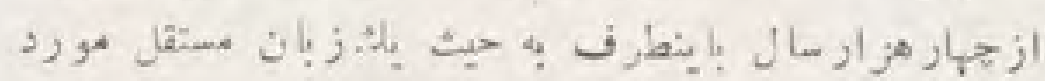

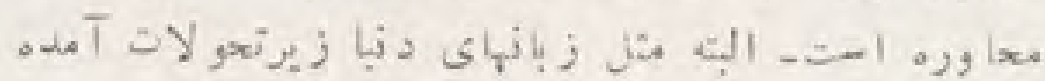

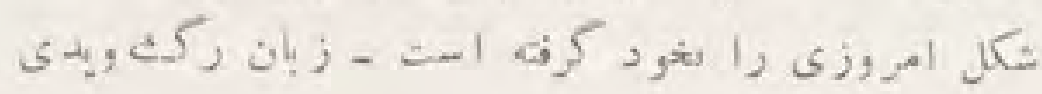

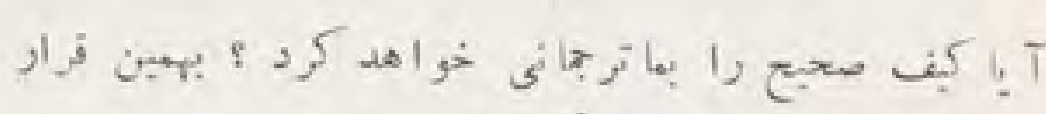

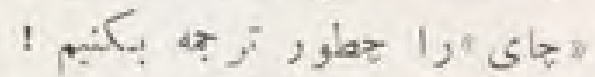

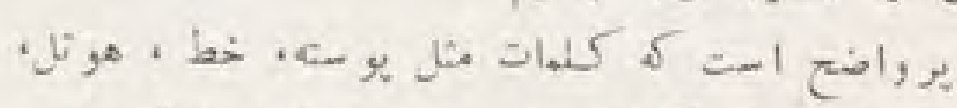

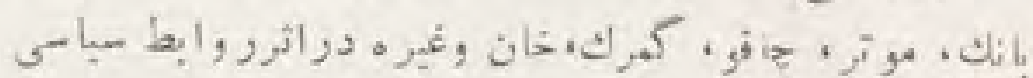

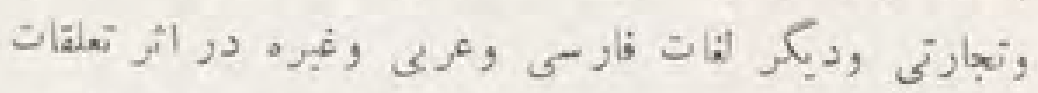

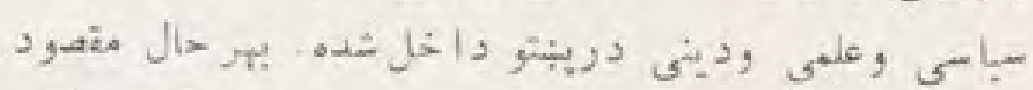

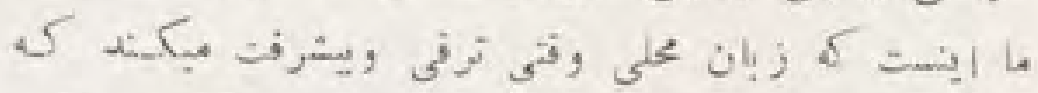

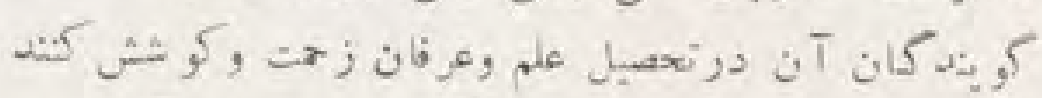

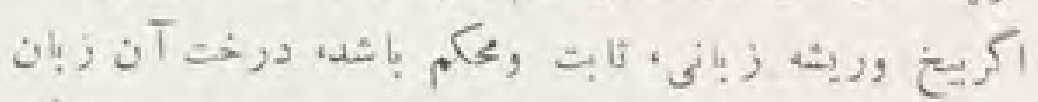

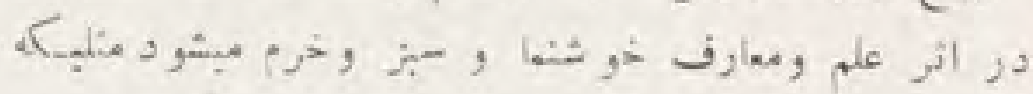

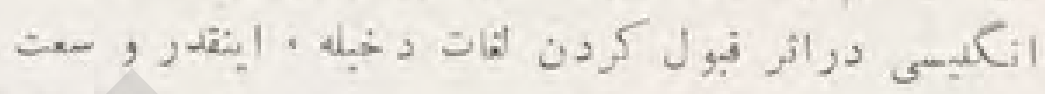

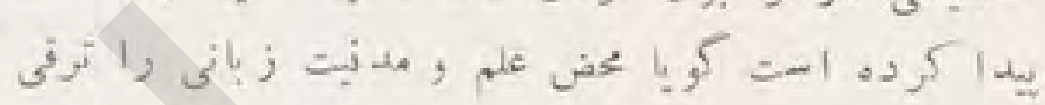

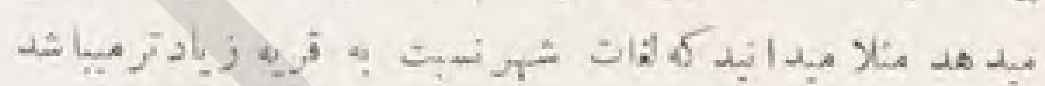

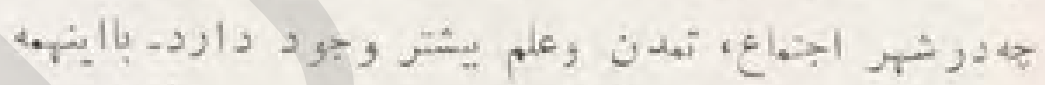

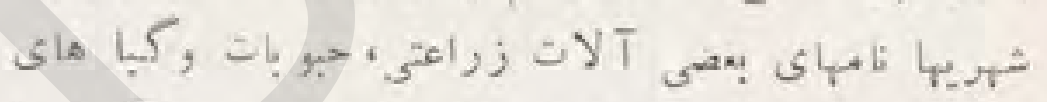

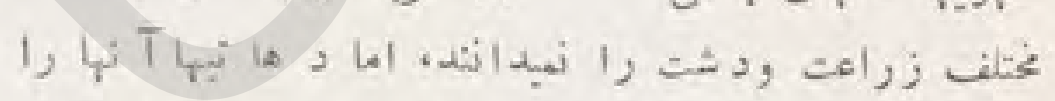

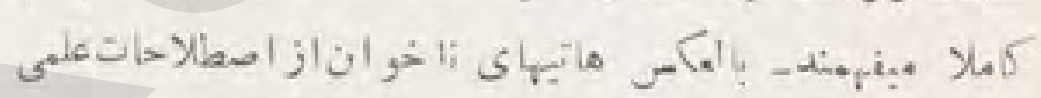

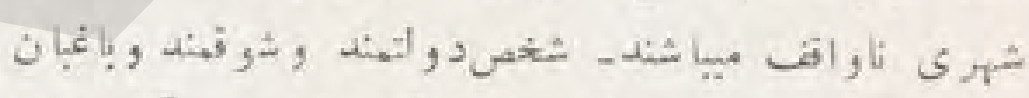

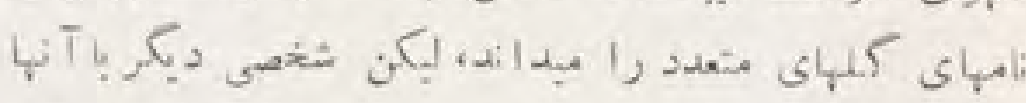

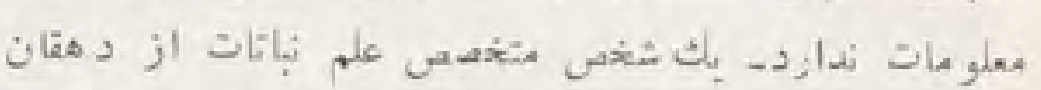

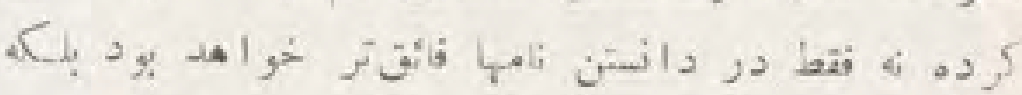

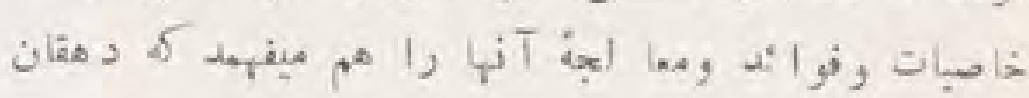

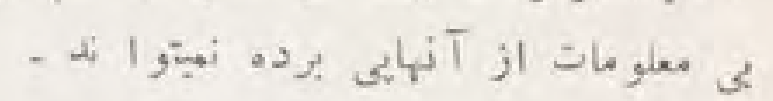

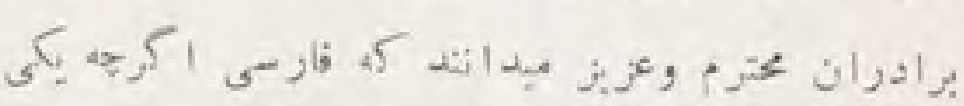

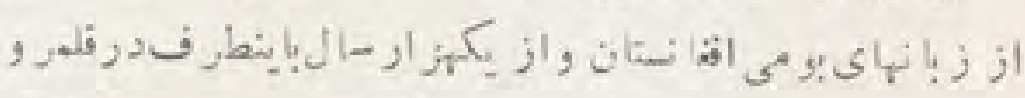

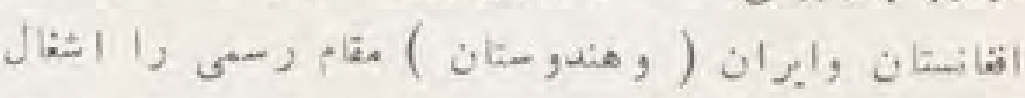

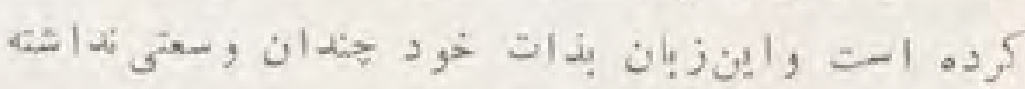

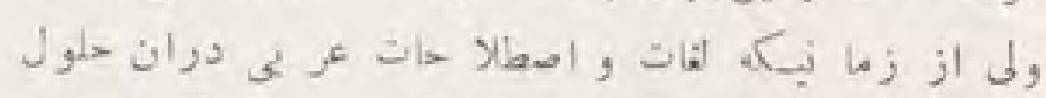

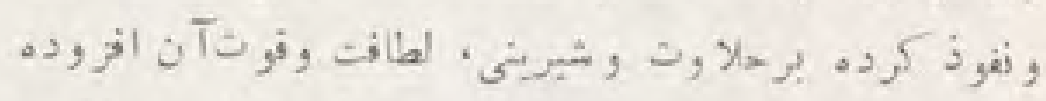

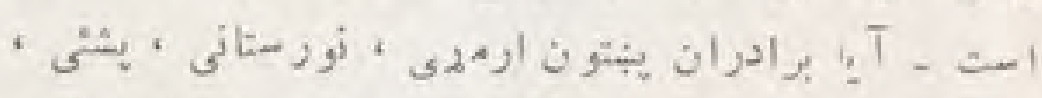

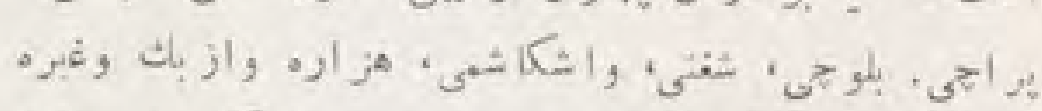

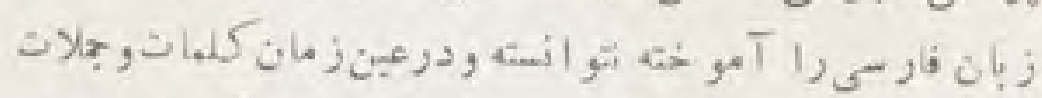

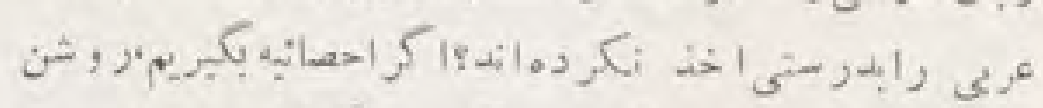

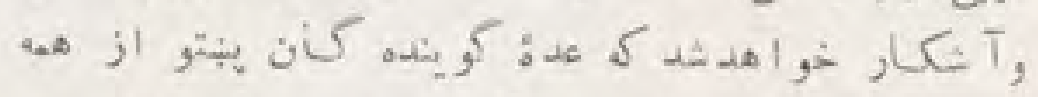

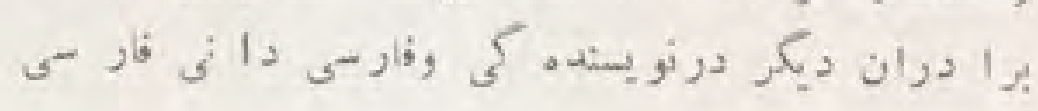




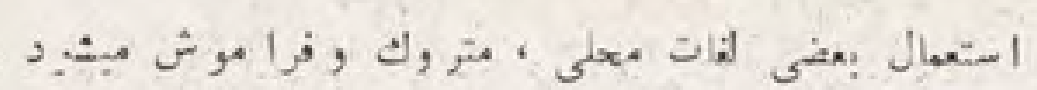

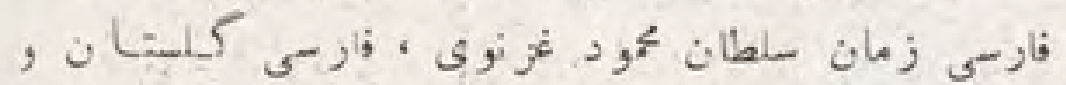

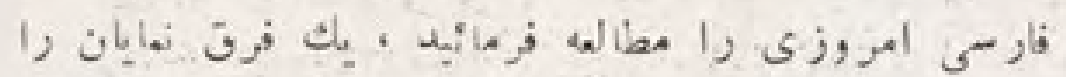

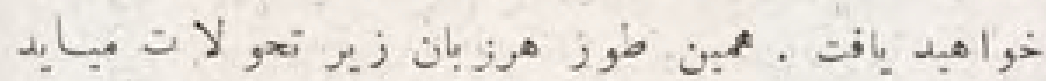

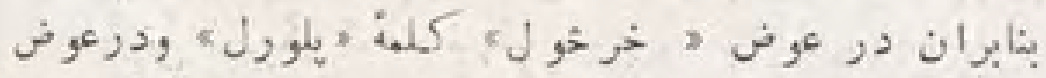

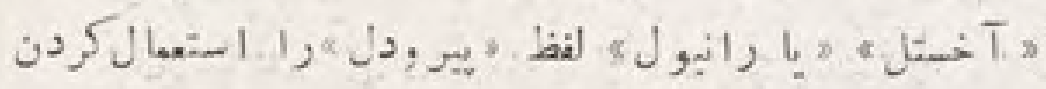

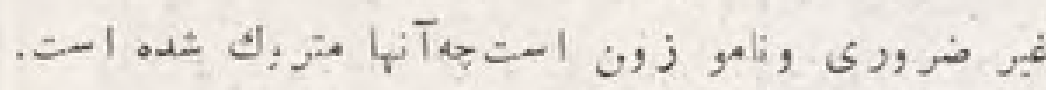

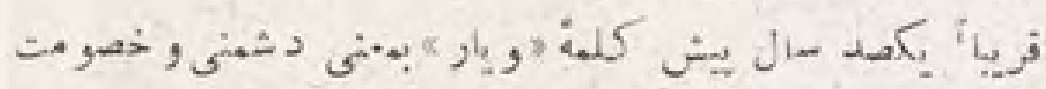

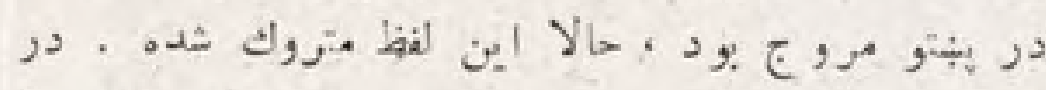

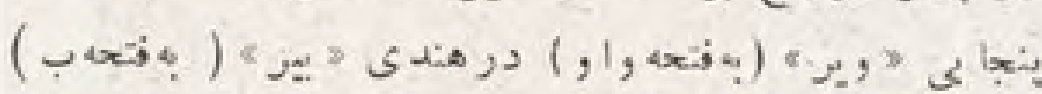

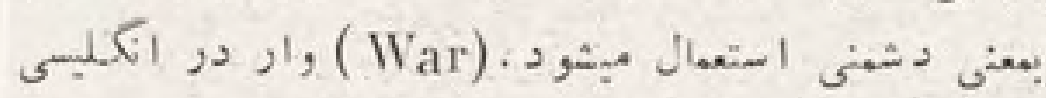

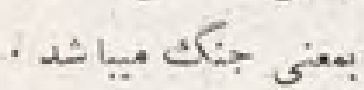

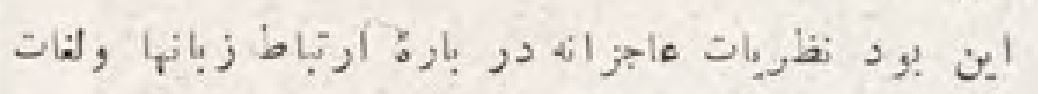

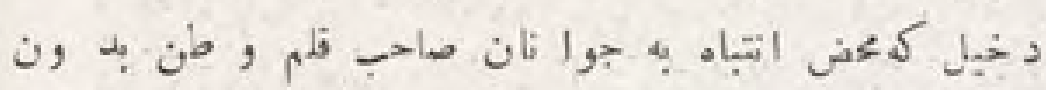

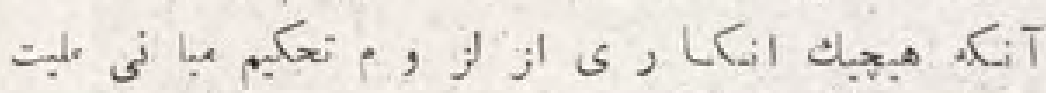

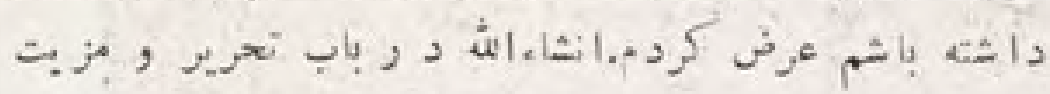

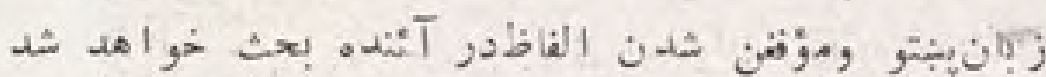

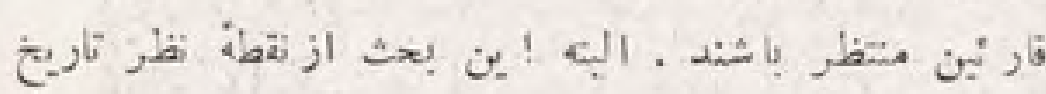

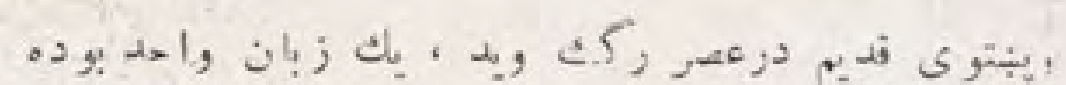

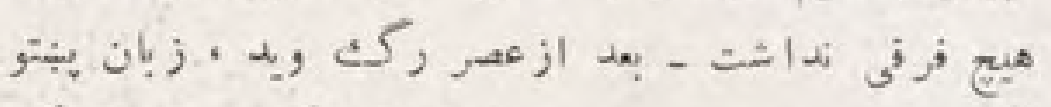

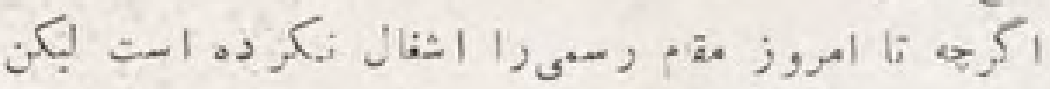
ز

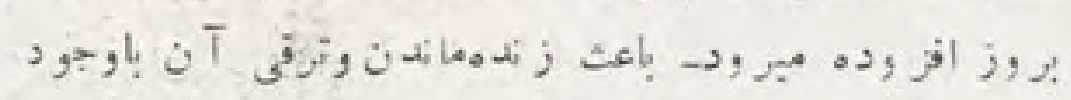

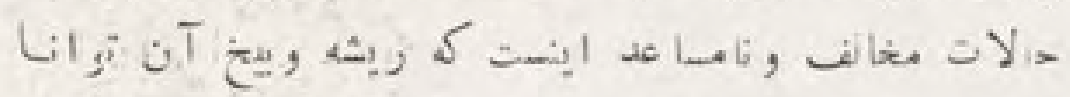

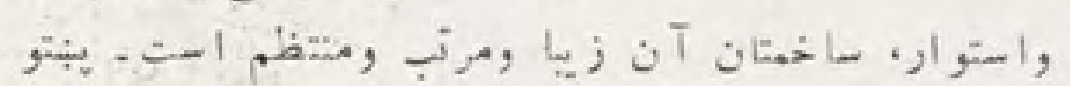

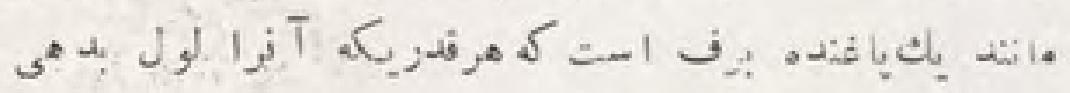

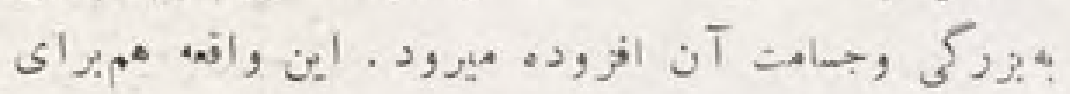

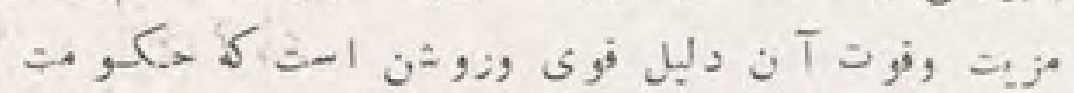

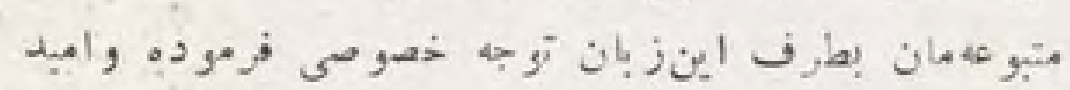

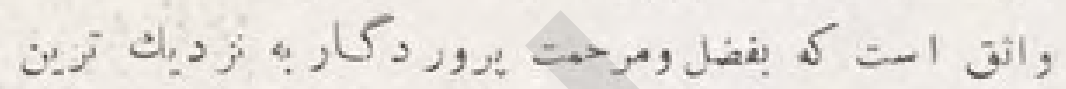

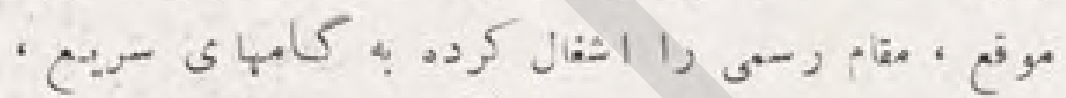

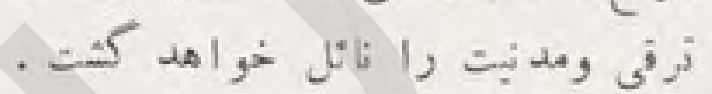

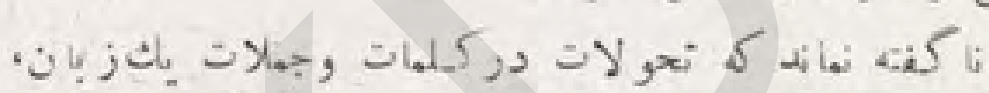

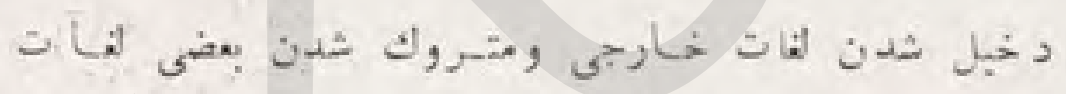

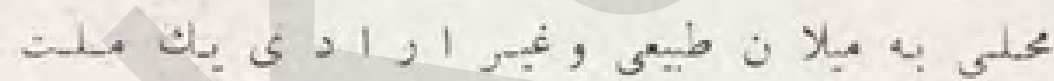

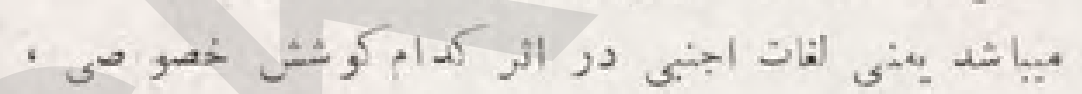

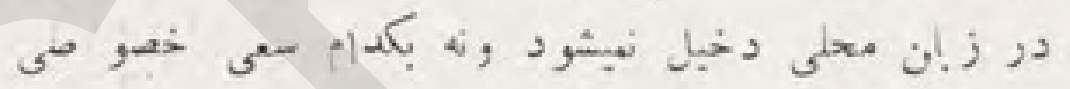

\section{هو از عمر كا هـ بلى انش فز انى}

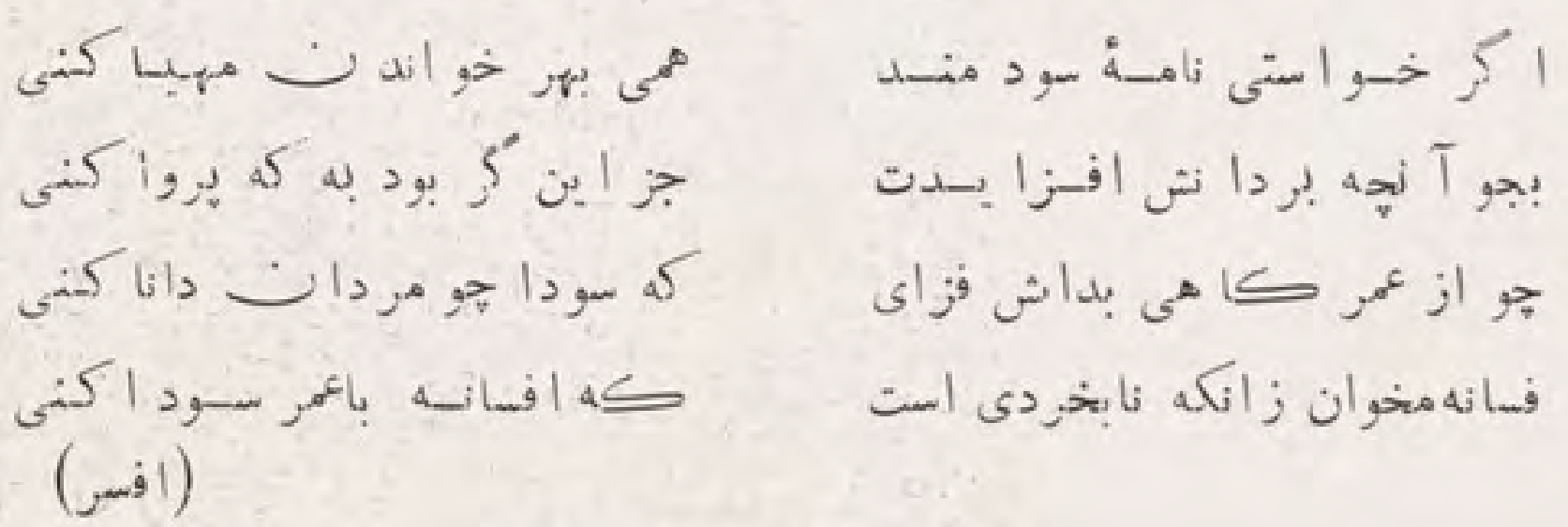




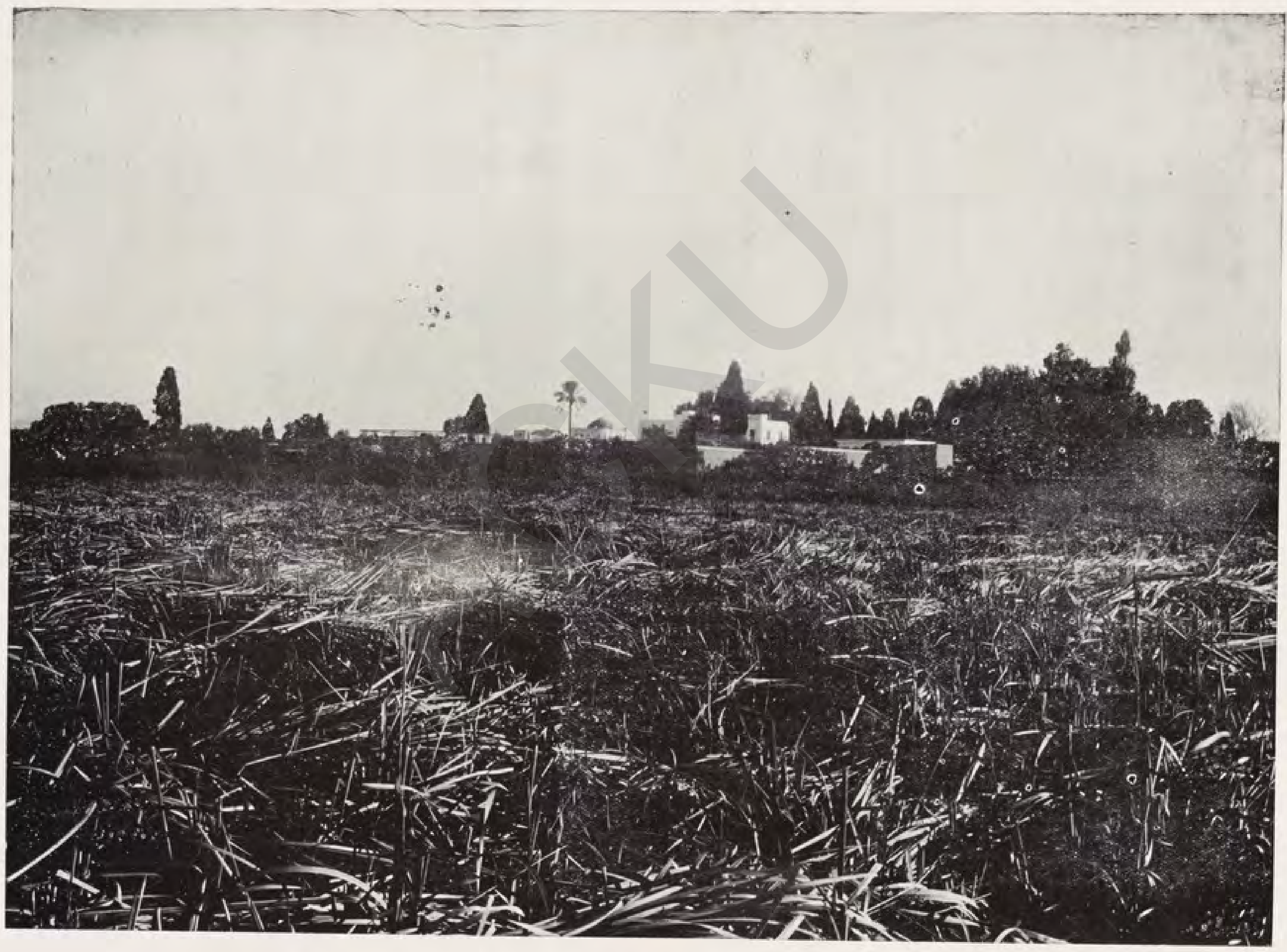




\section{S.4.

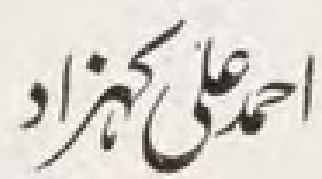

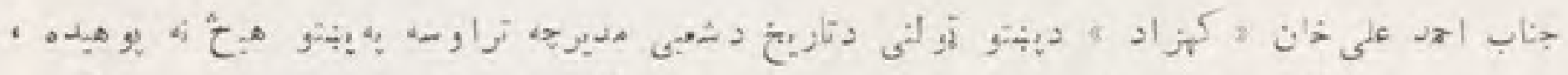

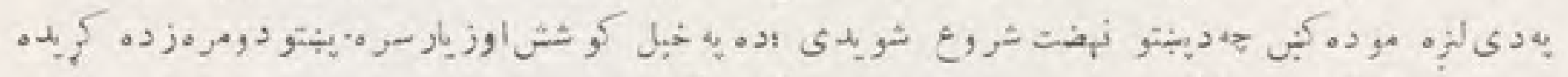

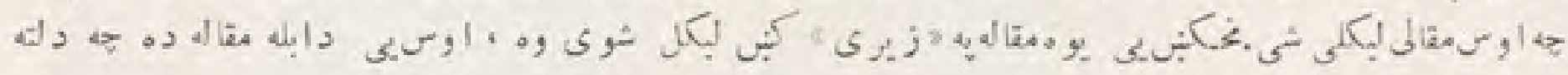

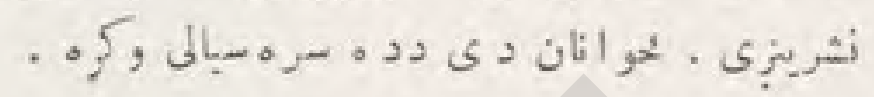

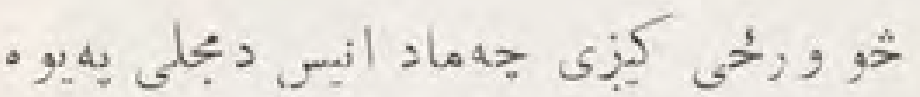

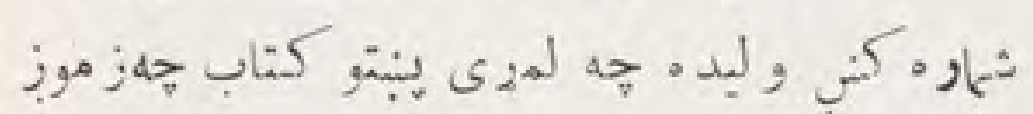
لاس آه , أغلى دى د نه

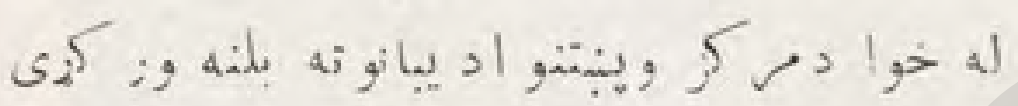
شوى و, م دبناغلى مديرصاحب انيس له وبنا خخه

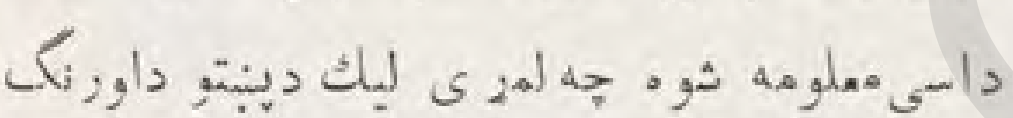

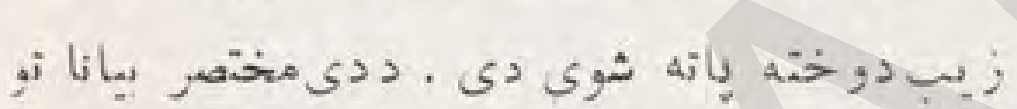

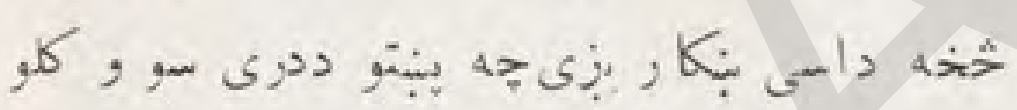

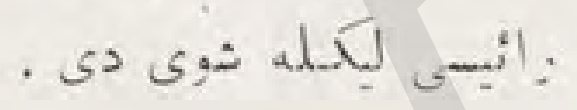

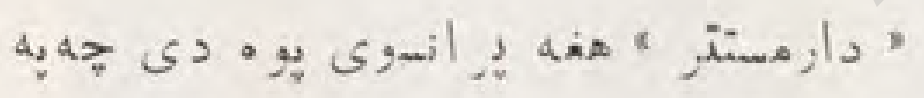

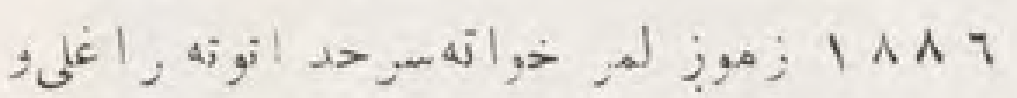

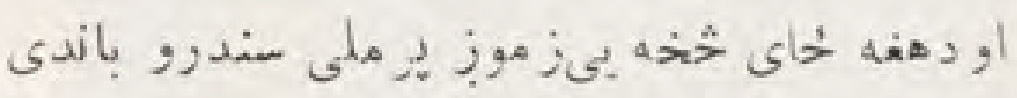
بلتزه كإى دماو هم يفي به خيل سعروف كتاب كني

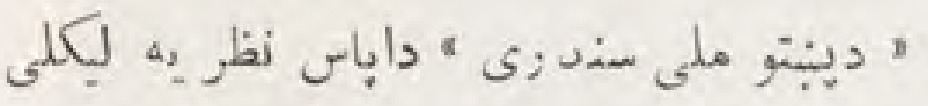

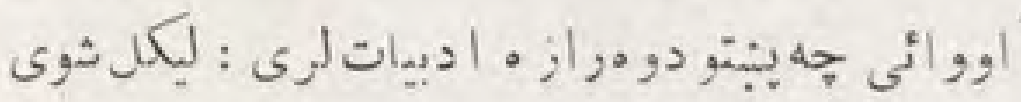

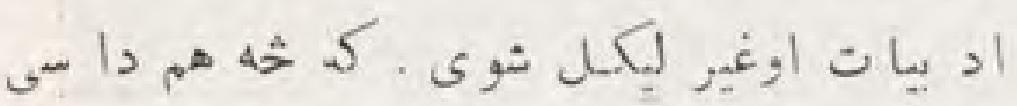

管

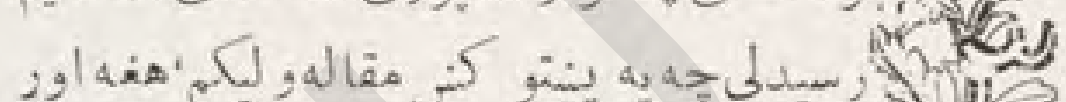

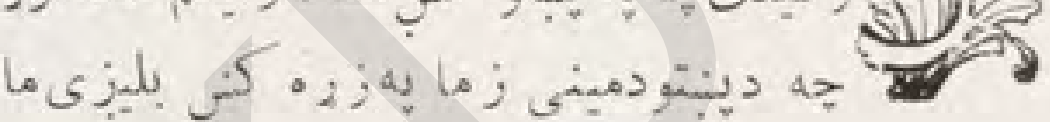

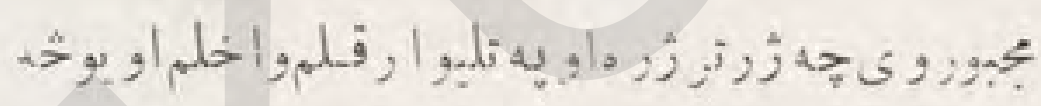

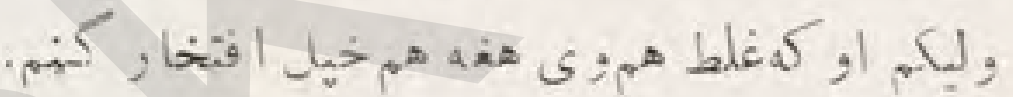

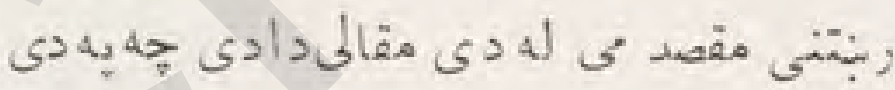

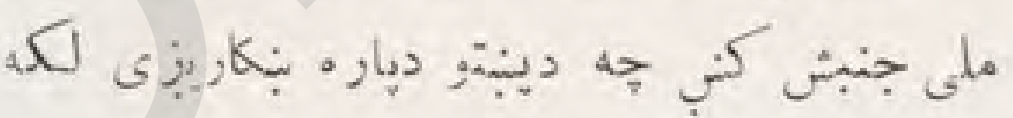

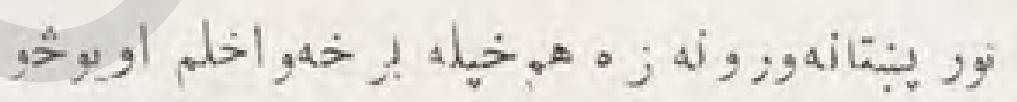

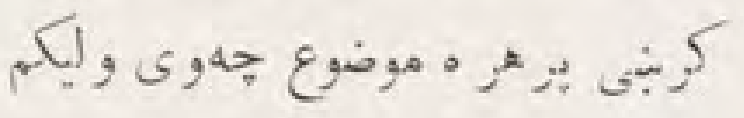
زه همى غوا2ى جها بر خهلو ملى ادبيا تو بأندى

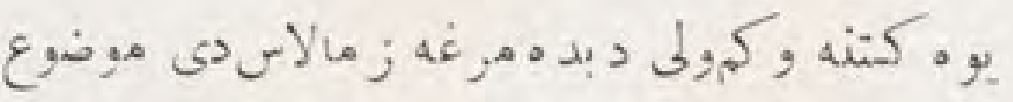

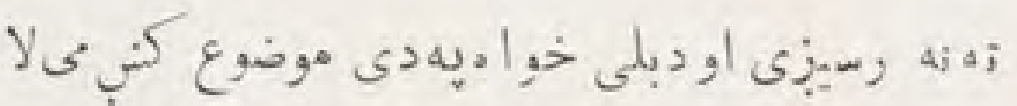

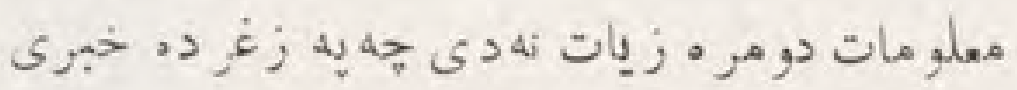

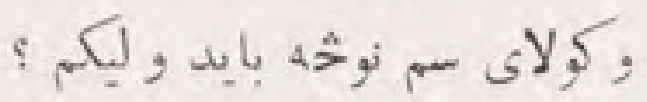

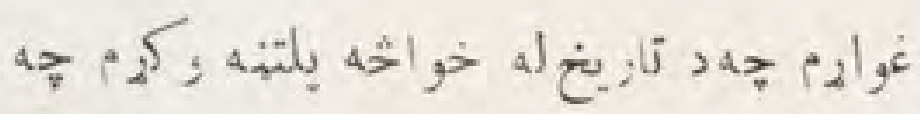

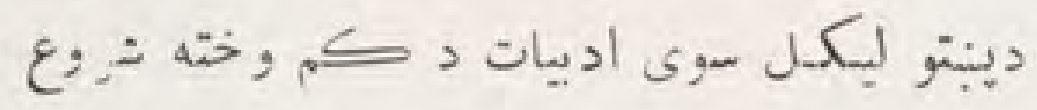

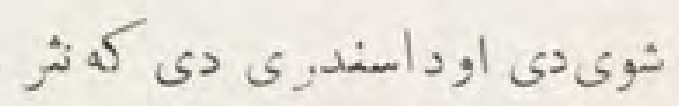




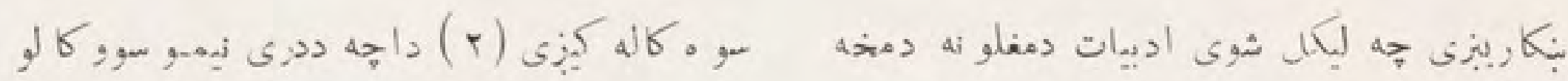

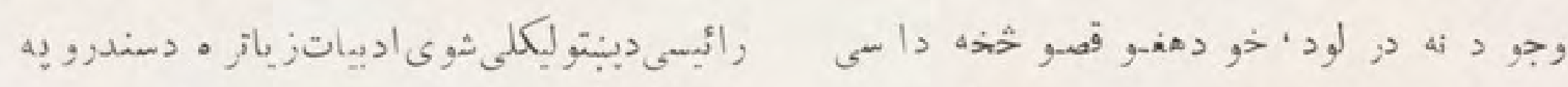

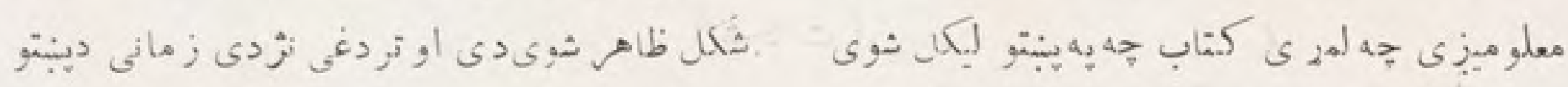

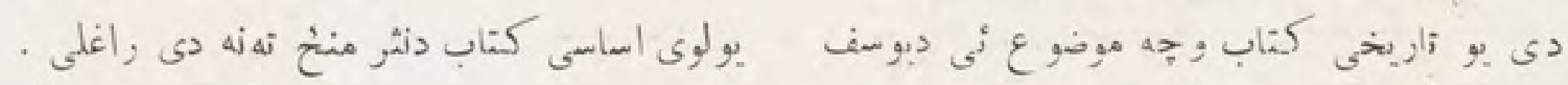

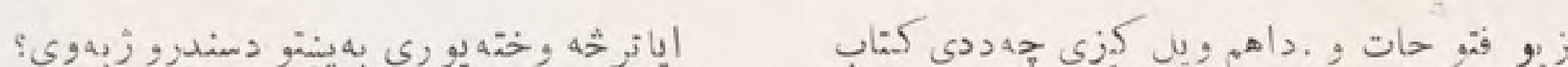

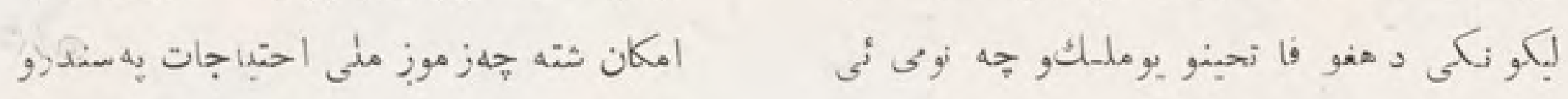

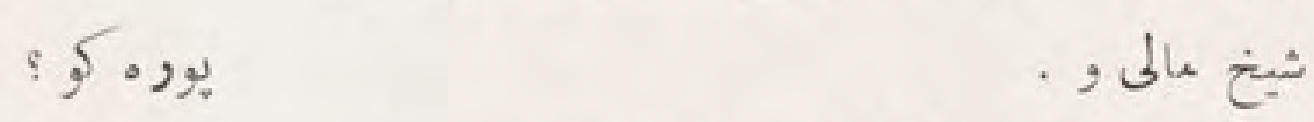

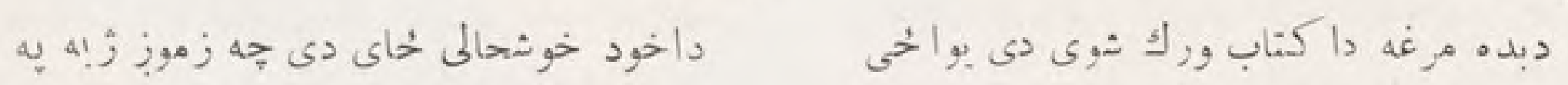

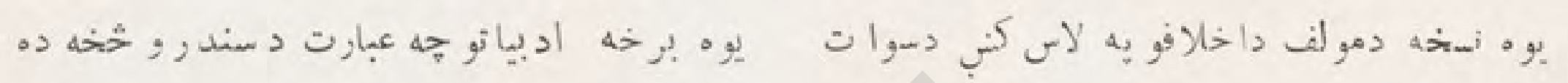

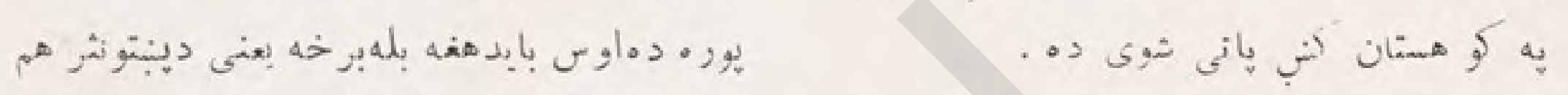

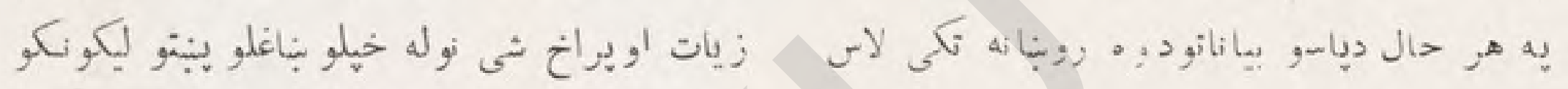

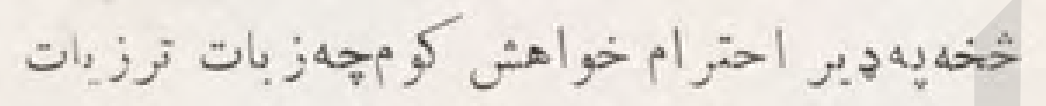
- : إخى

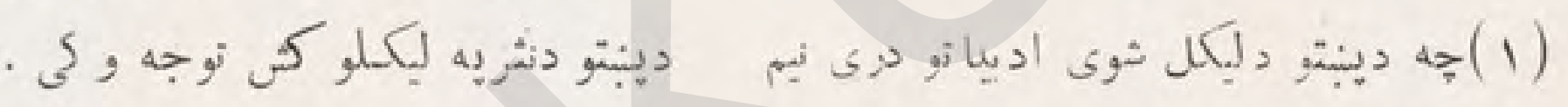

\section{}

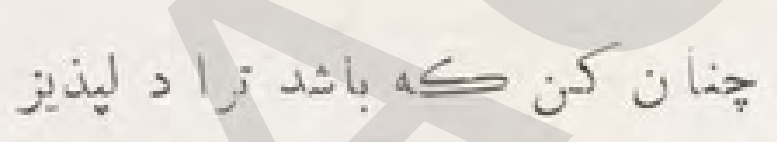

טָּח

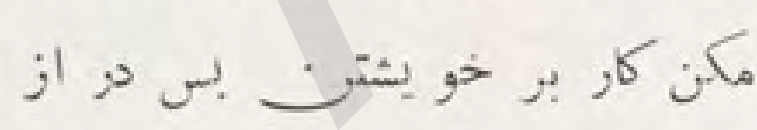

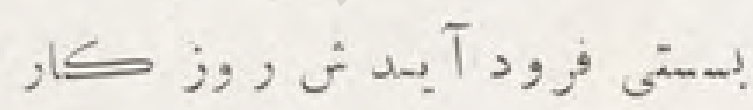

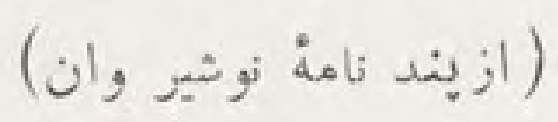

$$
\begin{aligned}
& \text { جو خواهى كه كارى كنى نا كز ير }
\end{aligned}
$$

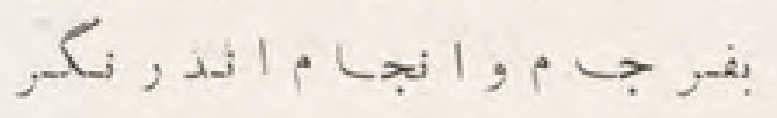

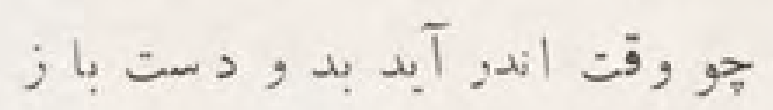

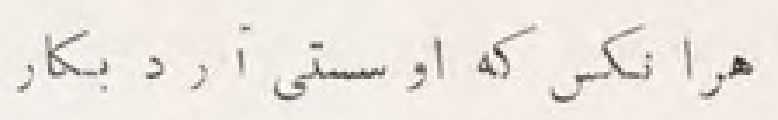




\section{(ij, $0, j$ \\ ( شجاءت )}

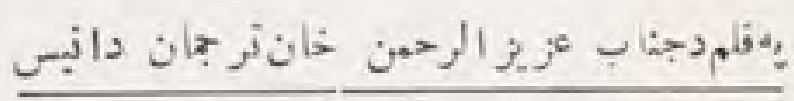

ثي داسى خلقو ته به ميدان كنب دعمل غمونه او

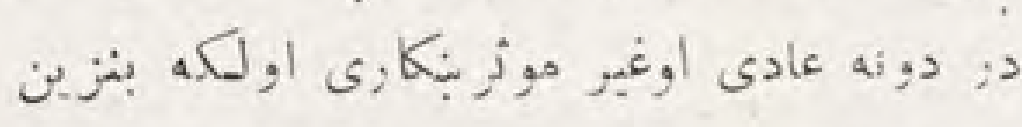

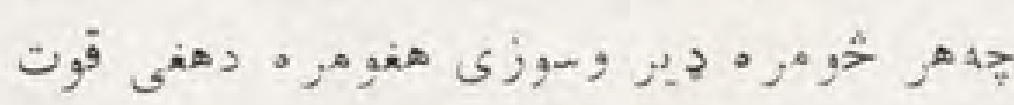

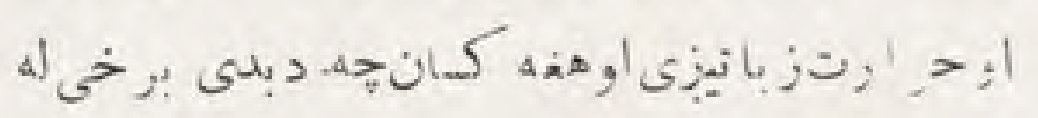

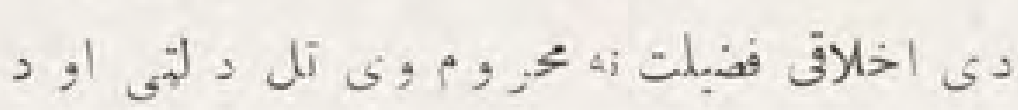

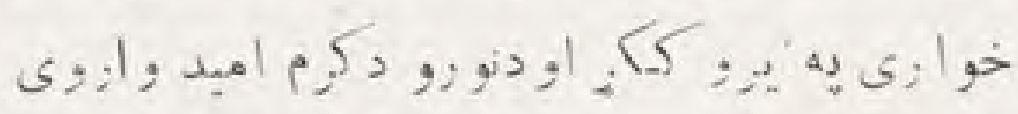

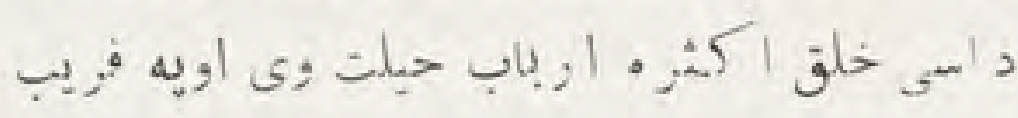

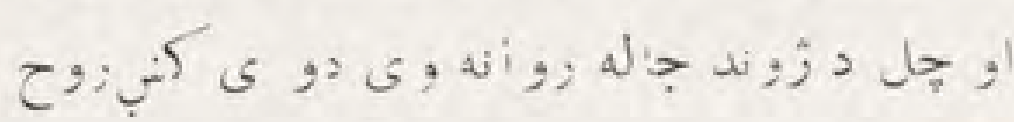

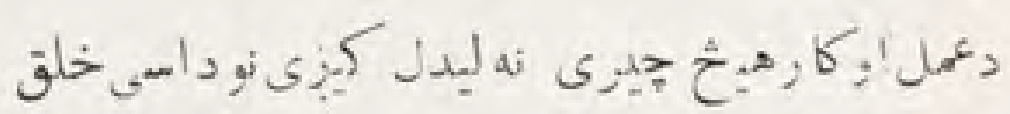

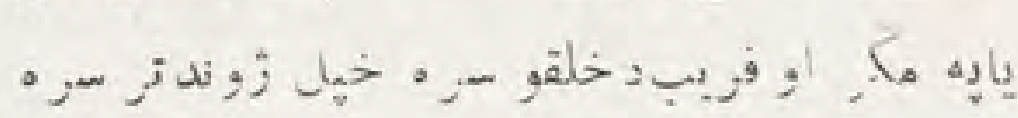

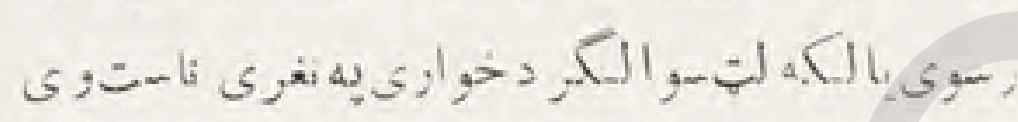
داسى خلق د رزيلت خاوندان اودجاهعى دبنمهنان

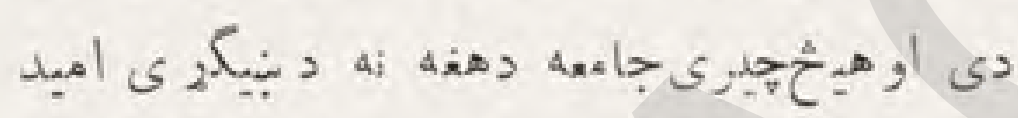

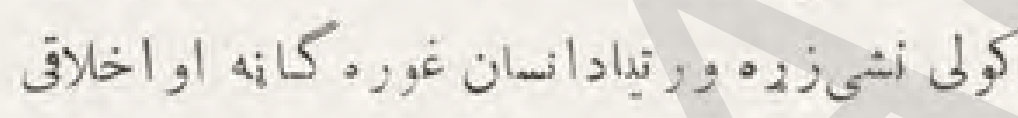

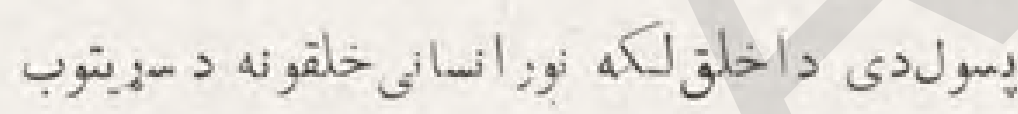

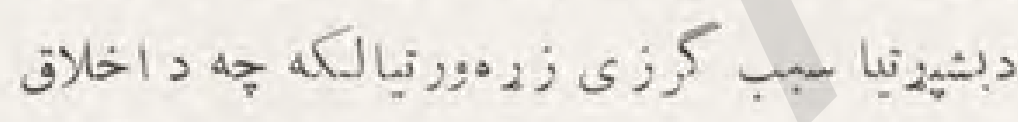

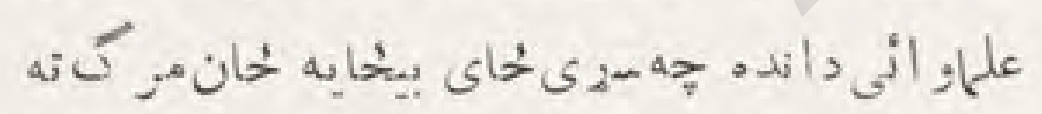

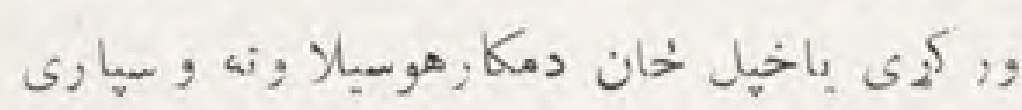

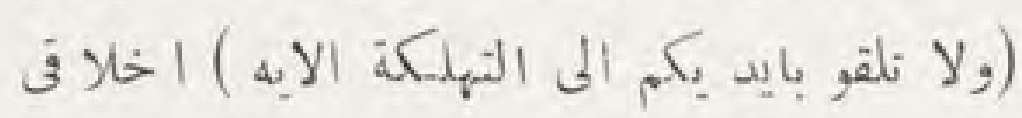

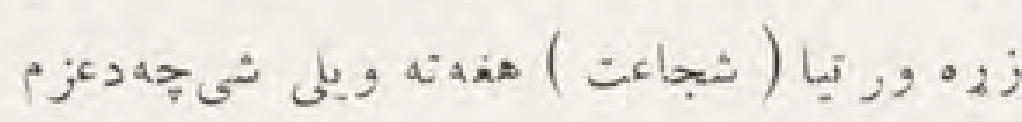

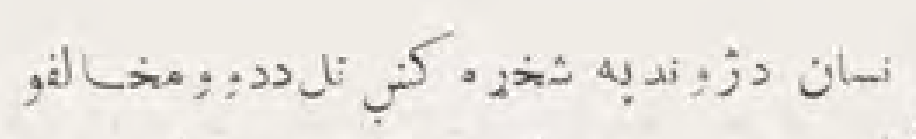

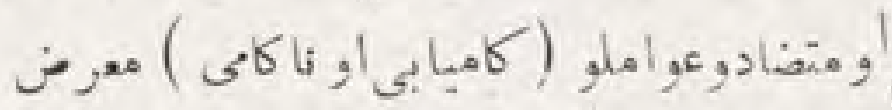

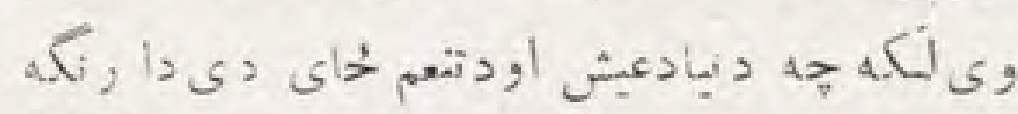

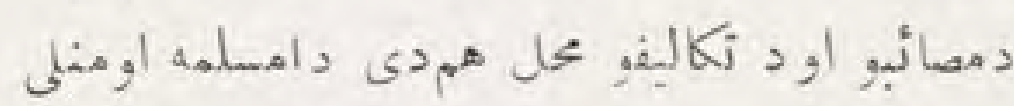

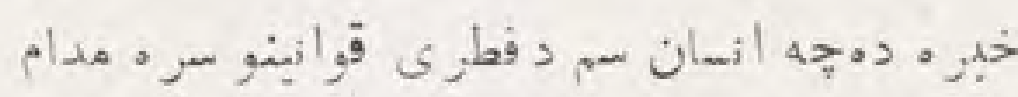

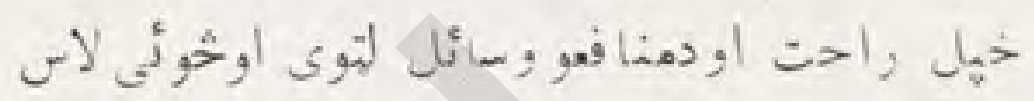
,

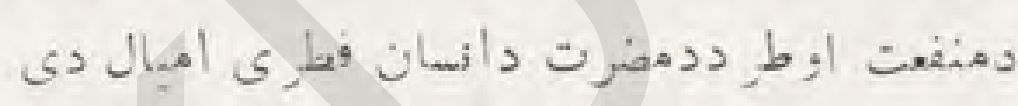

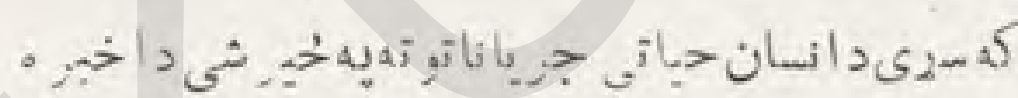
مآن خो

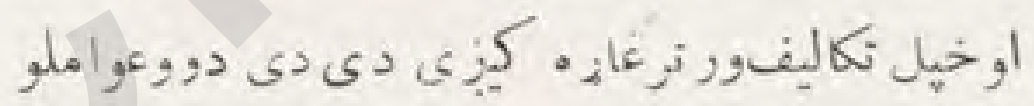

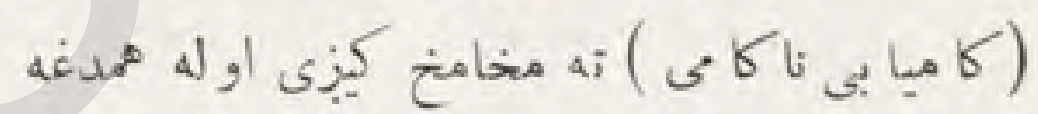

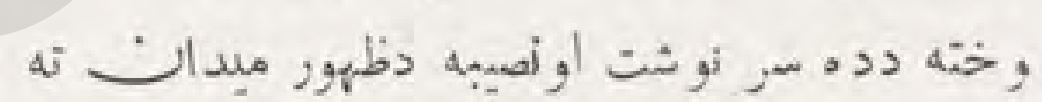
راوخى دى به بازيه ور اوقوى الار ادميابه جبون

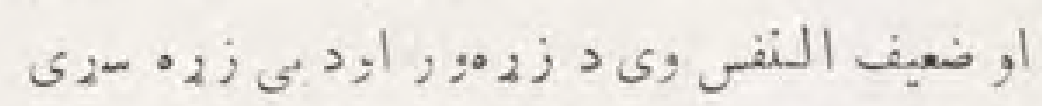

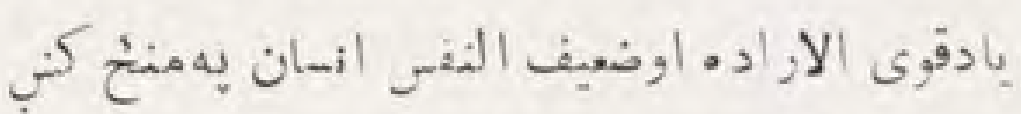

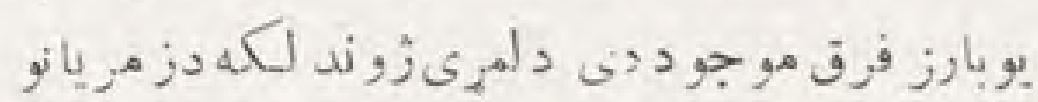

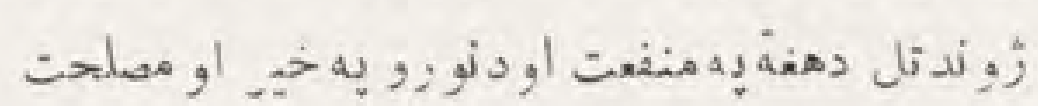

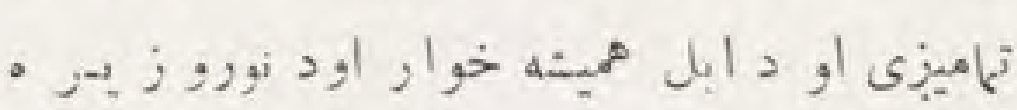

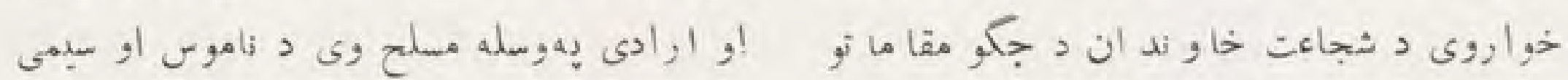

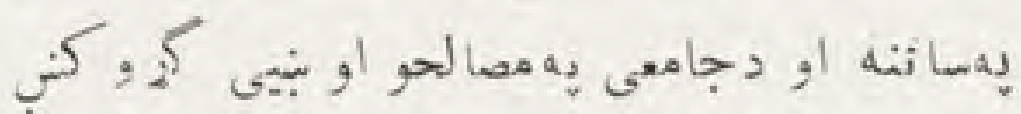

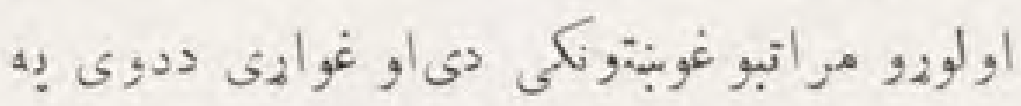

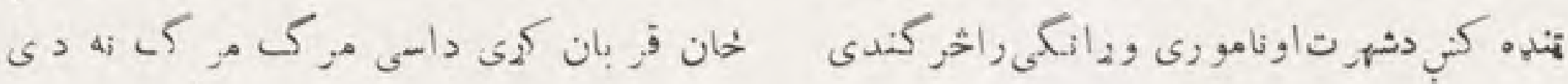




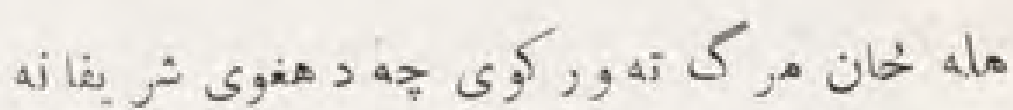

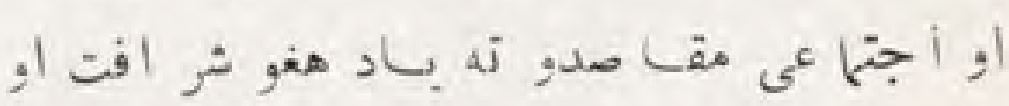

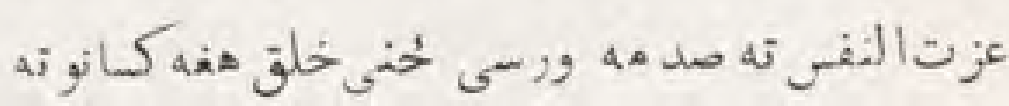

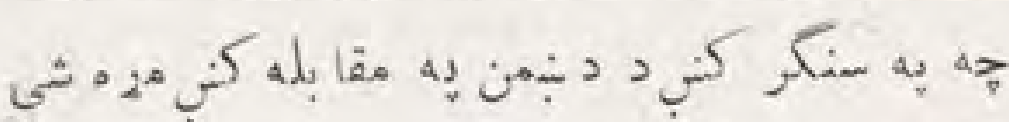

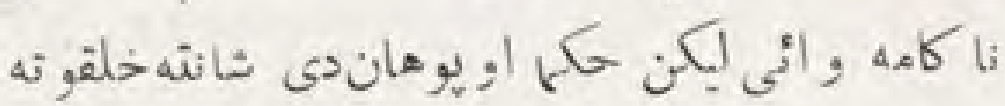

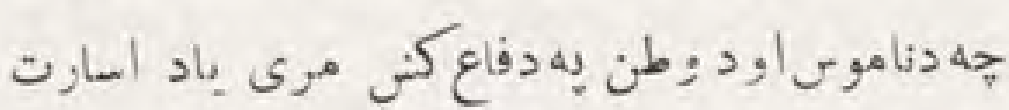
او: :هر ئيتوب دزو ندنه غانه غنوى حقيقى فا نحين

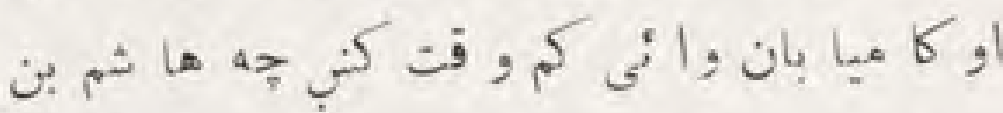

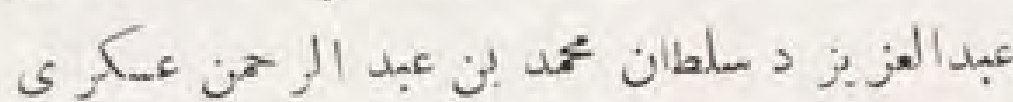

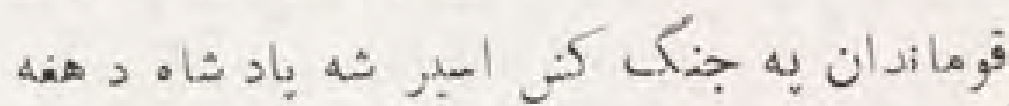

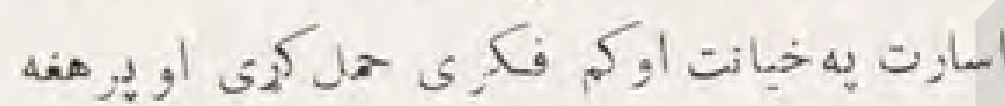

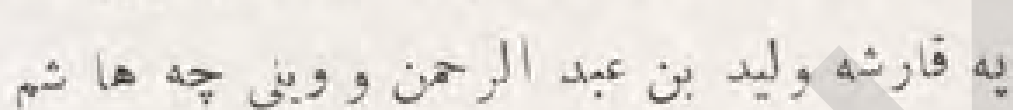

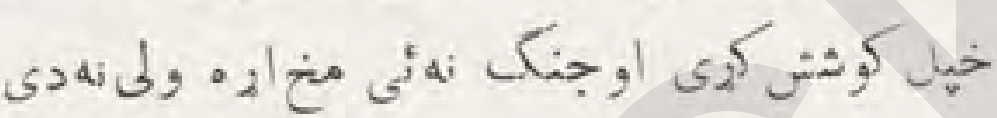

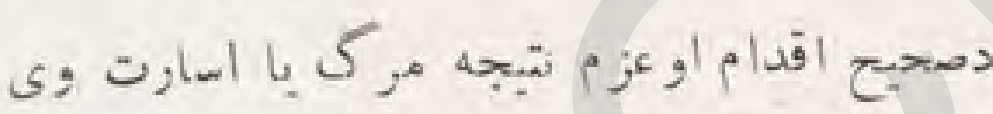

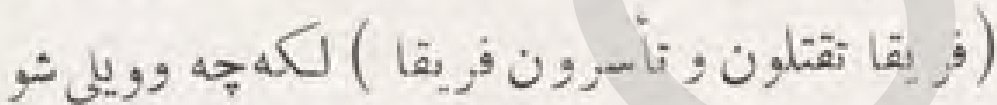

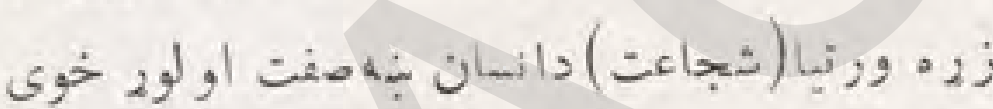

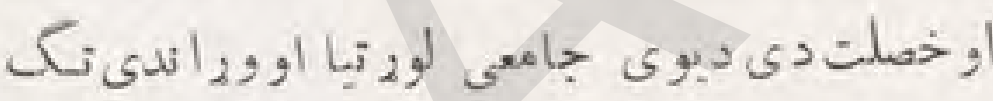

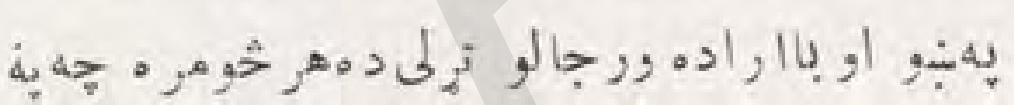

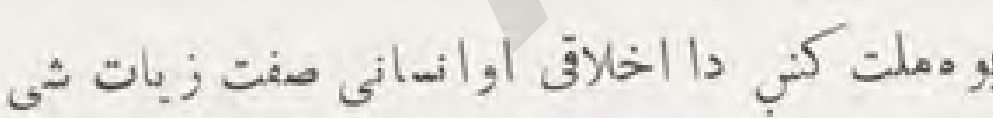
هرو مرو دهغي جامعى عظهت او آمد نى حالت

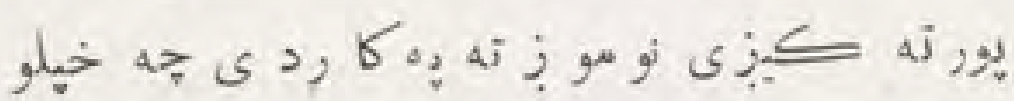

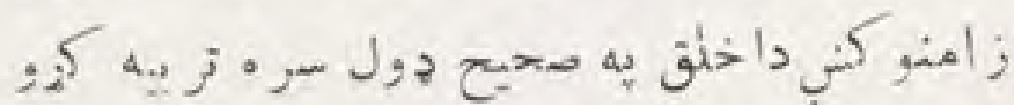

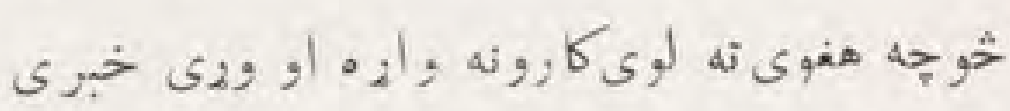

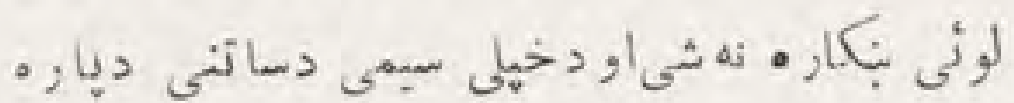

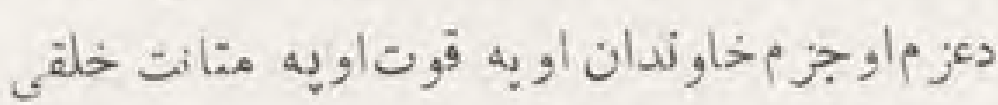

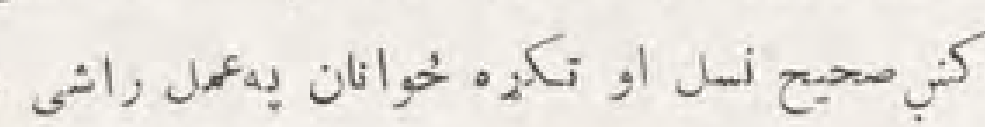

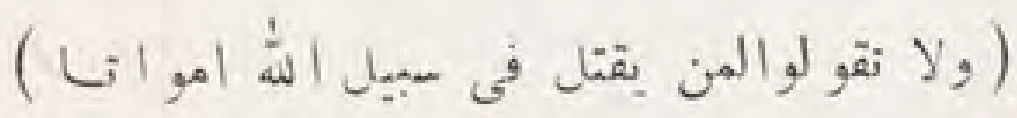

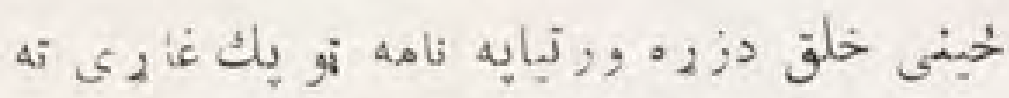

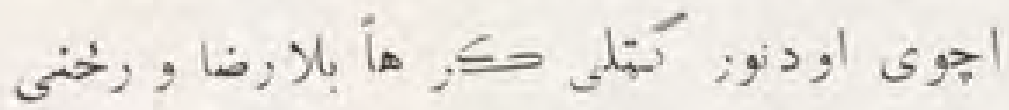

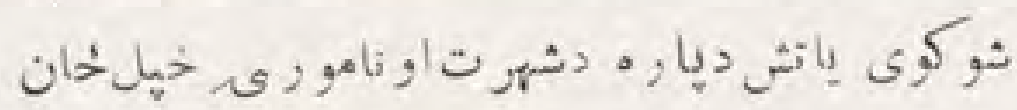

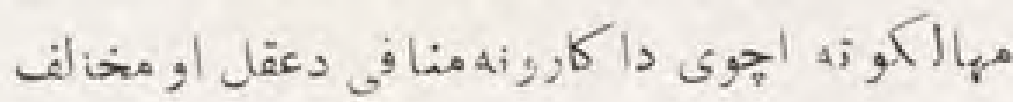
داخلاق ودى اوداسى خلق ظلهه اوار بابتهور

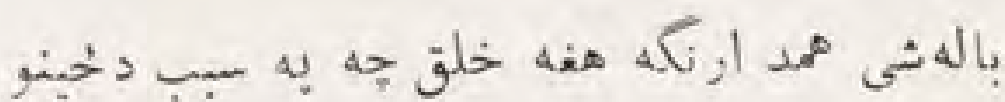

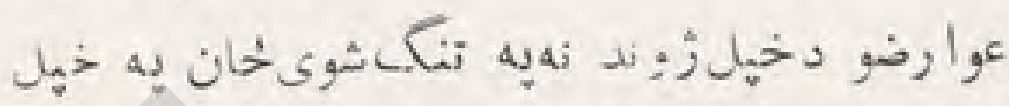

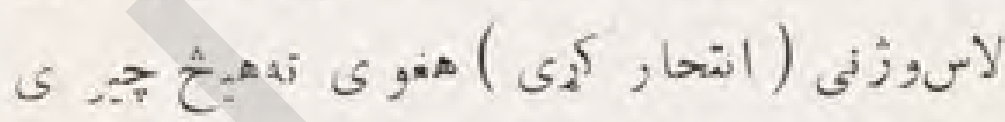

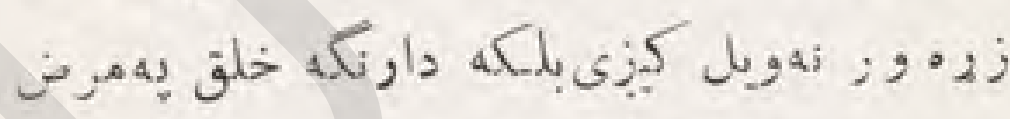

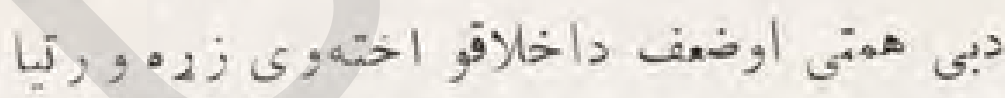

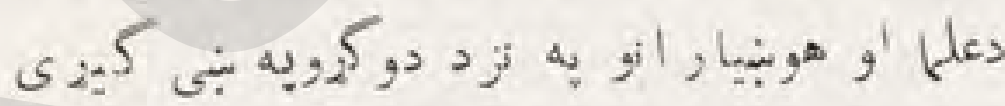

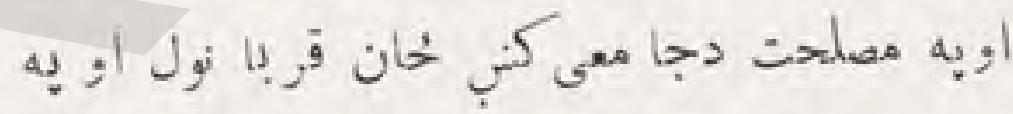

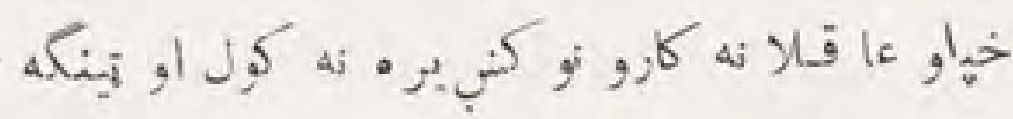

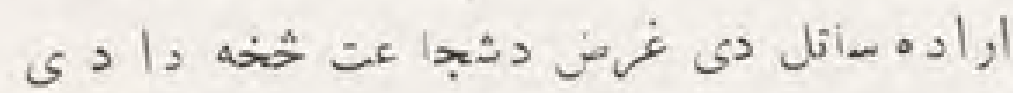

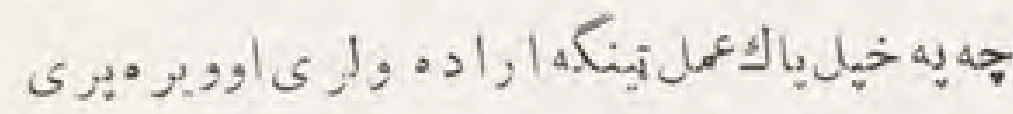

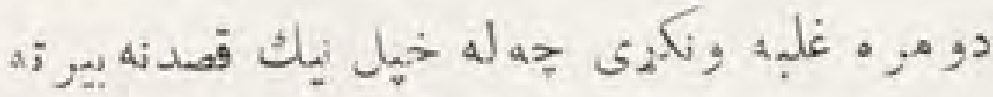
وا تيشى يه بل عبارتسر مكاز دهموكئى او خهل

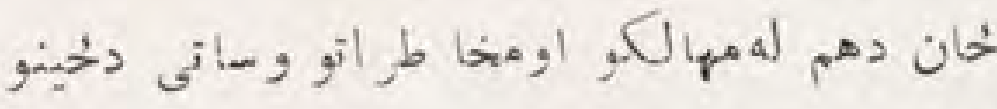

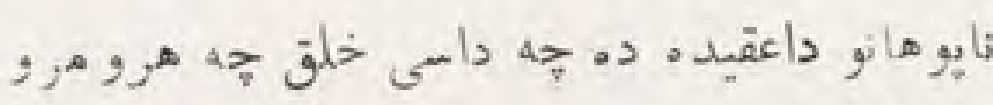

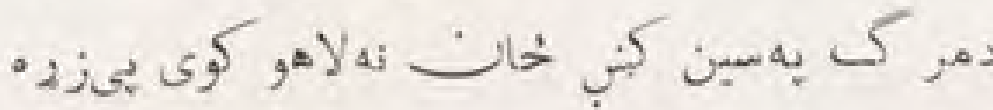

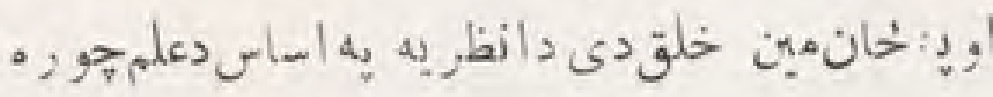
غلطه ده دشجاعت خاوندان جه خيلو عملونو كن به تعقل او احتباط سر م تله كيى أودبنىخايه هره

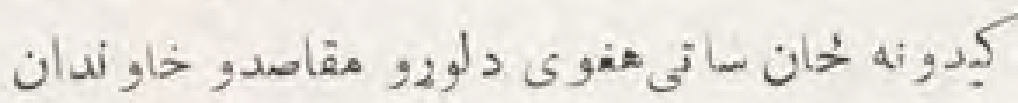

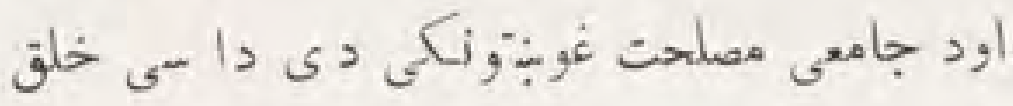


اوتباس ازاور يتّل مبكزين

\section{Guat a $6, \mid$}

و در آخر جلد دوم طبقات درج زمود كرحجه اعادئ

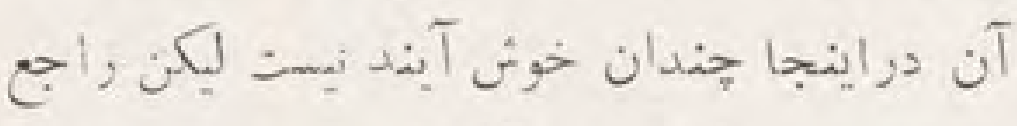

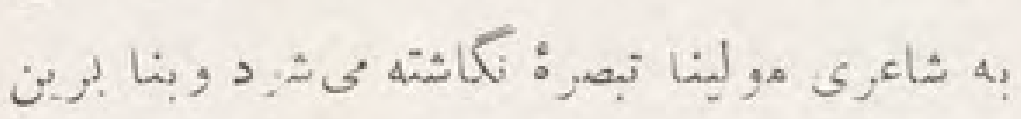

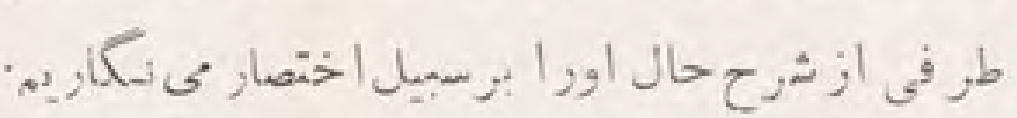

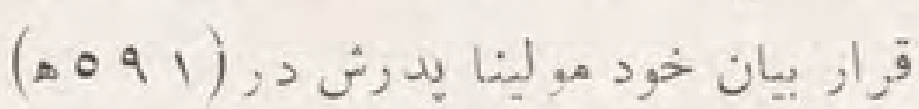

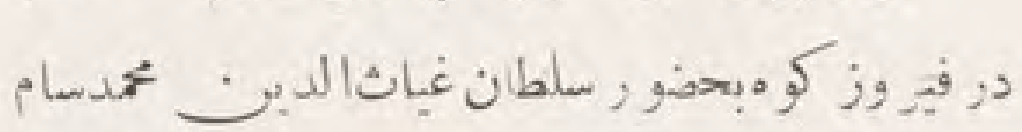
قوام دا ثت واز انجا بنابخو اهث سلطان بهاو الدين

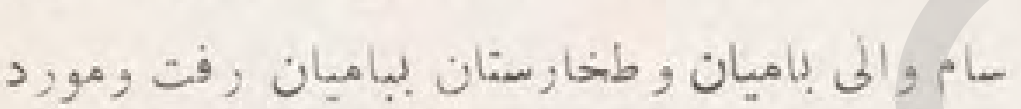

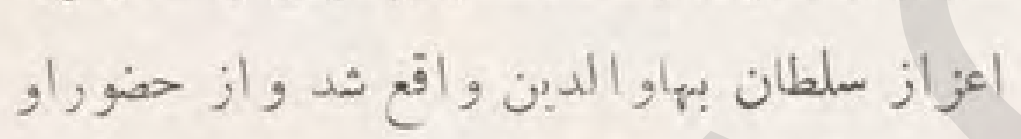

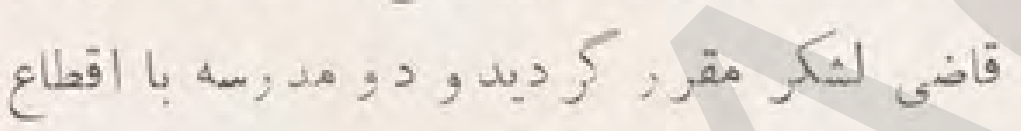
وانعام وافر بلاو تفويض دافت ودر بنوقت مولينا

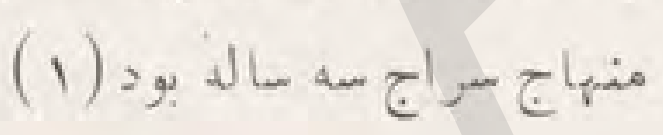

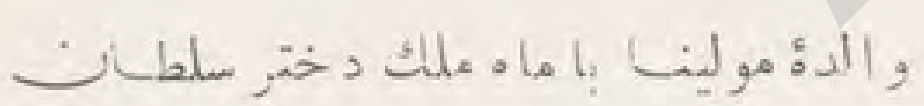

غياث الدبن محد سام ملقب بجالال الد بنيا و الدين

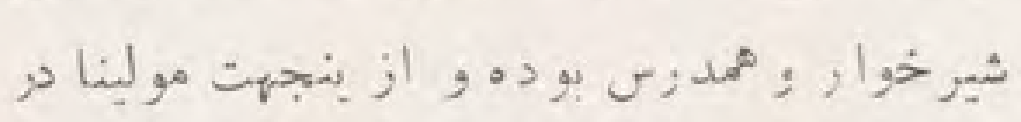

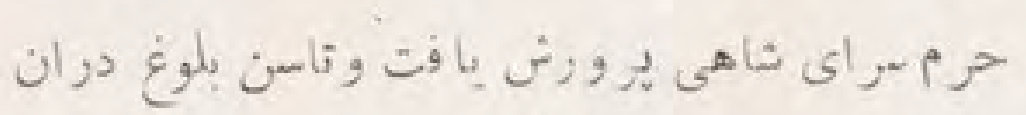

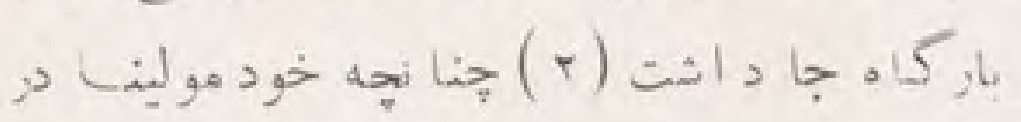

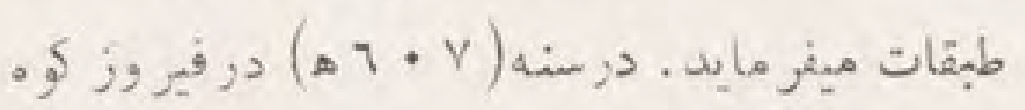

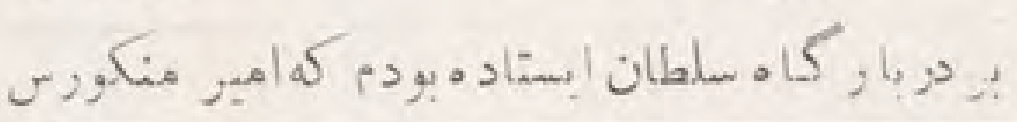

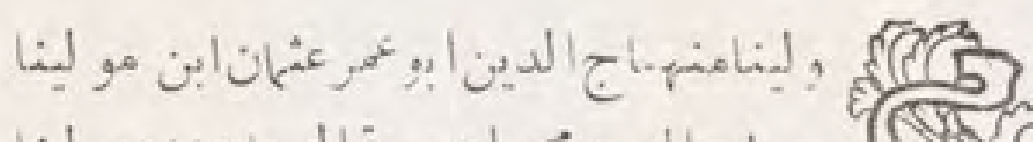

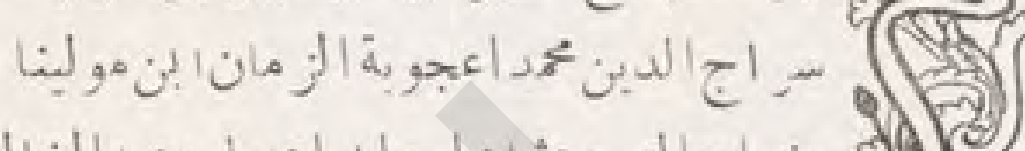

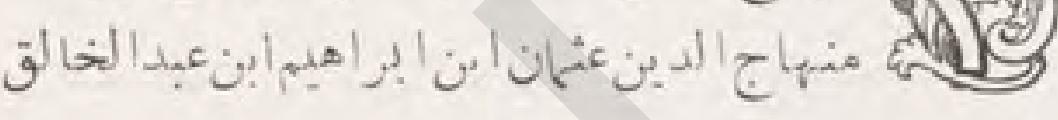
جوز جانى مؤ لف طبقات زاصرى مشهور بهنهاج

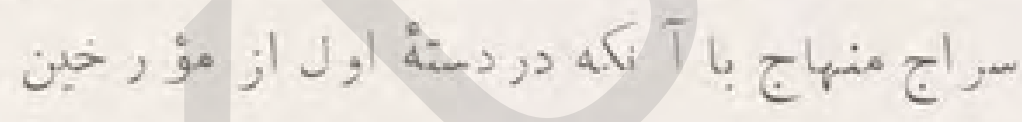

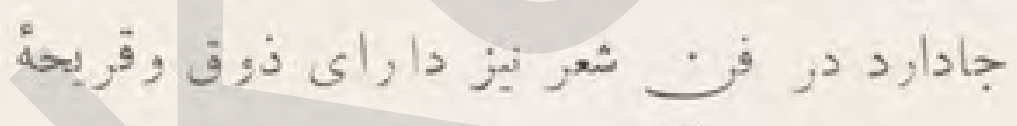

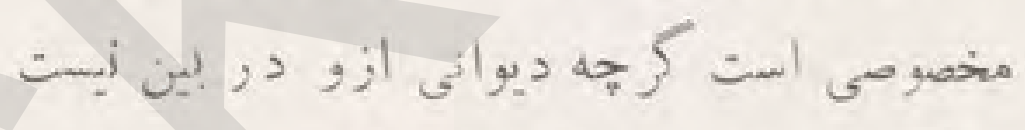

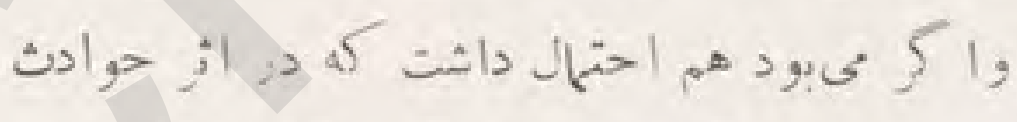

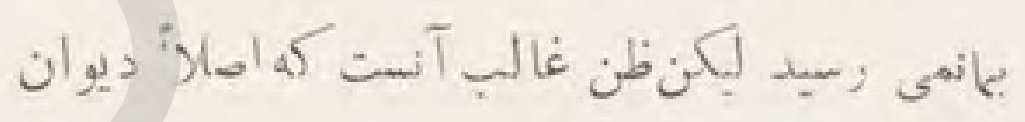

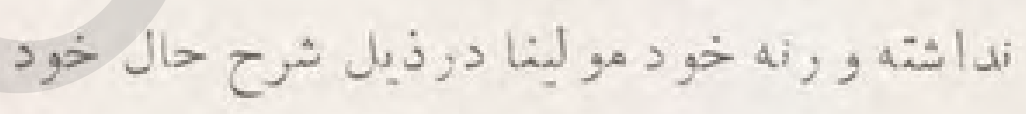

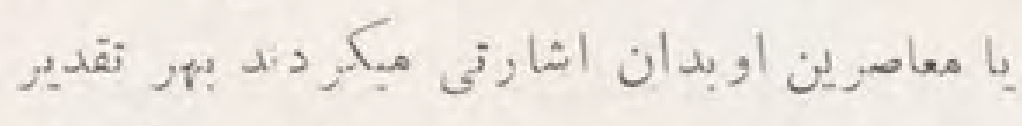

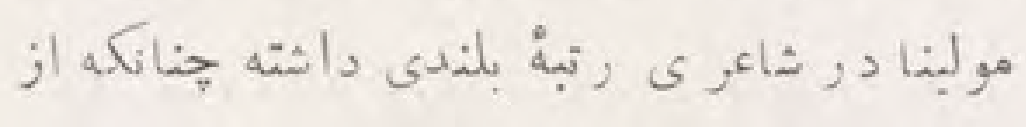
بعض قصائد مدحبه ور رباعيات وقحعاتى كيه در, طبقات ألصرى از خود آوردهدواز اشعار حبسئ

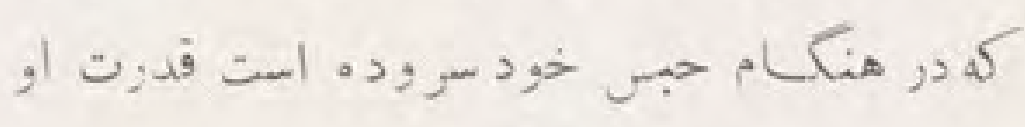
در فن شعر معلوم ميكردد - دئ

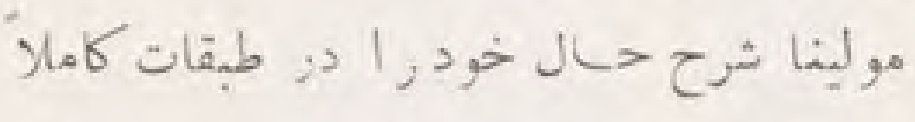

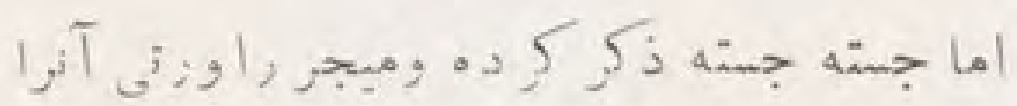

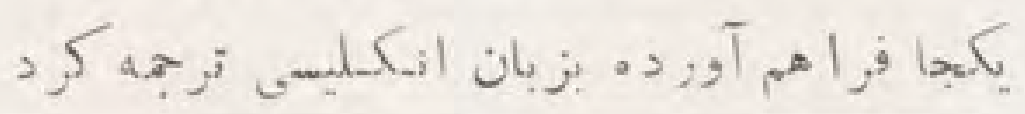


دزجر تر بيه هاه ملك ير زرن با فته بلكه قوار

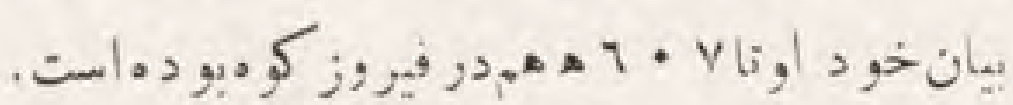

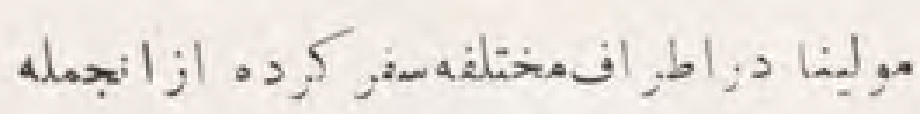

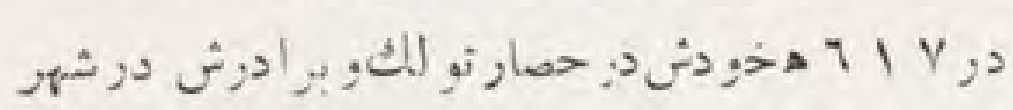

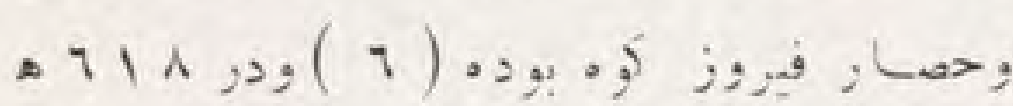

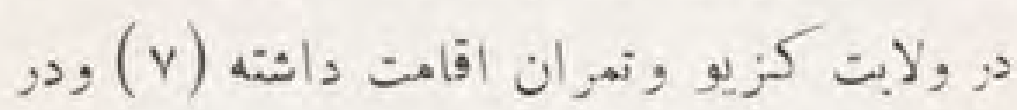

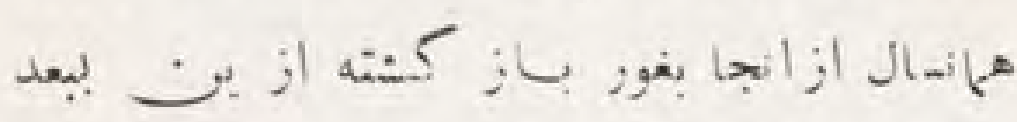

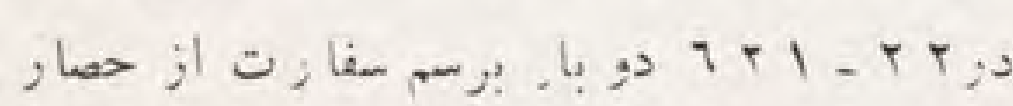

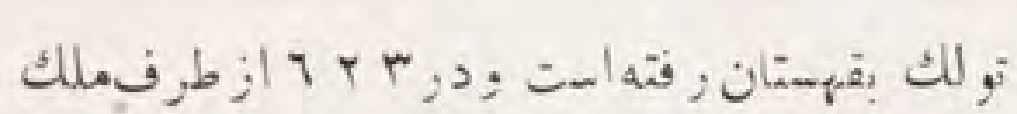

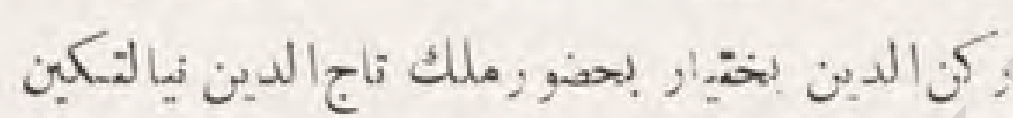

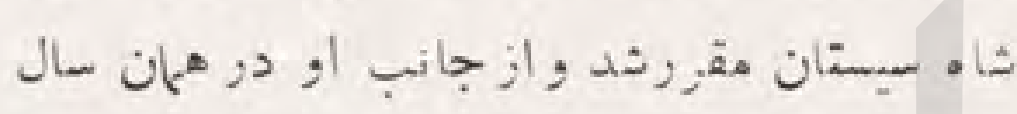

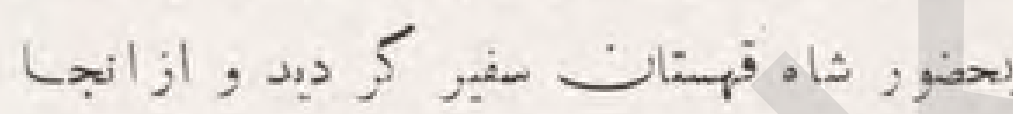

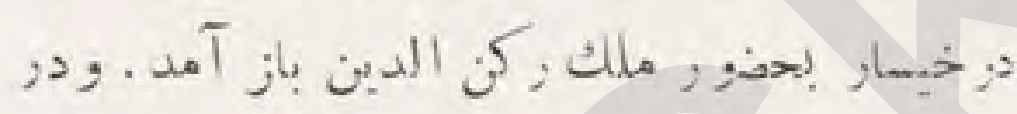

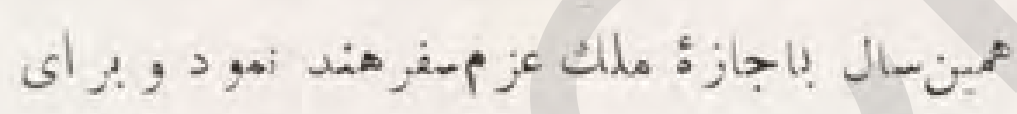

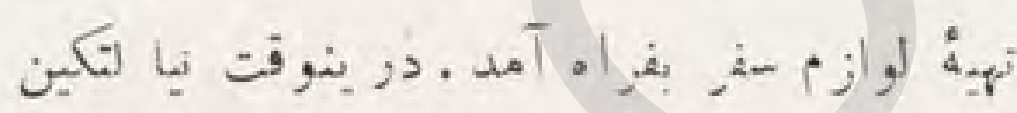

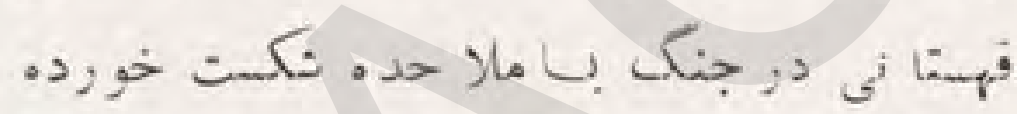

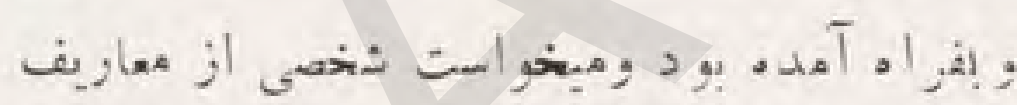
إبراى هصالحه تزد شهب الدين محتشم فرماندة

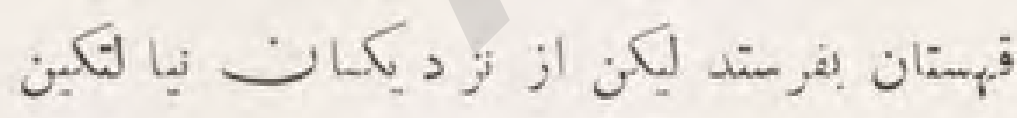

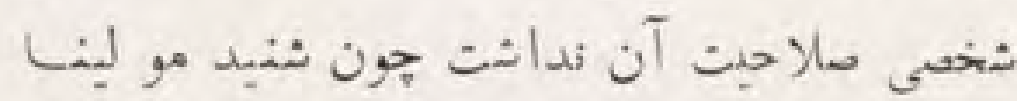

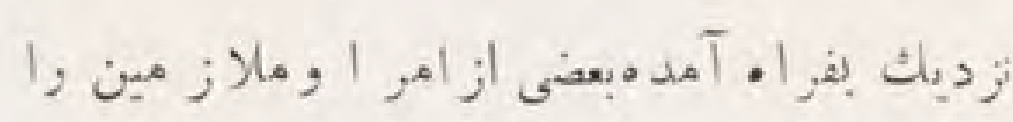
همراه اسيى باسازوير اق جهت سوازى بـ ستقبال هولنيا فرستاد واروا لبحضورخوأسته سفير ساخت

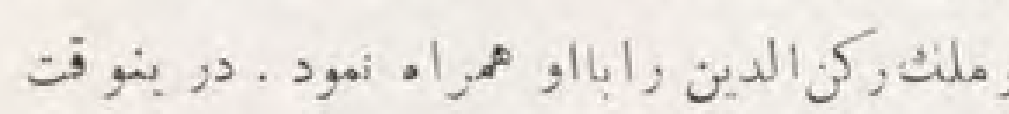

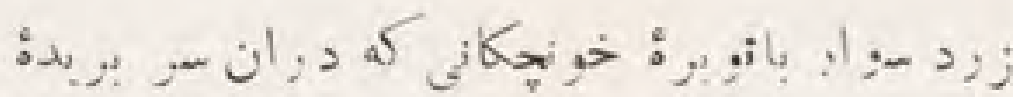

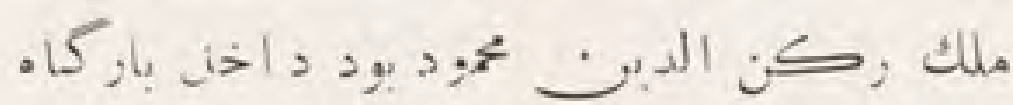
(1) . 1,25

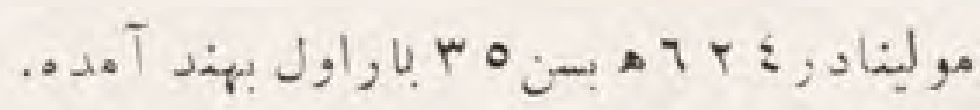
(r) (r), : 1 : هنكام جلو

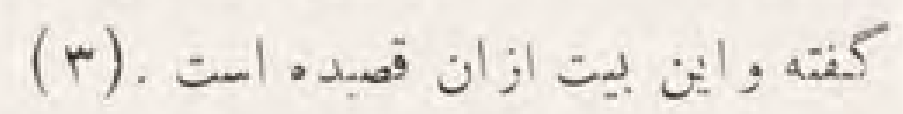

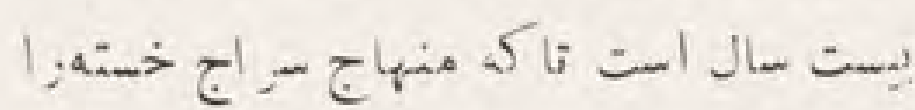

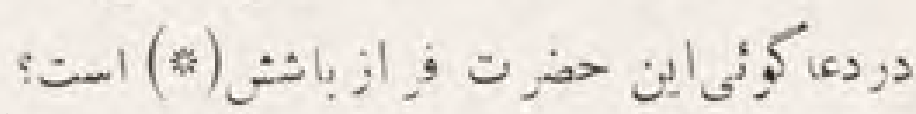

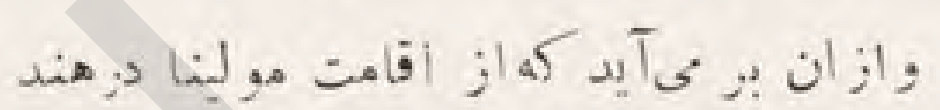

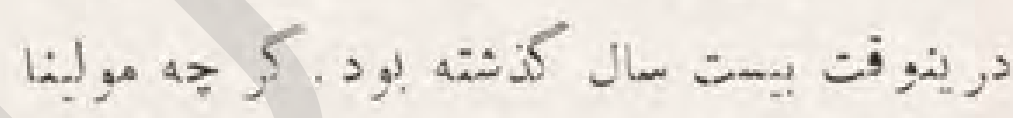

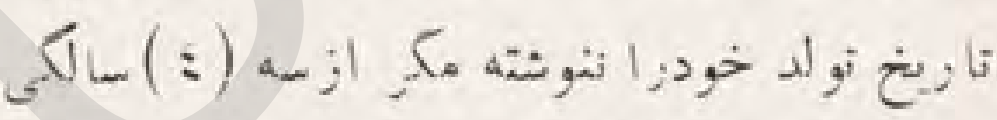

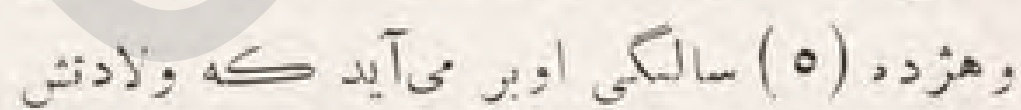

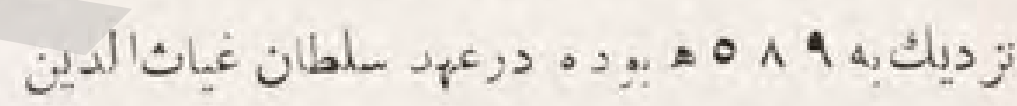

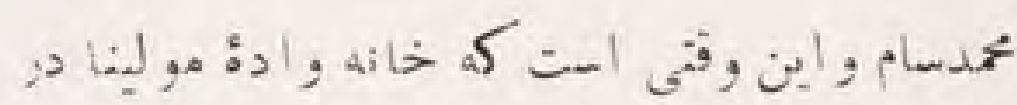

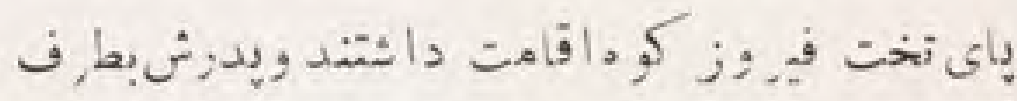

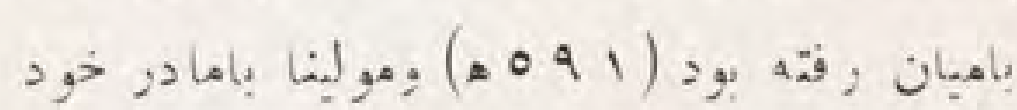

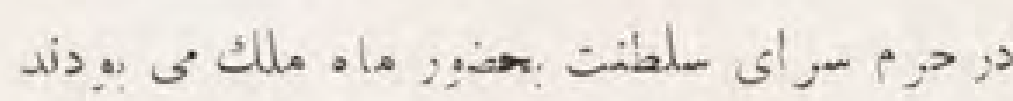

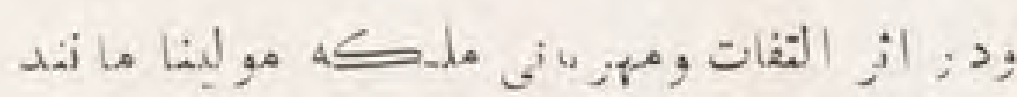

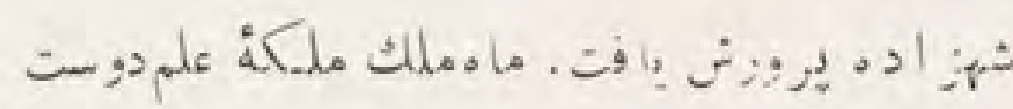

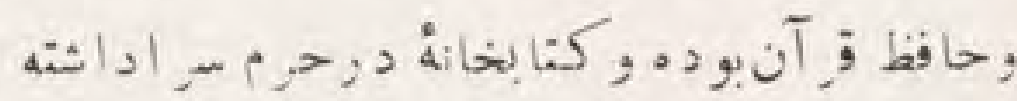

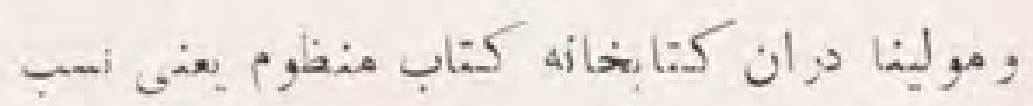

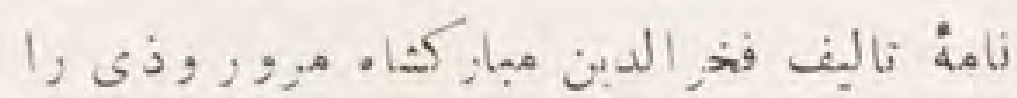

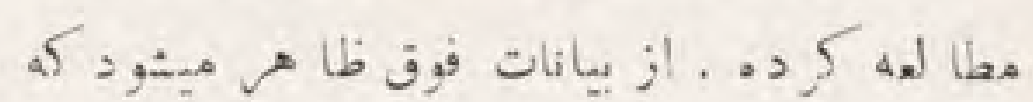

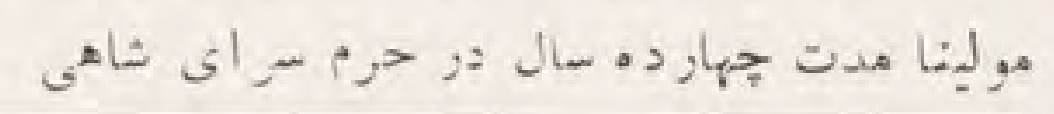

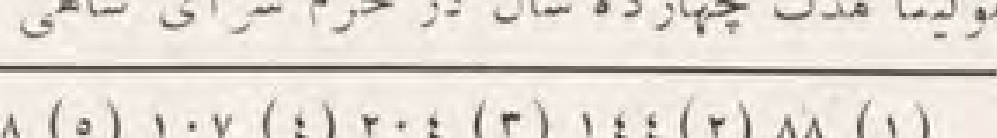
$r v z \operatorname{or}(A) r z: \operatorname{cis}(v)$ 


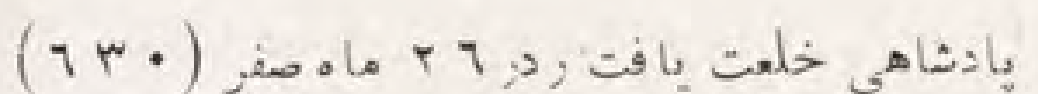

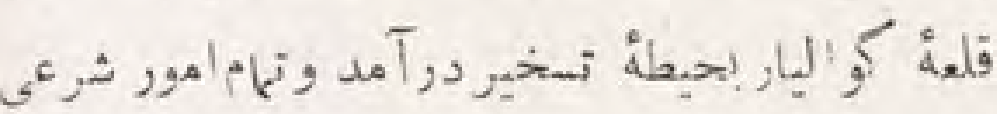

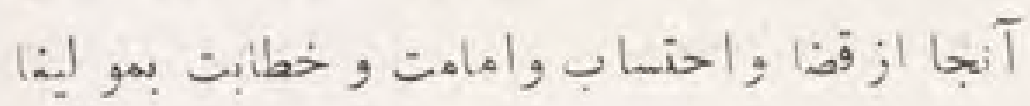

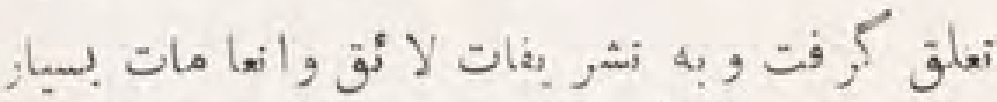

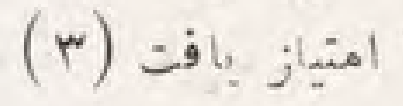

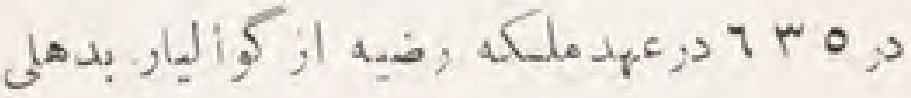

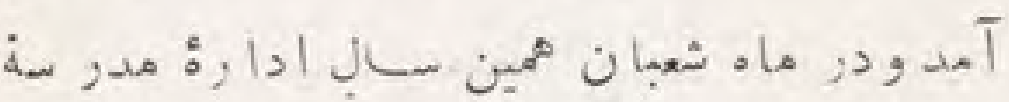

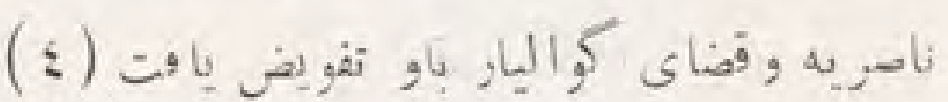

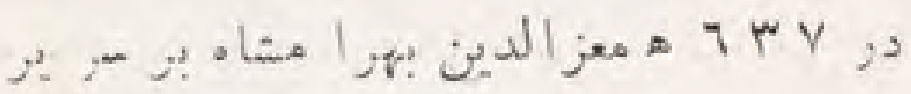

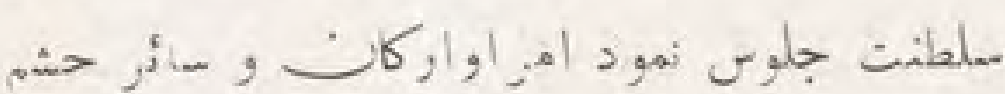

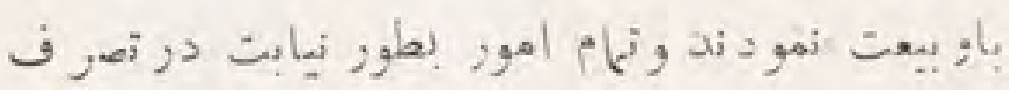

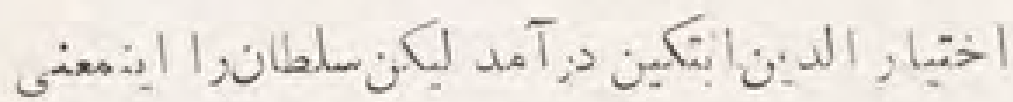
بسند نيفتاد ودربي دفع آن برآهد ونا دو سال اين اين

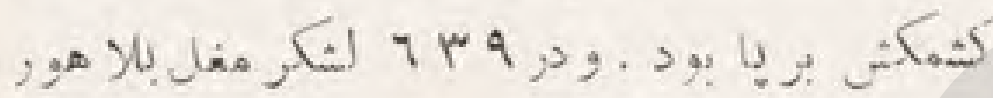

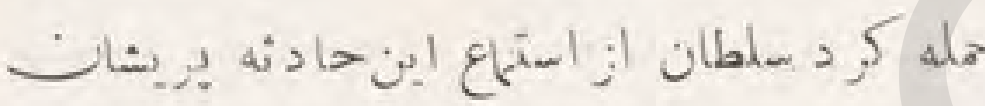

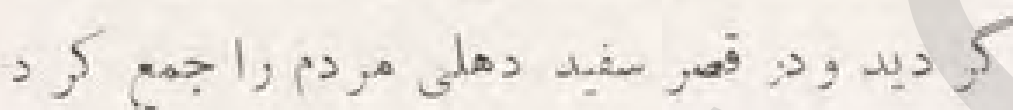

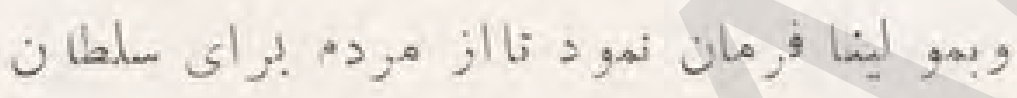

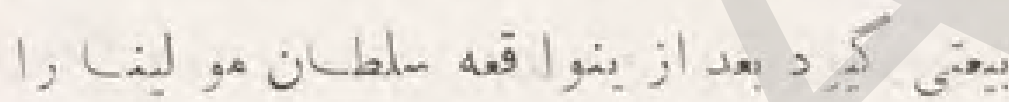
ع وز

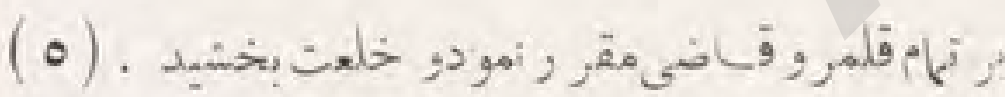

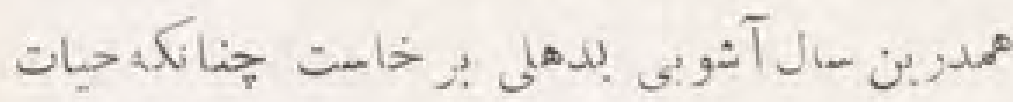
سلطاندر معرض خطر افتاد ودر د فو آن عولينا وسائز امراجد جهدكر دند اما فائدة له بخشيد

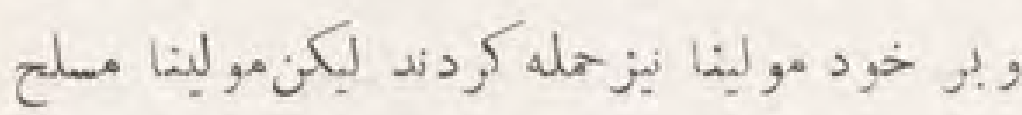

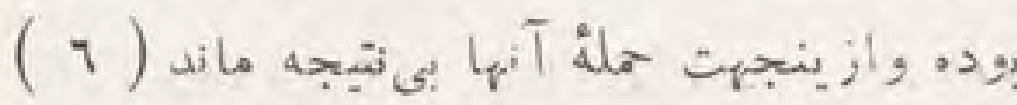

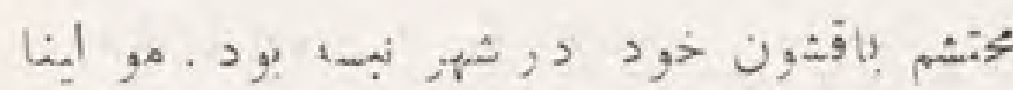

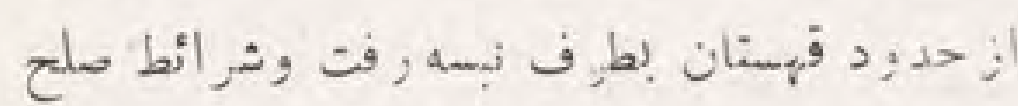

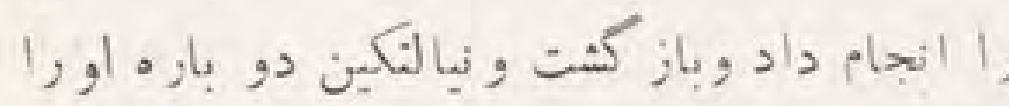

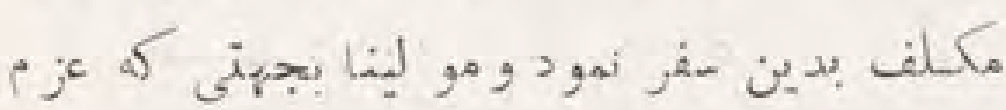

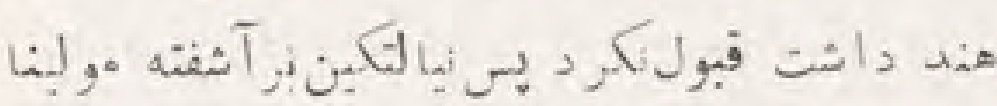

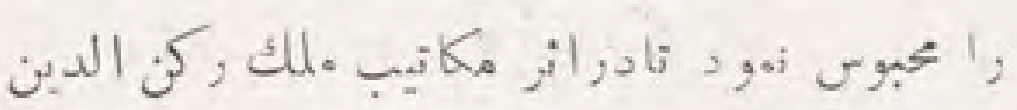

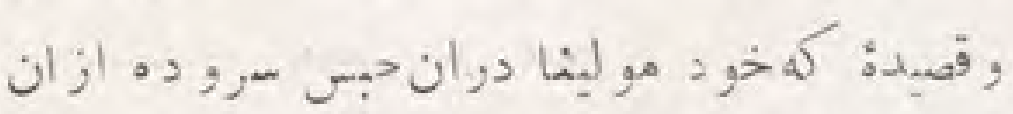

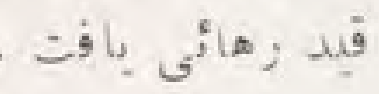

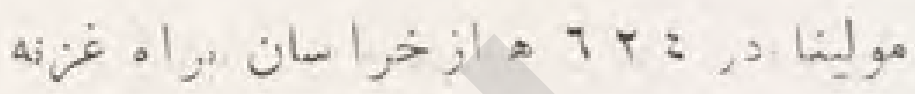

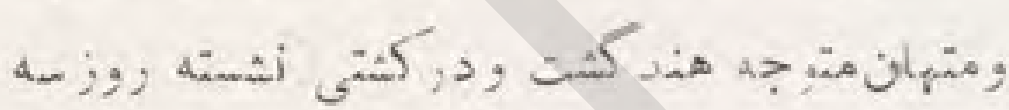

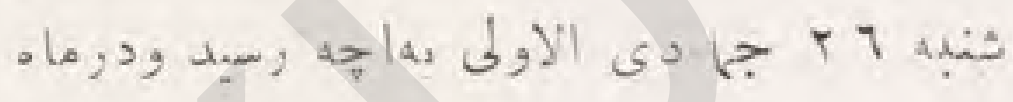

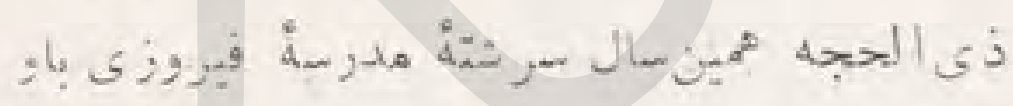

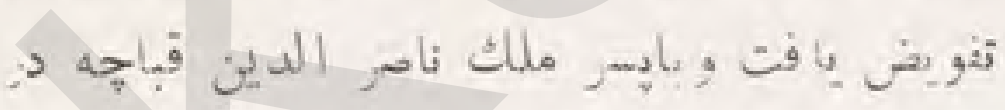

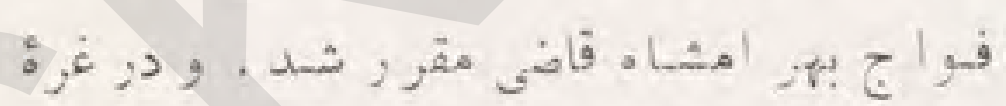

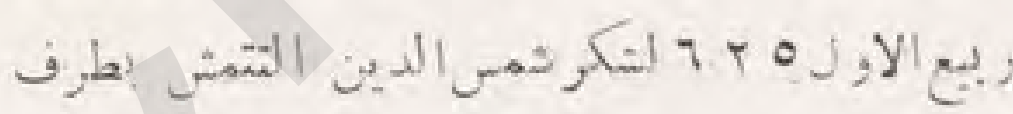

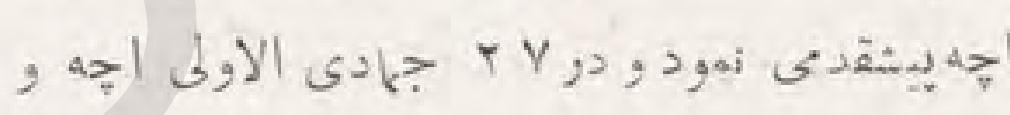

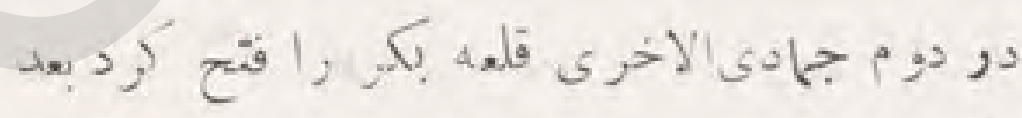

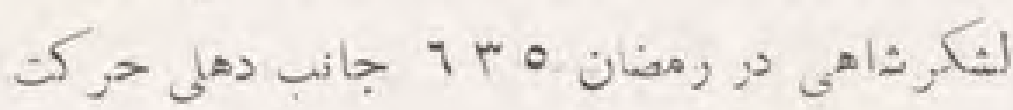

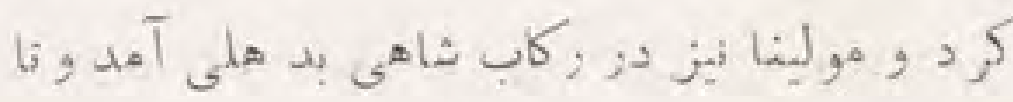

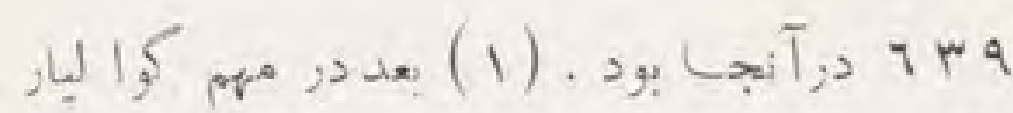

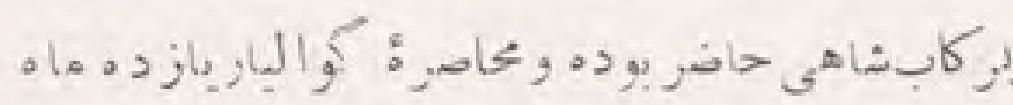

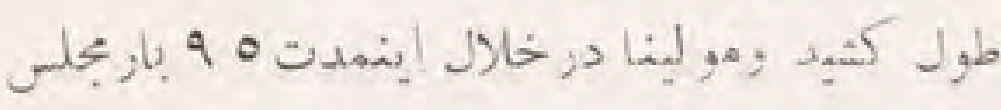

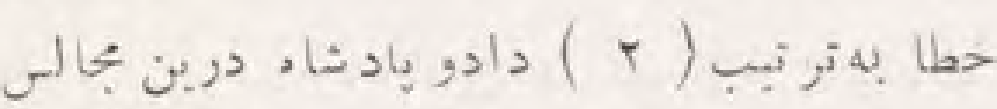

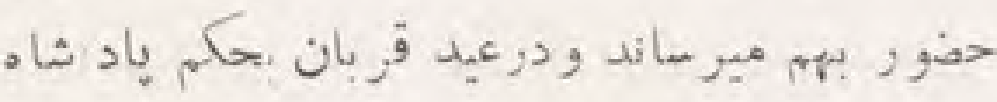

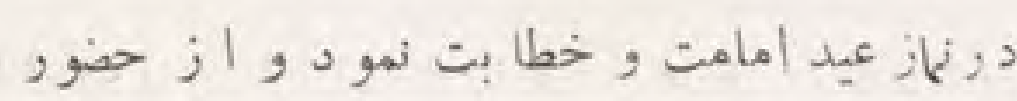

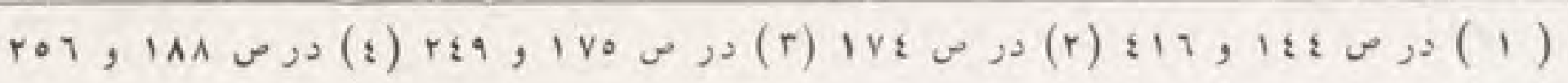
19v, 1970(1)1900( (०) 


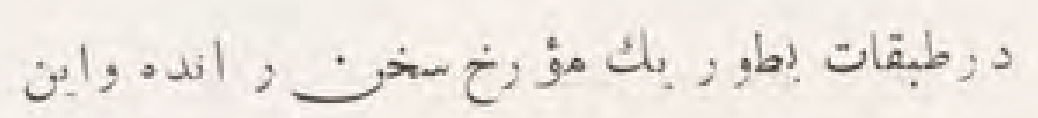

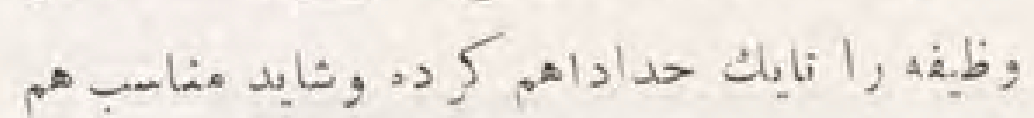
•. 9 .

طبق ت ت د

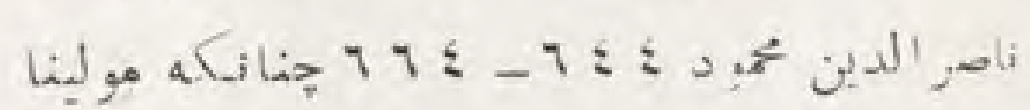

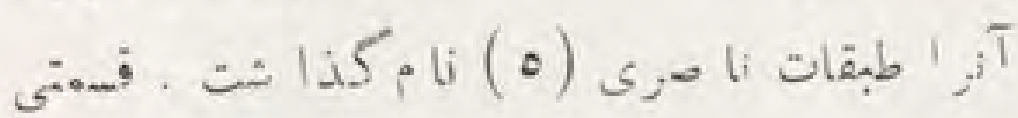

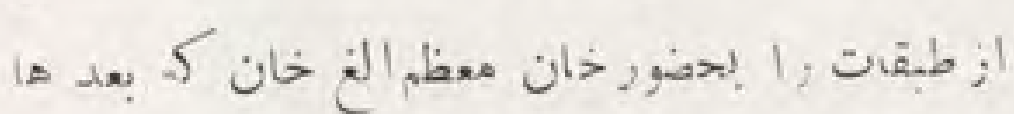

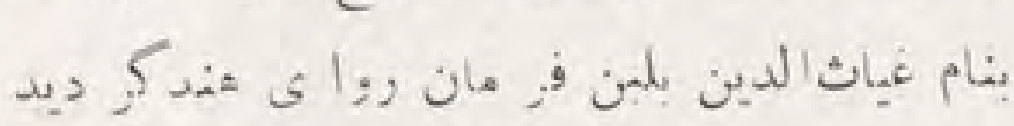

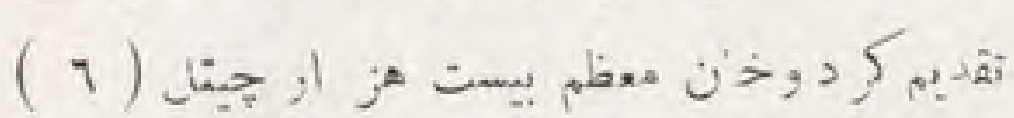

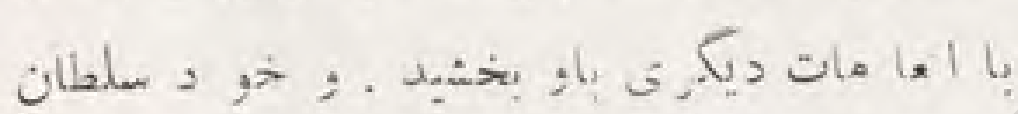

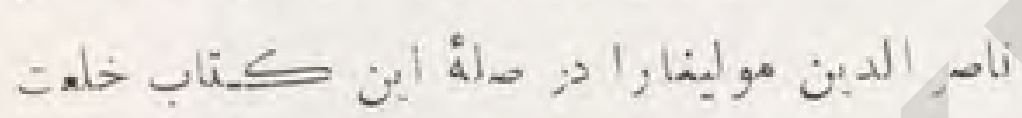

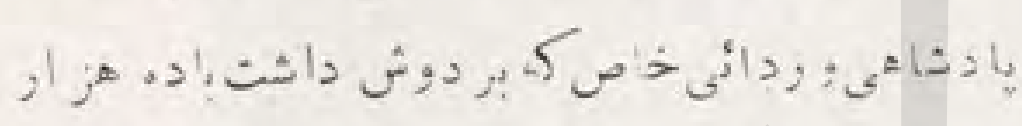

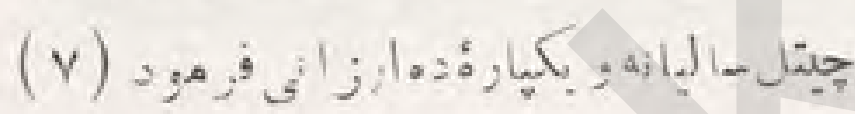

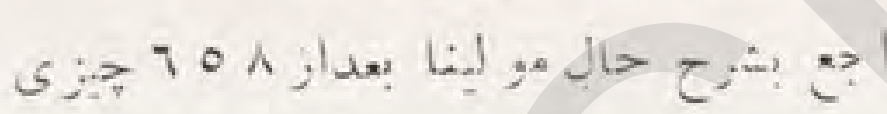

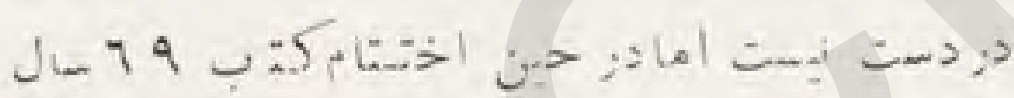

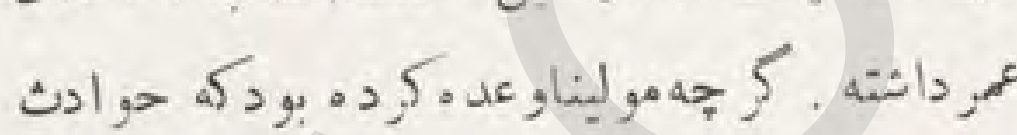

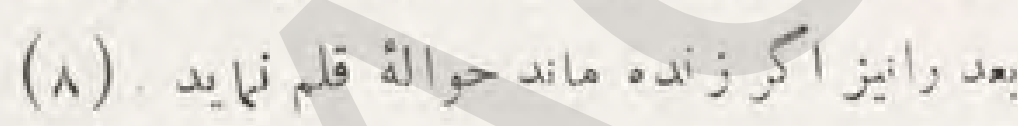

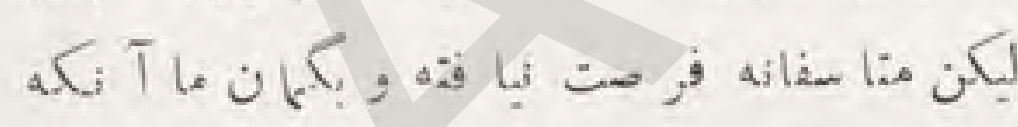

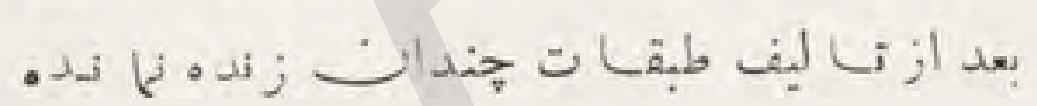

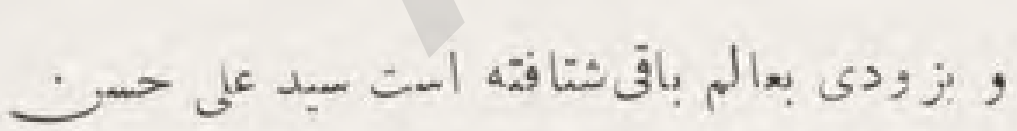

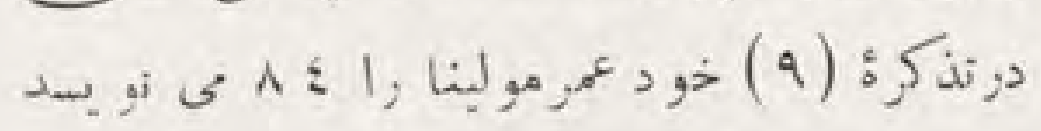

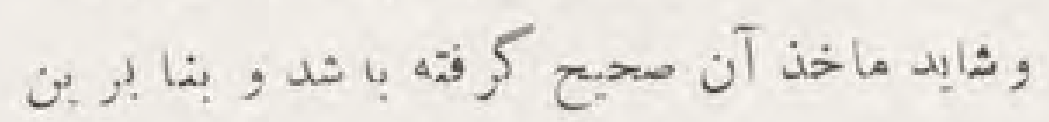

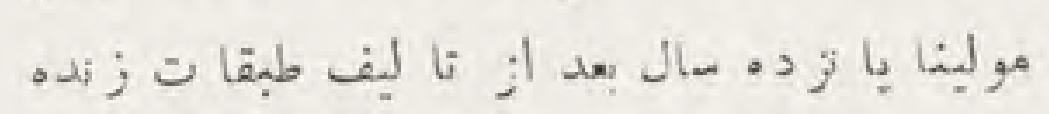

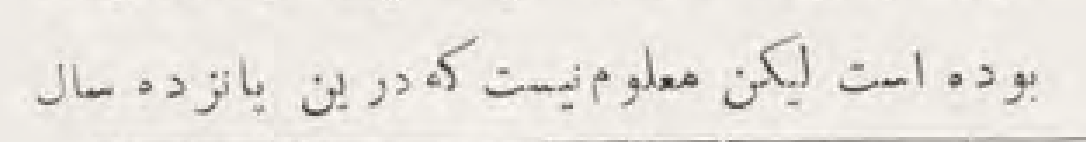

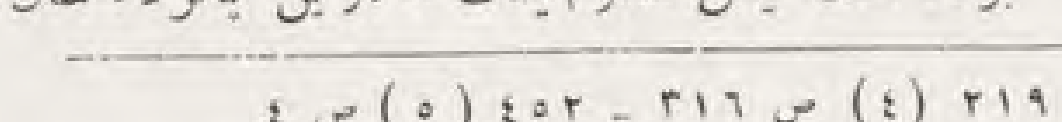

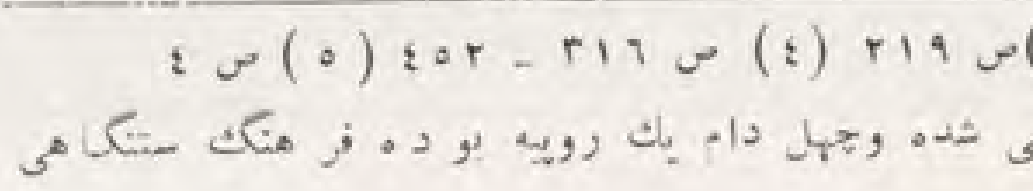

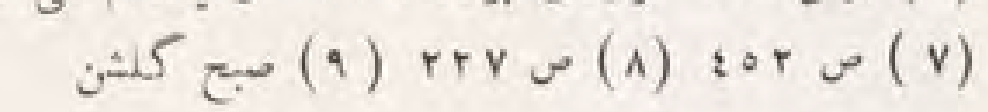

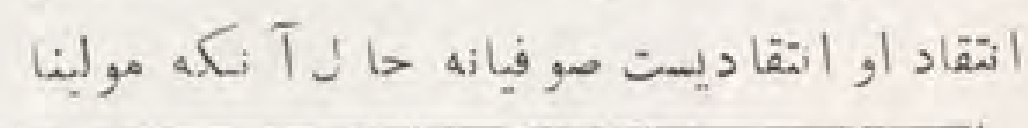

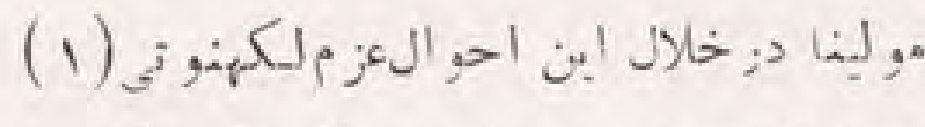

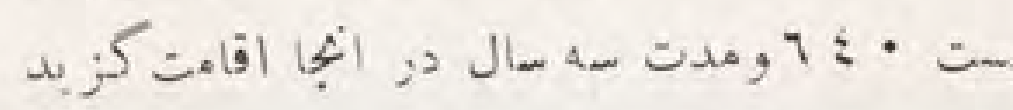

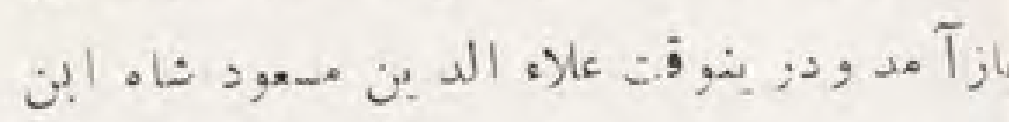

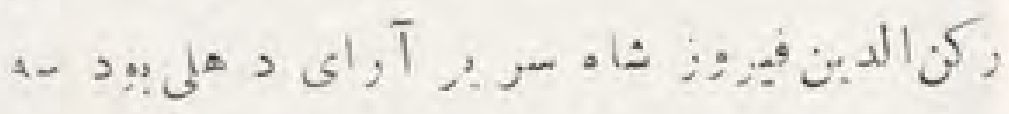

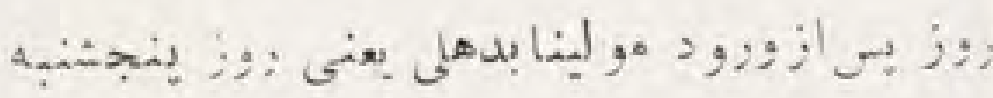

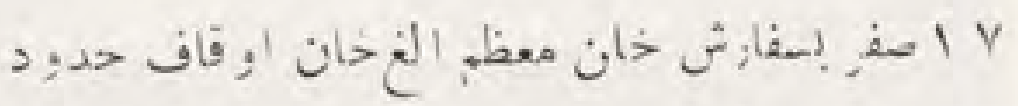

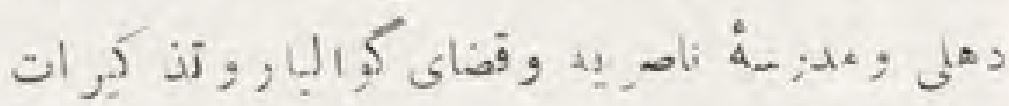

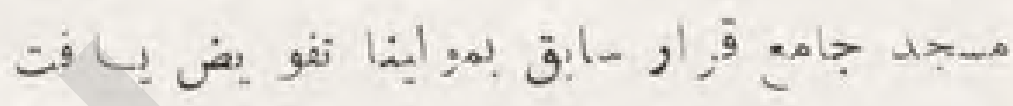

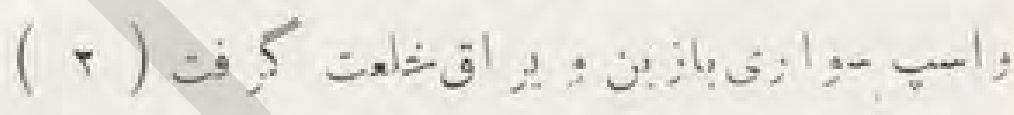

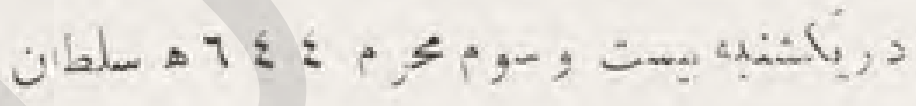

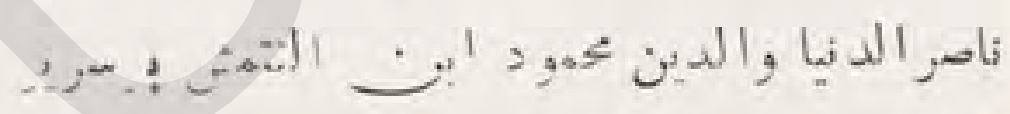

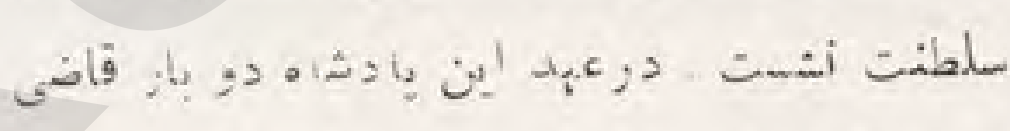

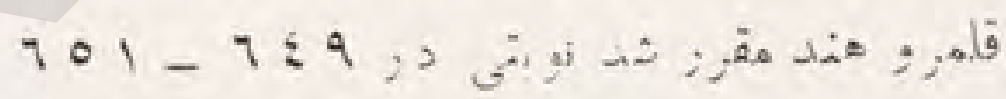

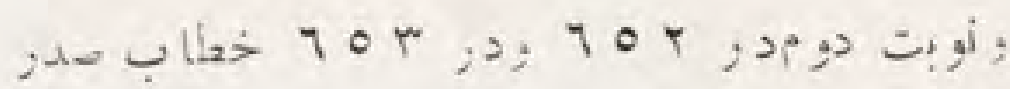

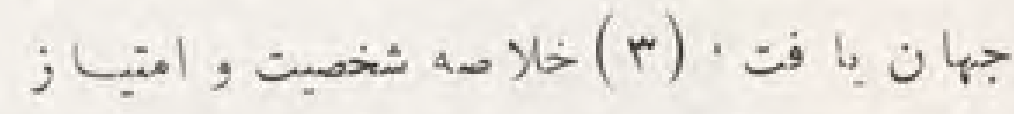

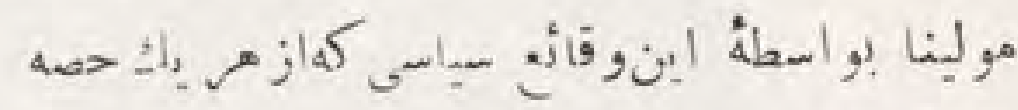

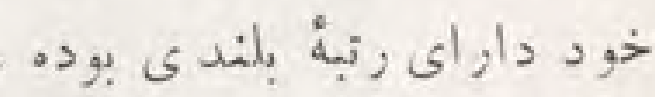

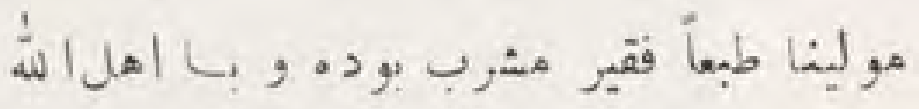

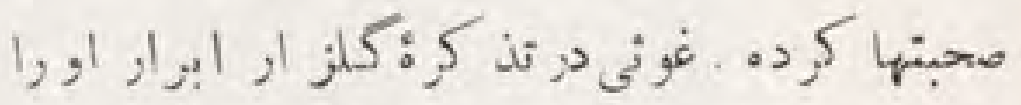

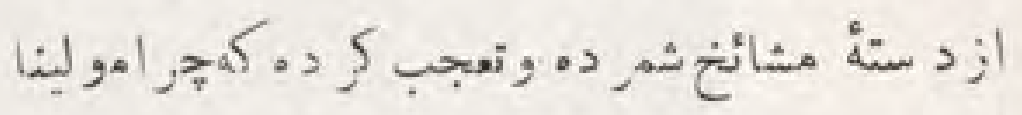

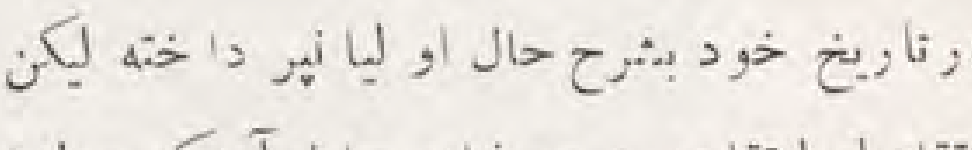

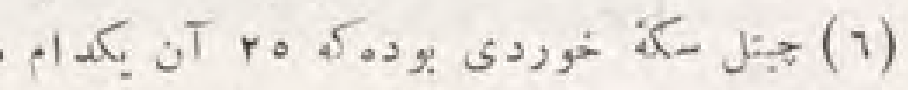

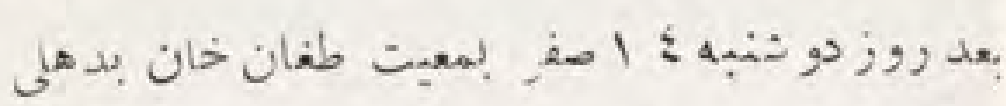

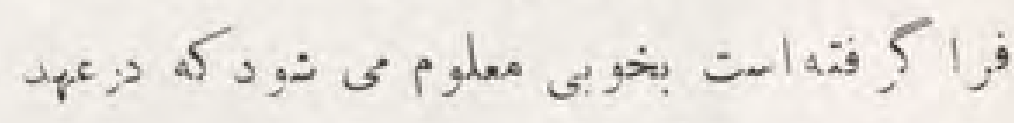




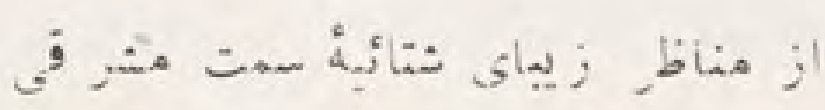
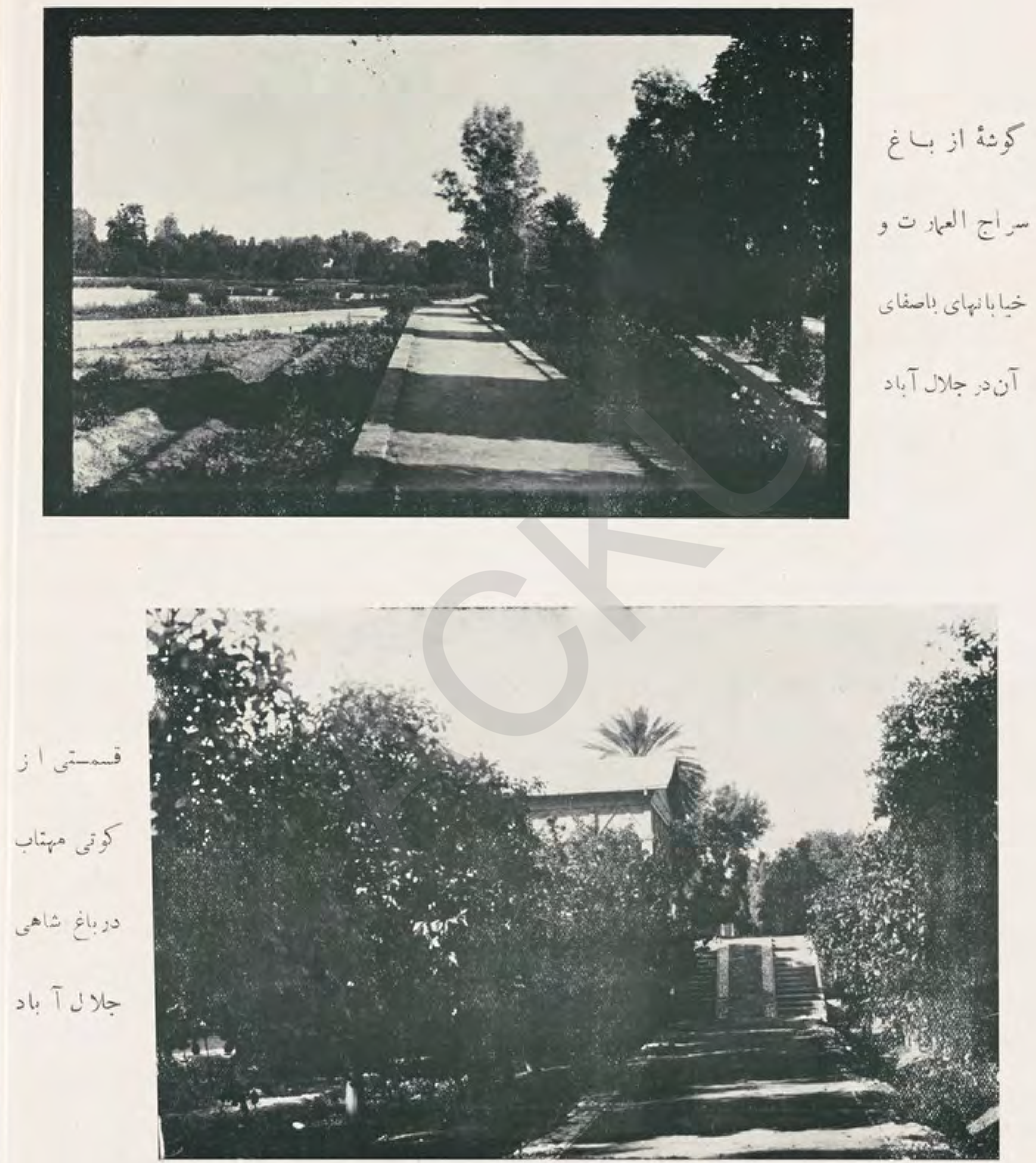


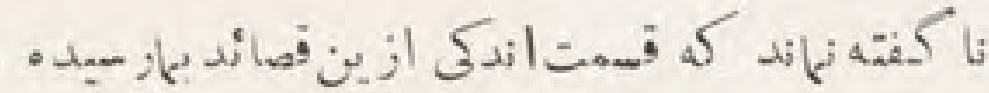

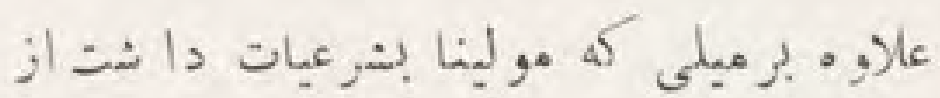

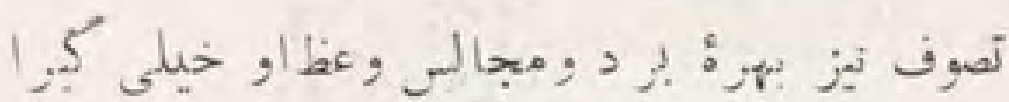

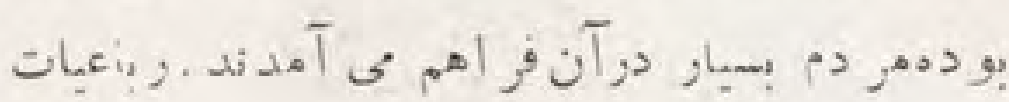

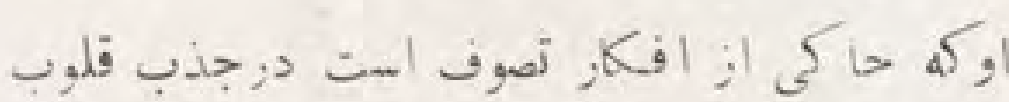

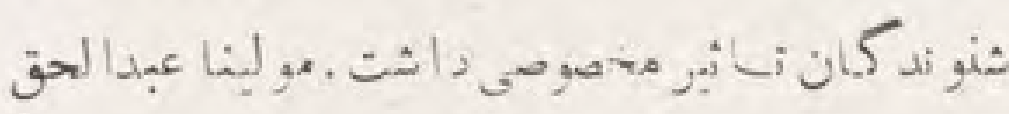

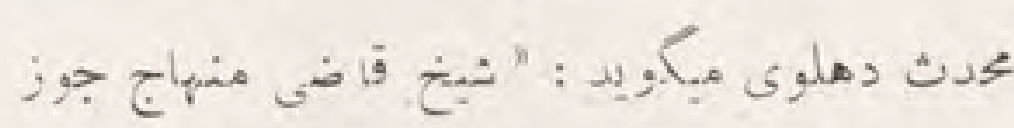

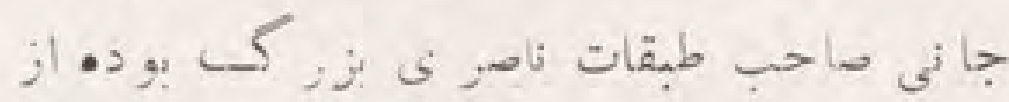

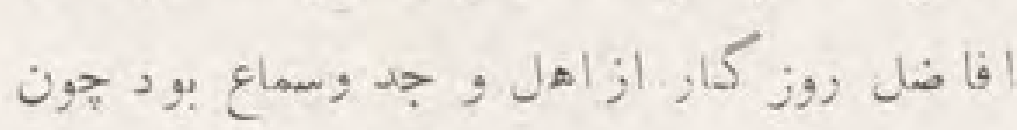

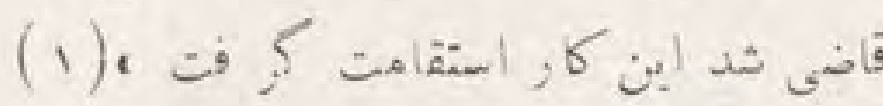
ثيح نظامالدين اورك

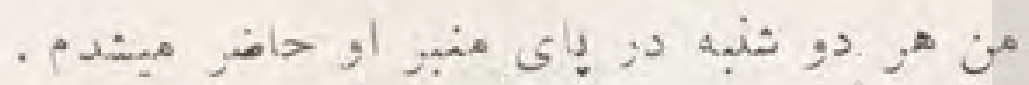

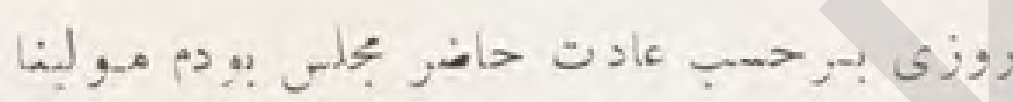

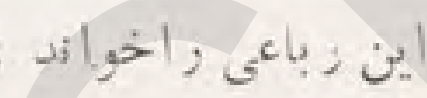

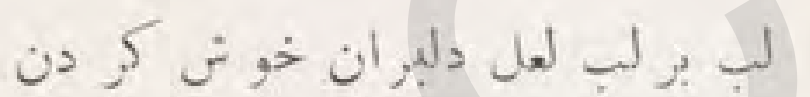
ن

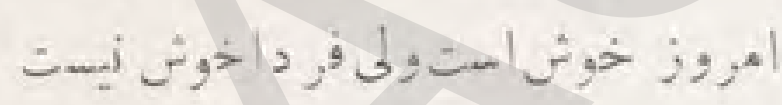
خو وقتى شنيد ماز خ; 2, فتم, وسا عنى بعهوث بودم

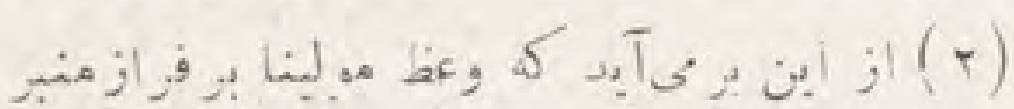

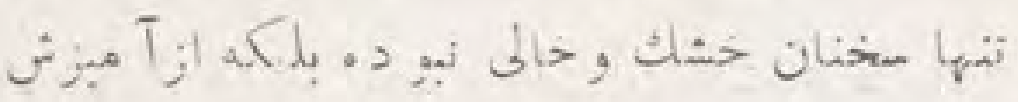

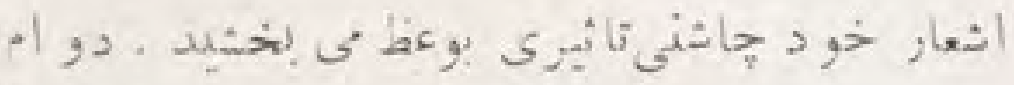

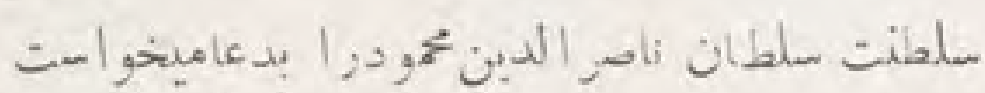

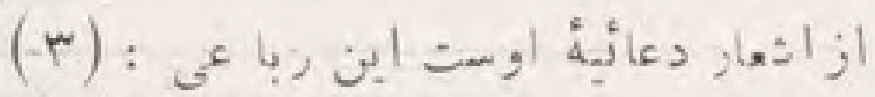

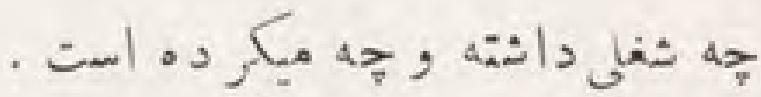

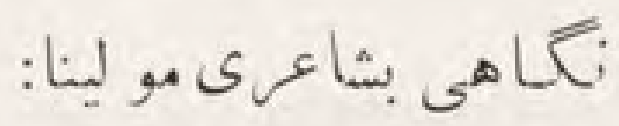

مو ا دى از ين هوضو ع در د ست نيست

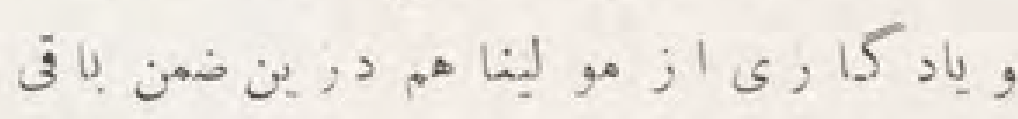

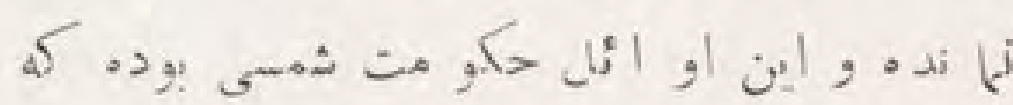
أوجهش بِشتر ازهر هيزى بجانب فتو حات تاز ه

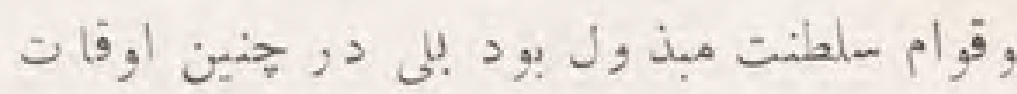
نو جه سلا طين بجا نب شعراكمة ميبا شدو بدين

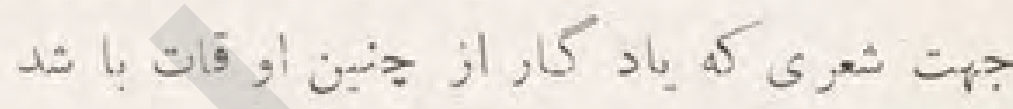

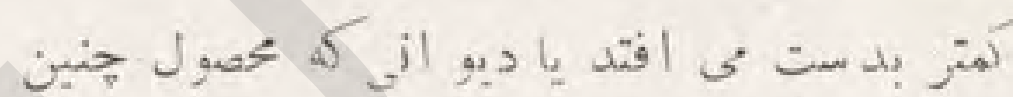
على عود هم ثادو است.

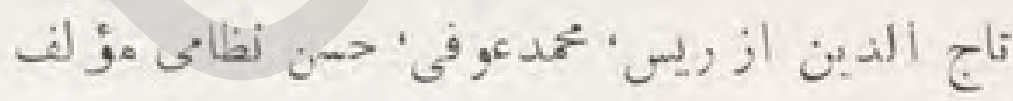

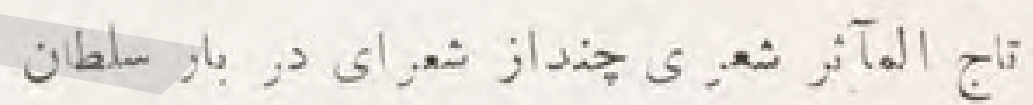

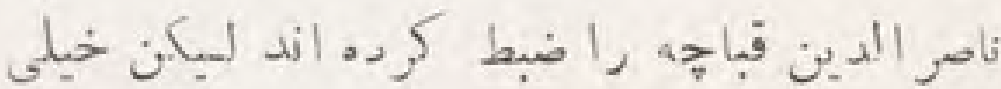

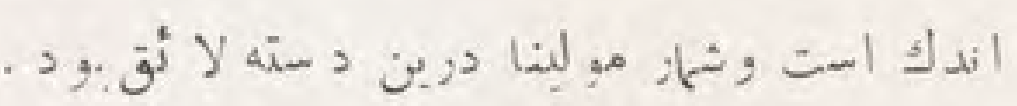

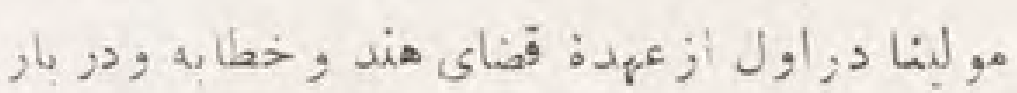
دارى وروصت نيا فتدر اوفـات فر اغت عالاو مبر عالئق

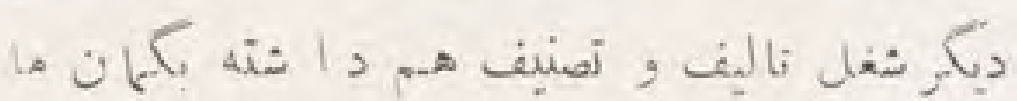

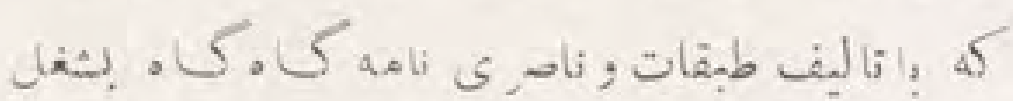

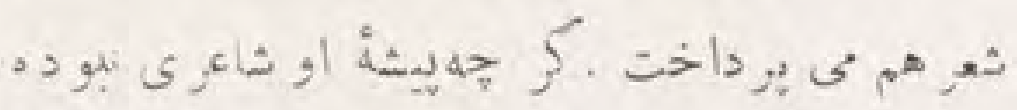

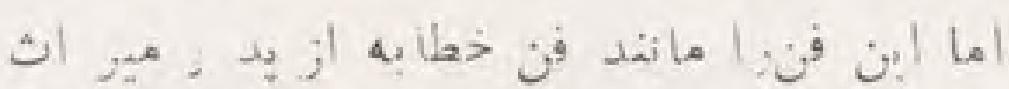

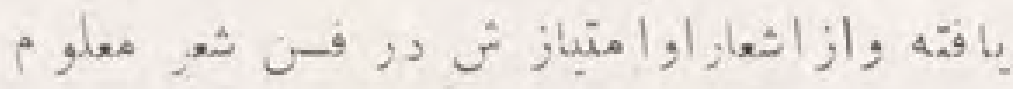

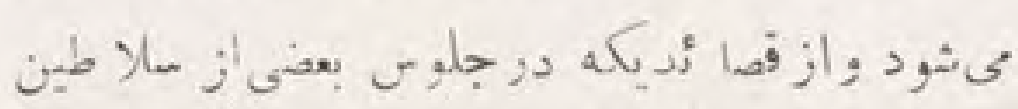

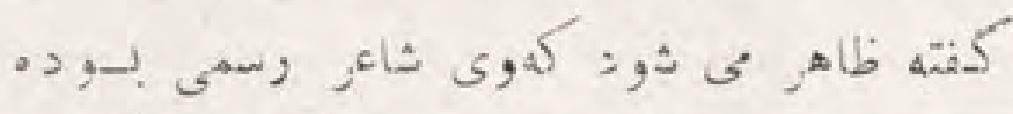

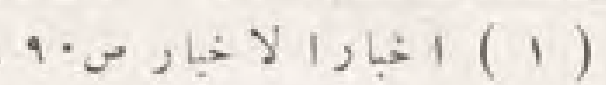

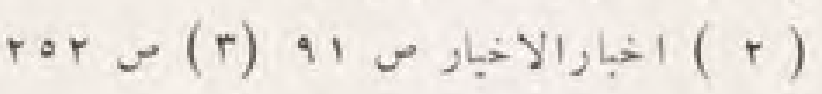


دربنوقت موليذا قصبدة حبيده كفته (r) مثتهل

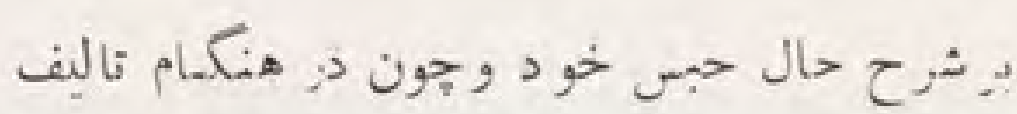
طبقات نسخه اين قصيده نزد مولينـ نبو ده بنقل

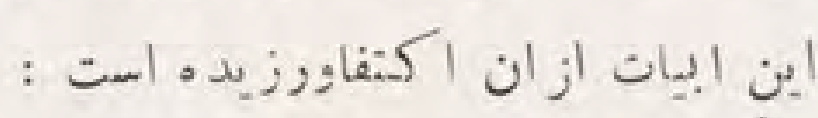

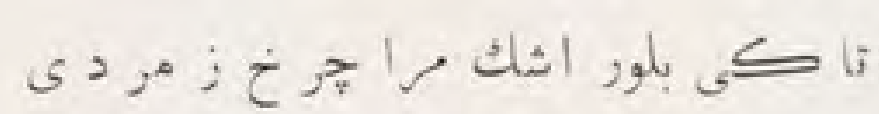

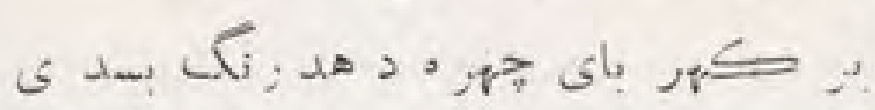

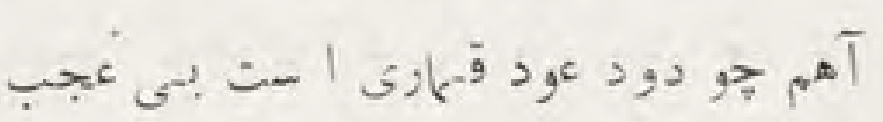

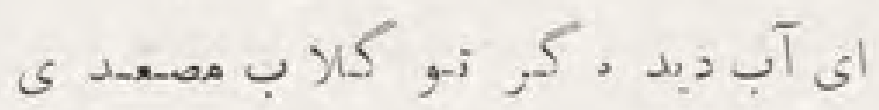

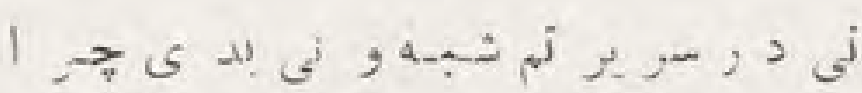
مخوسم , اسير بكوم صفهندى (صفهيدى)

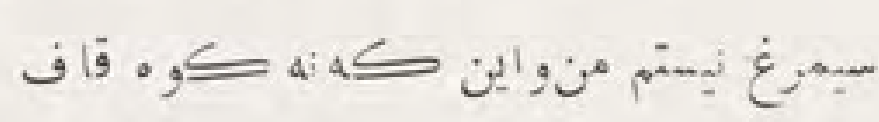

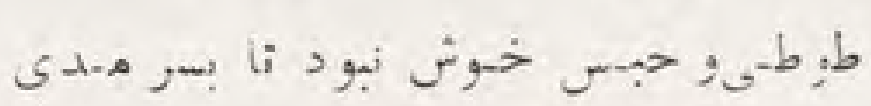

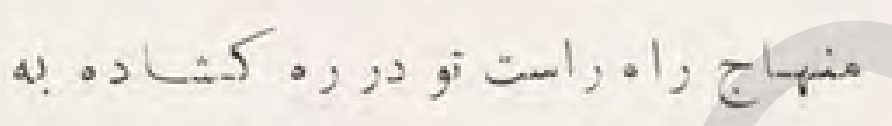

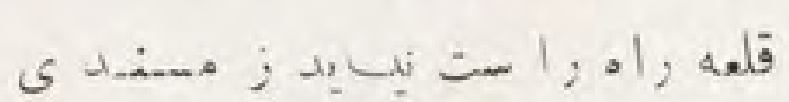

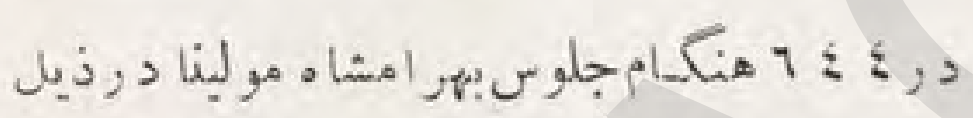
اهر ا حاضر بوده وبيعت كرده. وقصيده در نهنيت لجحضور عرضه دا شته كه إين جند بيت از ابن

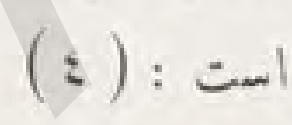

زهي درثان تو منزل ز لوح آياتسلطانى

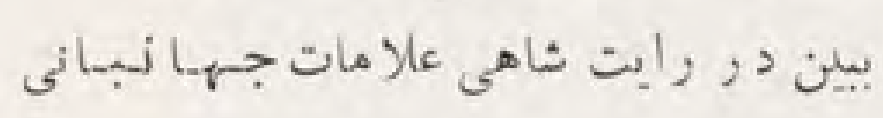

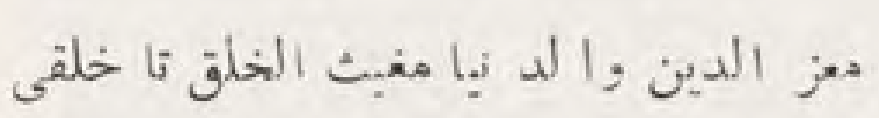

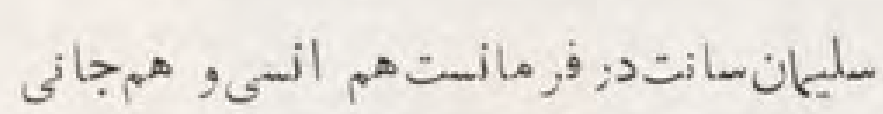

شهر اخضر از جام بقا سا قى باد

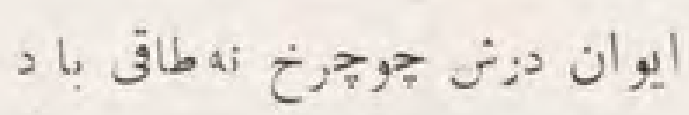

زام طبقات دز جهان نا با قى '-ست

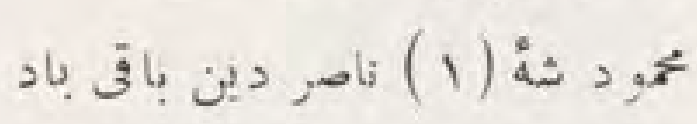

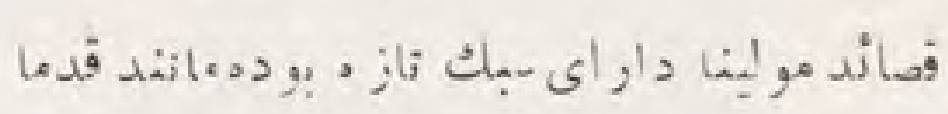

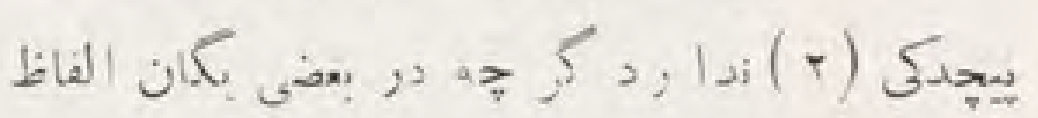

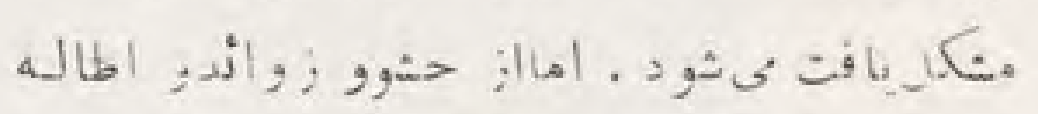

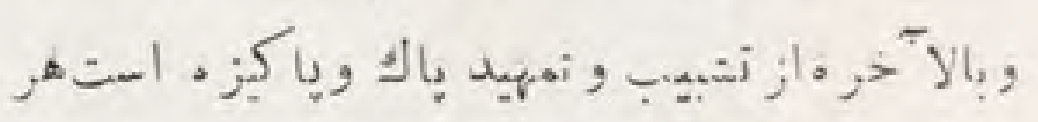

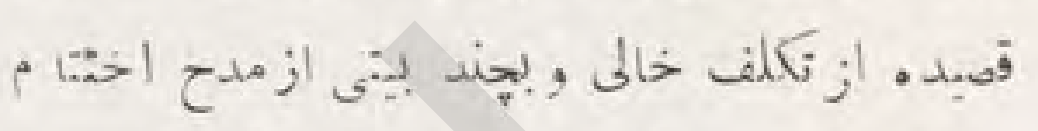

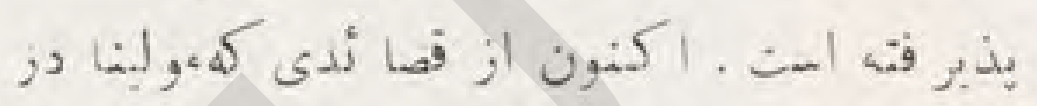

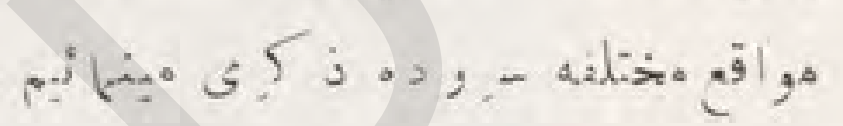

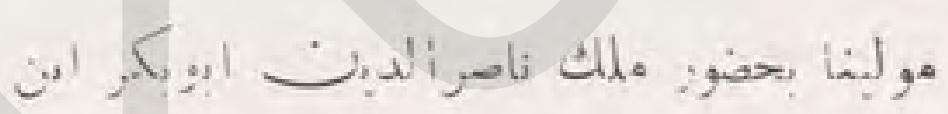

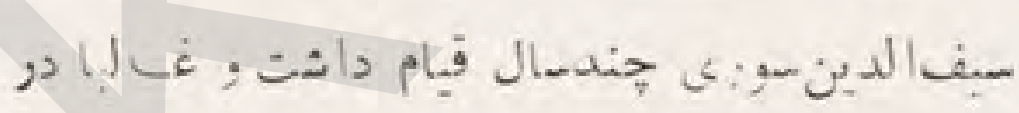

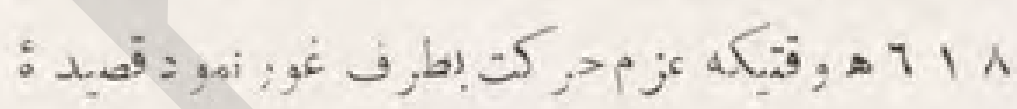

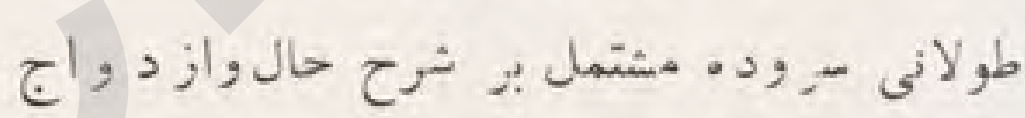
خود ودربن قصبده اسيى ازملك ناصرالد ير بـ

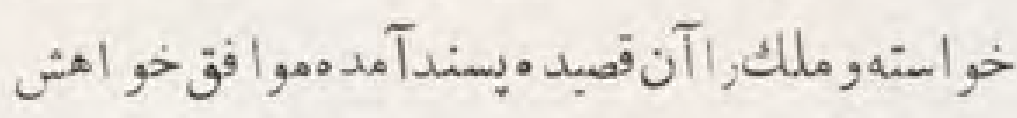

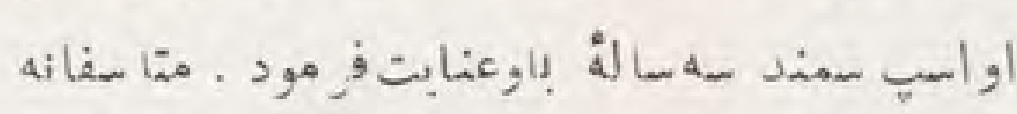
بكاكيت ازين قصيده هم در طبقات مذكور نيست

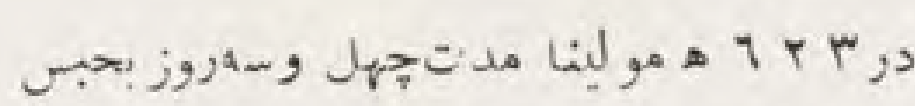

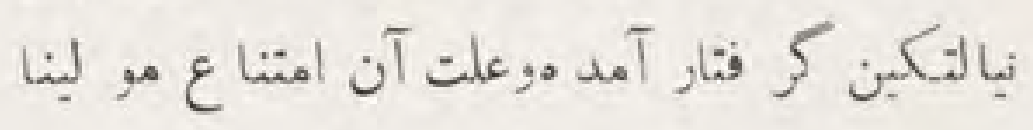

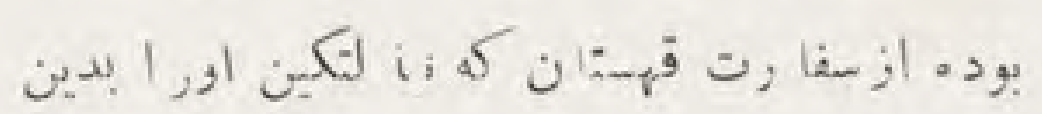

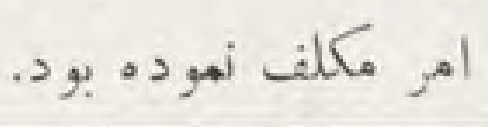

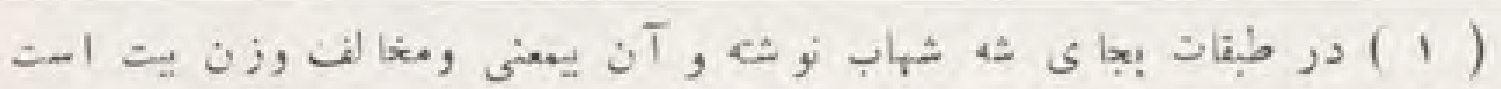

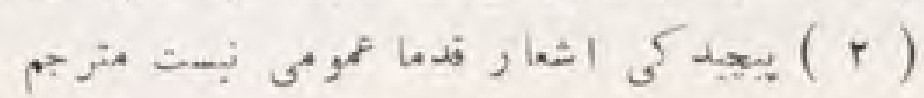

$$
\begin{aligned}
& 1910(\varepsilon) \leq 1 v e(r)
\end{aligned}
$$


, أحت ح الهاست و:ح عهد او باروح خلق

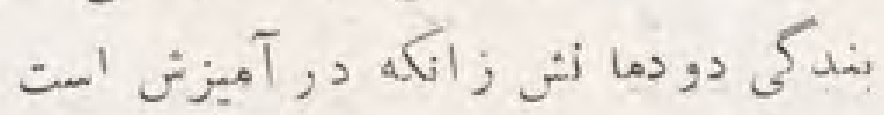

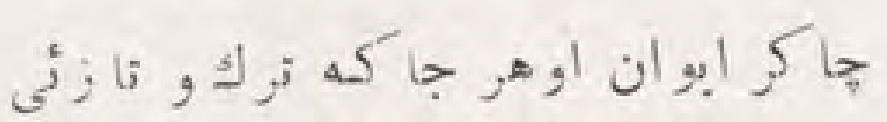

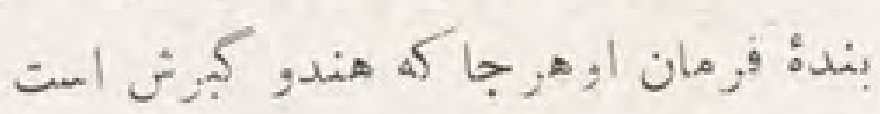

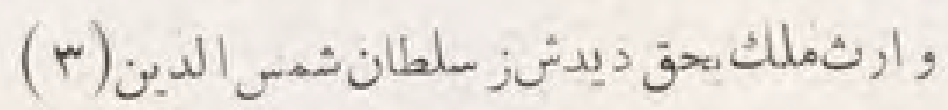
هركراز انصاف درجشم إصيرت بيثش است

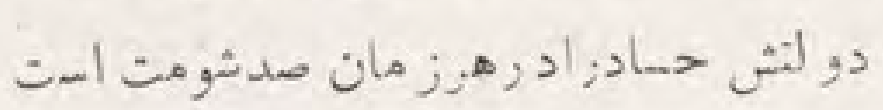
صو لتش احباب رادرهر مكان صدر إمثاست

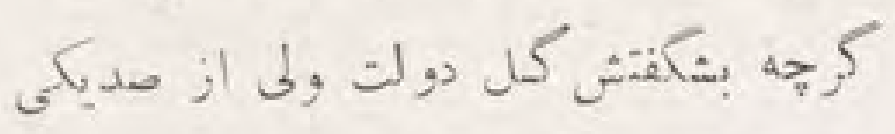

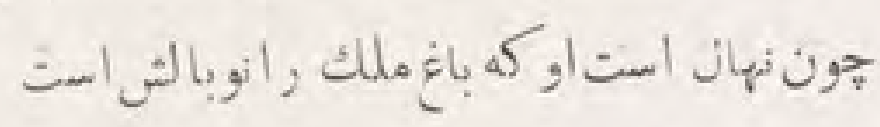

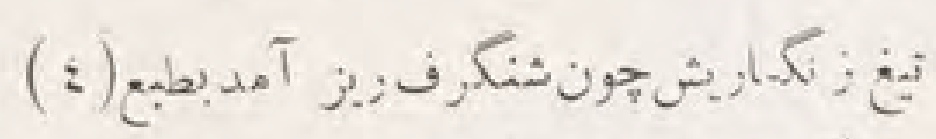

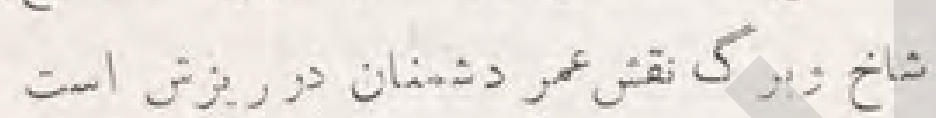

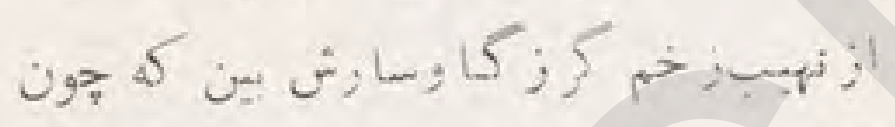

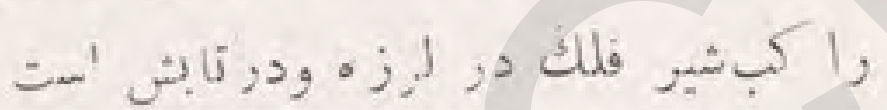

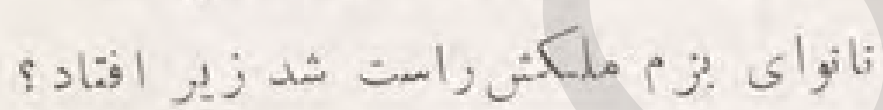

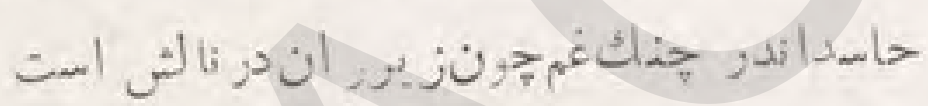

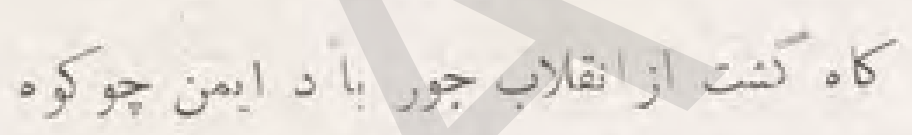

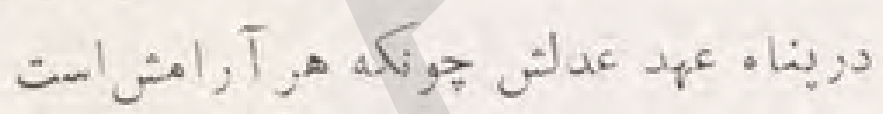

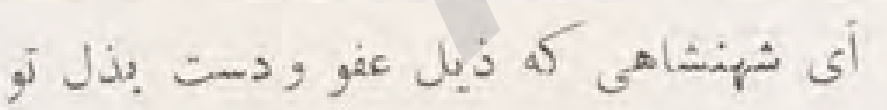

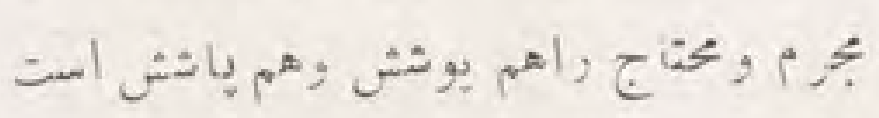

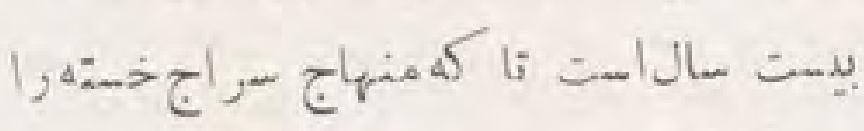

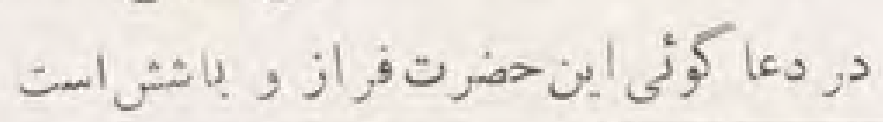

اكر سلطا نى هند است ارث دو دؤ شهسي

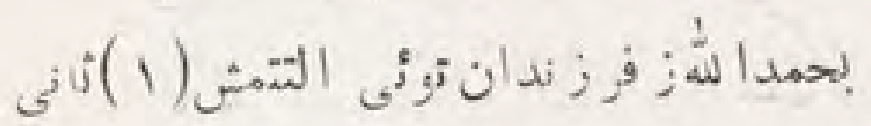

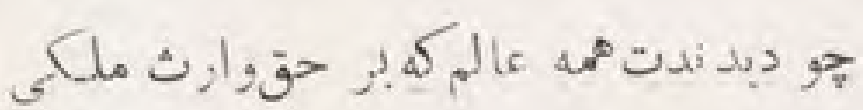

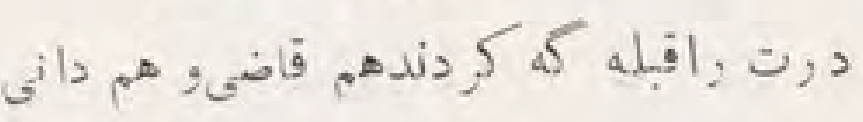

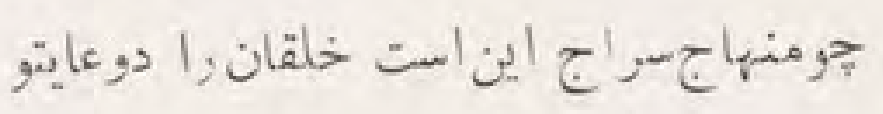

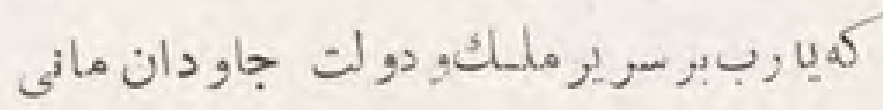

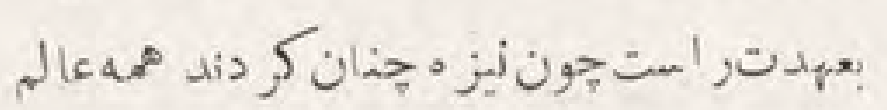

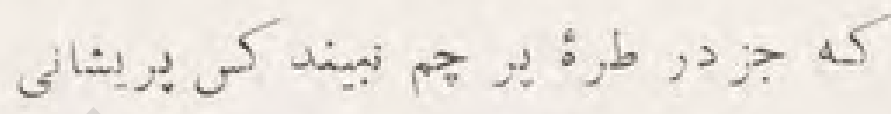

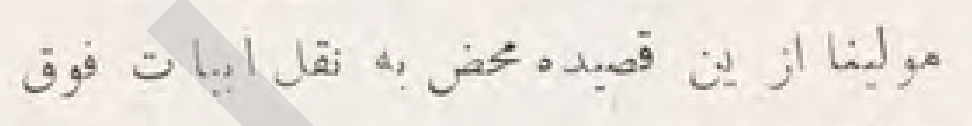
قناعت كرده است أن

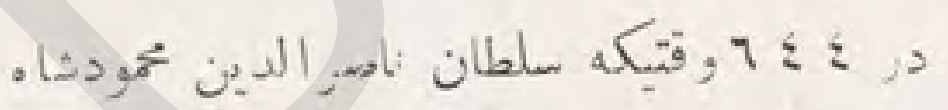

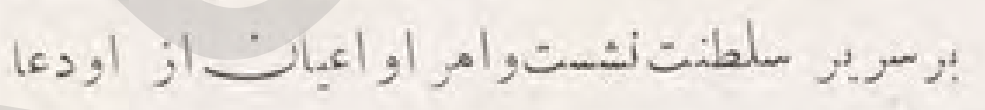

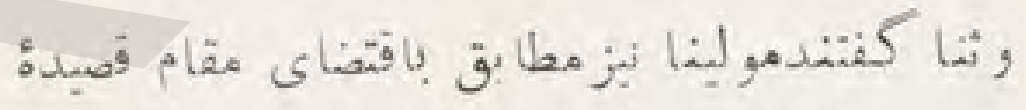

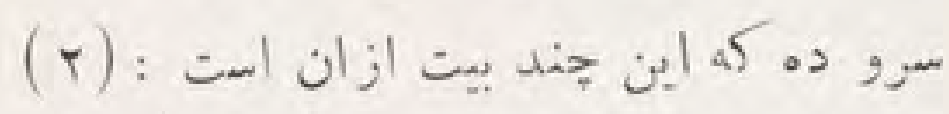

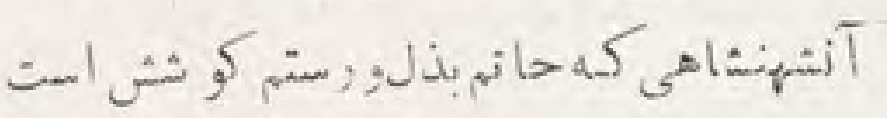

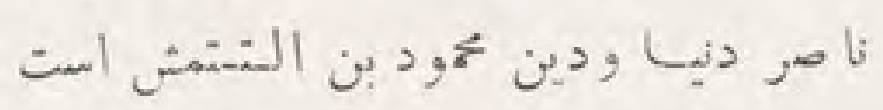

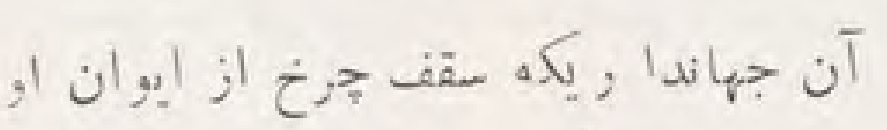

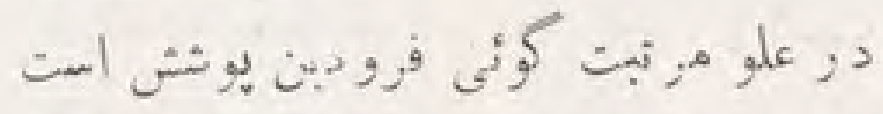

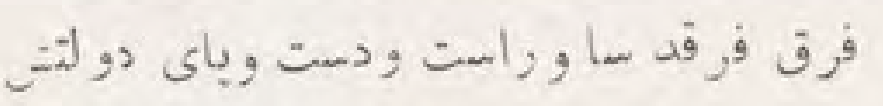

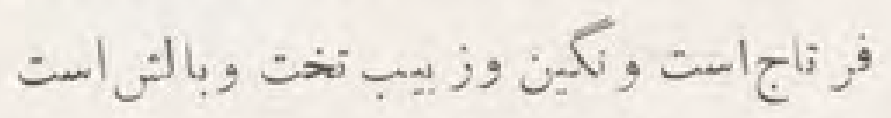

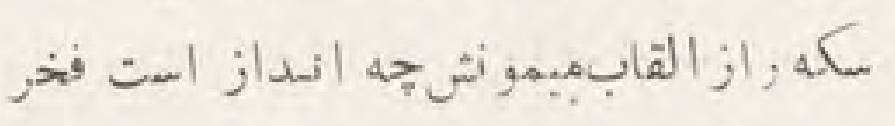
خطبه را ز اسمهمايونش حه بابه ناز ش است

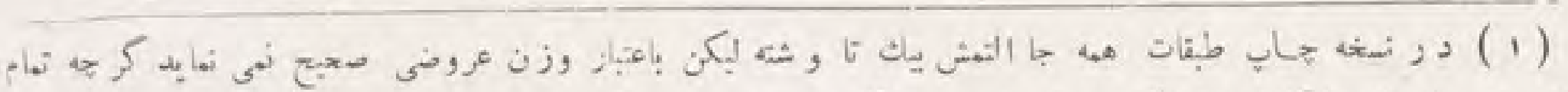

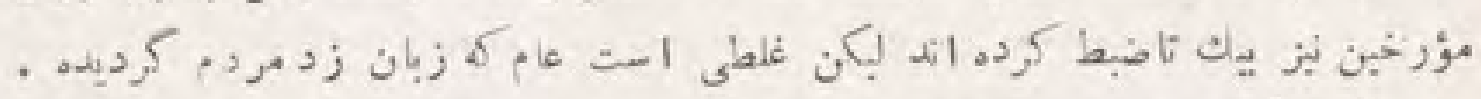
$r \cdot r \log (r)$

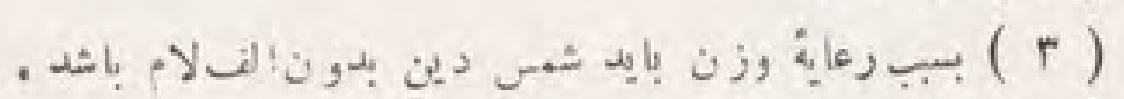

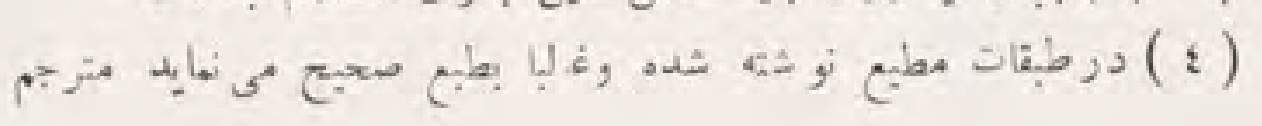




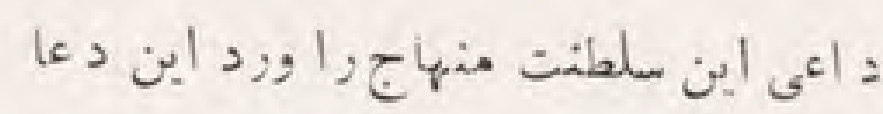
تاكه بادو خاك ر آبروآث است مورودباد

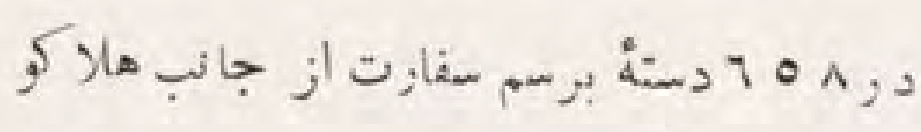

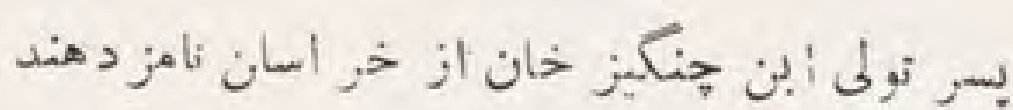

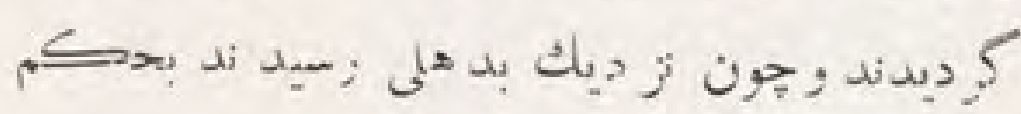

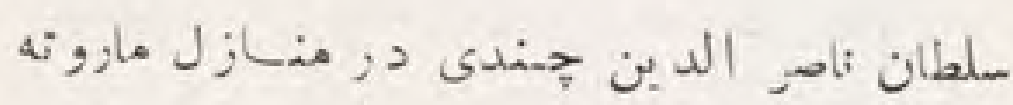
,حدود آن توقف نمو دند iا آنك سله سلطان بزم

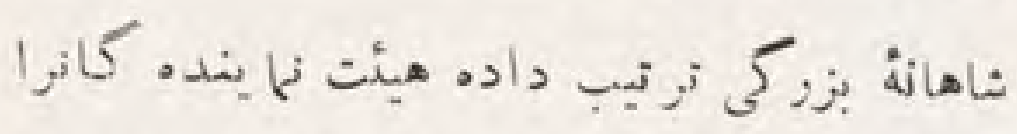

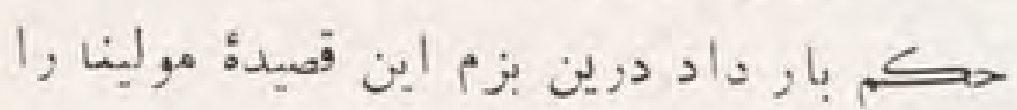

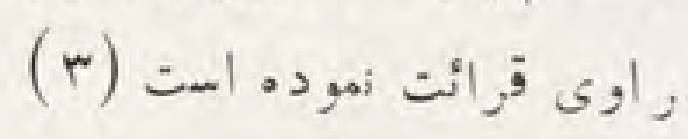

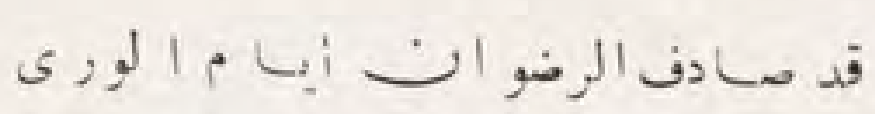

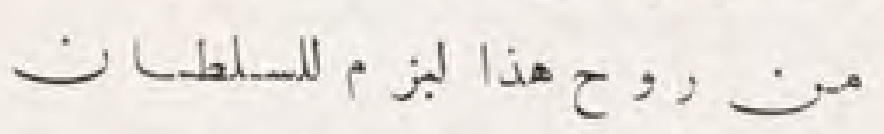

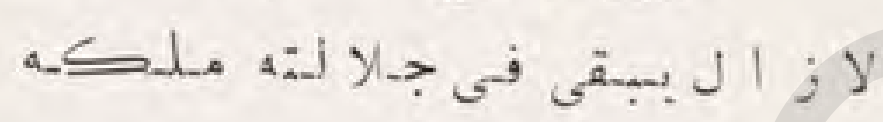

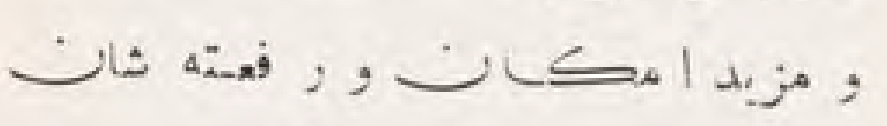

زهى جثنى كز راطر اف حو نخلد برين كثته حهى :زمى زموا كمناف عدل زاستين كشته

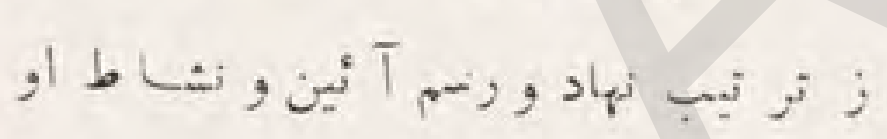

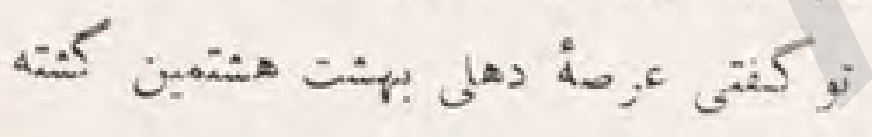

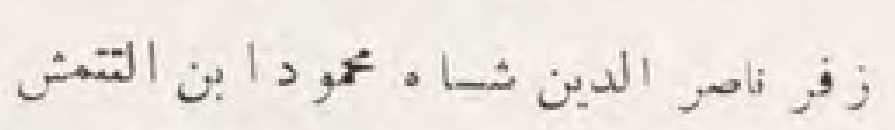

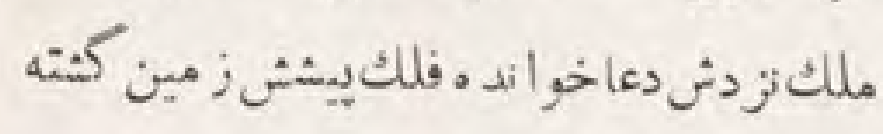

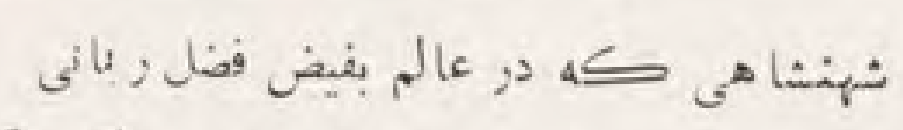

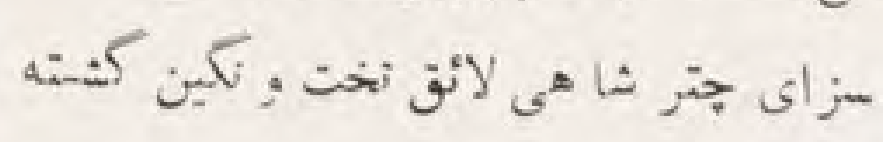

جوخاقا نان كين آورجهو سلطانان دين يرور بدل ماحى كفر استو بجان حامىدين كثته
از براى نصر ت ورنا ئيد شاه و بند كا نش

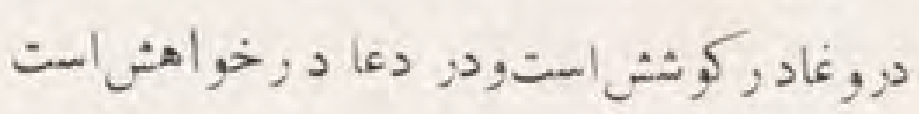

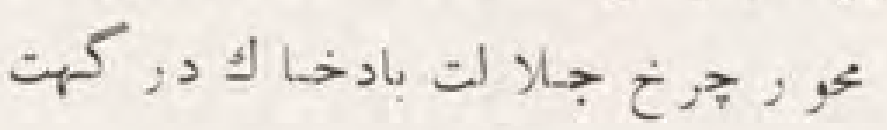

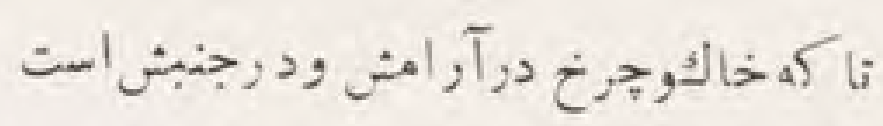

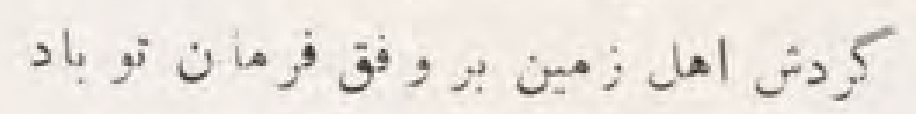

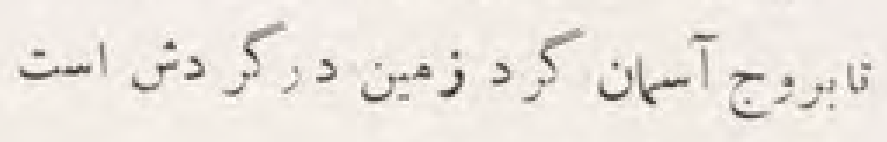
(1) : (1) شاه را جون نام خو يثش عاقبت عمود باد

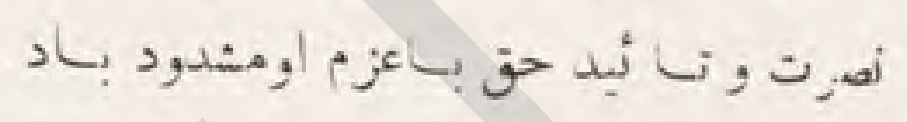

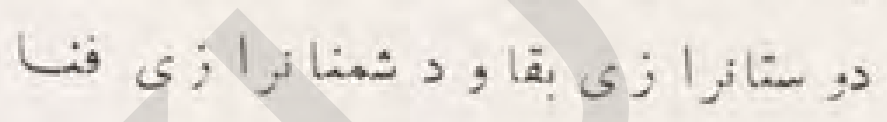

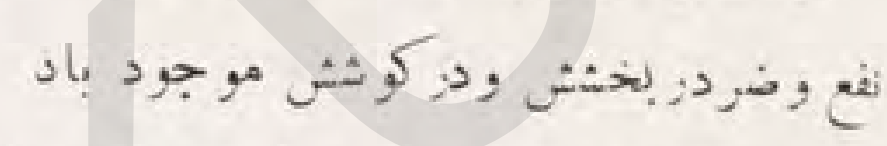

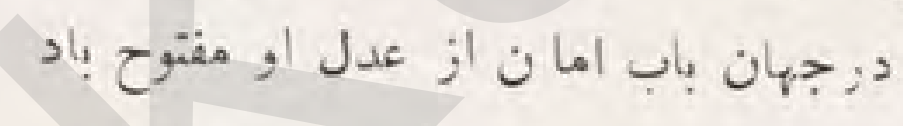
باب بيدا دى بعهد ني مغلق و مسدد ود باد

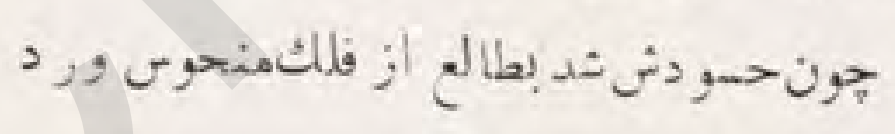

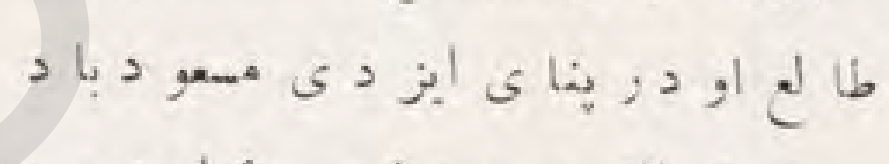

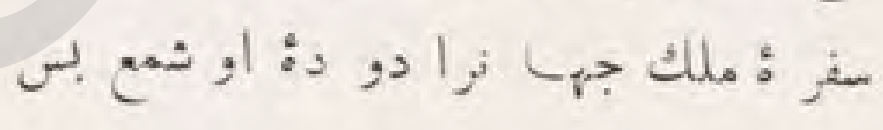
جهر • اعدا ى او دور ديدها جود:د باد

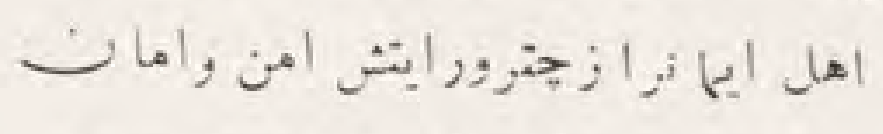
سابه بان دين حفند ظل ثان مهدو د بـاد مقصدث بر فضل حق جون نكيه كه دا رود مدام بى نو قف شاه راحل صل هره مقصوح باد خاتمسرش جو نقش عدل: احسان با فتهاست

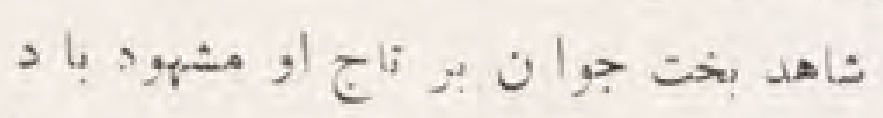

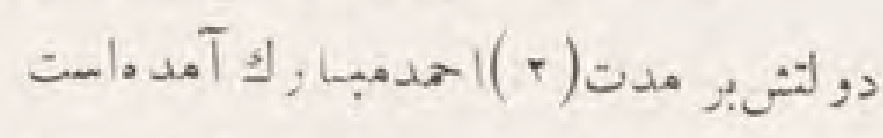

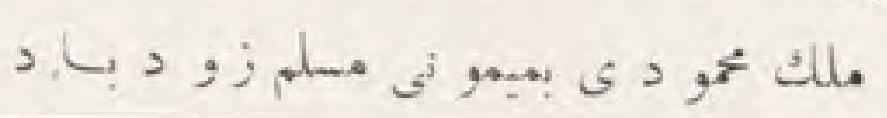

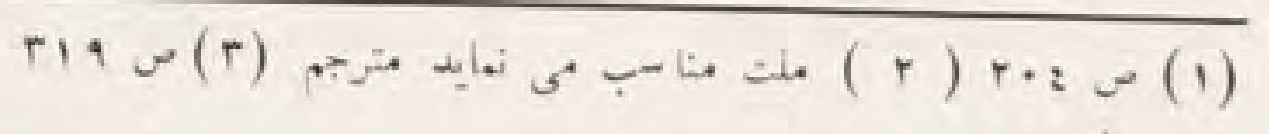




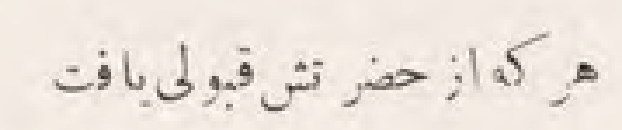

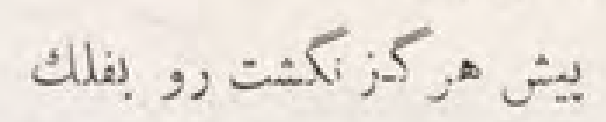

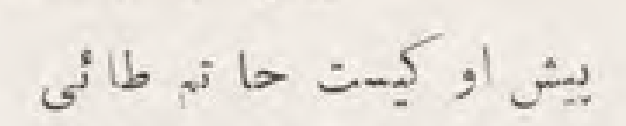

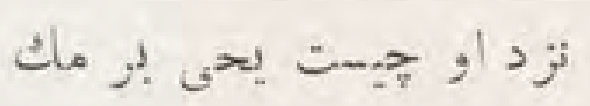

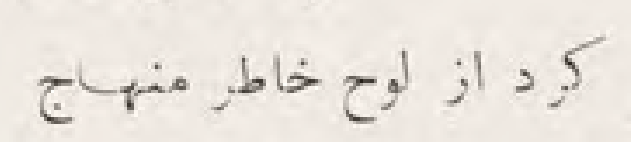

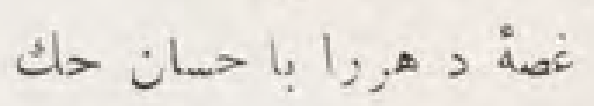

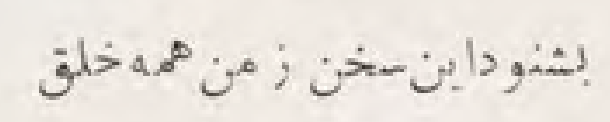

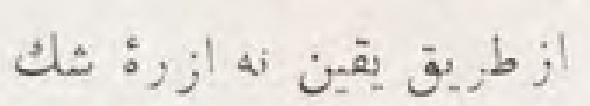

$$
\text { i }
$$

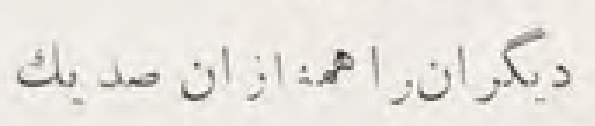

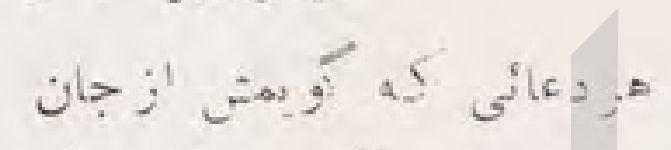

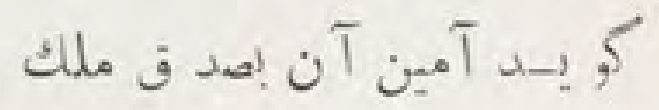

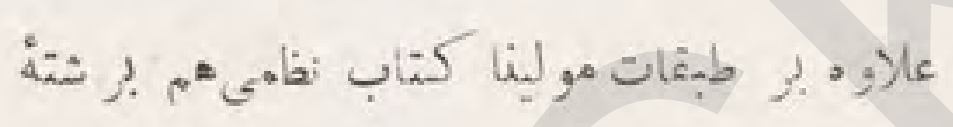

ه

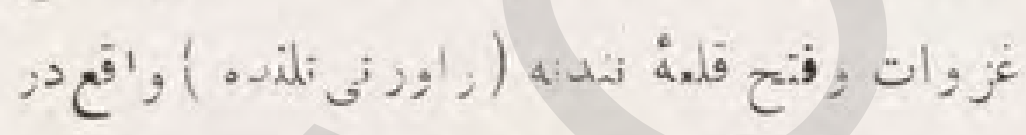

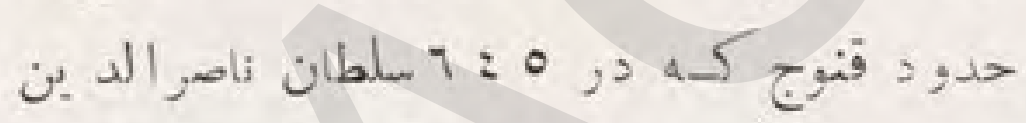

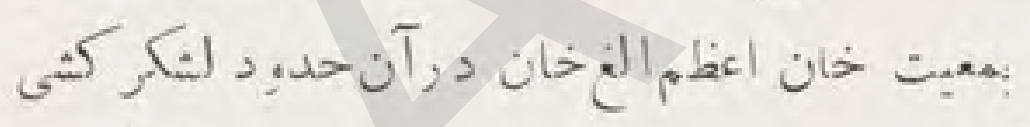

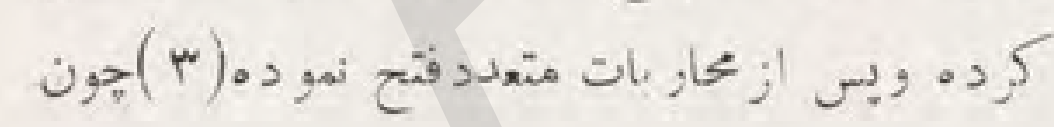
مو لينا د, موكب شأهى حاضر بوده فتوحات مذك رو

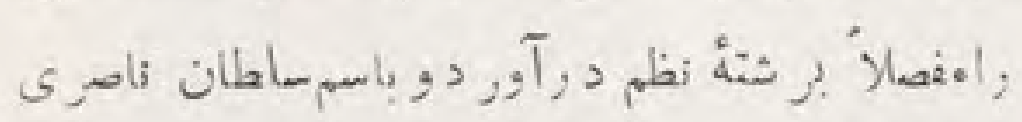

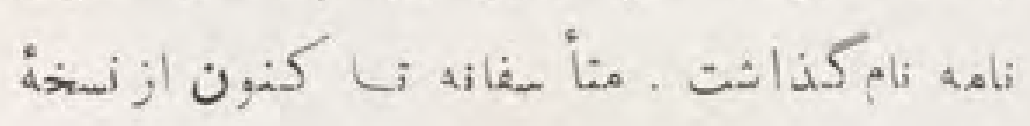

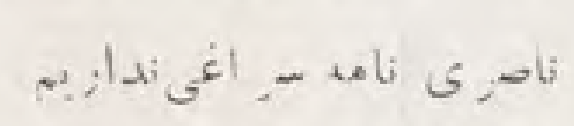

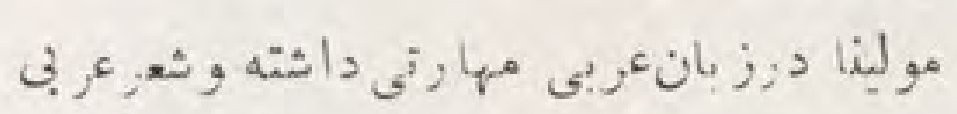
on

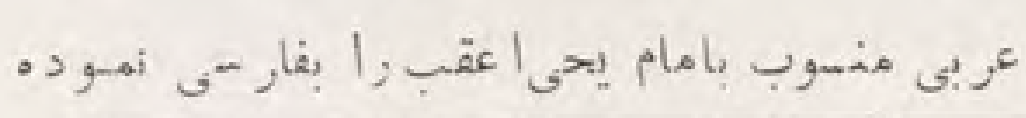

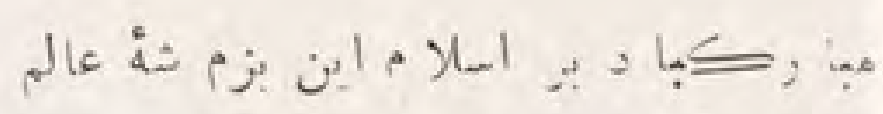
كزيتر تيب هندستان بسى خو شترز جين كشته

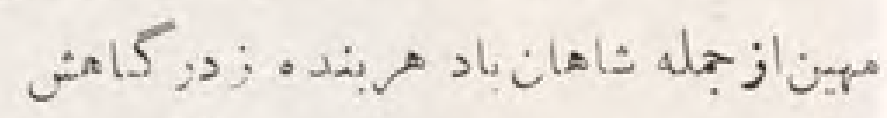

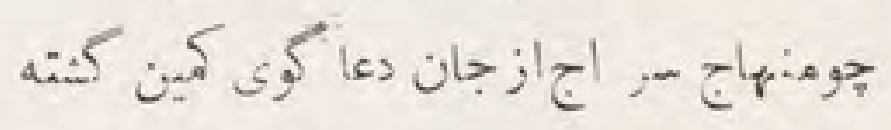

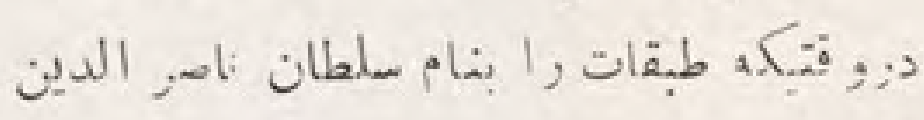

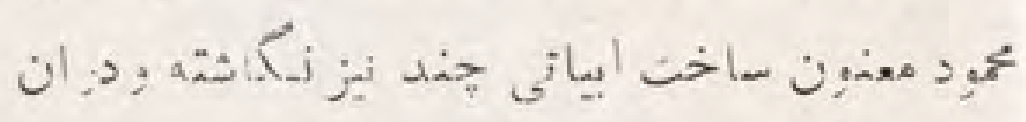

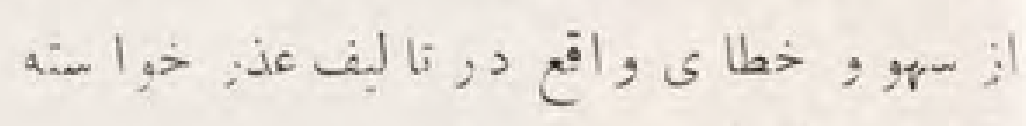
(1): $:$, s.

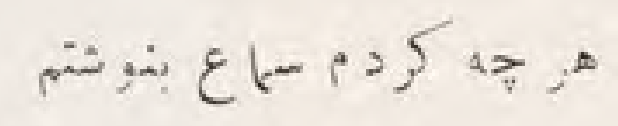

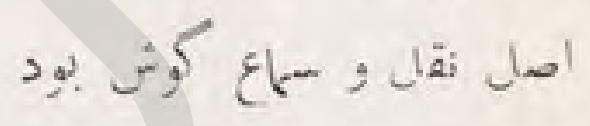

$$
\begin{aligned}
& \text { ن }
\end{aligned}
$$

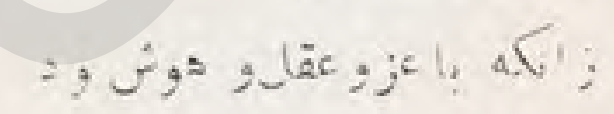

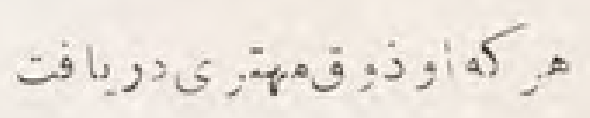

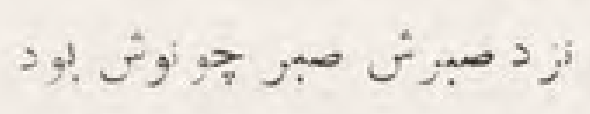

دامن عنو هبرورئ ه-بدام

در رو: حلم عيب بـوثى بود

بد عايباد

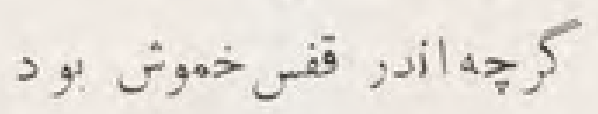

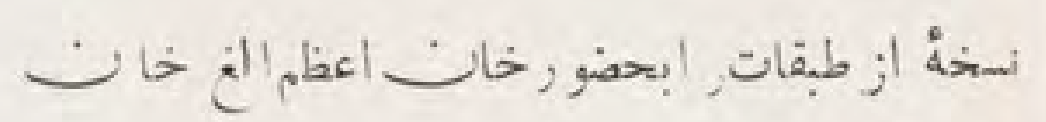

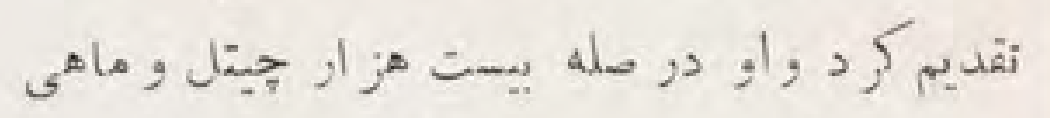

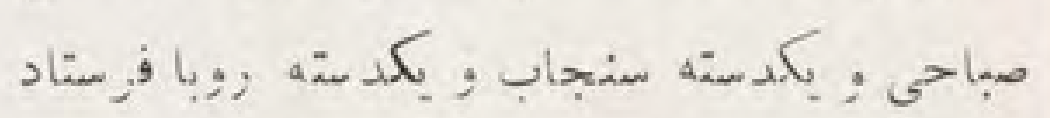

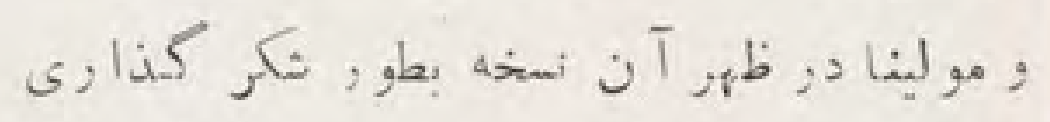

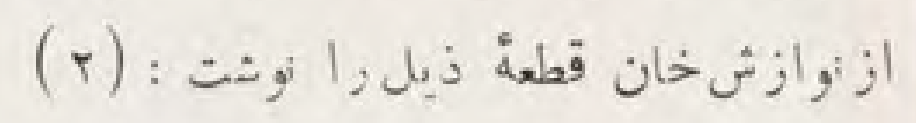

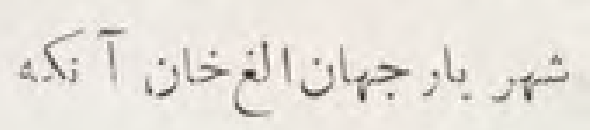
خان الجر ز بست , ثاء سماك 


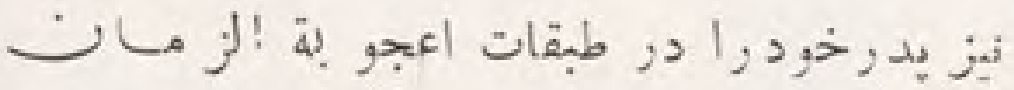

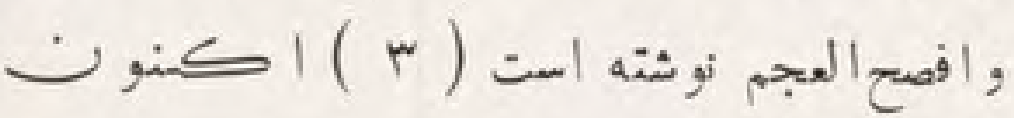

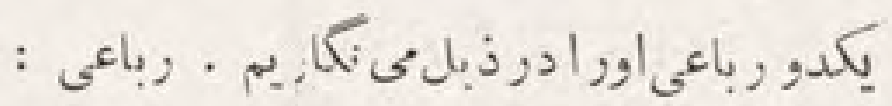
آ آندل كه; وزهر شادى كم بودرباكث كردى

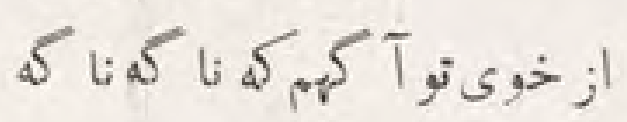

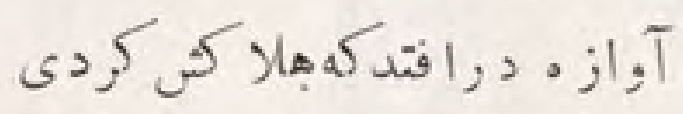

$$
\text { دل, برخخ خوبتوميل افتادهاست رباعى }
$$

جانديده بر اميد لبت بكثادهاست

$$
\text { جشم آبز نخا كدرت خواهدبود }
$$

كرعمروفا كندقر ارايندادهاست

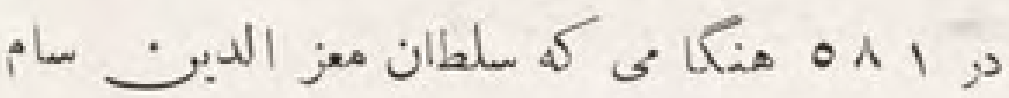
بر لا هور لثكر كشيد و فتح كرد مولينا سراج را 1

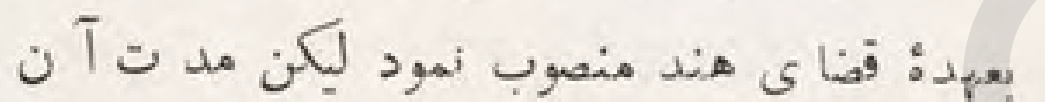

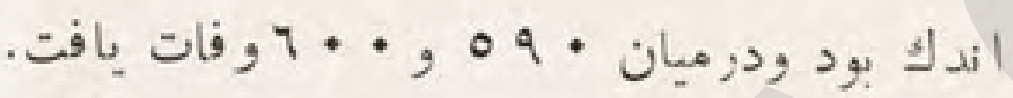
مولينا سر اج ازطرف سلطا ن غياث الدين سـم ودم بدربار خالافت بغداد بحضور خليفه النا صر الدين

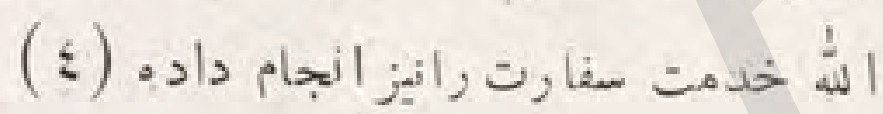

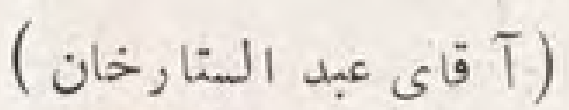

$$
\begin{aligned}
& \text { واز ابندو بيت عربق (1) اوكه بِيشت هم نو ثته } \\
& \text { إبم معلوم ست : } \\
& \text { قد صاد ف الر ضوان ابام الو رعى }
\end{aligned}
$$

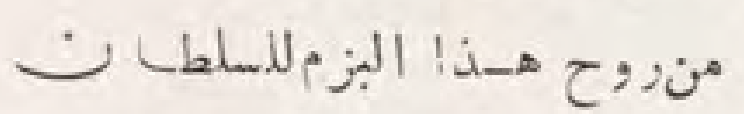

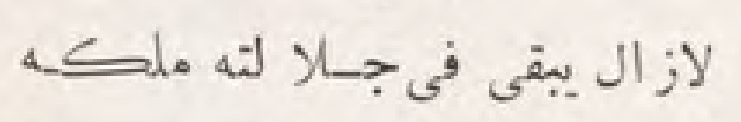

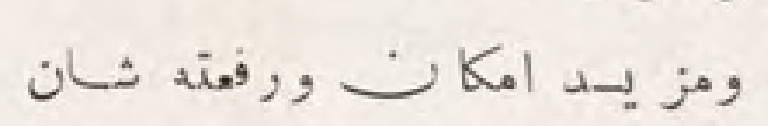

لعضى از تذكرم هـاما تندهفت اقليم' صبح كلثن.

كلزز ار ابرار در بين مولينامنهاج:بدر ار سراج منهاج اثنباهى كر دمرباعبات بدروا إنامبسرضبط

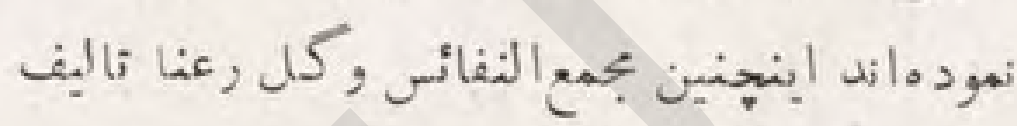

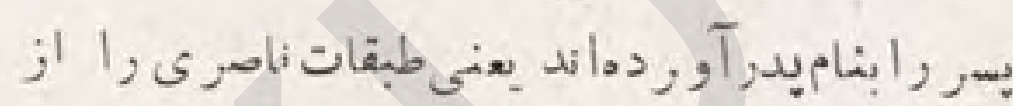

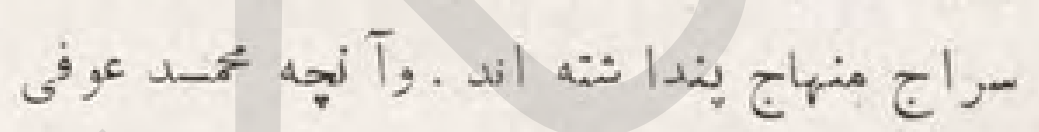

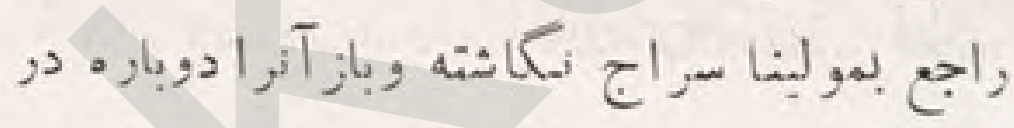

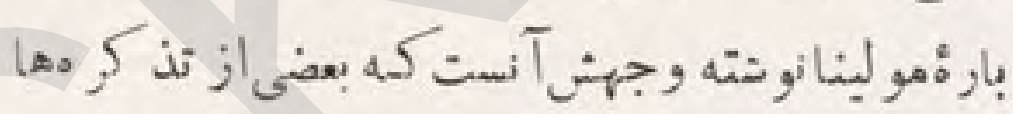

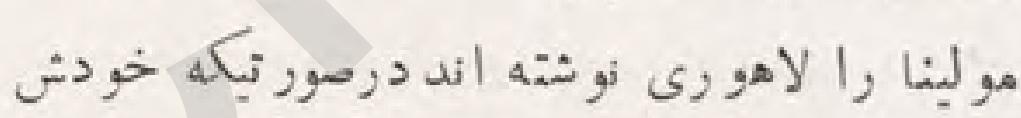
خودرا جوز جنانى كفته است .

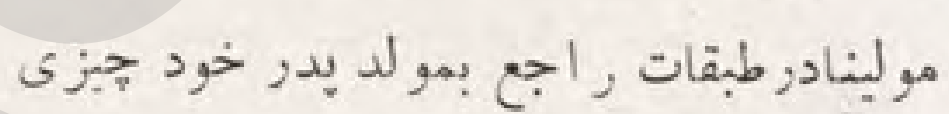

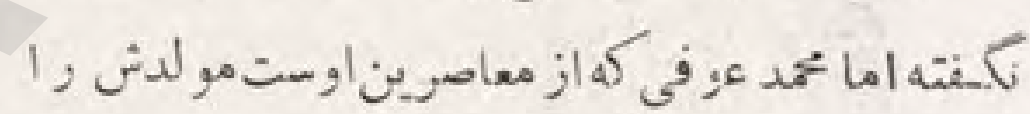

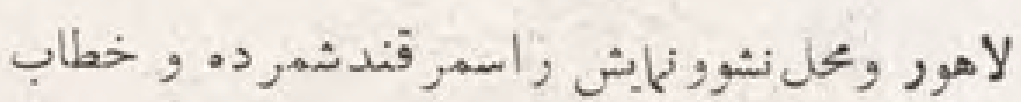

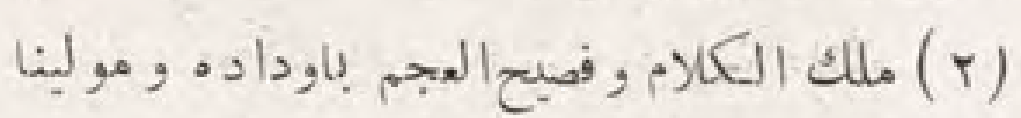

\section{(1)

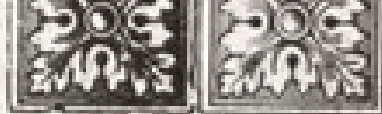

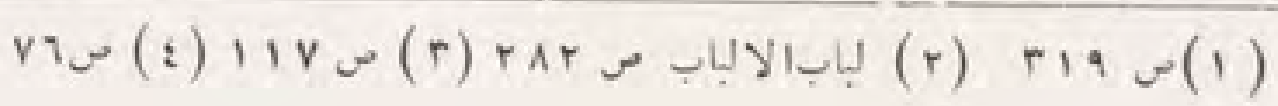




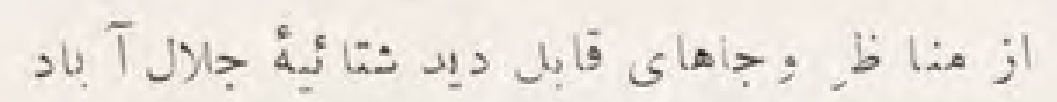

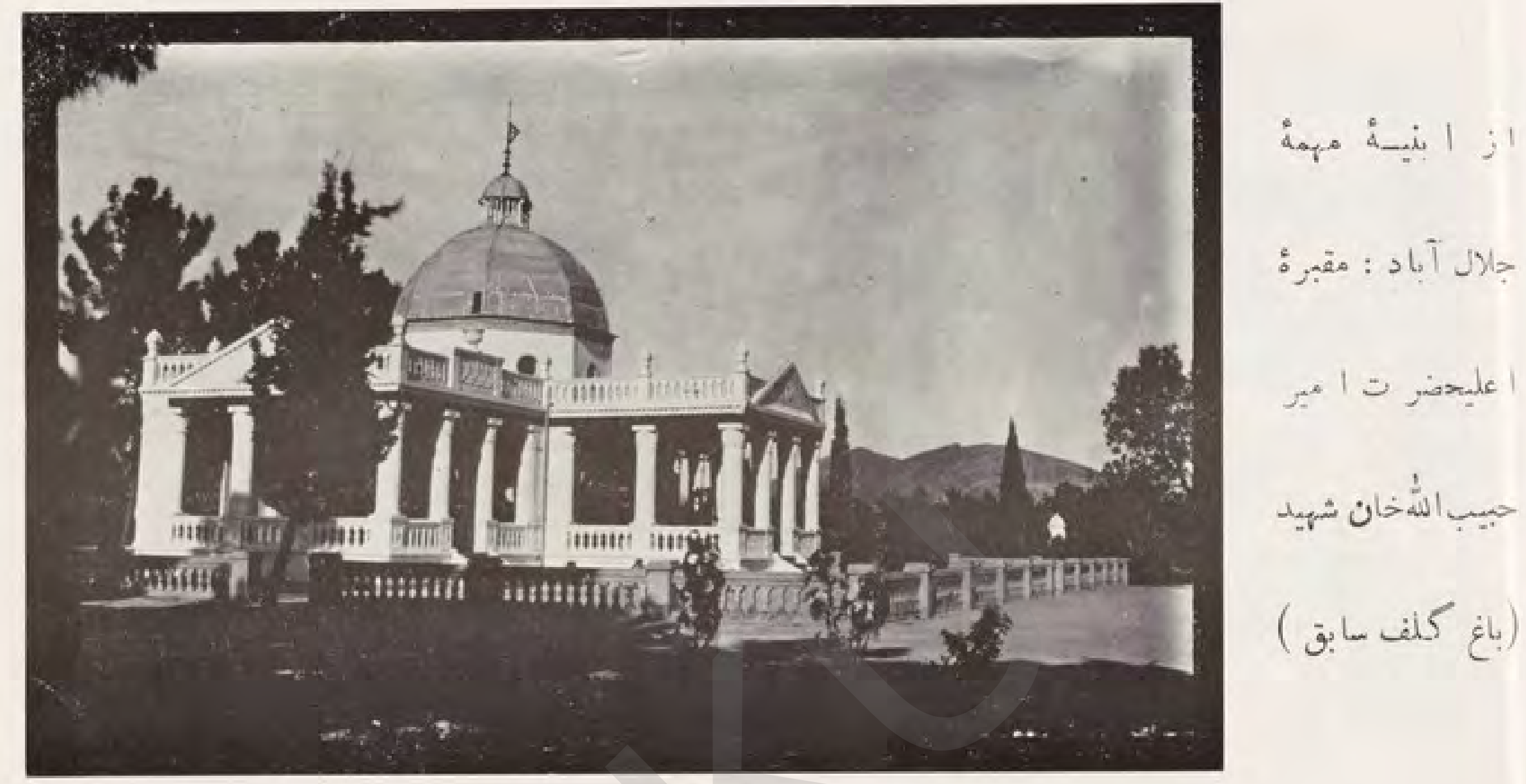

$$
\begin{aligned}
& \text { ونه جنو } \\
& \text {. } \\
& \text { دور نزاى كنبد } \\
& \text { بز } \\
& \text { مهناب (از حصه } \\
& \text { لخز ارلب دريا }
\end{aligned}
$$

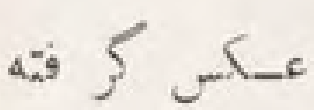

$$
\begin{aligned}
& \text { ( . A }
\end{aligned}
$$

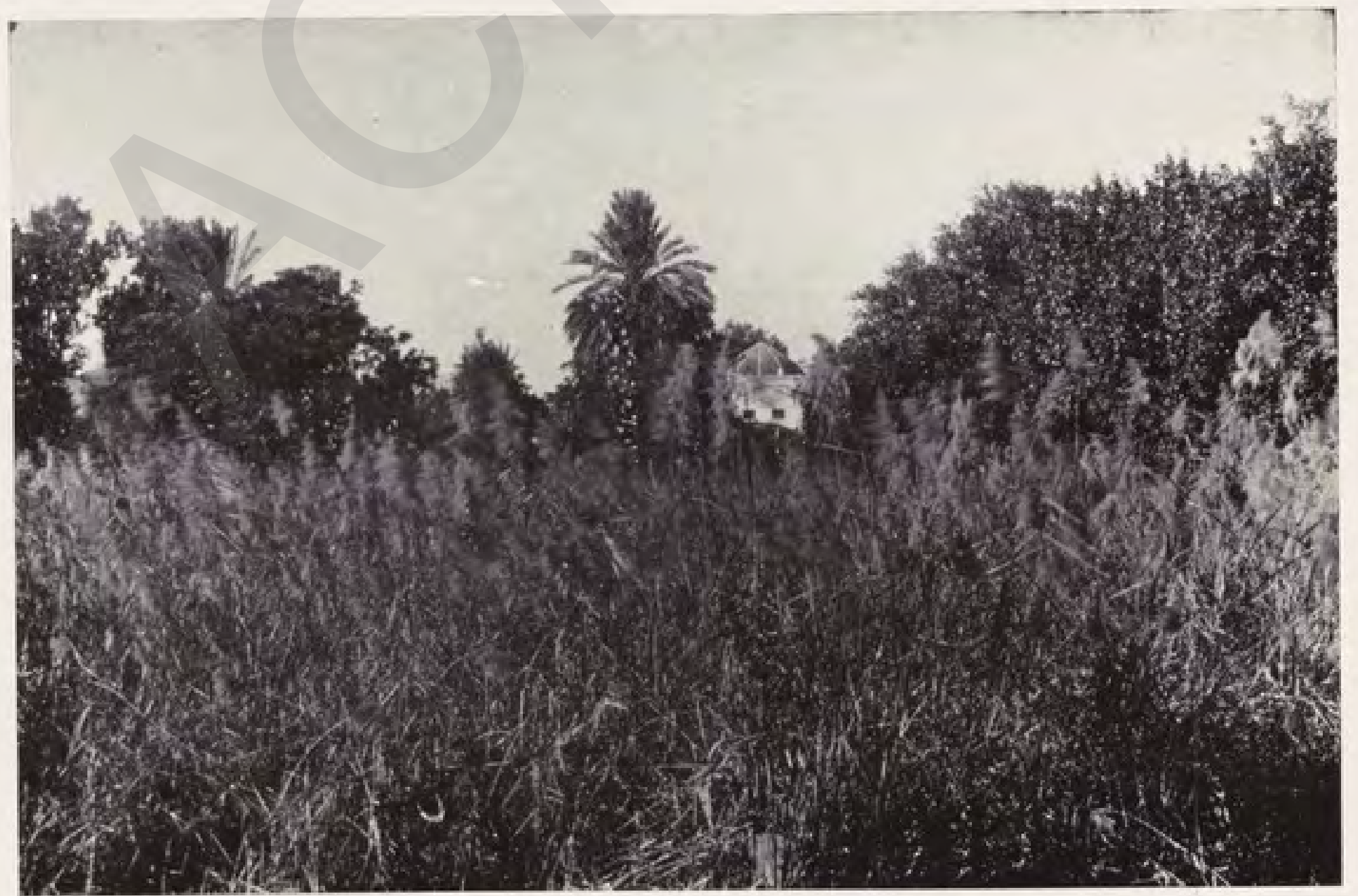




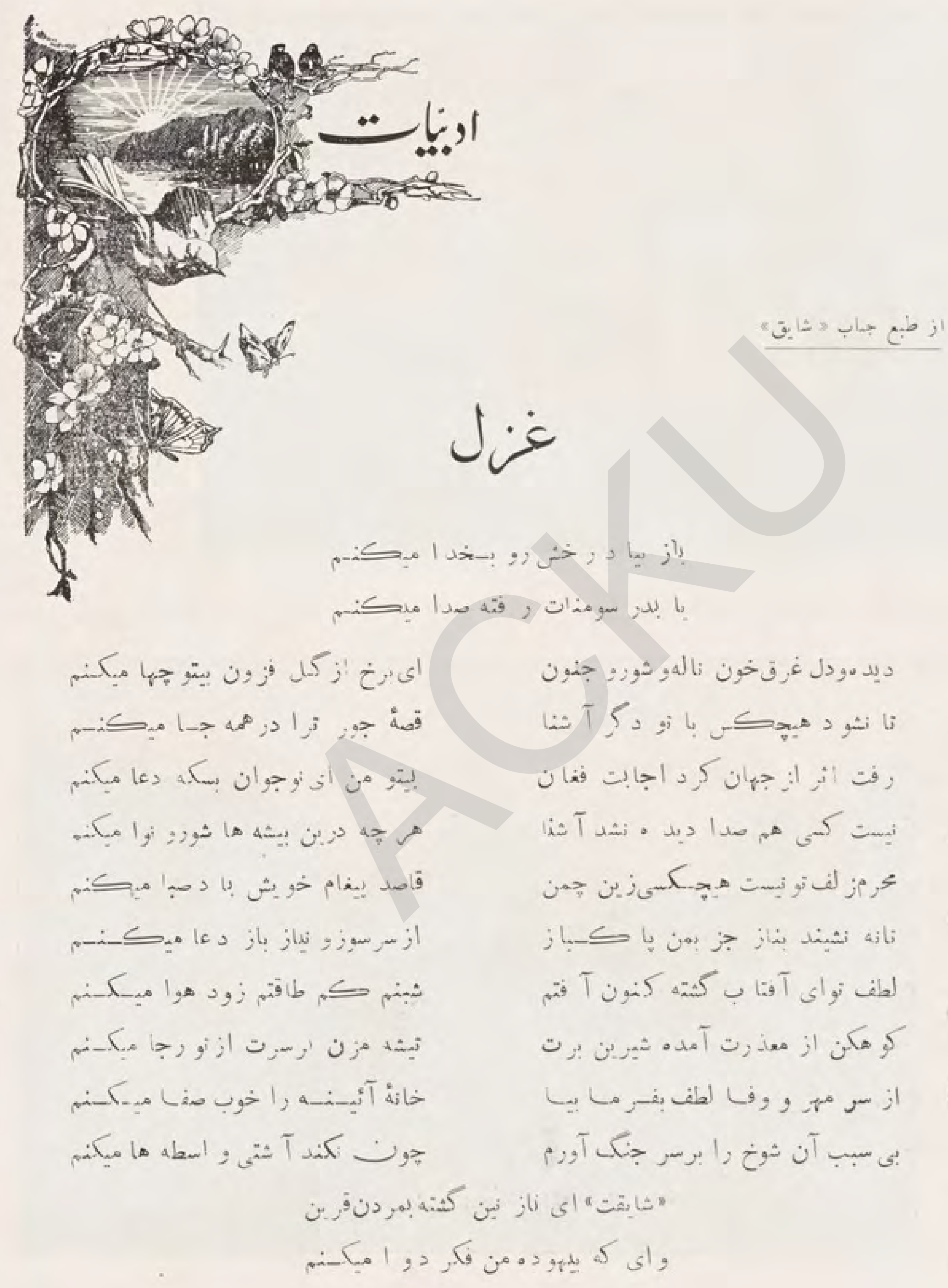




\section{غنل}

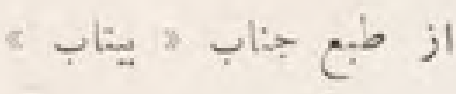

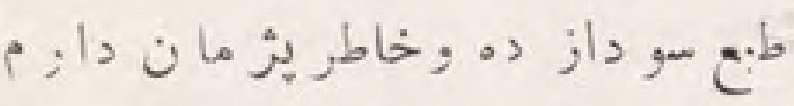

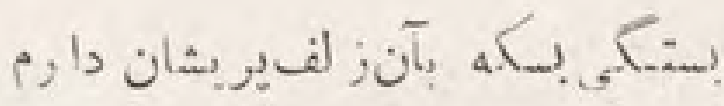

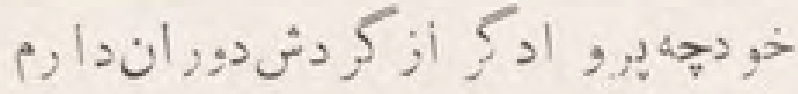

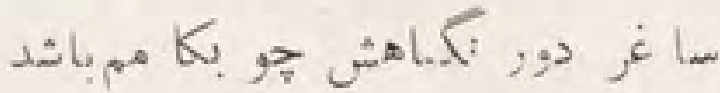

كه بآن هصجف ,خسا; زو إِعان دارم

تر سم از ;2ز ني هندوى زز لفت نبود

من هم آخر مرخت ح ديدة حيران دارئم

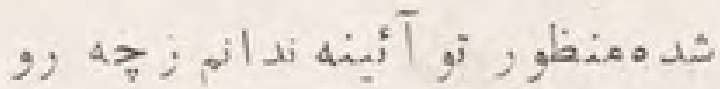

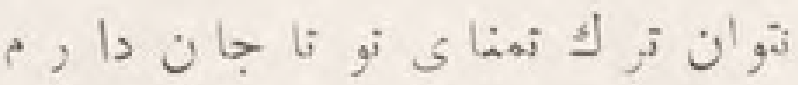

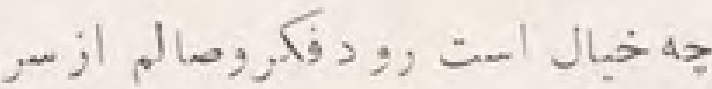

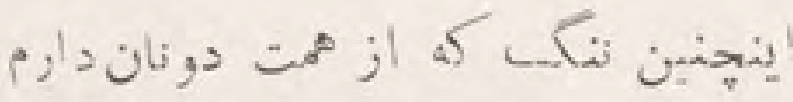

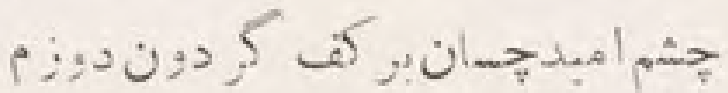

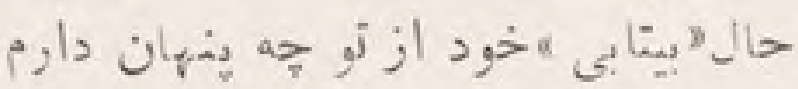

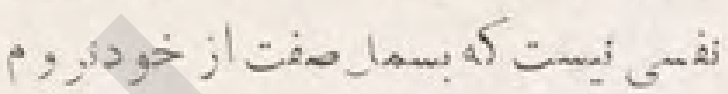

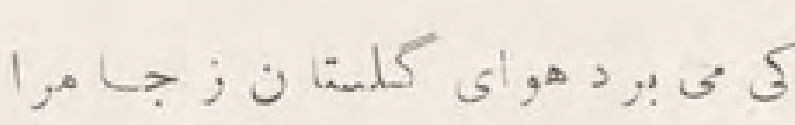

*

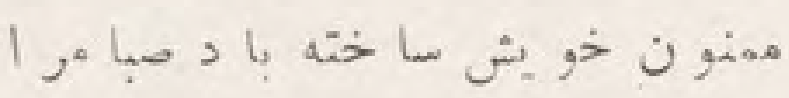

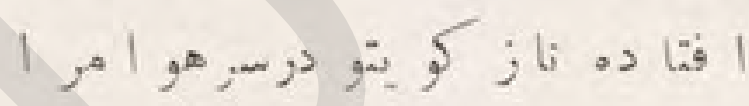

آ

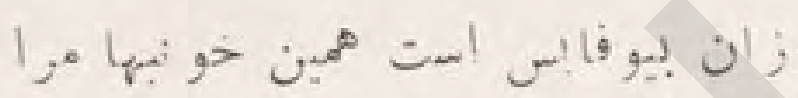

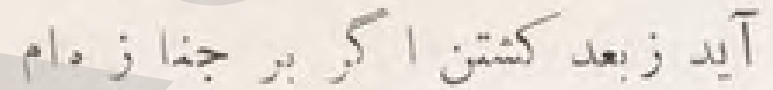

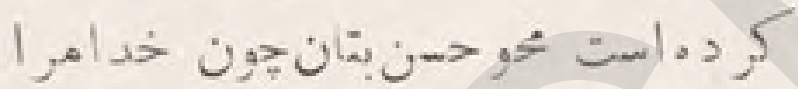

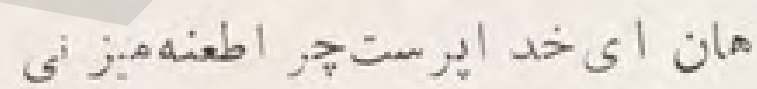

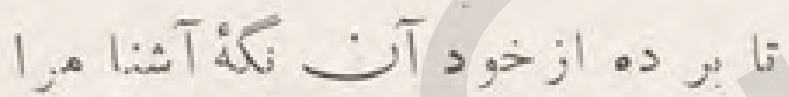

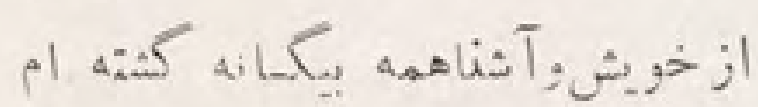

فرها د ساخت عشق تو شير ين اداهرا هرا

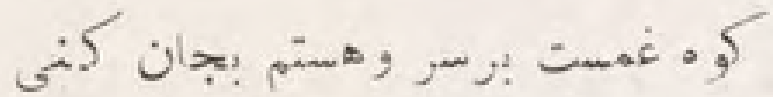

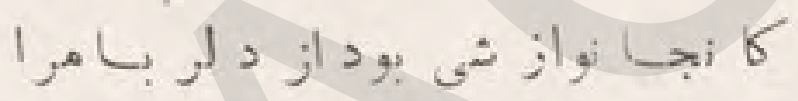

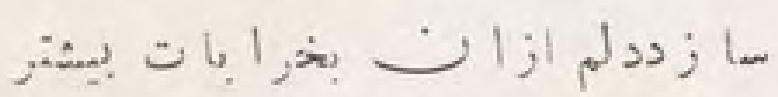

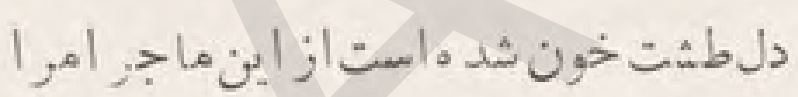

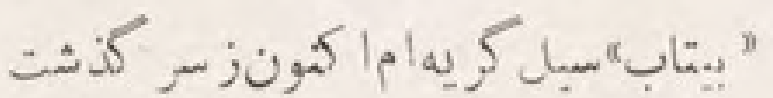

\section{غزل}

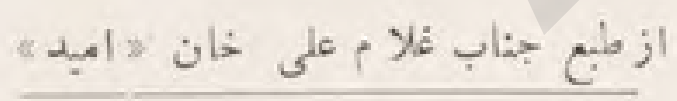

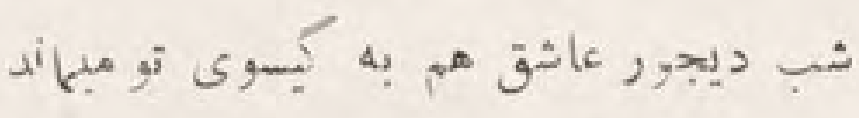

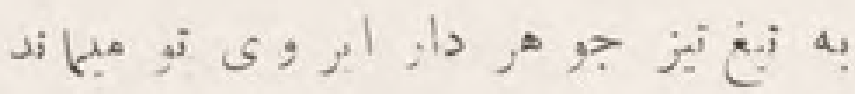

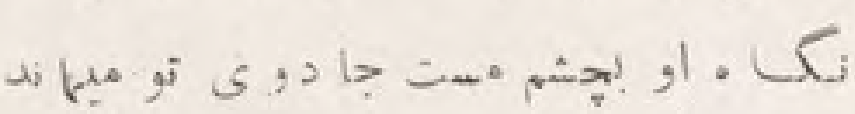

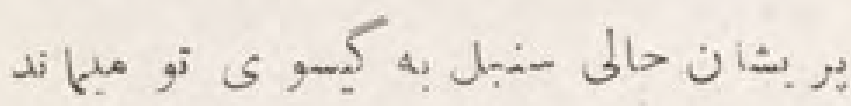

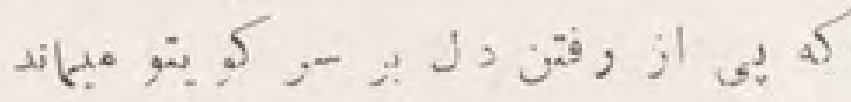

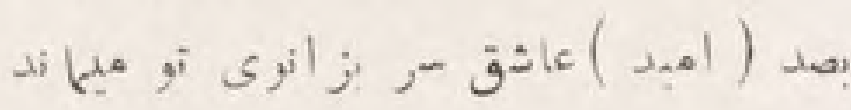

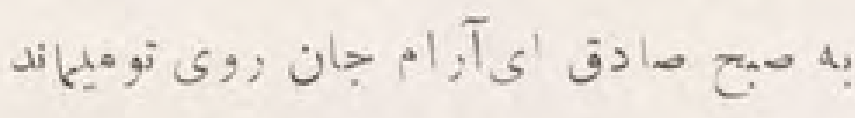

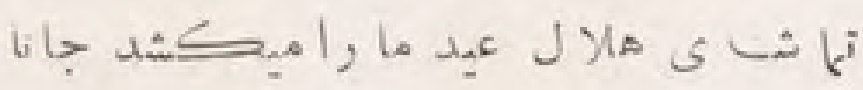

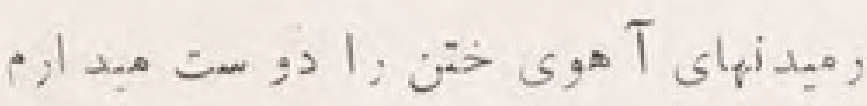

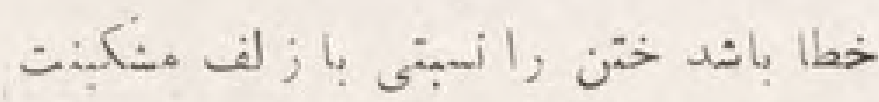

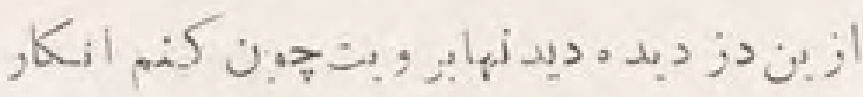

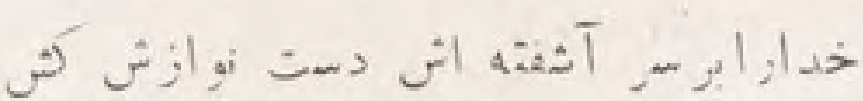


از طبع جناب عبد اللطبن خان ملك خيل

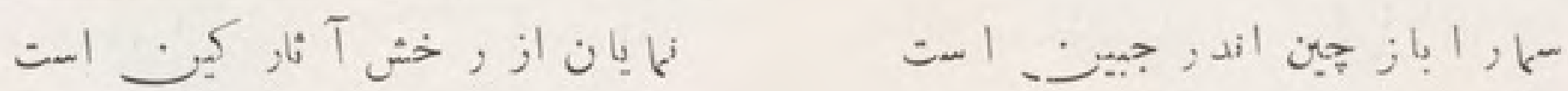

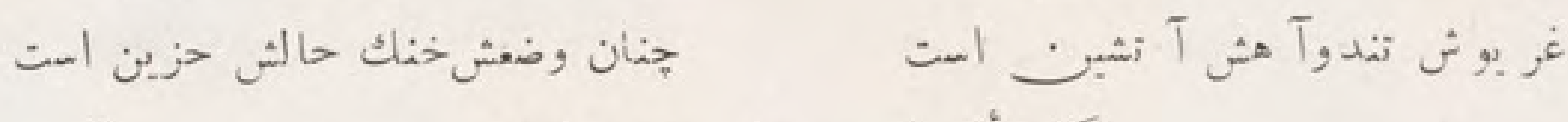

$$
\begin{aligned}
& \text { كه تأ نيرث هو بدا بر زمين است }
\end{aligned}
$$

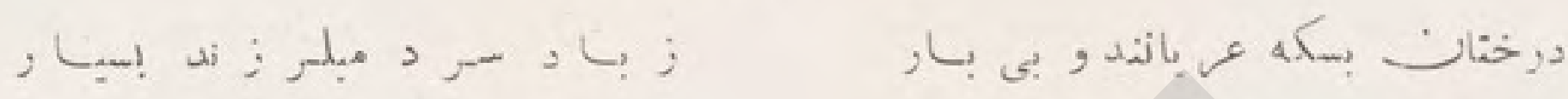

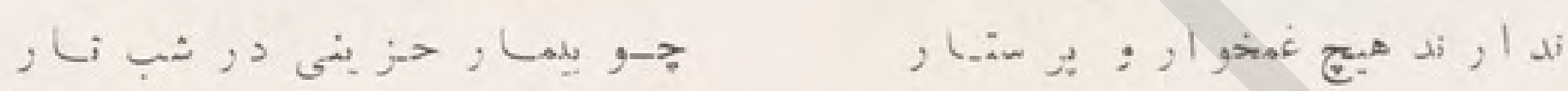

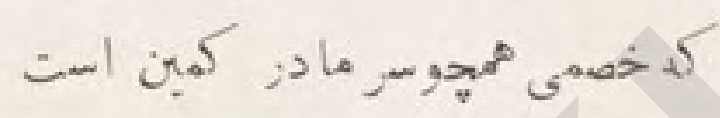

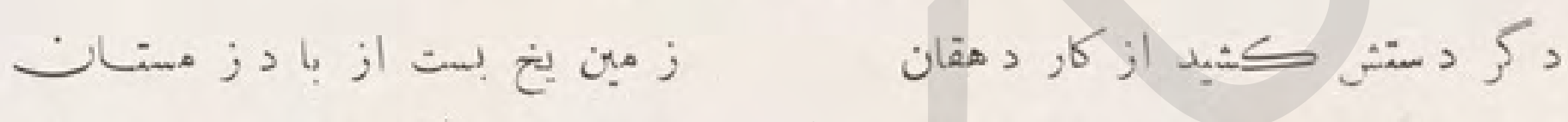

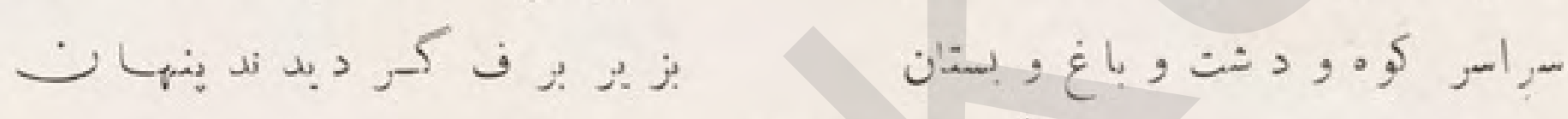

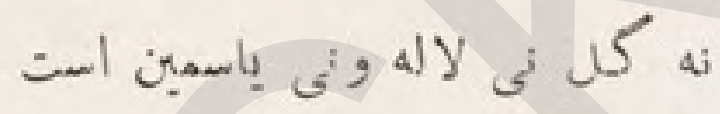

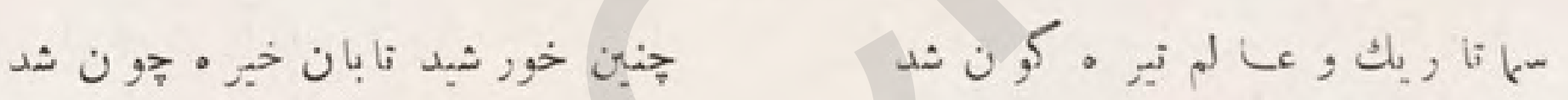

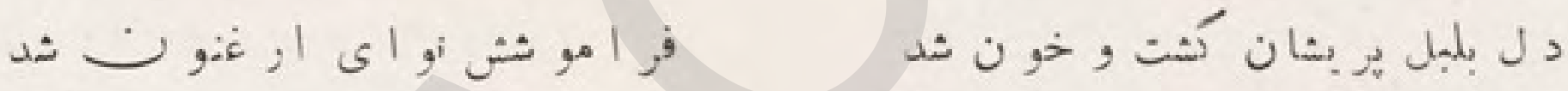

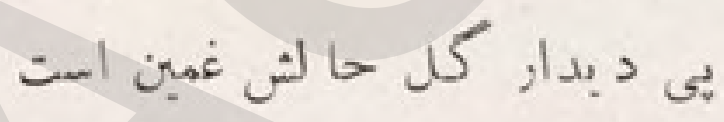

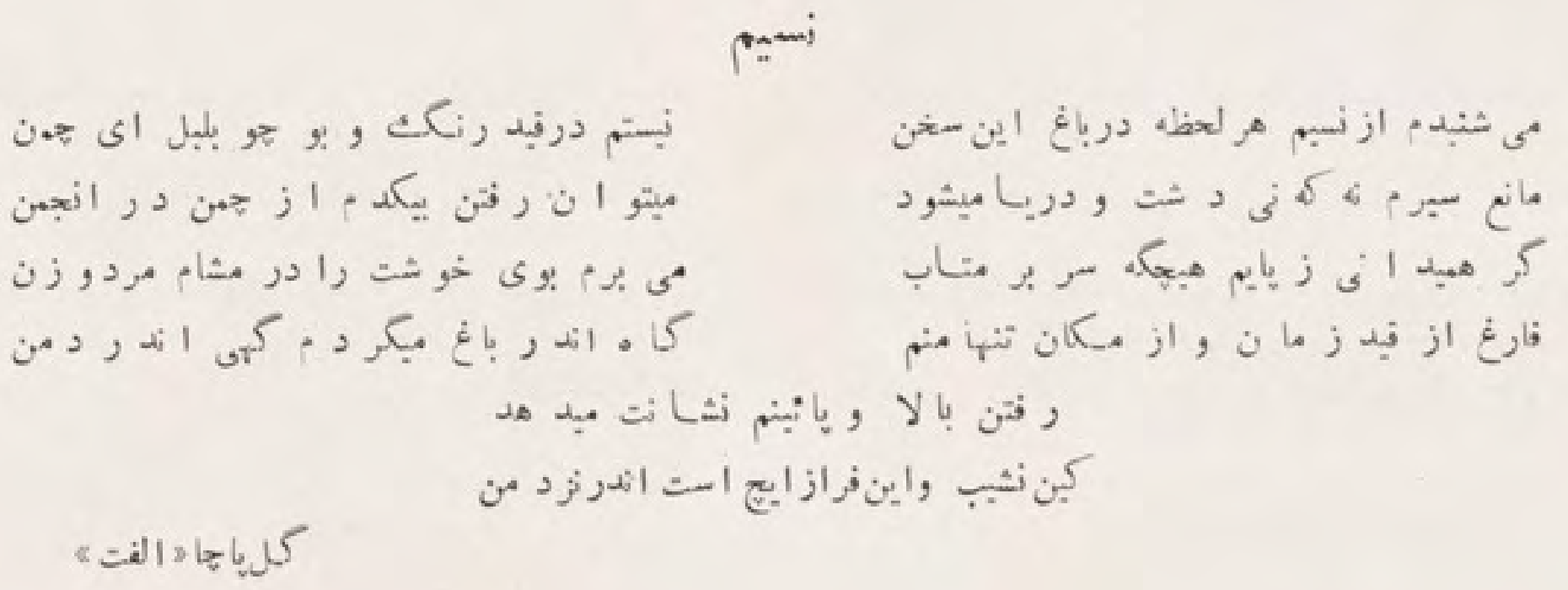




\section{اذدرزدو ست}

\section{موبص}

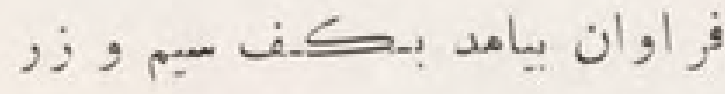

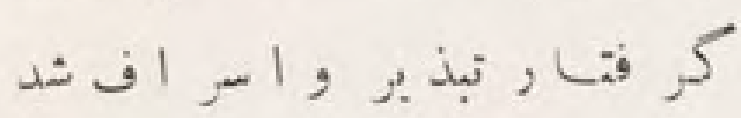

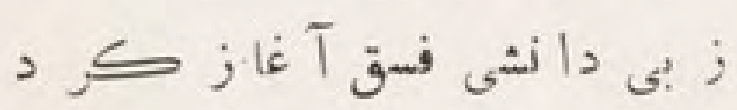

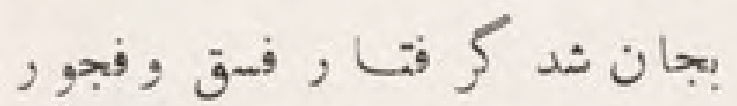

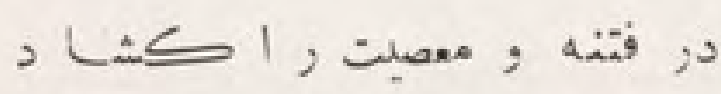

جدا كثت از صحبت عقل و هو ثن

نه بر مبك:ت خو يشتن مى فز و د

خر sis

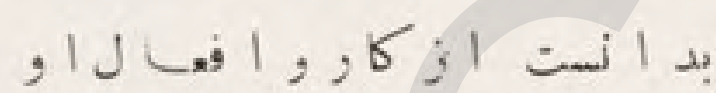

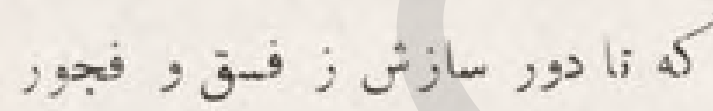

جنين كفت

بـ

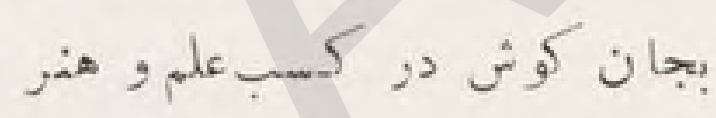

بههت بـى عهلم

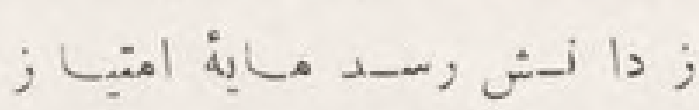

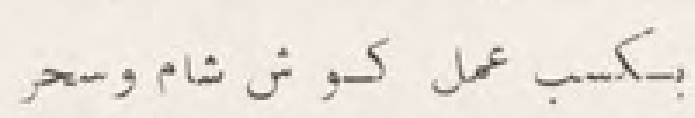

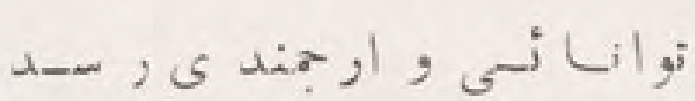

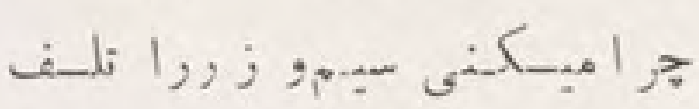

حذ; كنز هis

- مزدخرج كـردن بـقدر ضر ور

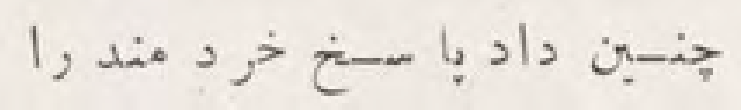

ب. جو در دست او كنتج اسلاف شد

سركنج ا جد اد, را بازز

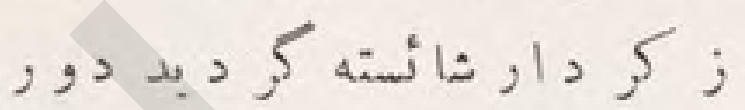

قدم دز ر : عيش و عشرت زهـا

شب ور روز شد همدم ناى ور زونى

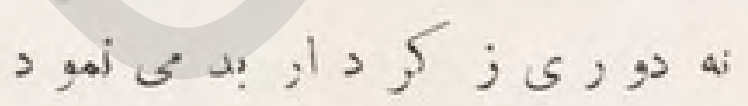

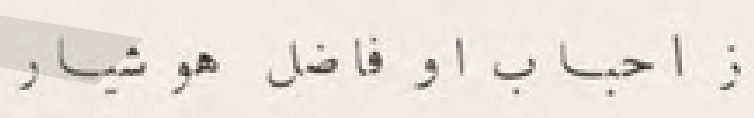

جو واقف ثد ازحال ر, احو ال او به نز د بك ار آ هد از زاه

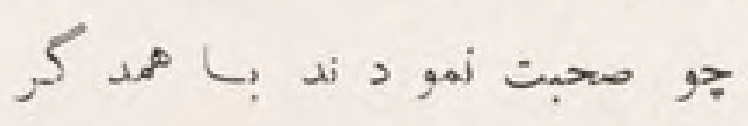

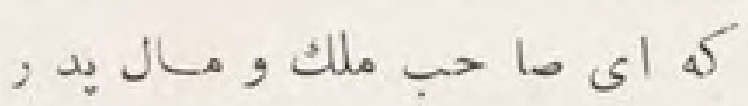

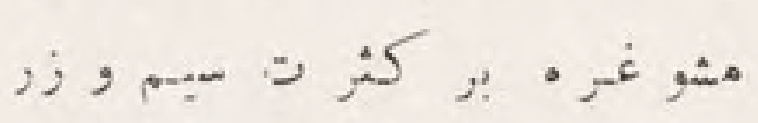

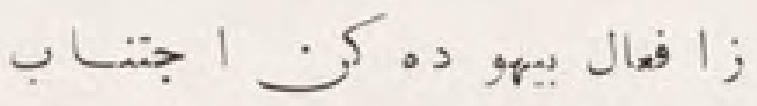

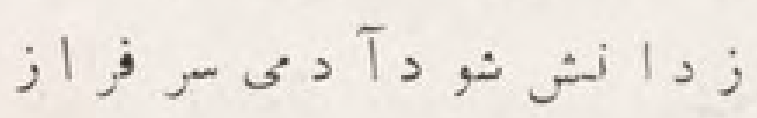

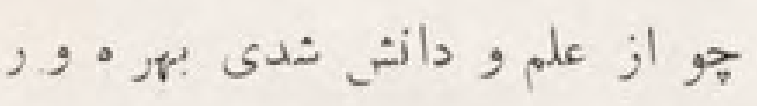

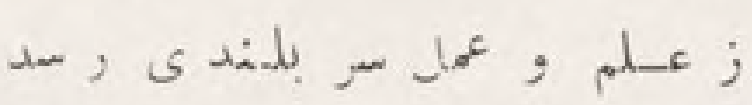

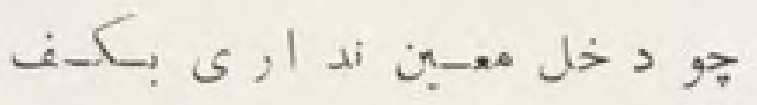

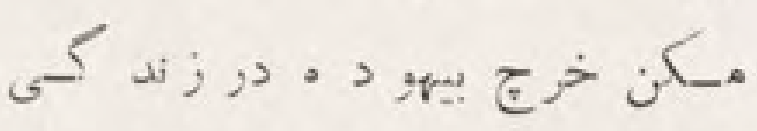

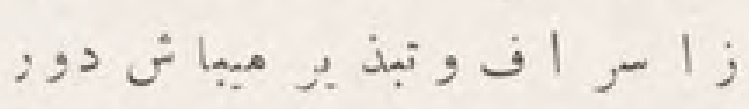
جד 


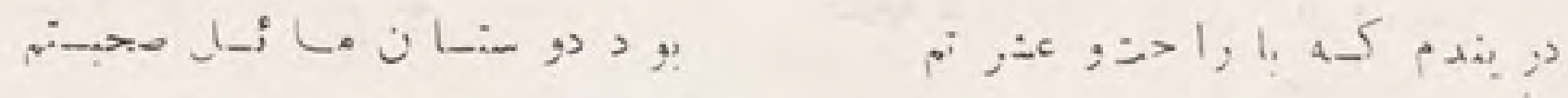

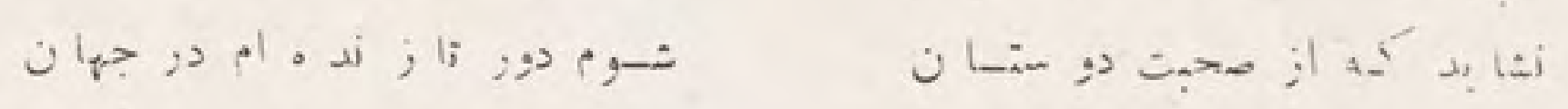

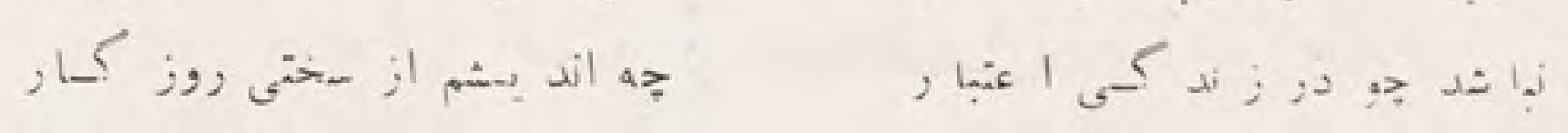

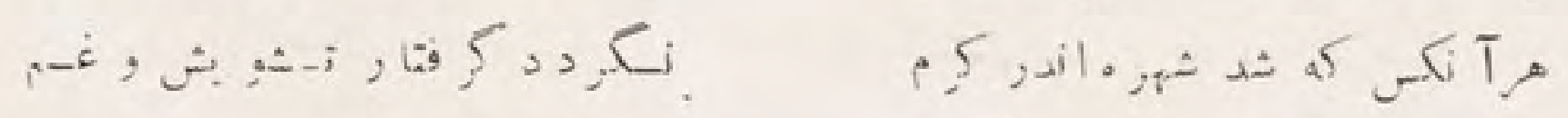

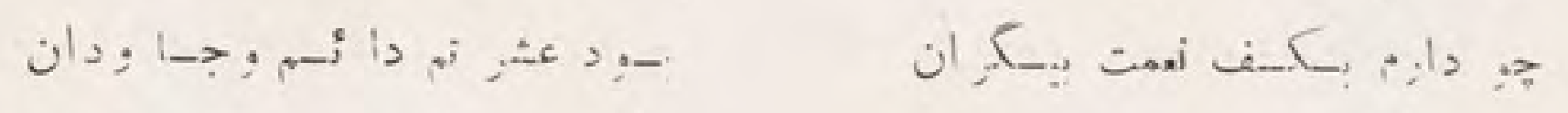

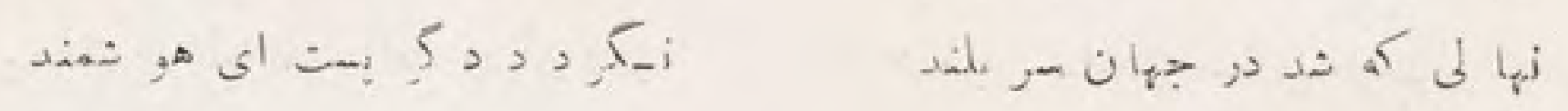

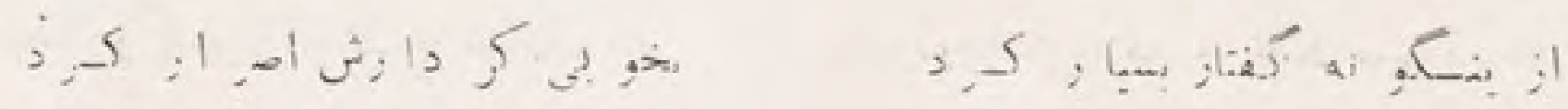

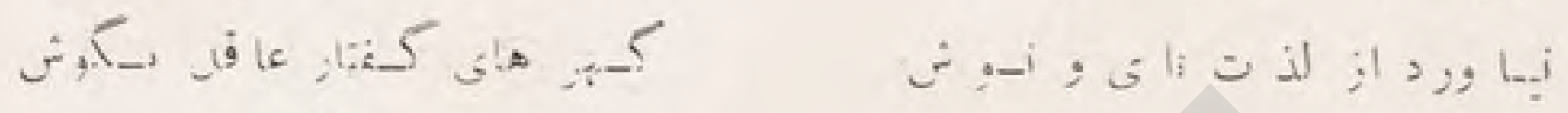

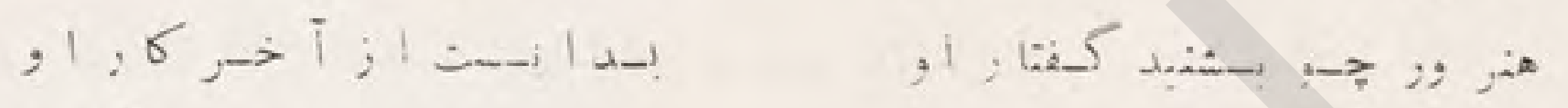

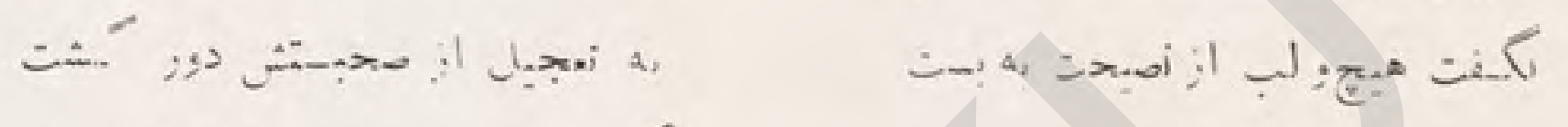

$$
\begin{aligned}
& \text { لش }
\end{aligned}
$$

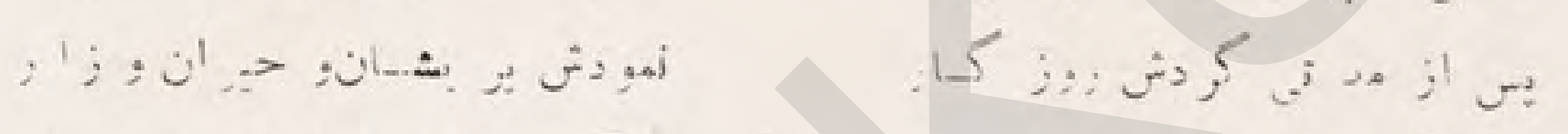

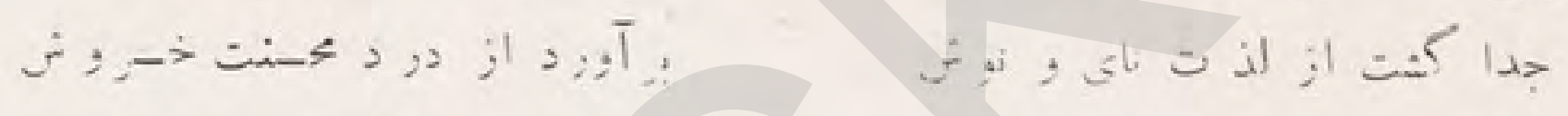

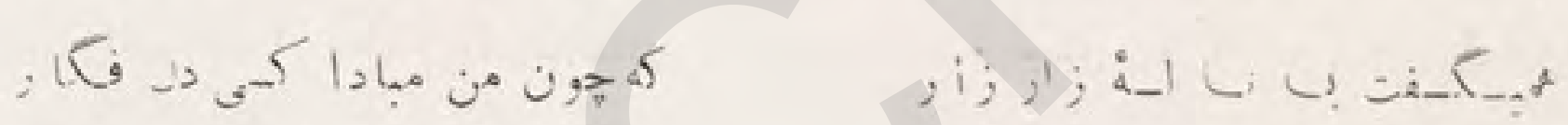

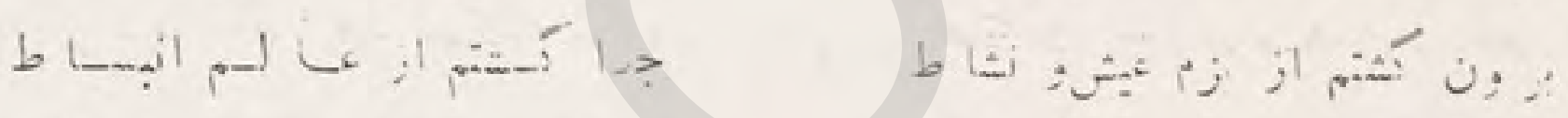

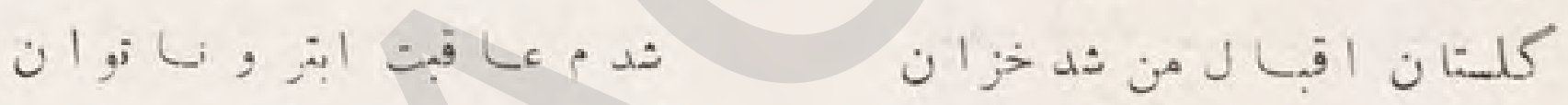

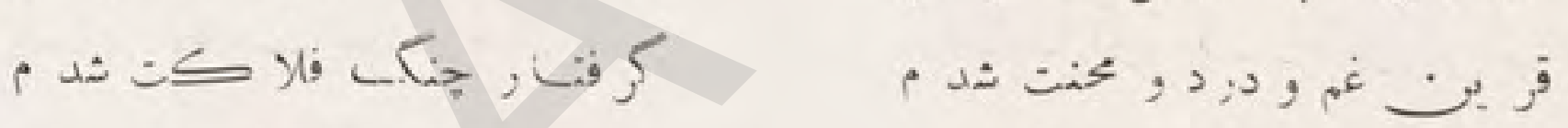

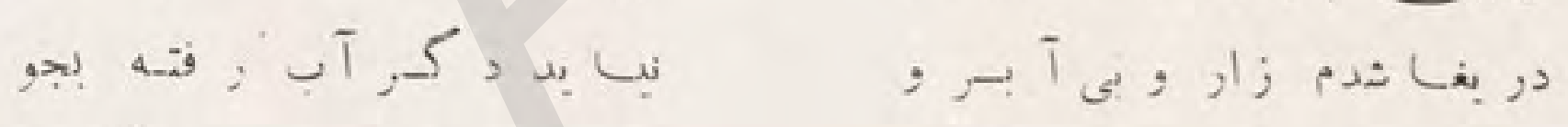

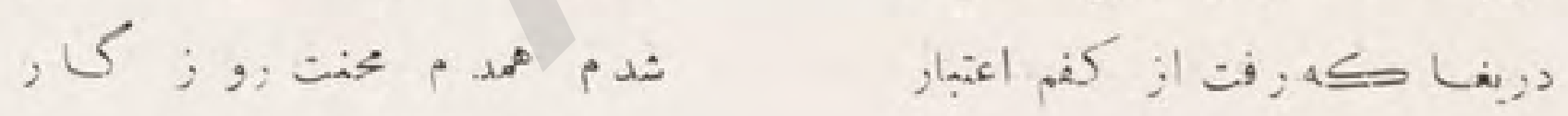

$$
\begin{aligned}
& \text { در. }
\end{aligned}
$$

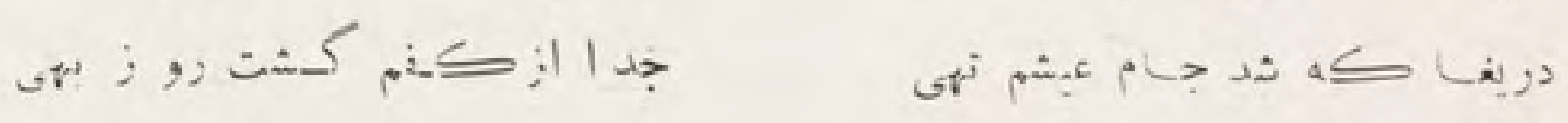

$$
\begin{aligned}
& \text { 2, }
\end{aligned}
$$

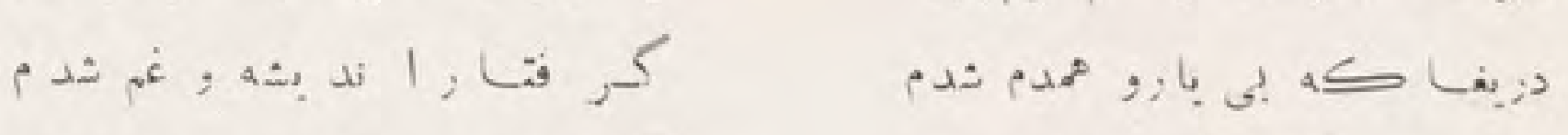

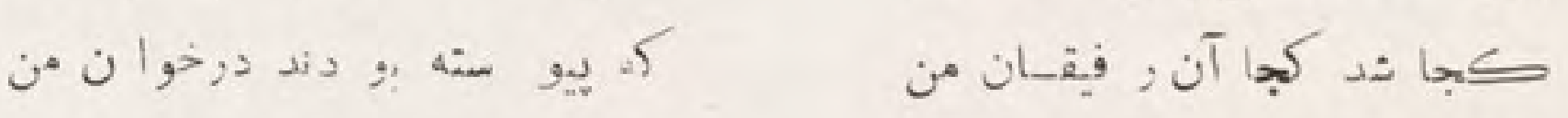

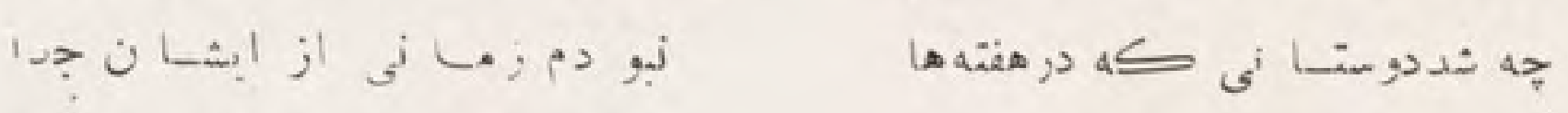

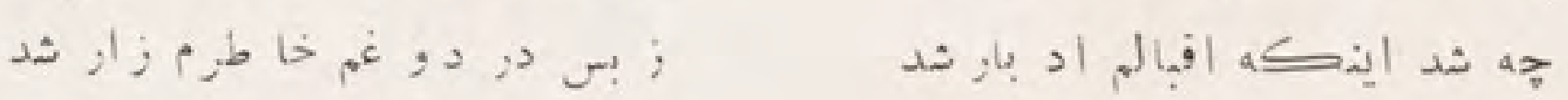




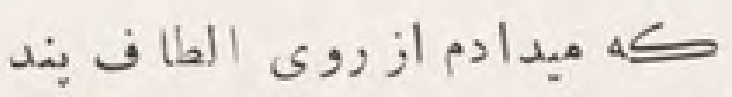

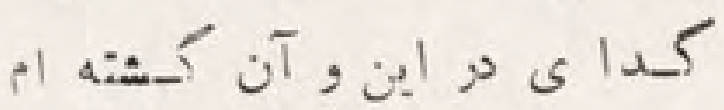

$$
\begin{aligned}
& \text { كيه :مزيز دوغم كُثت احوالمن }
\end{aligned}
$$

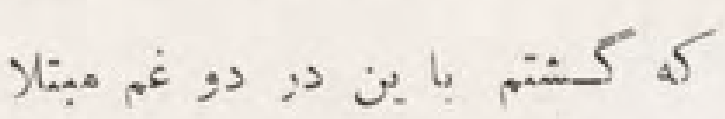

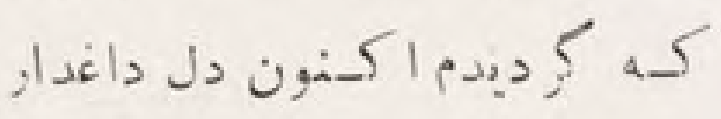

$$
\begin{aligned}
& \text { از انزر: بر بشـان ند رو در بدر } \\
& \text {; } \\
& \text { بود ش-شاء آن نسا صح هو, شهند }
\end{aligned}
$$

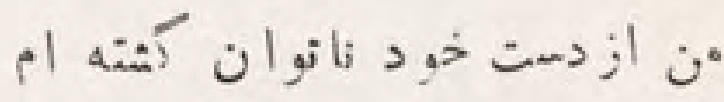

$$
\begin{aligned}
& \text { شد م د شهن نهمت خو مبشتن } \\
& \text { بكفتـا , i-سا صح i } \\
& \text { : }
\end{aligned}
$$

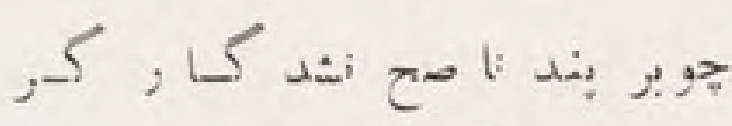

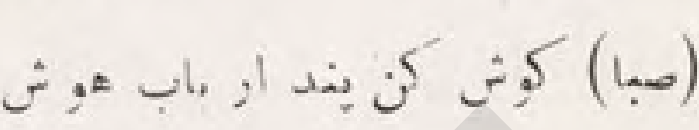

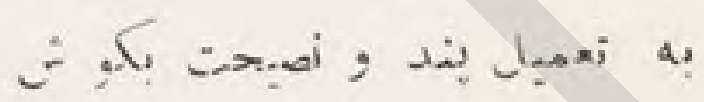

\section{|}

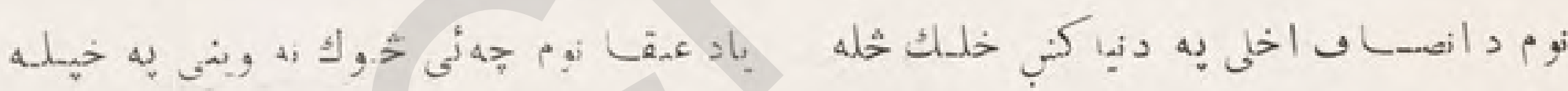

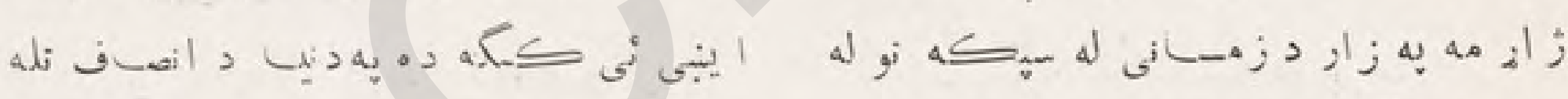

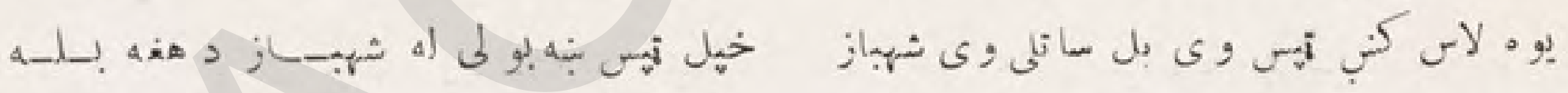

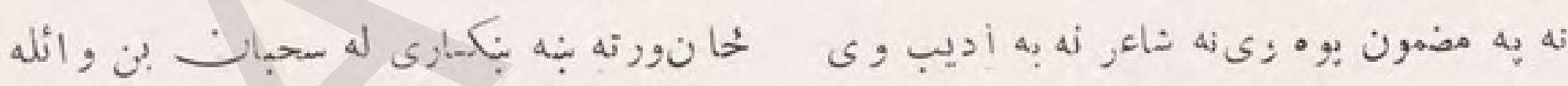

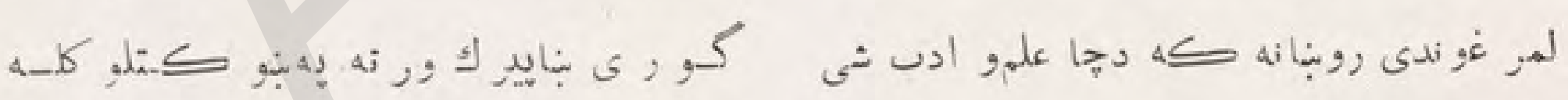

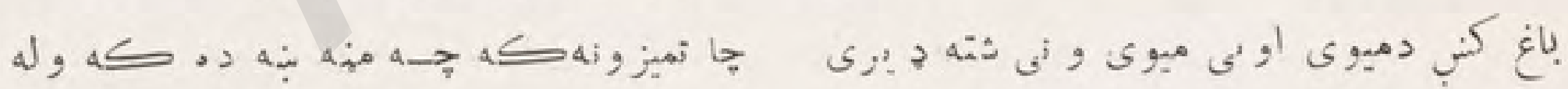

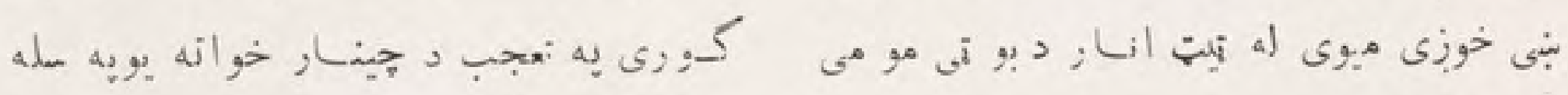

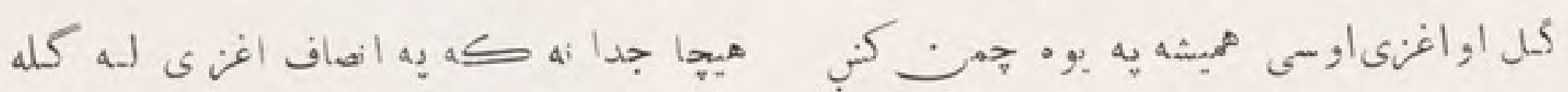

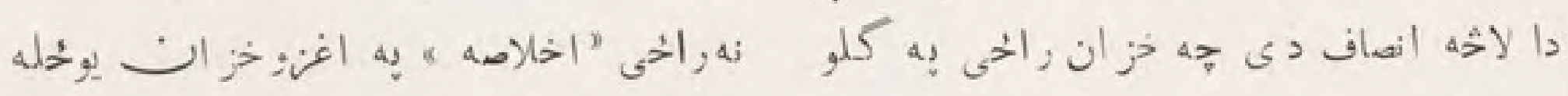
(عبدالخالق اخلاص ) (ع) (ب) 


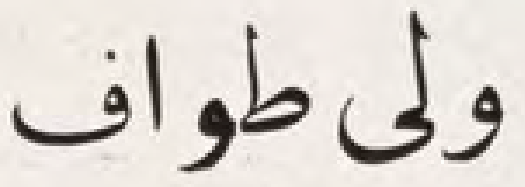

4 - ف

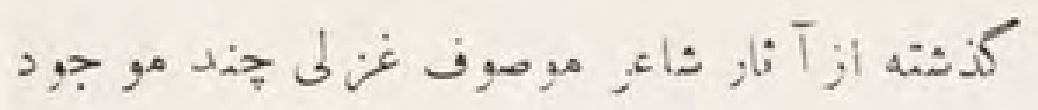
آفاى مدبر نشربات !

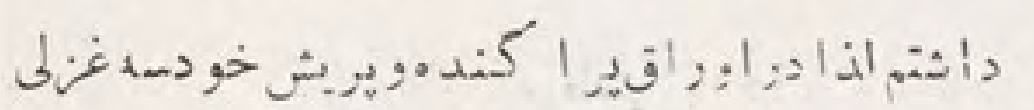

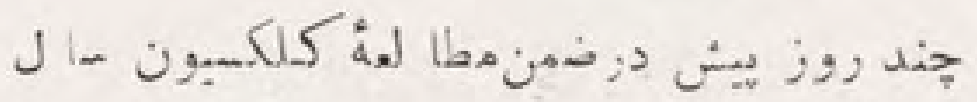

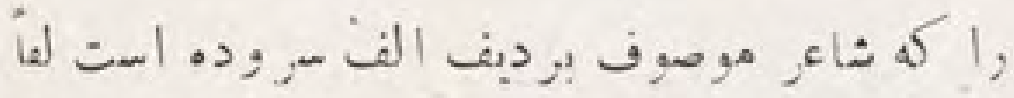

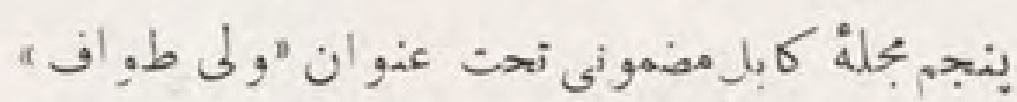

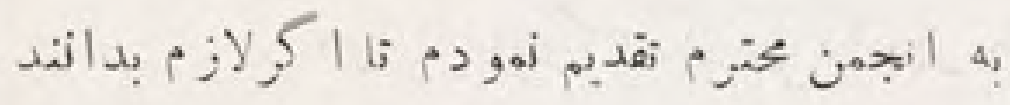

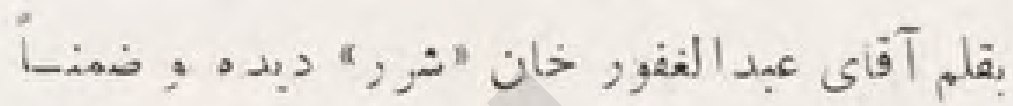

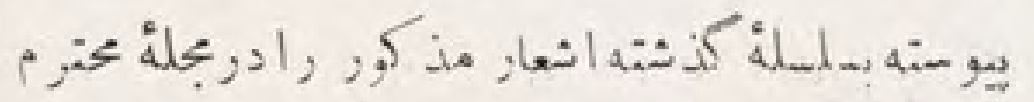

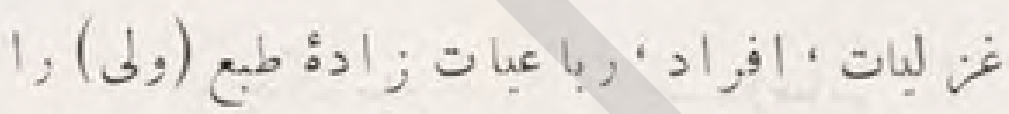

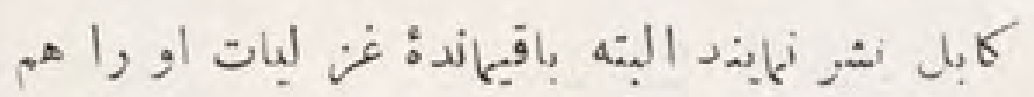

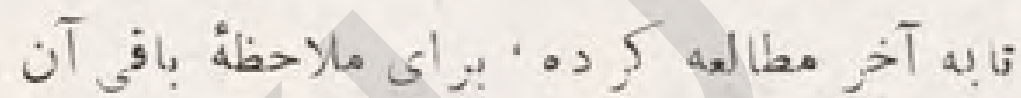

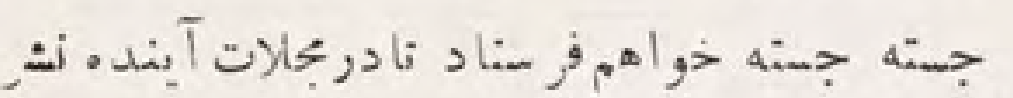

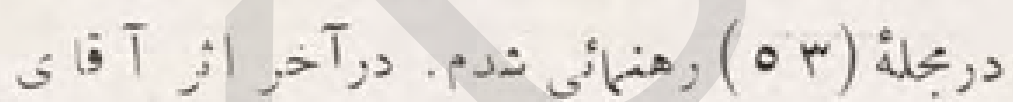

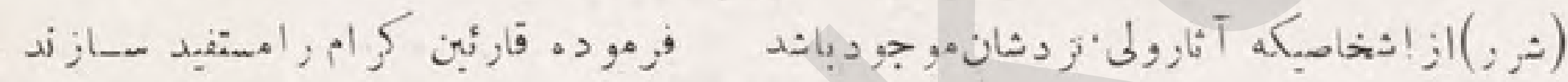

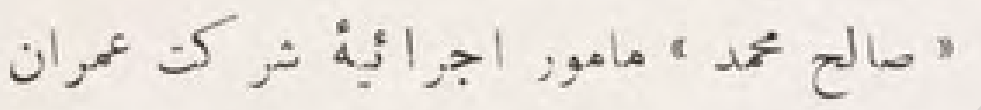

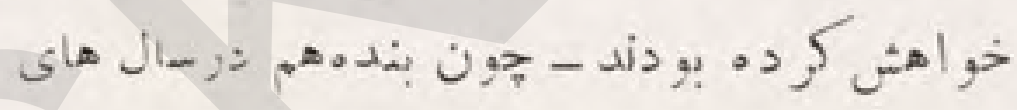
* * *

$$
\begin{aligned}
& \text { دل بتنك آماده اسه دور بر ما } \\
& \text { خم شد از د أغ عشق بيكر ما } \\
& \text { ثوز عشق است بسكه برسر هـا } \\
& \text { لباى كوبان ود ست افثا نيم }
\end{aligned}
$$

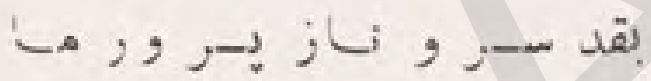

$$
\begin{aligned}
& \text { قامت سرو اي-ن خمن نـر سد }
\end{aligned}
$$

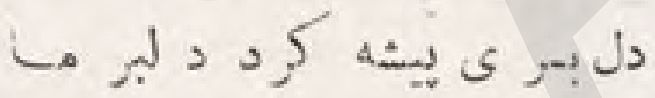

$$
\begin{aligned}
& \text { دل بد ستش اكردهيم بجنسأست }
\end{aligned}
$$

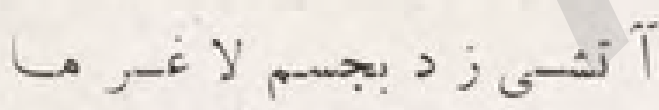

$$
\begin{aligned}
& \text { يكير مـا جو ديد قابل سوخت } \\
& \text { نامه بر زيست هم كبو أتر ما }
\end{aligned}
$$

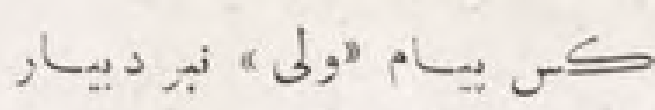

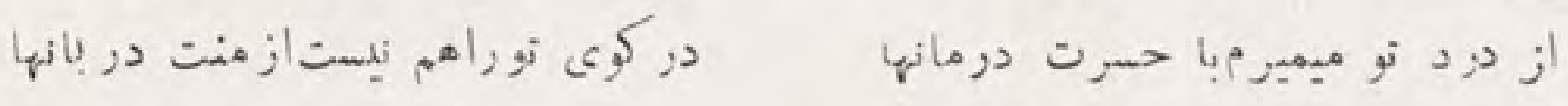

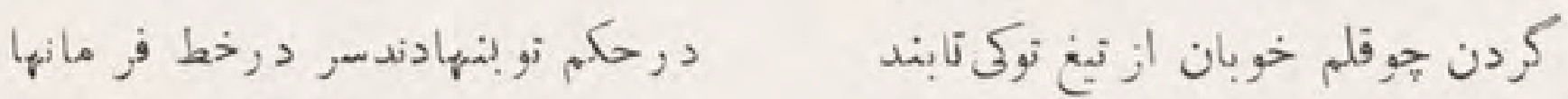

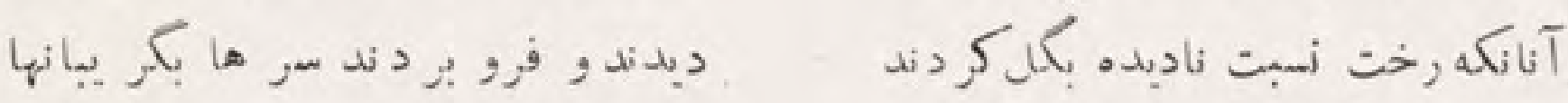

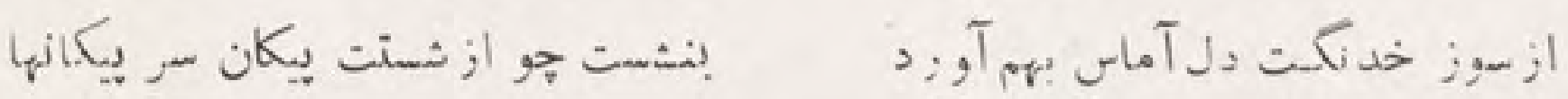

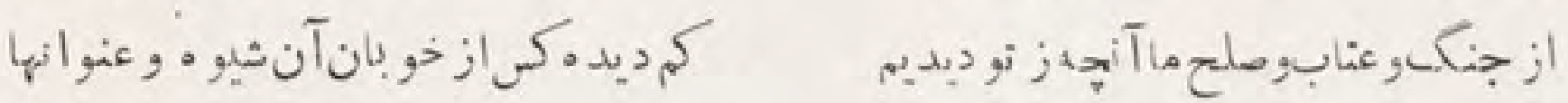




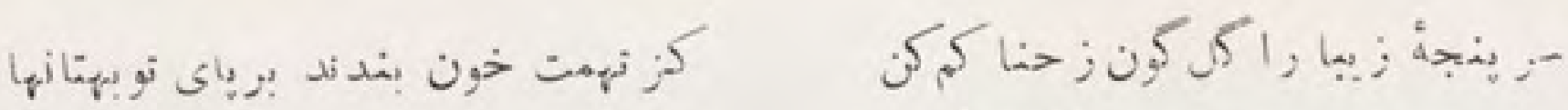

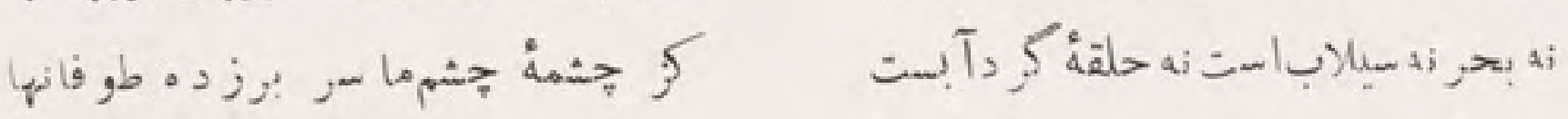

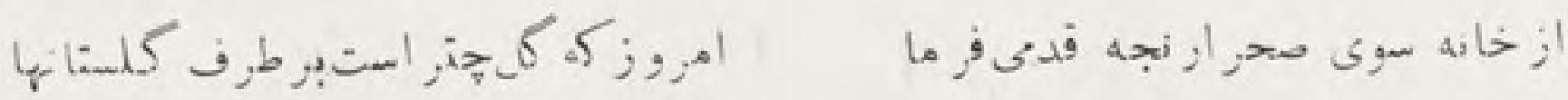

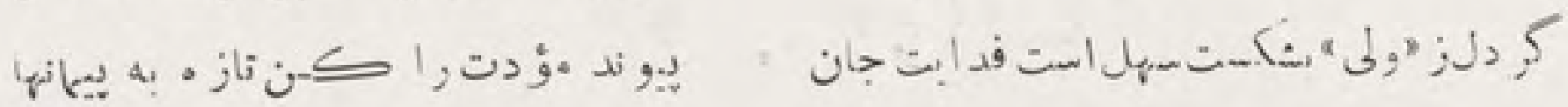

$$
\begin{aligned}
& \text { * * * }
\end{aligned}
$$

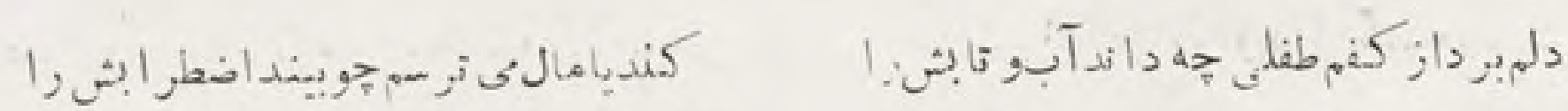

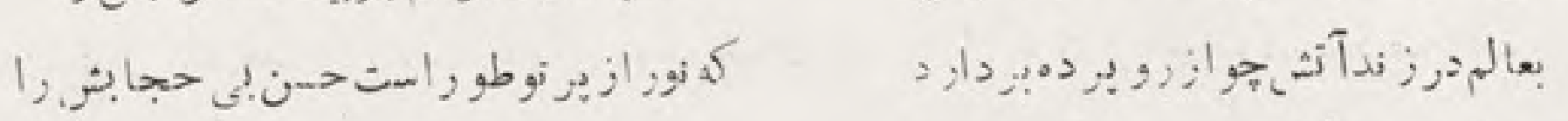

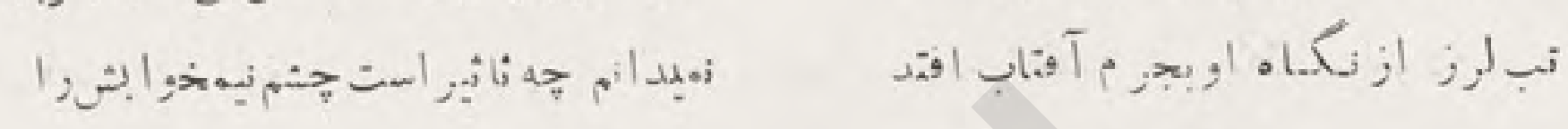

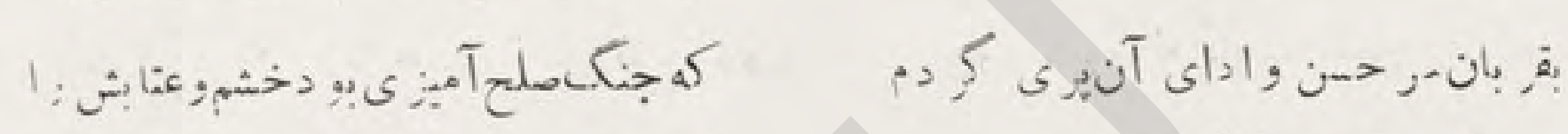

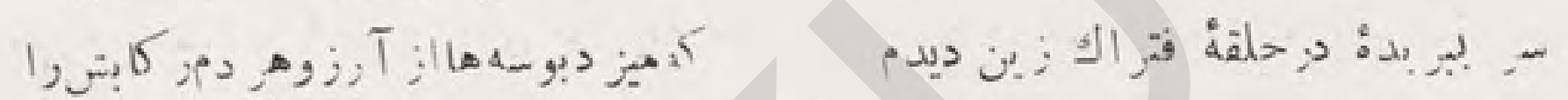

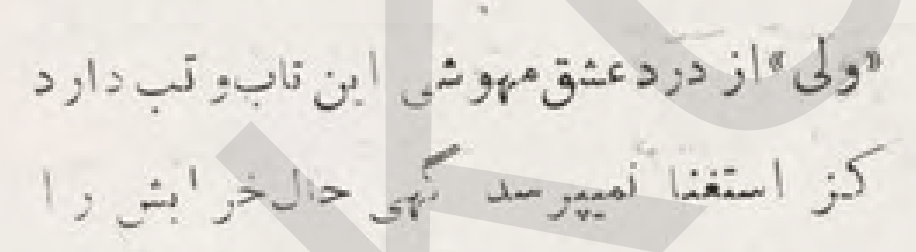

مادر مازام

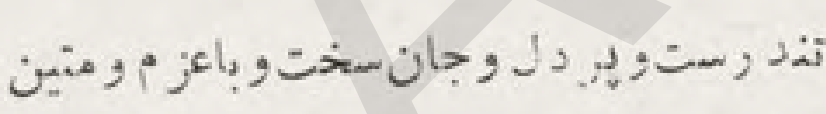

كى نوان از نا توانان خواست إوصا في جنين

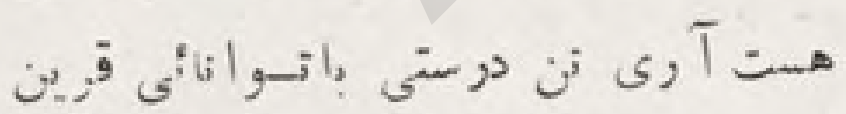

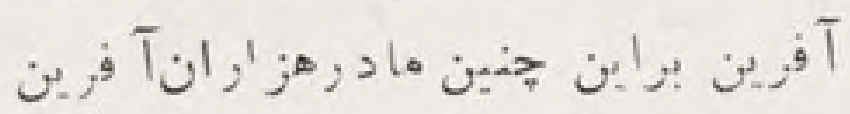
بجهه ناز ال دن بلهاز ششماهه| فهكندن جنين $(1)$
ما دز دانا أهو أنـد بير ورد فرز زتـد را

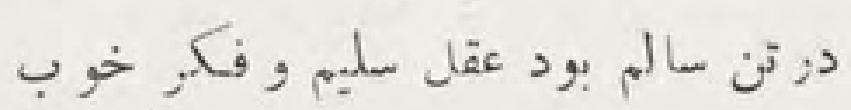
نا وانى خيزد از ناتن در ستو, دورجهان

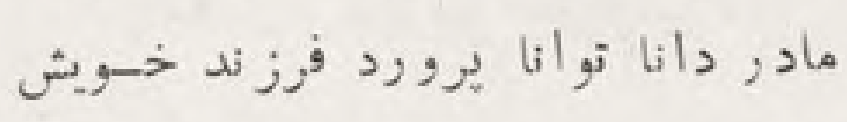

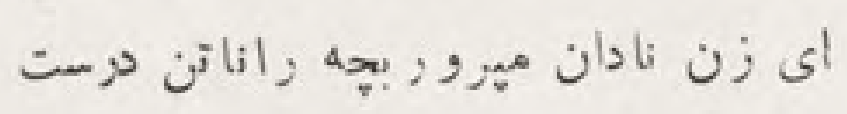




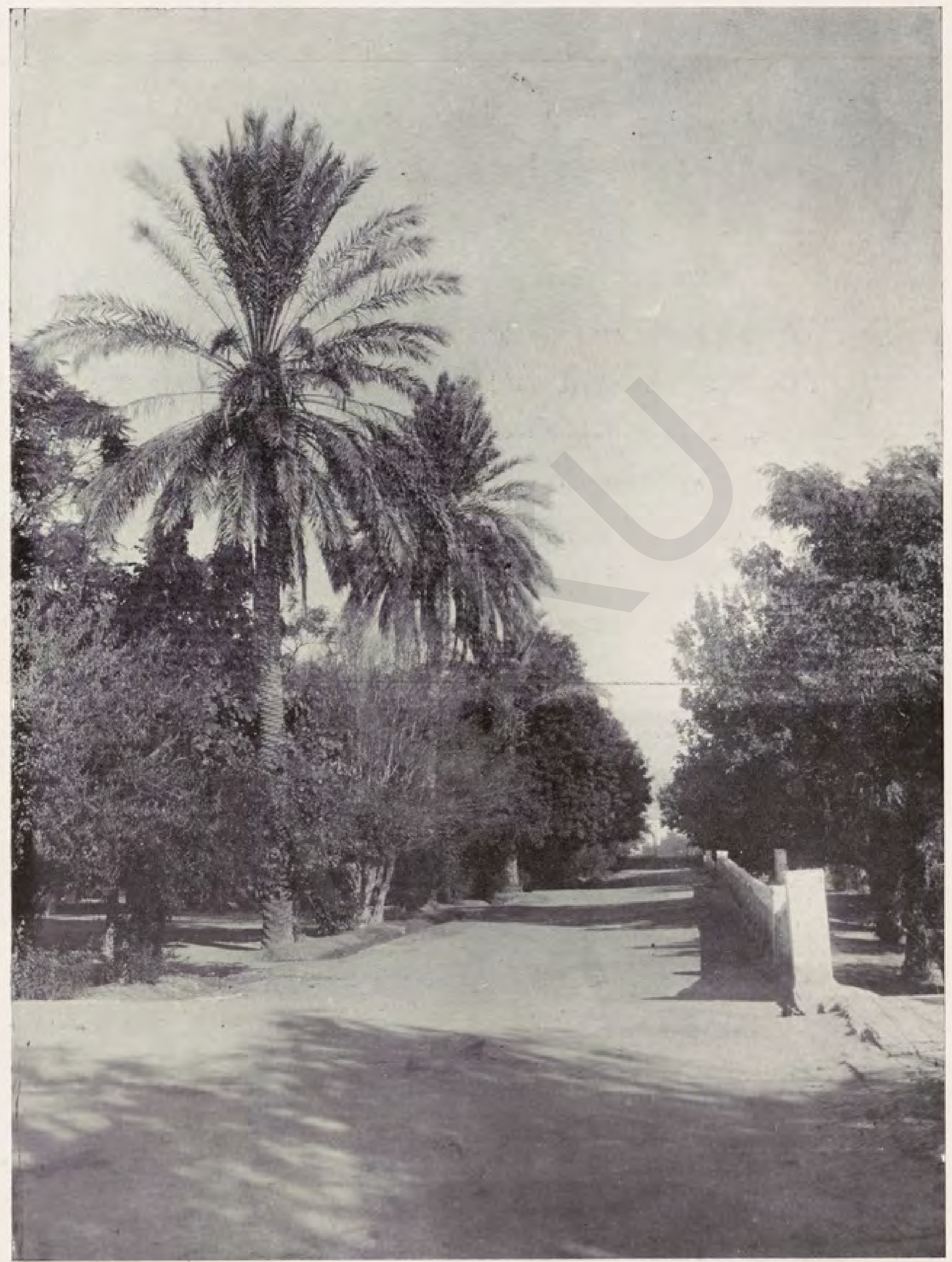

$$
\text { الز باغهاى قينكى جلال آ باد : يكىاز خيابانهاى باغ شاهى بادرختان خرما }
$$



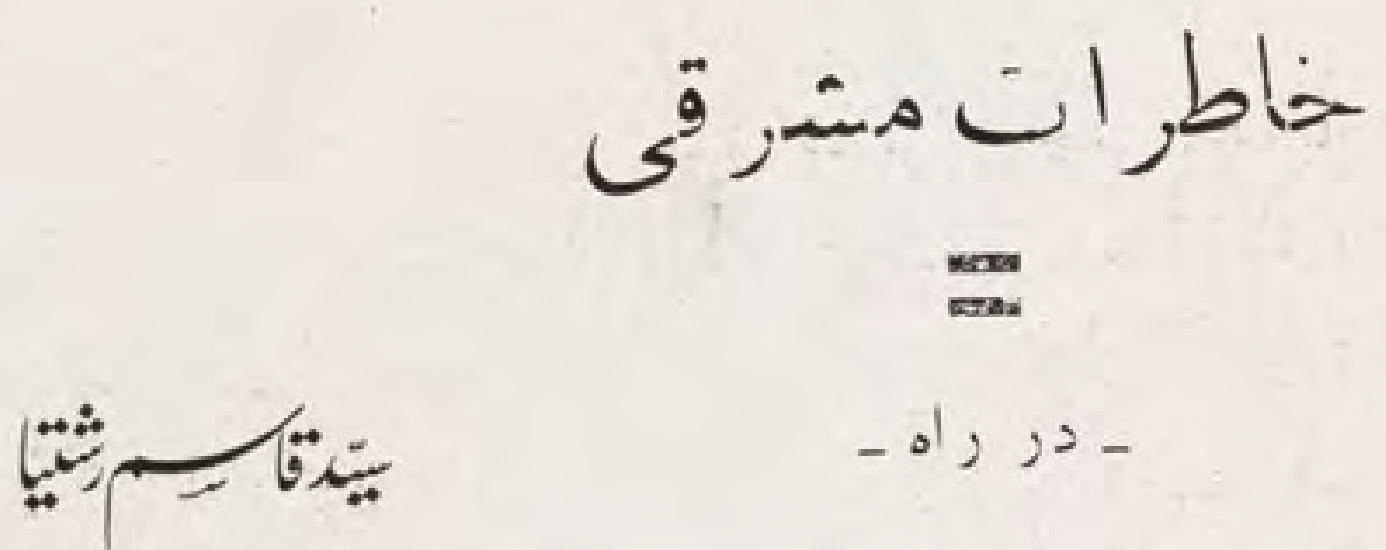

$-01,02-$

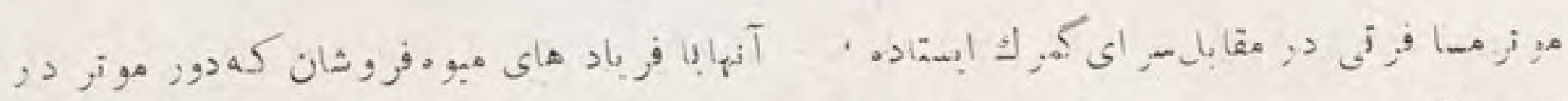

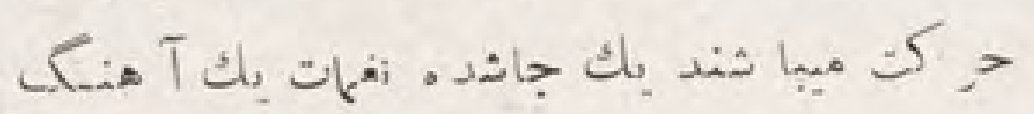

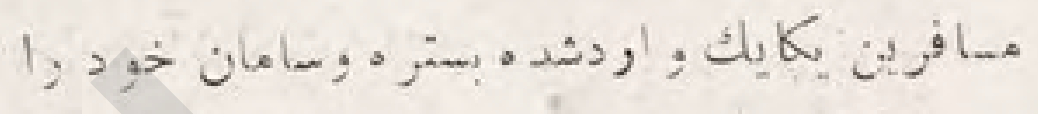

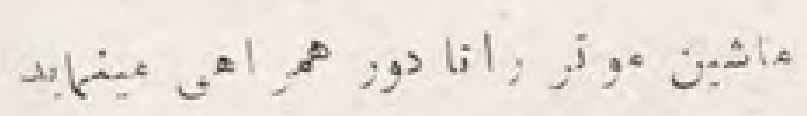
* * *

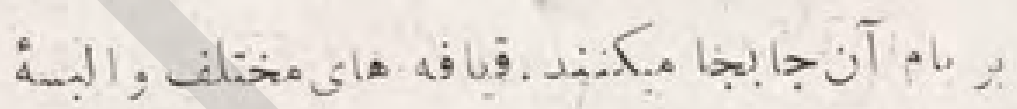

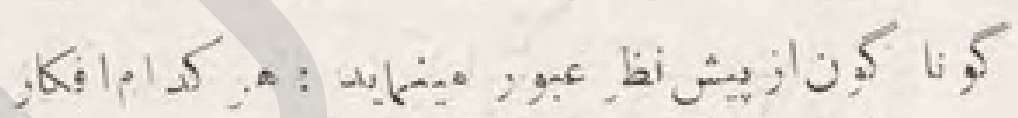

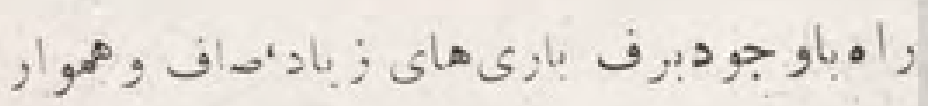

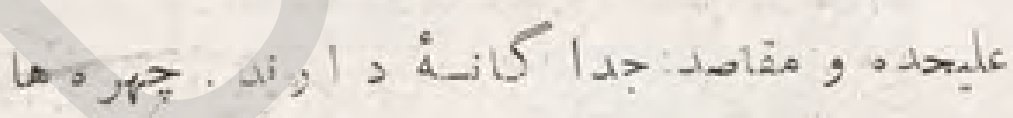

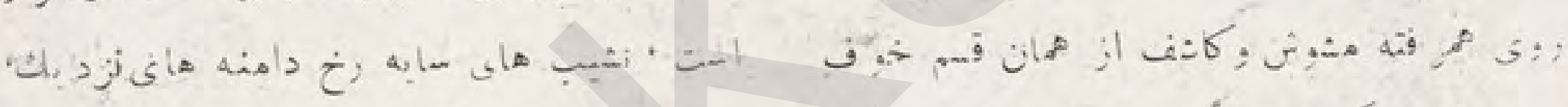

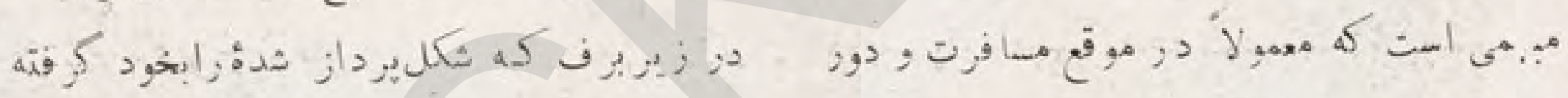

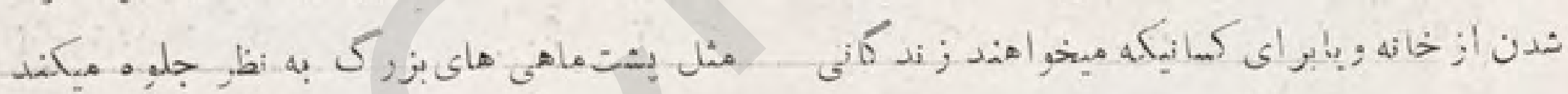

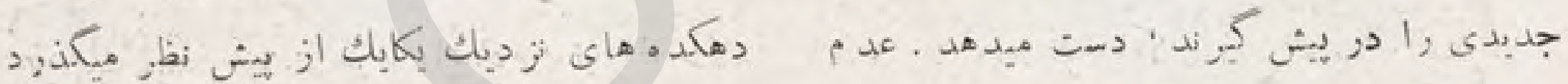

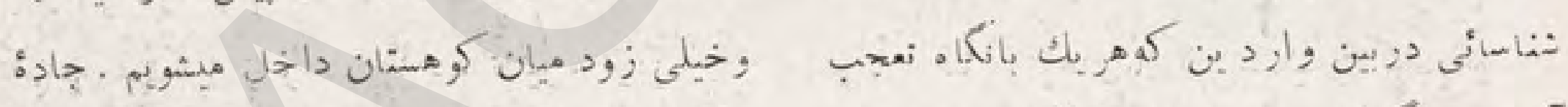

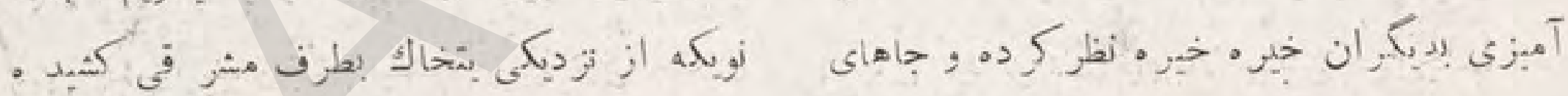

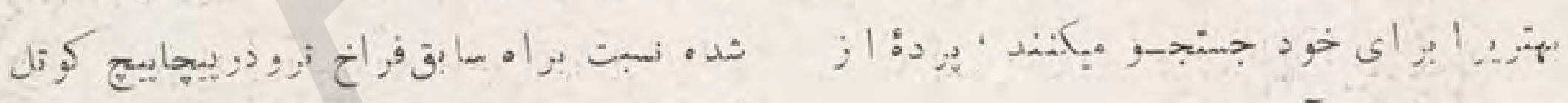
( .

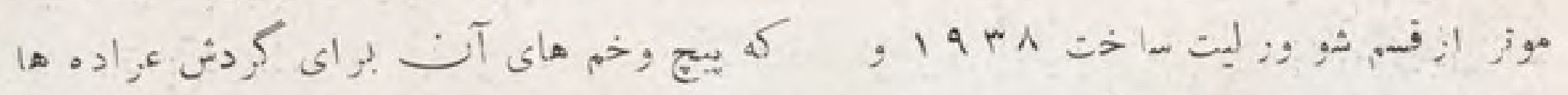

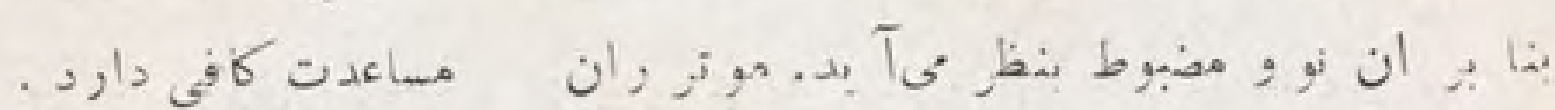

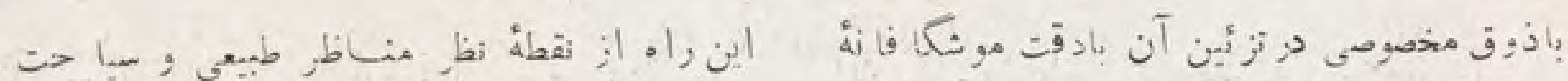

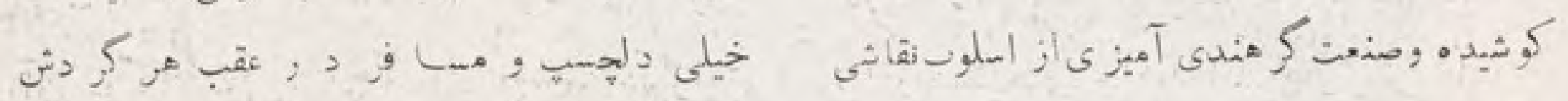
هندو ستان بران افزوده استي .

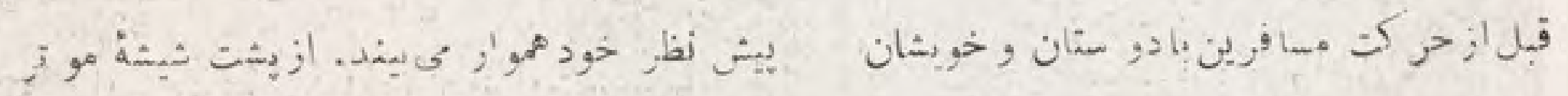

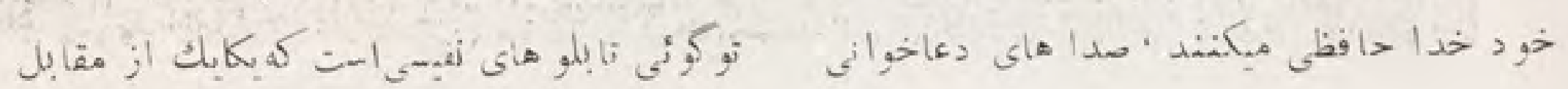


لذت بى بايانى د ست ميد هد . ساعتهاى طولانى

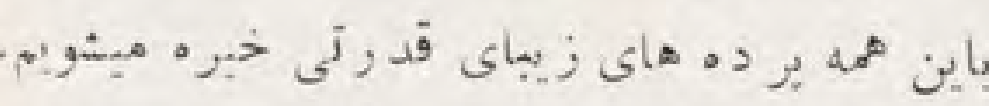

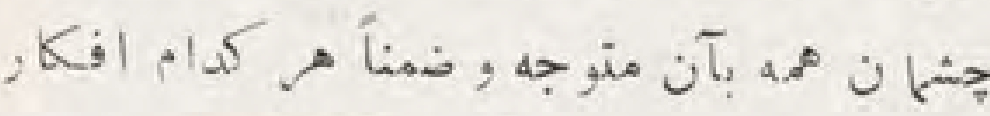

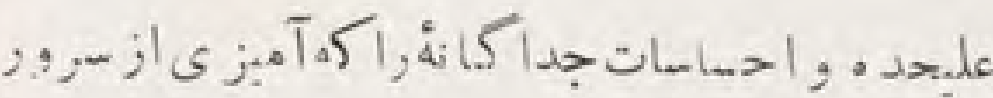

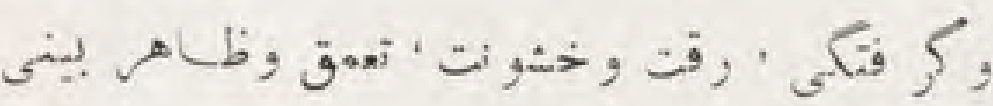

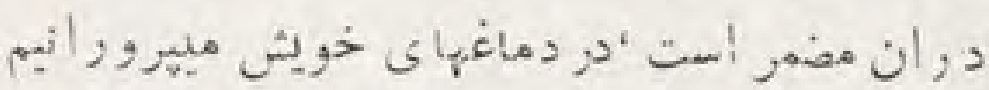

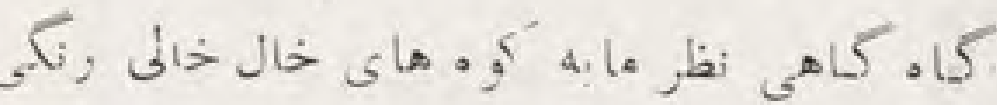
مى فتد كه هستور از جنكال هاي بلوط وصنو براست ساقهاى ,است وشاخهاى ازئه كثادئ آنها سينة

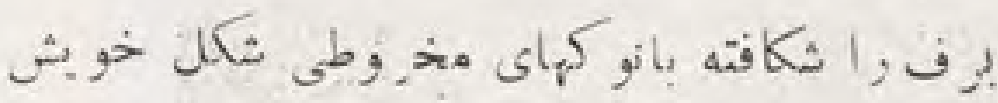
كنازة قله هائ بلند را دندازه دار زشان ميدهد.

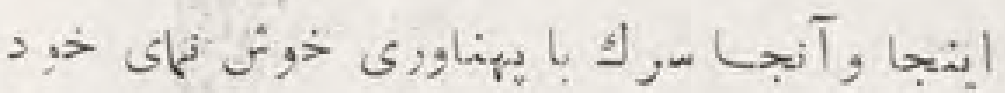

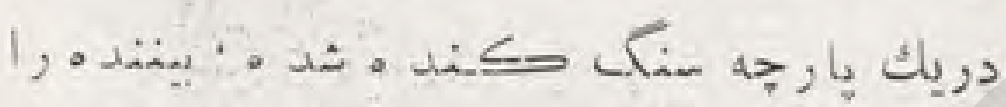

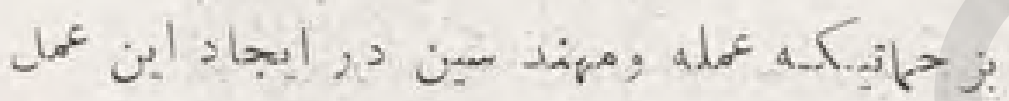

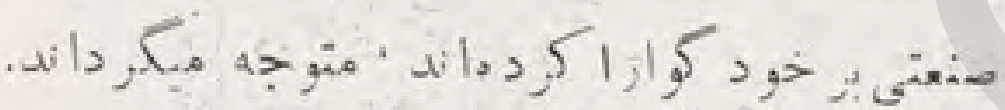

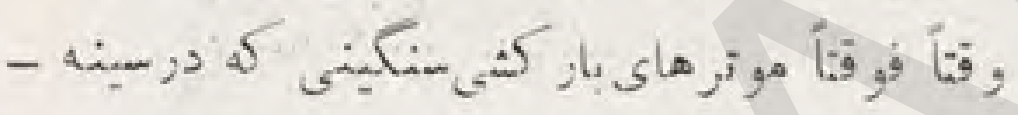

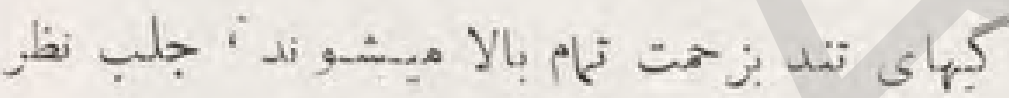

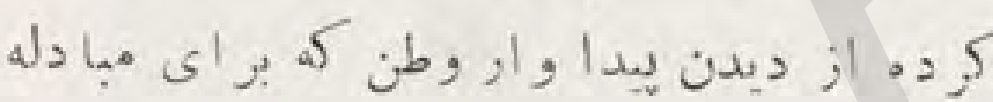
باسيمناب' روانه سرز مين بر بركت هند هيباشند،

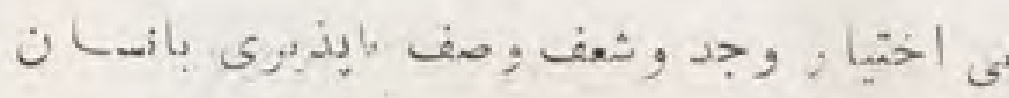

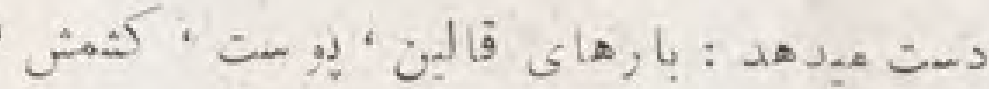

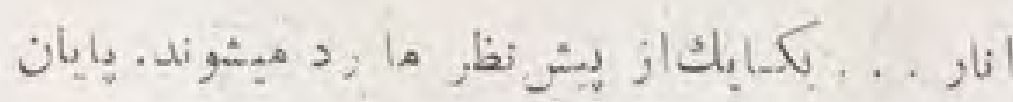

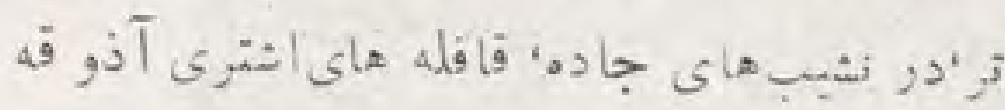

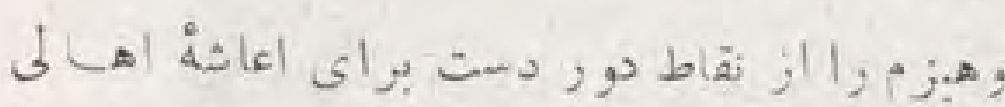

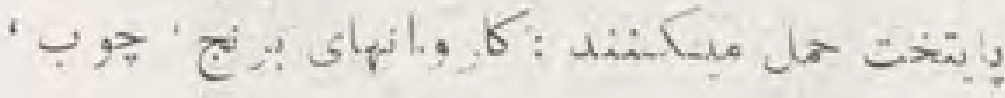
ذوغنال ... بهر سو صف كثبده است ... بواصل

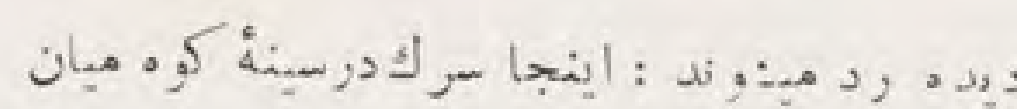

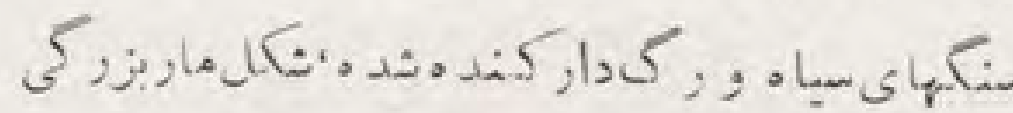

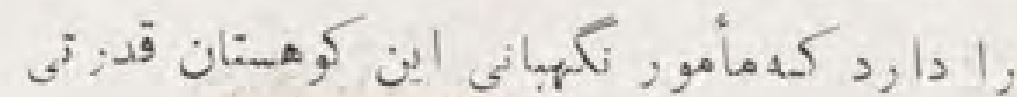

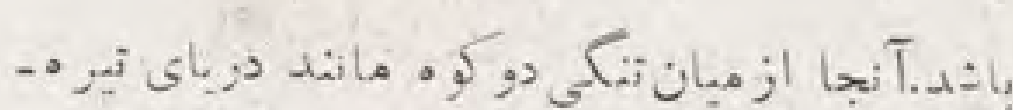

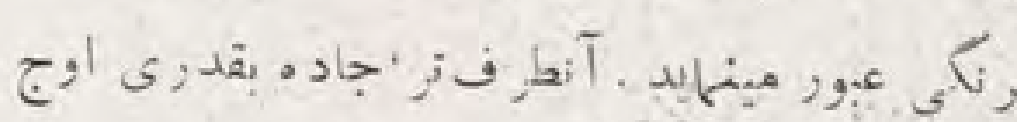

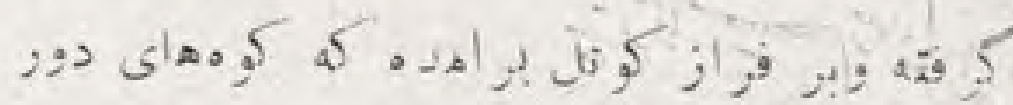

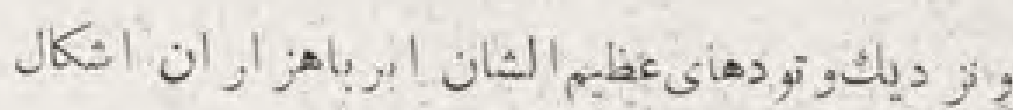

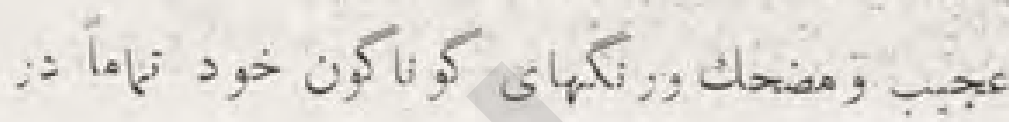

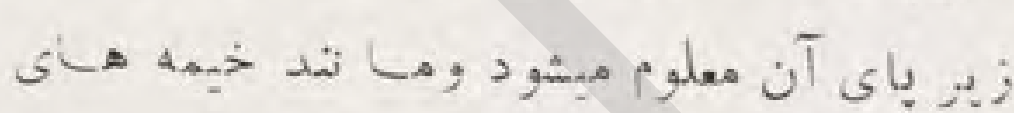

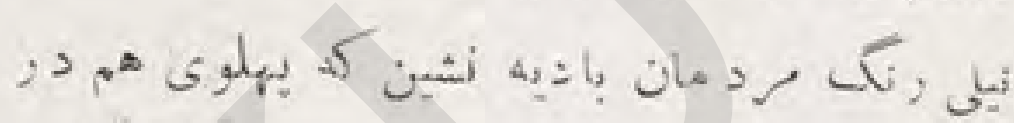

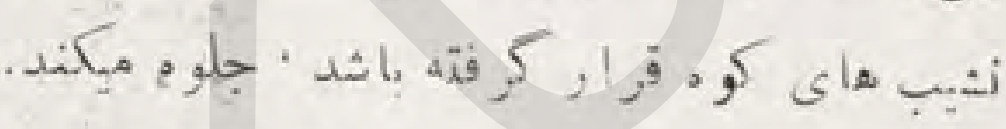

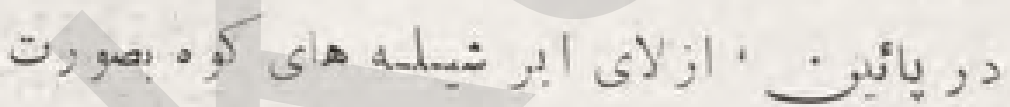

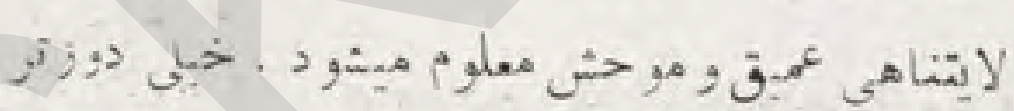

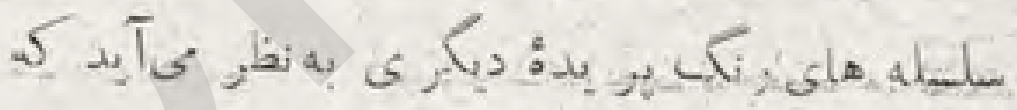

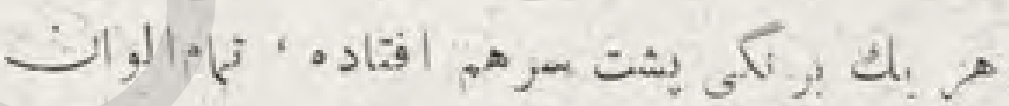

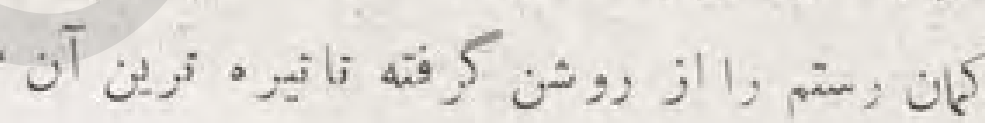

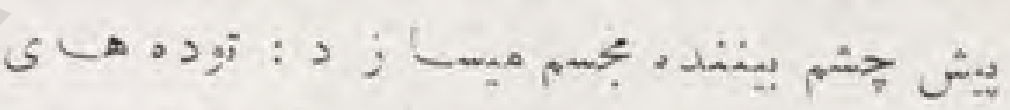

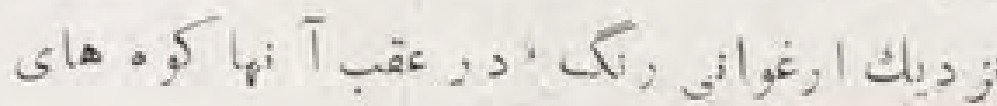

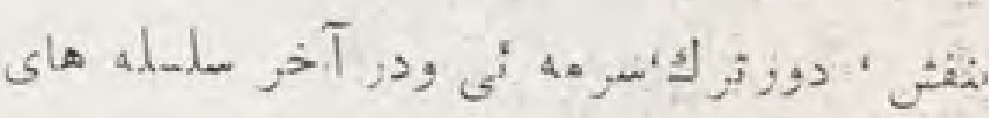

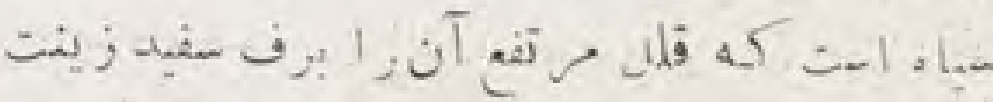

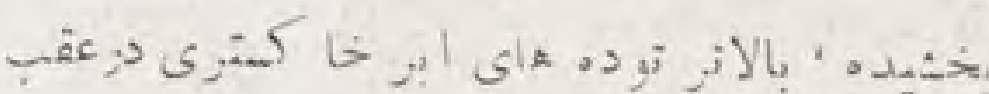

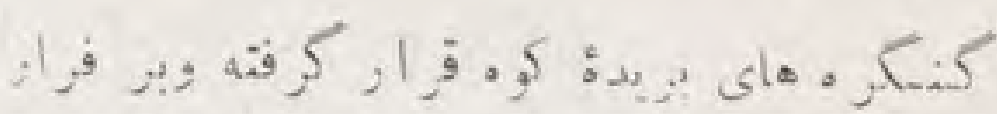

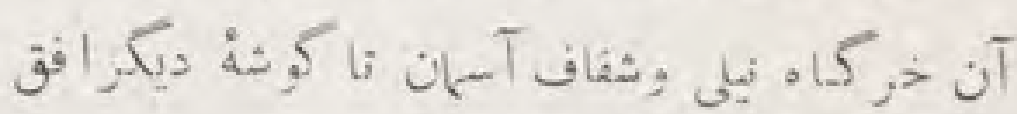

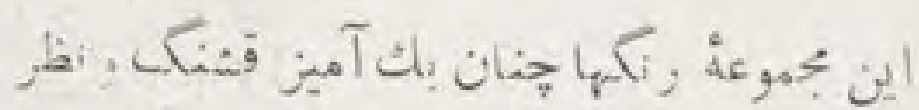

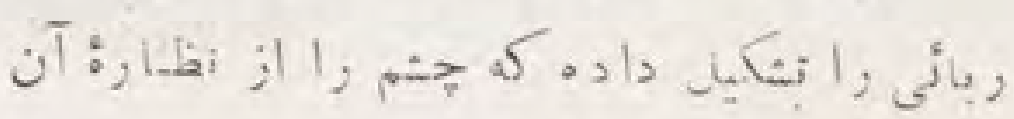



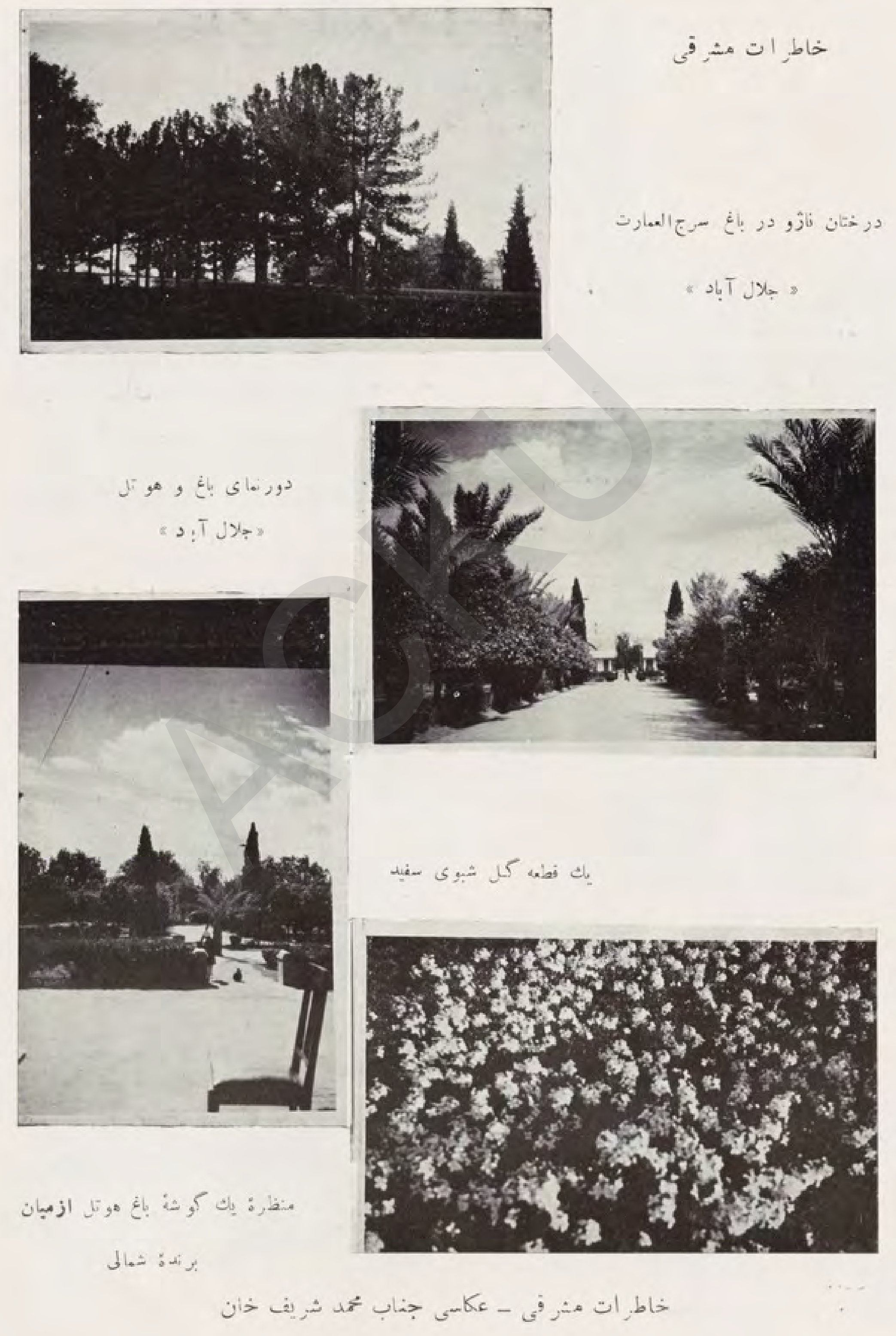
درميان باز ار بهريو برا كذده ميشوند ' وديرى ك

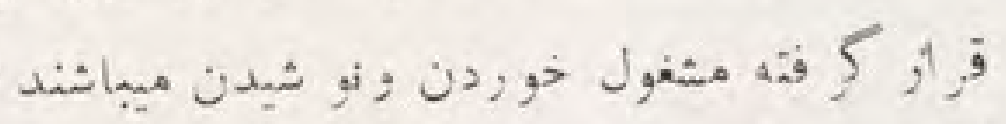

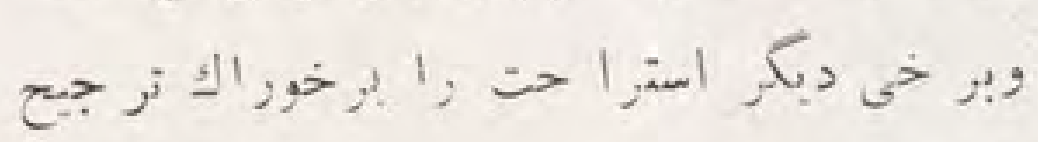

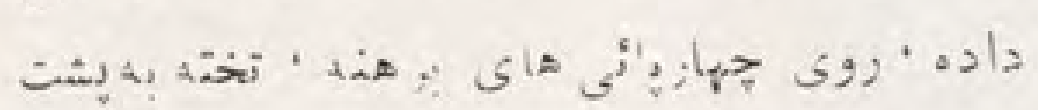

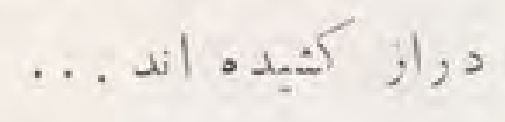

$$
\text { * * * }
$$

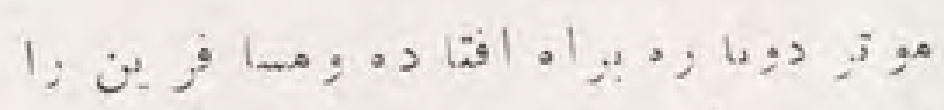

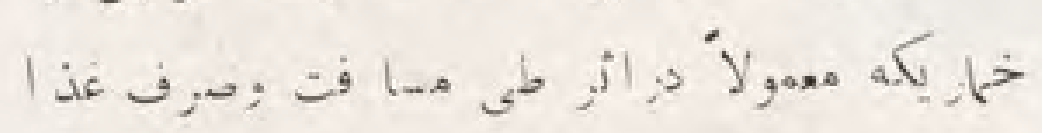

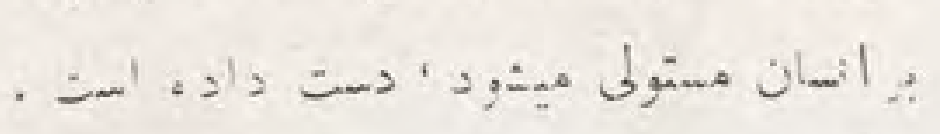

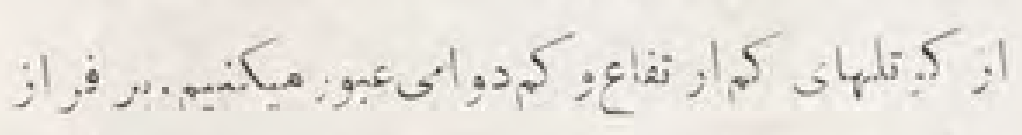

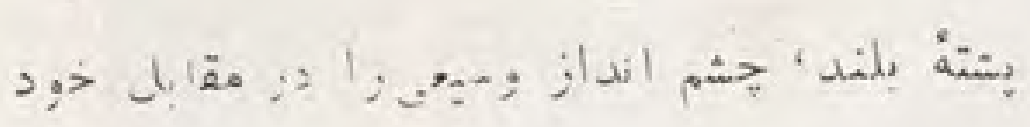

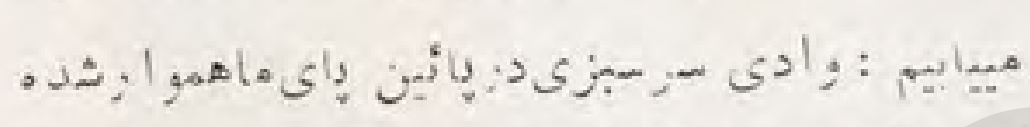

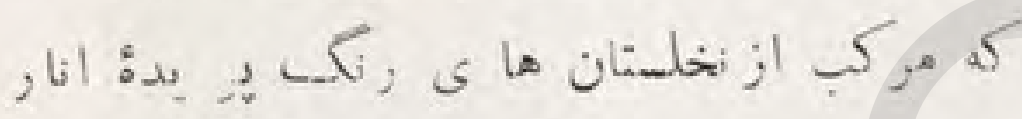

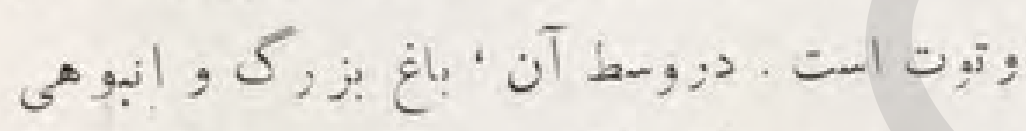

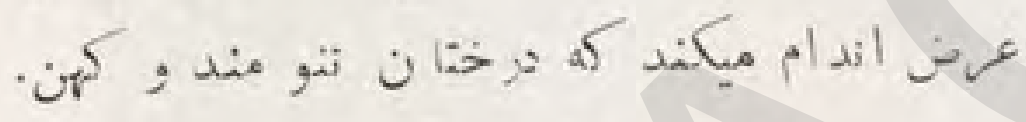

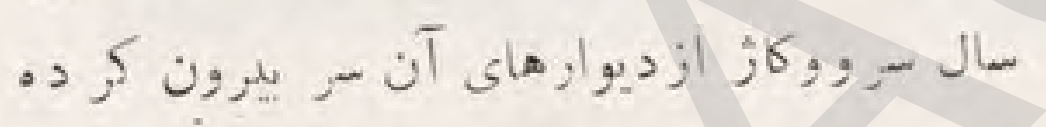

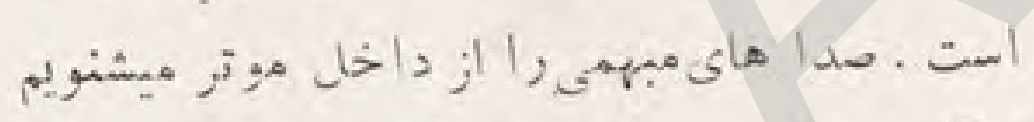

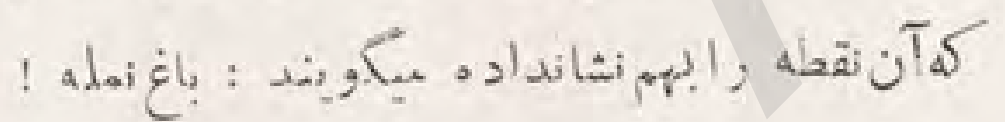

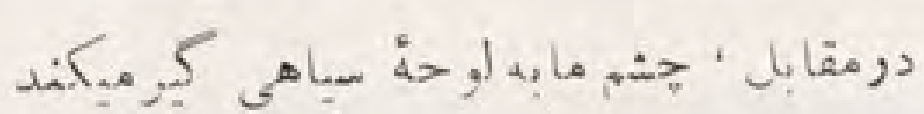

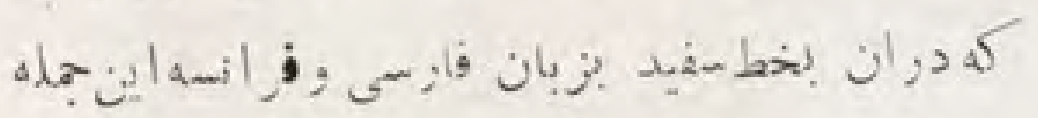

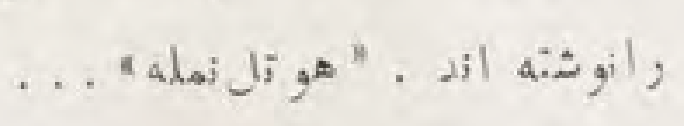
* * *

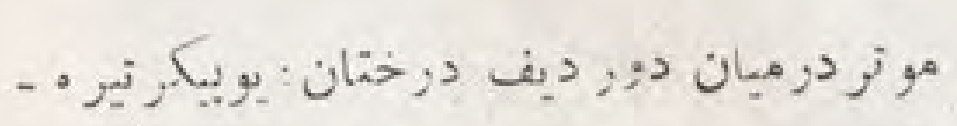

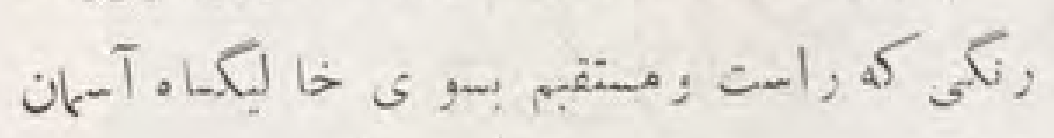

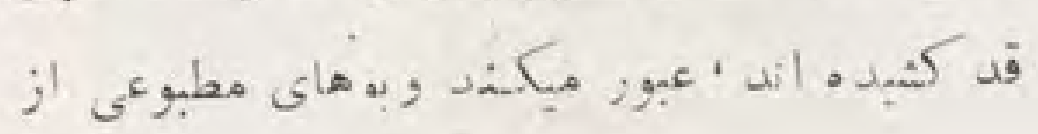

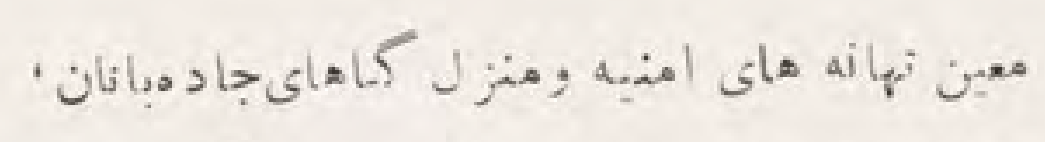

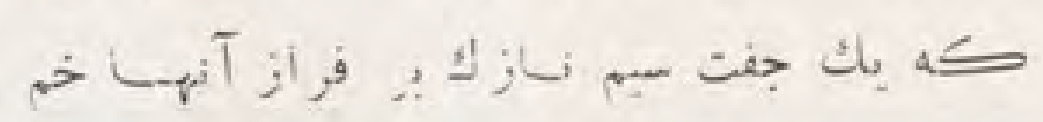

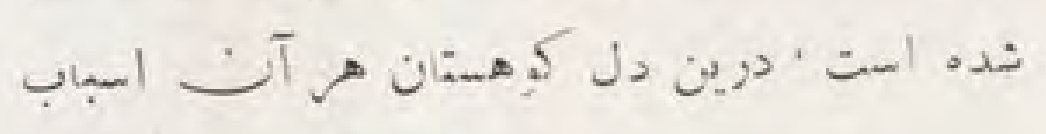

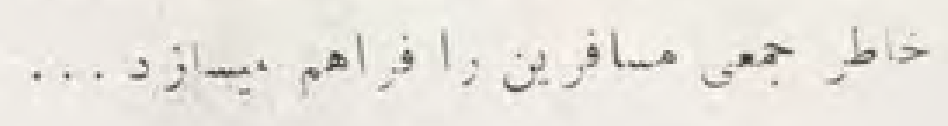

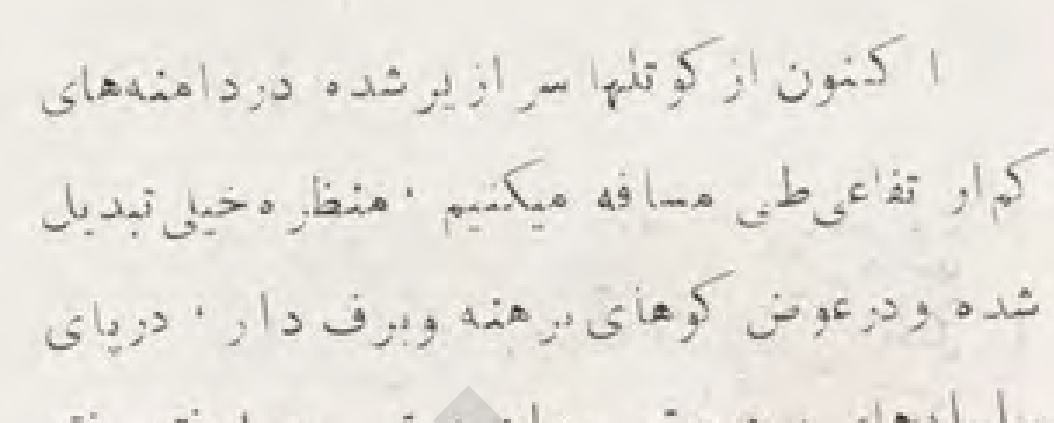

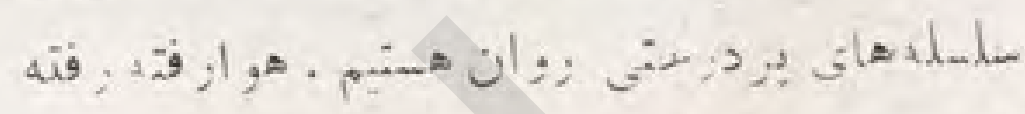

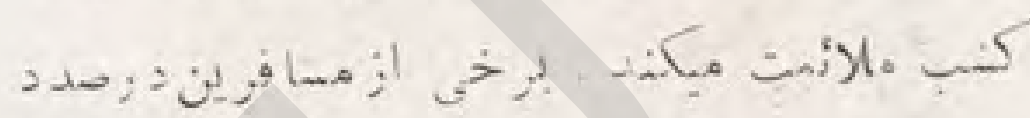

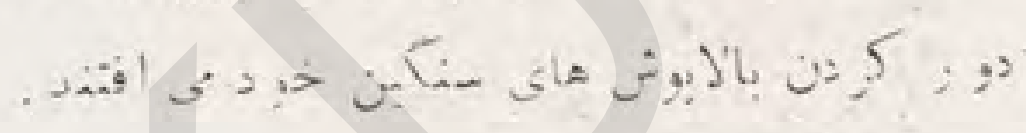

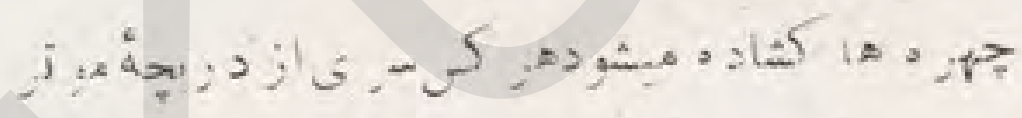

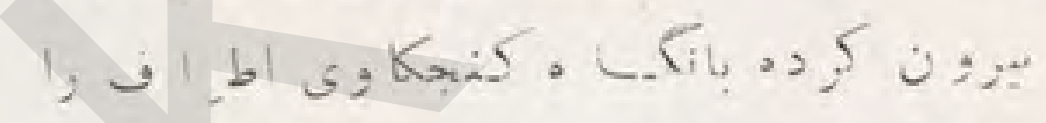

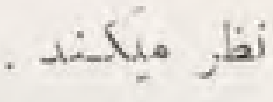
ازدو, آبا ديهاى زبادى به أظرمى آيده كم

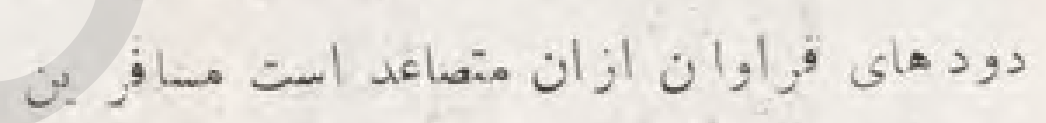

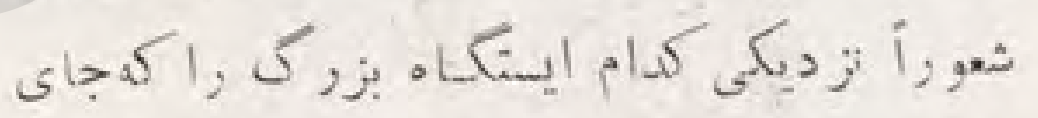

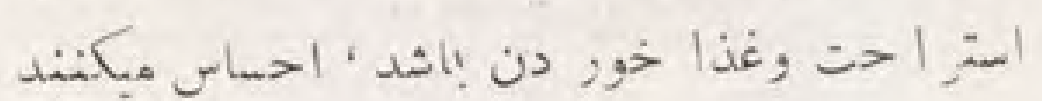

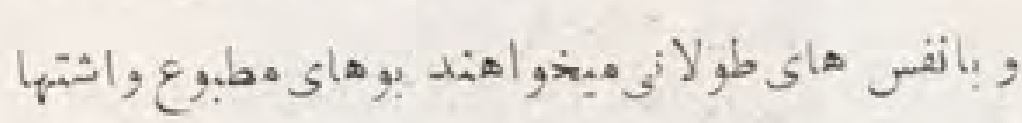

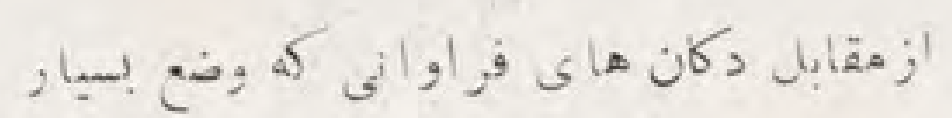

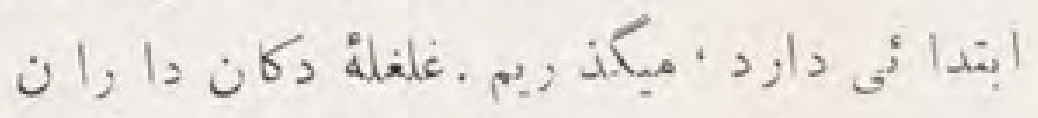

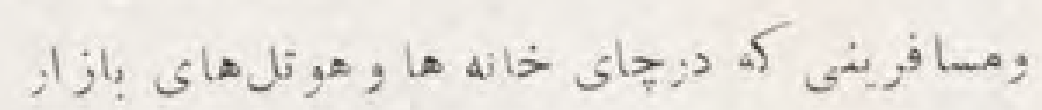

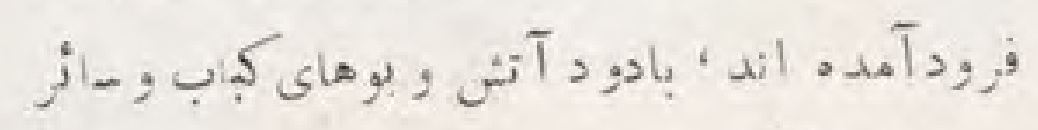
خور الك هايكجا شده اعصاب همهر ا حهلى نحربك

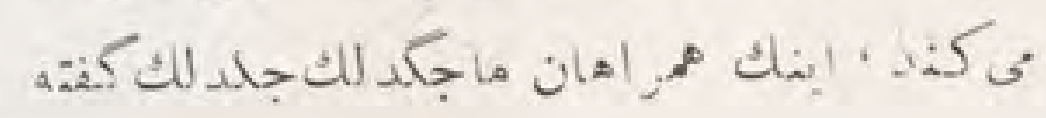



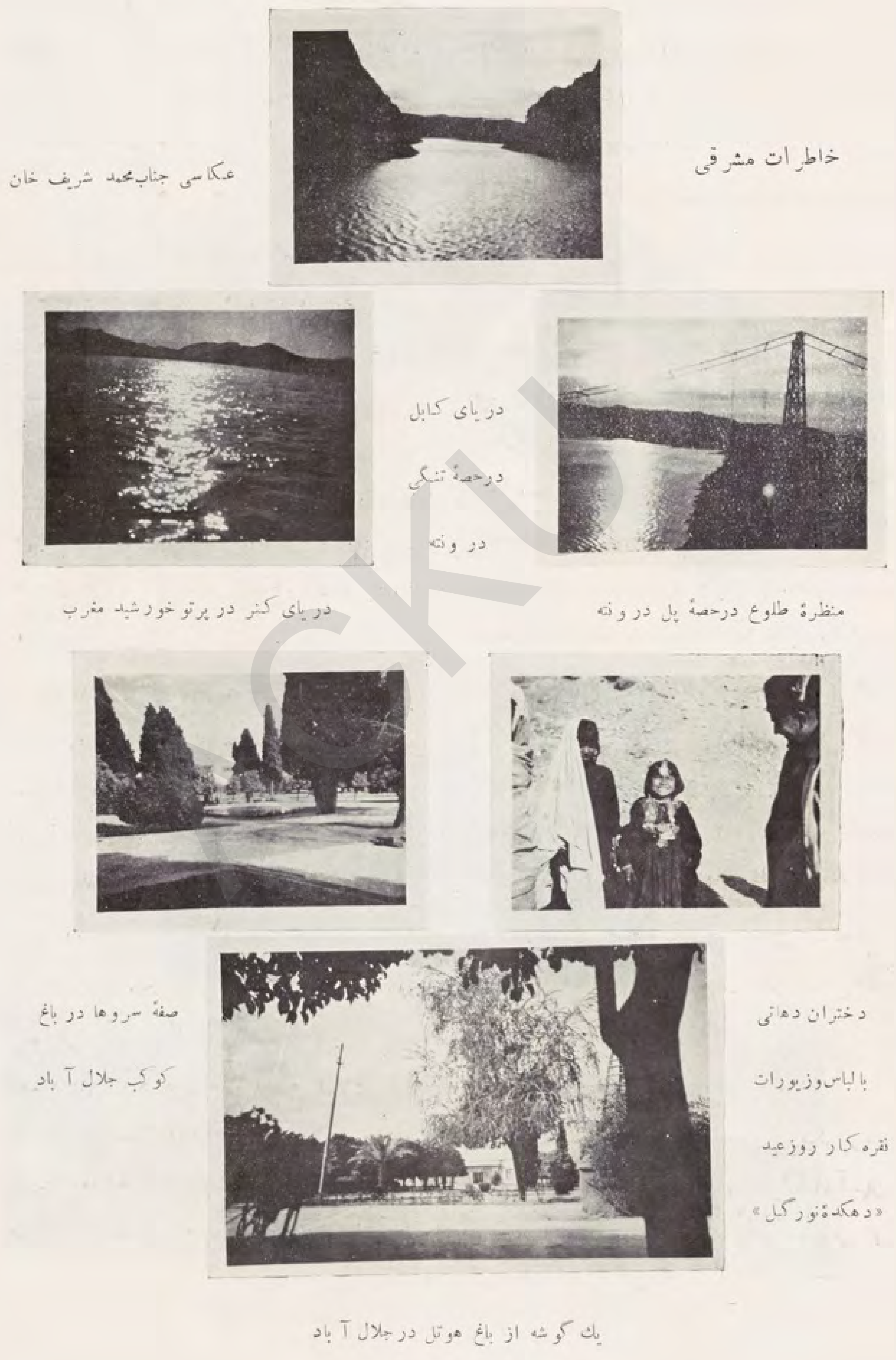


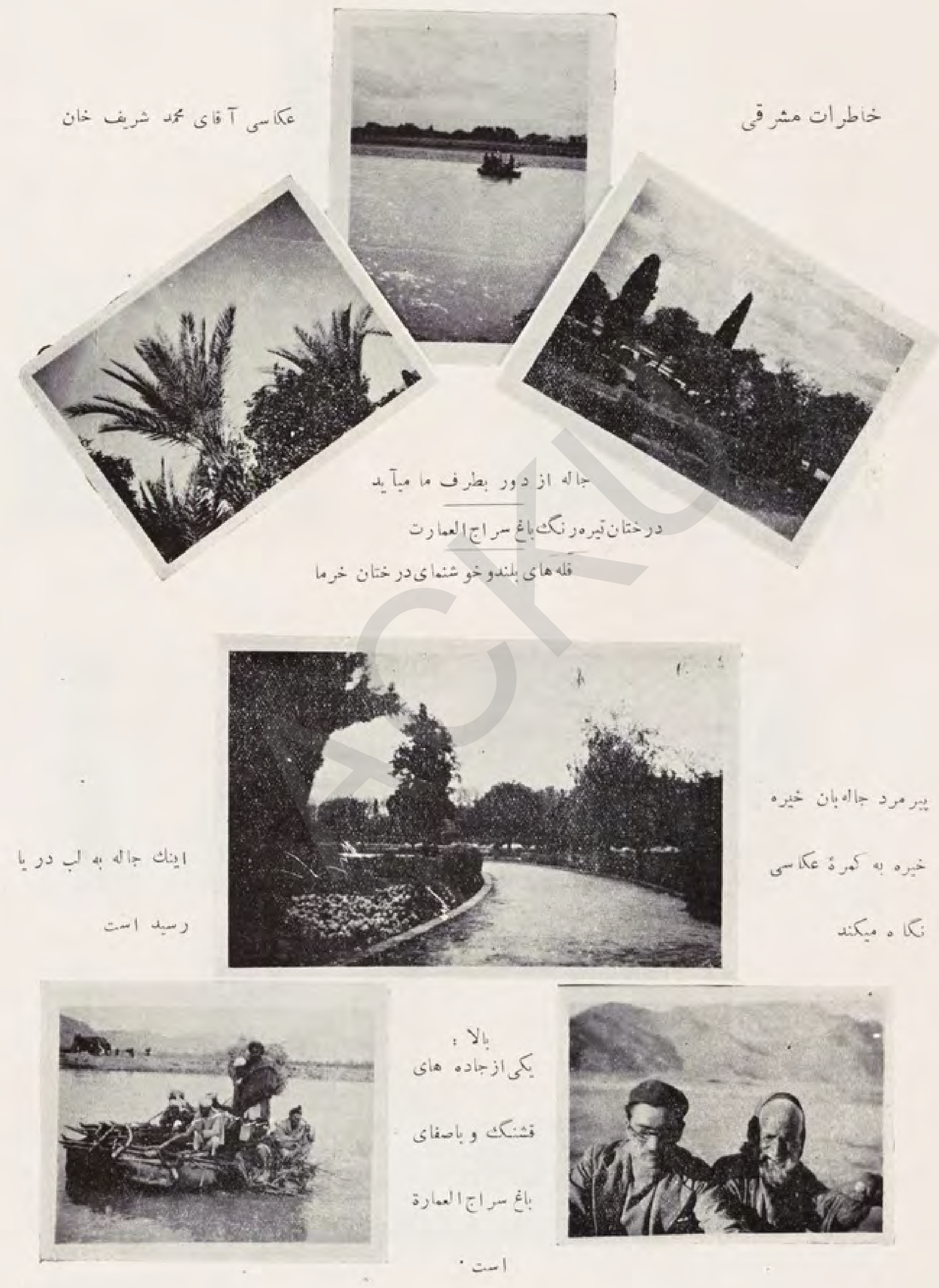




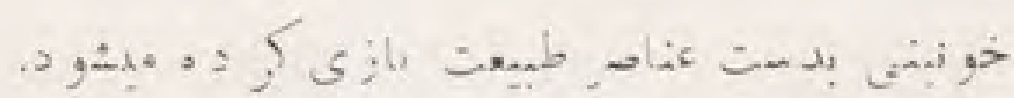

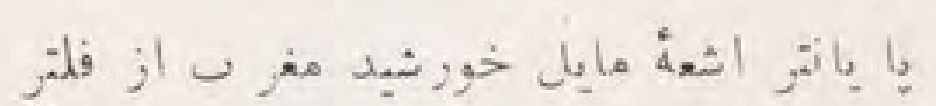

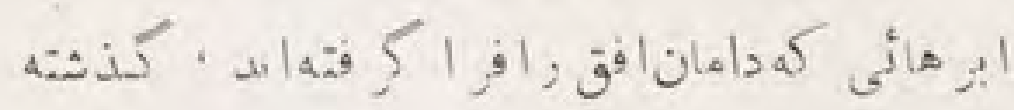

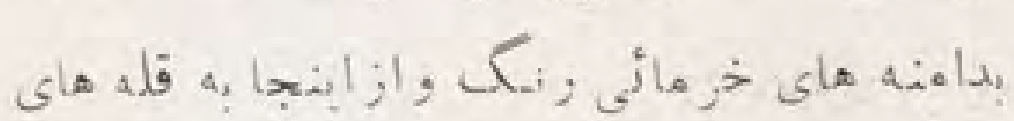

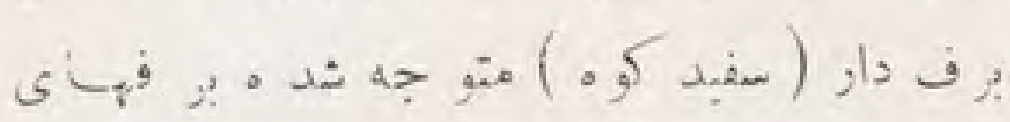

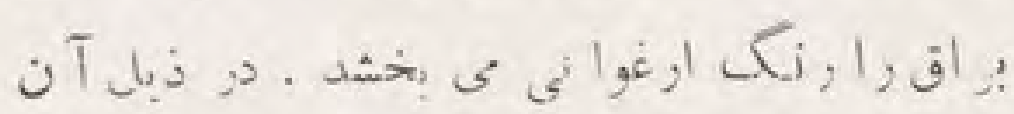

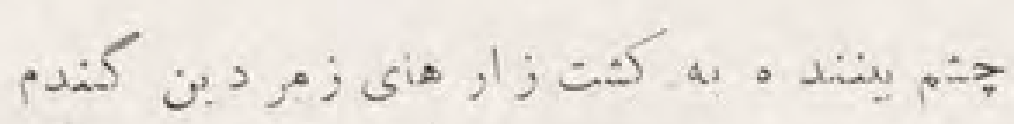

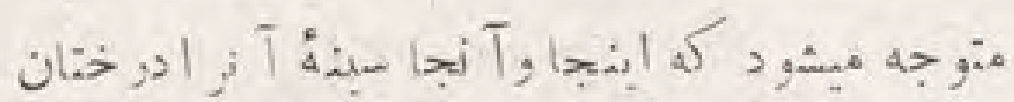

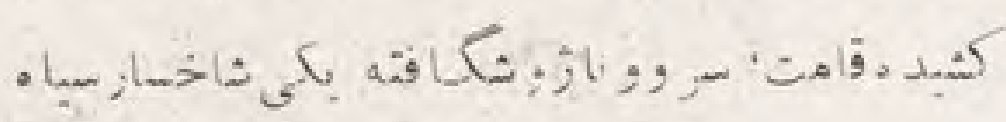

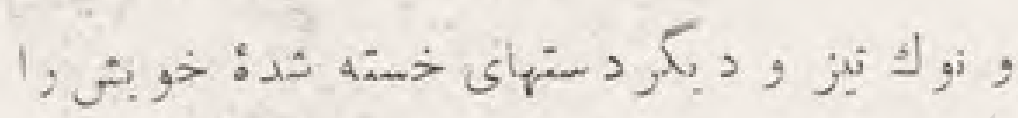

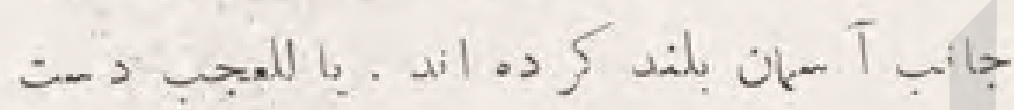

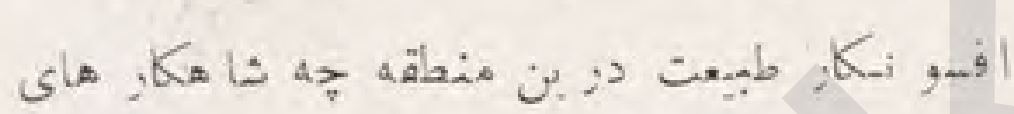

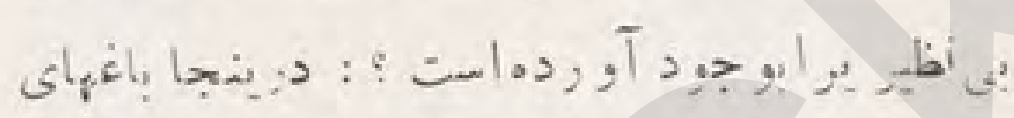

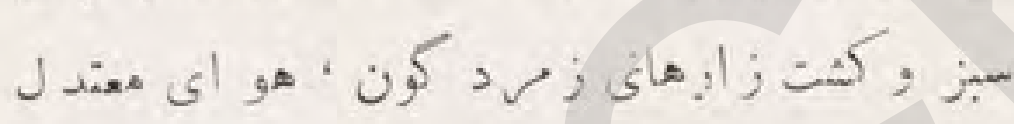

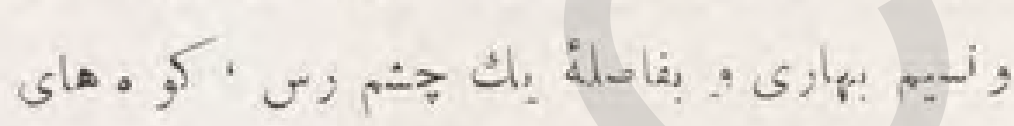

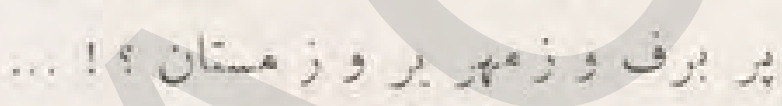

\section{***}

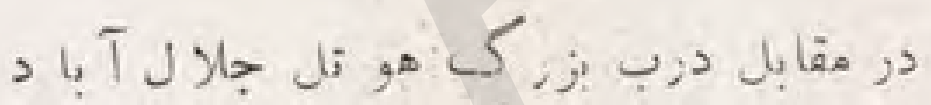

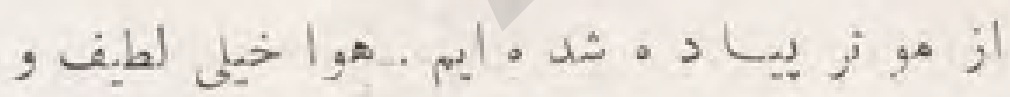

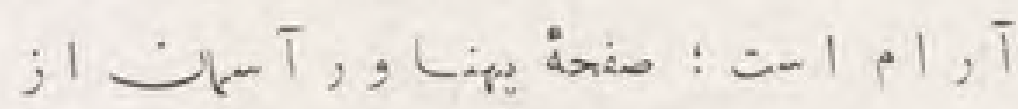

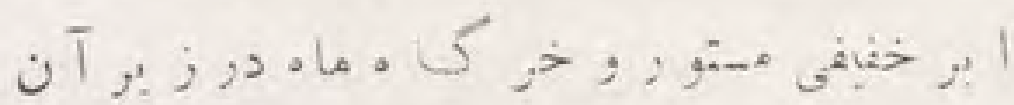

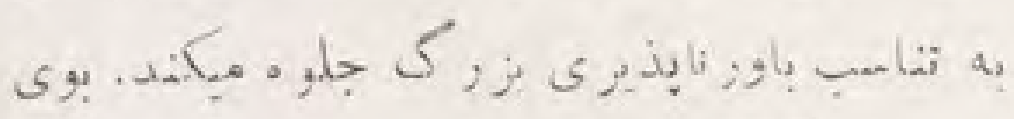

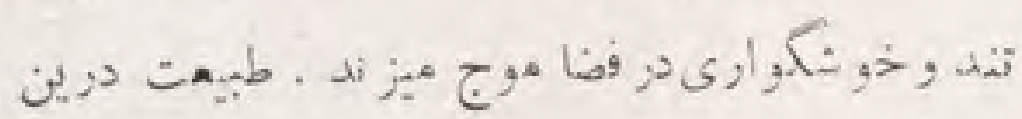

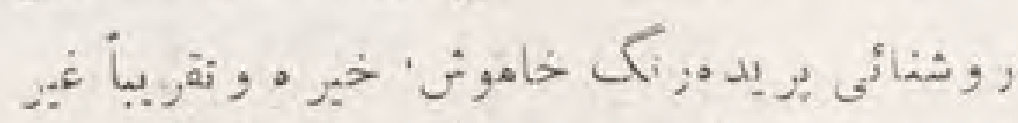

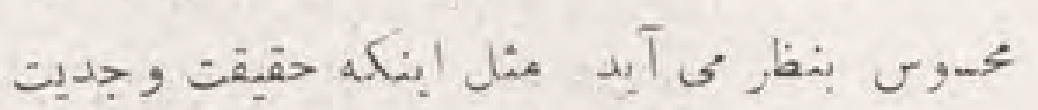

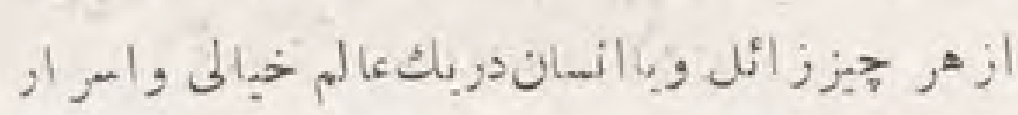

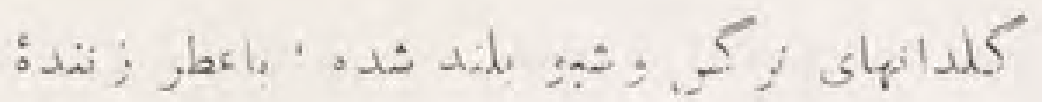

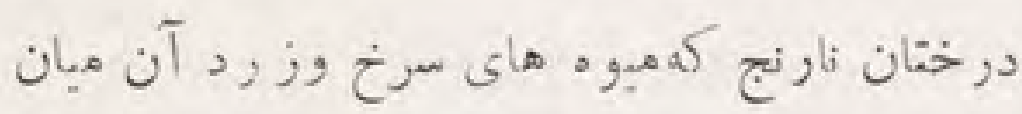

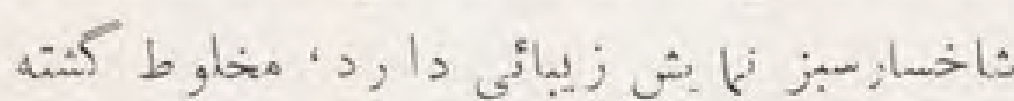

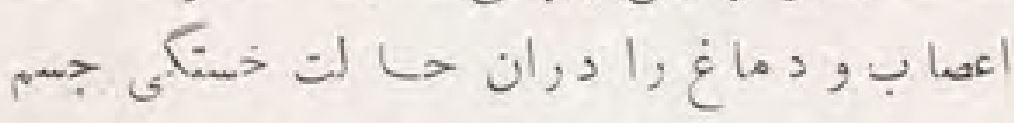

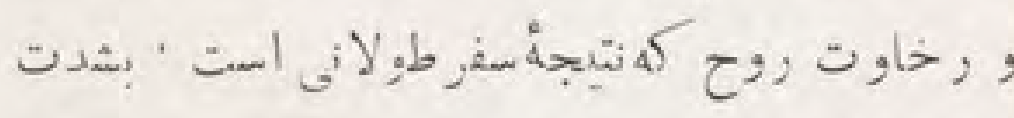

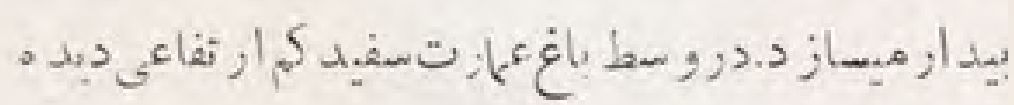

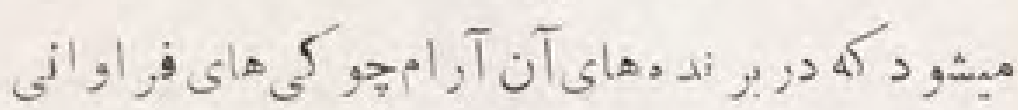

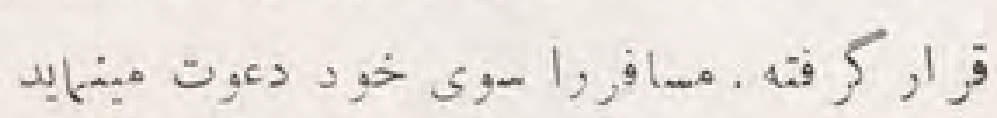
هو ا شتهه وخو شنو 'خيابا نها صاف و عارى

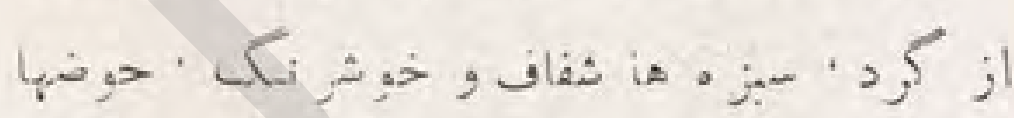

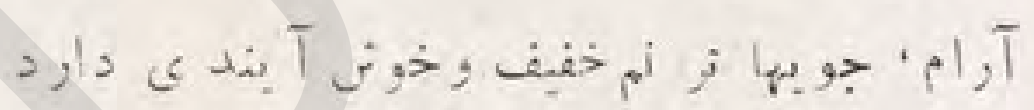

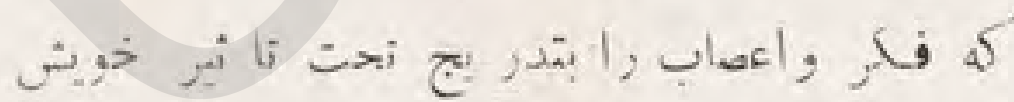

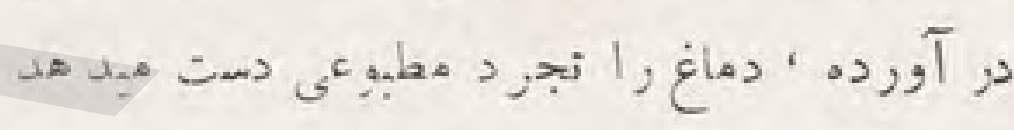

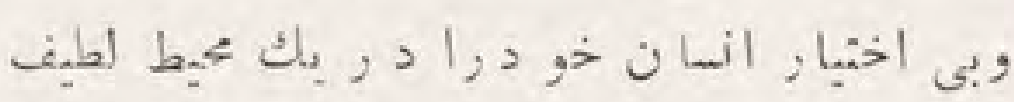

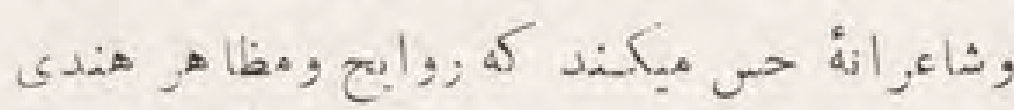

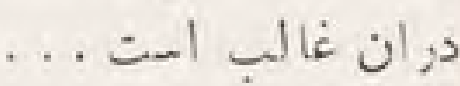
* * *

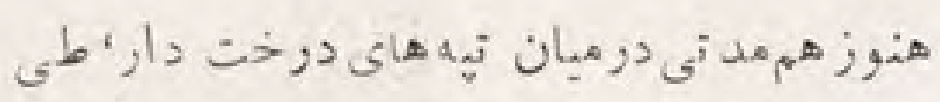

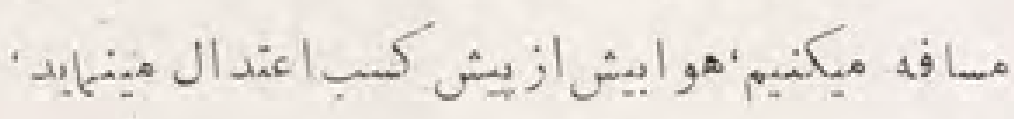

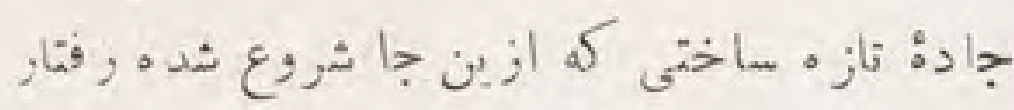

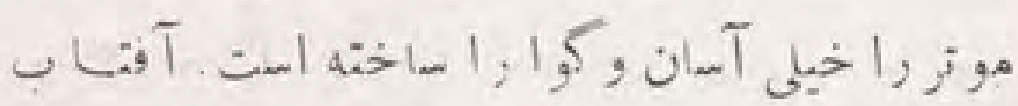

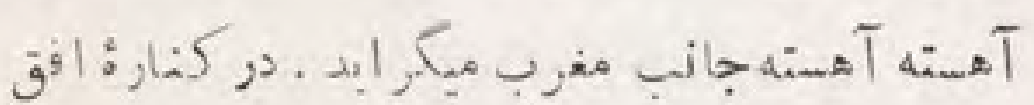

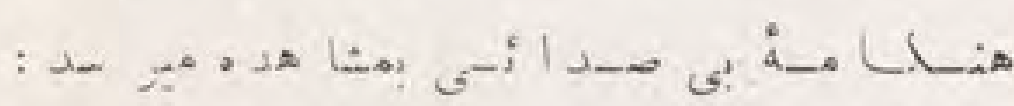
.

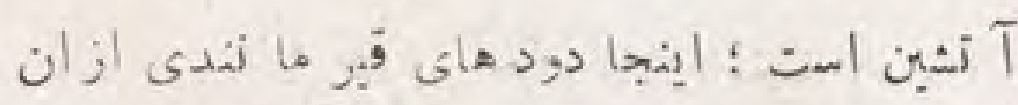

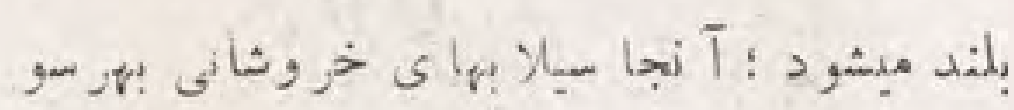

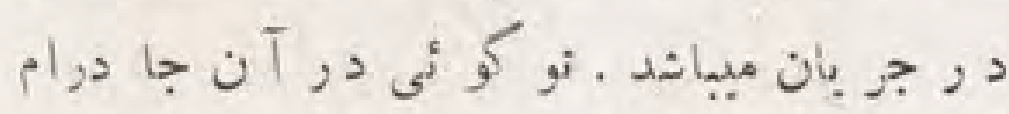




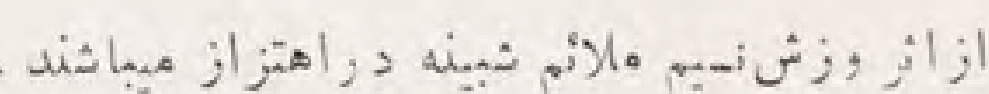

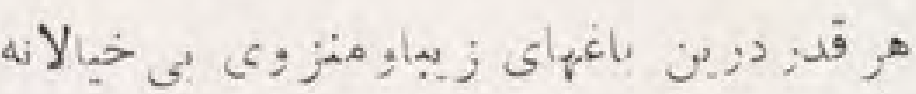

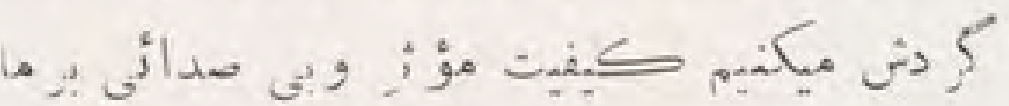

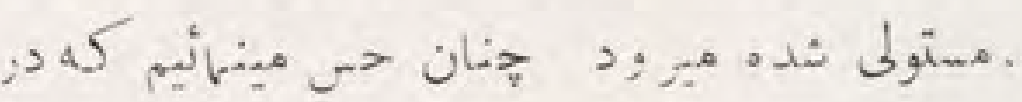

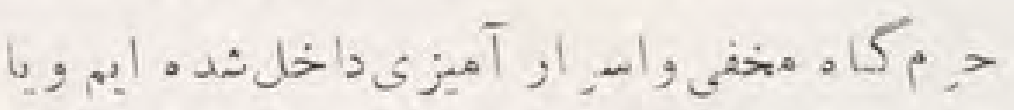

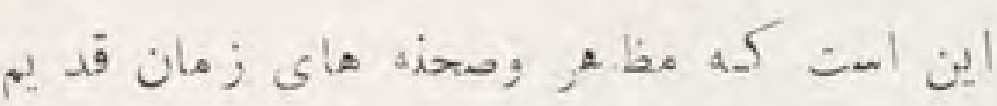

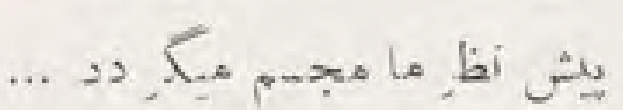
$* * *$

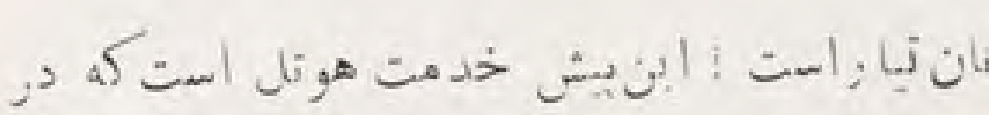

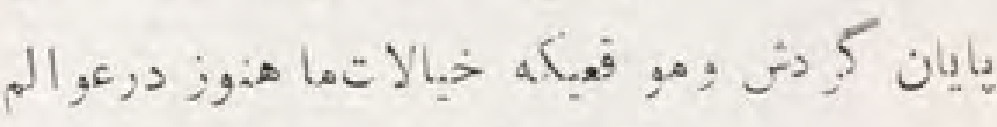

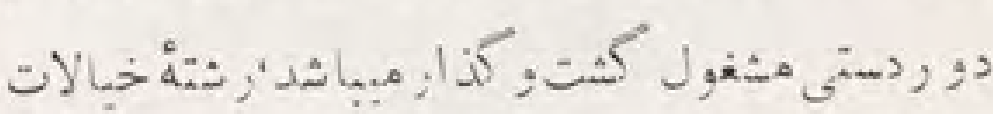

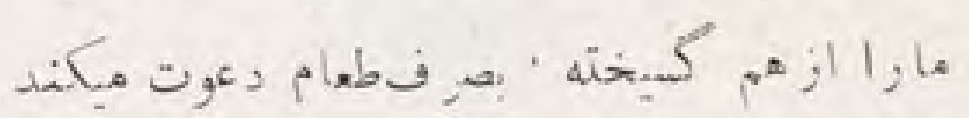

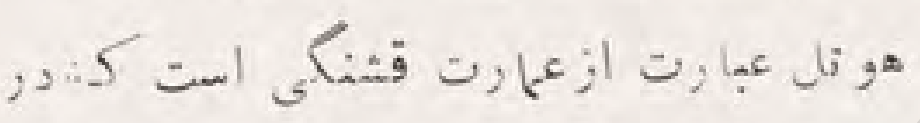

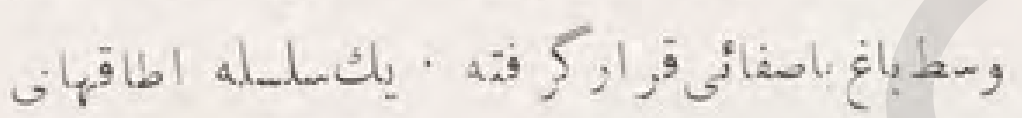

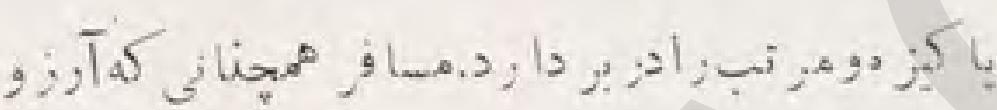

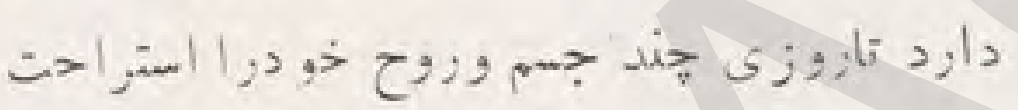

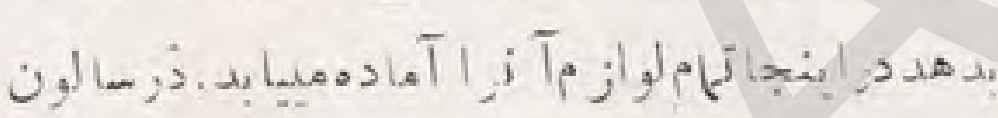

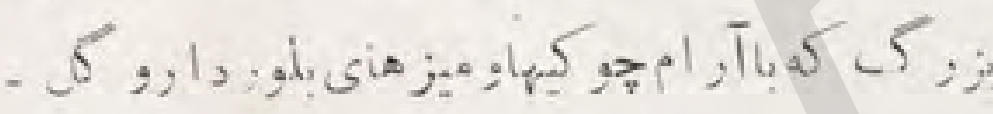
2

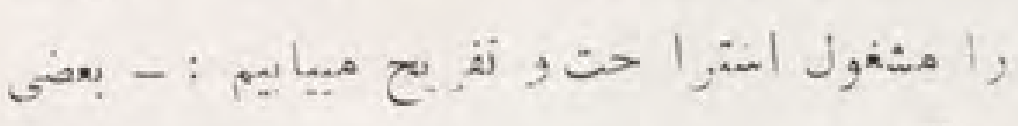

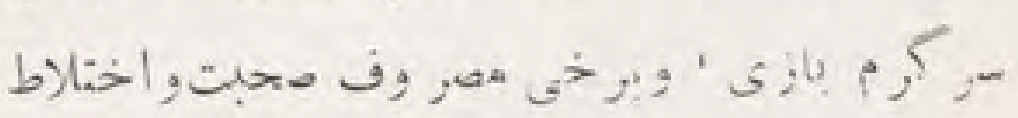

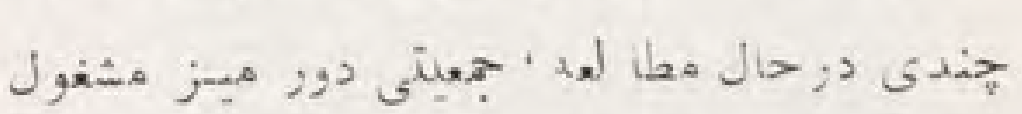

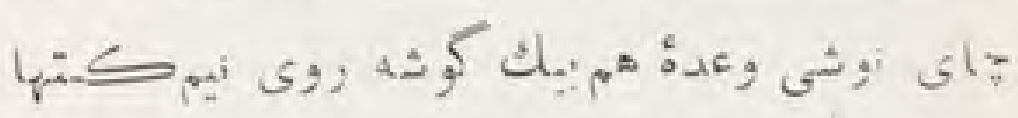

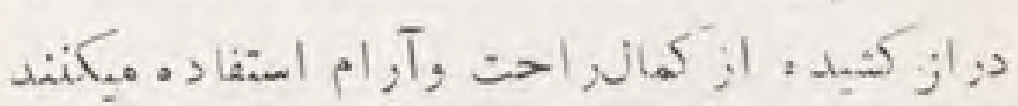

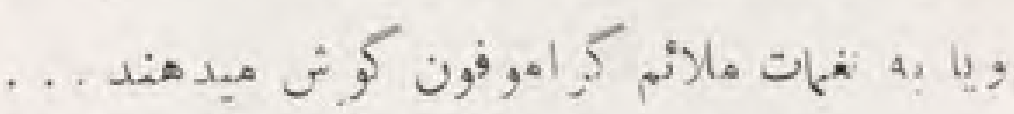

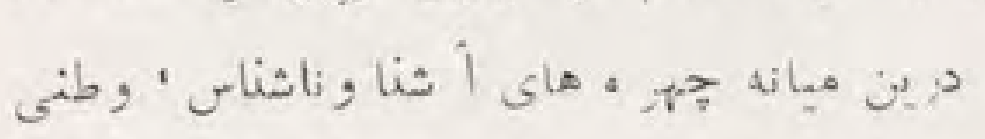

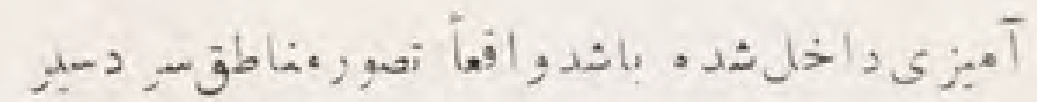
定

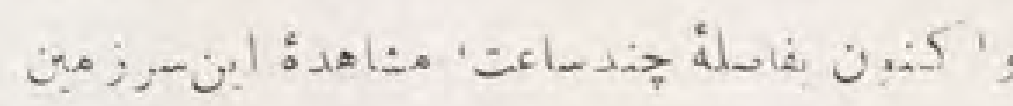

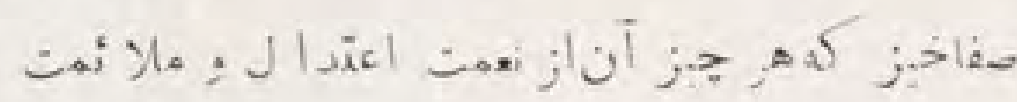

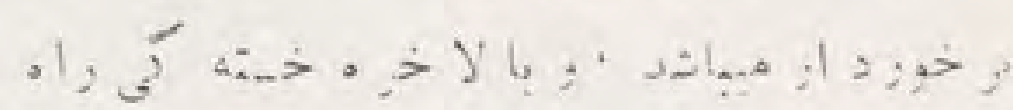

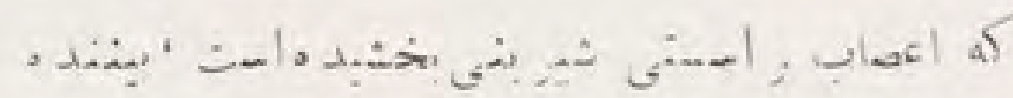

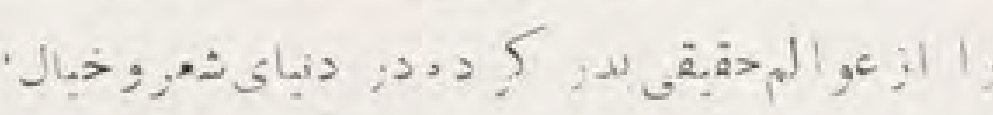

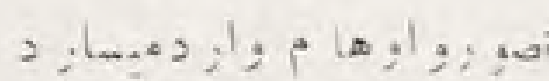

$$
\text { . }
$$

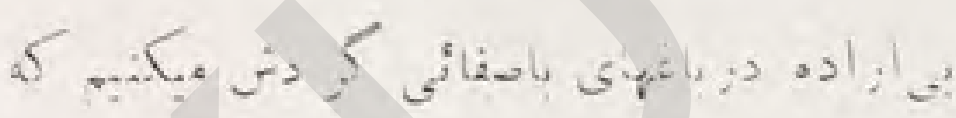
灰

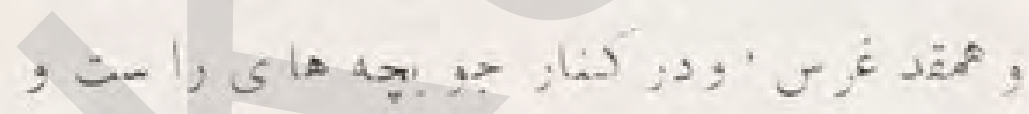

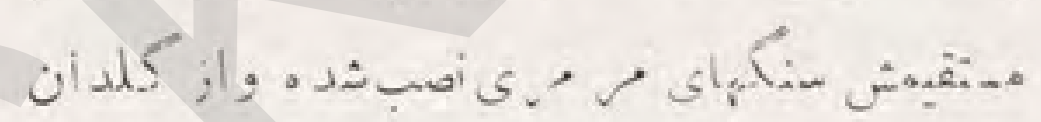

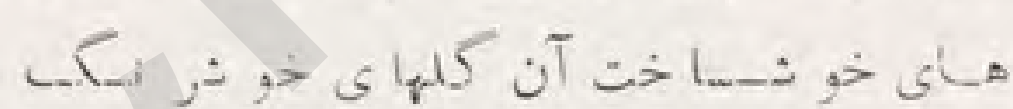

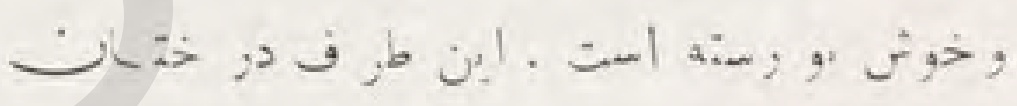

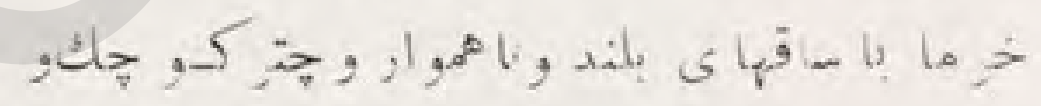

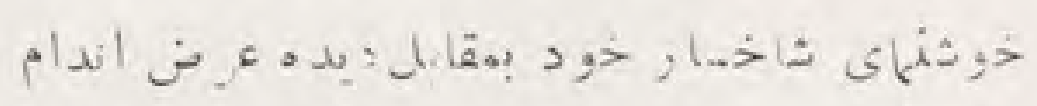

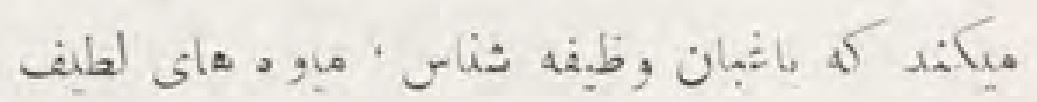

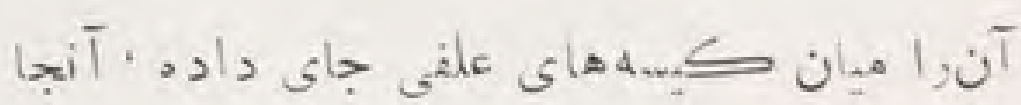

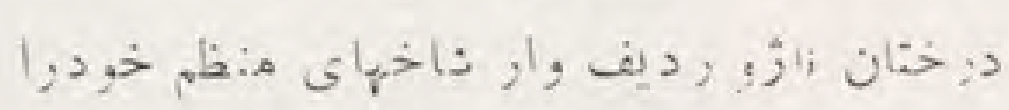

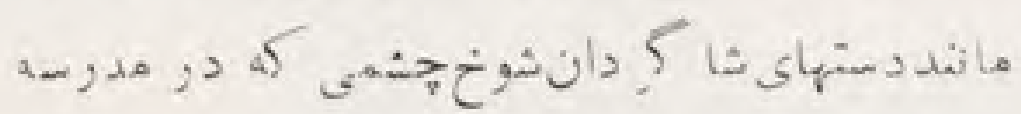

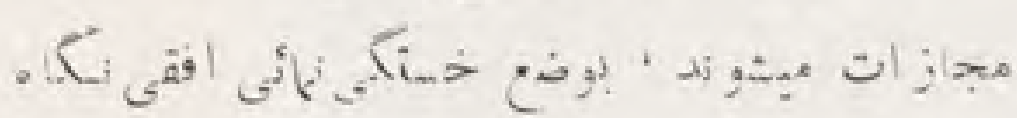

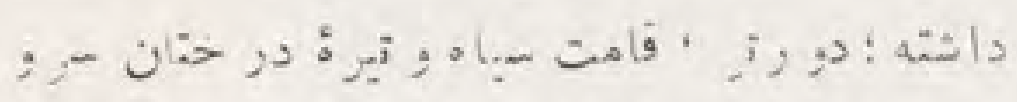

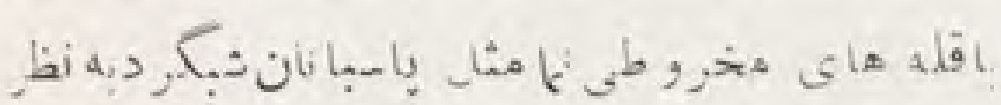

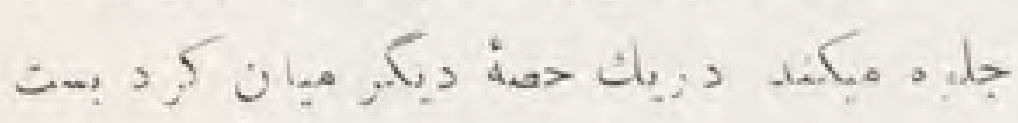

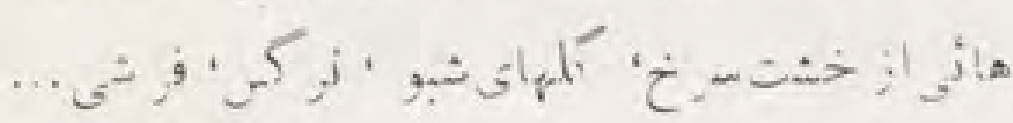




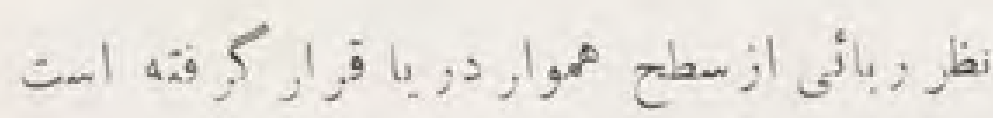

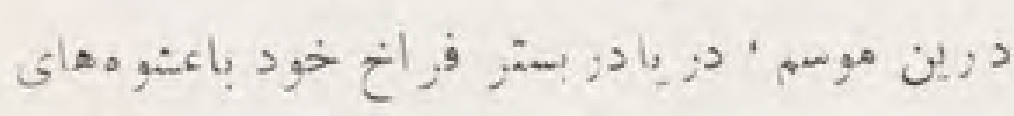

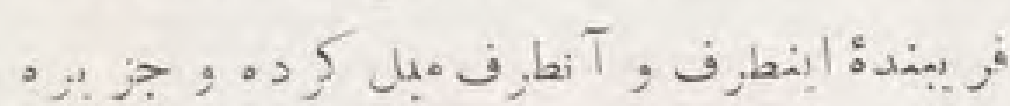

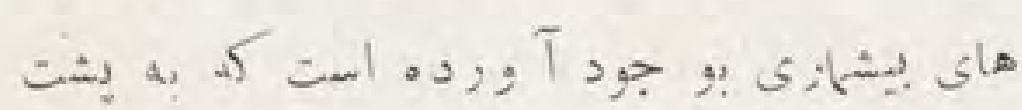

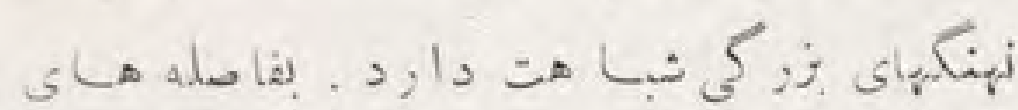

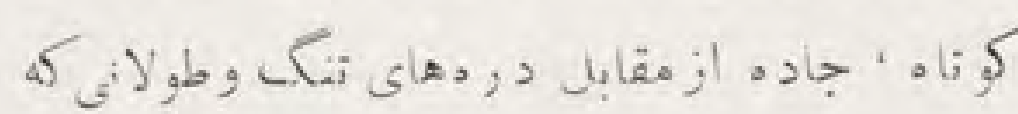

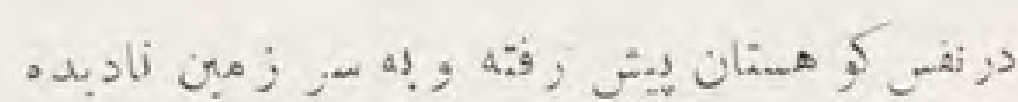

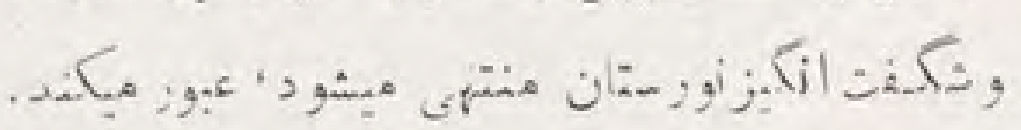

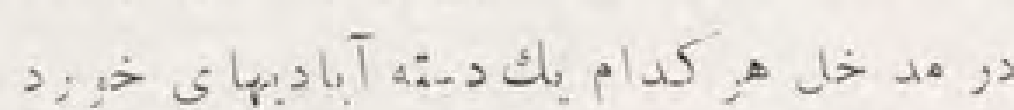

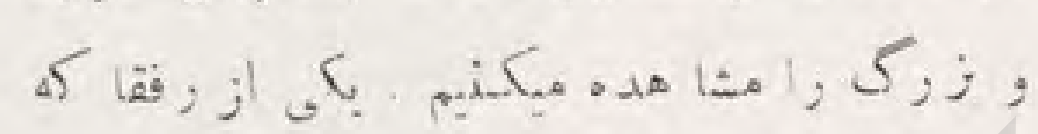

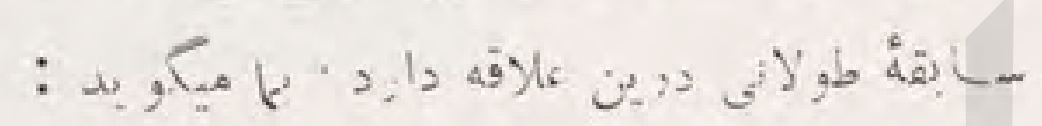

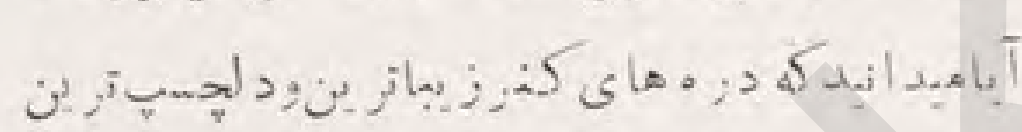

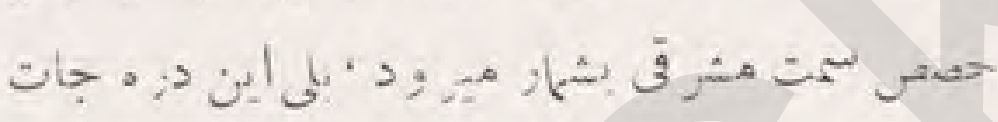

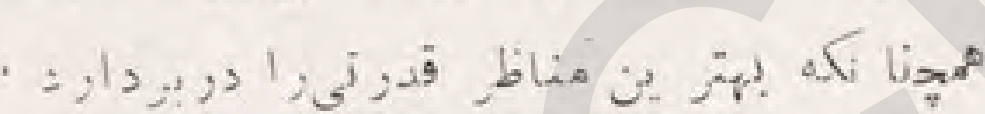

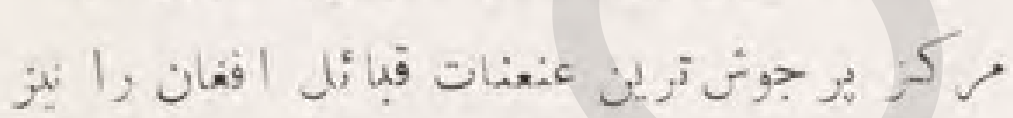

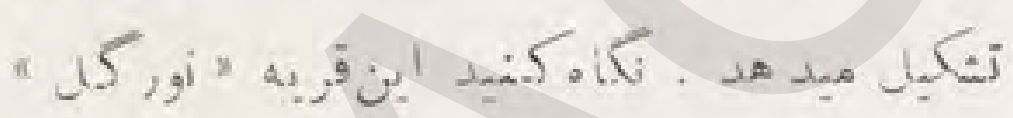

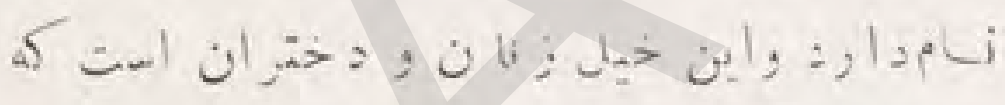

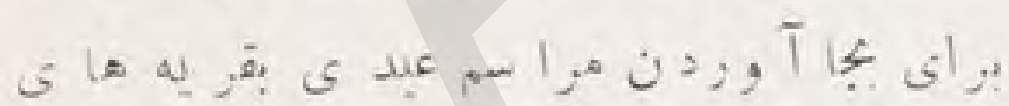

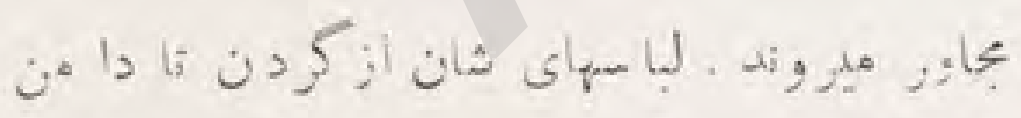

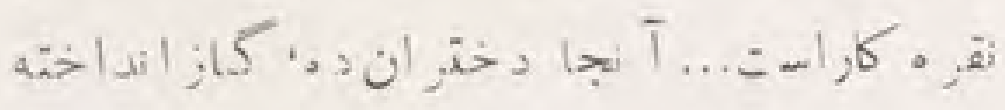
هil:

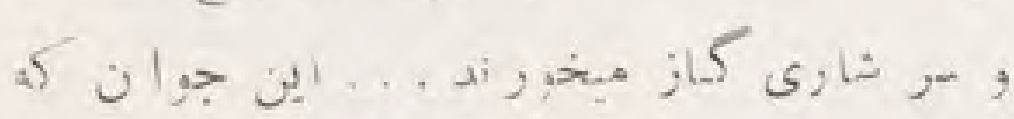

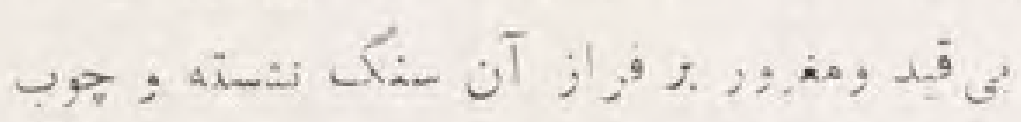

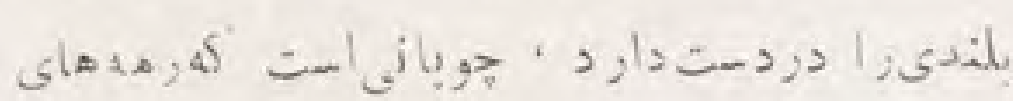

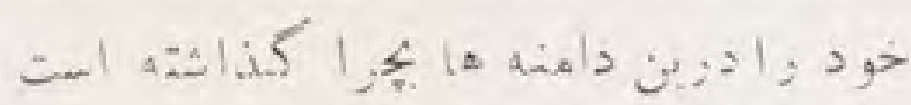

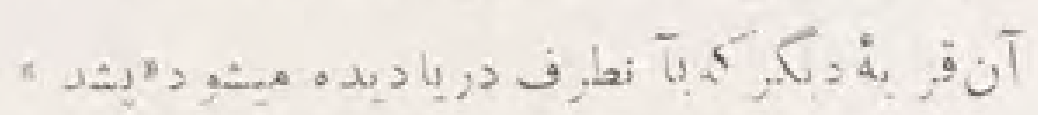

وخاز جى ' ير وجوان دو بر نو هجر اغ برق بيث

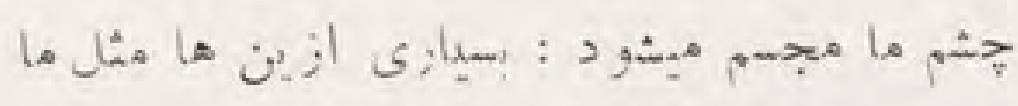

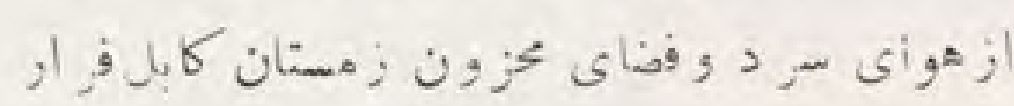

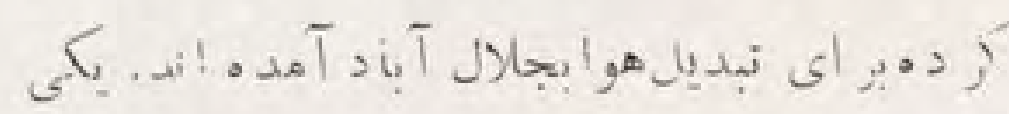

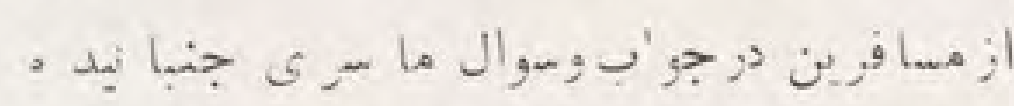

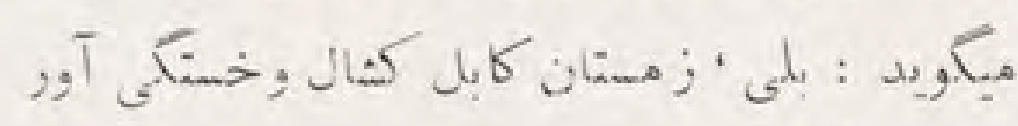

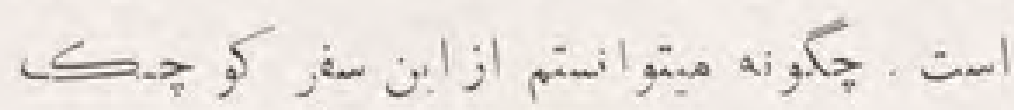

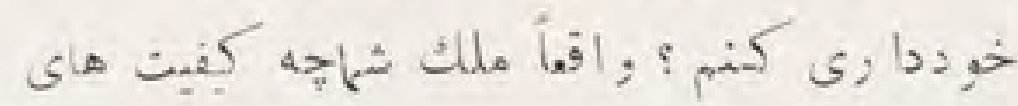

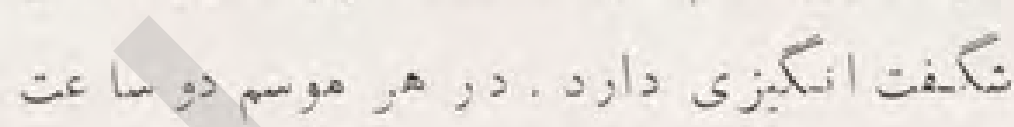

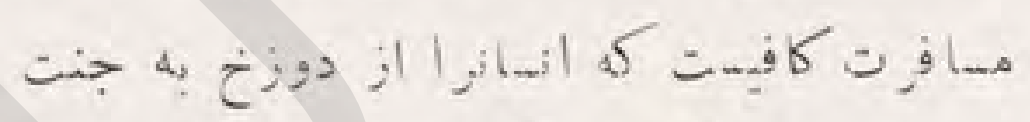

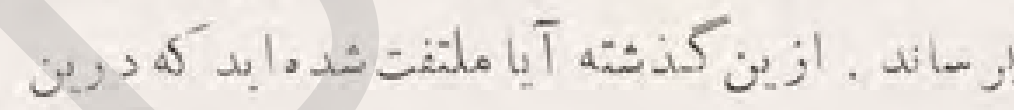

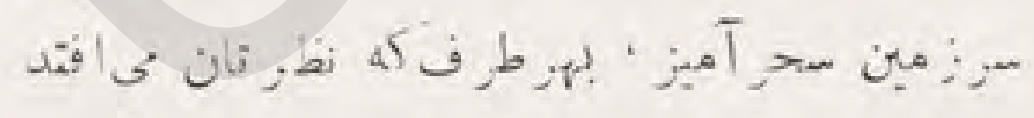

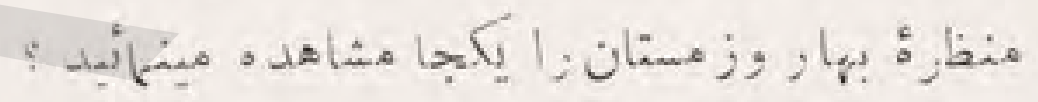

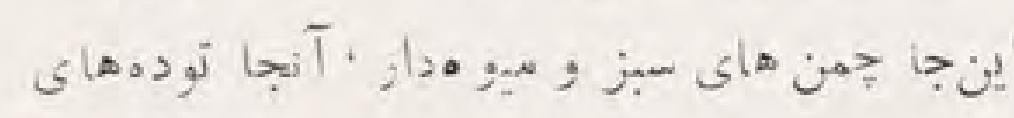

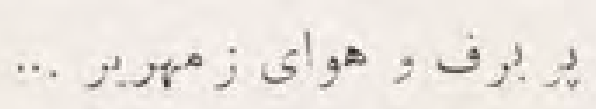

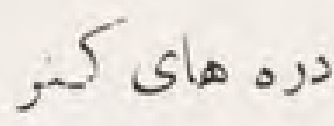

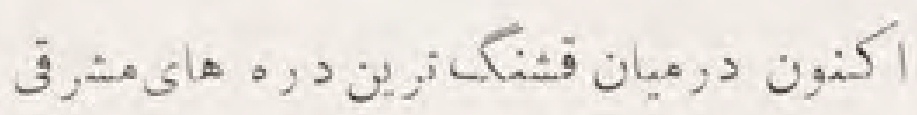

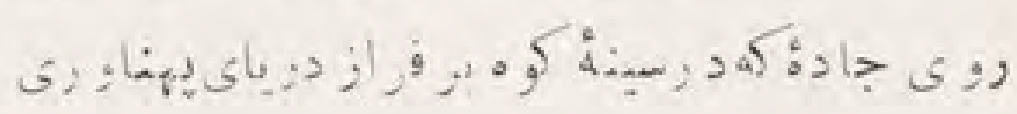

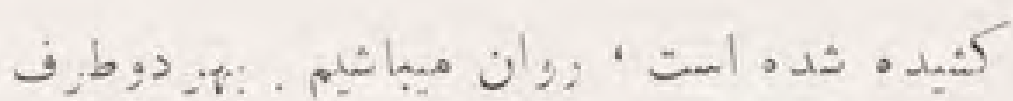

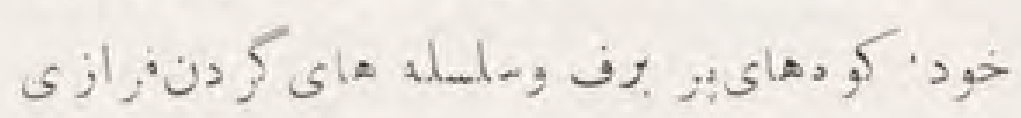

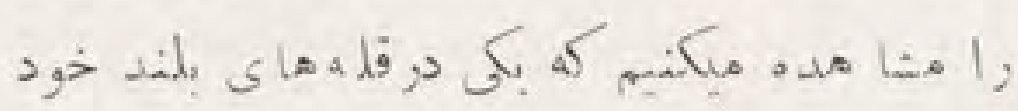

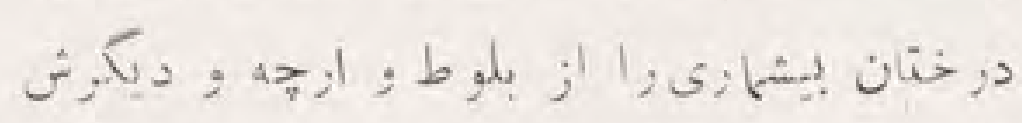

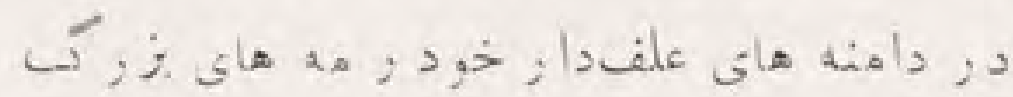

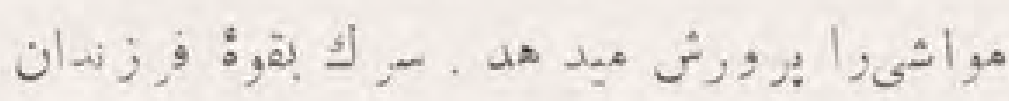

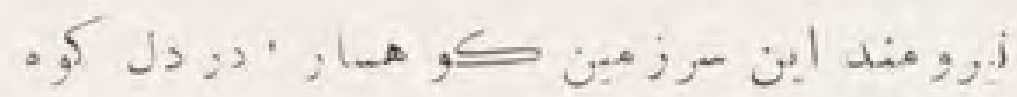

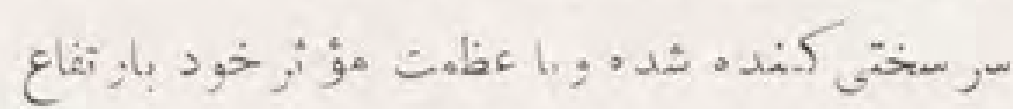


* * *

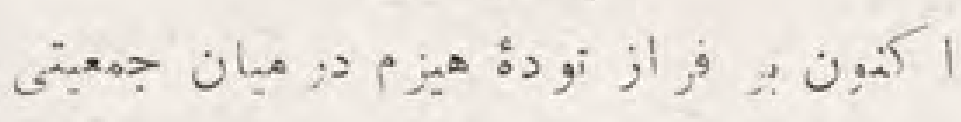

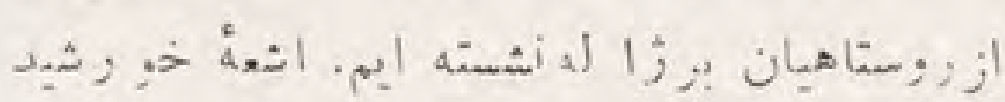

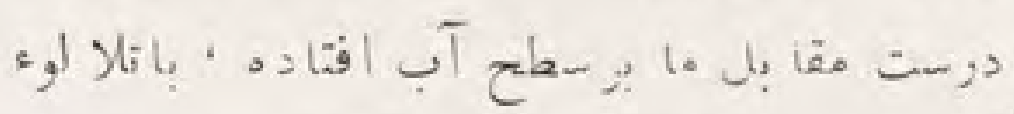

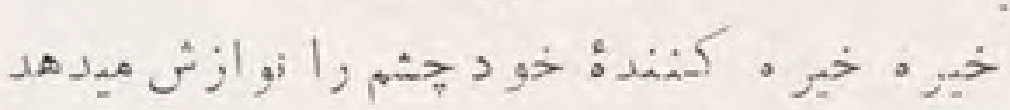

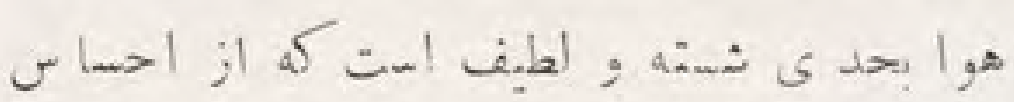

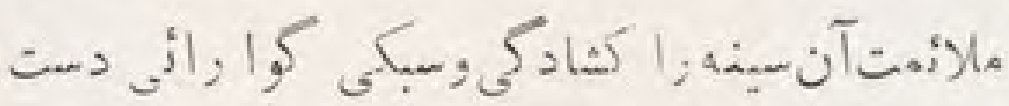

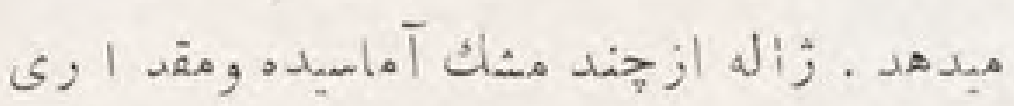

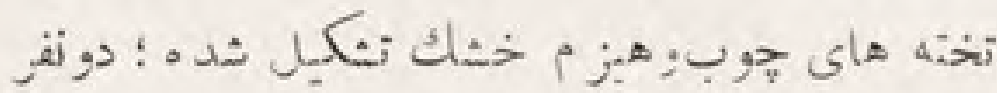

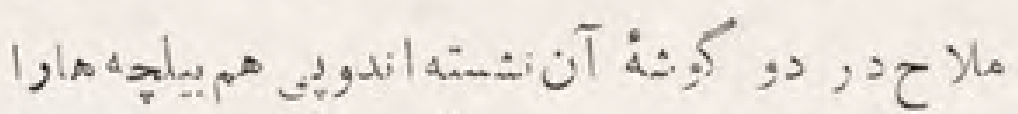

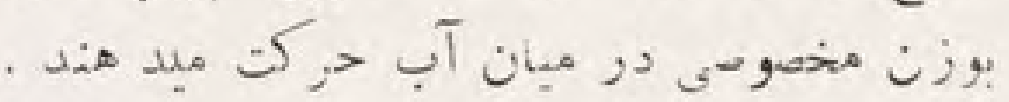

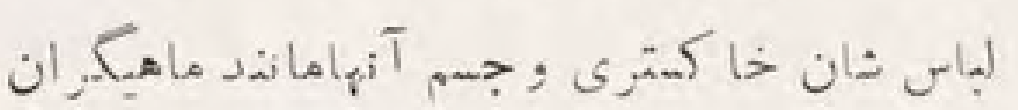

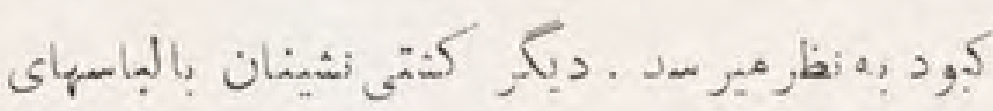

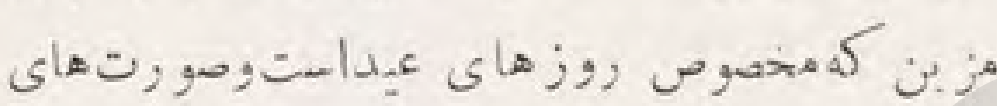

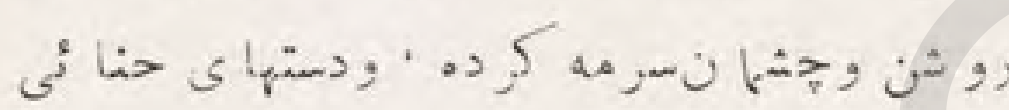

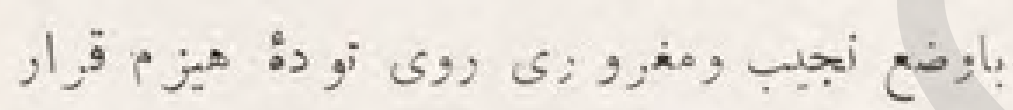

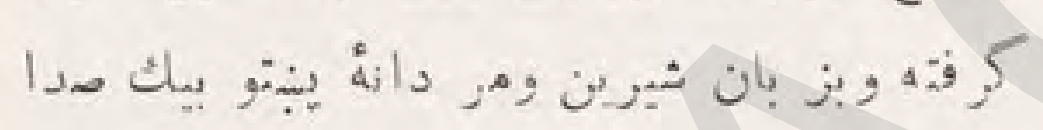

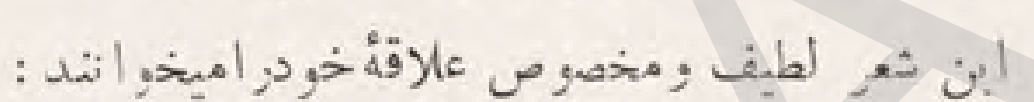

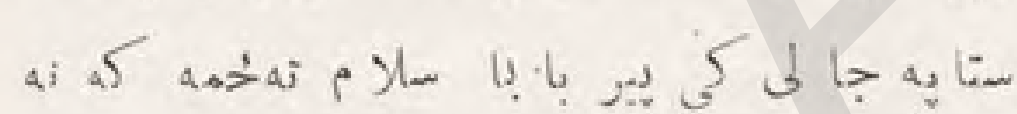

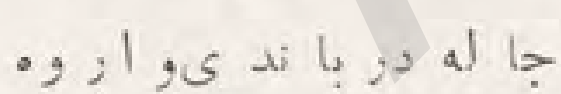

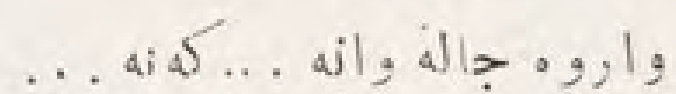

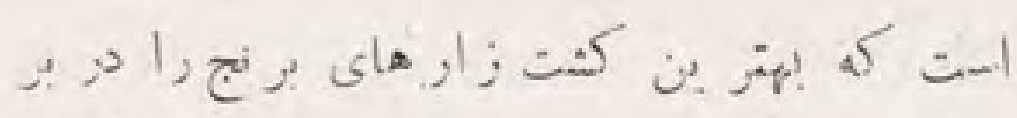

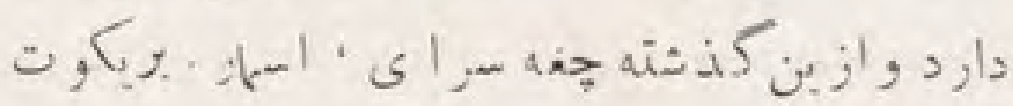

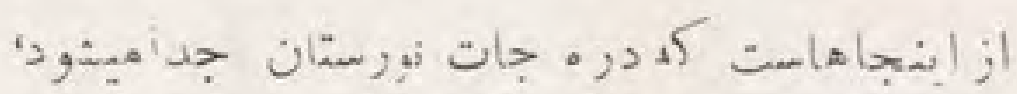
,

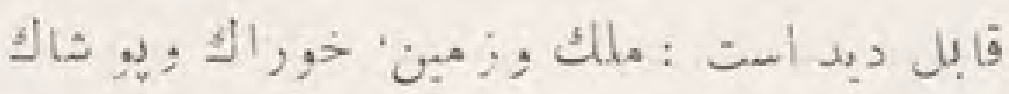

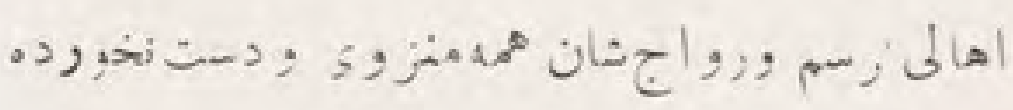

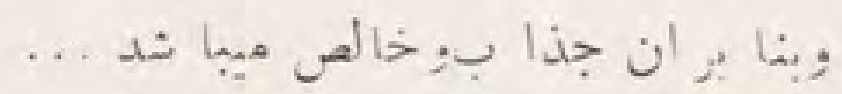
* * *

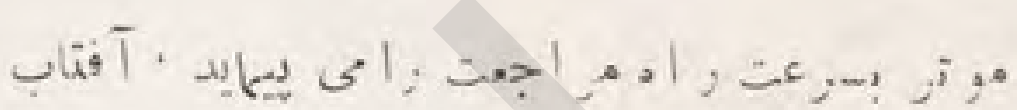

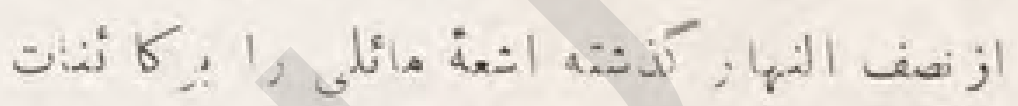

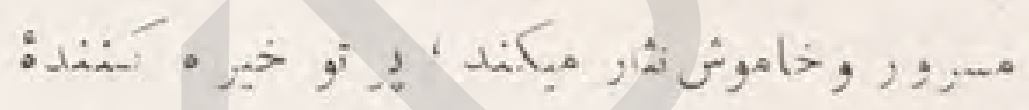

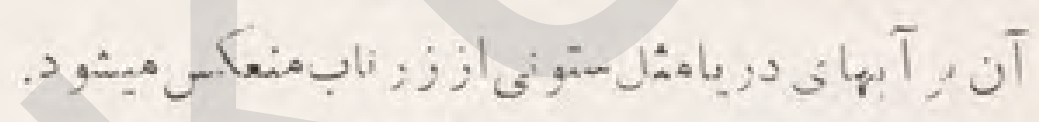

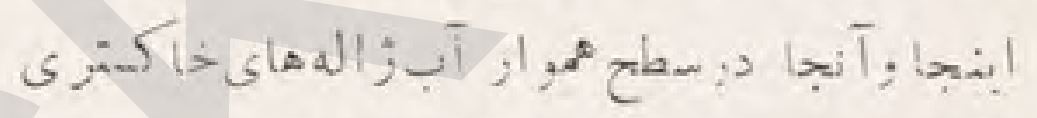

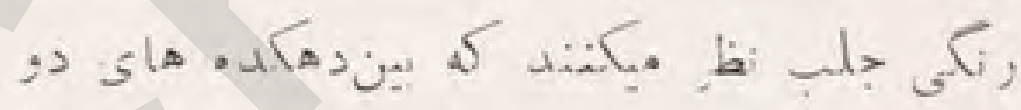

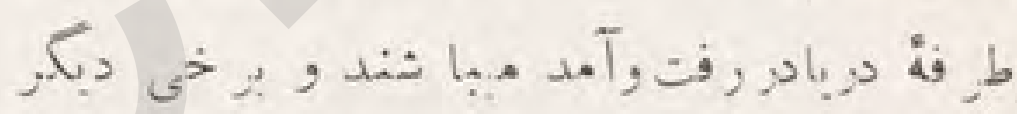

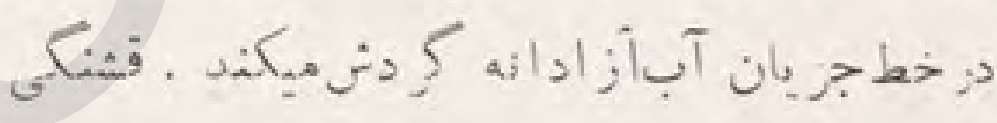

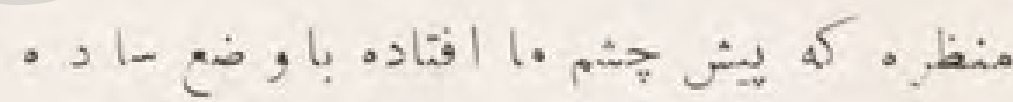

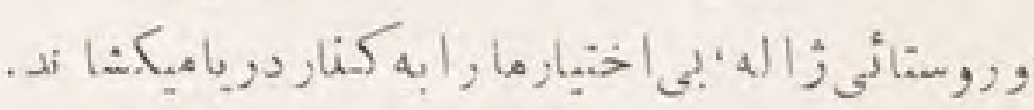

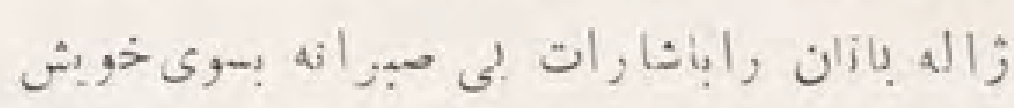

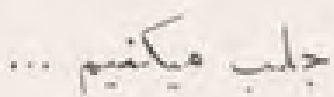
بكام
دز ؤلى :

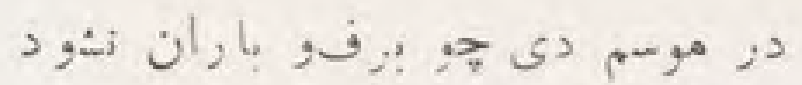
خر من سز د ار بـكم د هما ن نشيد

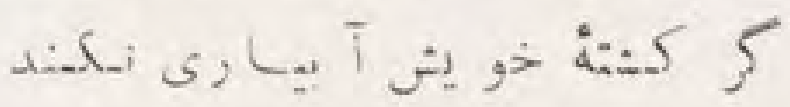
"مستغني مرحوم" 


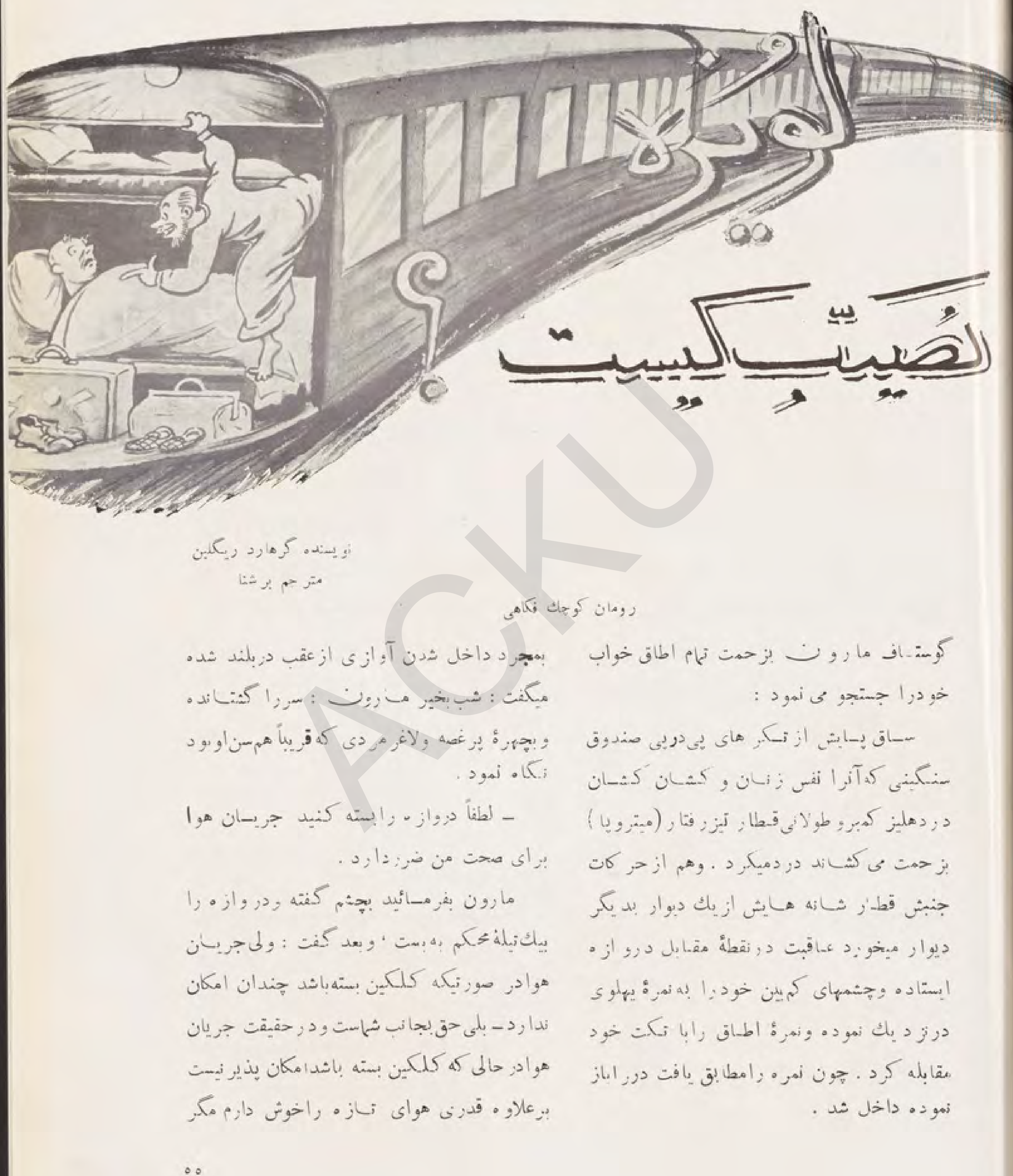




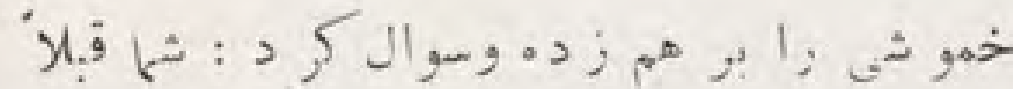

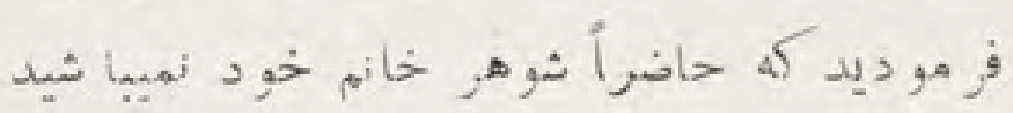

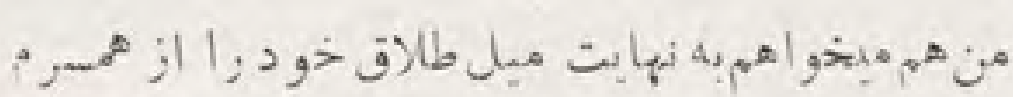

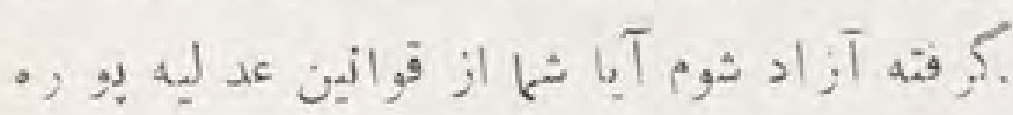

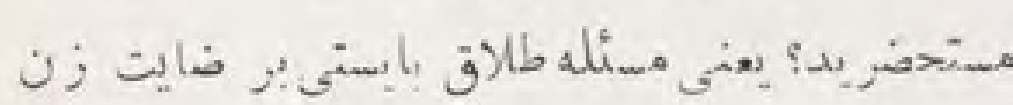

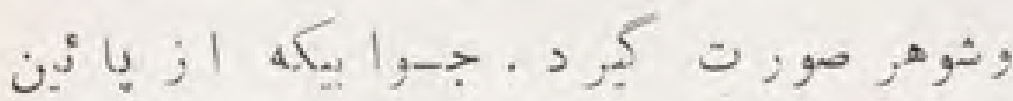

$$
\text { شنيد ابن بود : البته . }
$$

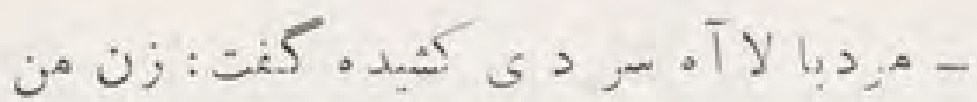

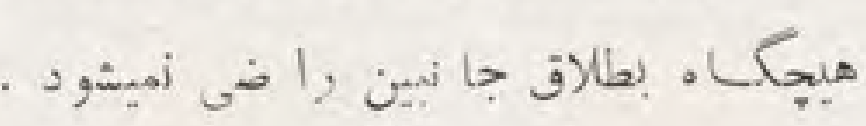

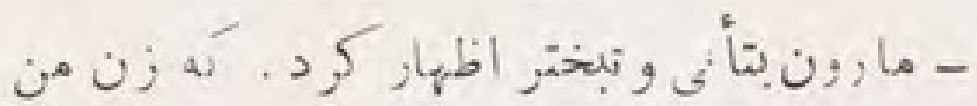

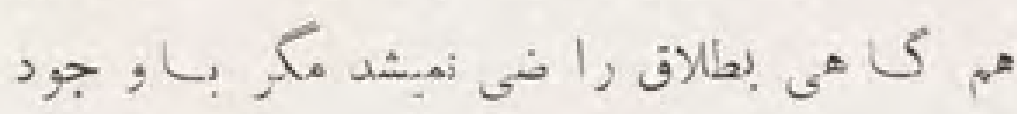

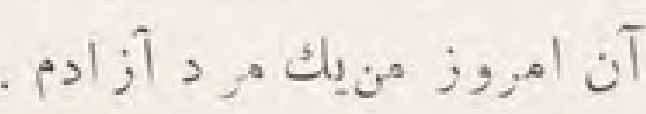

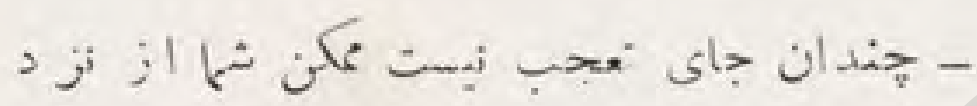

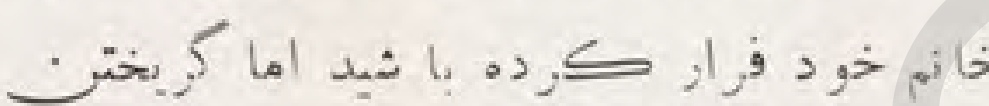

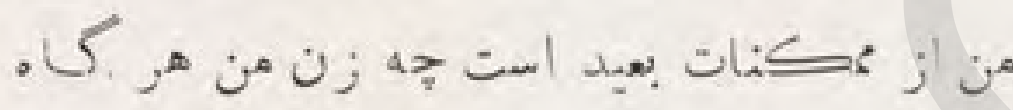

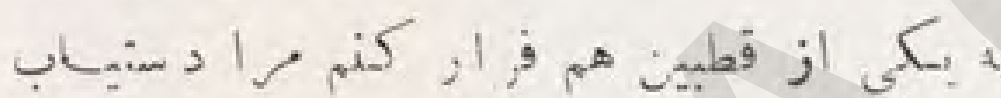

$$
\text { on a }
$$

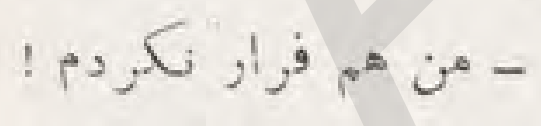

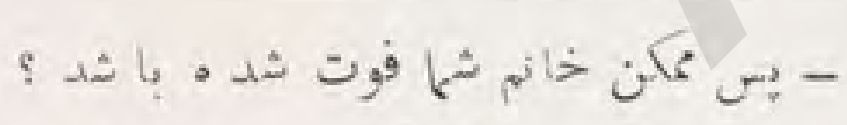

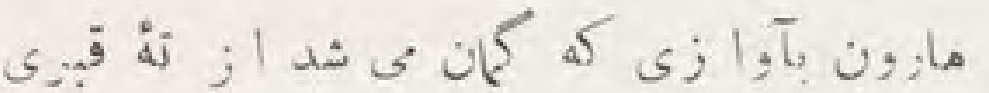

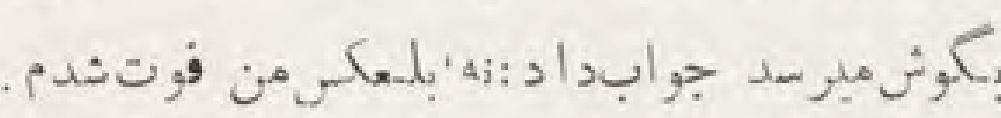
- م.

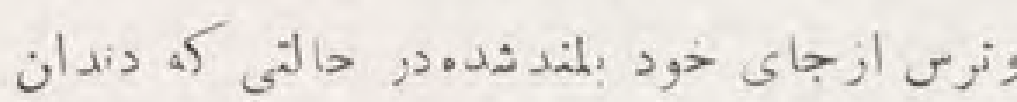

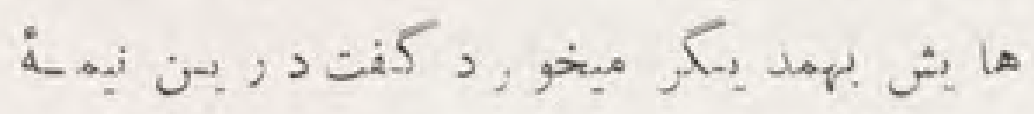

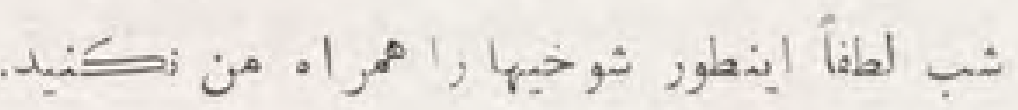

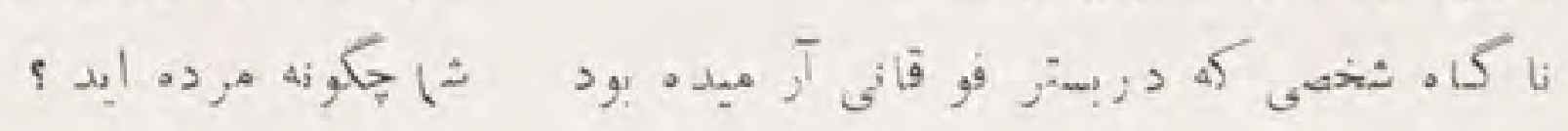

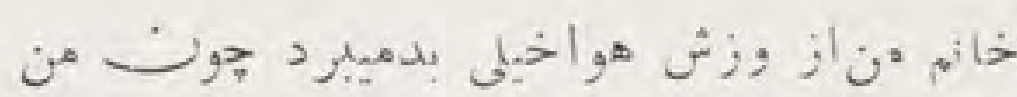

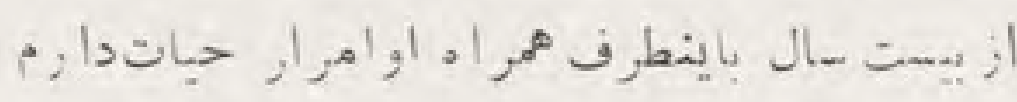

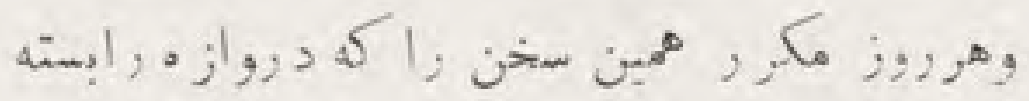

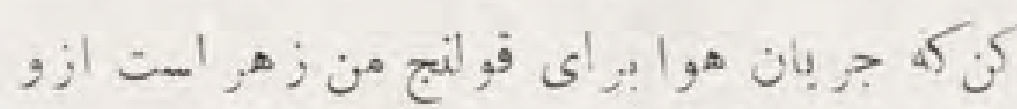

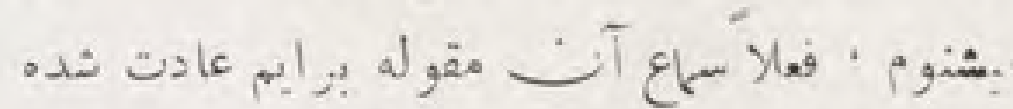

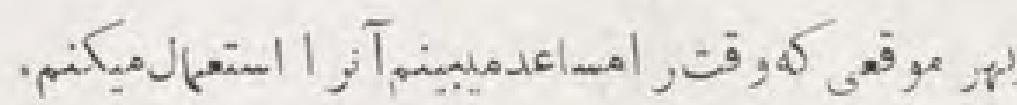

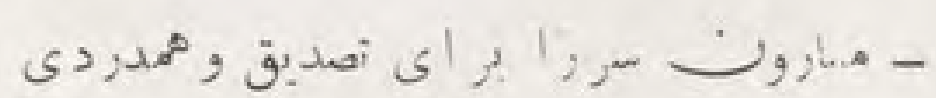

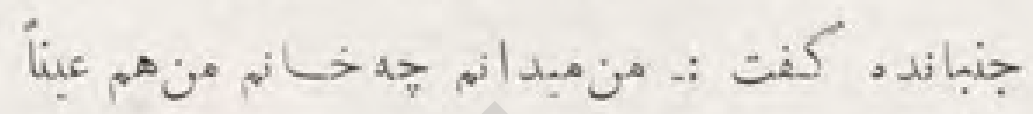
- خوب بفرمائيد بشنوم كه ج2قور شحاتوا نستيد اين عادت را إزبر, خانم خود دو:كنيد

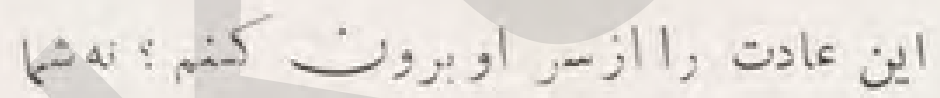

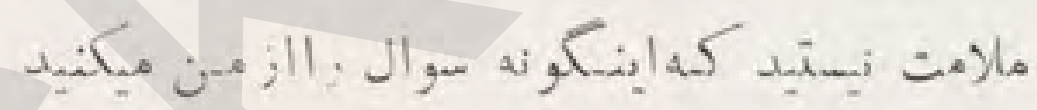

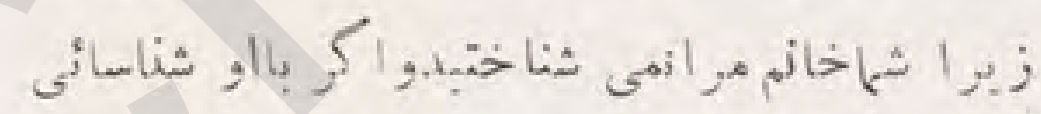

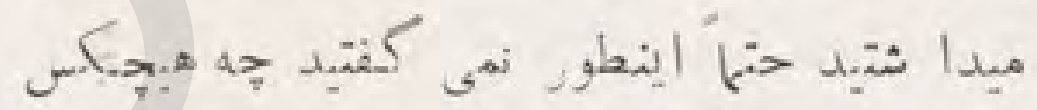
خالف نظا ب-4 , ف.كر او جيز

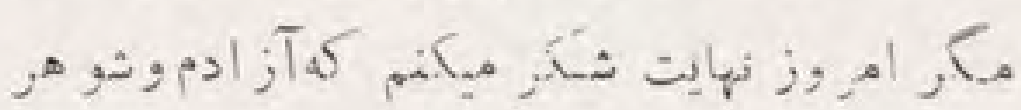

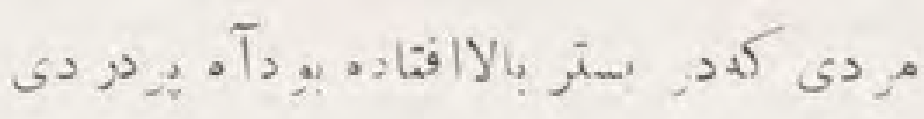

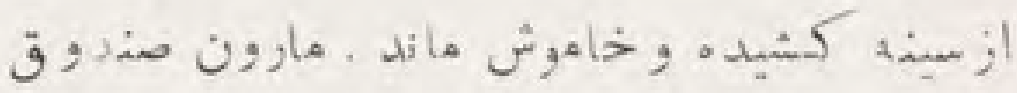

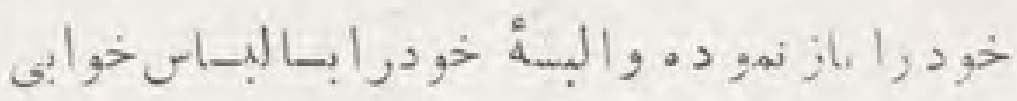

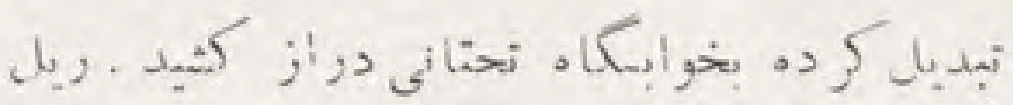

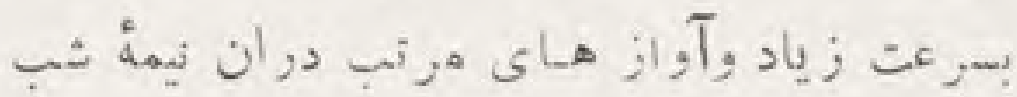

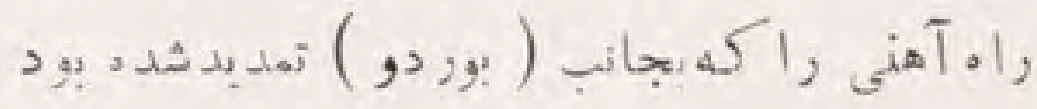
باين دومسافر خاموث مبكثانيد. 


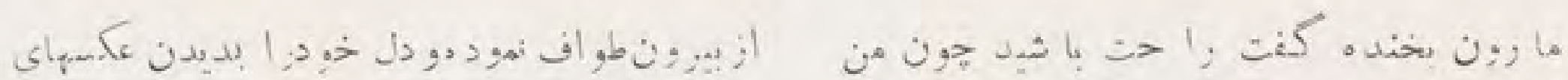

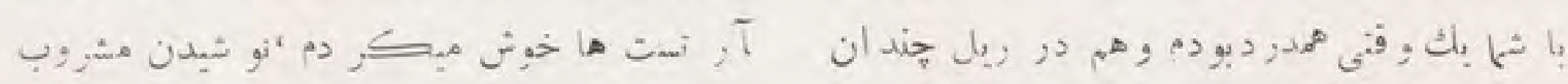

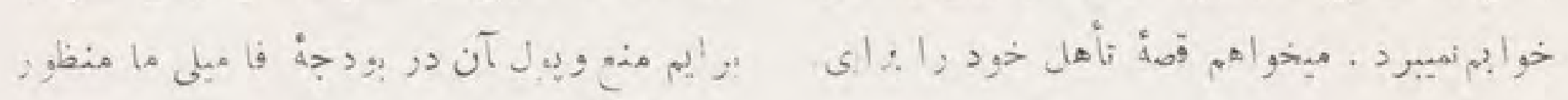
أش

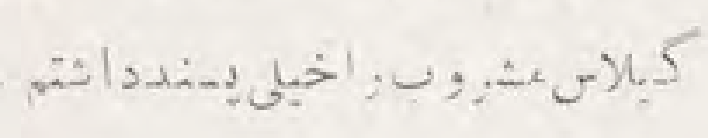

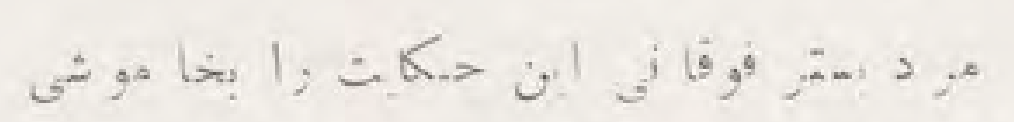

ق

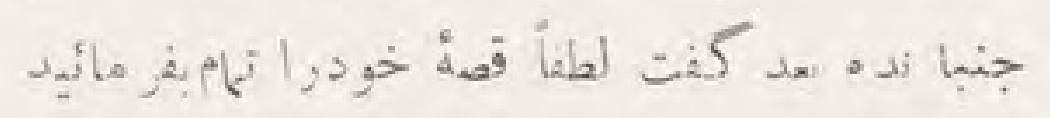

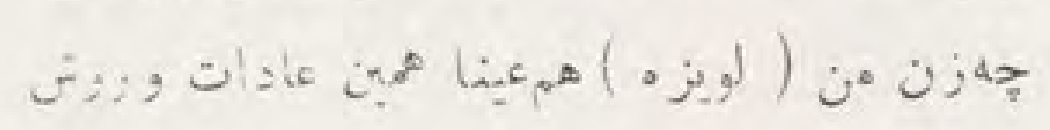
2,121 ,

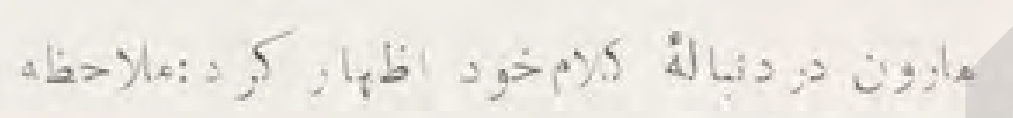

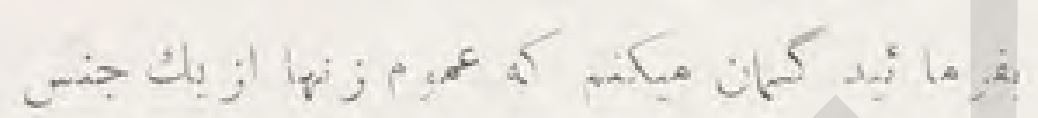

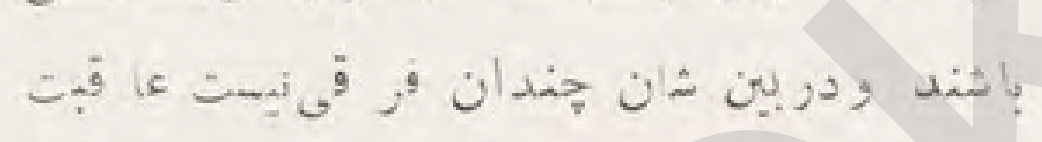

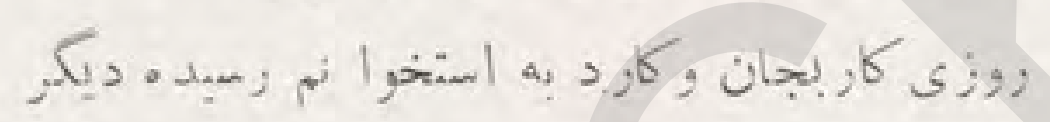

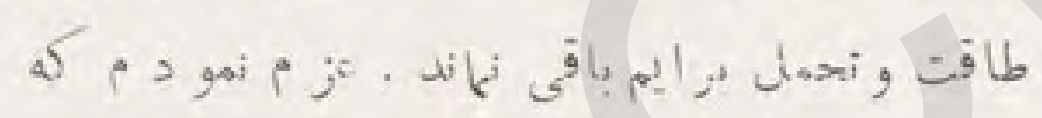

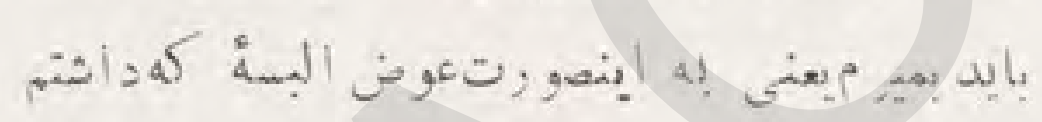

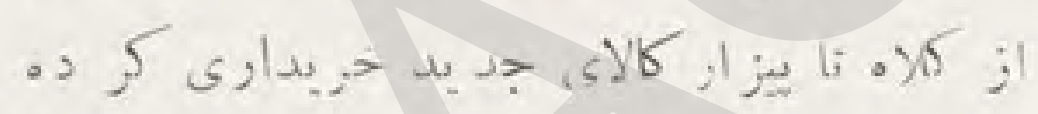

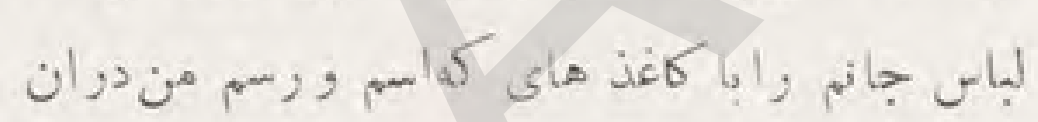

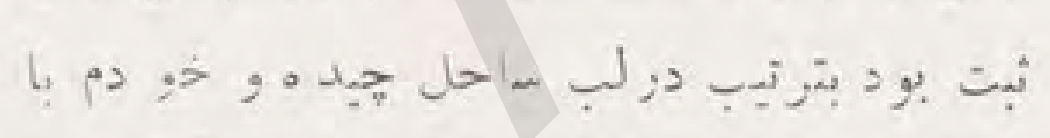

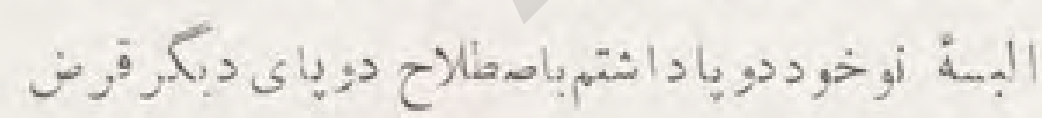

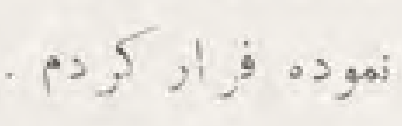

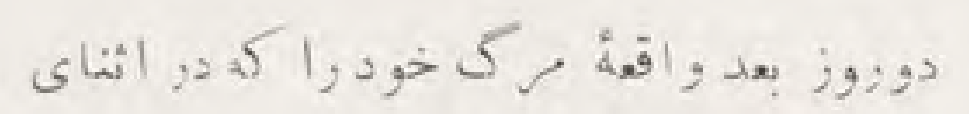

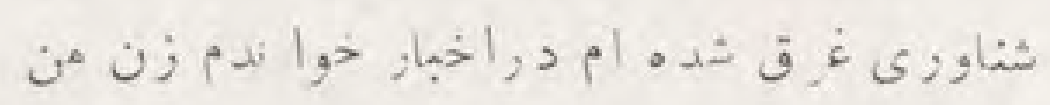

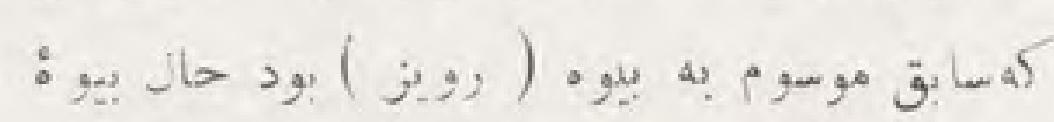

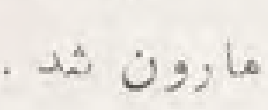

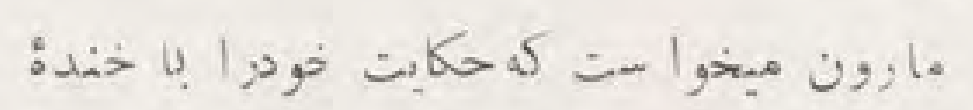

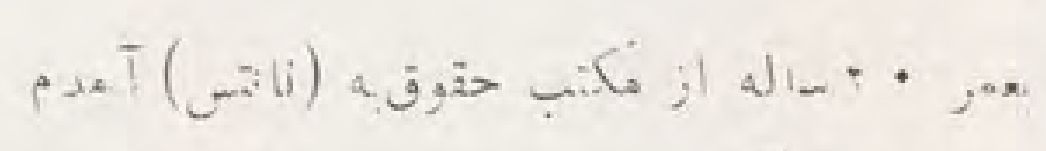

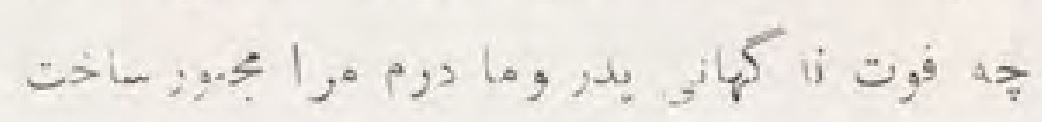

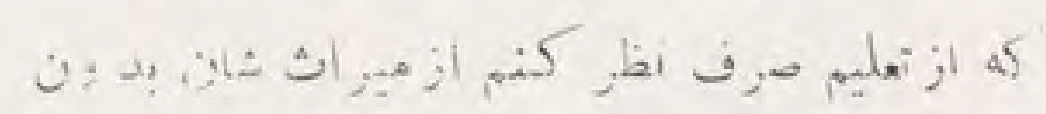

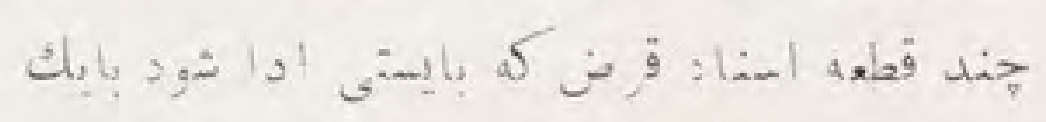

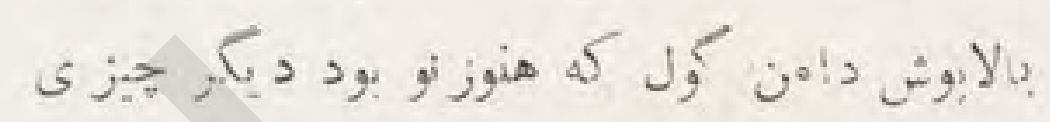

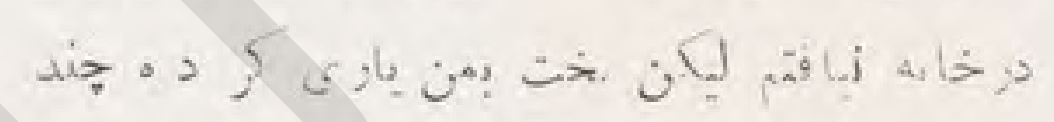
مش

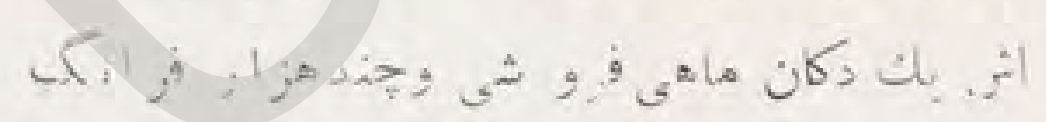

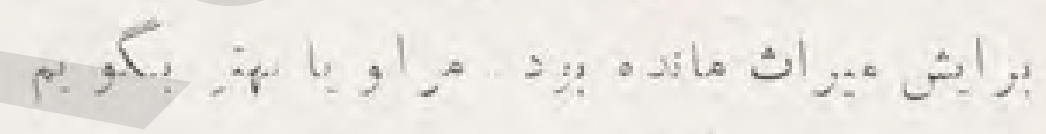

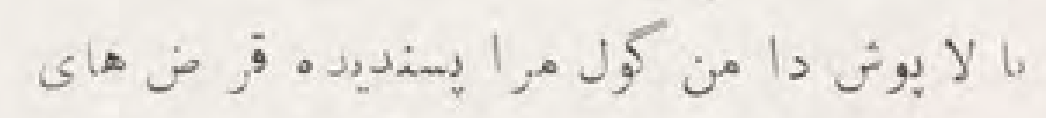

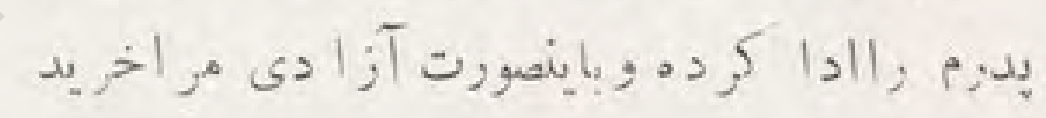

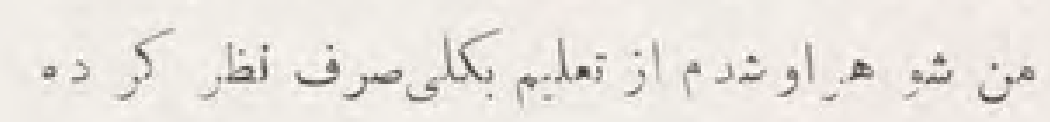

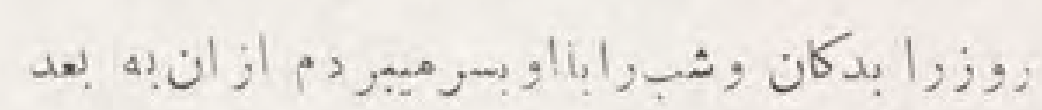

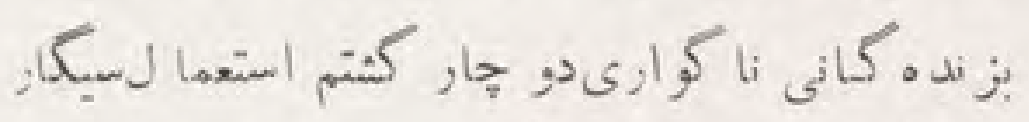

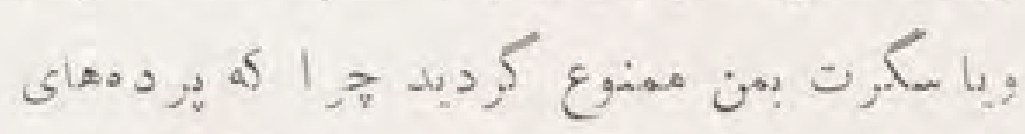

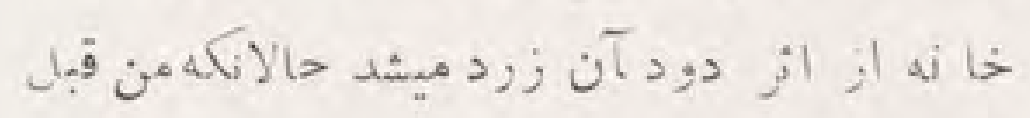

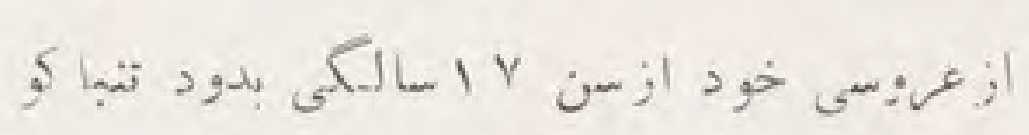

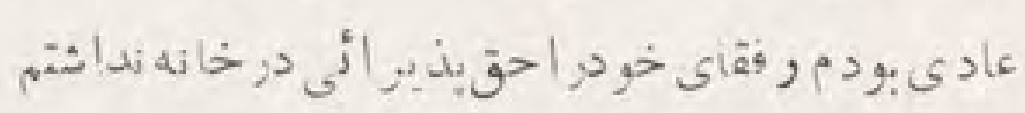

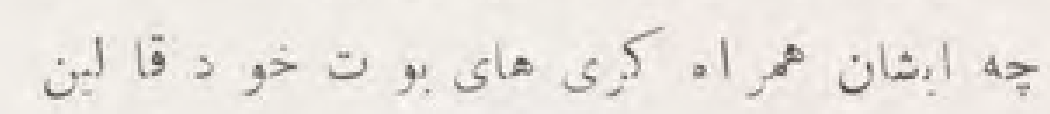

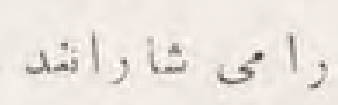

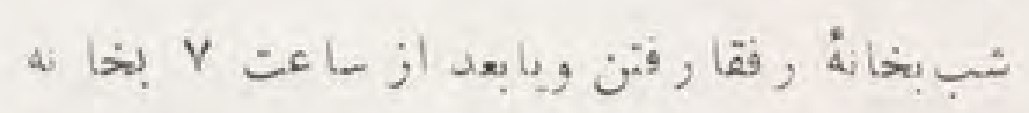

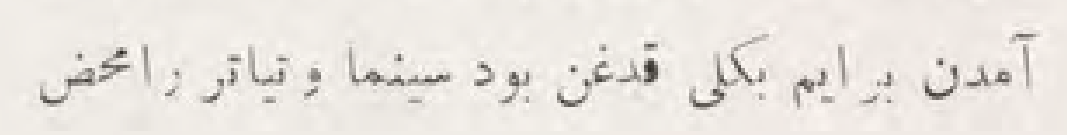
ov 


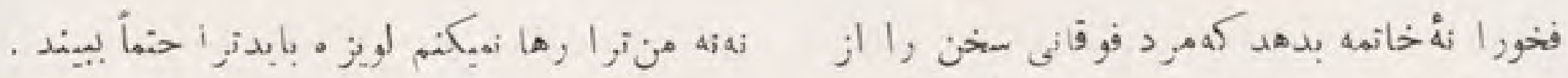

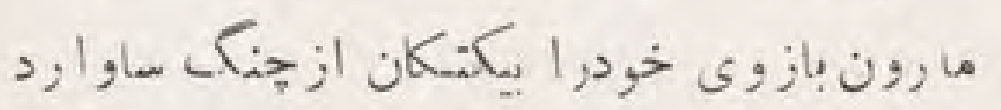

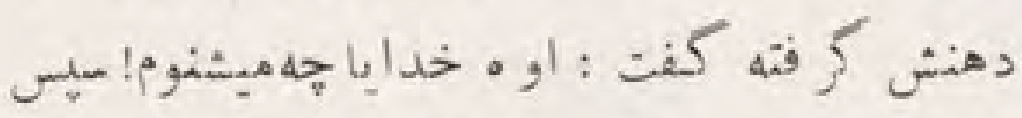

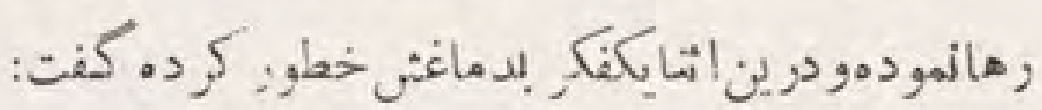

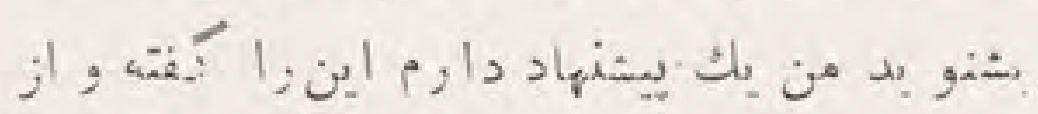

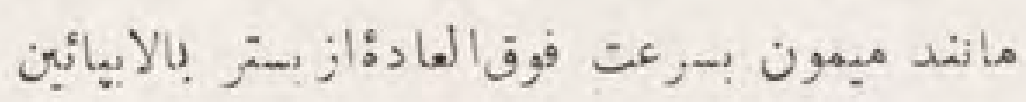

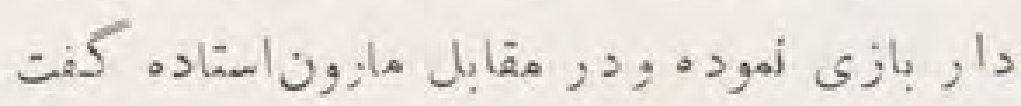

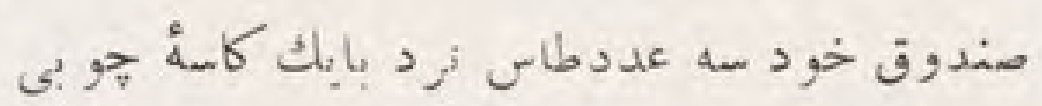

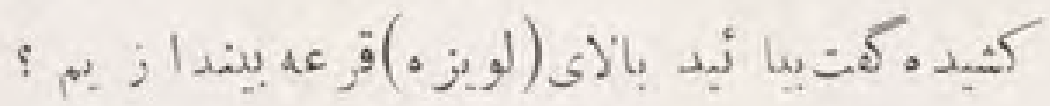

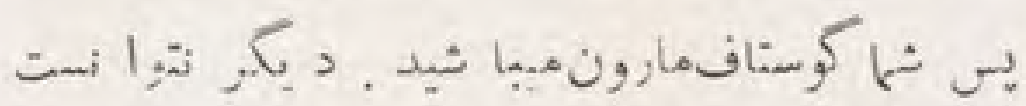

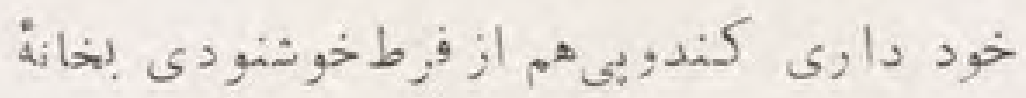

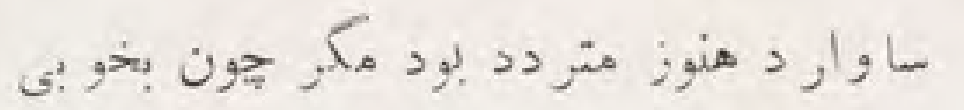

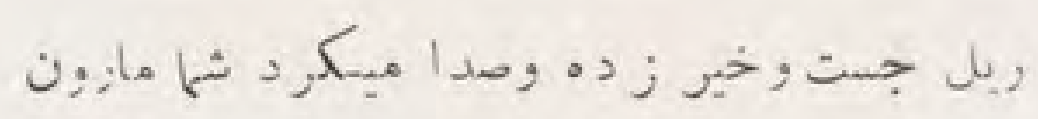

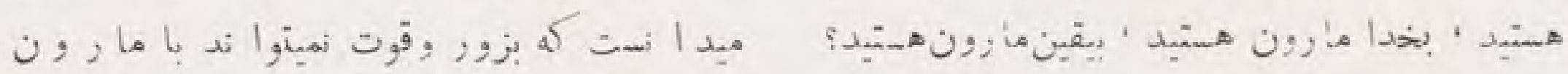

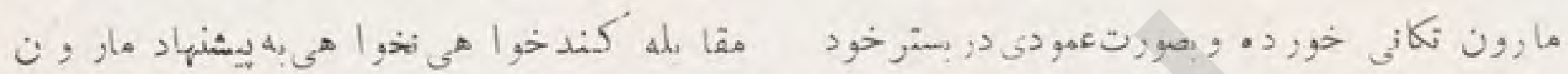

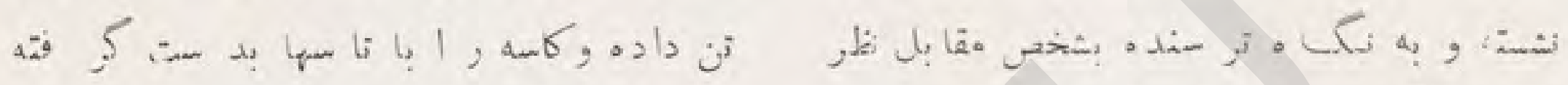
جند مر تبه جنبا نده به برثت صندوق إنداخت

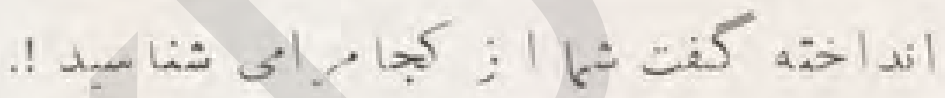
مارون صدا كر د دنز نو به بهان ون رسب تأسهارا شد ت شور كأ

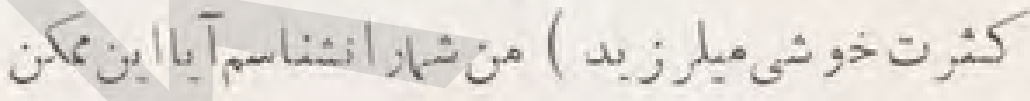

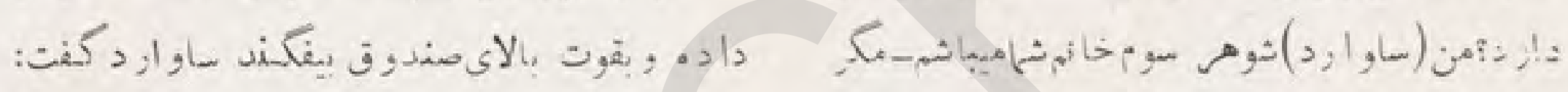

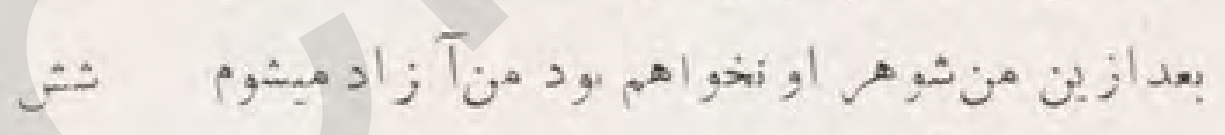
سه م.رتبه هر كدام بنو به قر عه اند ا ختند

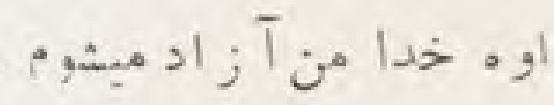
$r \cdot$ •

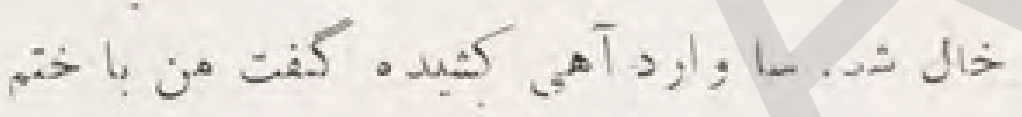

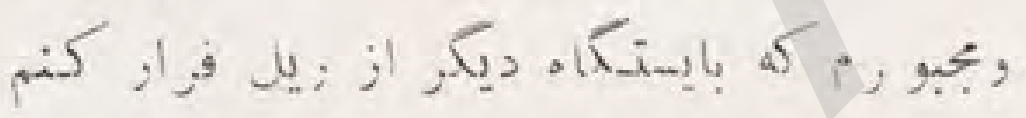

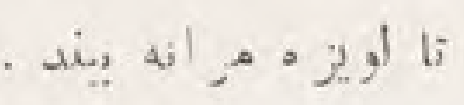

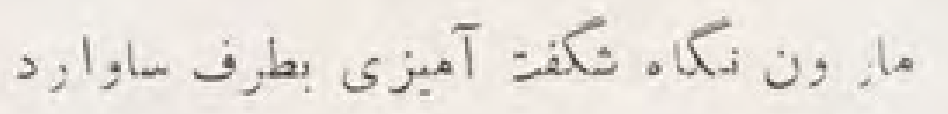

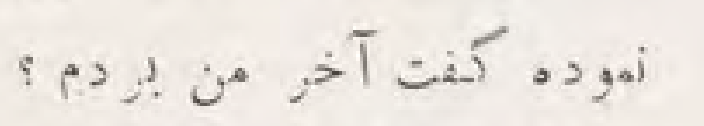

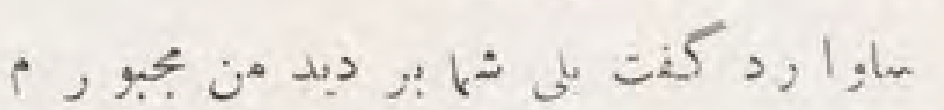

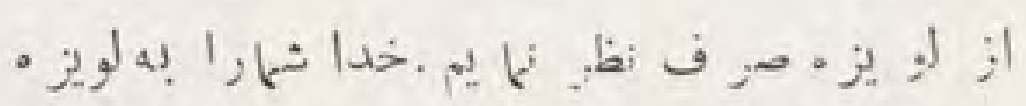

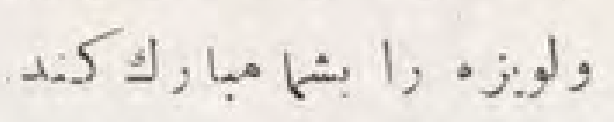

- مازون فر ياد كرد بضولى فوفإ شرطها 
كَفت عيب ؟ سا وارد عز يزم ككفتبد عيب ؟ا بن

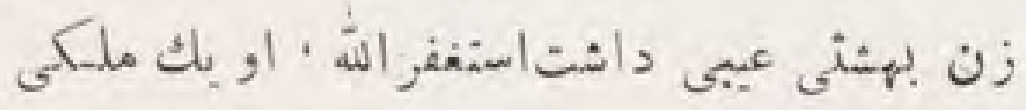
بو د بلبا س انسا ن · ادنى تقعى وعيبى بو جو 2

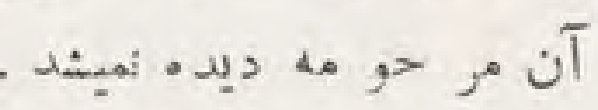

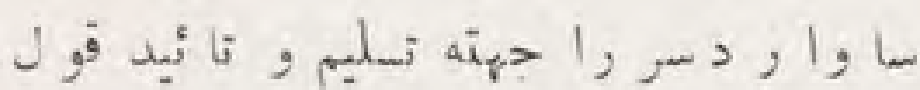

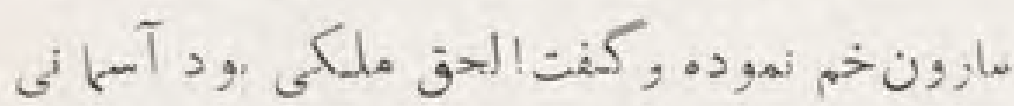

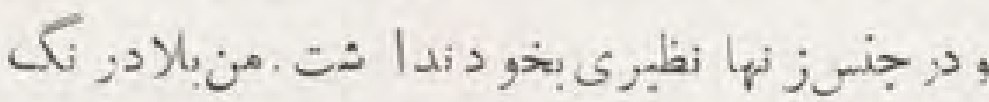

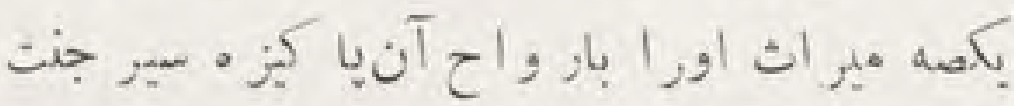

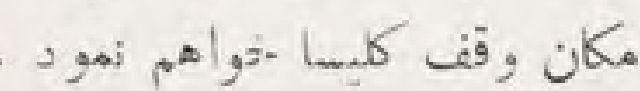

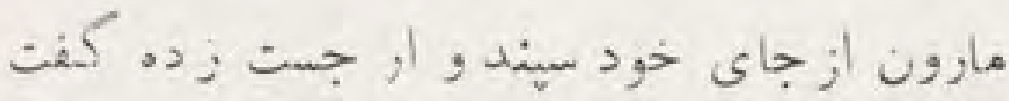

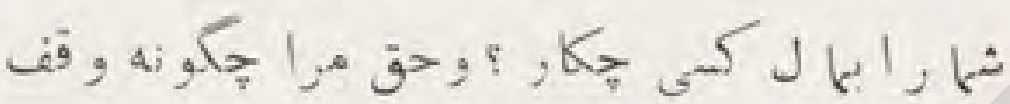

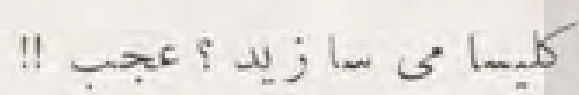

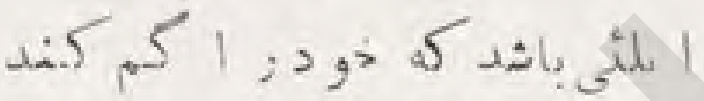

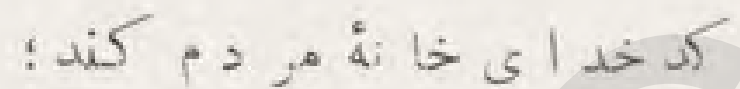

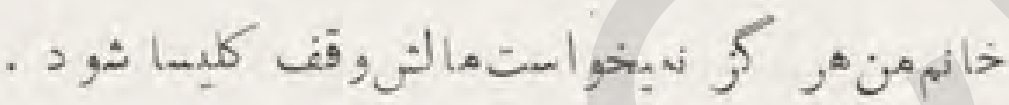

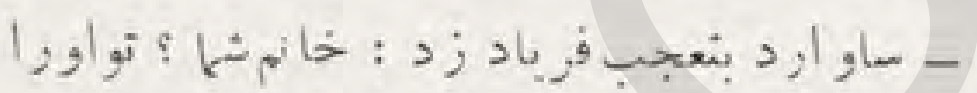

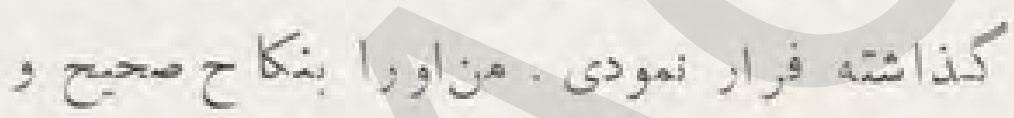

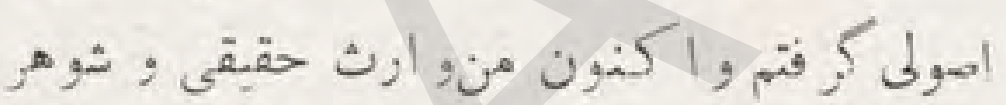

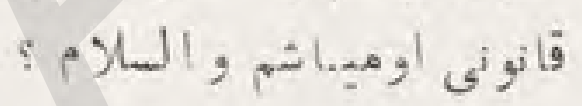

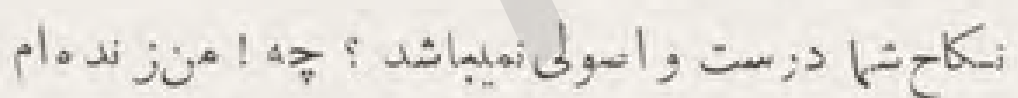

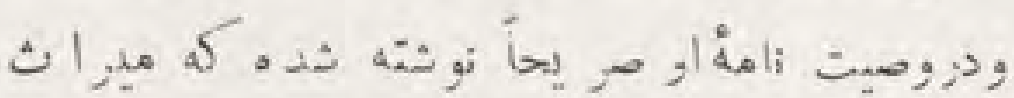

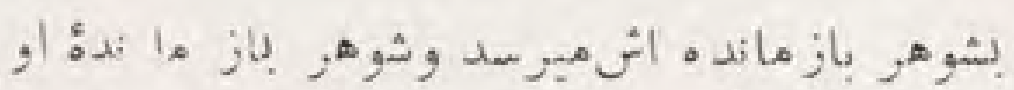

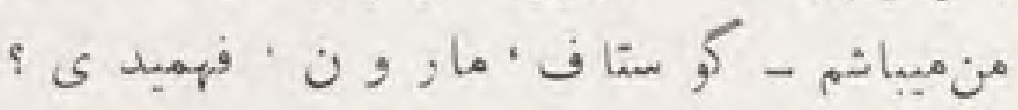

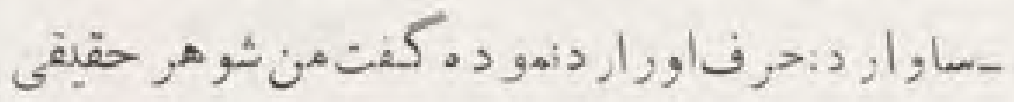

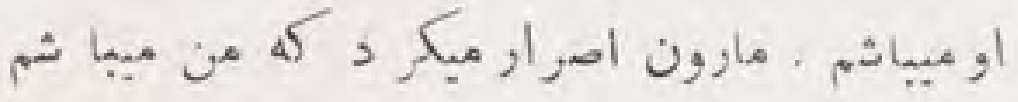

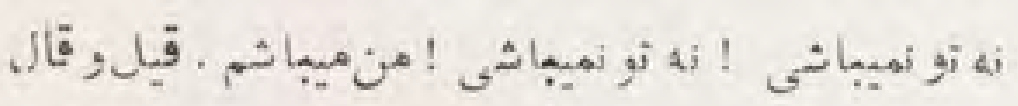

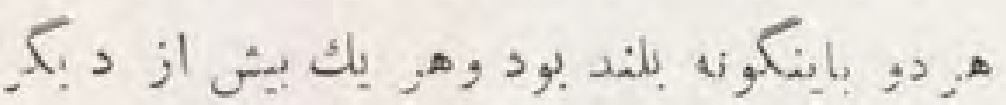

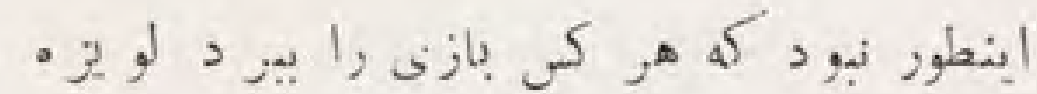

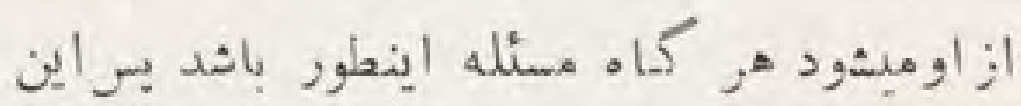

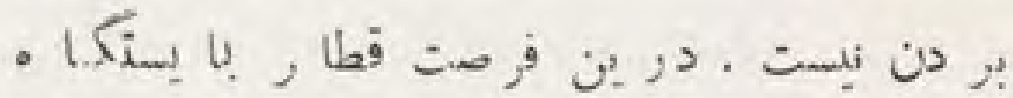

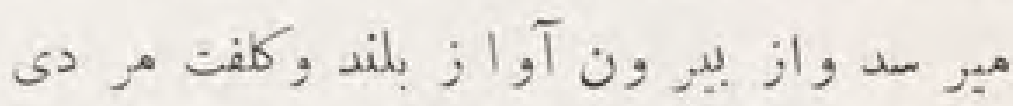

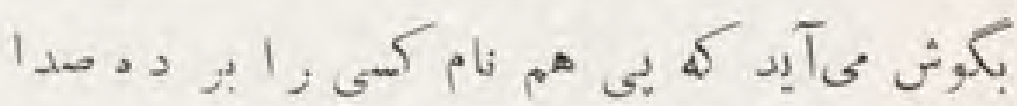

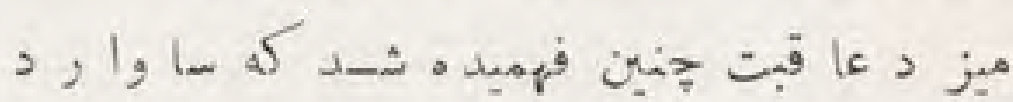

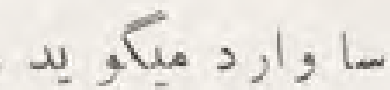

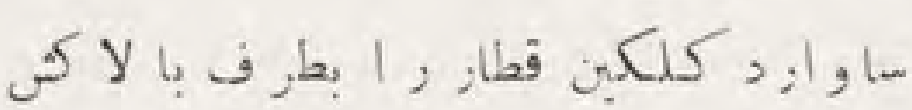

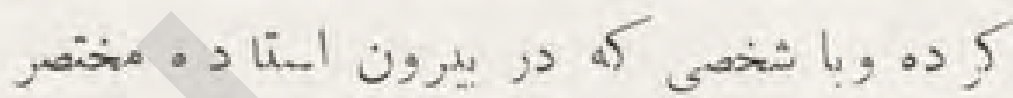

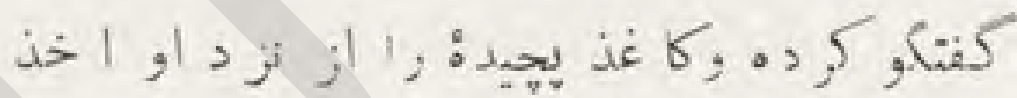

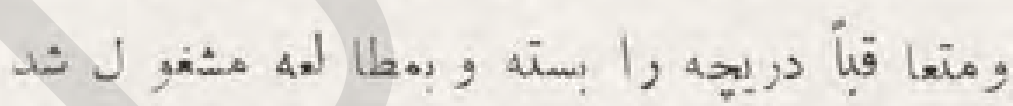
演

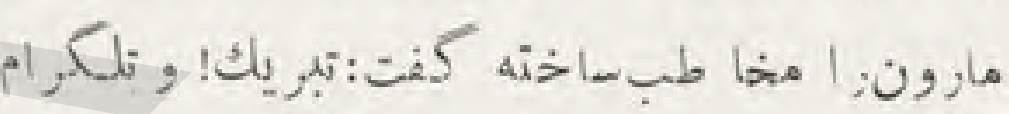

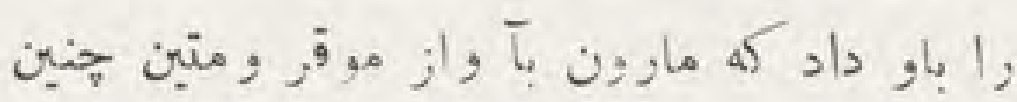
قرائت نمود : خانم مو سيو سا وأرد امر و ز صبح ساعت

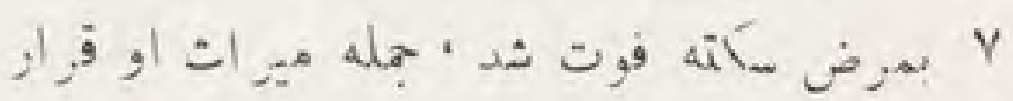

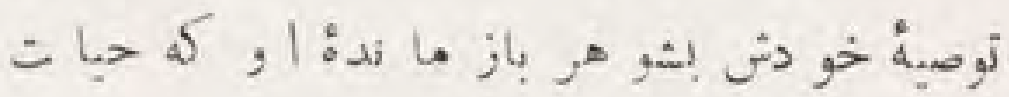

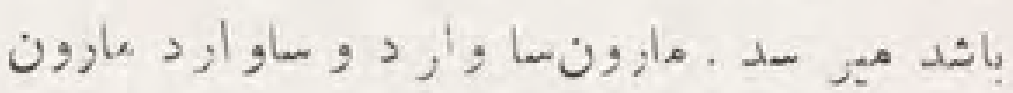
1, إنون جان ثير يندر آغونى كثيده و انكهاى خوشى وانبساط از جش: هالى هر دورجارئ

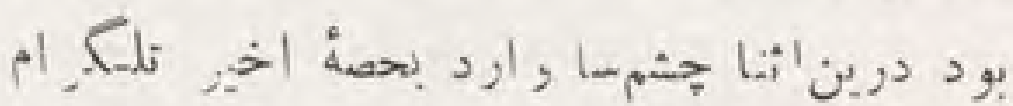

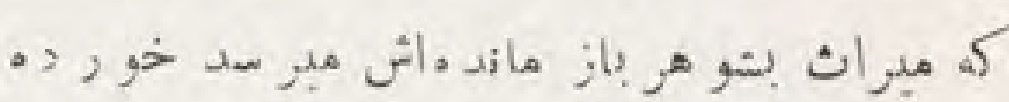

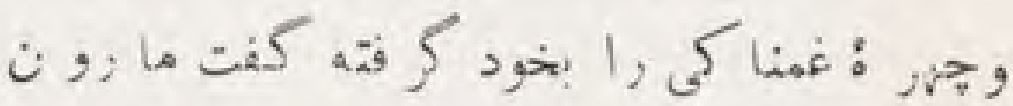

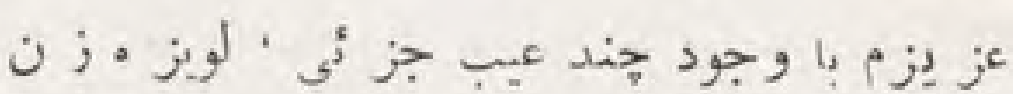

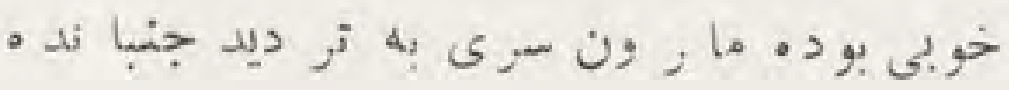


으.

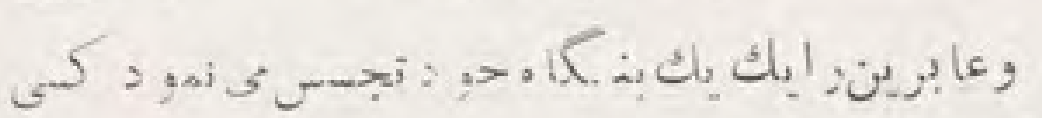

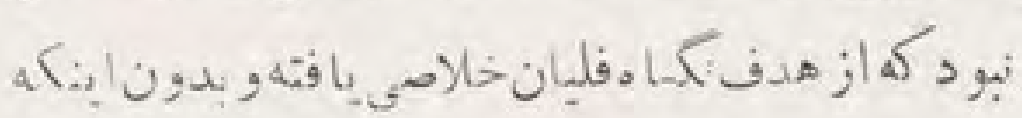

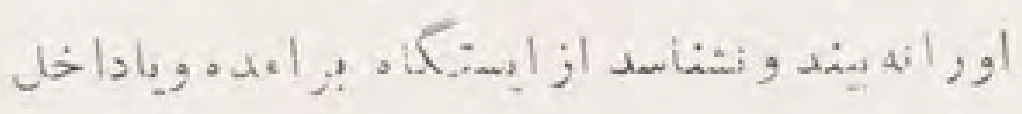

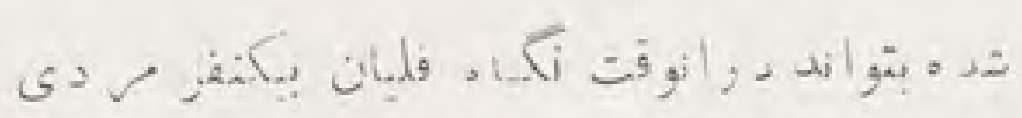
كn

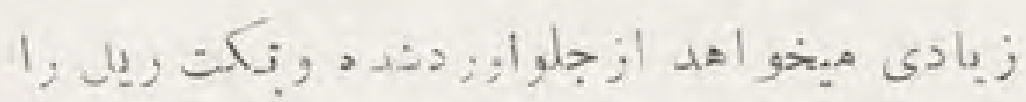

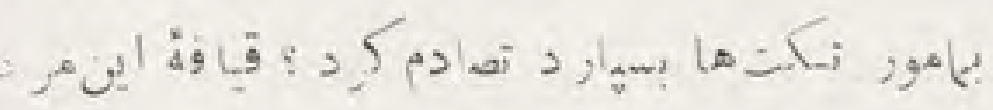

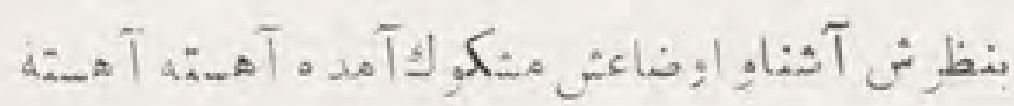

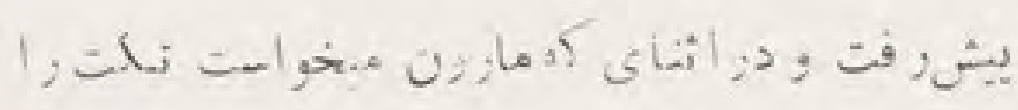

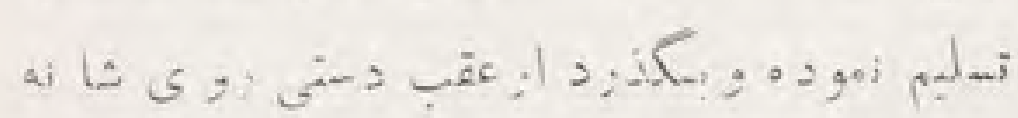

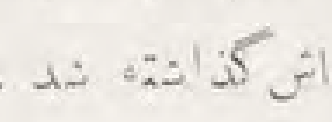

ما

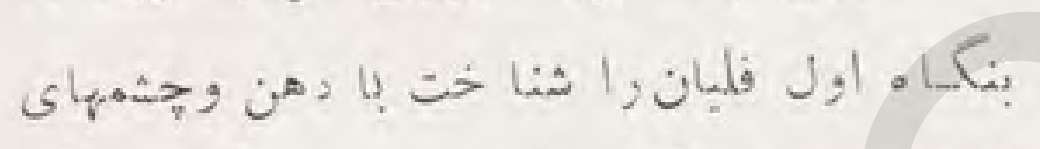

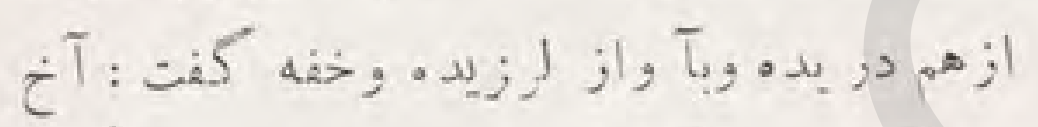

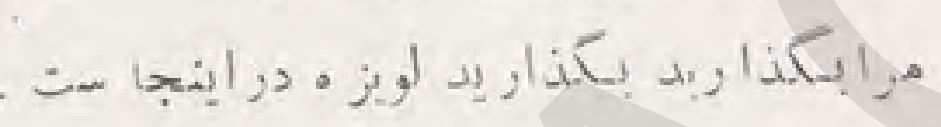

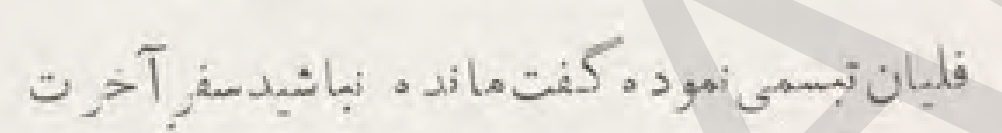

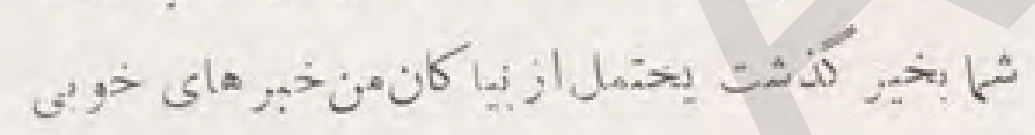

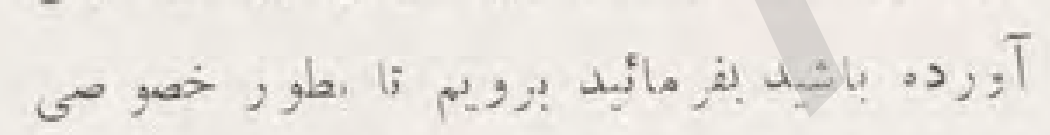

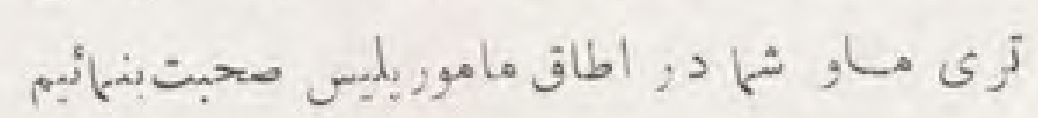

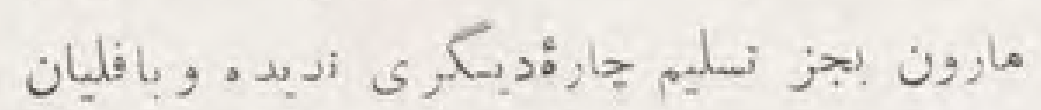

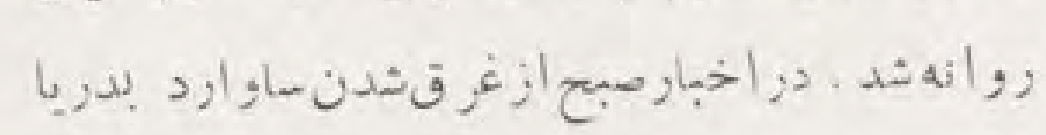

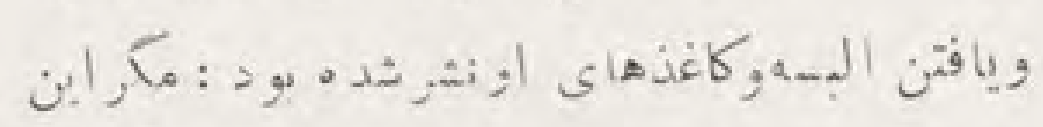

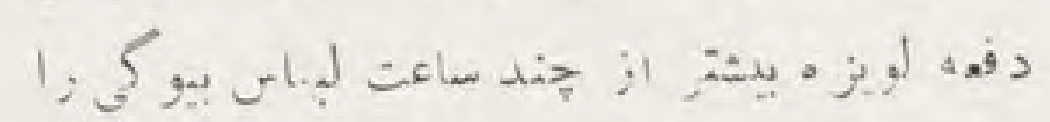

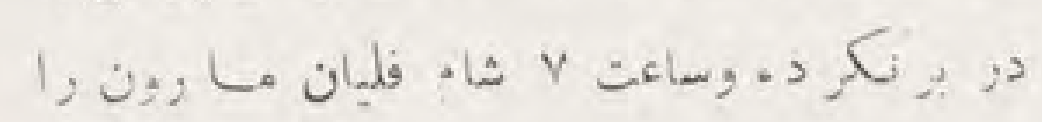

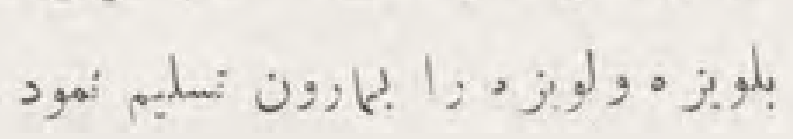

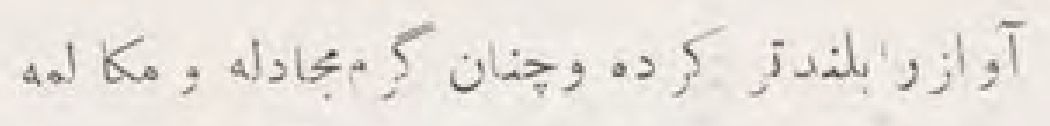

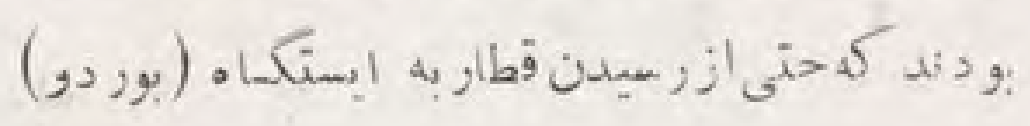

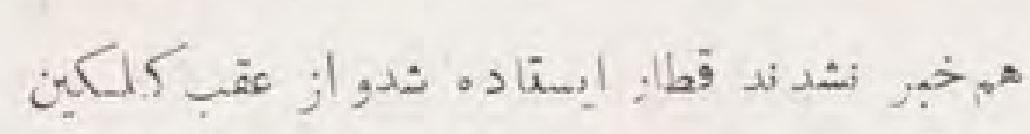

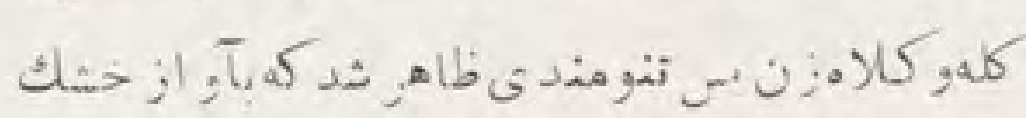

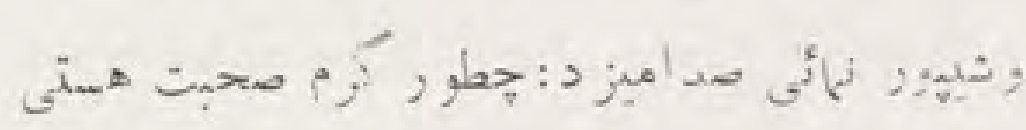

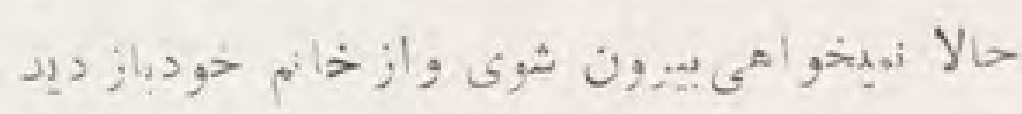

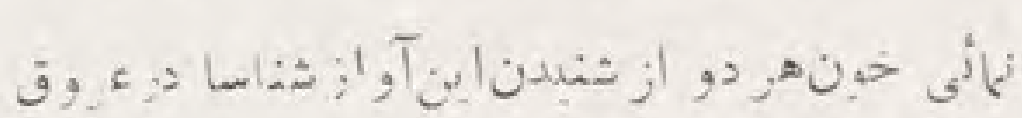

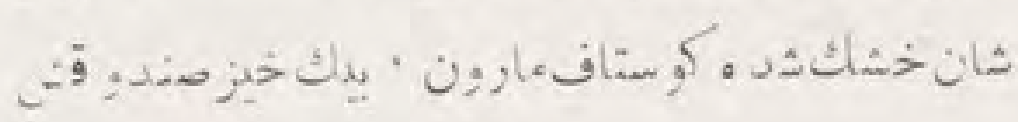

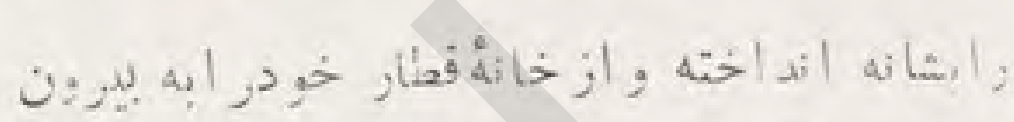
د, زاب :

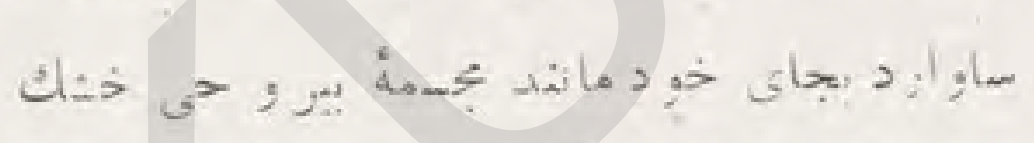
olo

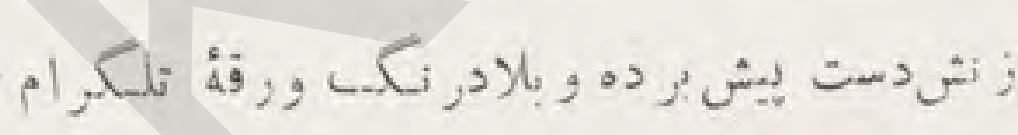

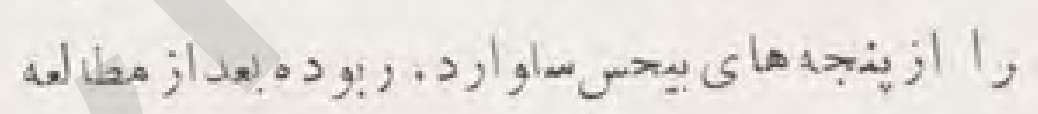

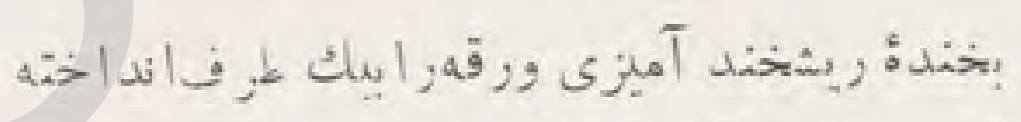

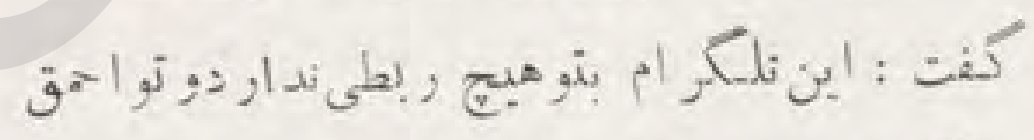

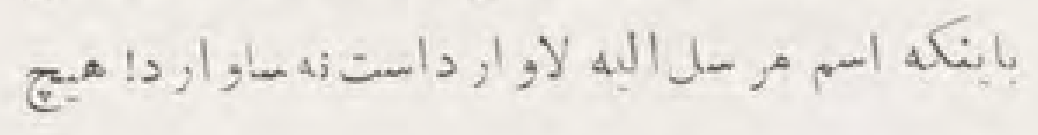

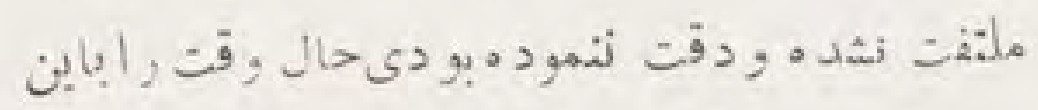

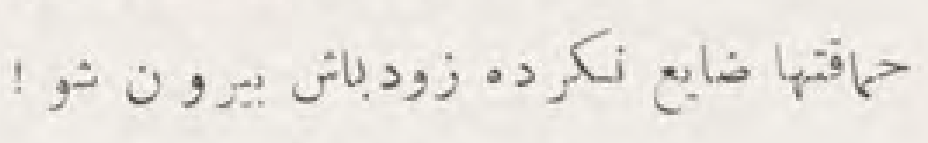
* * *

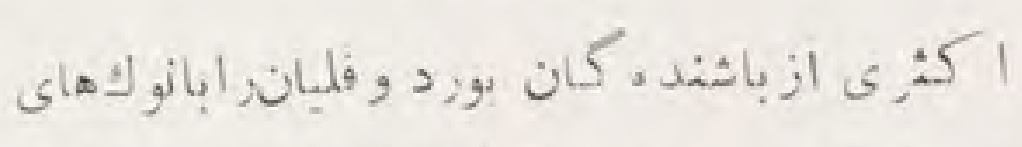

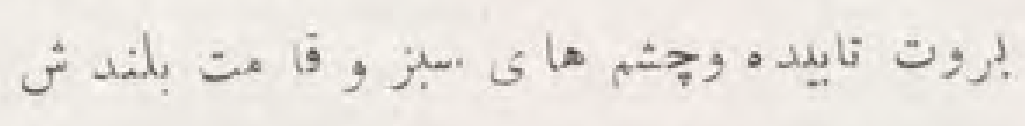

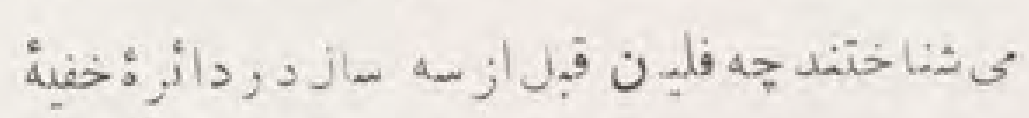

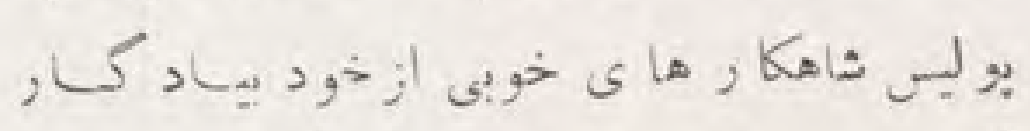

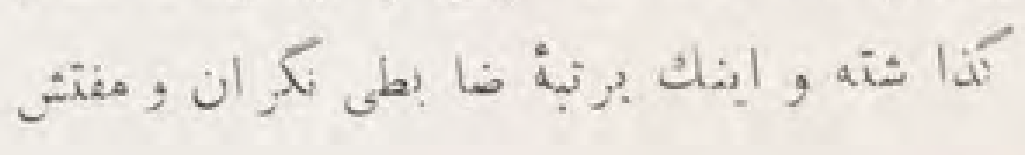




\section{Au文}

\section{(1)}

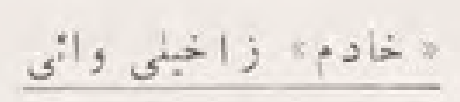

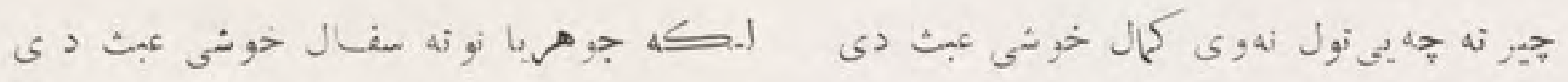

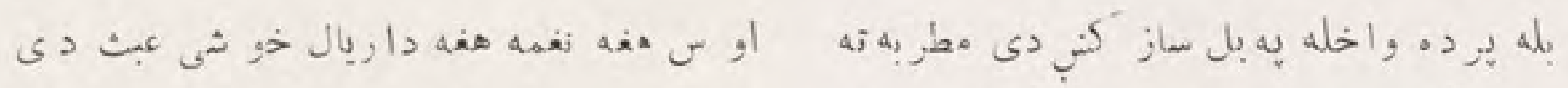

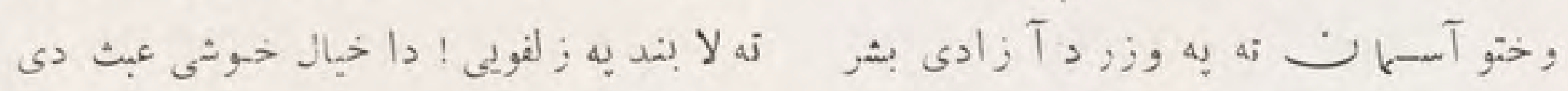

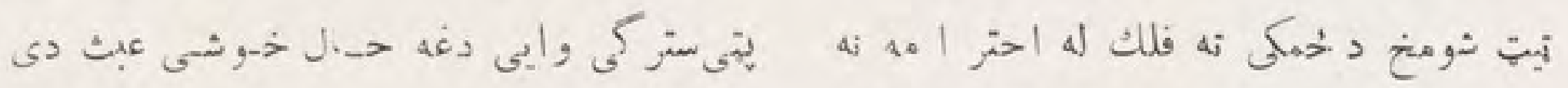

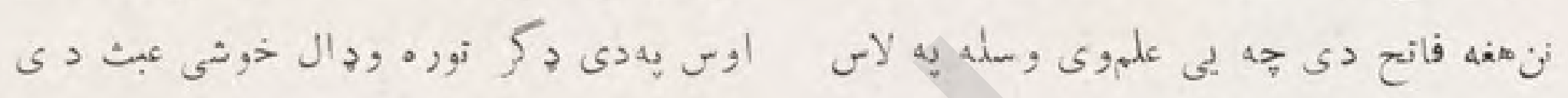

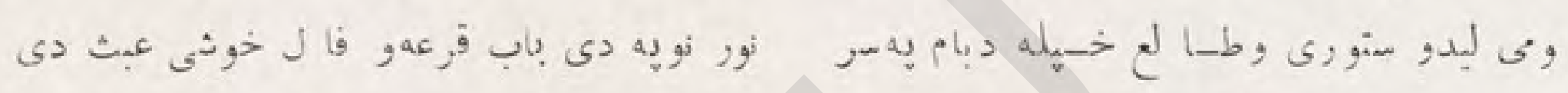

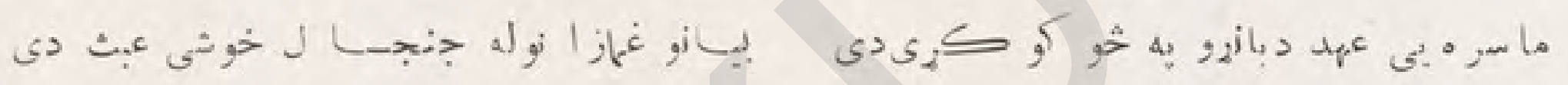

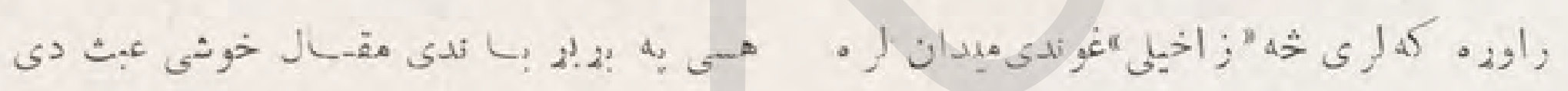
$(r)$

Aj

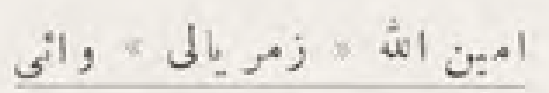

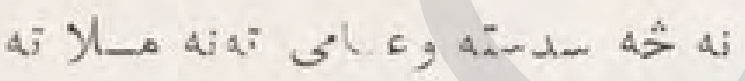
هi

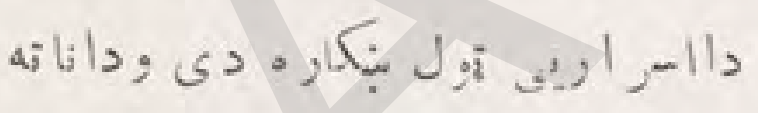

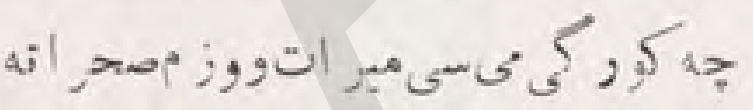

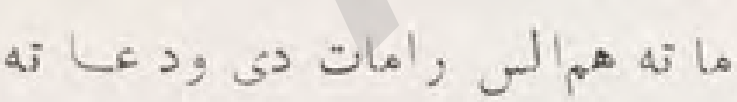

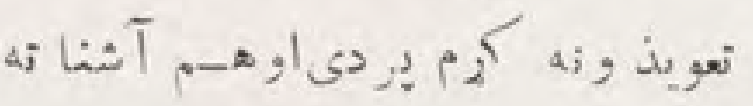

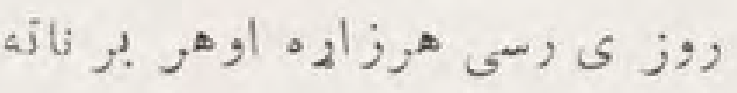

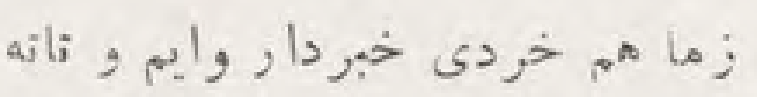

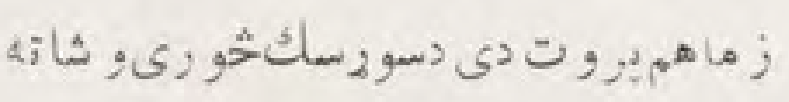

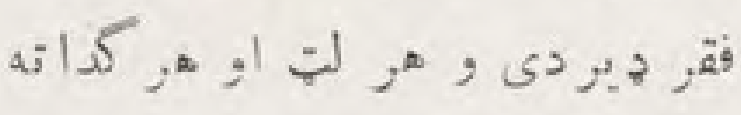

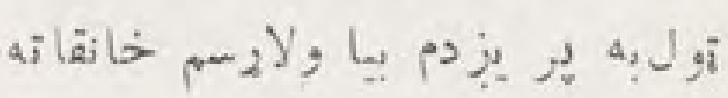

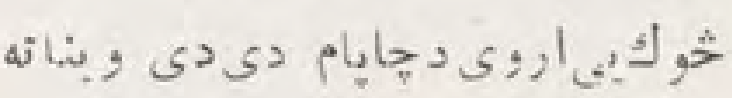

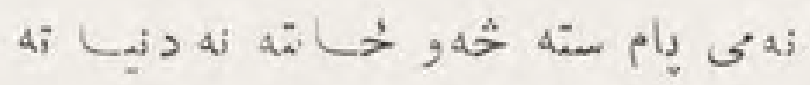

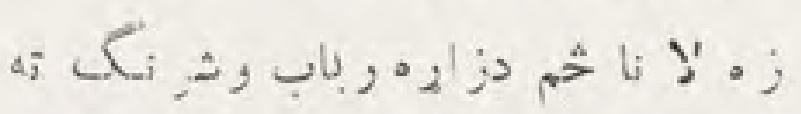

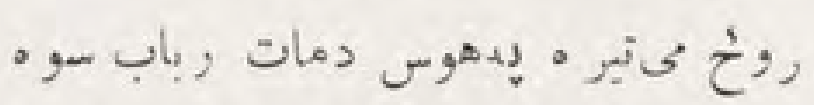

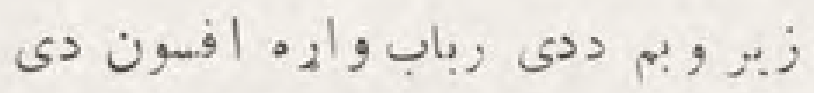

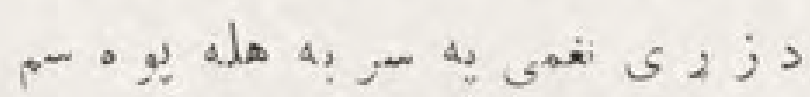

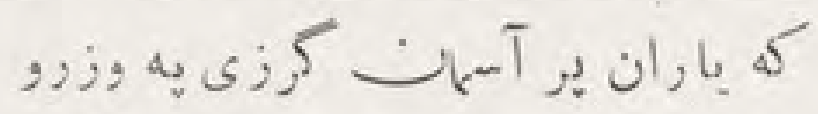
شبكرانى او خبر اتونه ماتهديردى

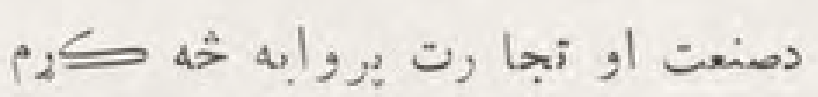

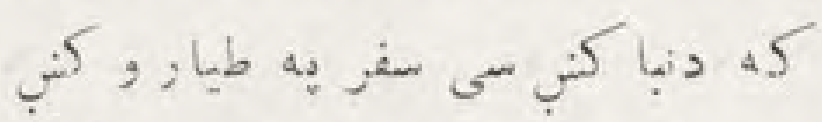
مسافر كه خ خه

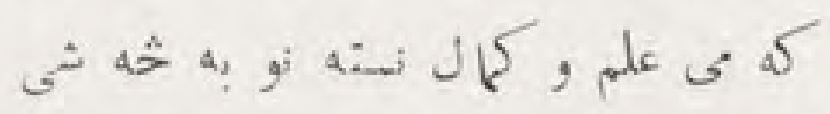

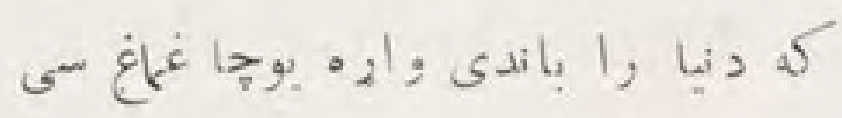

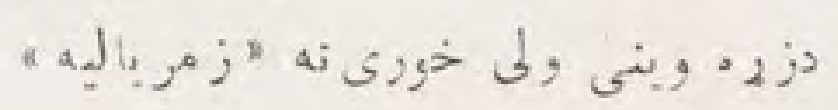


(r)

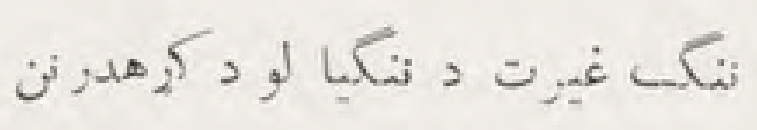

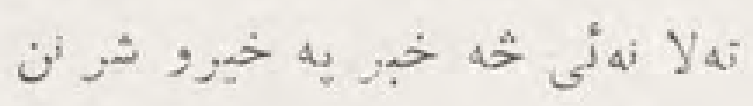

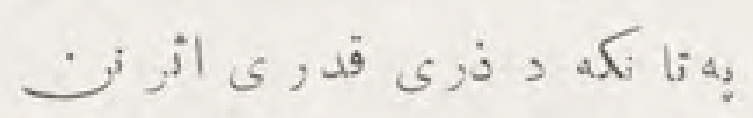

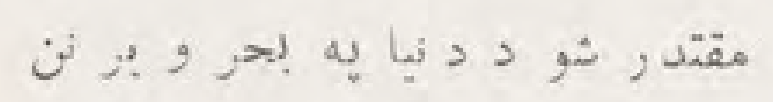

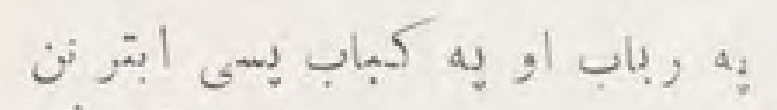

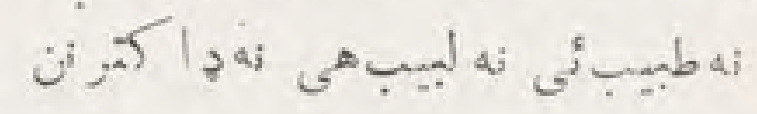

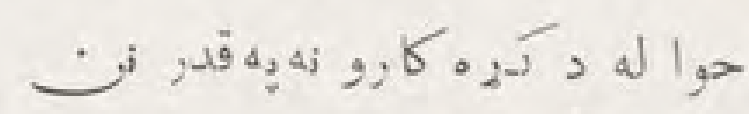

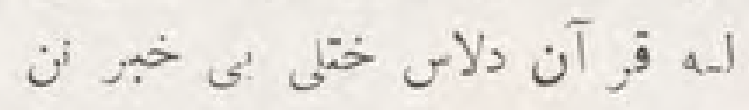

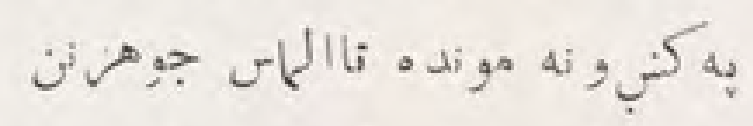

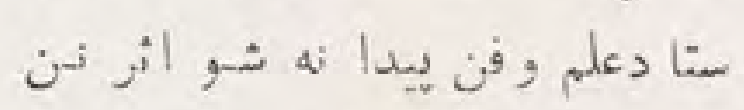

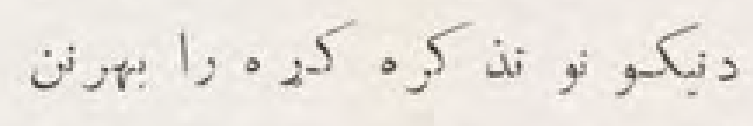

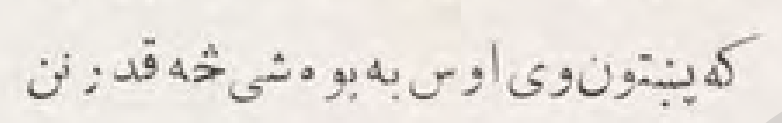
(ะ)

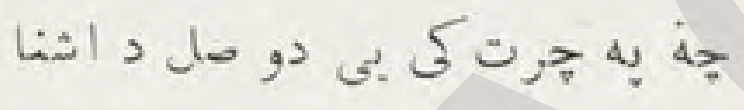

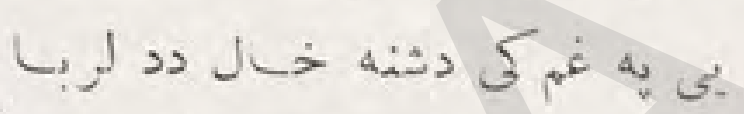

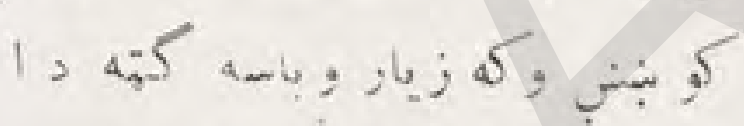

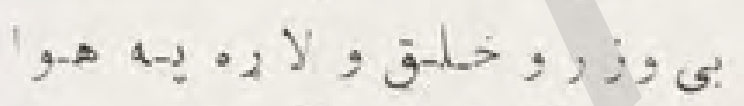

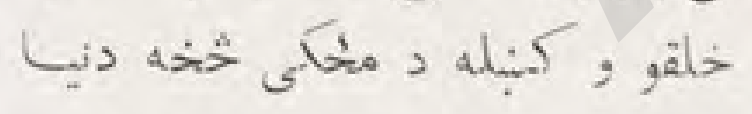

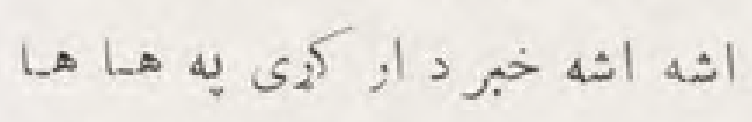

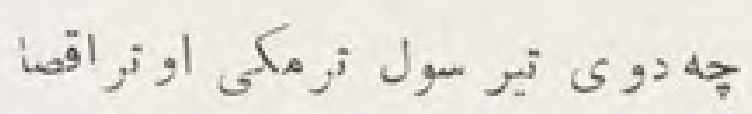

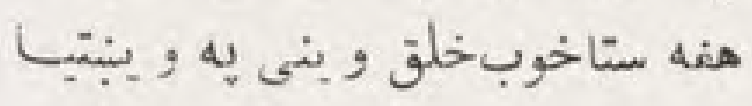

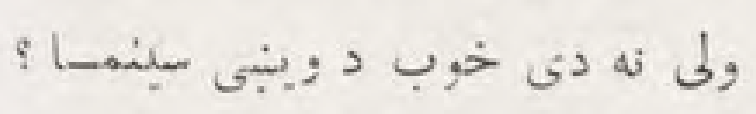

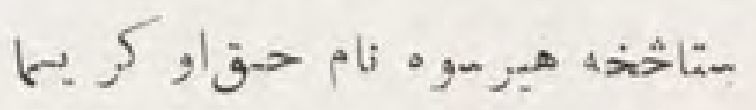

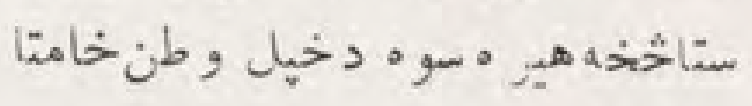

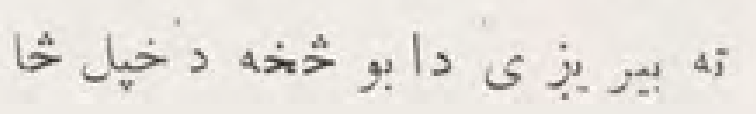

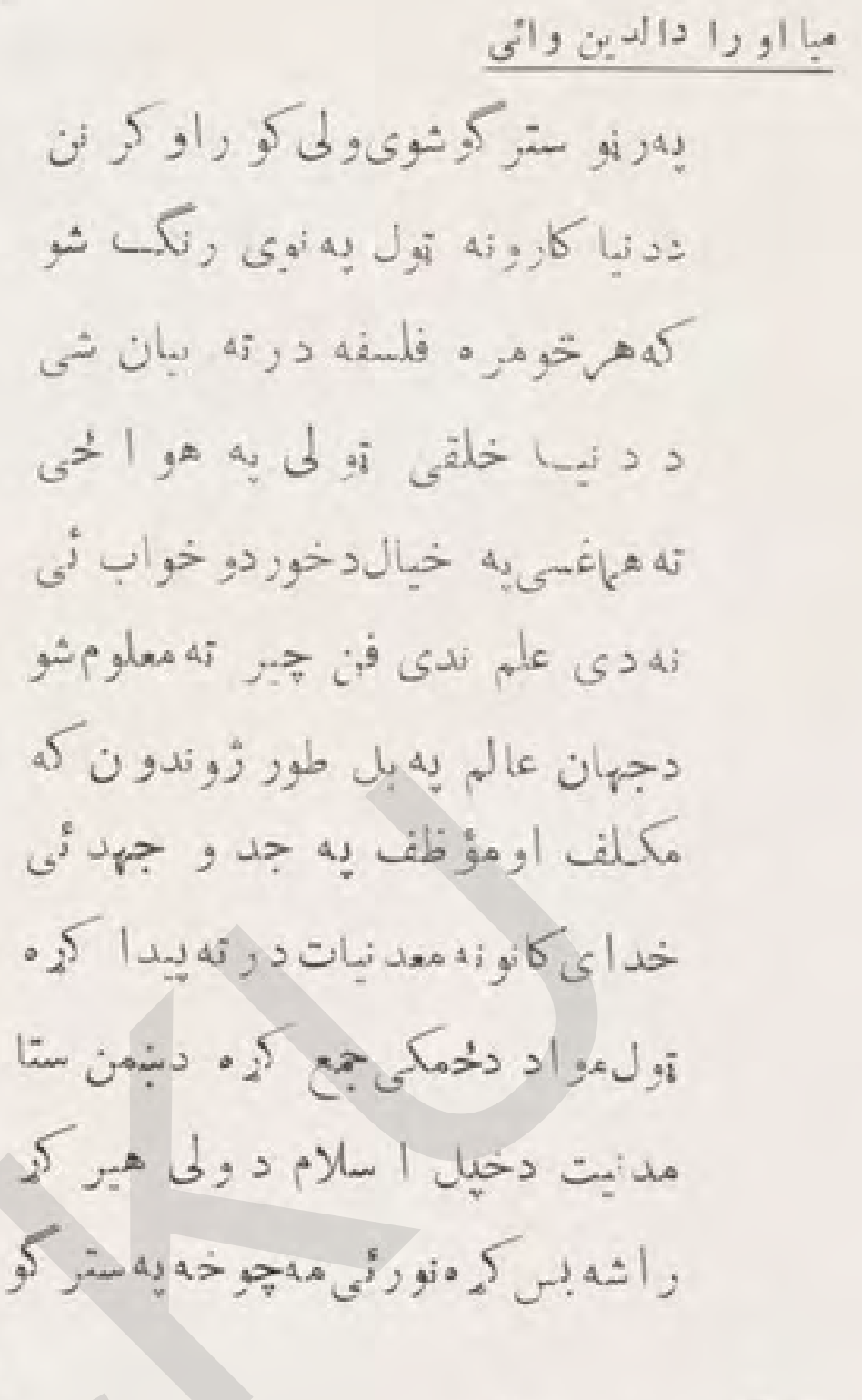

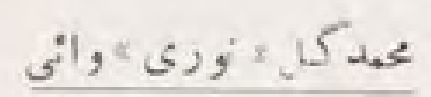

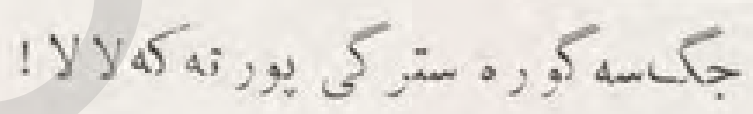

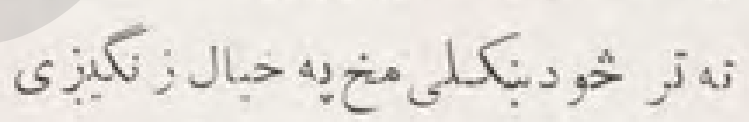
به كا

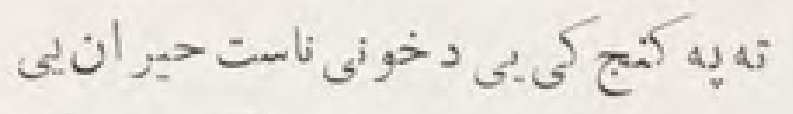

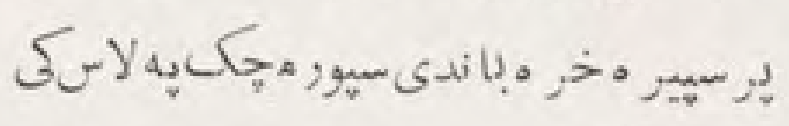

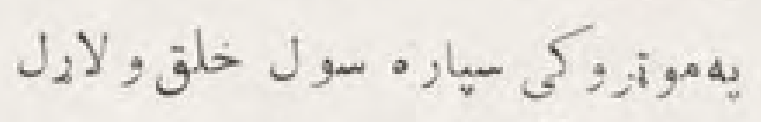

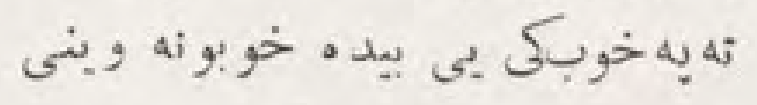

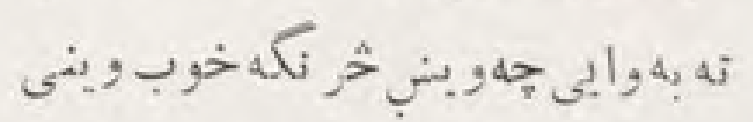
ا فالاطون خلقو خجل كلى بـ خهل علم

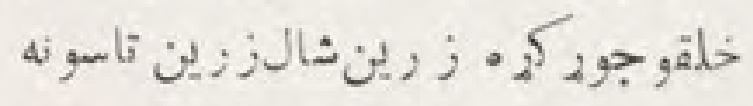
خلق درومى به دو بابكى لـكه كمه ونه 


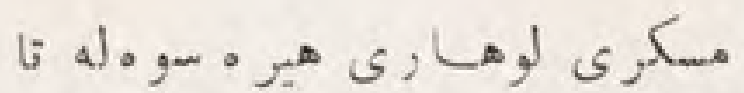

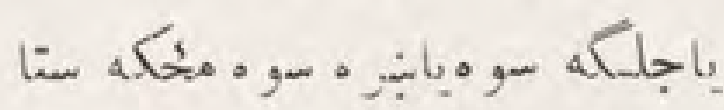

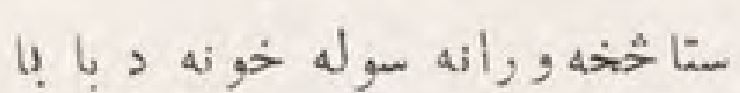

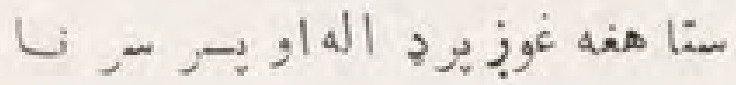

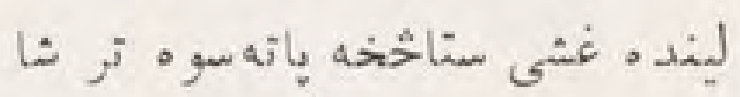

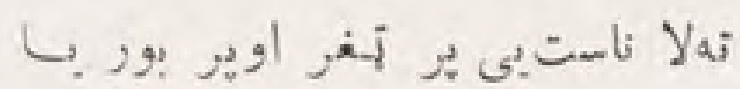

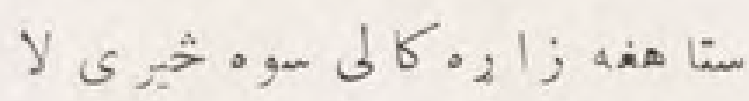

ستركى

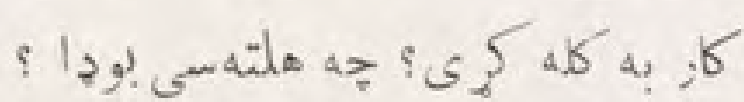

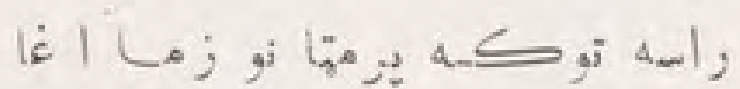

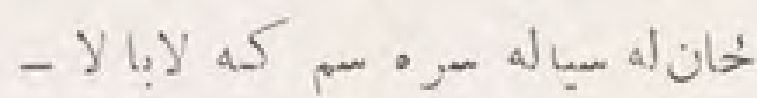

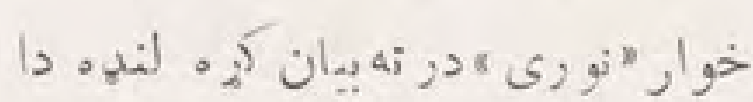

خلقو جور كمه , رنكار نكه ماشينو نه

خلقو وروز له هخكله نرغر ولاندى جكى جكى مأنى جونى كألى خلقو

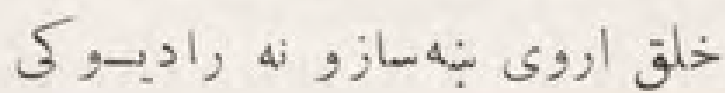

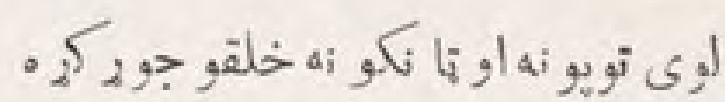

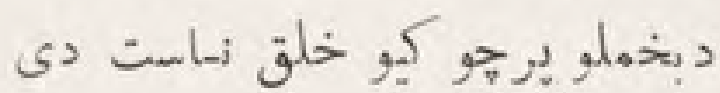

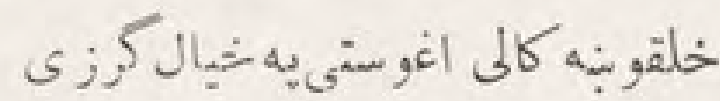

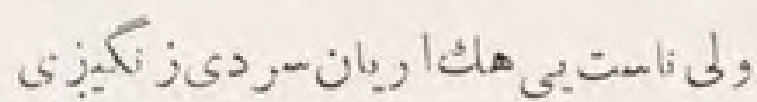
دغه عمر دى جها تيرسو نورخهو نسته

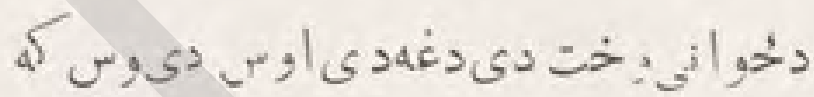

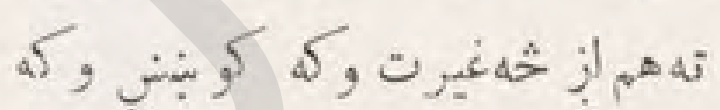

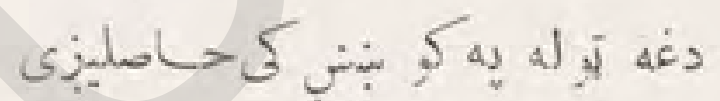

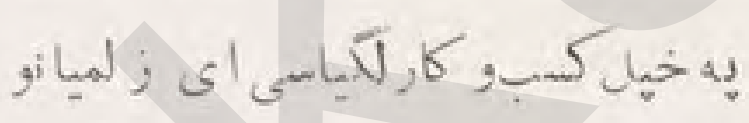

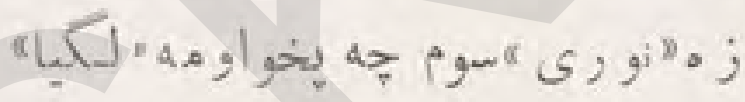

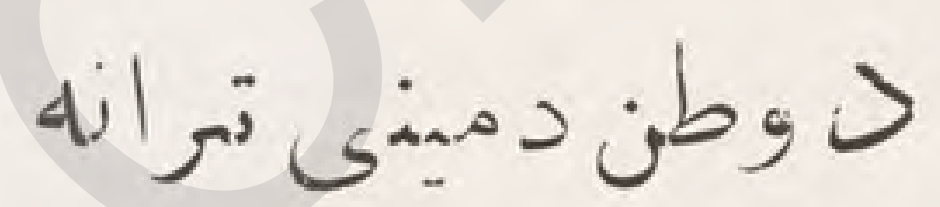

年

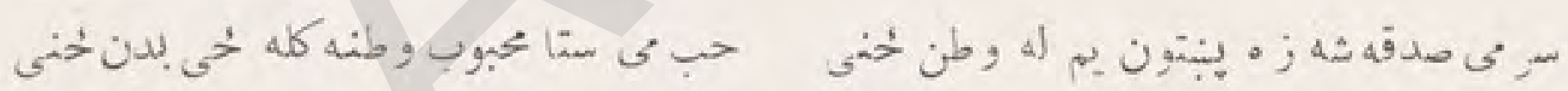

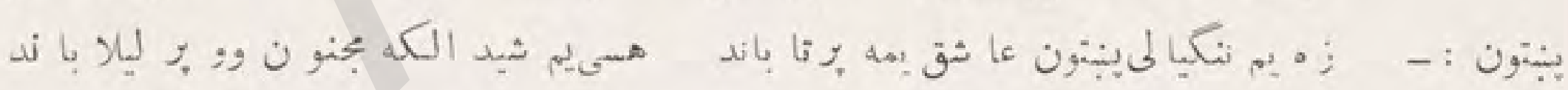
لا لا

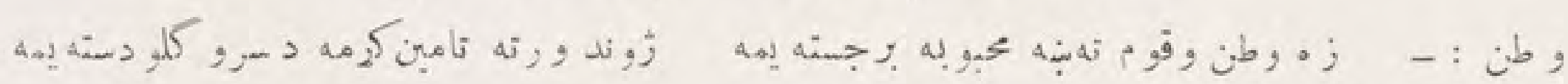

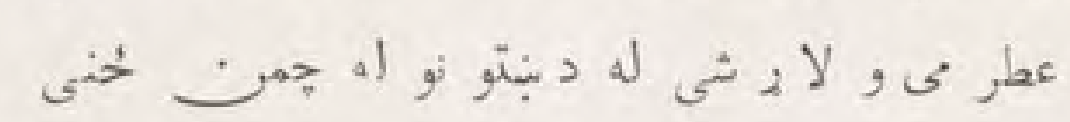

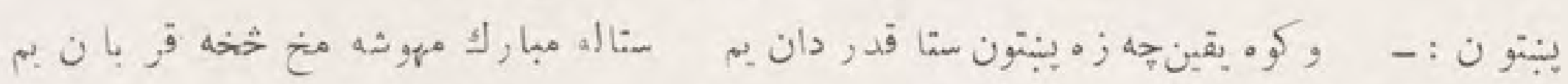

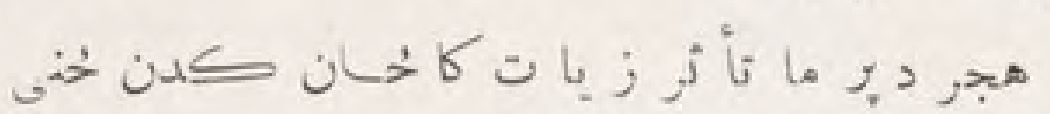

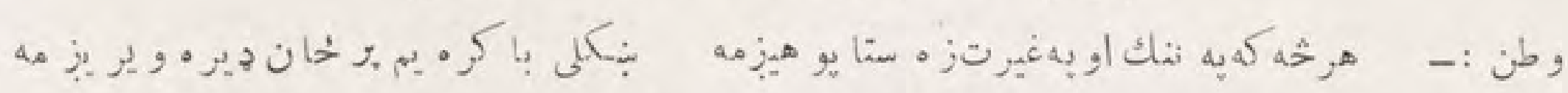

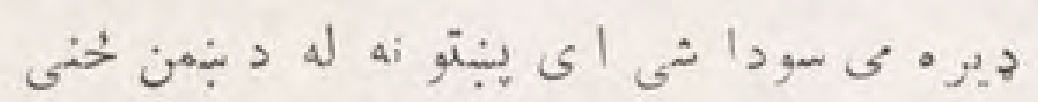




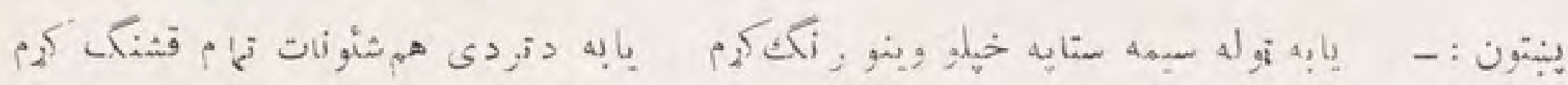

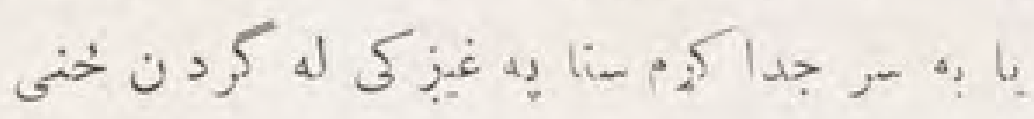

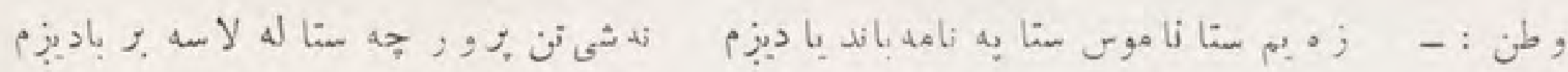
定

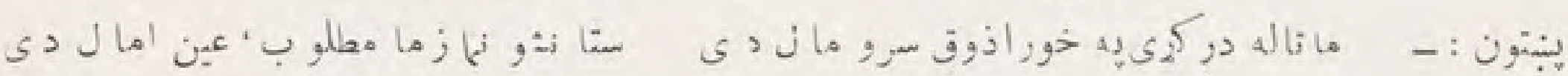

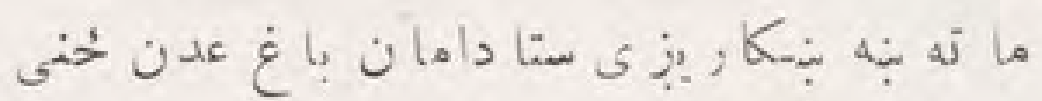

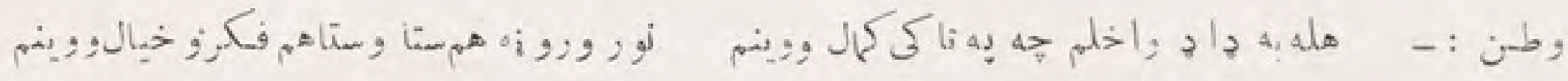

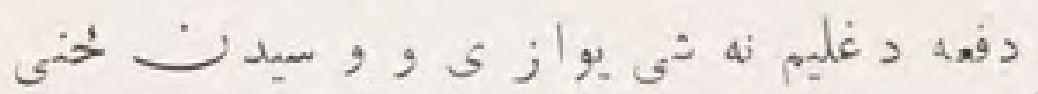

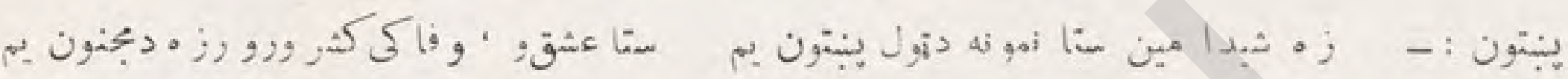

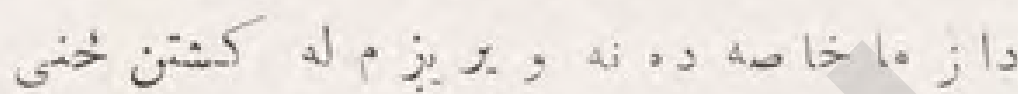

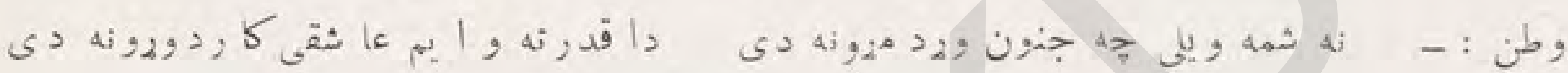

$$
\text { نه }
$$

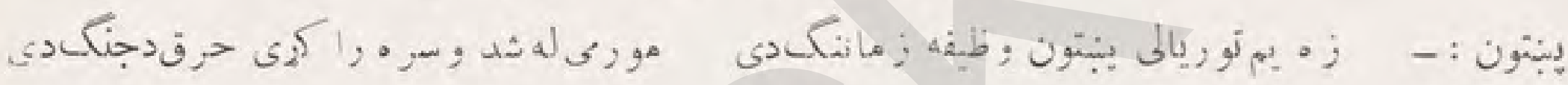

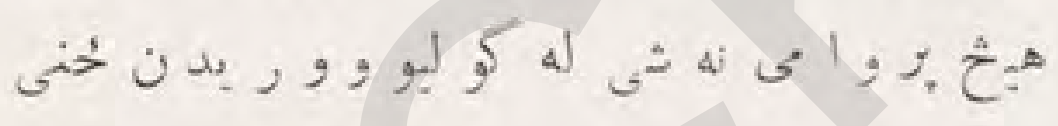

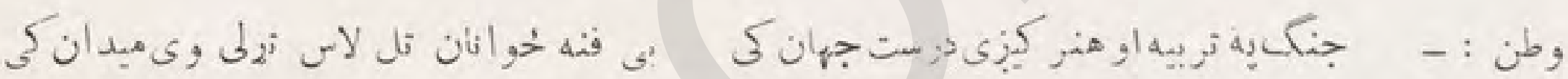

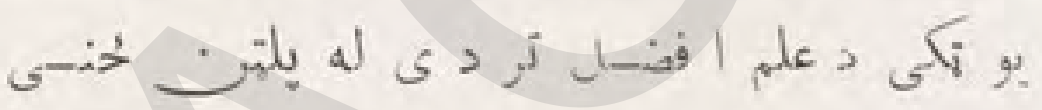

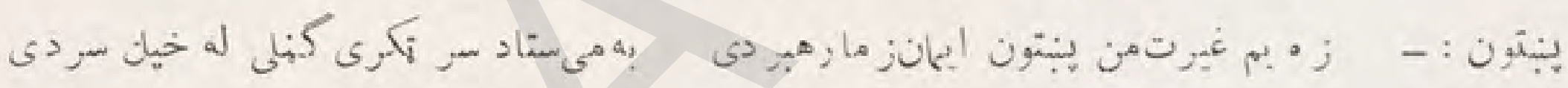

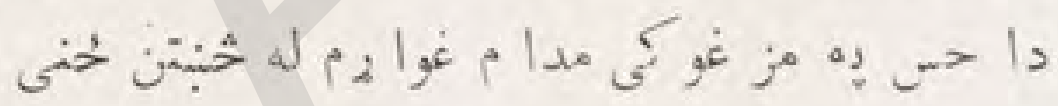

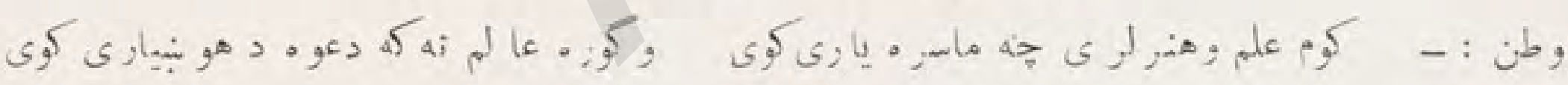

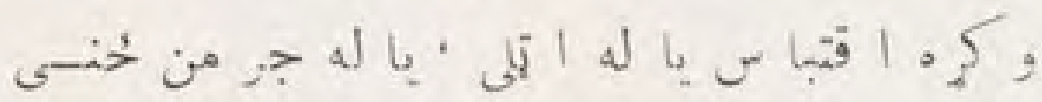

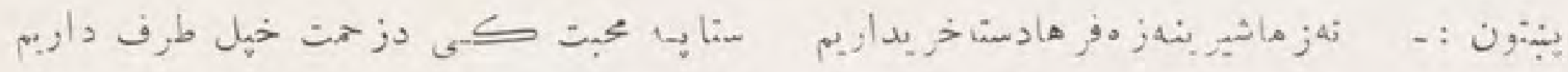

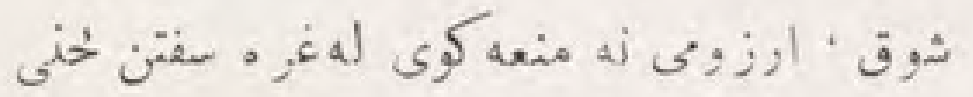

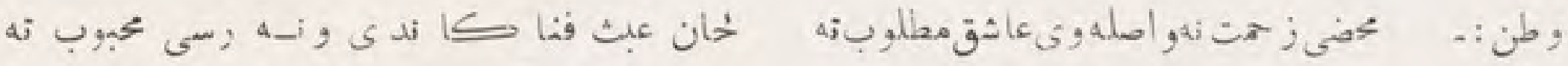

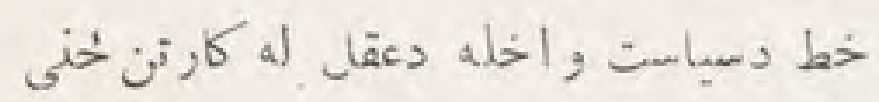

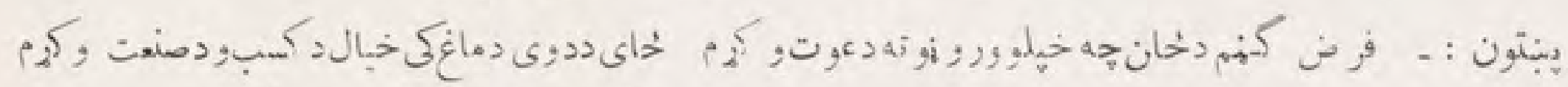

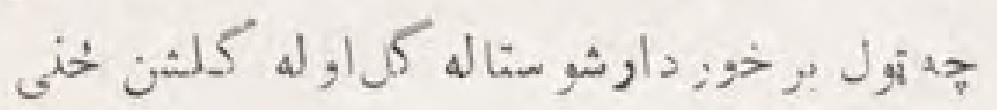




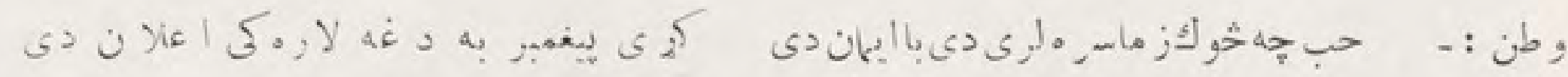

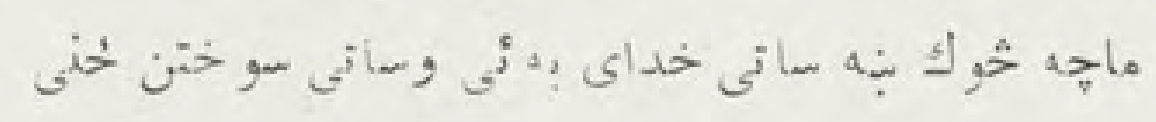

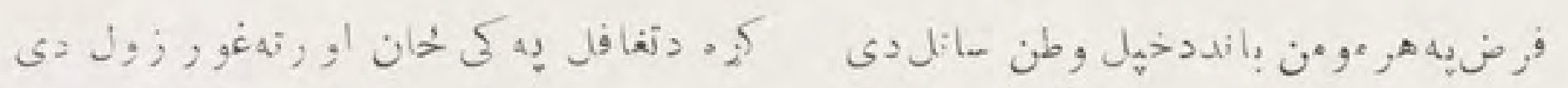
مانl

\section{رشتون زه تذ كار}

"ران

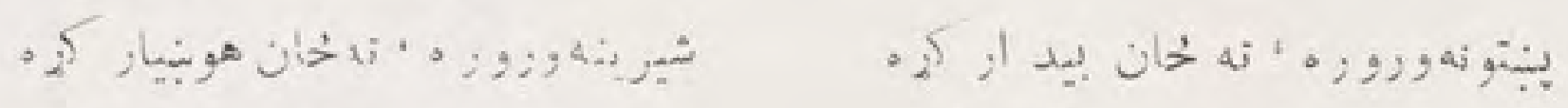

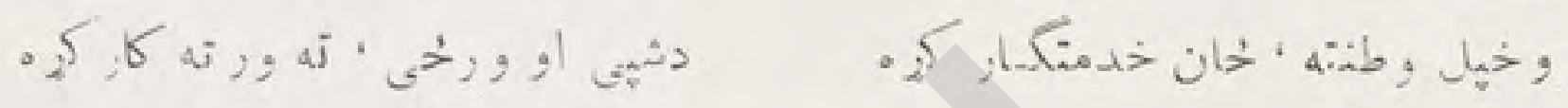

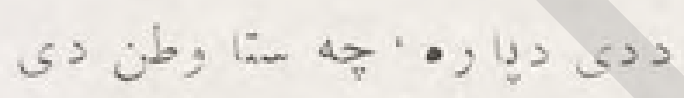

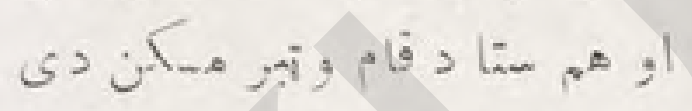

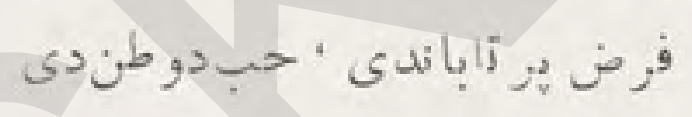

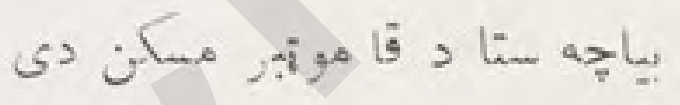

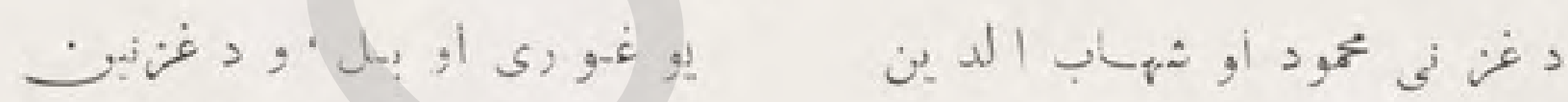
دوى هندوستان كکب ' نشر كردين

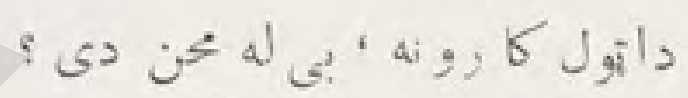

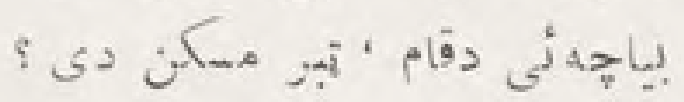

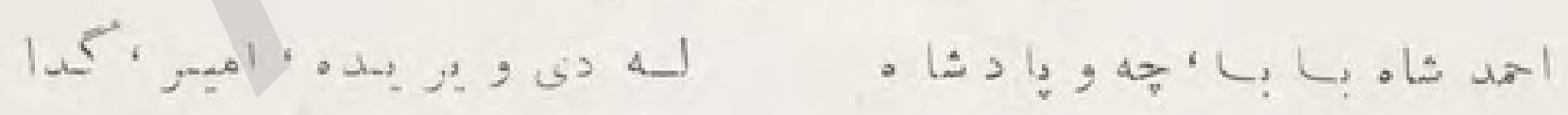

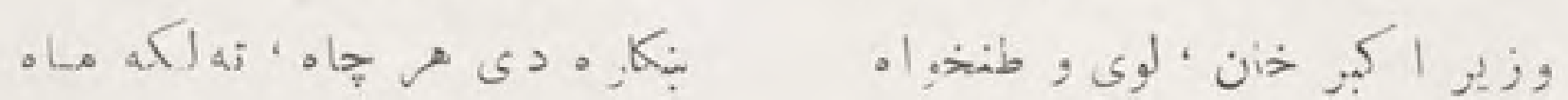

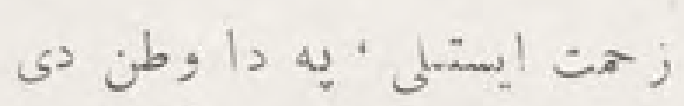

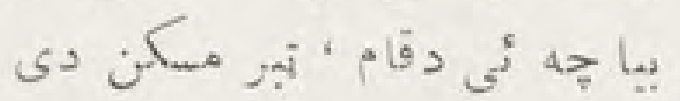

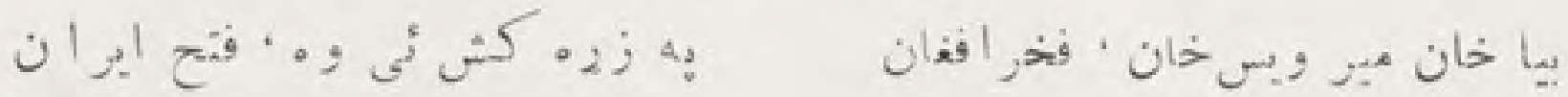

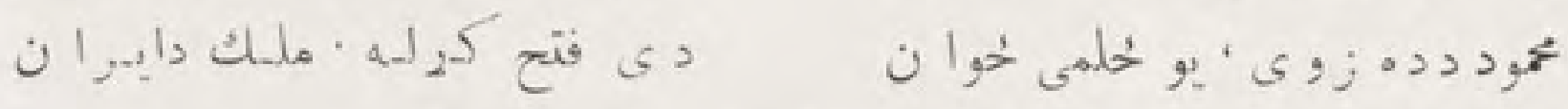

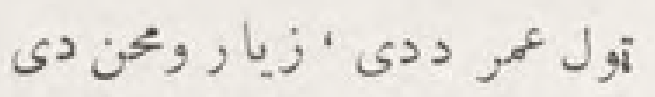

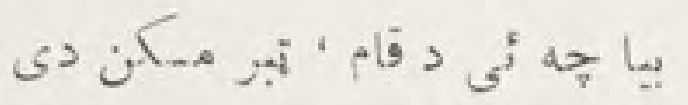




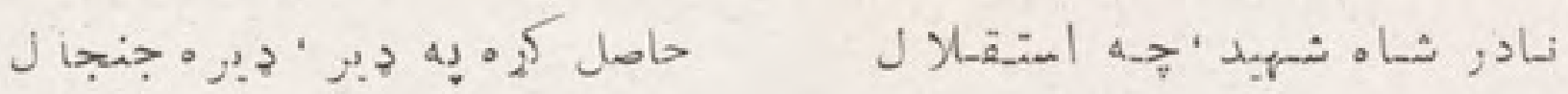

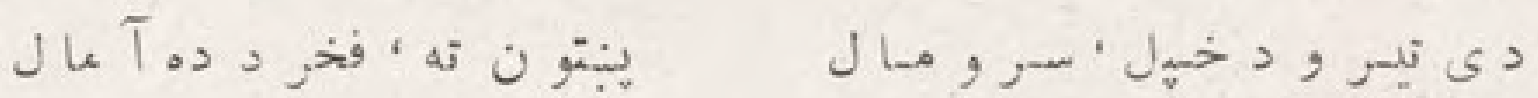

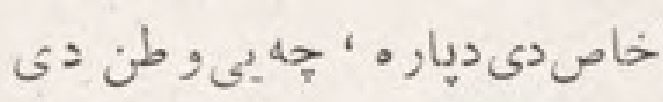

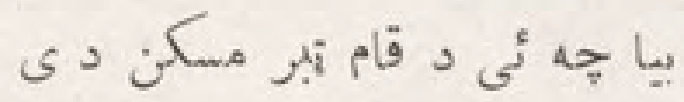

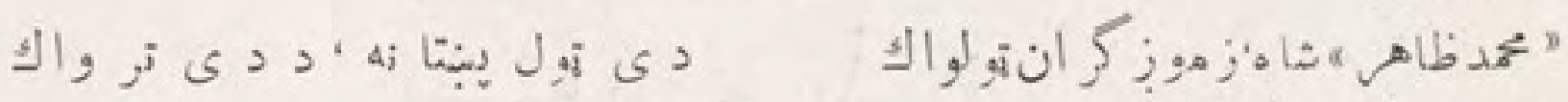

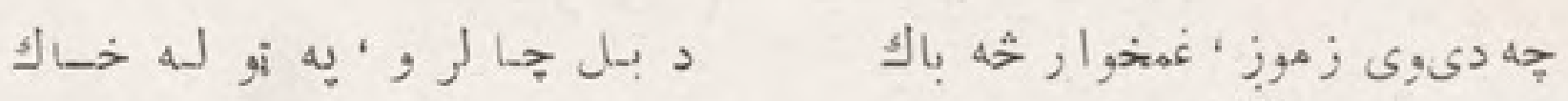

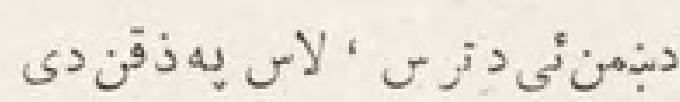

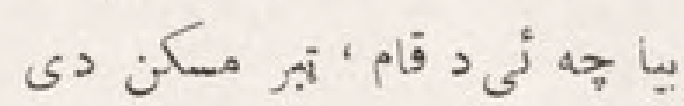

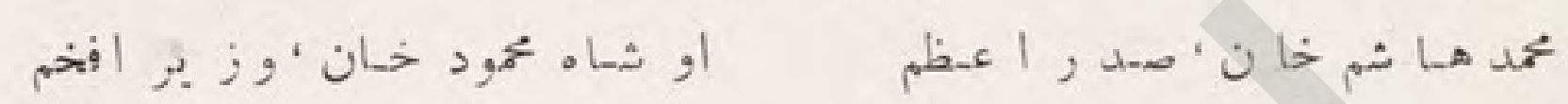

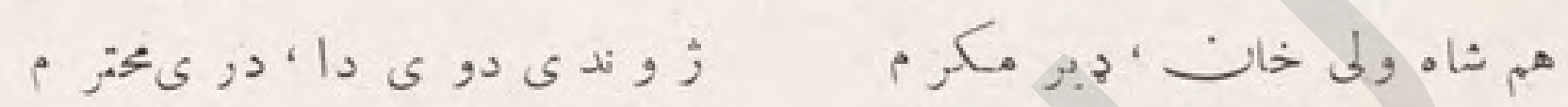

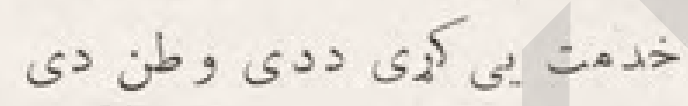

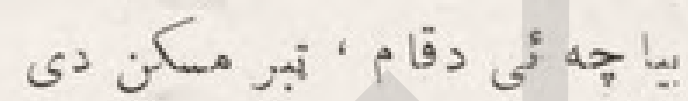

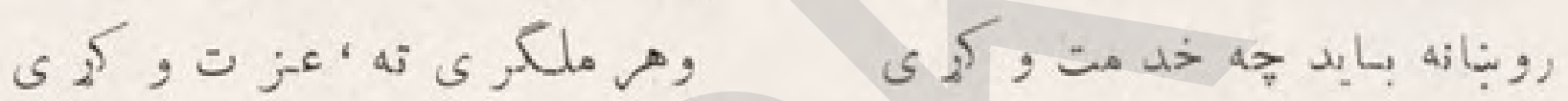

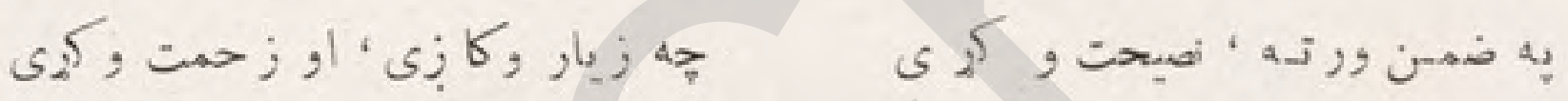

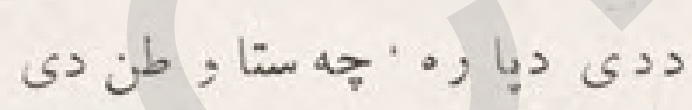

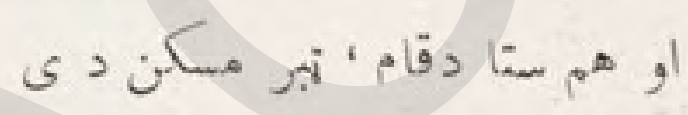

\section{لـ:}

بابها ز ما بهه و ينوو وهى خـا لو نه

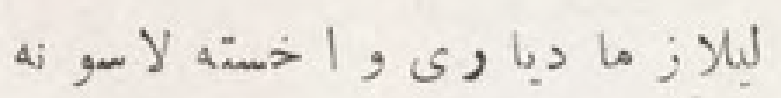

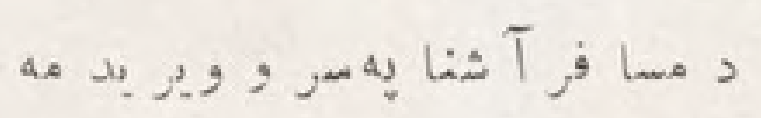

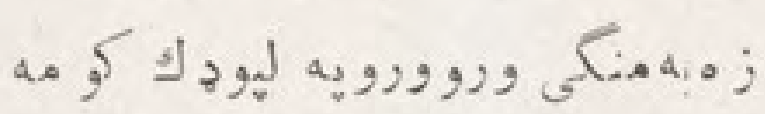

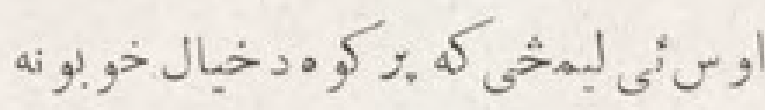

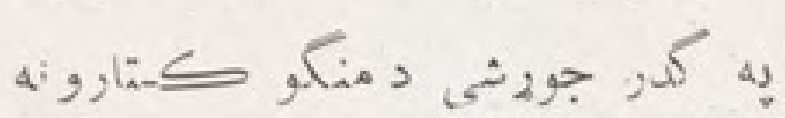

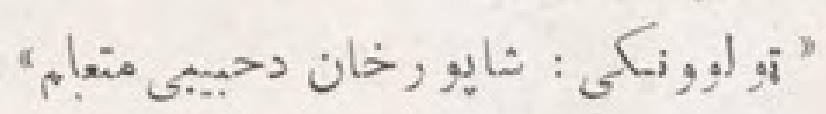

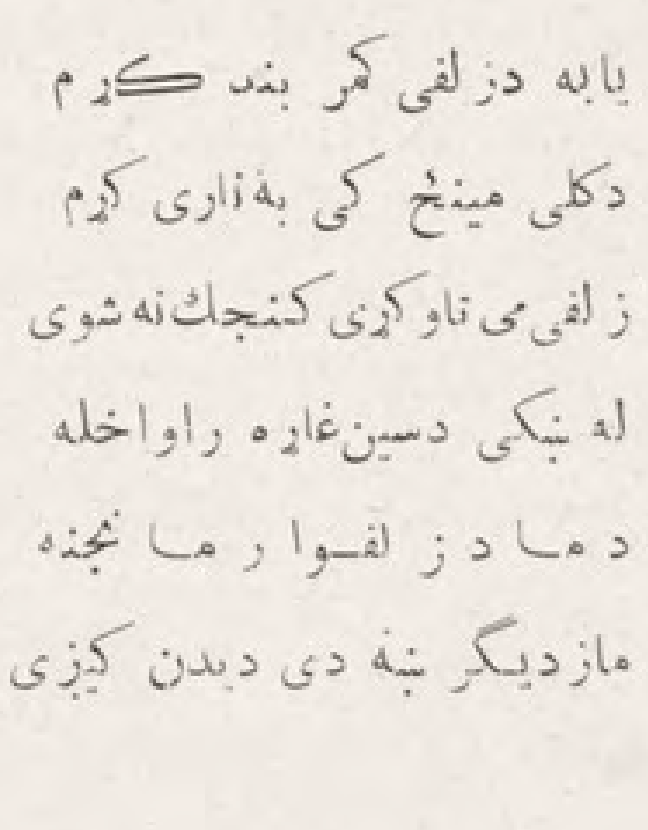

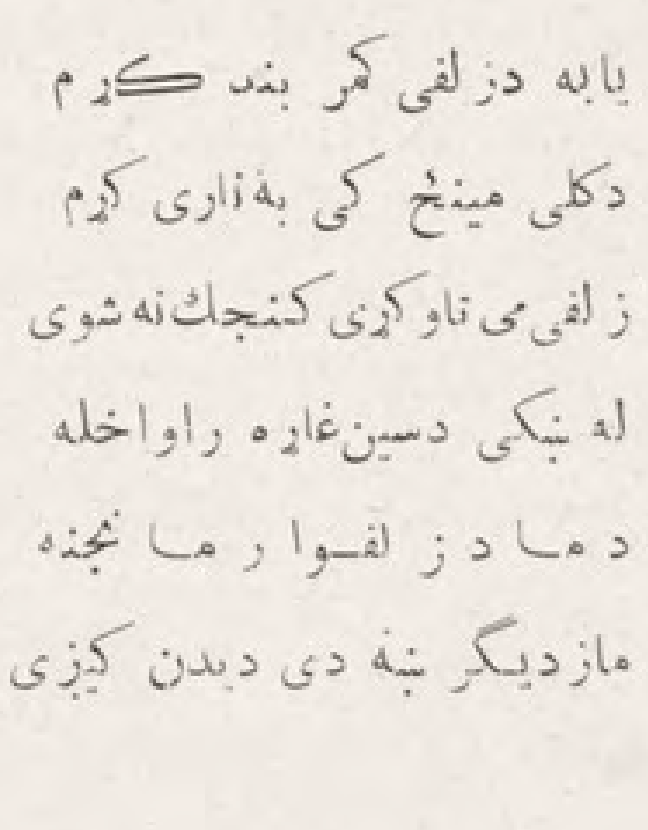

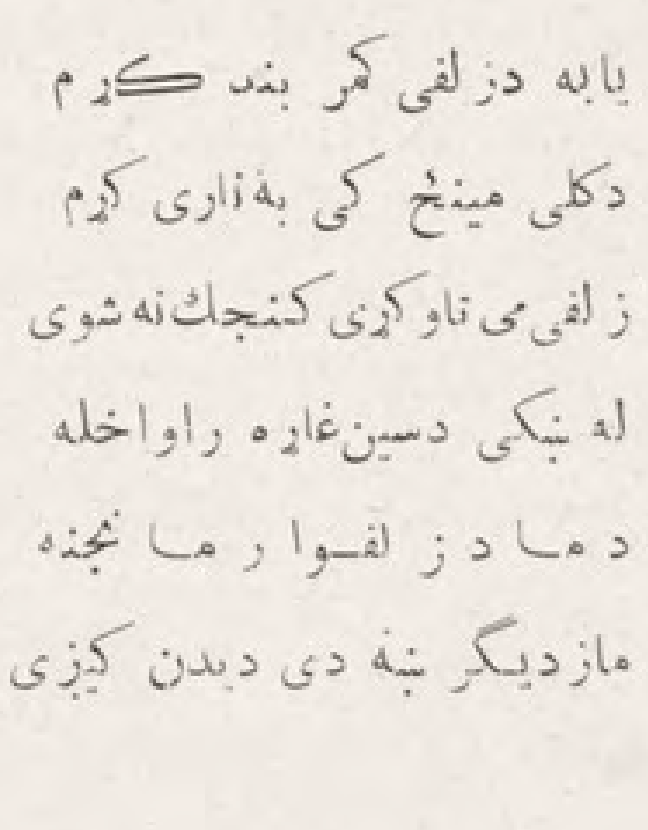

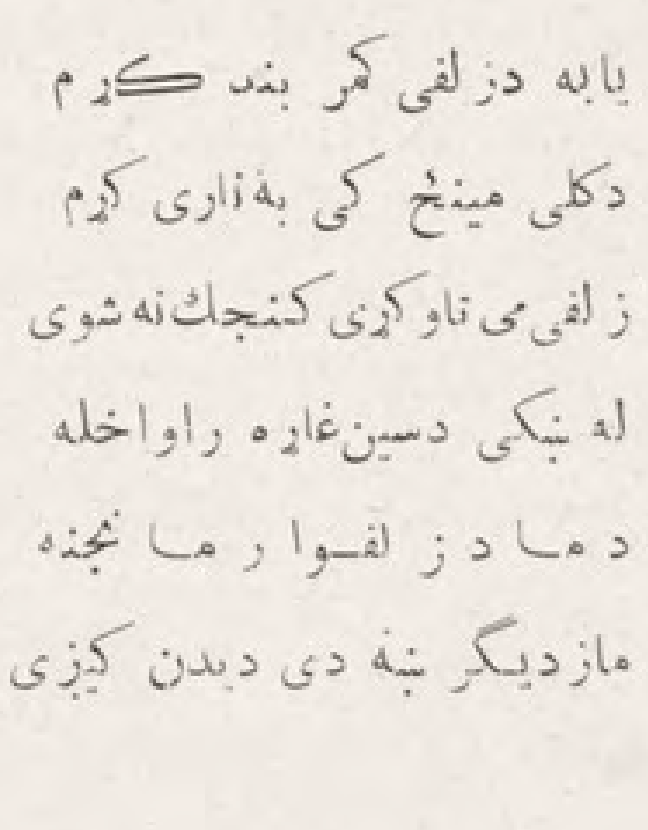

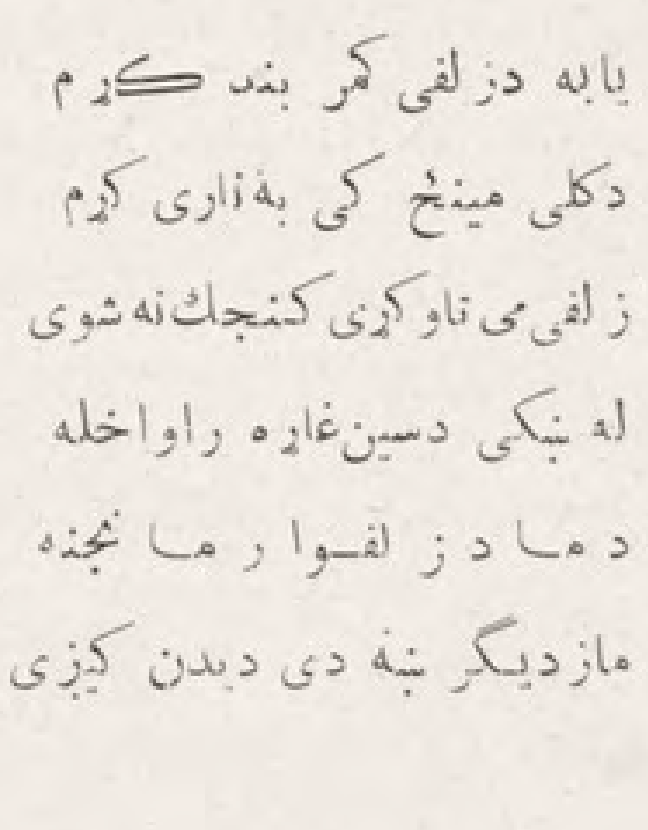

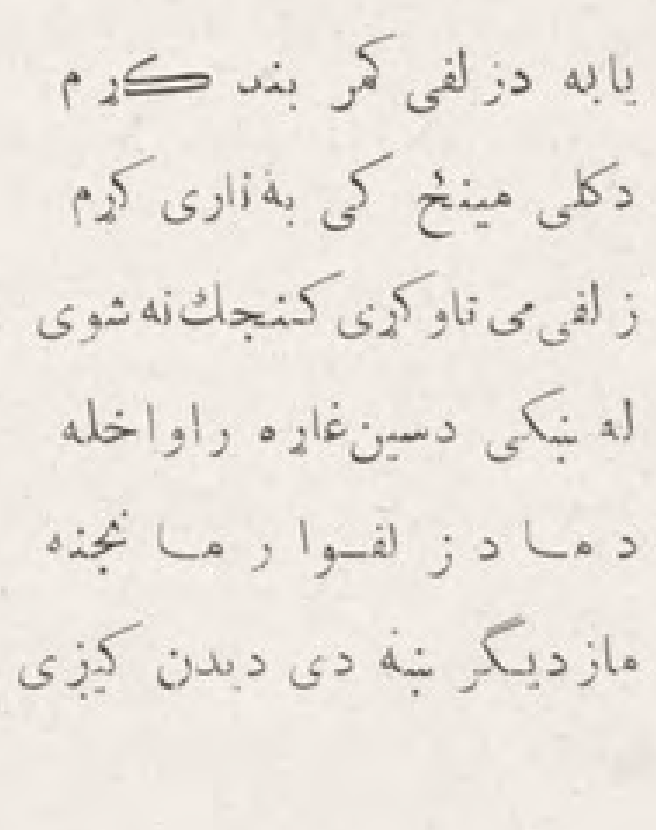




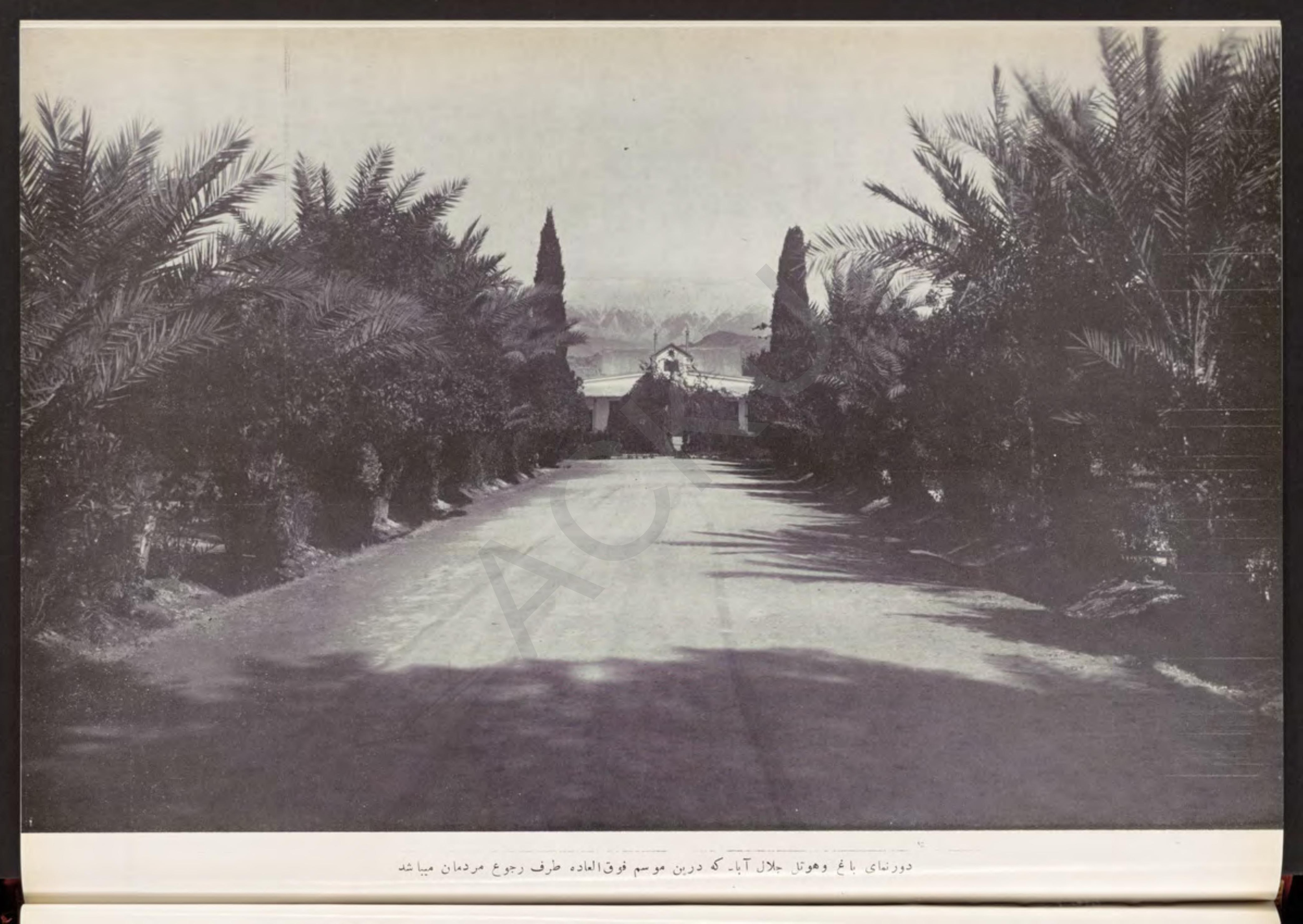


خيالى درامة

\section{دير بيدوفاوى}

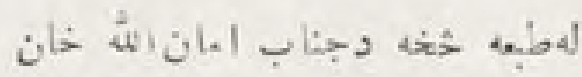

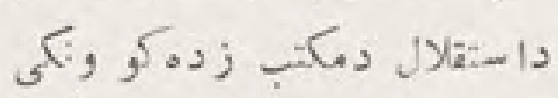

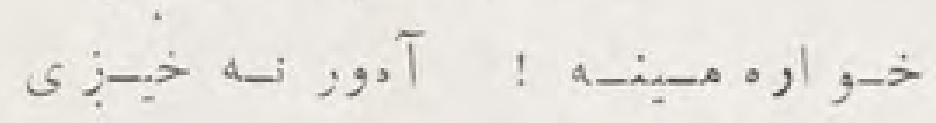

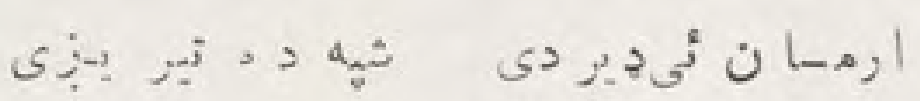

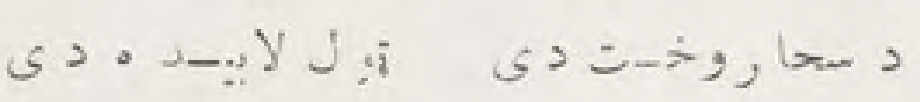

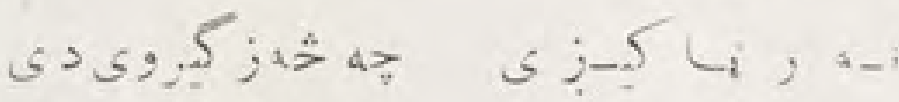

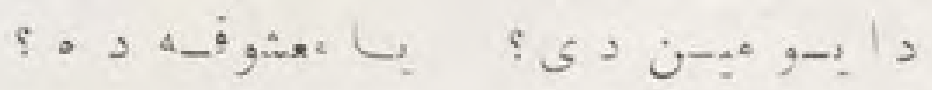

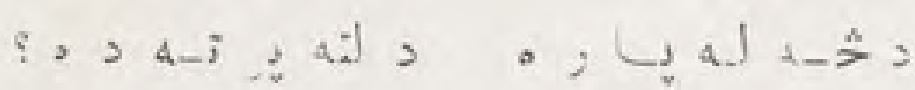

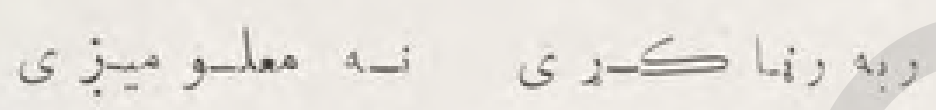

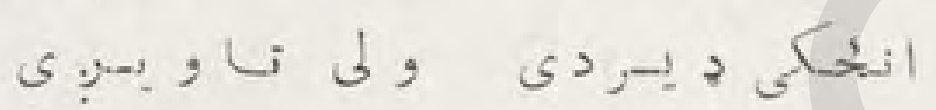

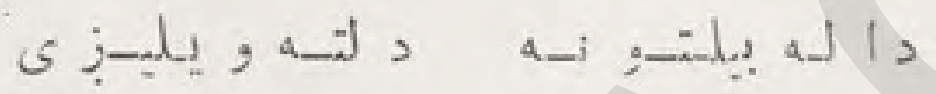

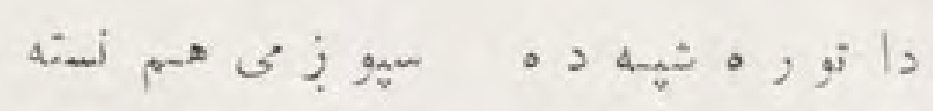

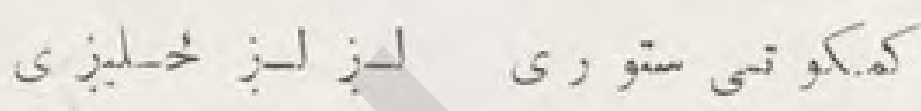

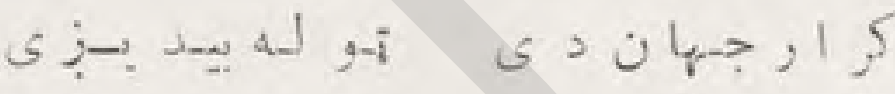

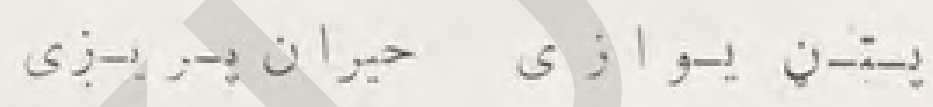

ك, ك, ا, ك,

بنه وزب هـ كر كرز

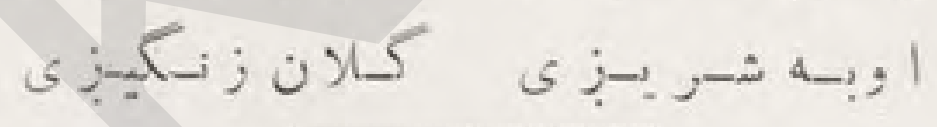

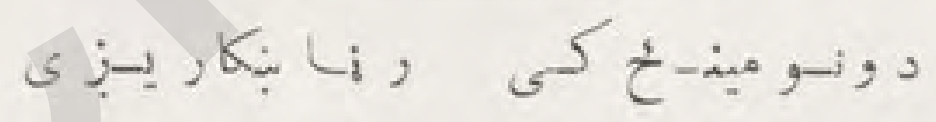

دسا

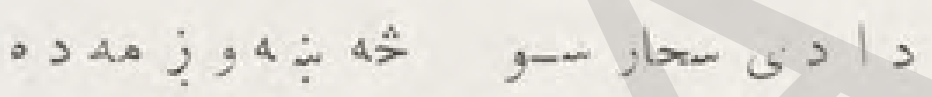

زكير وى هـ

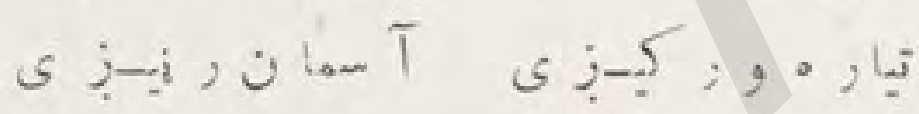

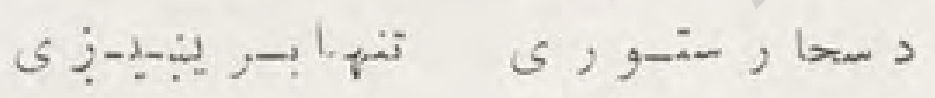

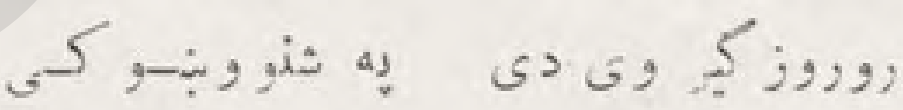

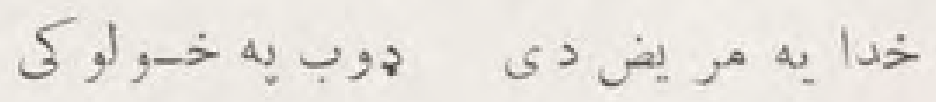

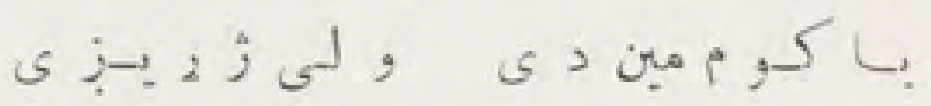

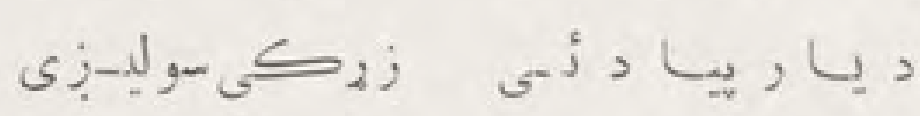

غهج

خها لكى تيز بــز

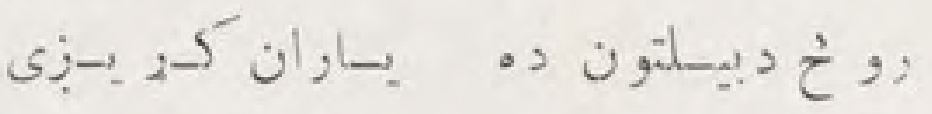

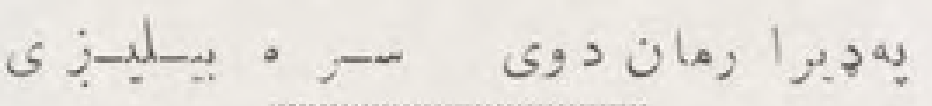

s

دز كيروى زبغ دم

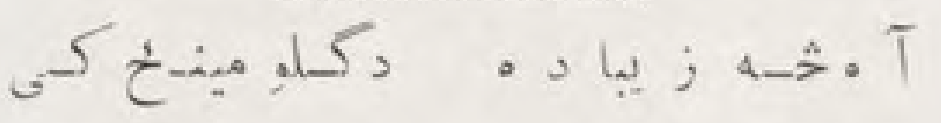

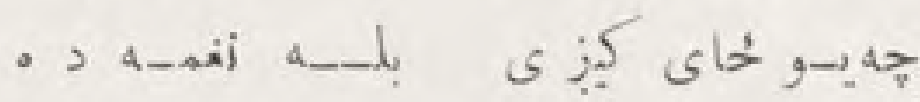

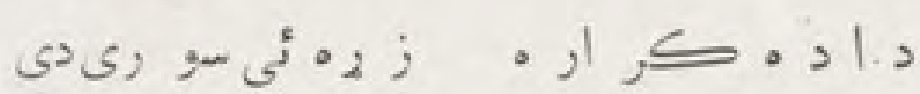

خو, أخو, شينها

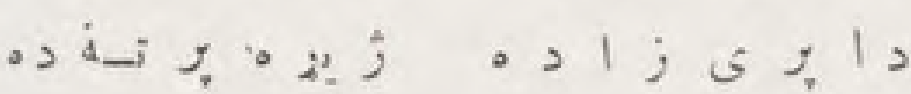

لِهه زيسروبم دوى 


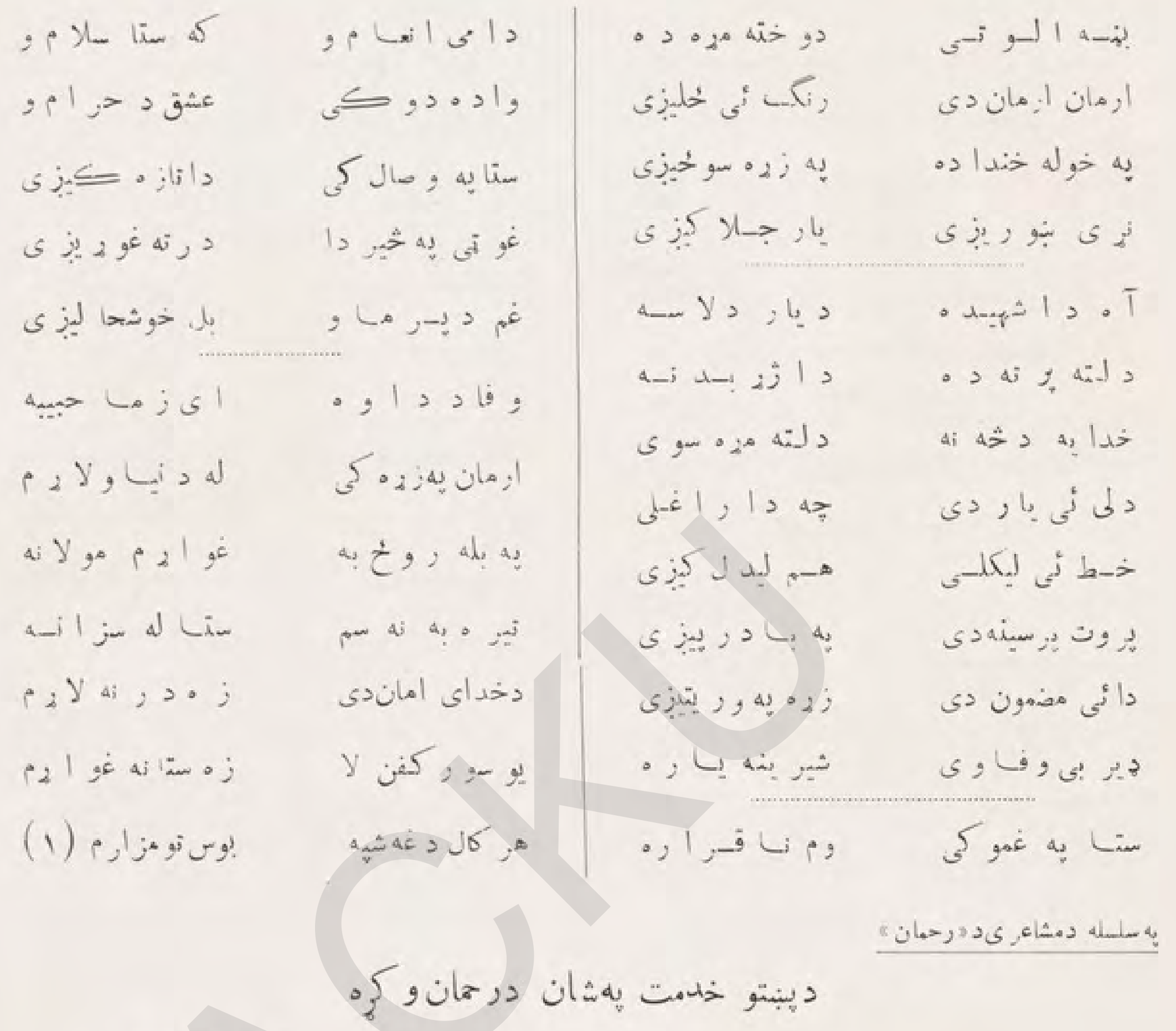

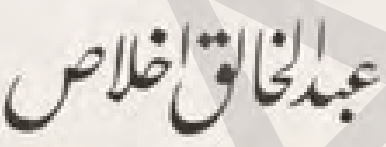

يو نظر يه كوزو باسى دجهان و كأه

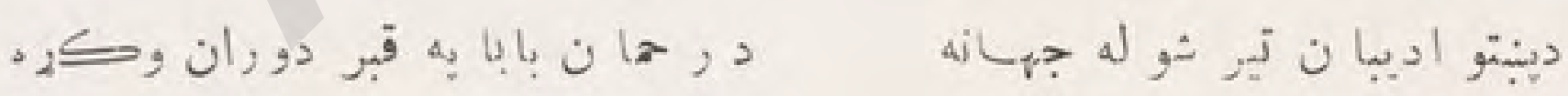

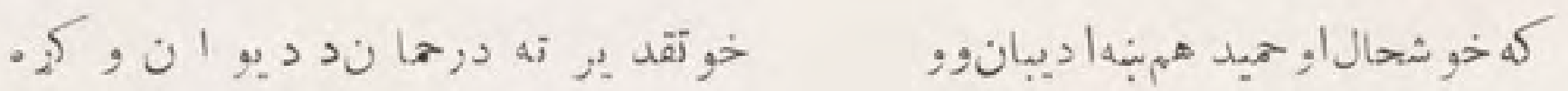

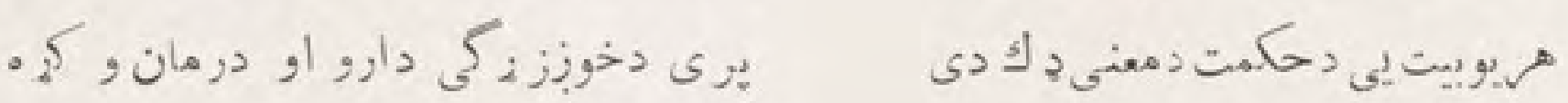

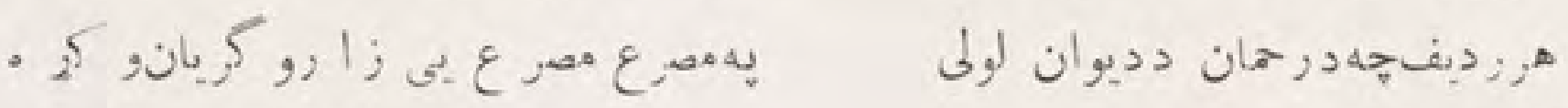

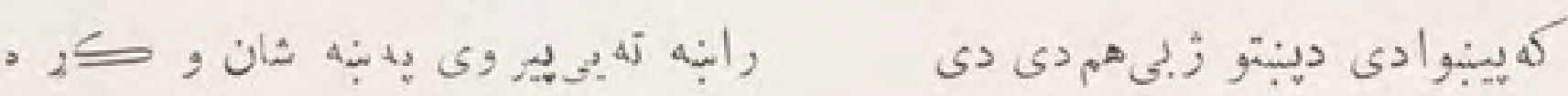

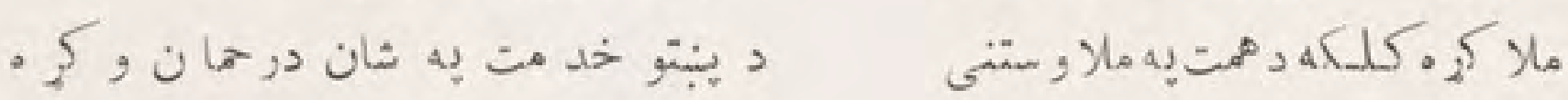

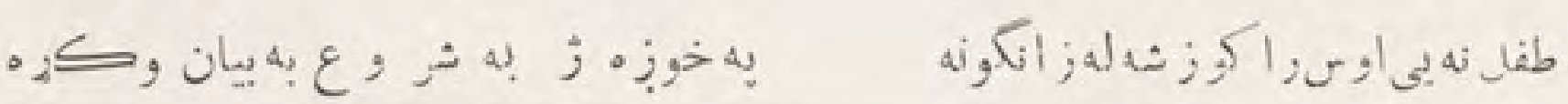

(1) اين مصرع فار سي است كو يندة اين مصرع را نها يت بيا آ ورده است . 
اله بنجز ى اوز • يوسياد بستان وكئ.

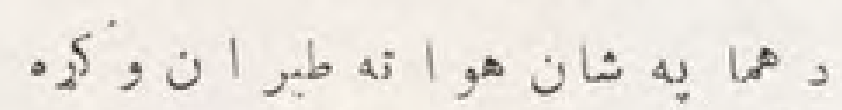

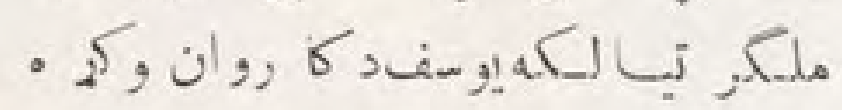

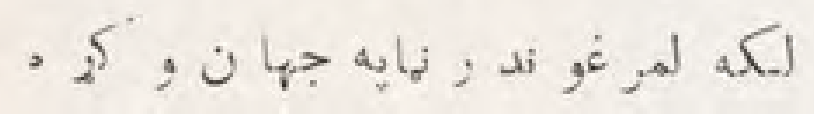

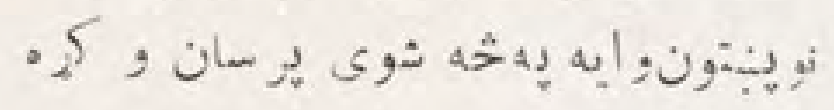

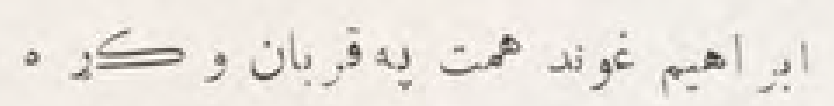

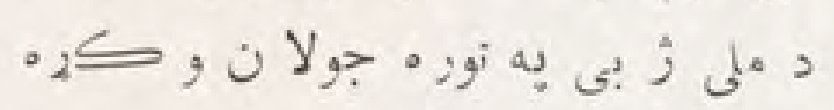

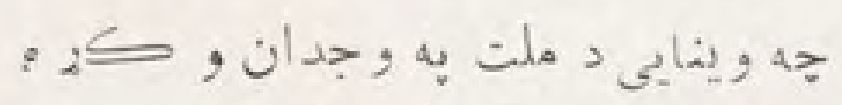

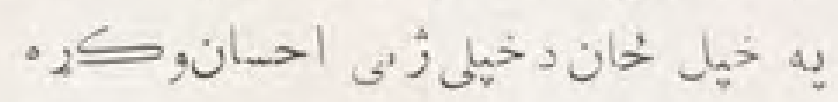

(9) 8

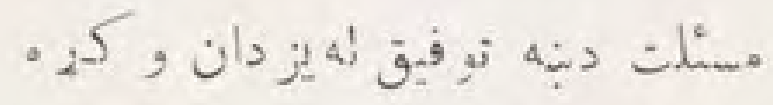

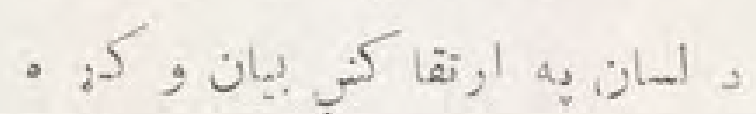

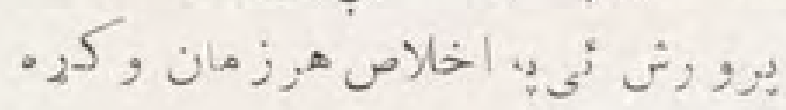

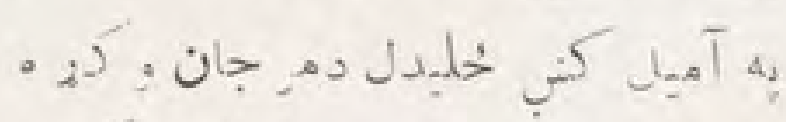

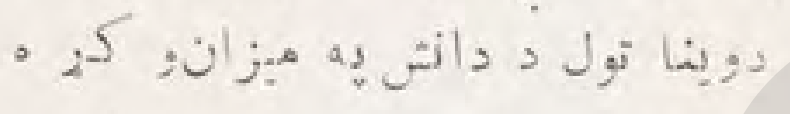

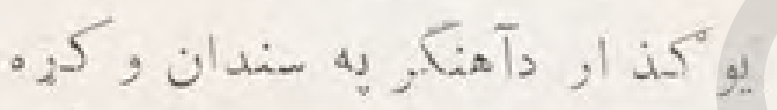

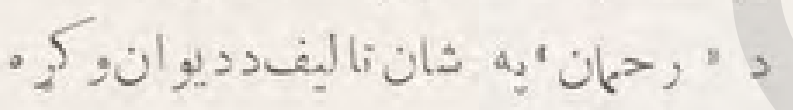

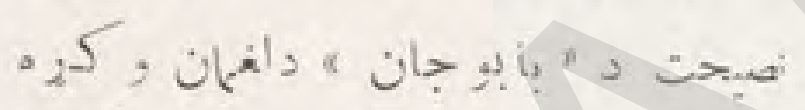

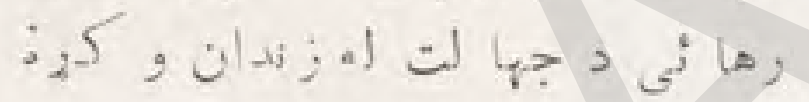

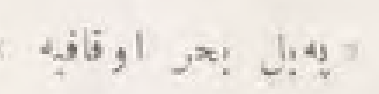

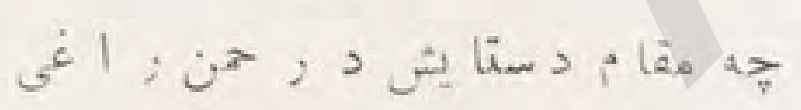

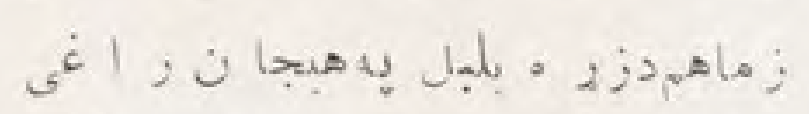

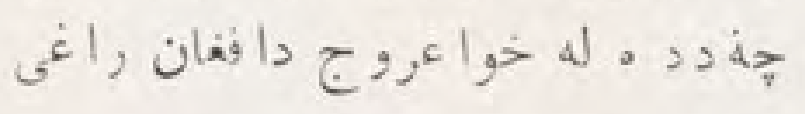

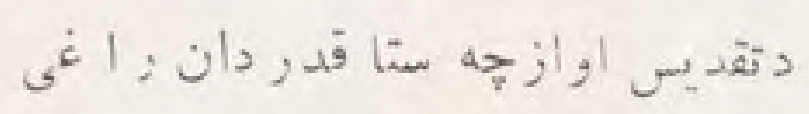

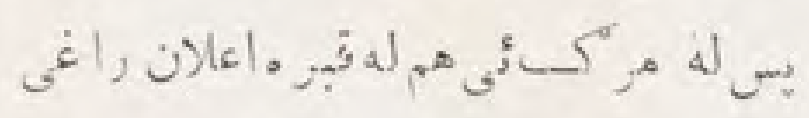

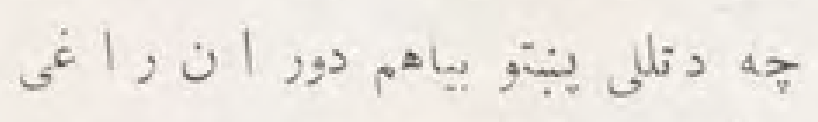

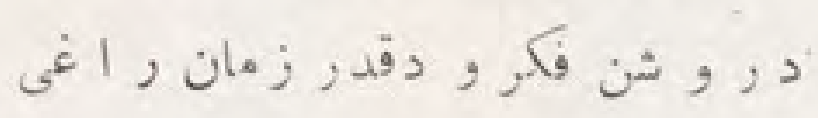

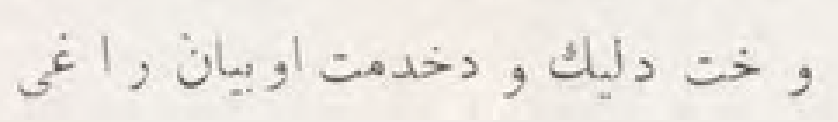

دطوطى يه نكير دى خبر ى يرينز 2.

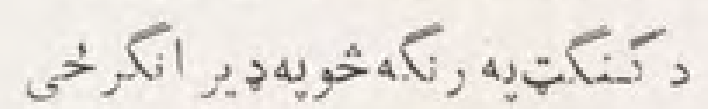

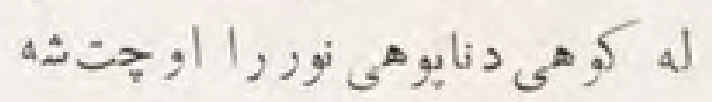

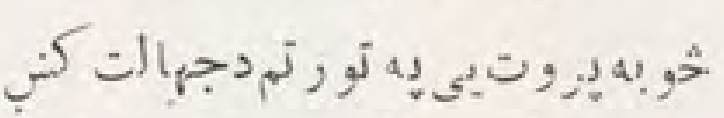

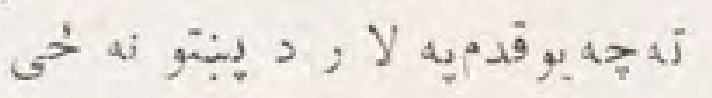

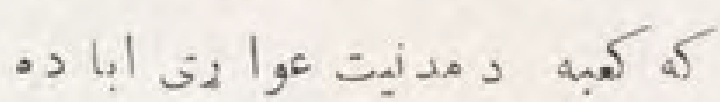

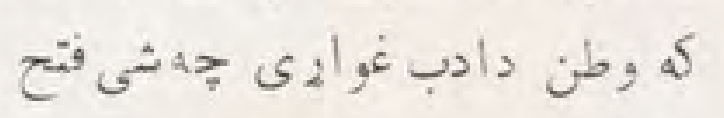

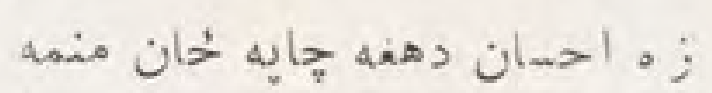

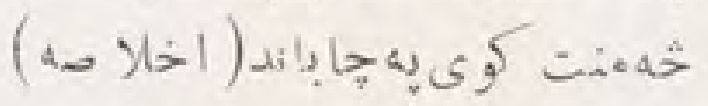

(2)

صديق الشخان ربتبنين وائي

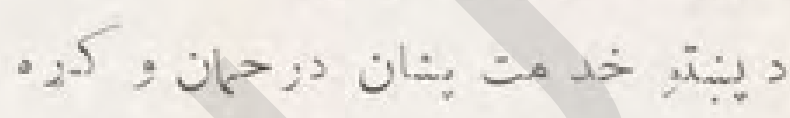

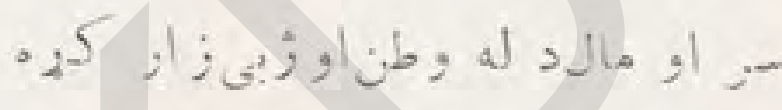

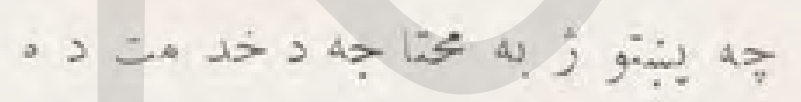

,

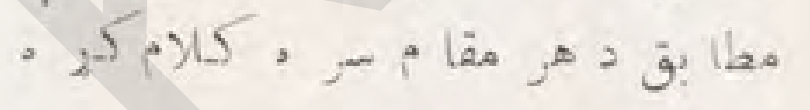

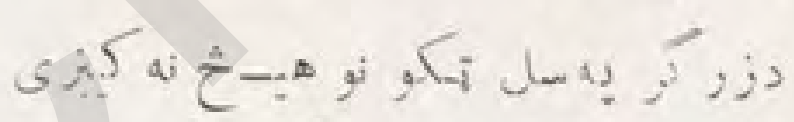

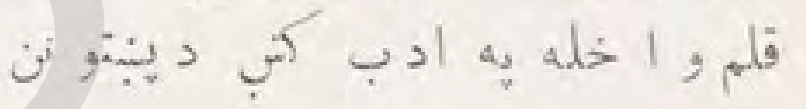

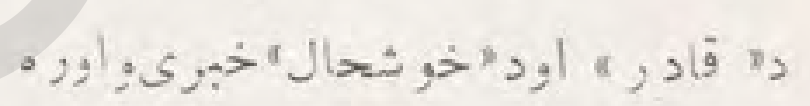

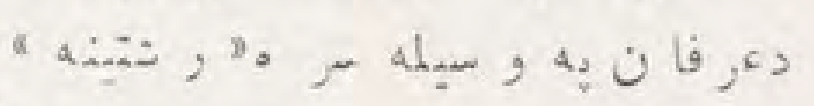

6)

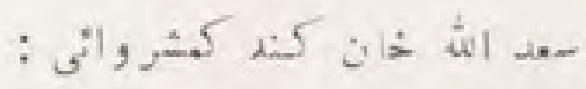

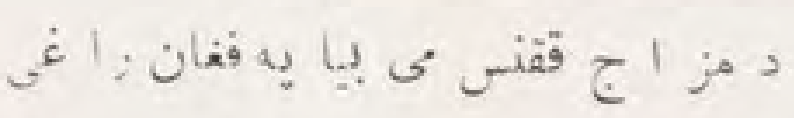

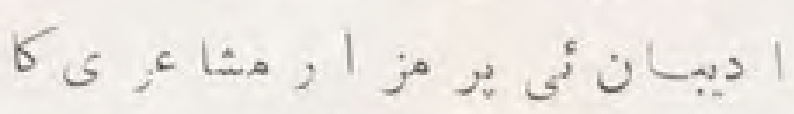

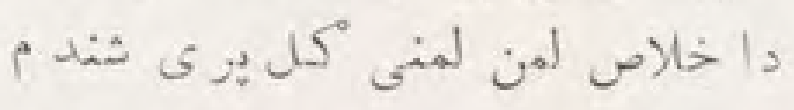

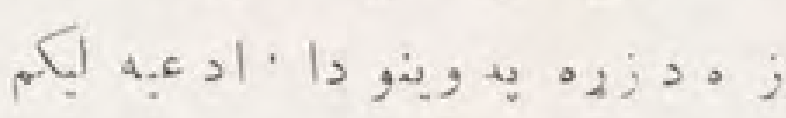

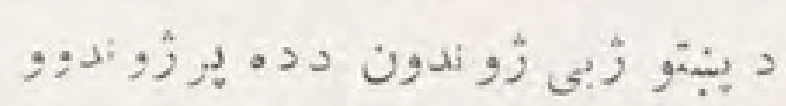

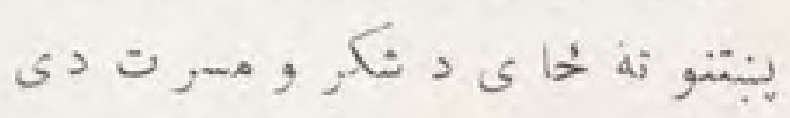

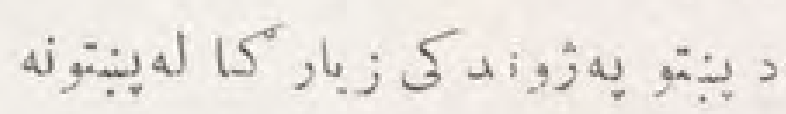

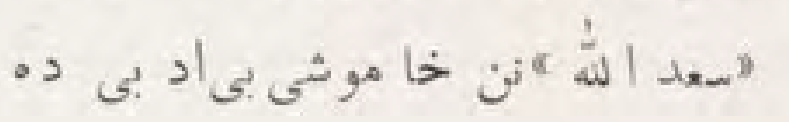




\section{$ت$ grais}

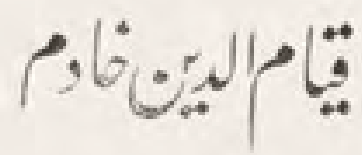

$$
\text { آغوش مادز !. . . كشيدن دستمحبت ! }
$$

شنيدن كلماتشير بن ! ... تسلى مادن ، بالاخره

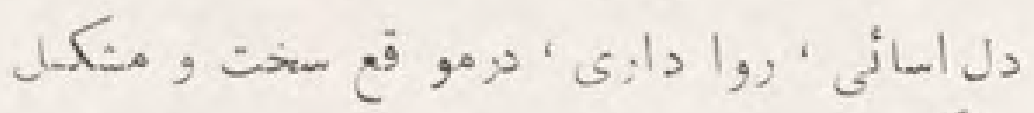

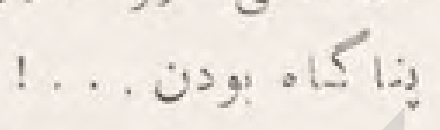

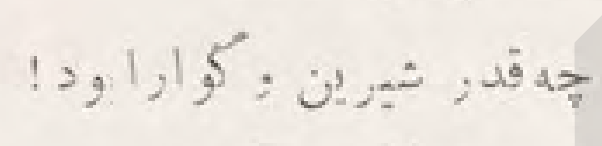

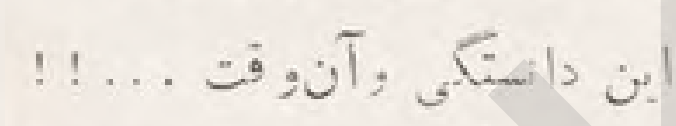

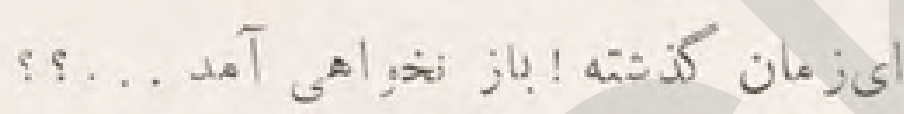

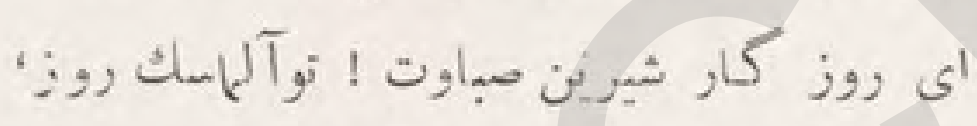

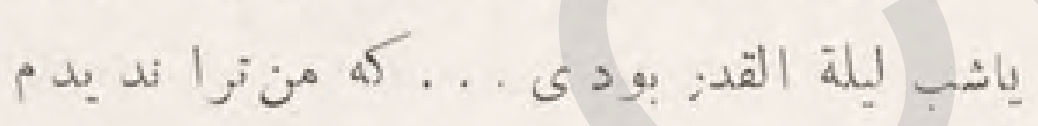

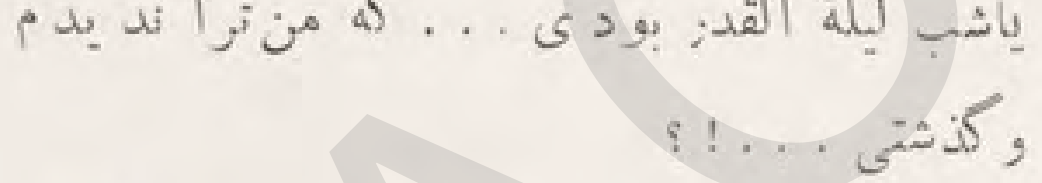

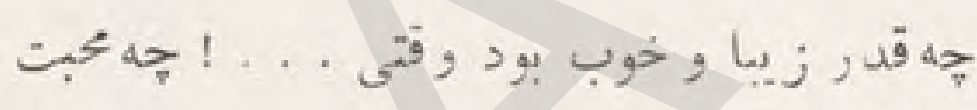

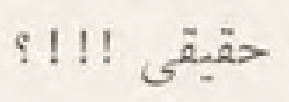

$$
\text { آم من عشق ومكبت مي جويم .... }
$$

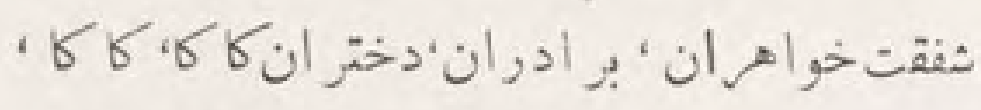

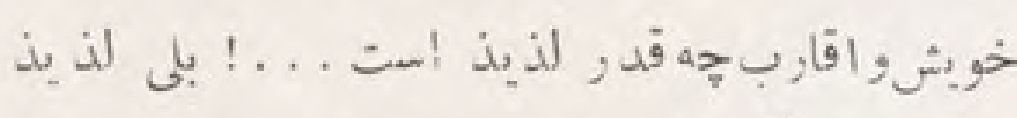

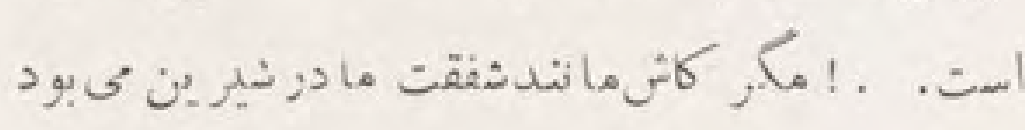

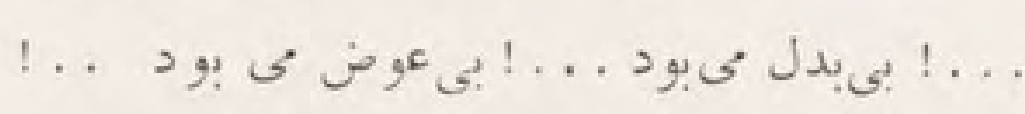

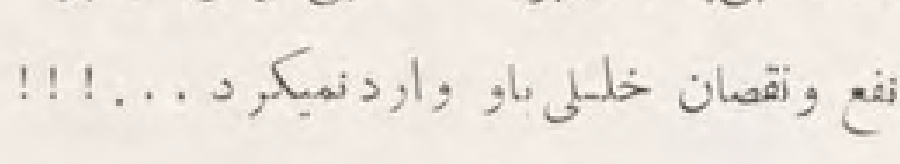

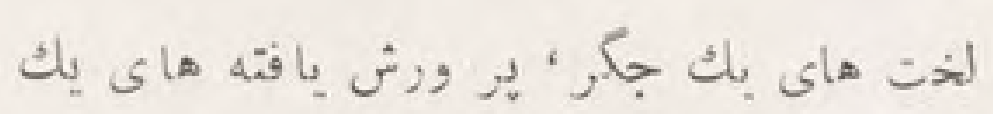

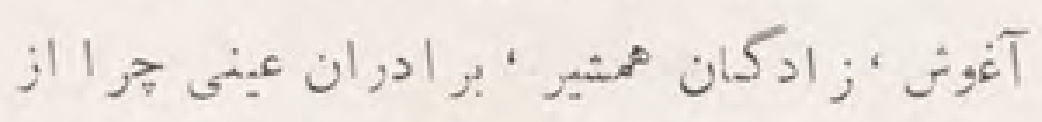

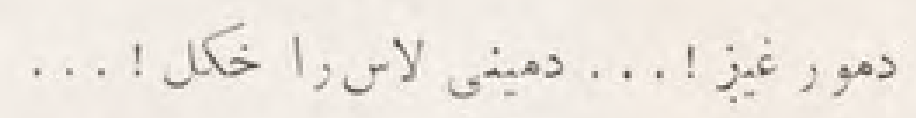

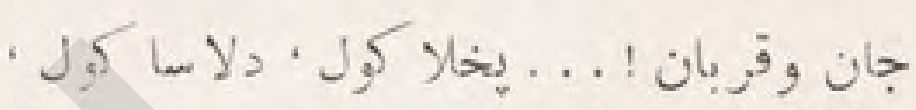

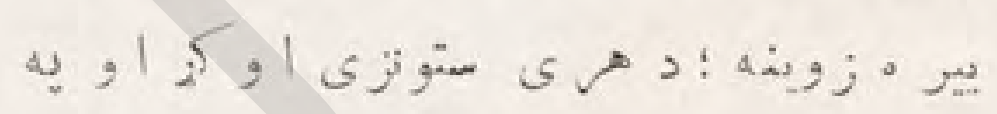

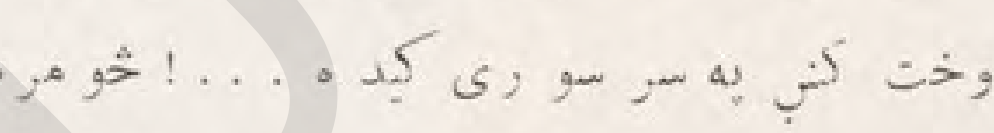

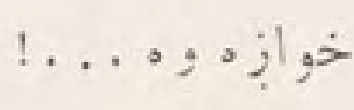

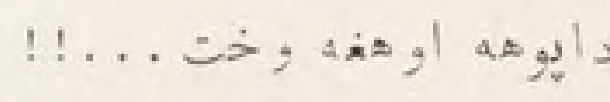
تير هوخته ! بيابهر انه شى ....؟؟

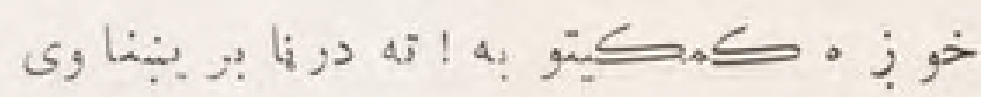

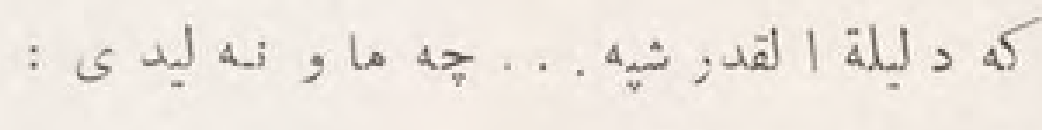
تير شو ى ...!

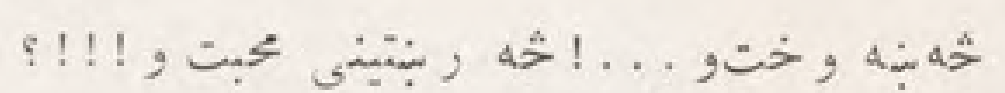

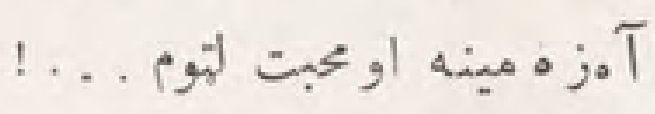

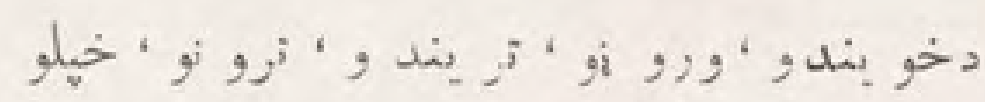

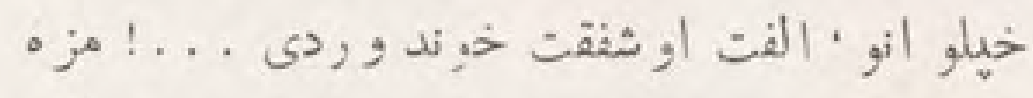

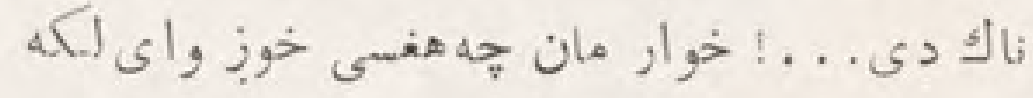

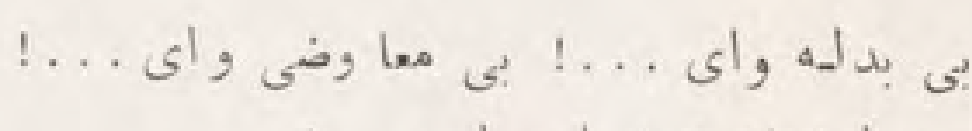

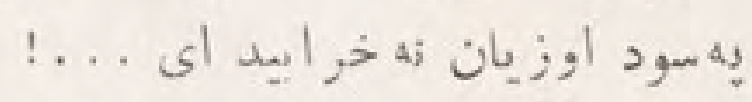

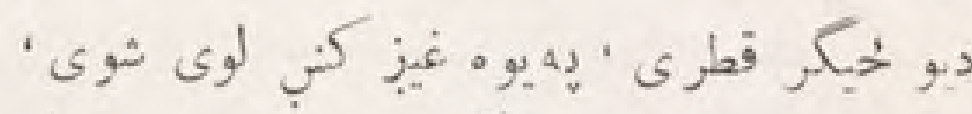

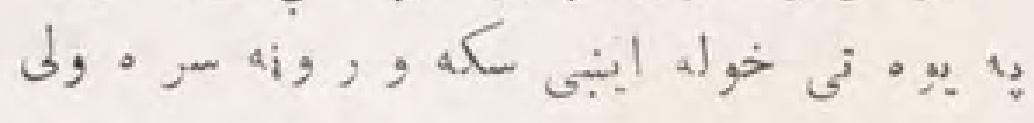




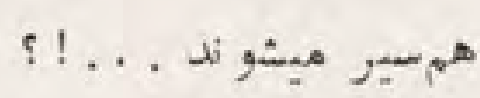

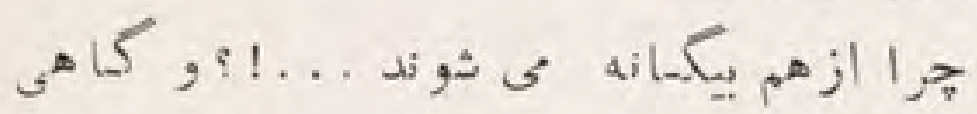

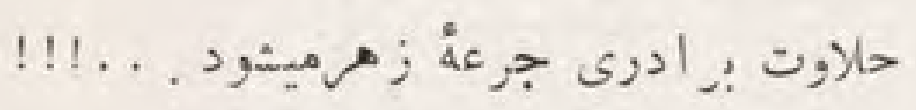

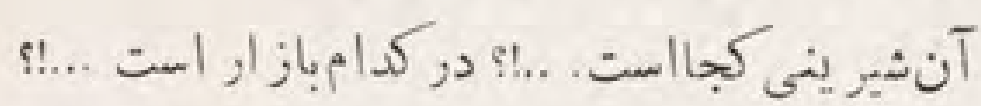

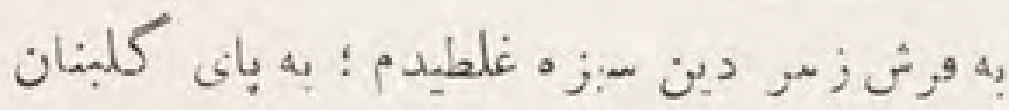

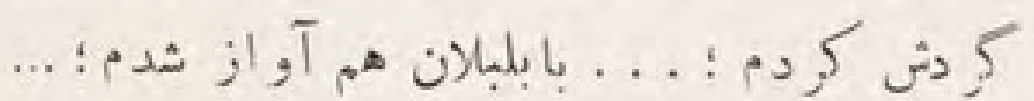

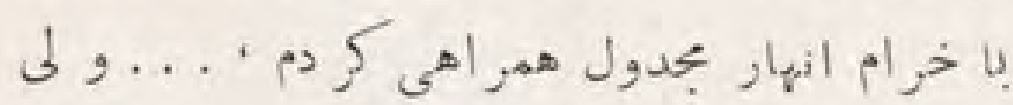

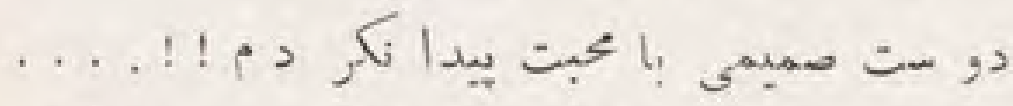

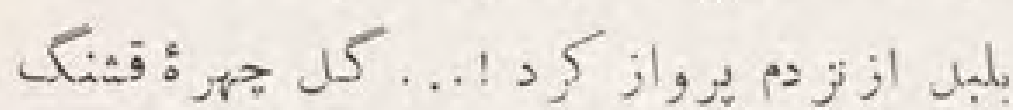

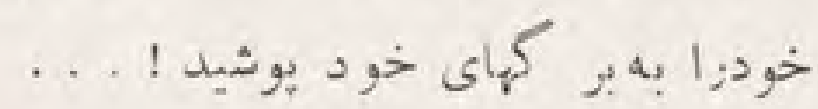

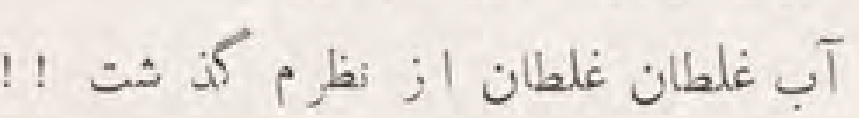

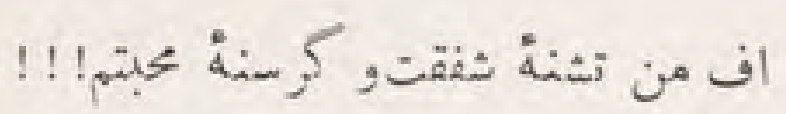

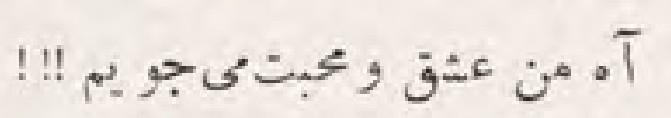

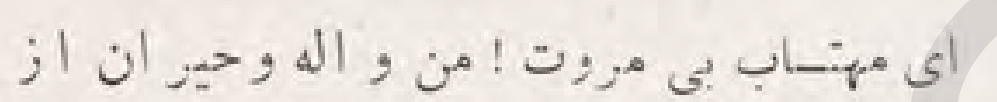

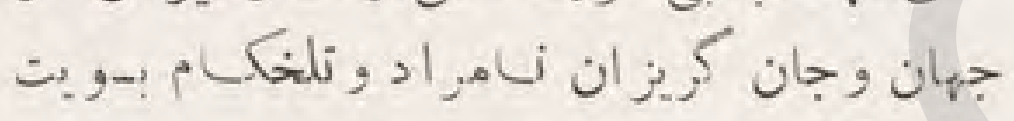

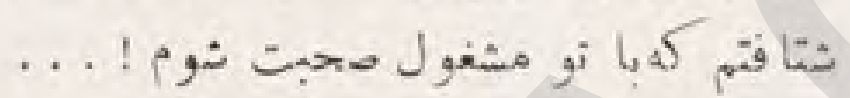

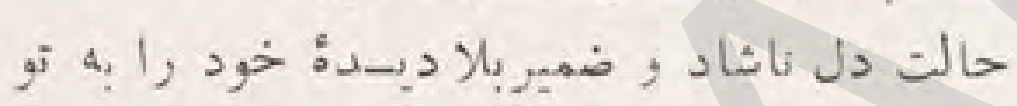

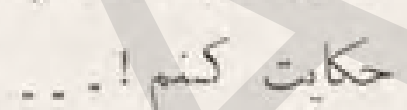

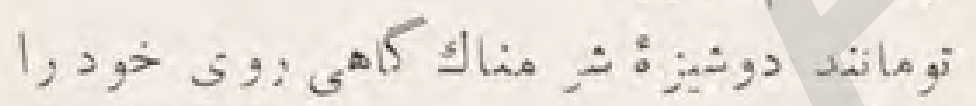

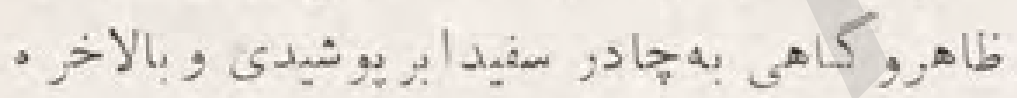

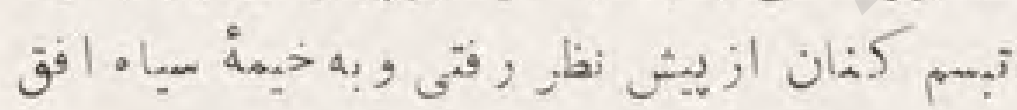

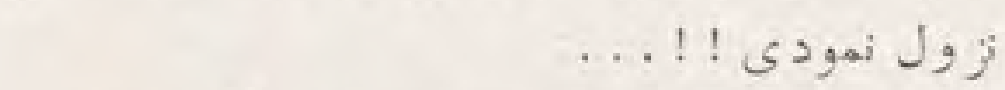

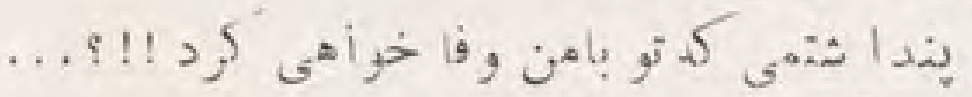

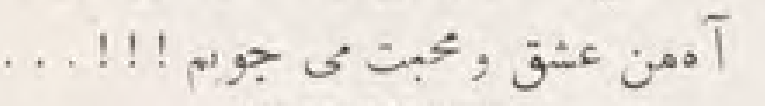

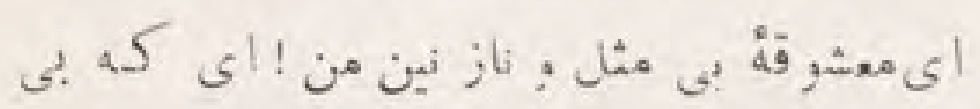

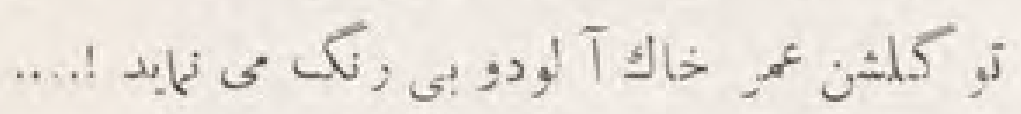

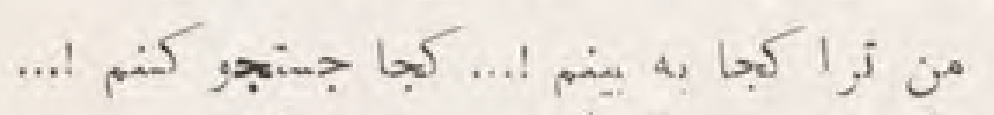

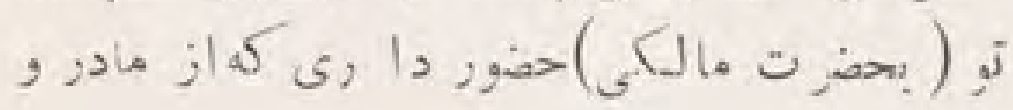

$$
\text { c) }
$$

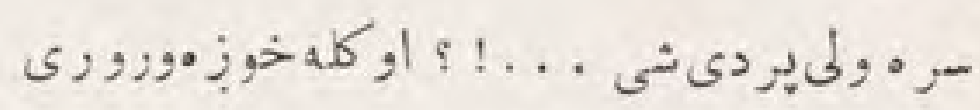

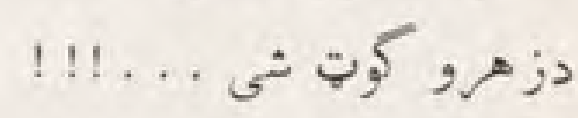

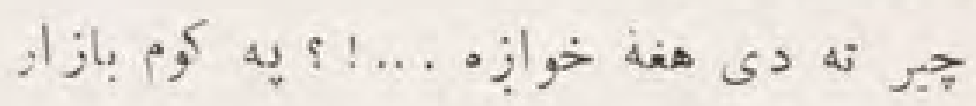

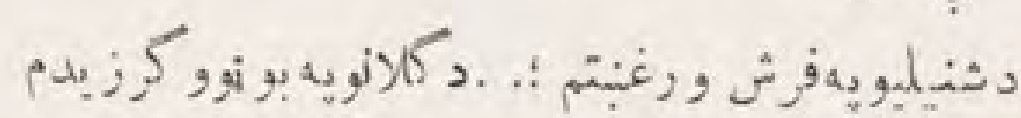

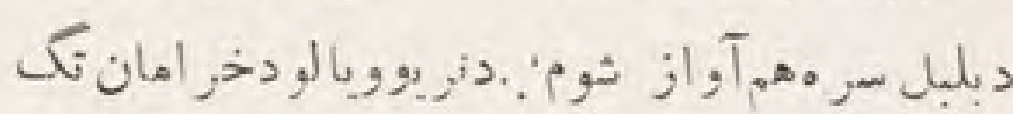

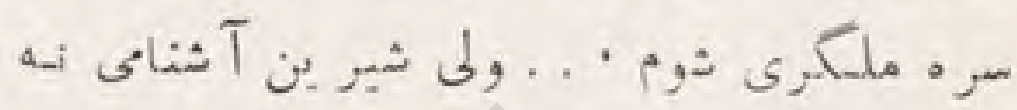

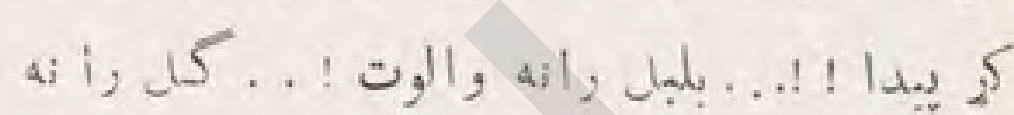

! 120

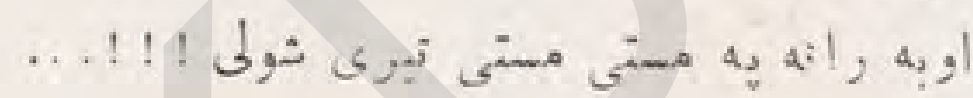

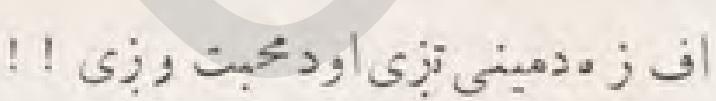

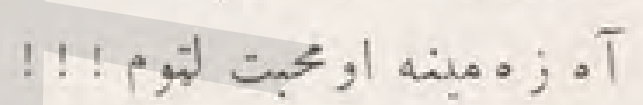

نامردى سيوزيى ! اريان ولريان دخان ارد جهان

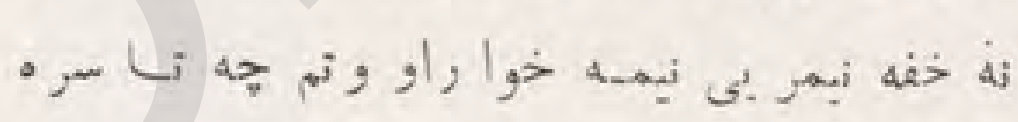

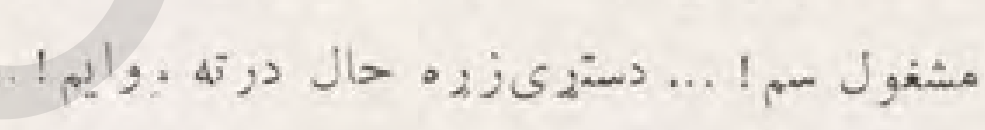

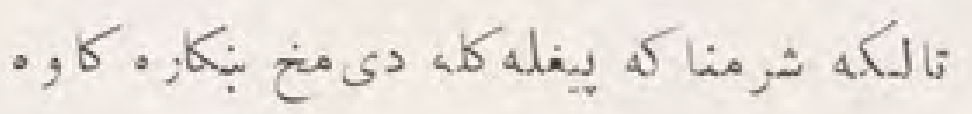

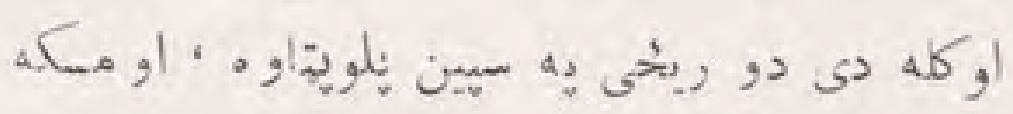

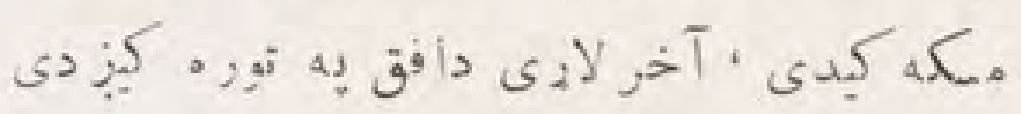

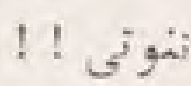

$$
\begin{aligned}
& \text { ماويل زه ربه راسرم ورفاوكى !! }
\end{aligned}
$$

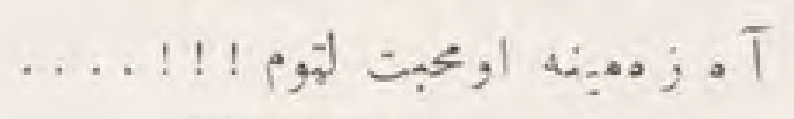

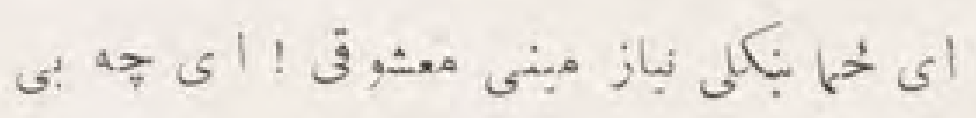

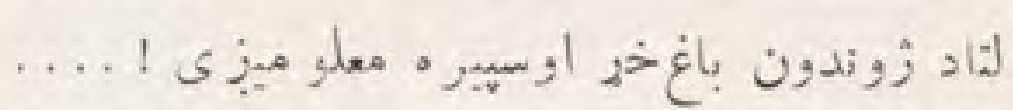

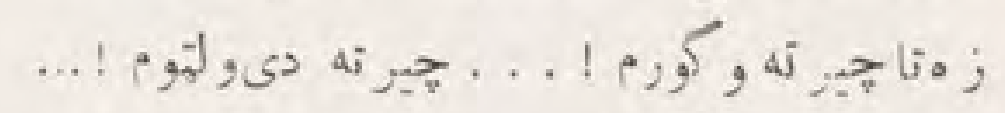

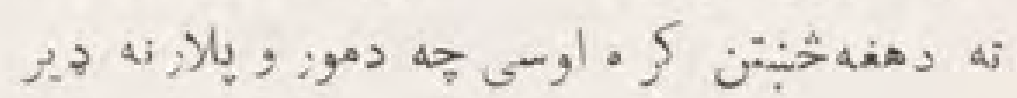




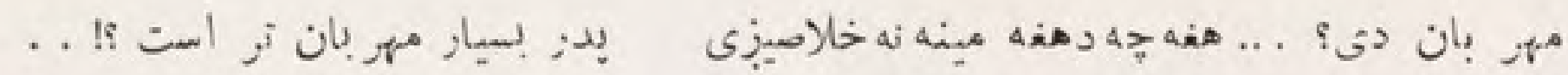

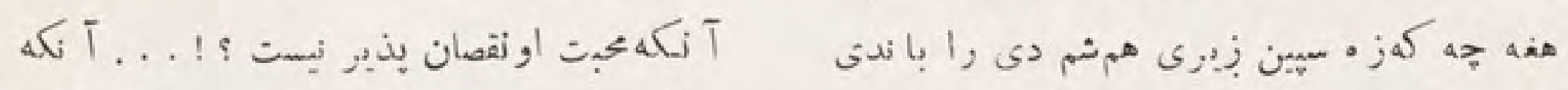

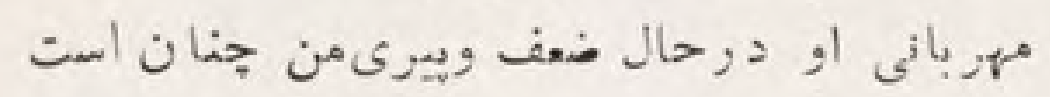

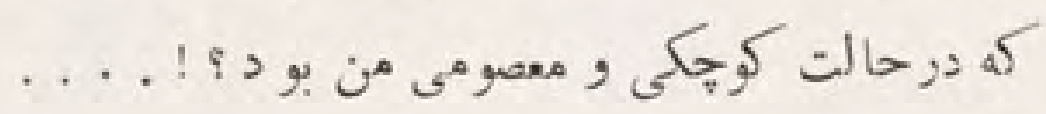

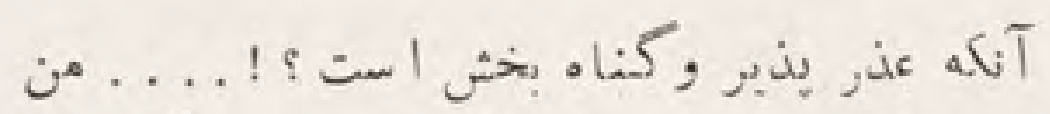

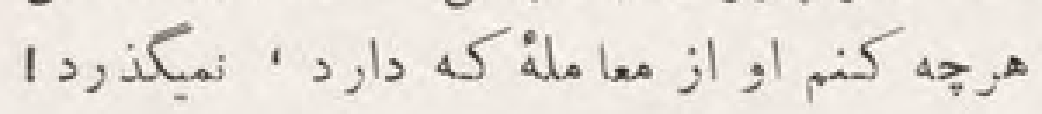

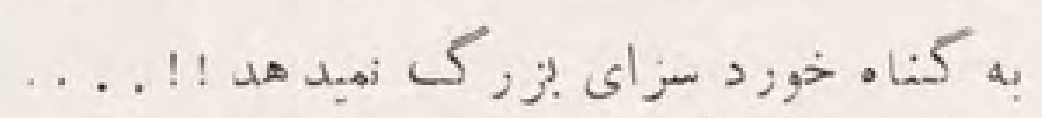

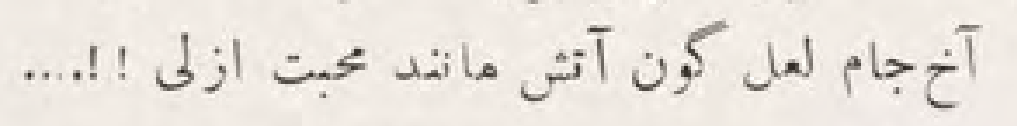

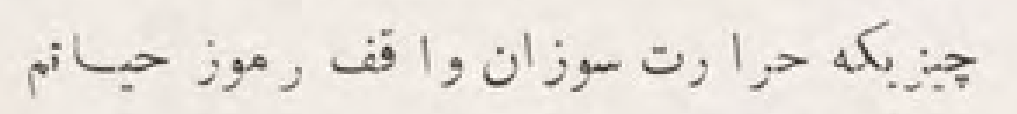
جذ بذ خد متى كه بوسيلة آن رضاى صاحب و وصال همان معشوق - شيرين رابيا بم !! .. . . . .

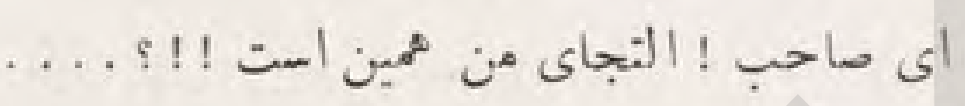

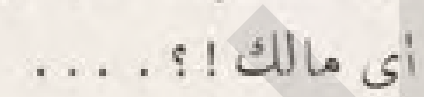
هاغسى مهر بانى كوى المه جه ها شوم وم ؟!...

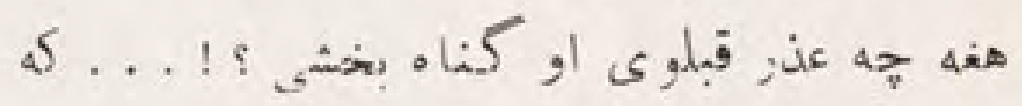

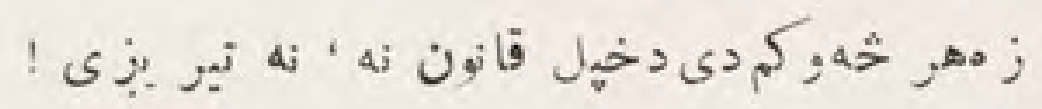

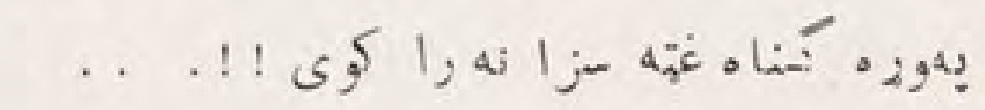
آخ دازلمحبت داوزيه شان سورجام !!.......

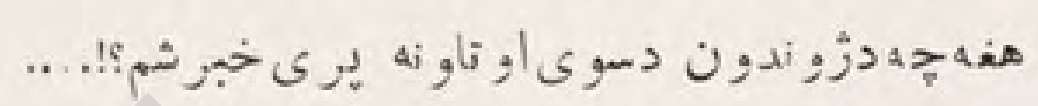
دخدمت هنه جذ به جه دجنتّن رضا مربى حاصله اودهنه خوزى معش; قى وصال يزى ومومم !! ... خاو نده دغٔه مى سوال دى ! ؟؟؟...

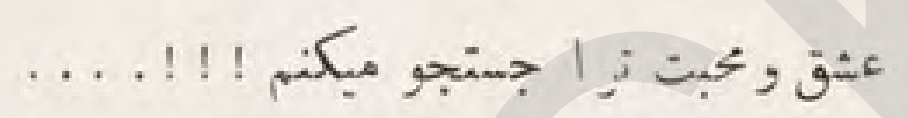
..

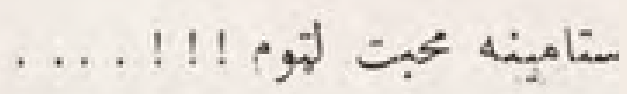

$$
\text { د, د, د }
$$

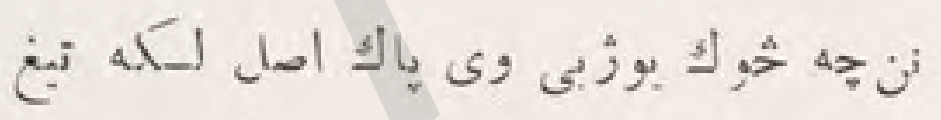

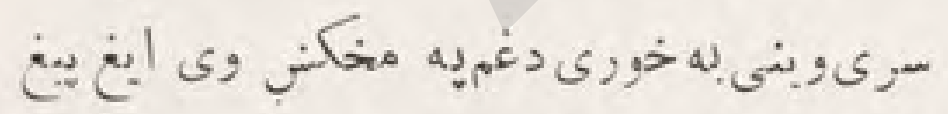

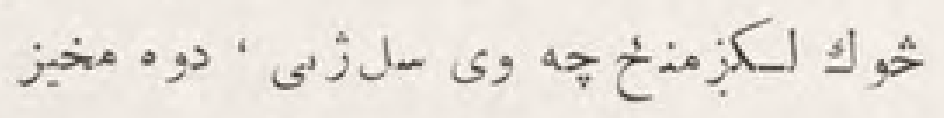

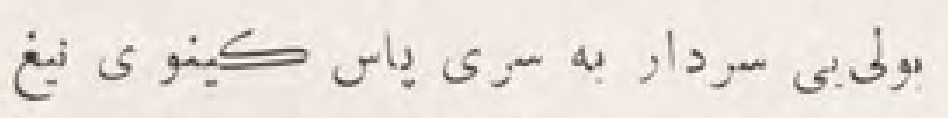

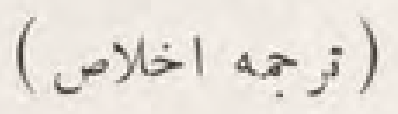

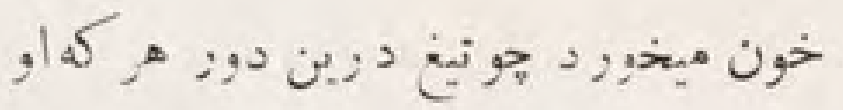

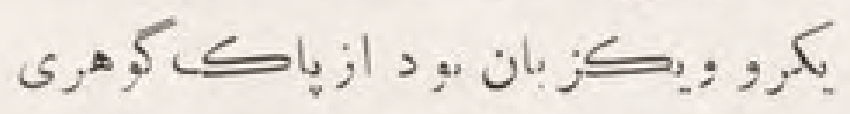

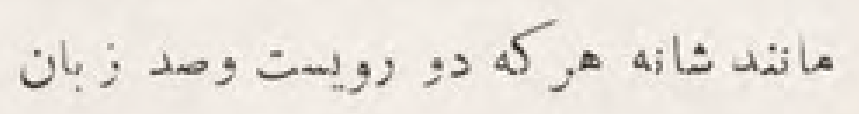

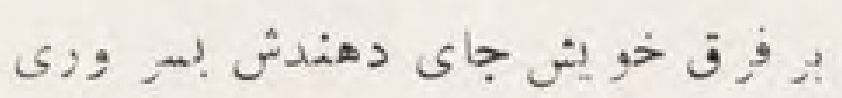




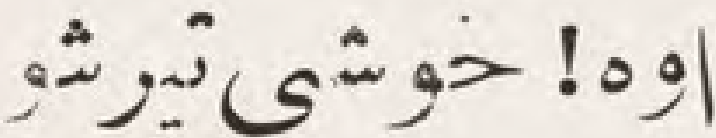

"يه قلم 2 جناب م ارسلان د سليبى"

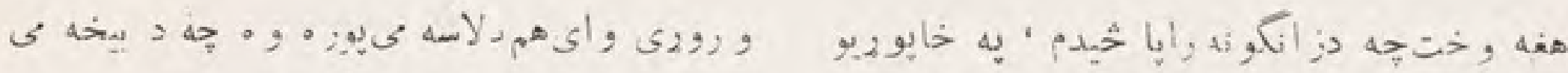

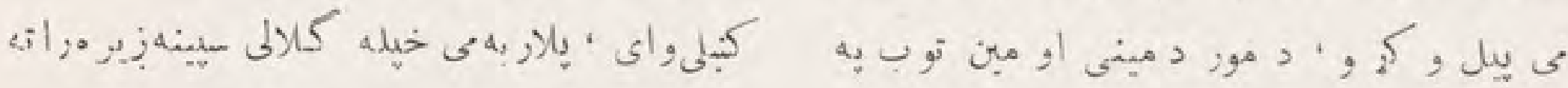

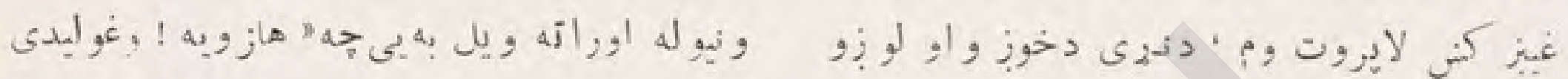

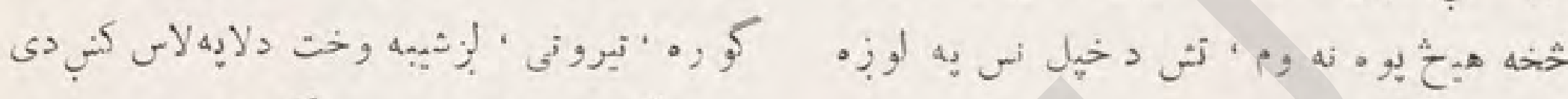

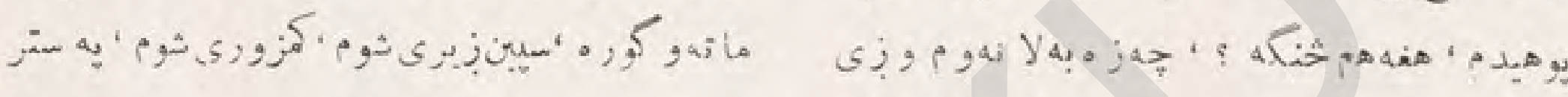

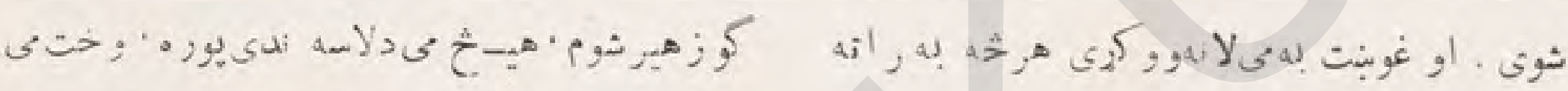

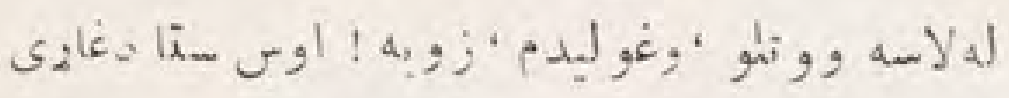

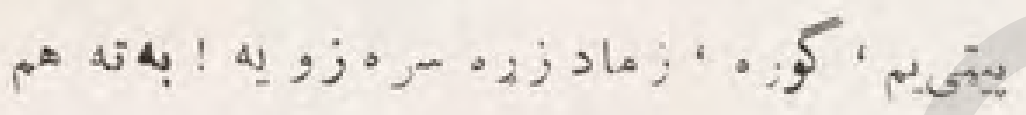

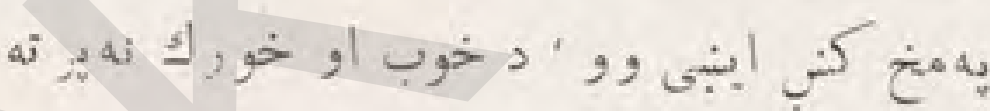

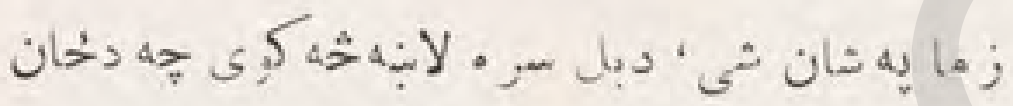

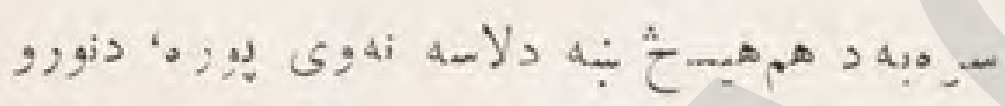

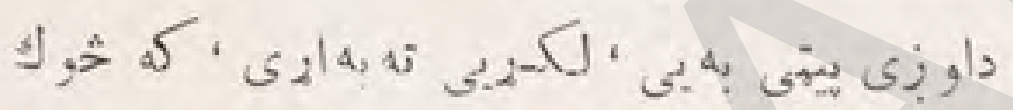

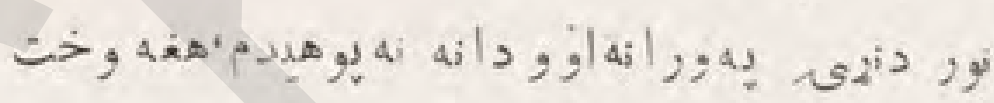

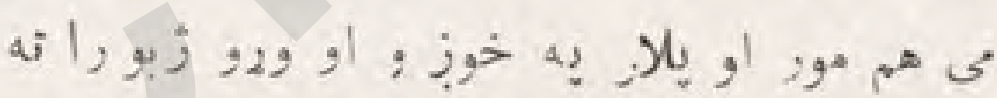

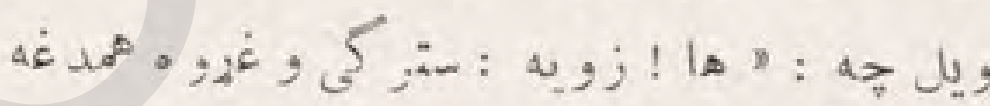

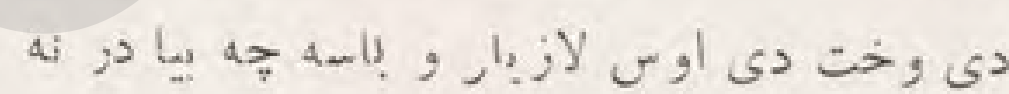

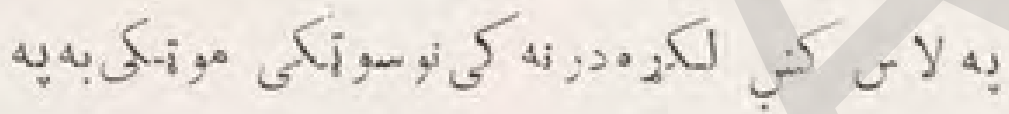
I! ! 1

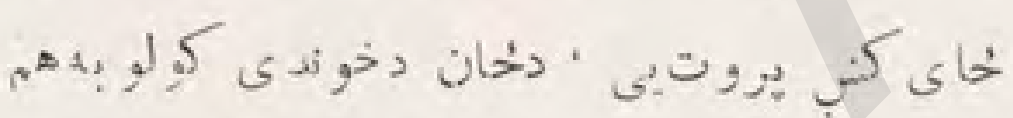

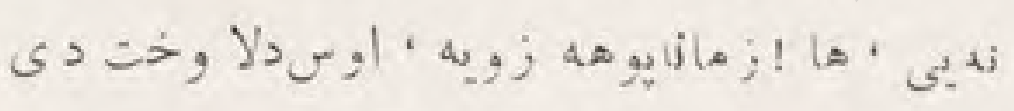

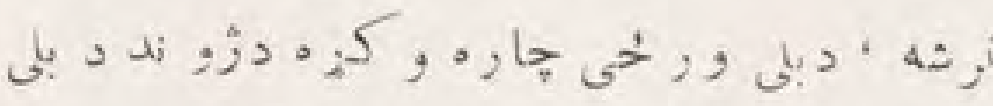

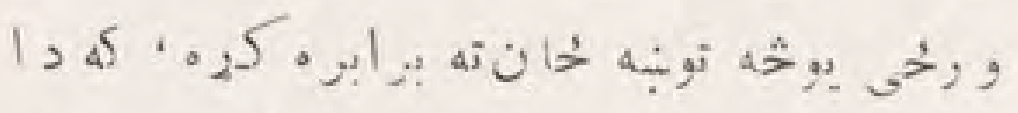

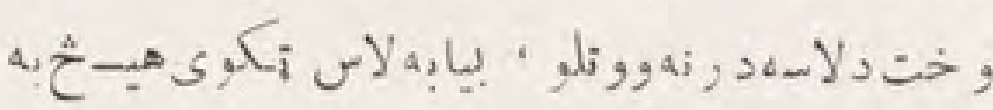

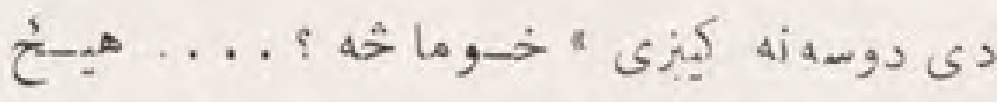

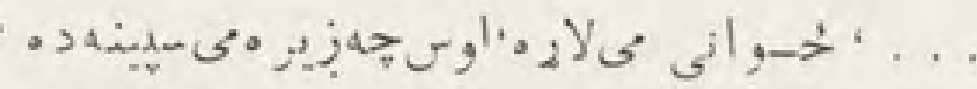

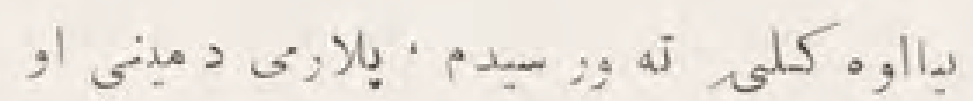

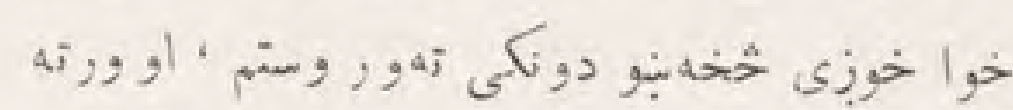

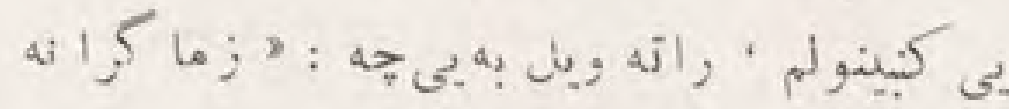

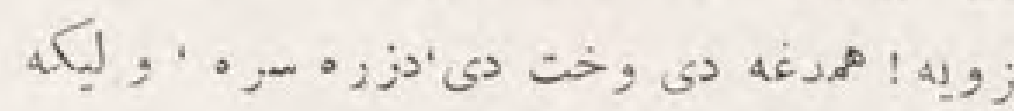

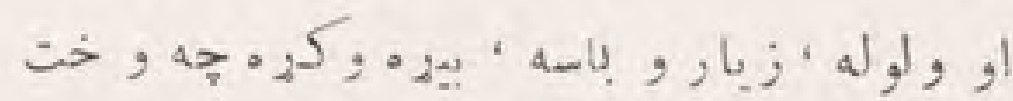

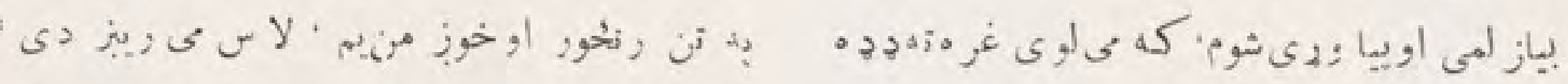


.

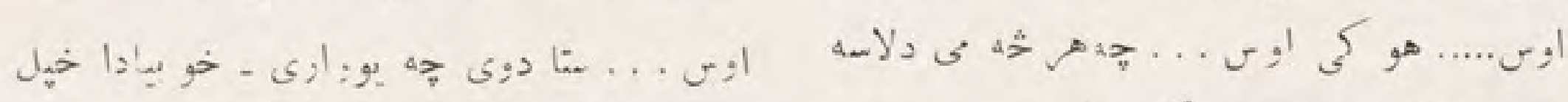

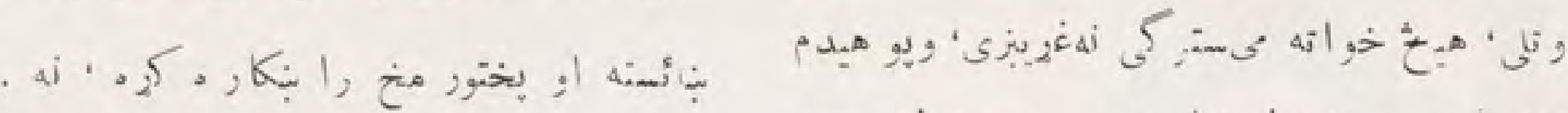

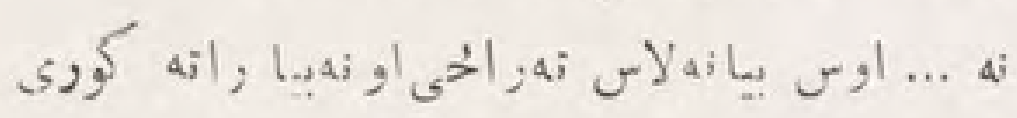

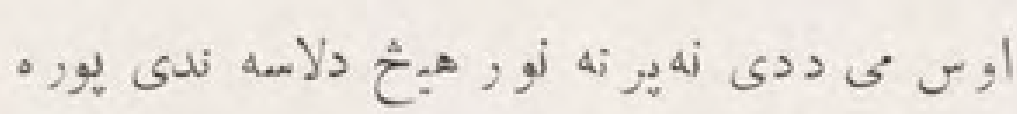

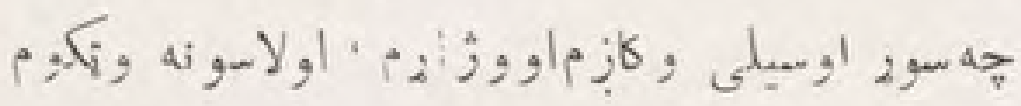

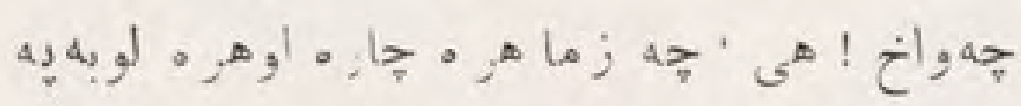

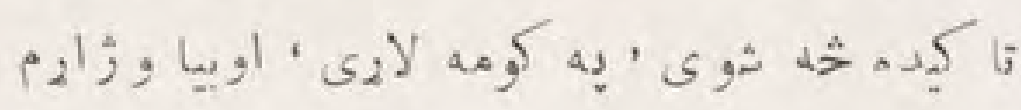

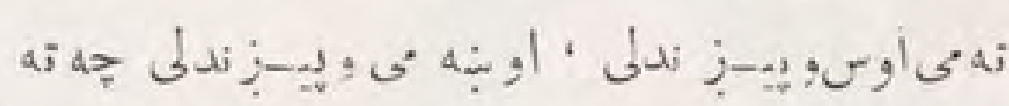

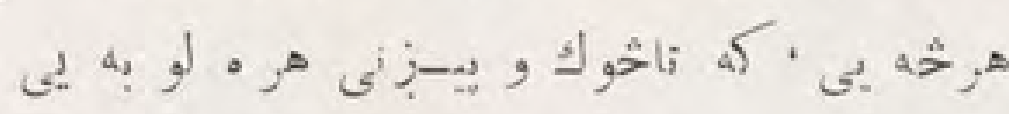

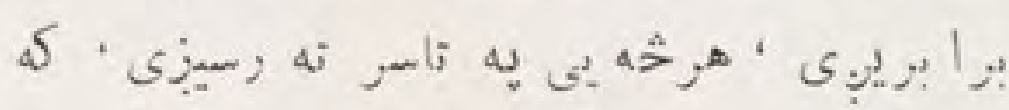

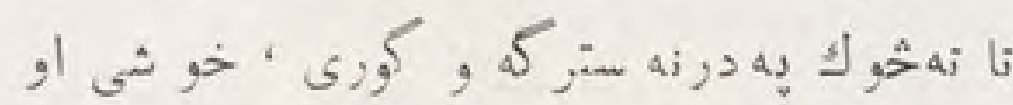

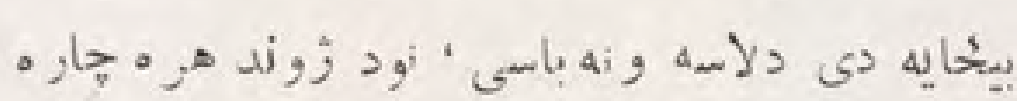

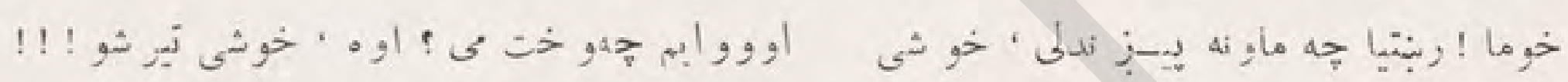

\section{जن}

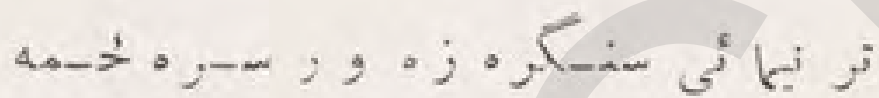

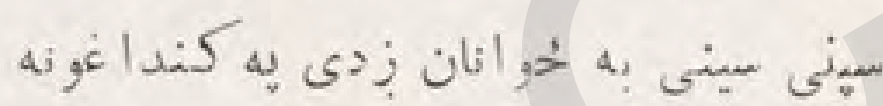

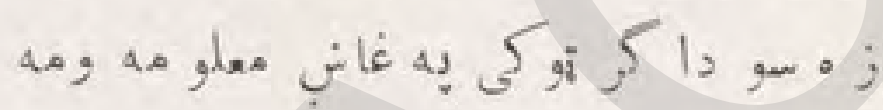

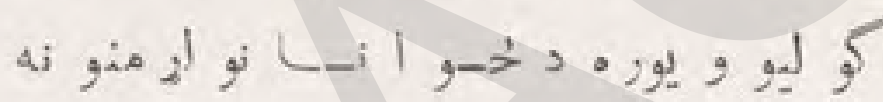

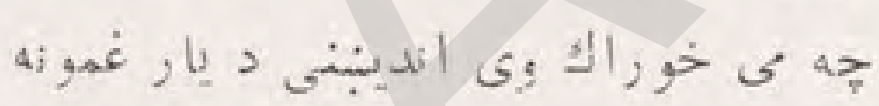

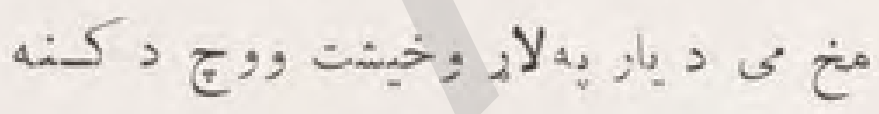

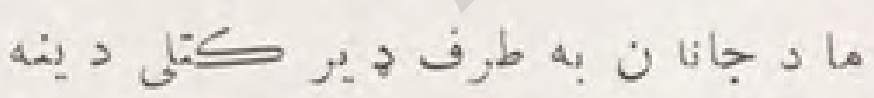

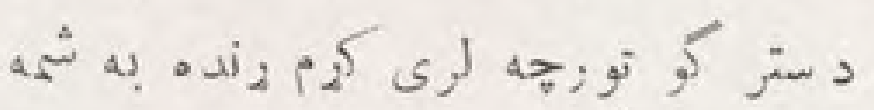
جه به ورو ورو د رانه و يلى صبـا شونه لونه
هـ

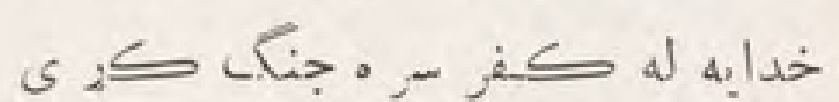

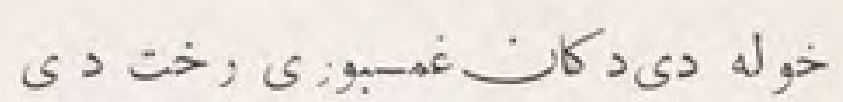
توريكو, بأناف

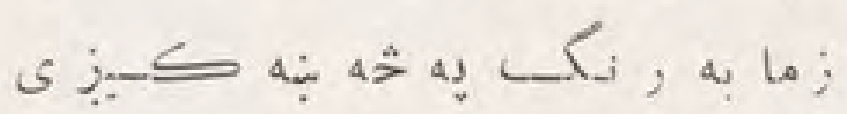

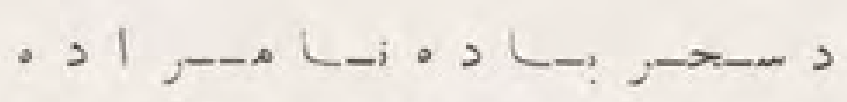

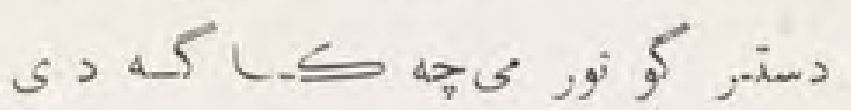

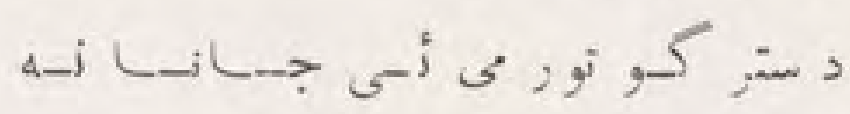

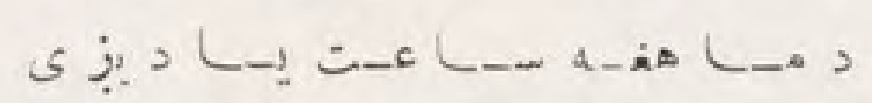

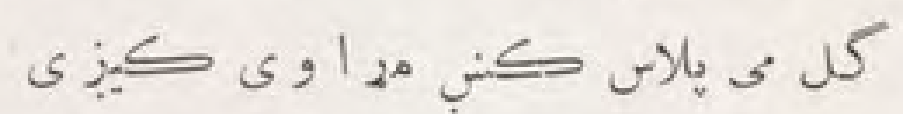

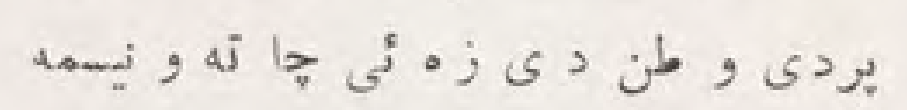

تولو ونكى : شأيور خان حجبيبى متعلم 


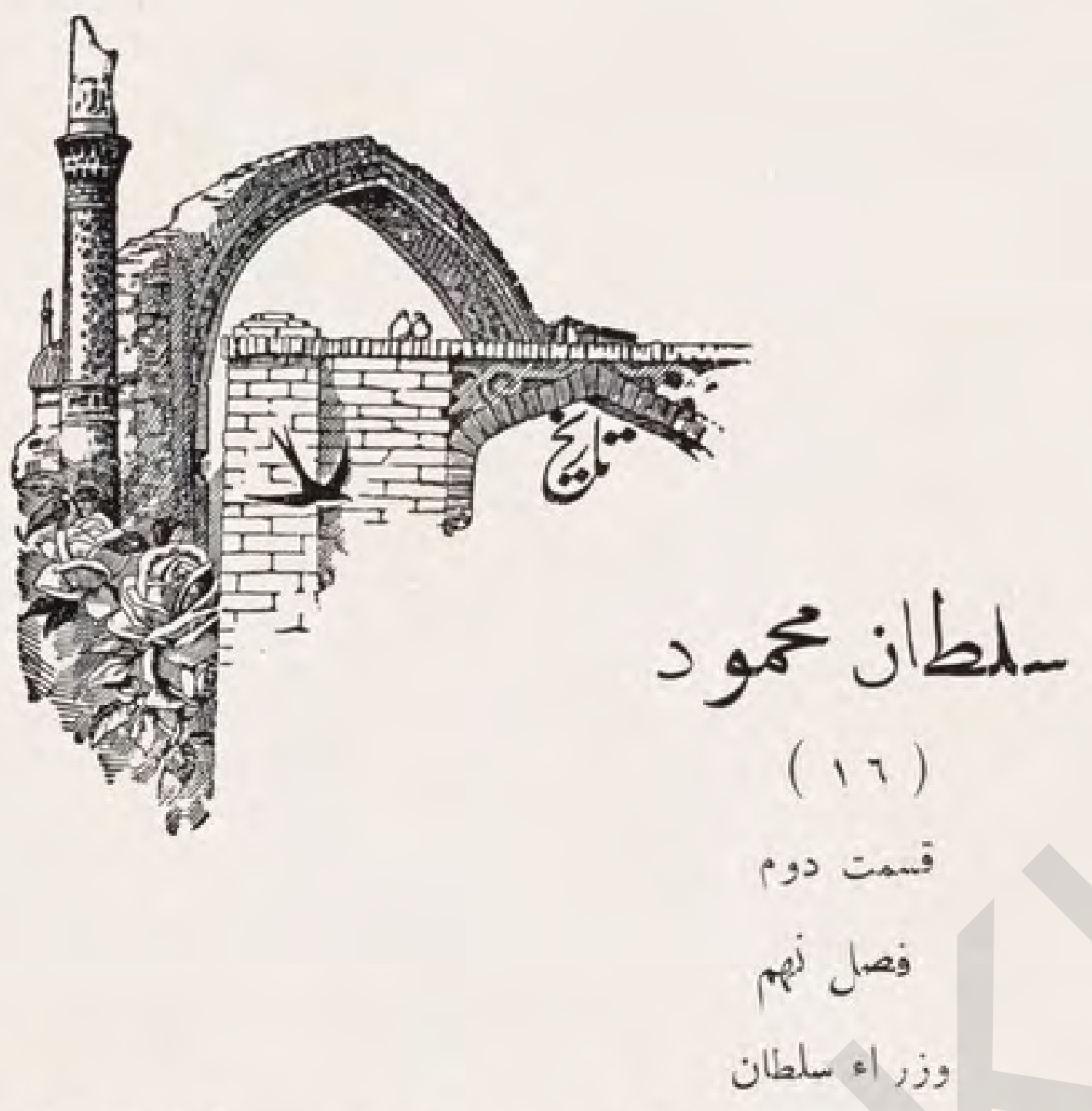

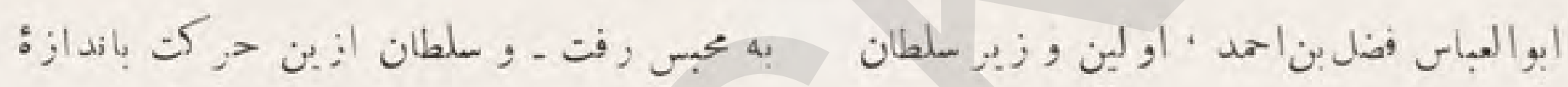

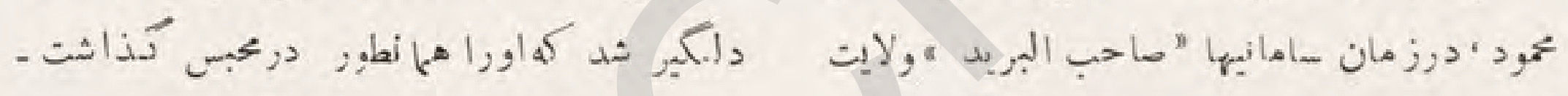

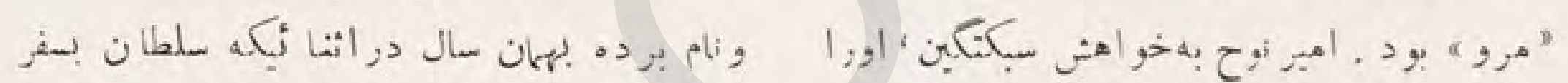

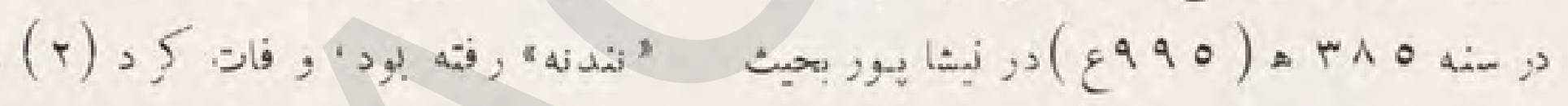

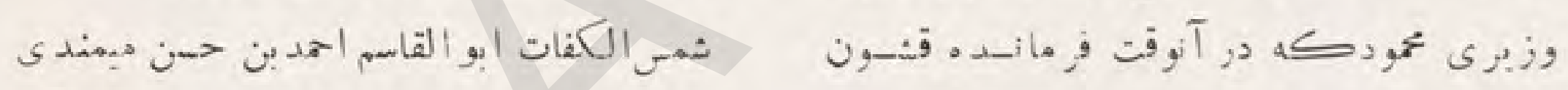

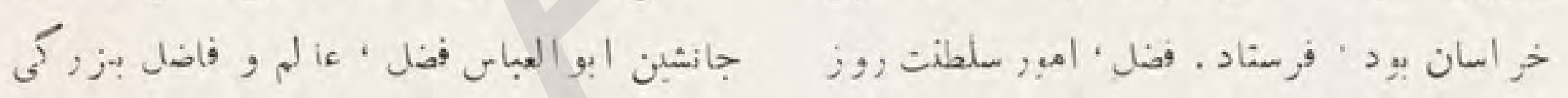

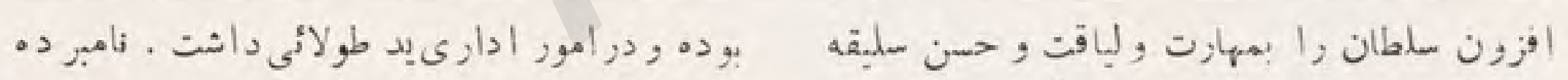

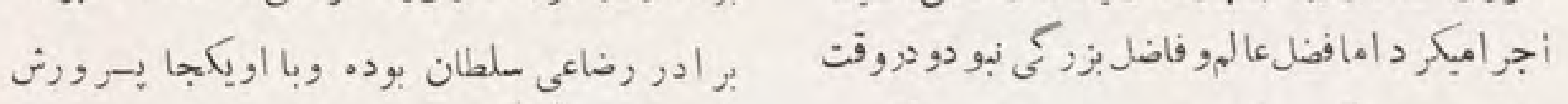

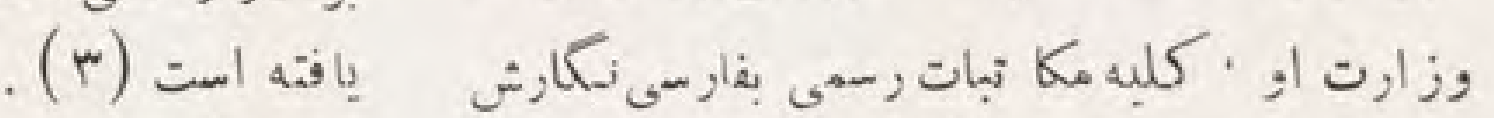

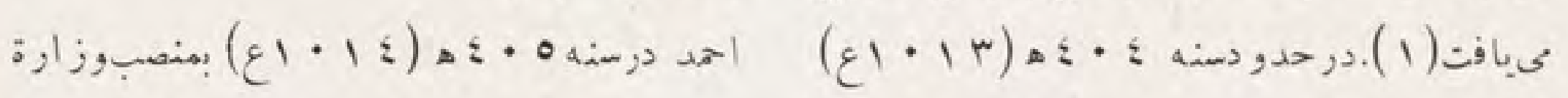

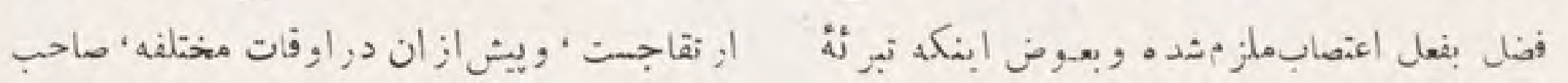

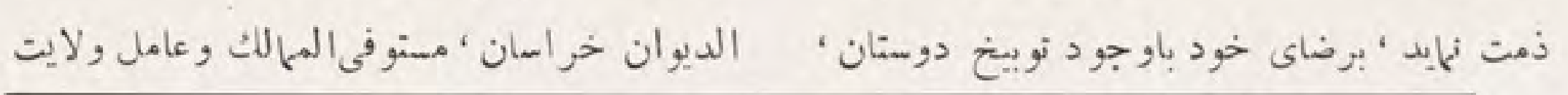

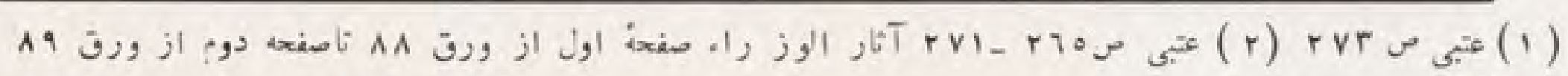
A 1 (r) 


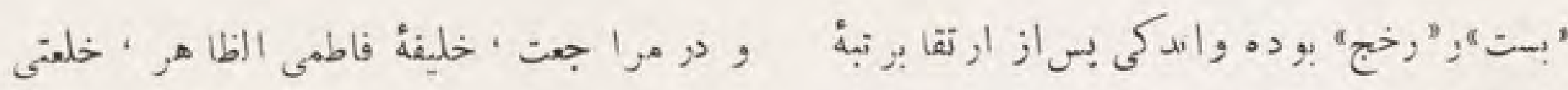

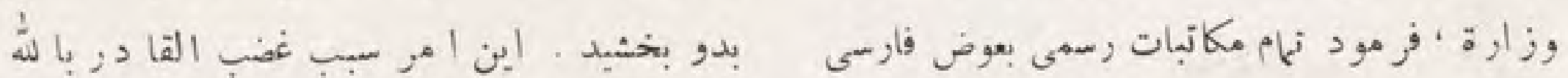

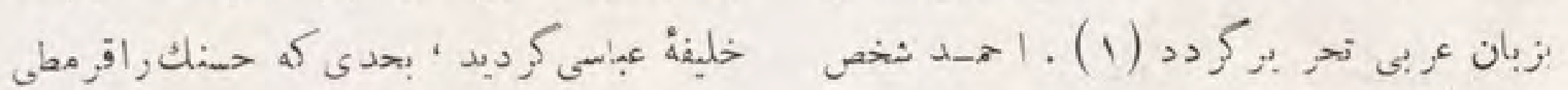

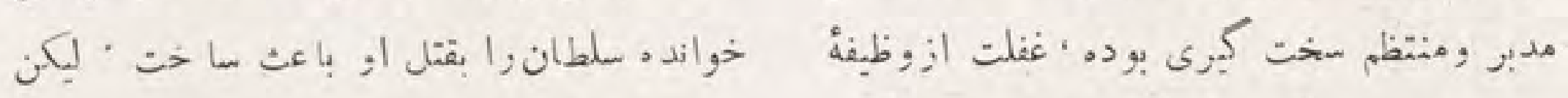

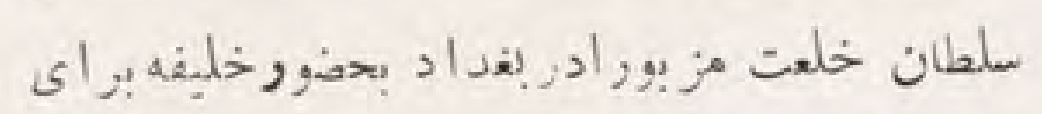

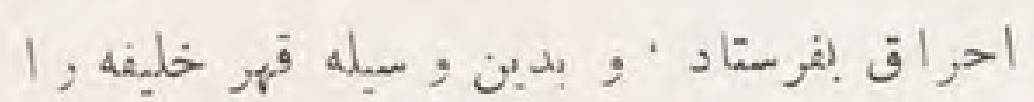
(a)

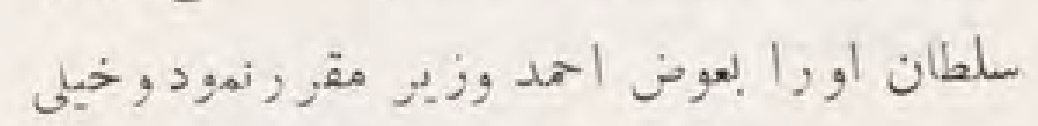

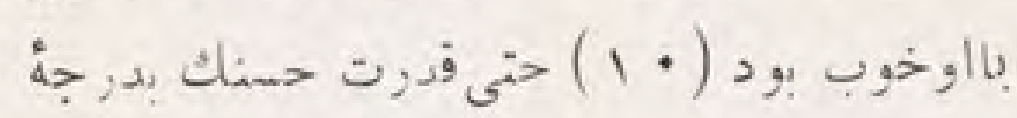

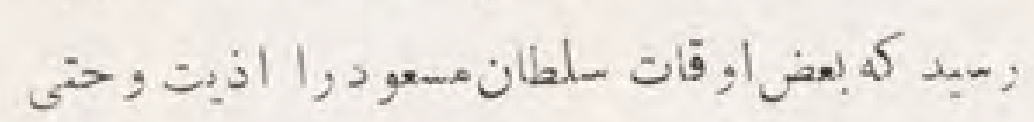

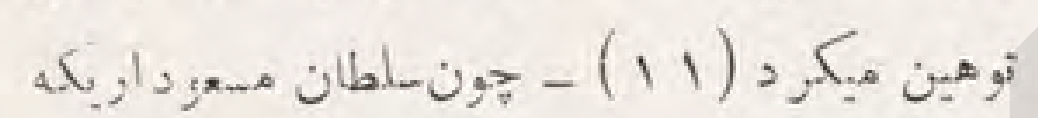

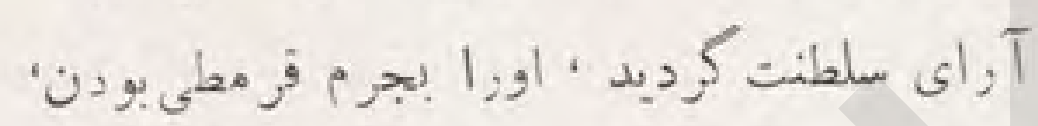

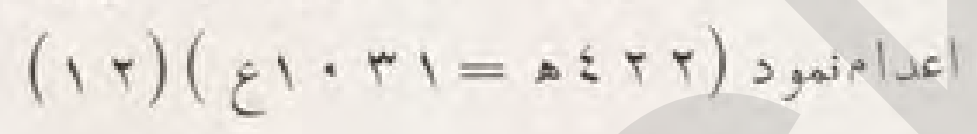
عارص وصلاحتت وى

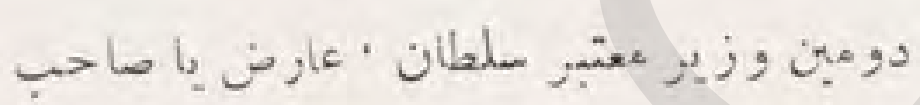

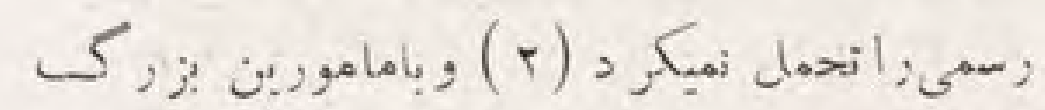

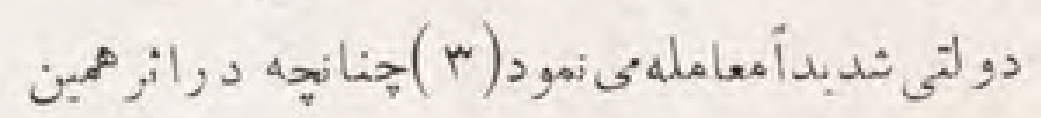

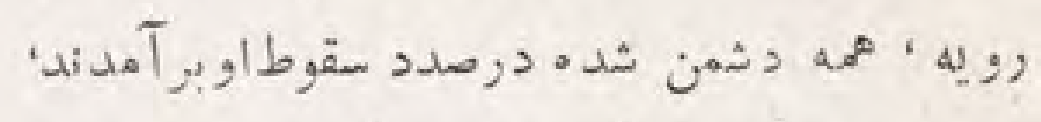

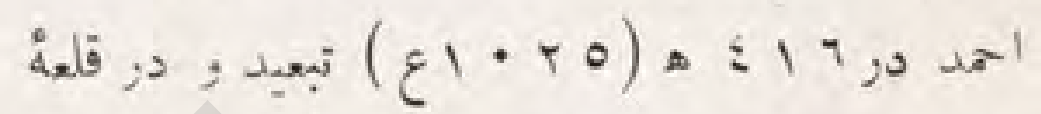

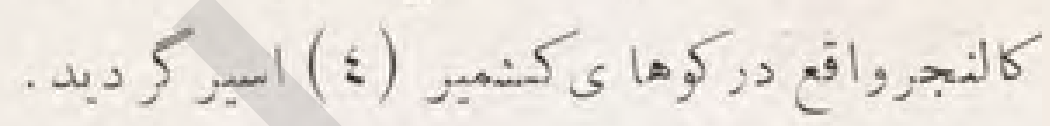

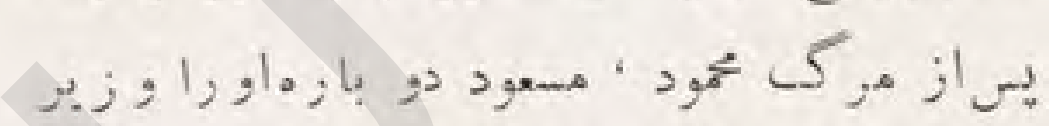

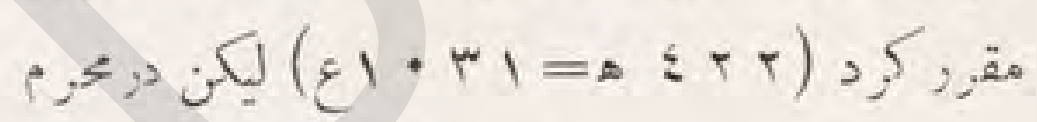

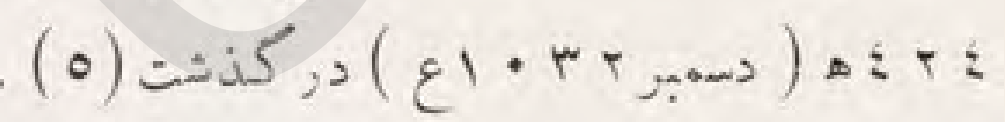
الحمد فأضل معرو في بودمو بعضى از أصويبات

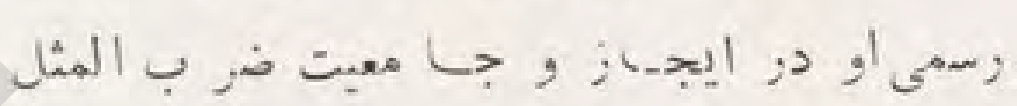

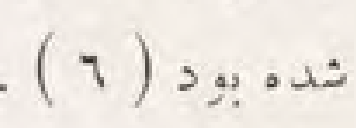

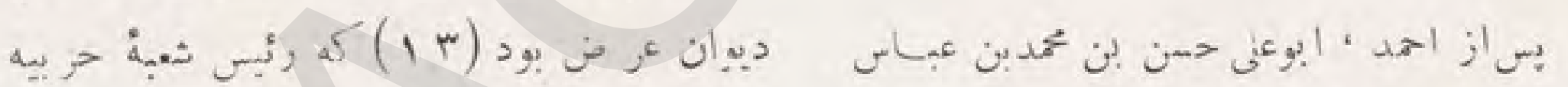

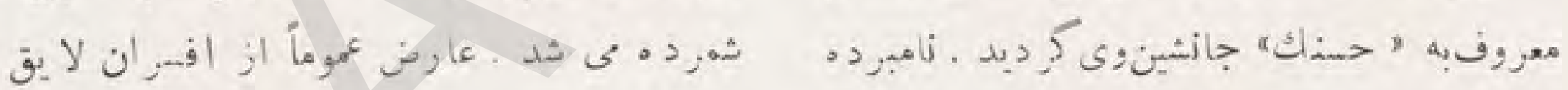

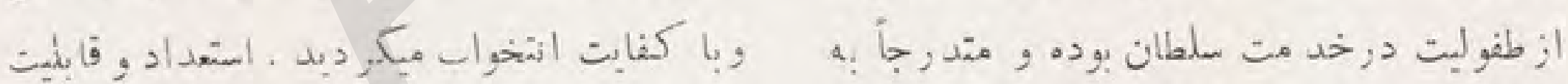

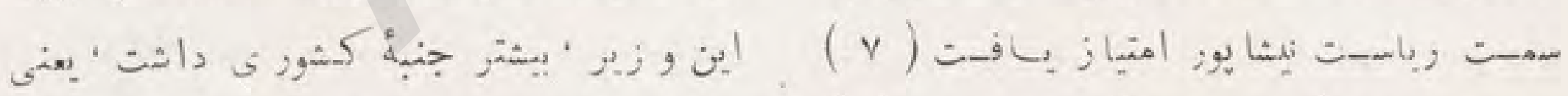

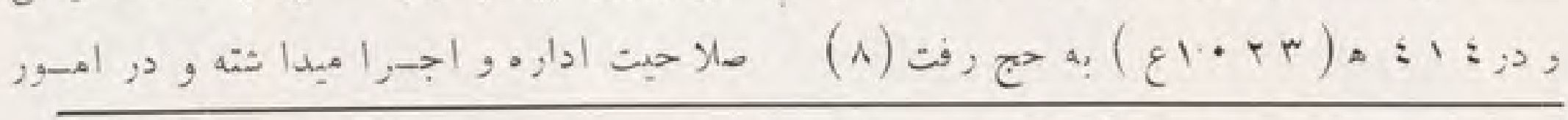

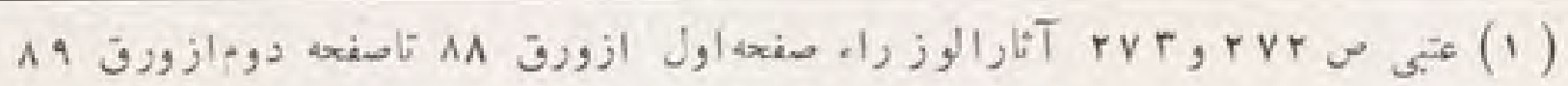

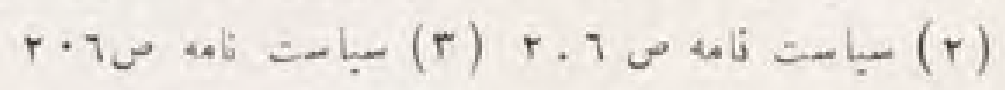
ra

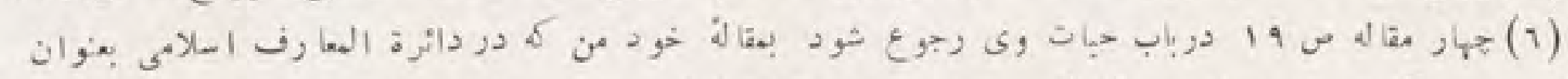

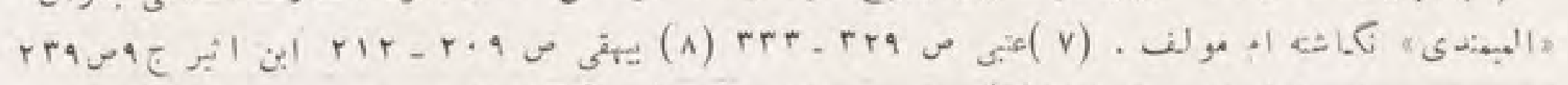

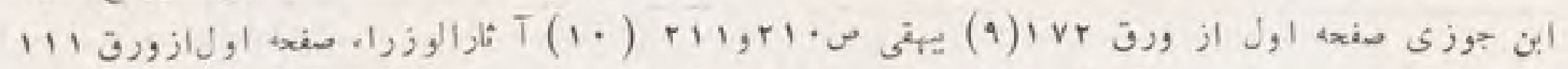
(1)

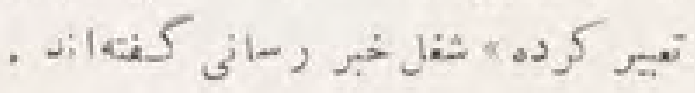




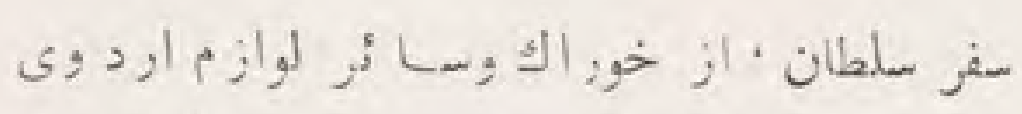

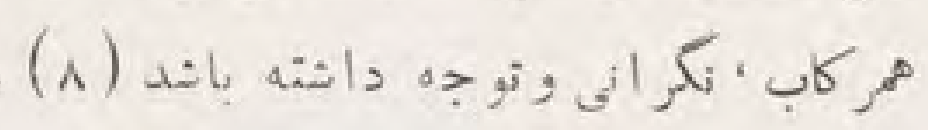

وظايف عارض بو قت جنا

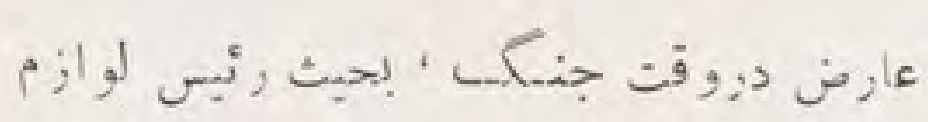

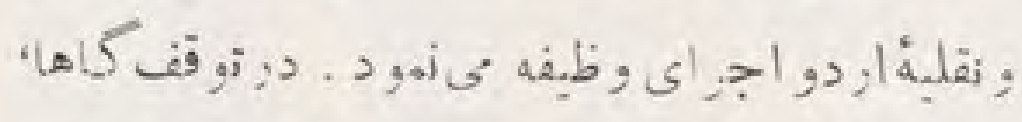
اسمباب نسهيات قشون را از قسميم آذوقه وروسائل

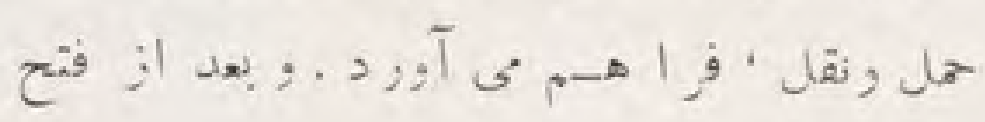

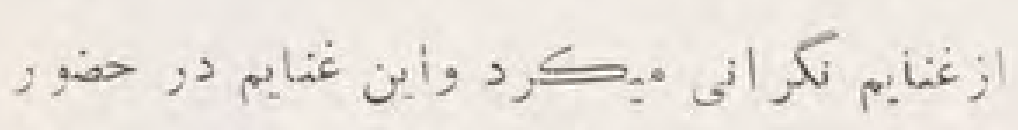

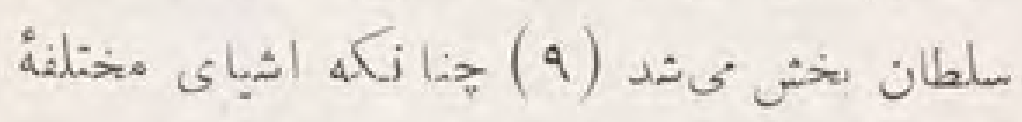

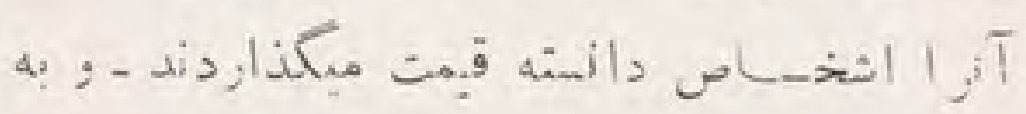

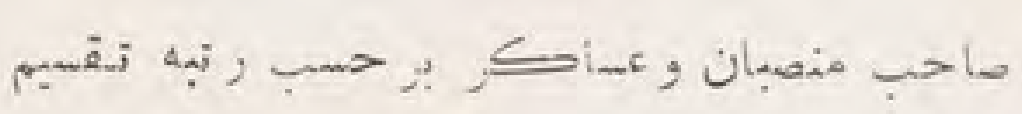

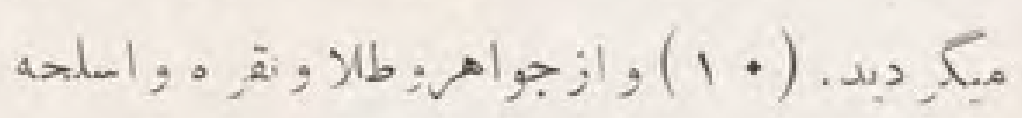

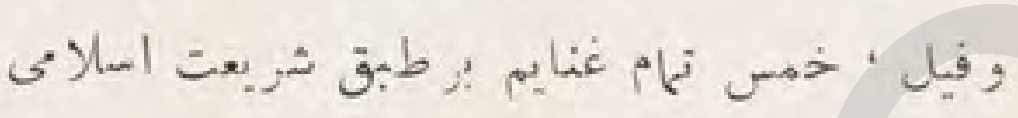
بسلطان iعلق ميكر فت (1 1) . وَشَون

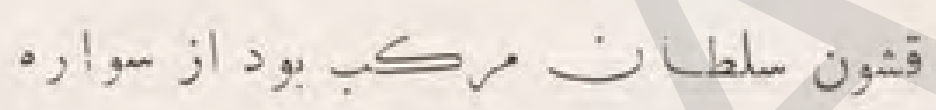

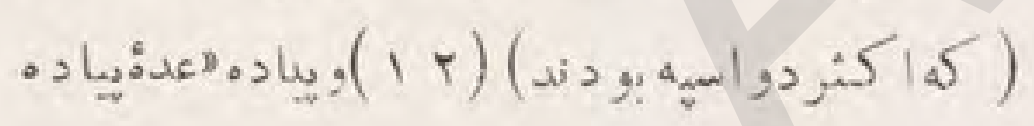

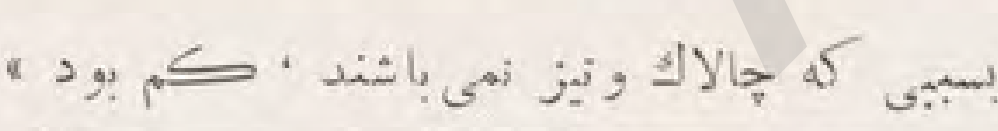

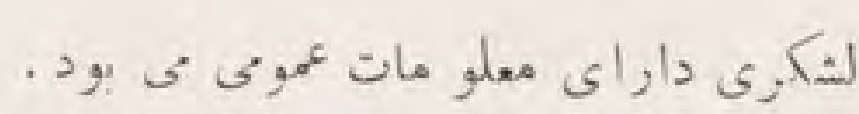
وظا ,ف عارض در و,ت صلح

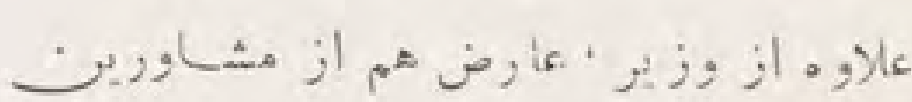

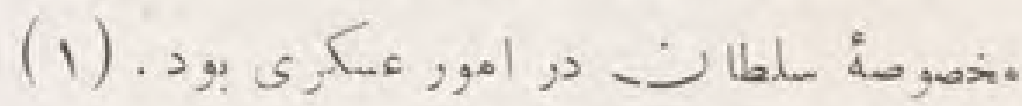

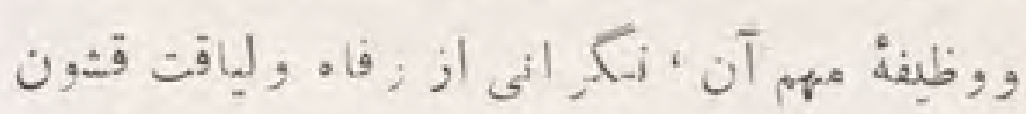

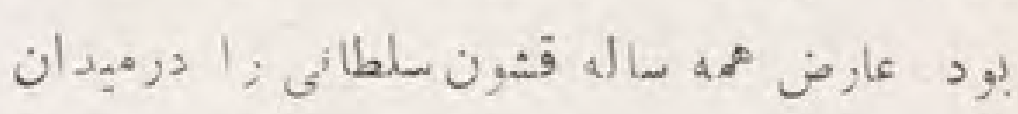

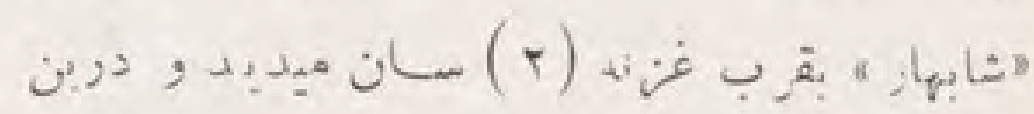

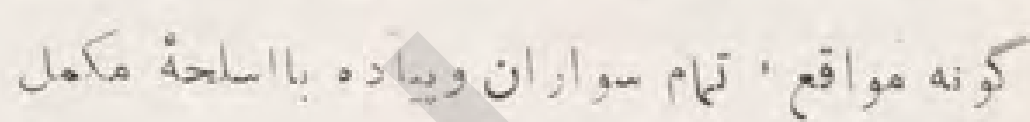

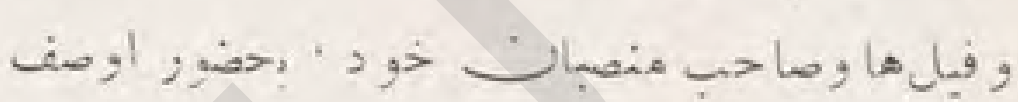

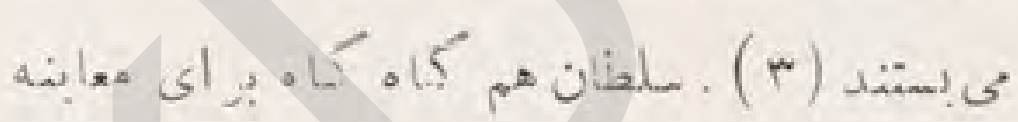

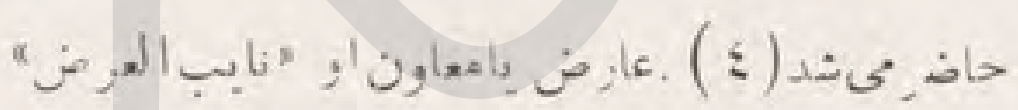

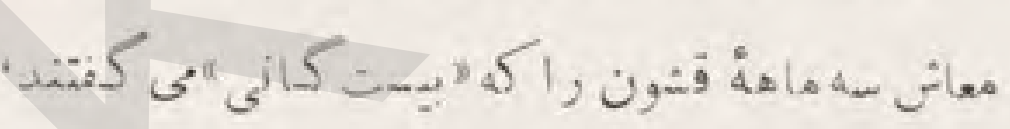

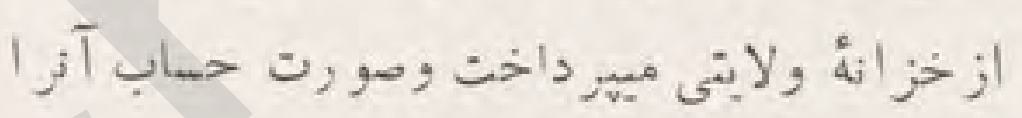

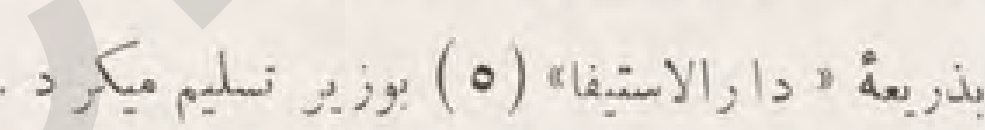

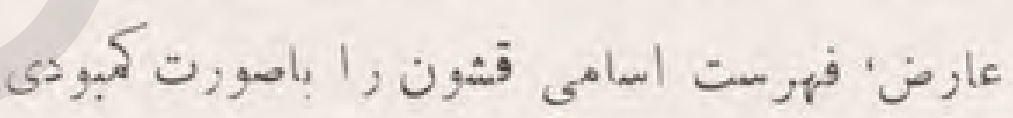

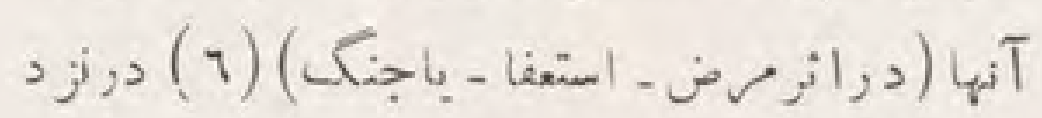
خود نكاه ميداشت وبك نسخه آنر ابه دار الثتحر.بر

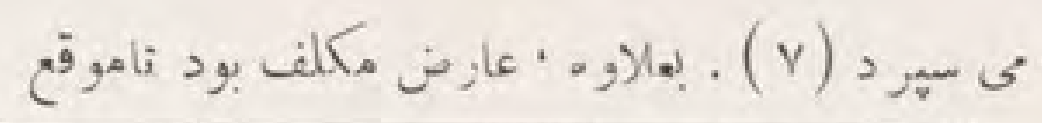

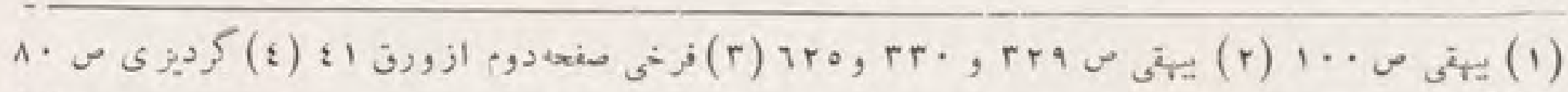

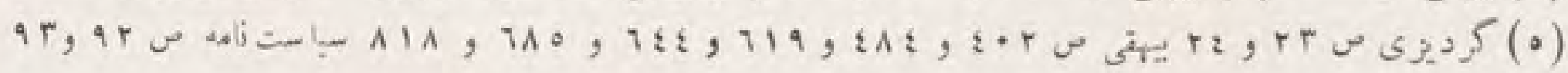

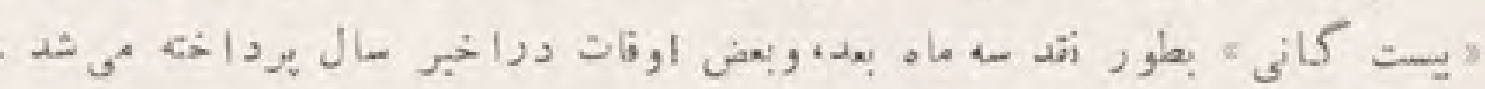

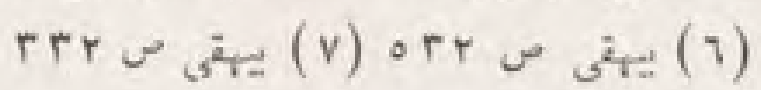

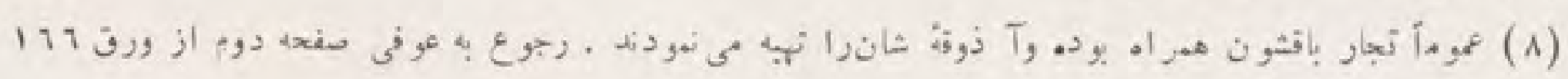

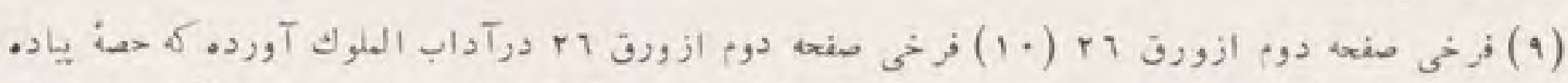

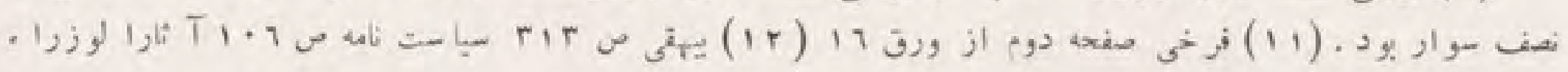




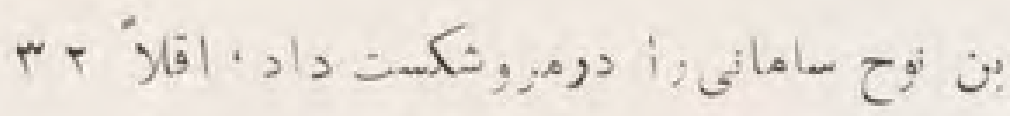

محا فظين شاهي وفيلها

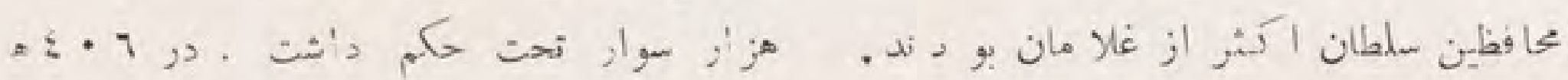

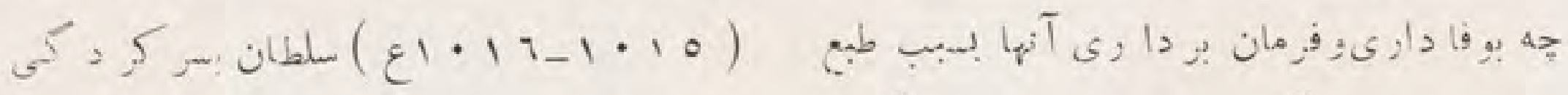

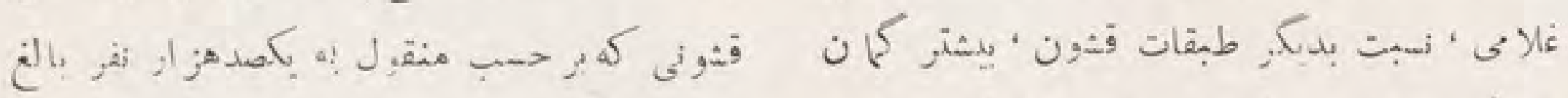

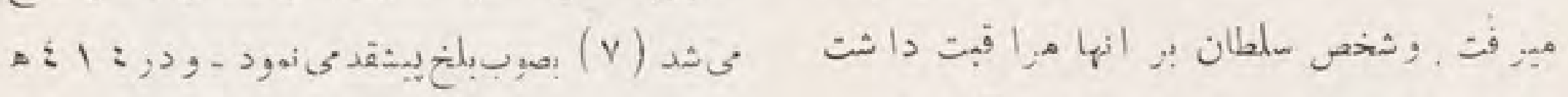

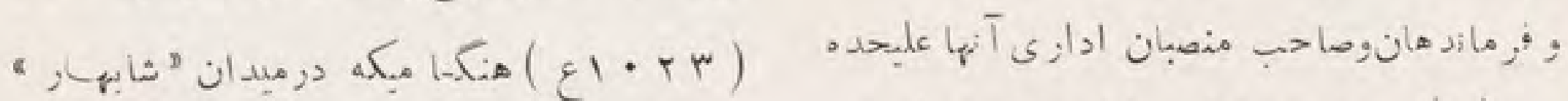

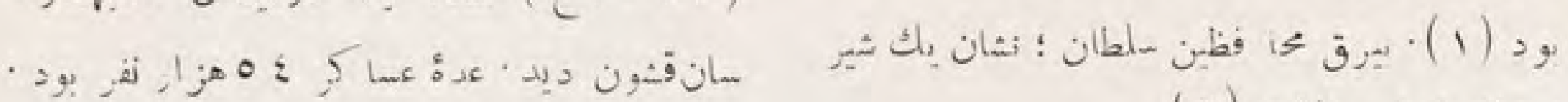

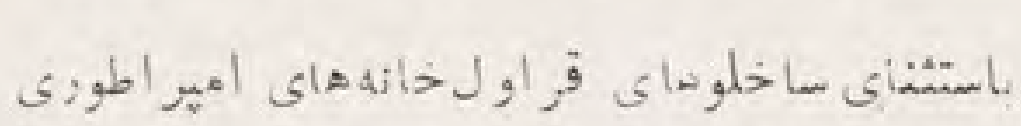

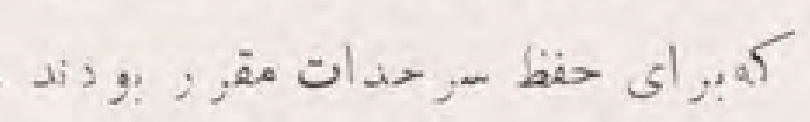

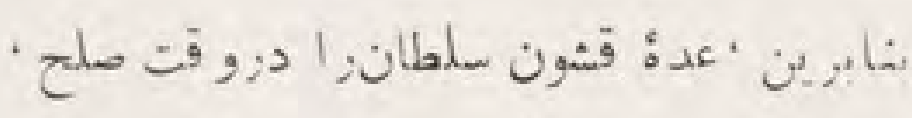

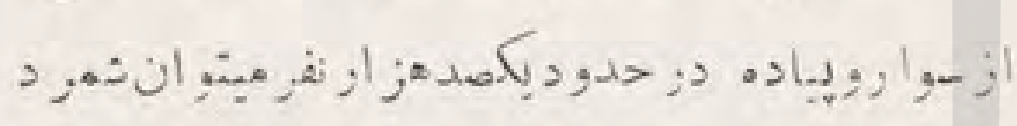
定 (r) فإلها ,

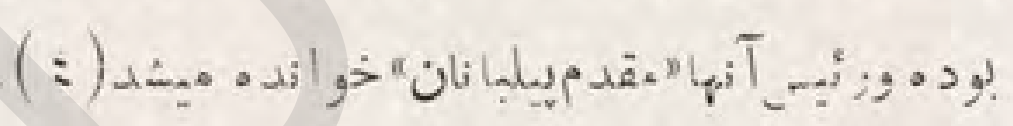

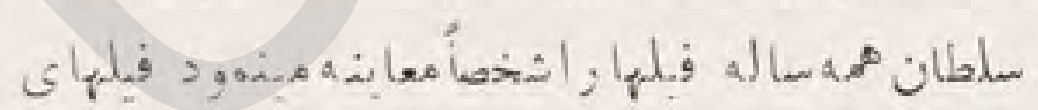

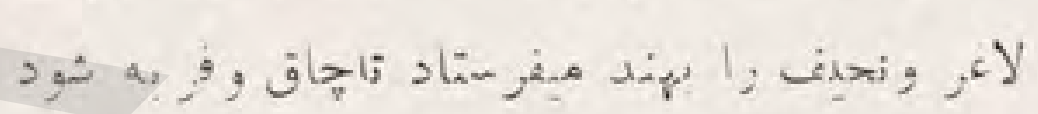

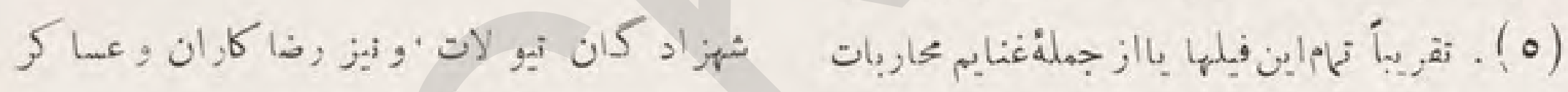

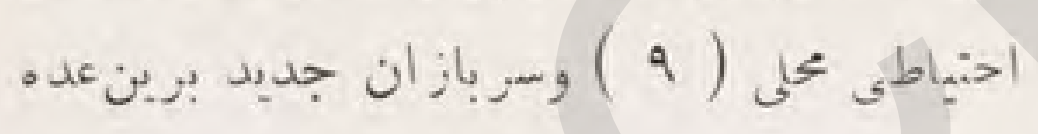

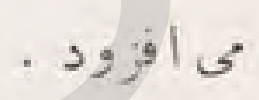

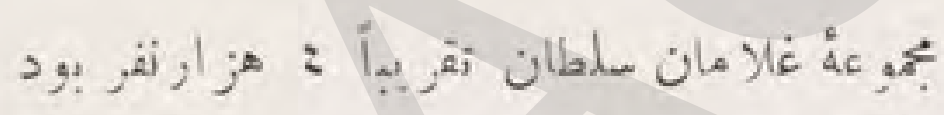

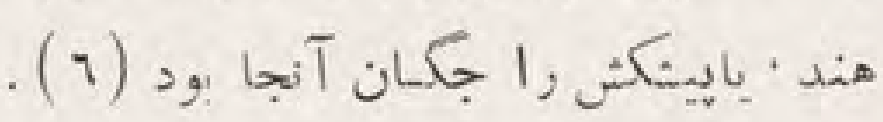
عدم: قدشون

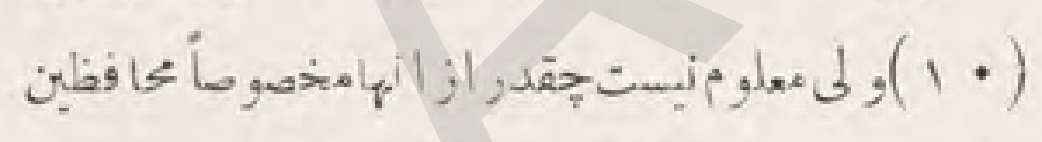

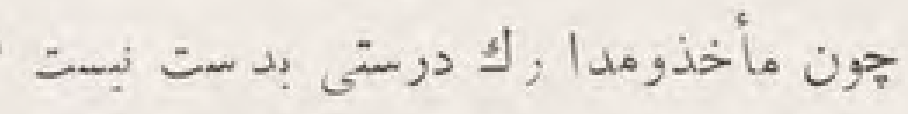

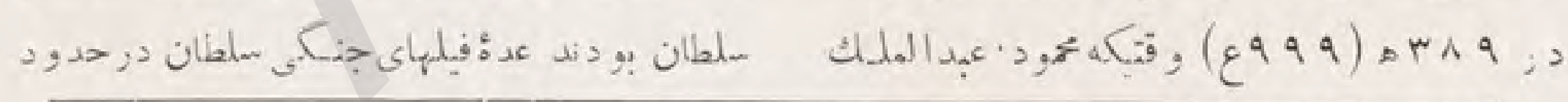

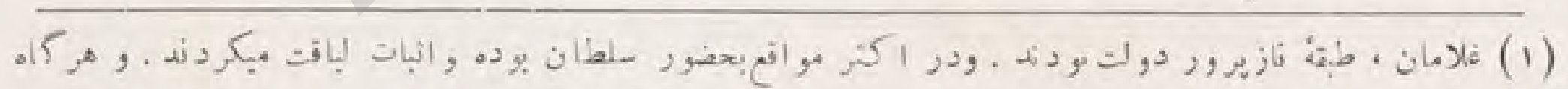

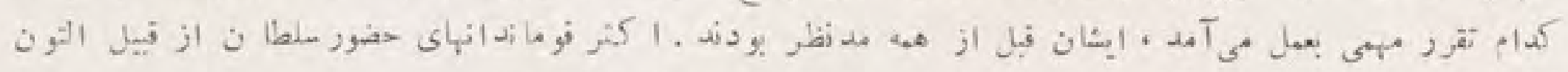

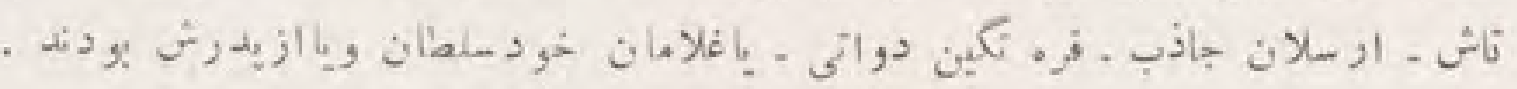

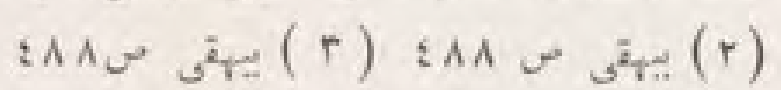

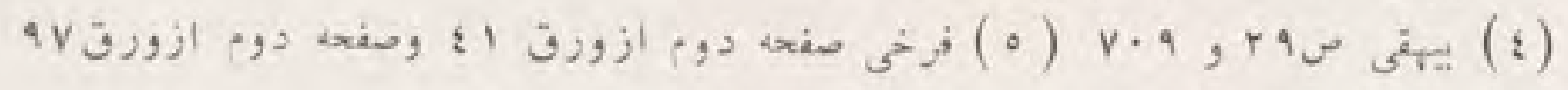

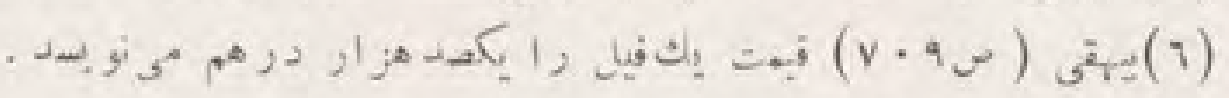

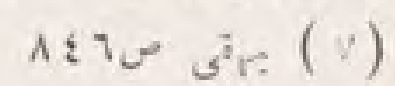

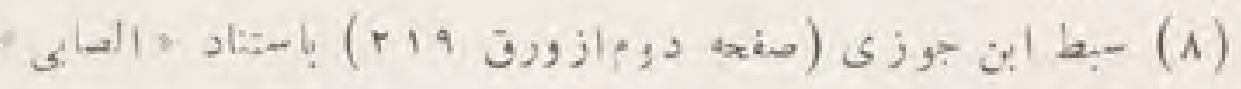

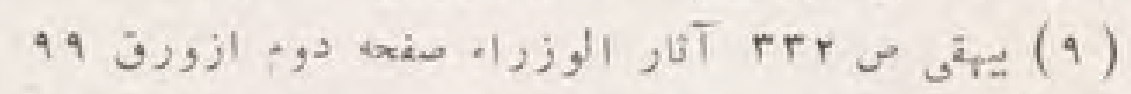

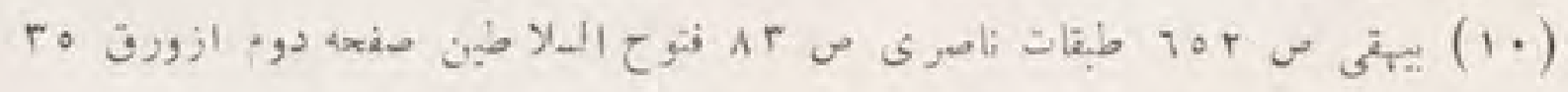




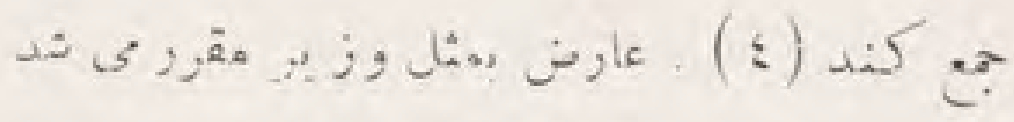

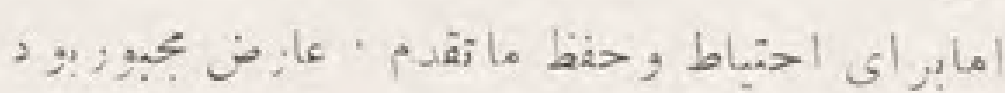

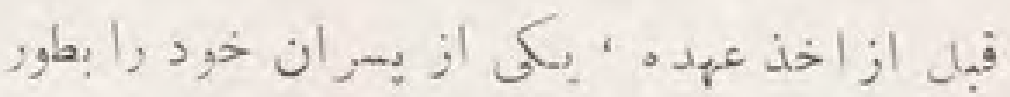

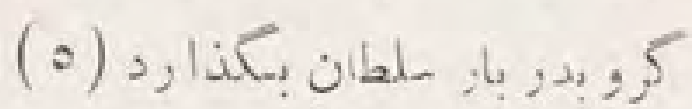

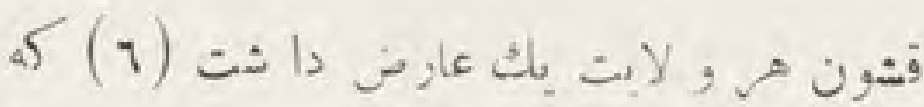

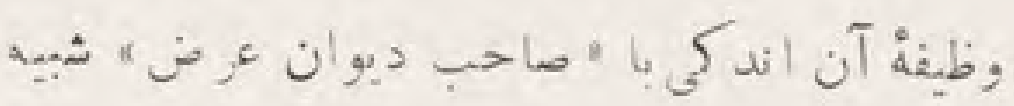

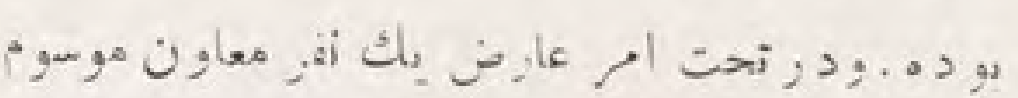

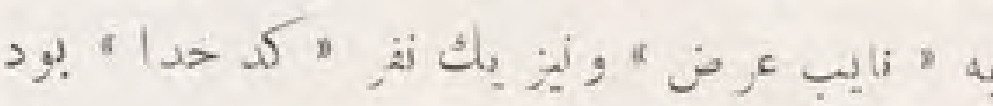

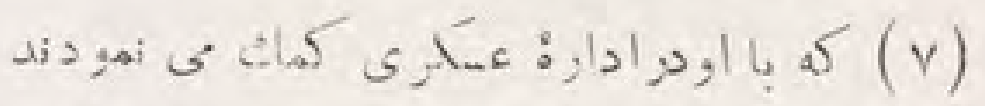

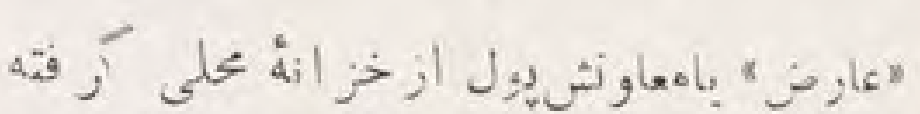

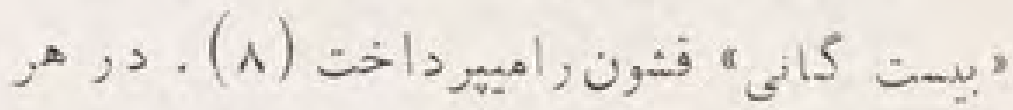

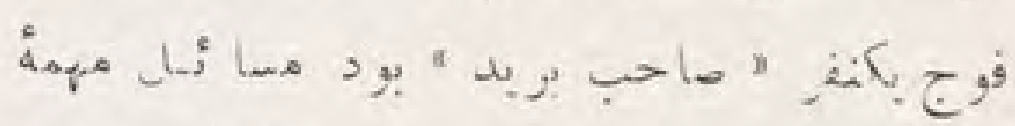

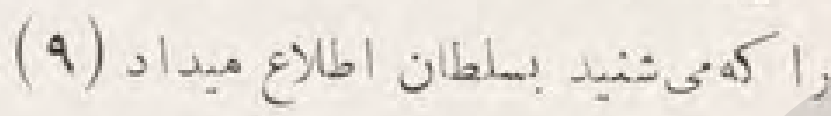

خدما تع عكرى جند در جه دا شت : بٕست

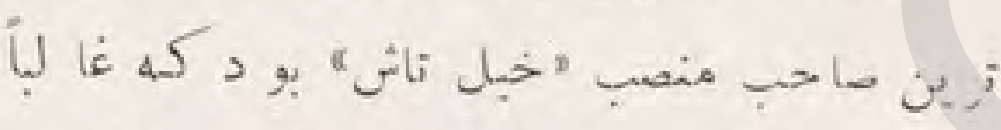

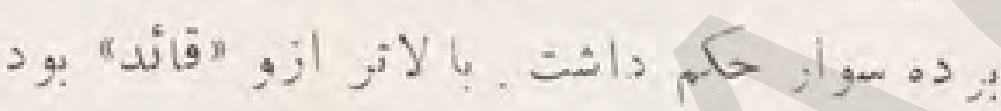

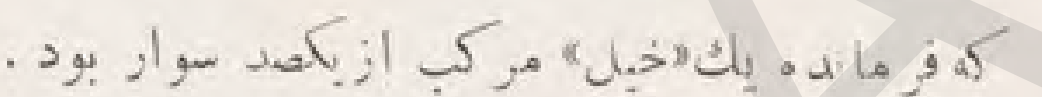

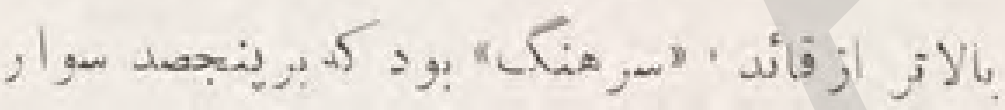

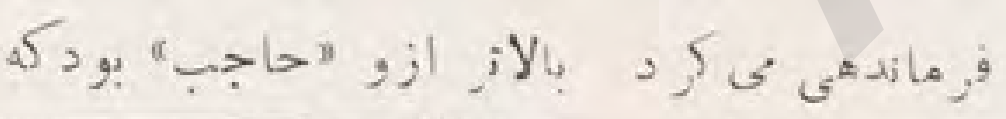

(1) $=2,1 \times \cdots$

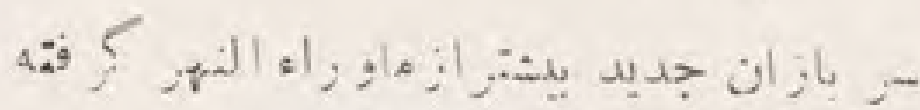

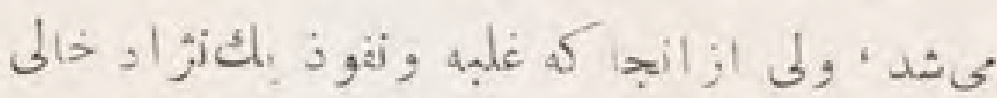

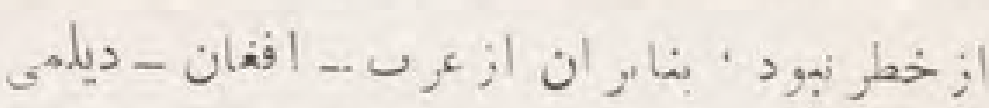

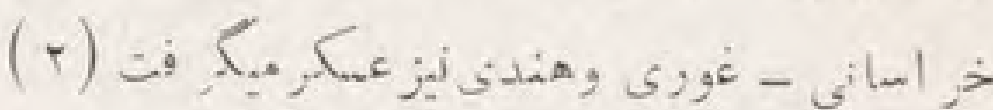

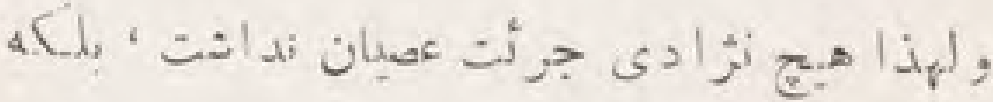

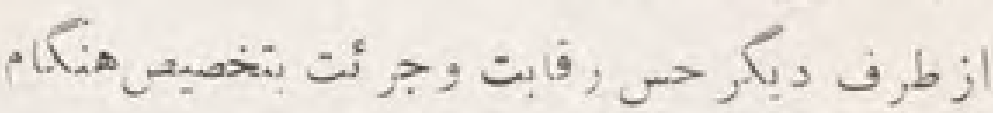

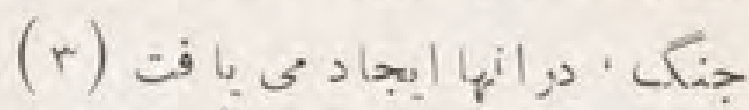
نظام وراد ارؤ قشون

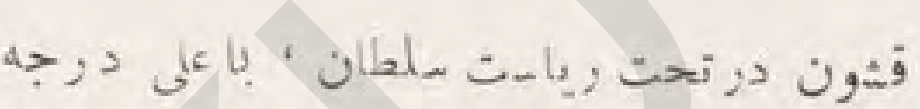

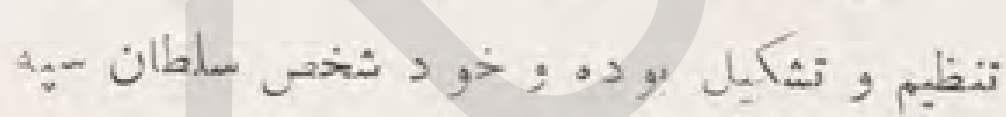

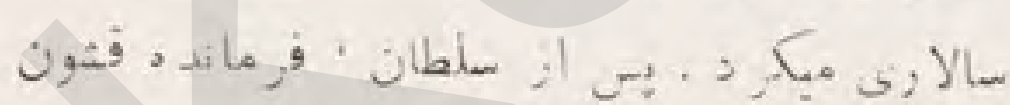

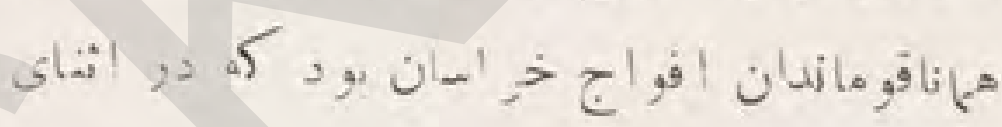

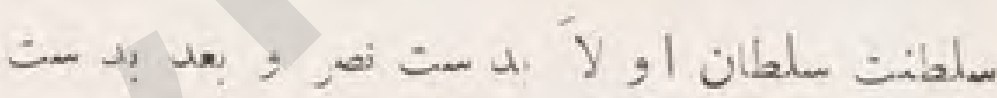

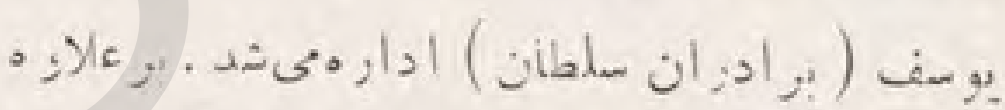

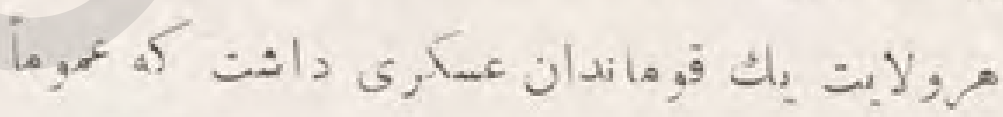

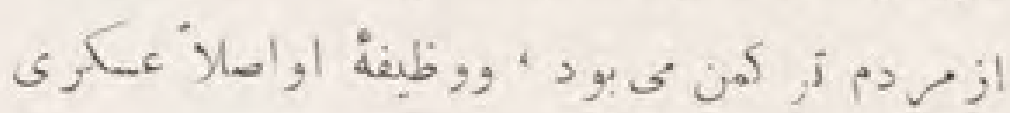

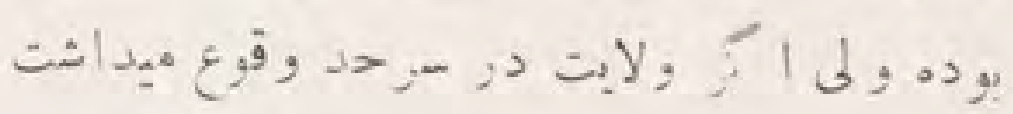

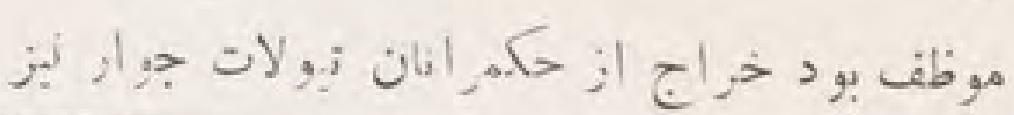

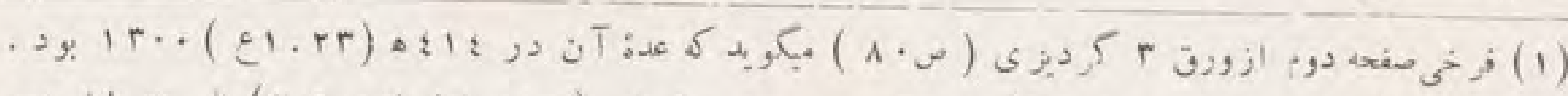

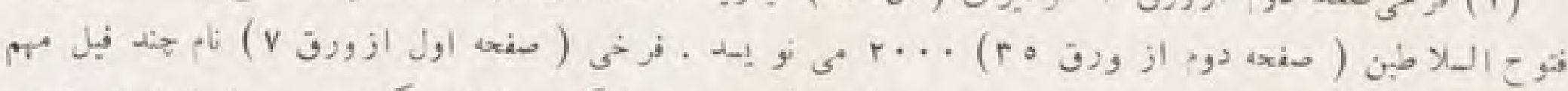

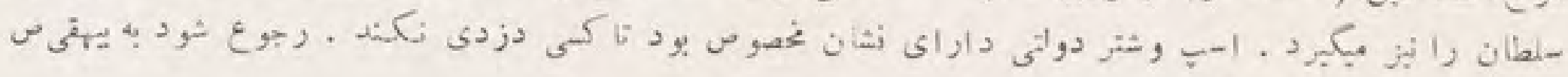

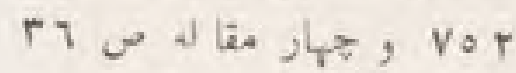

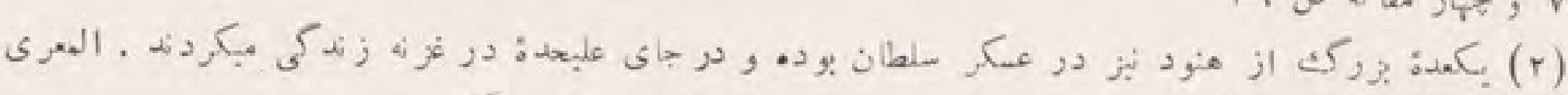

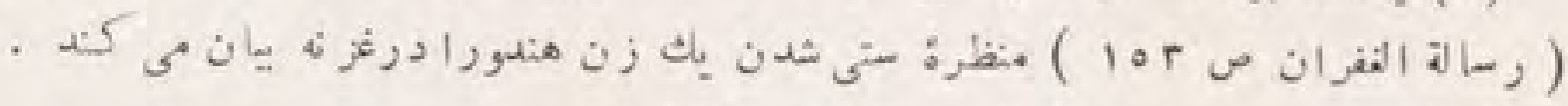
IVT

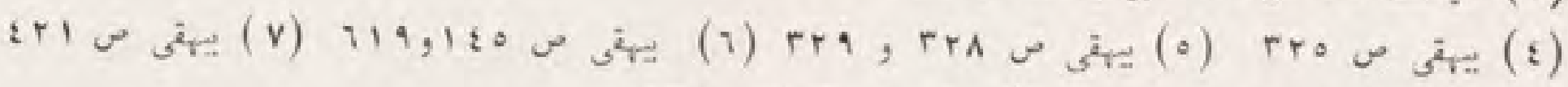

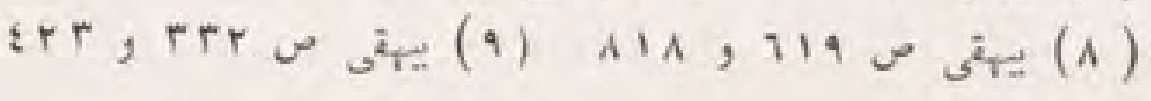




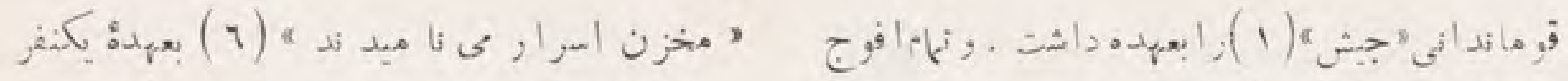

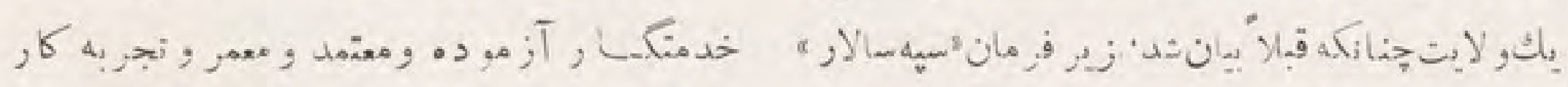

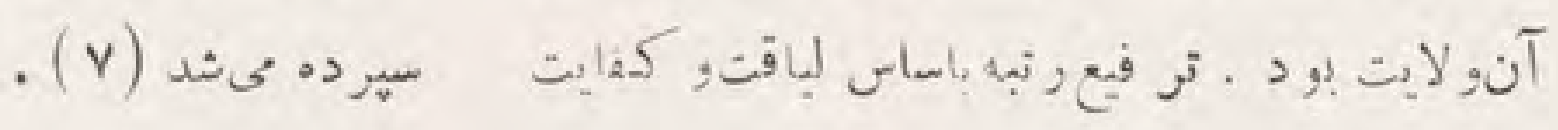

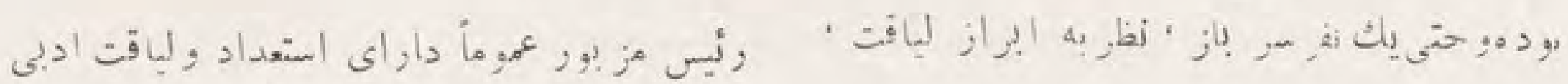

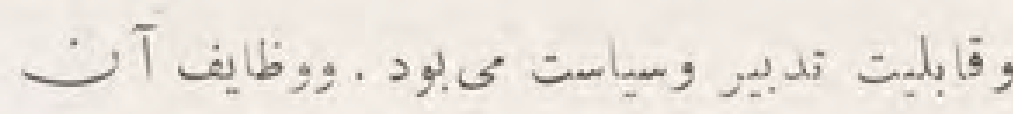

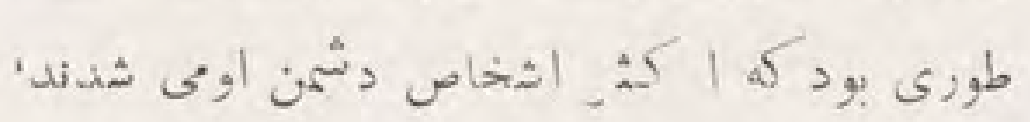

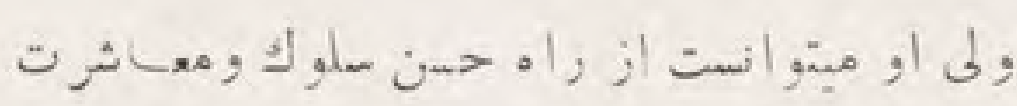

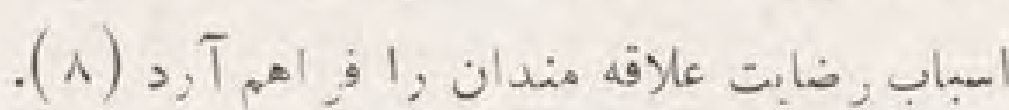

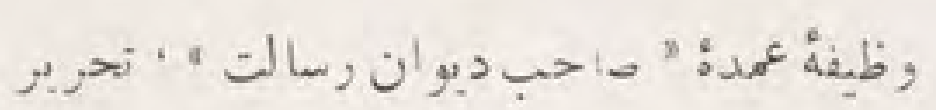

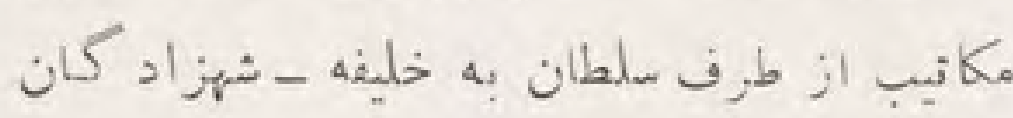

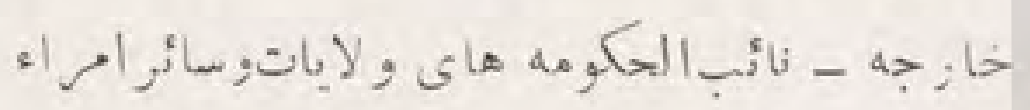

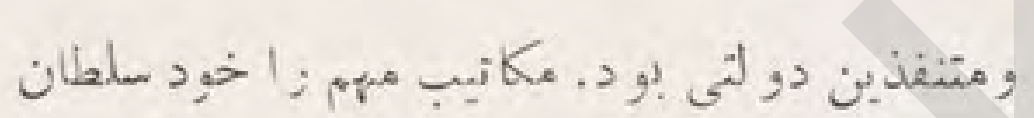

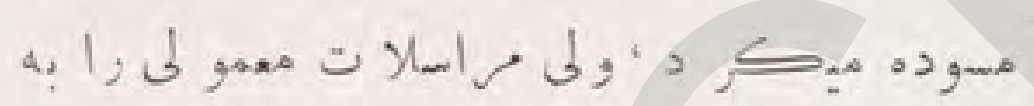

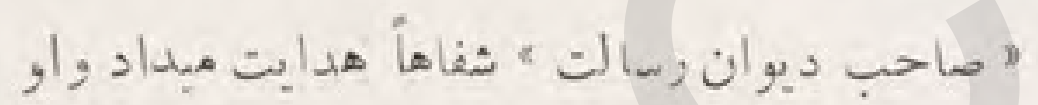

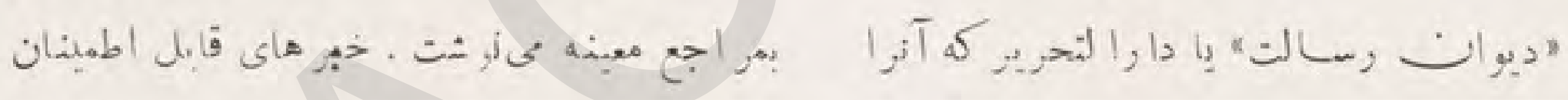

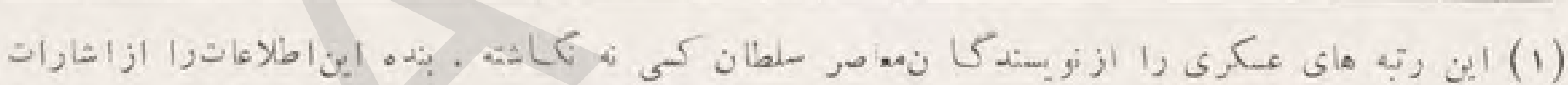

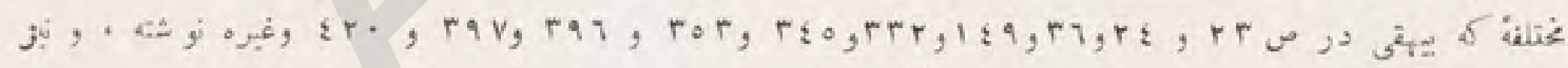

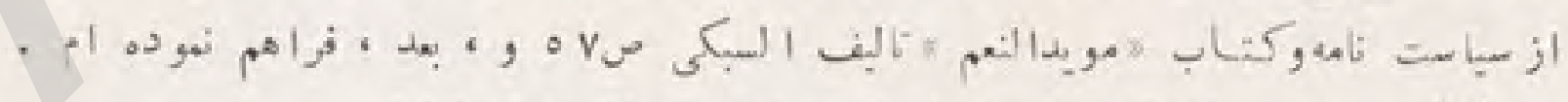

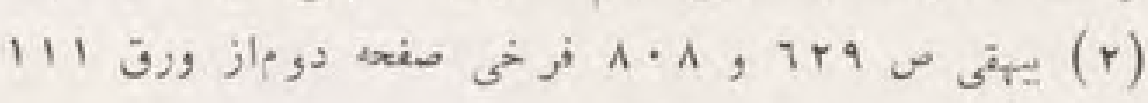
r

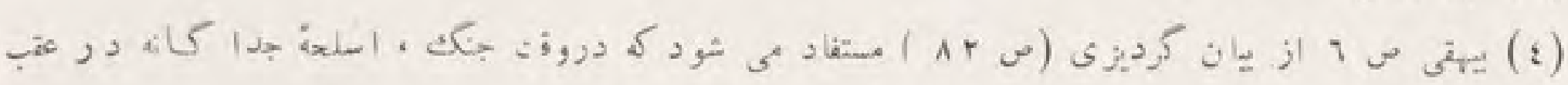

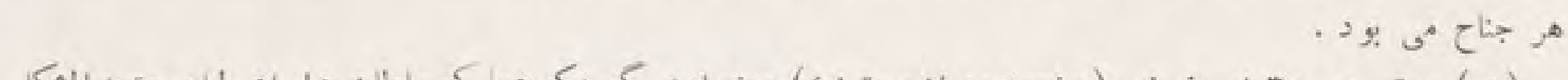

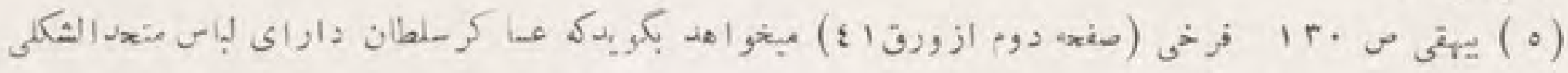

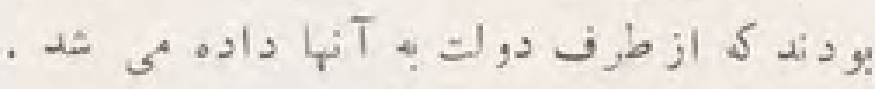

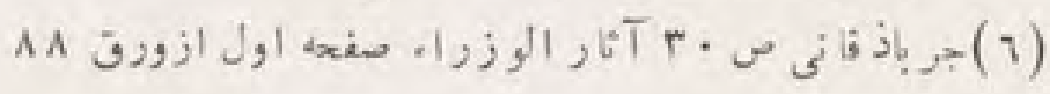

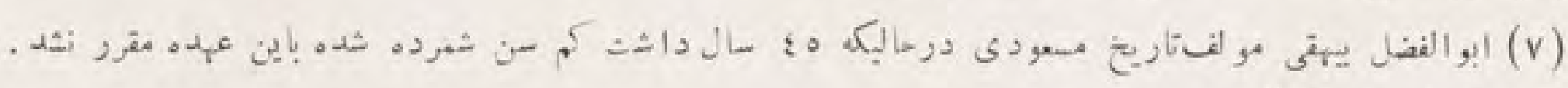

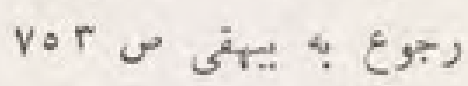

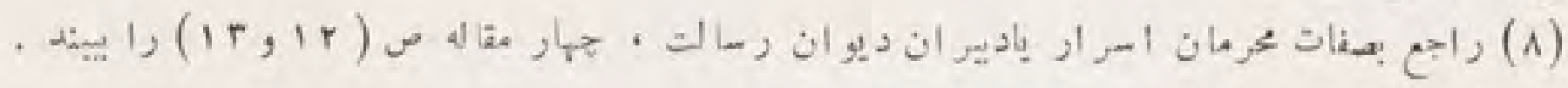




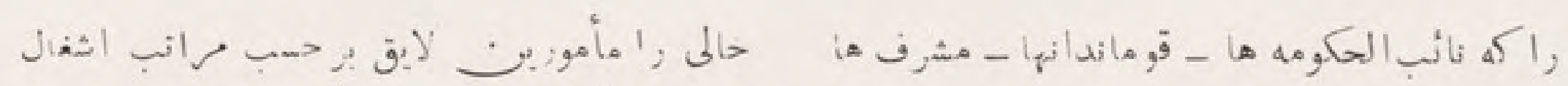

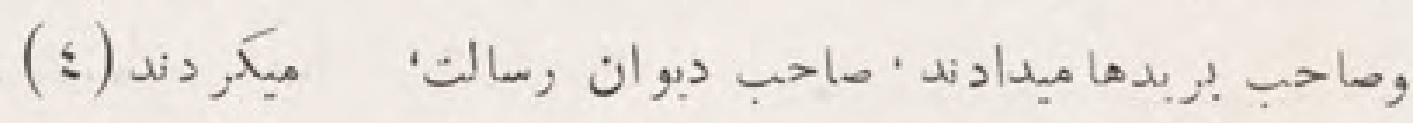

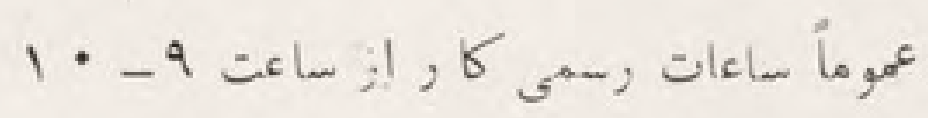

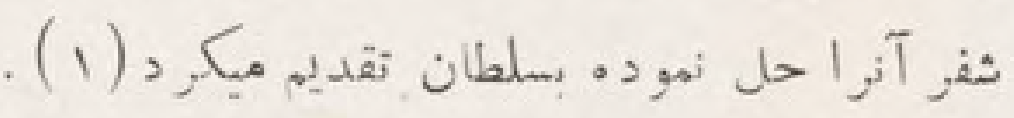

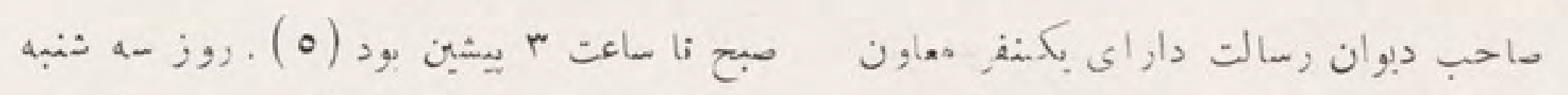

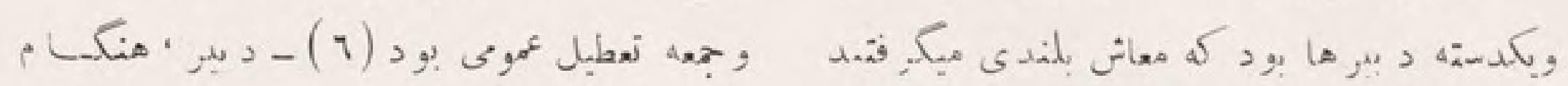

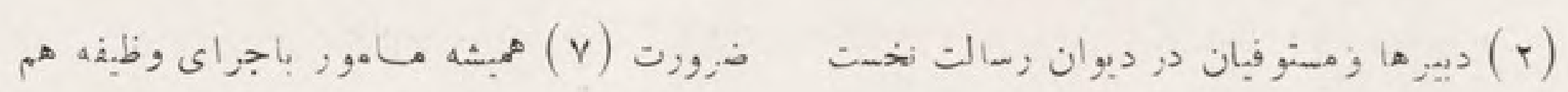

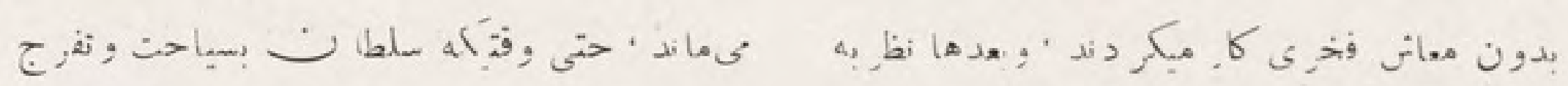

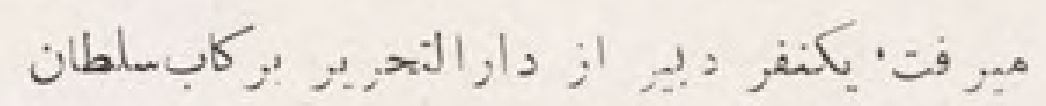

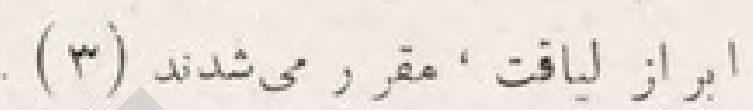

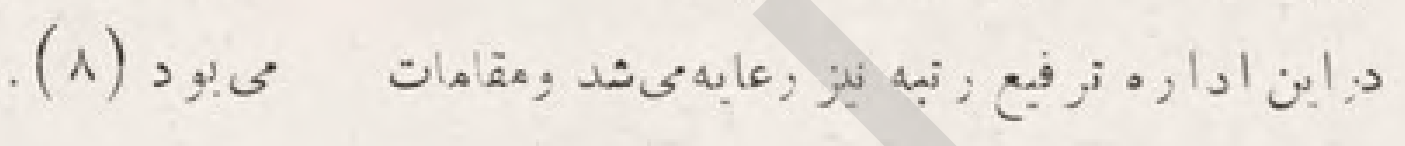

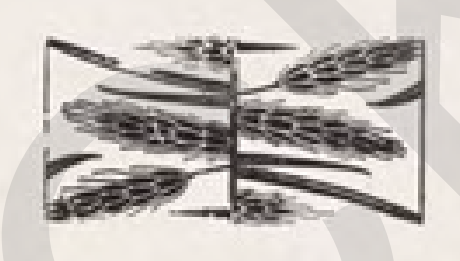

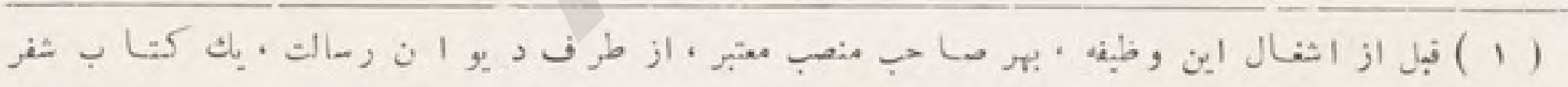

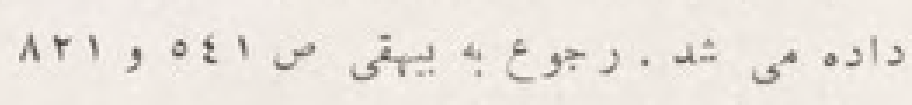

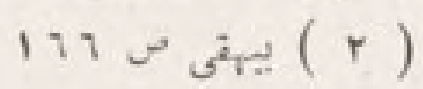
117 (r) (r)

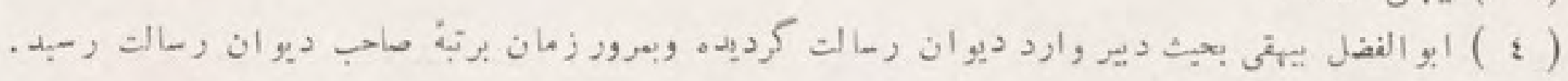

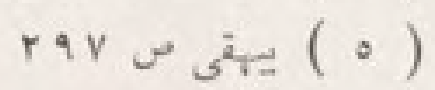

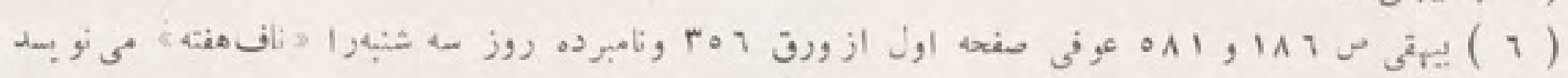

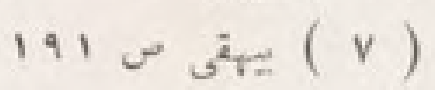

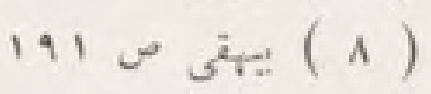




\section{in

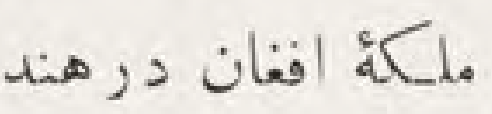

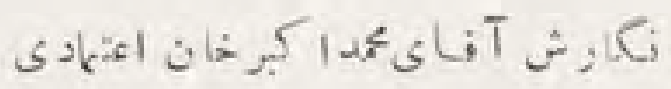

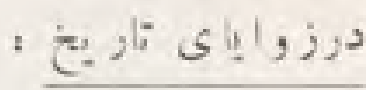

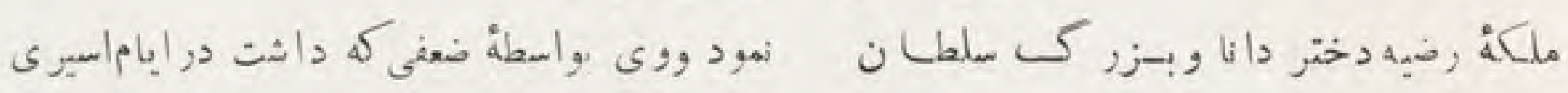

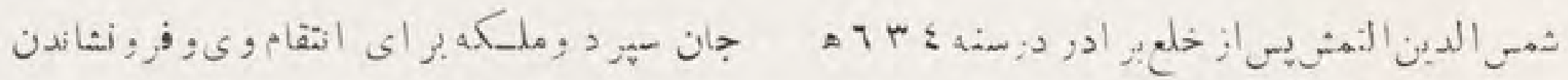

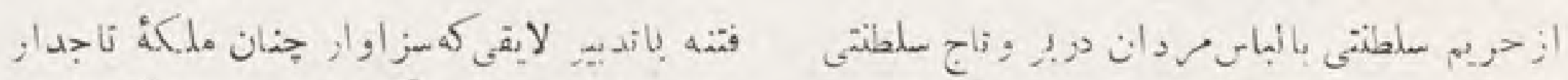

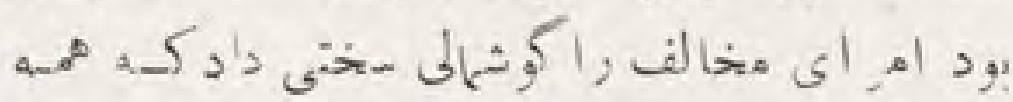

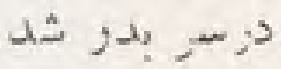

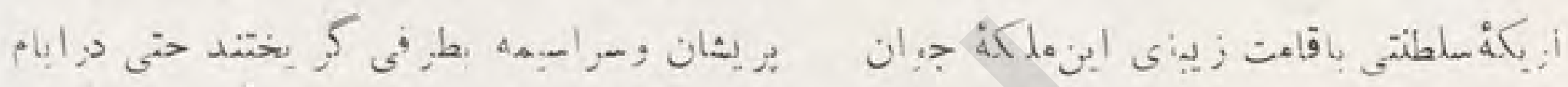

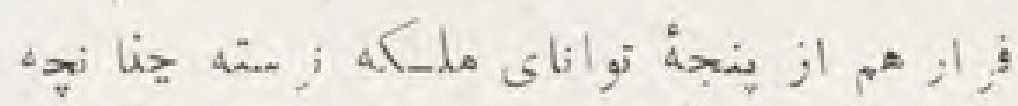

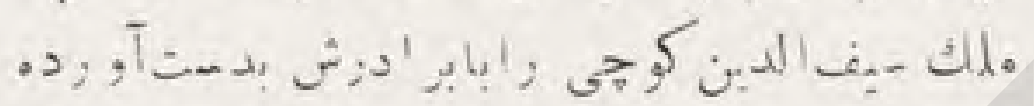

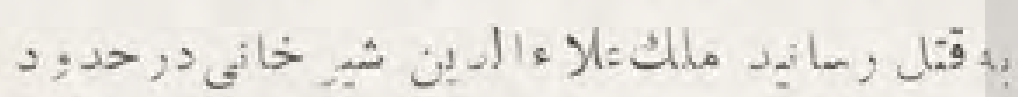

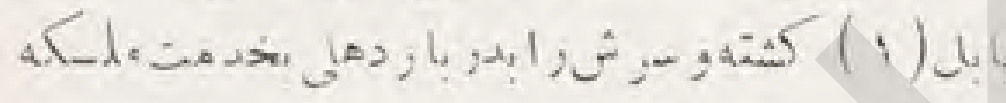

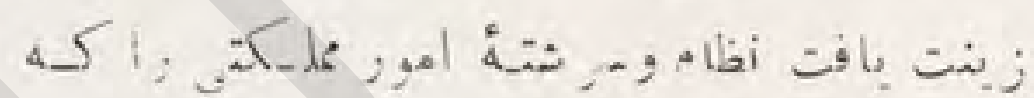

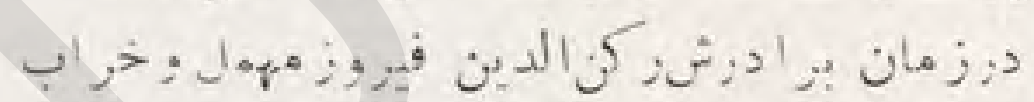

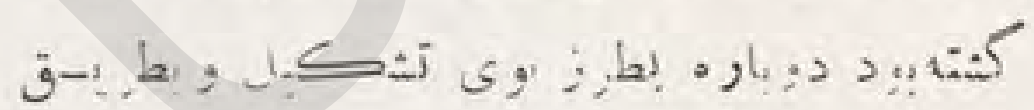

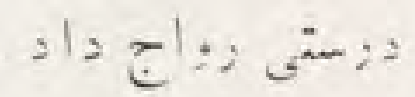

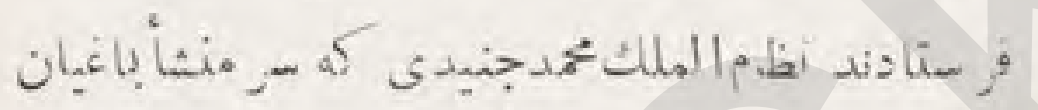

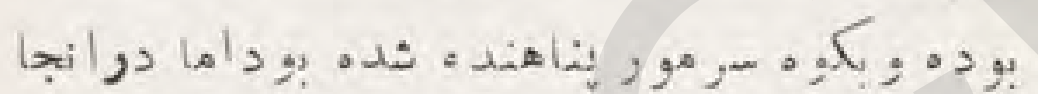

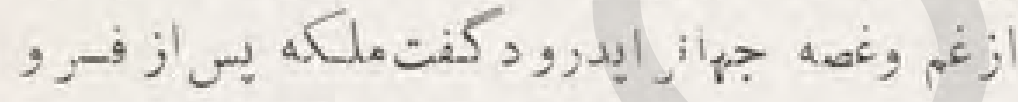

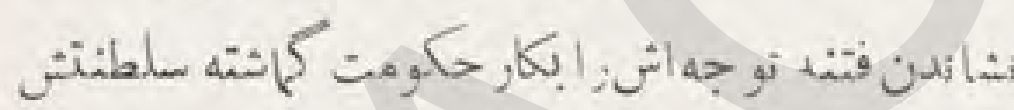

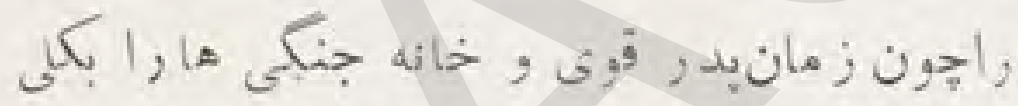

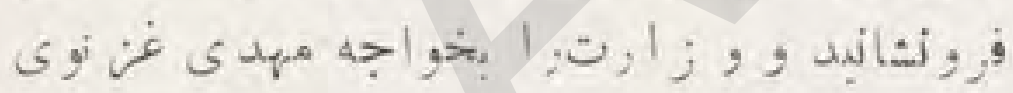

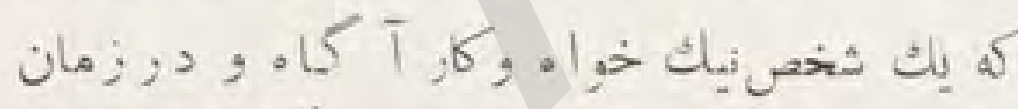

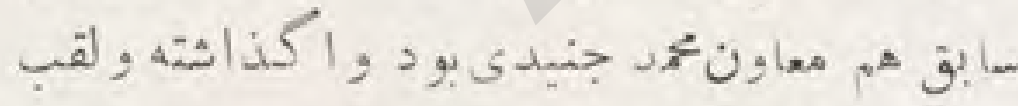

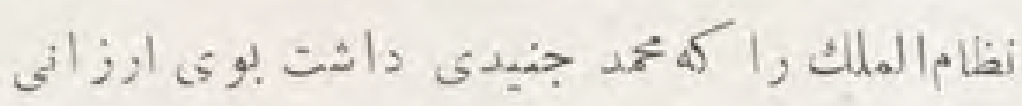

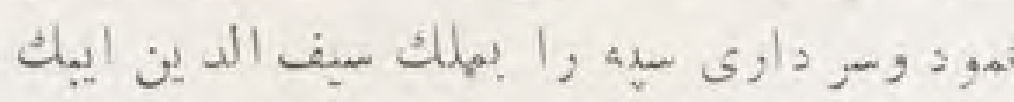

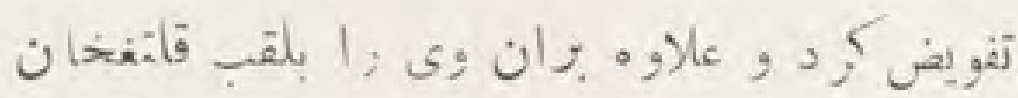

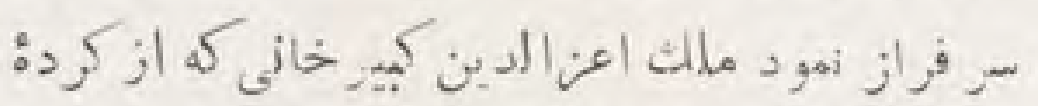

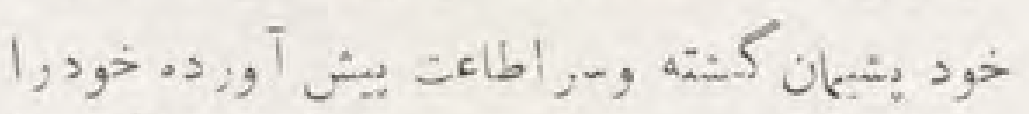

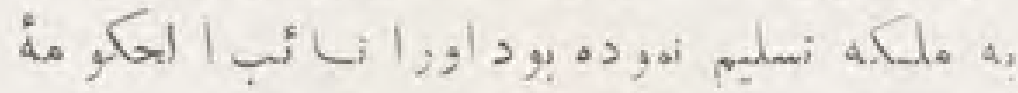

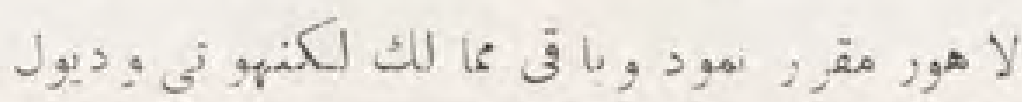

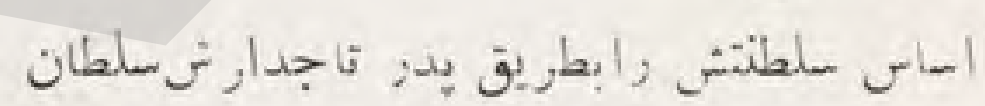

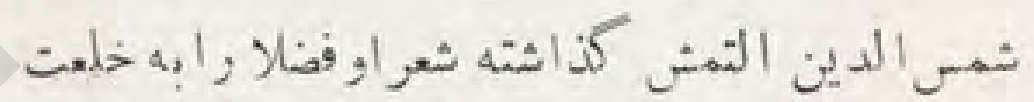

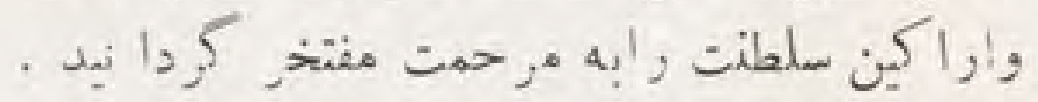

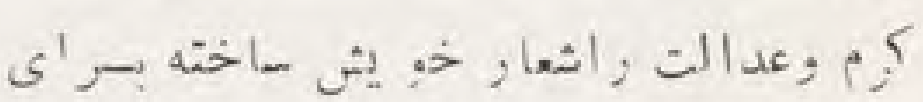

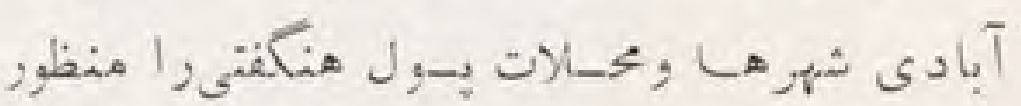

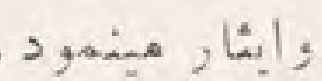

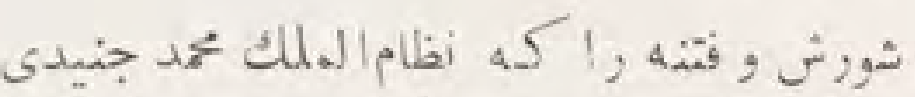

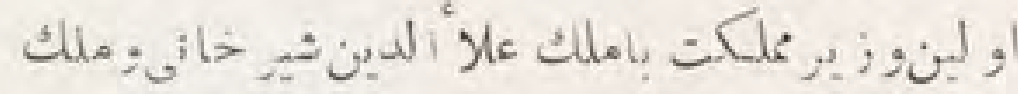

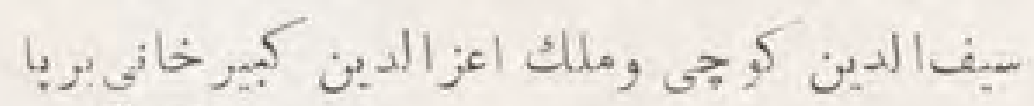

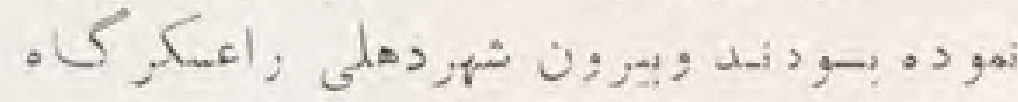

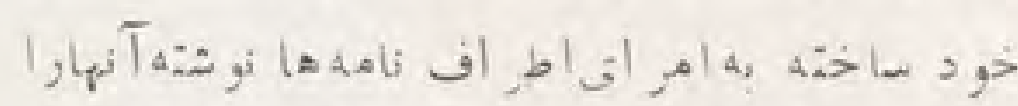

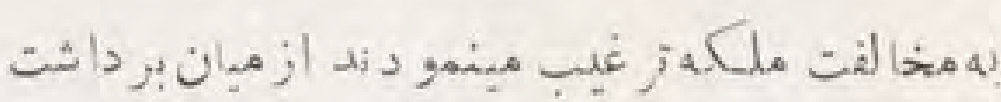

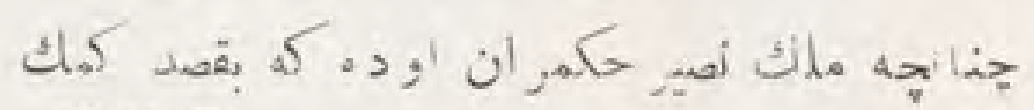

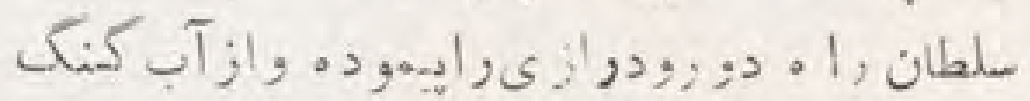

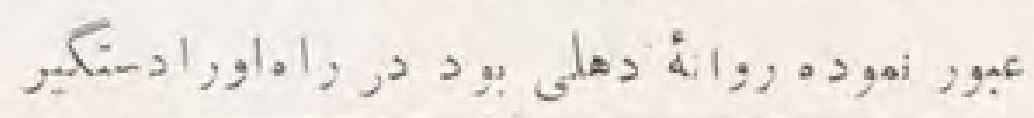




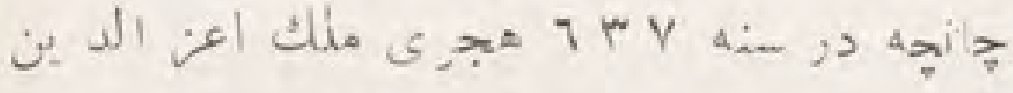

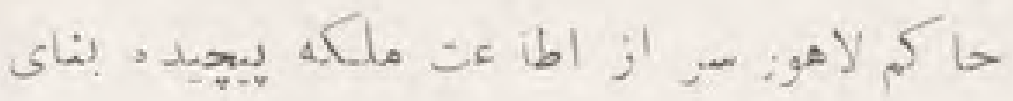

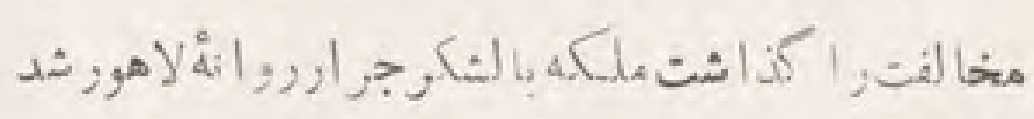

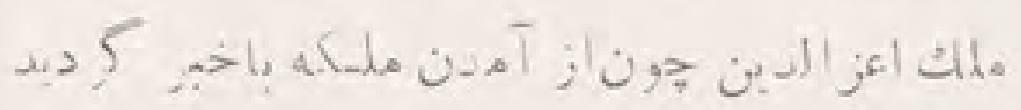
j

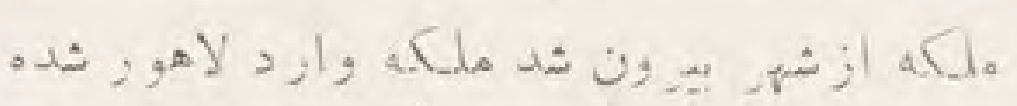

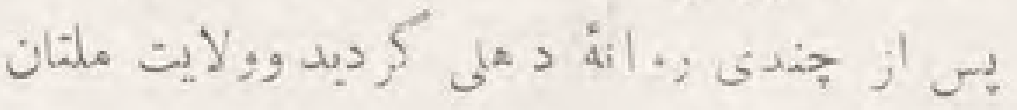

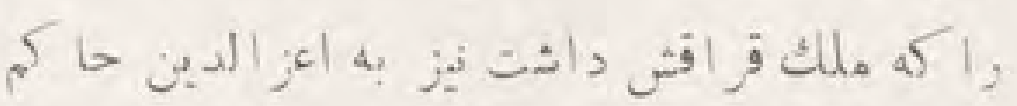

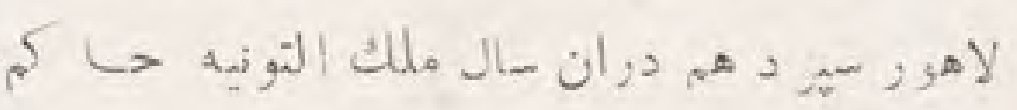

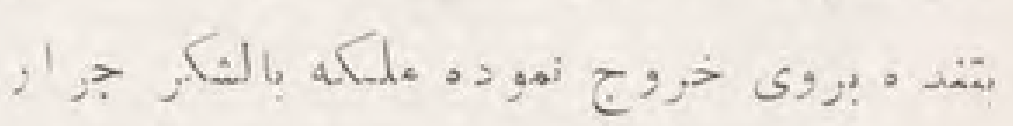

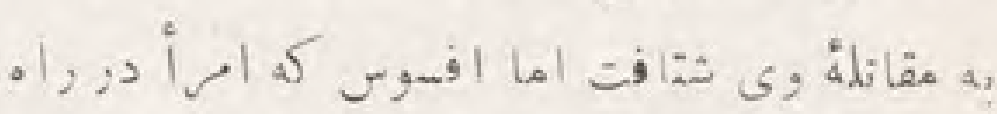

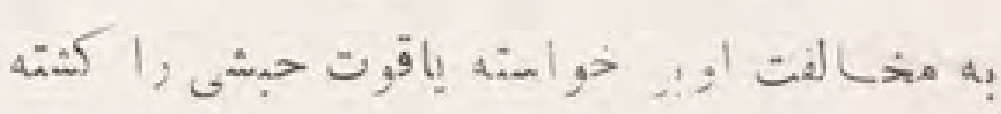

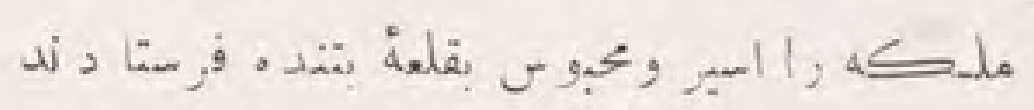

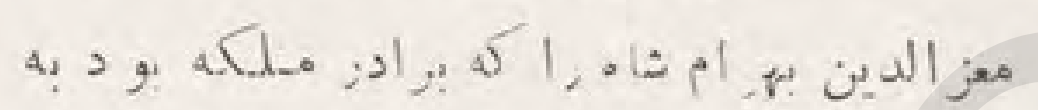

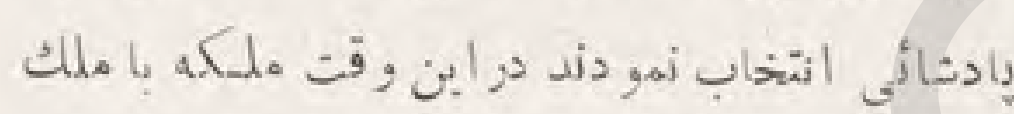

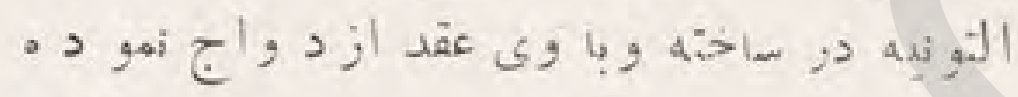

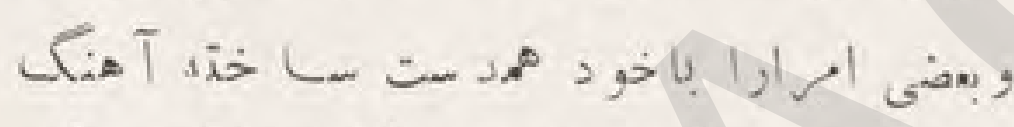

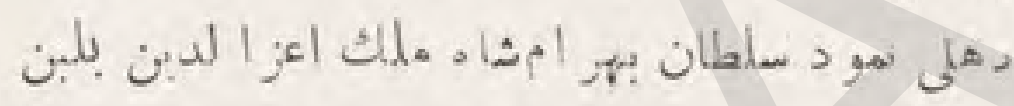

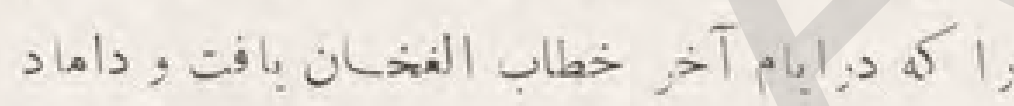

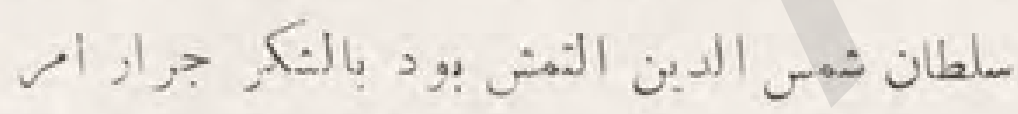

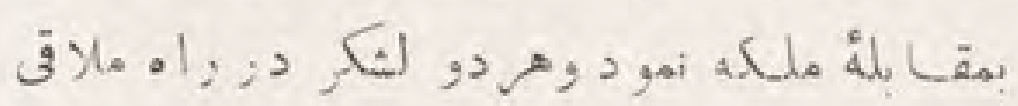

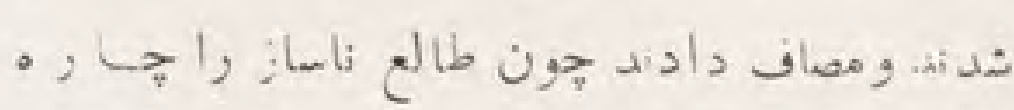

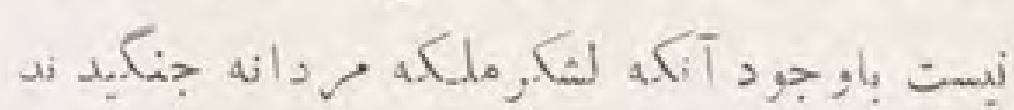

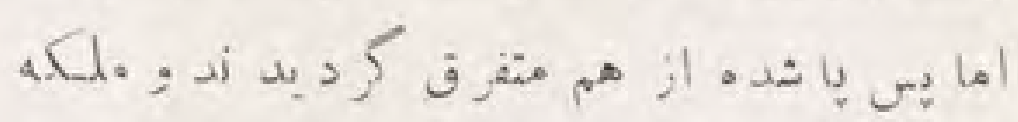

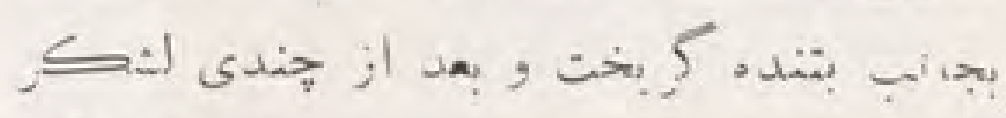

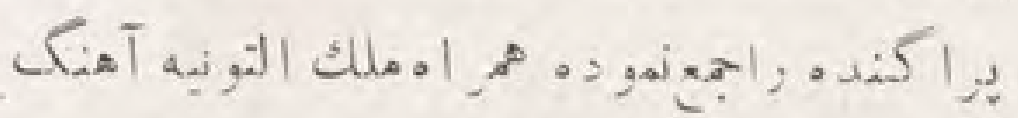

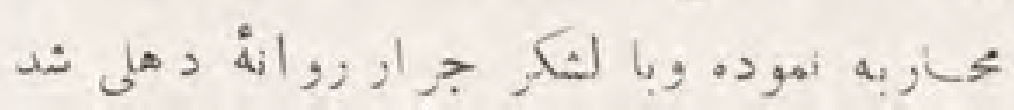

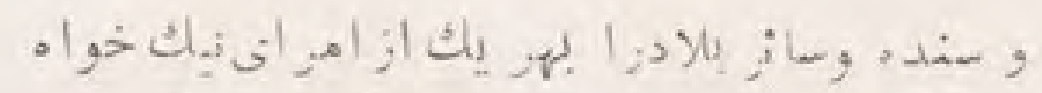

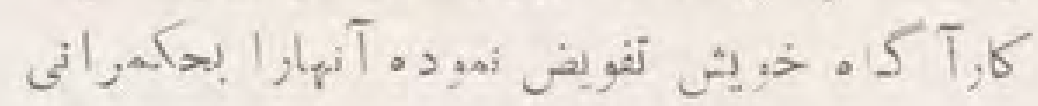

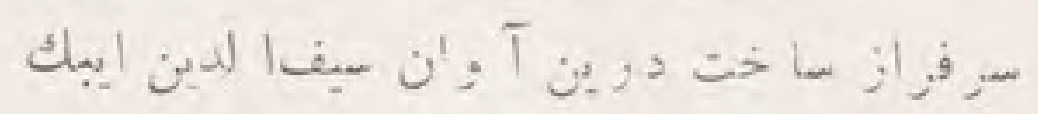

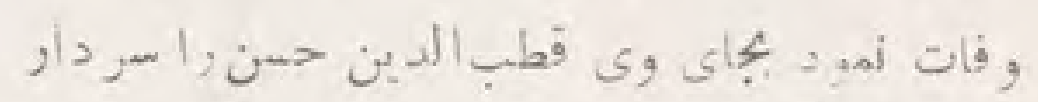
2,5, , 2 a

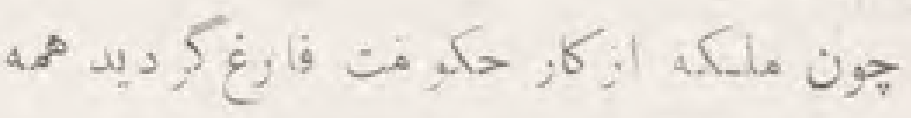

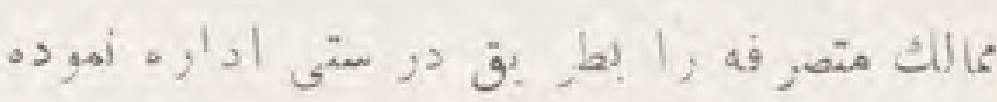

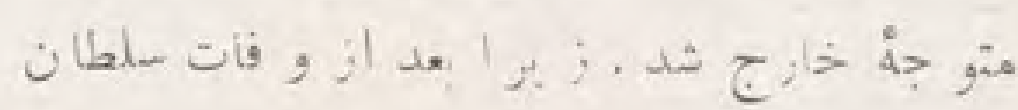

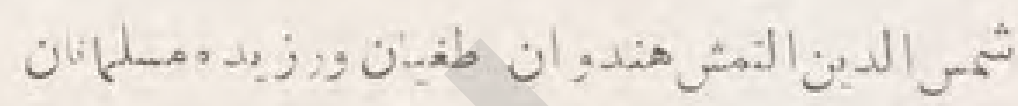

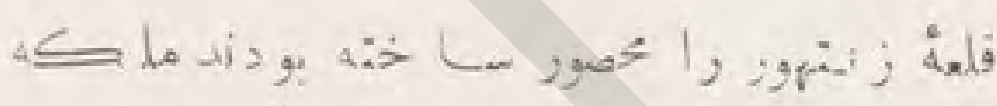

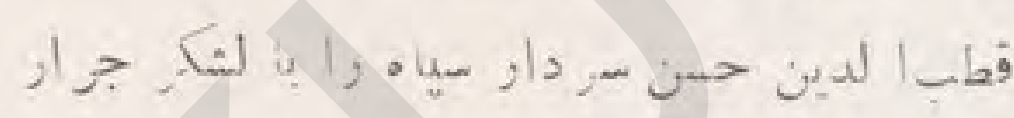

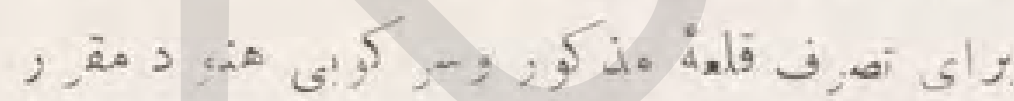

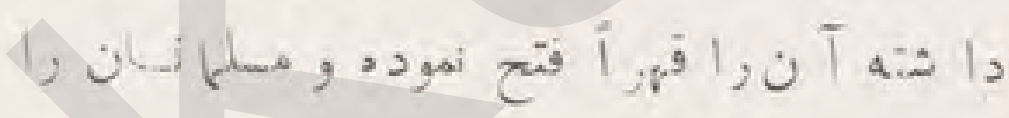

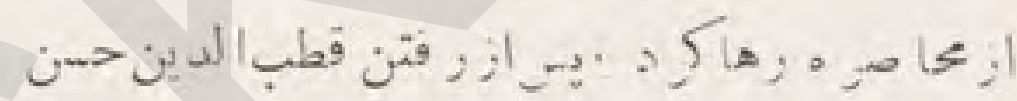

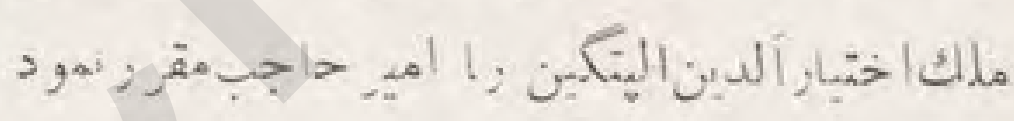

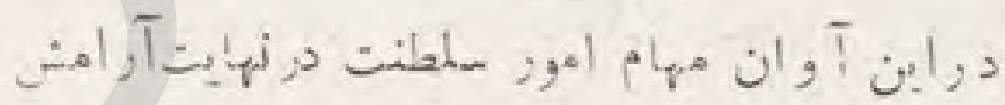

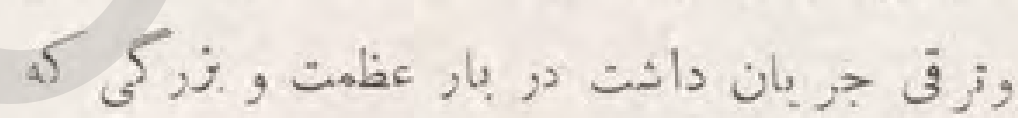

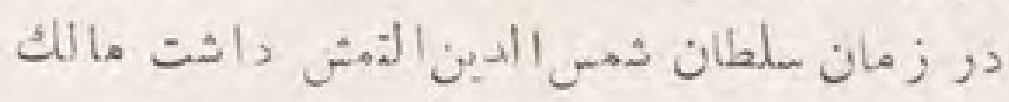

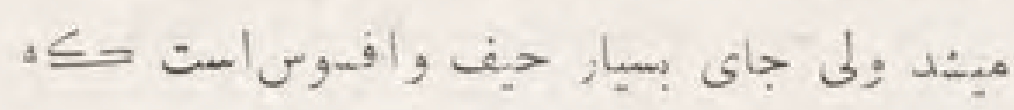

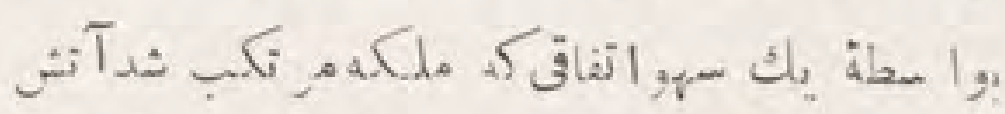

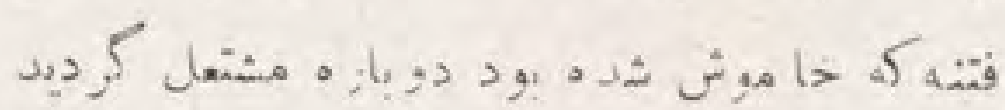

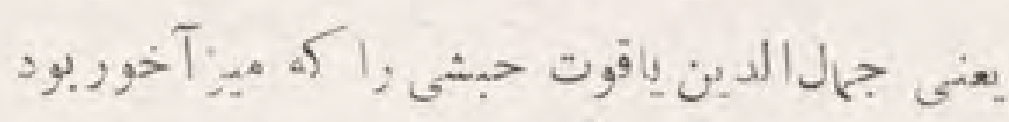

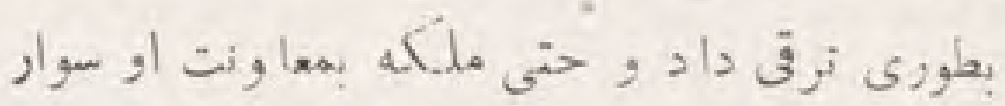

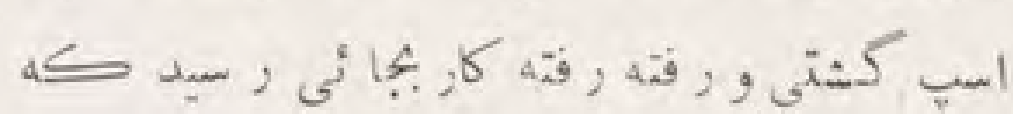

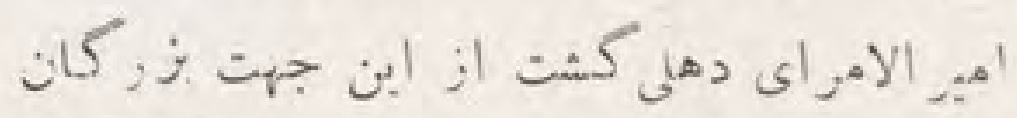

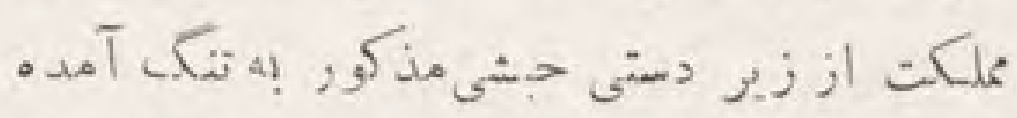

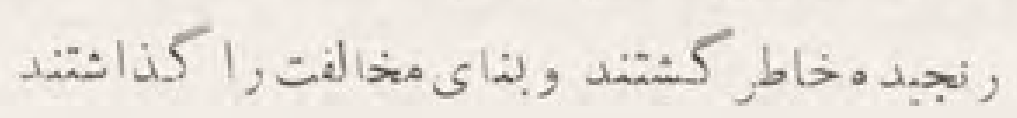




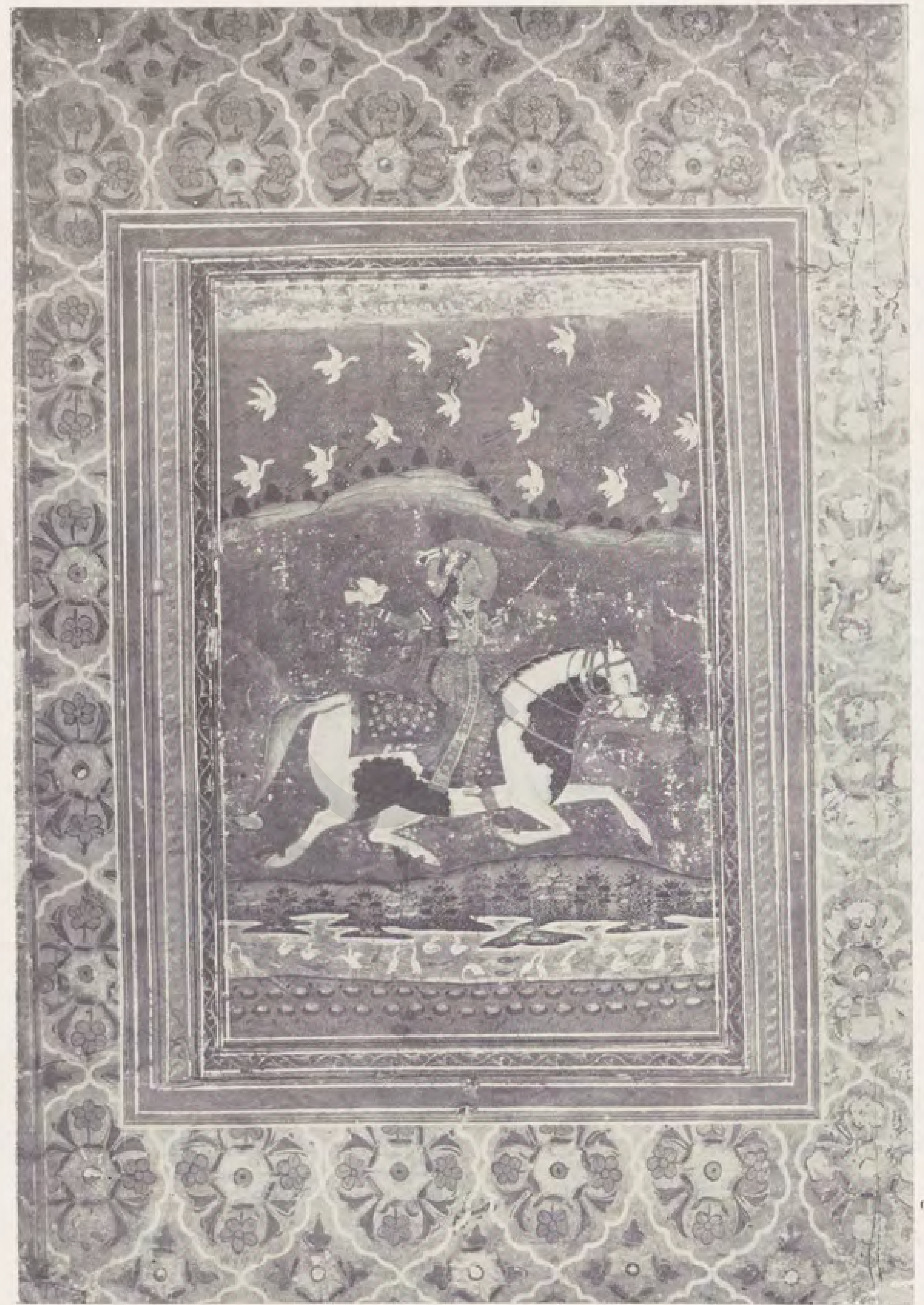

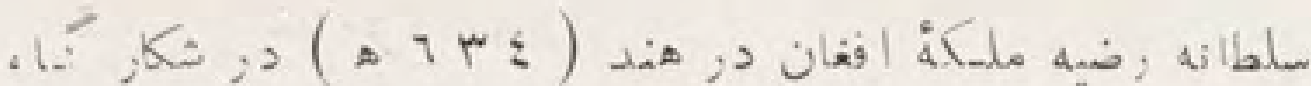

$$
\begin{aligned}
& \text { " تصو ير از بوزئ دماند }
\end{aligned}
$$




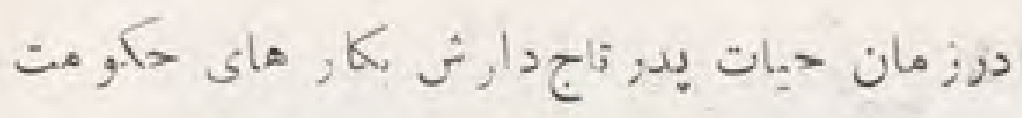

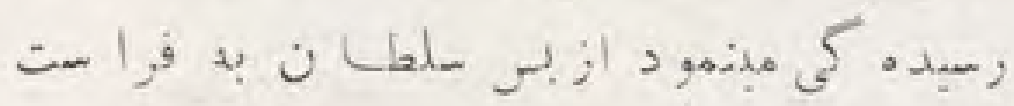

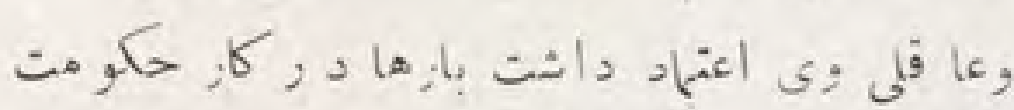

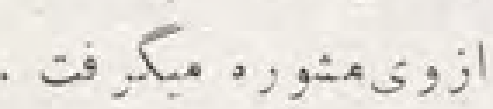

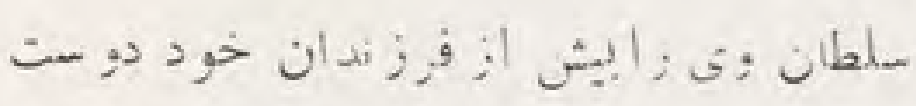

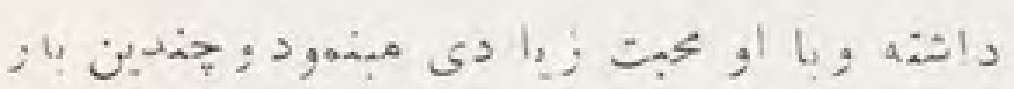

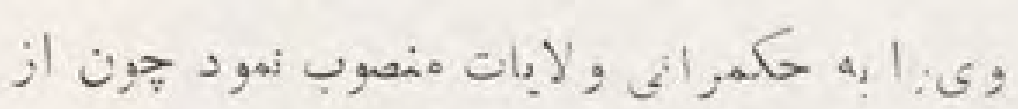

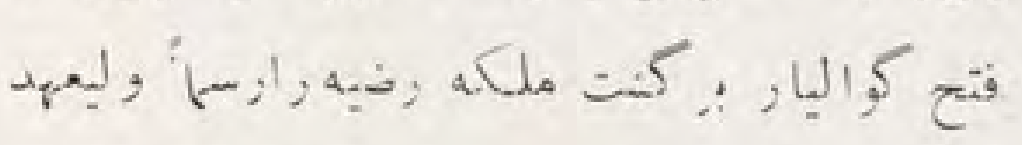

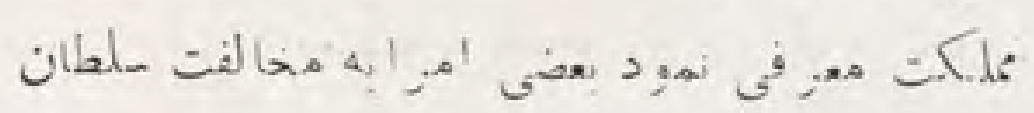

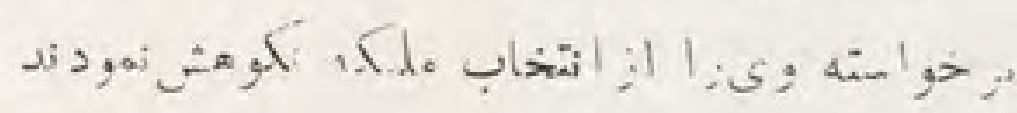

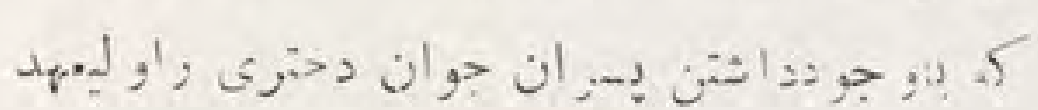

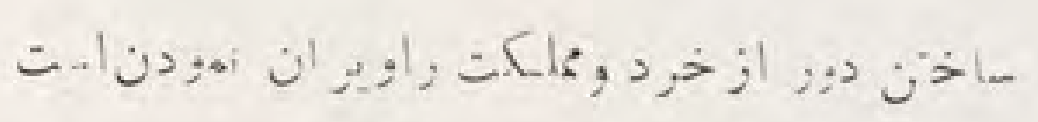

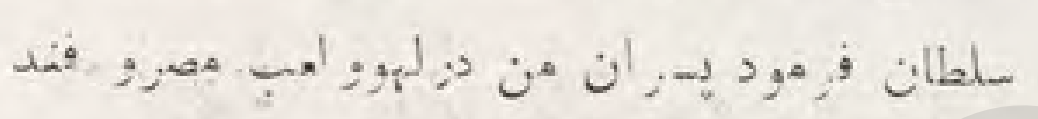

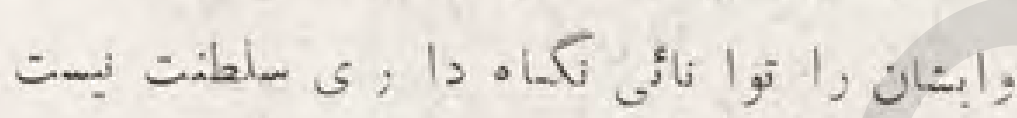

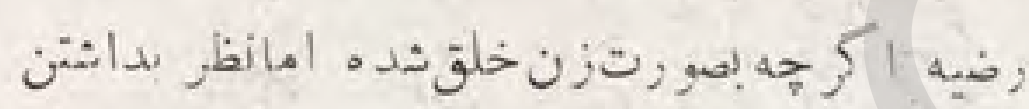

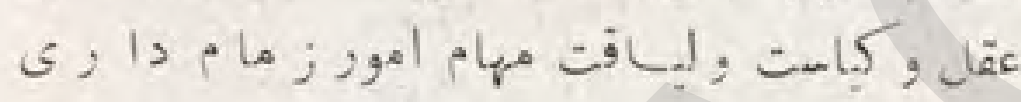

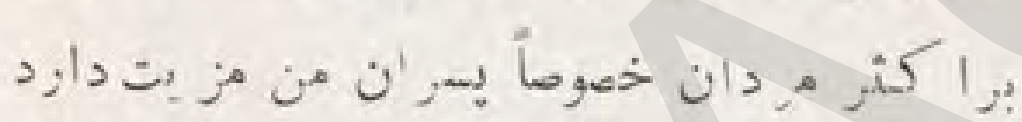

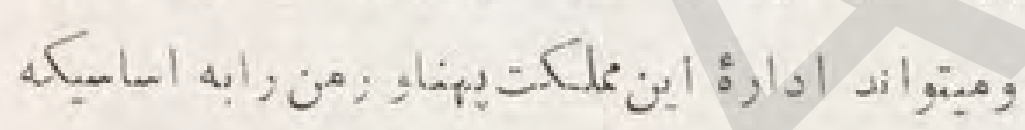

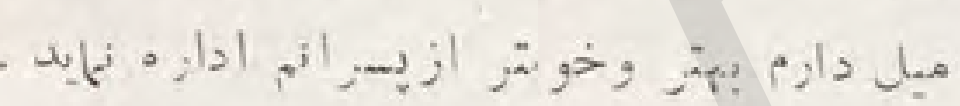

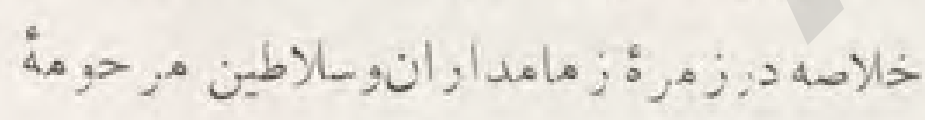

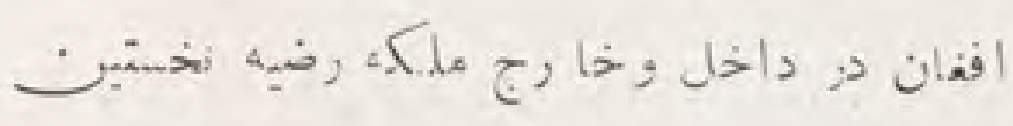

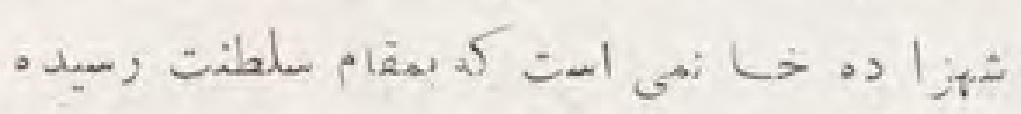

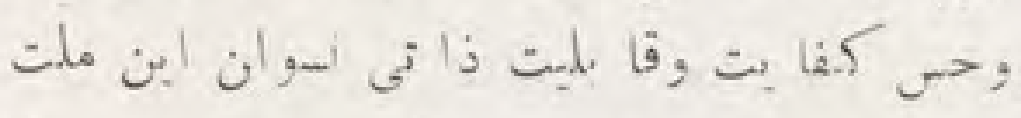

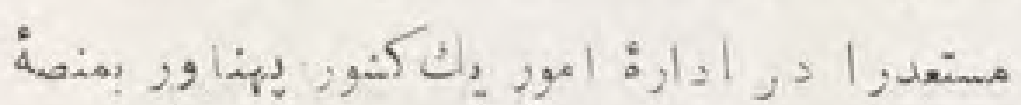

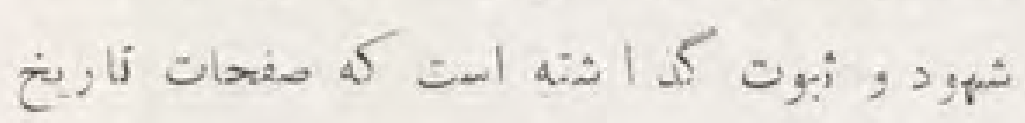

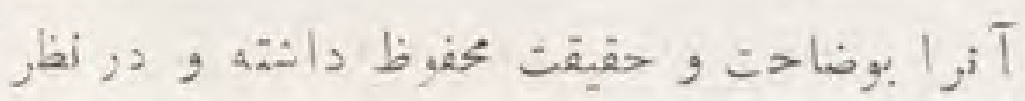

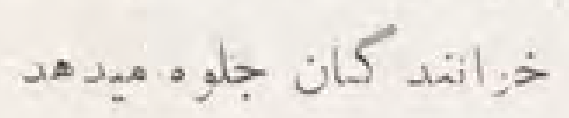

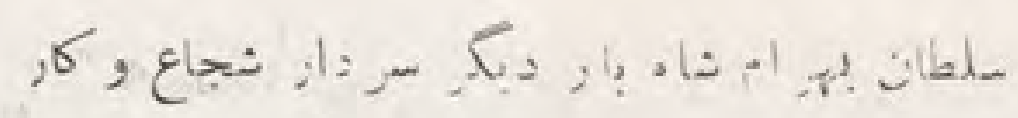

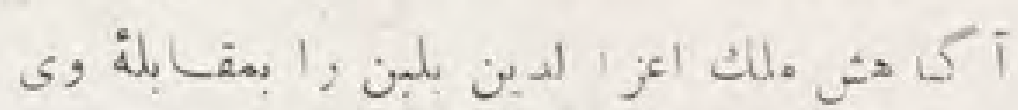
g

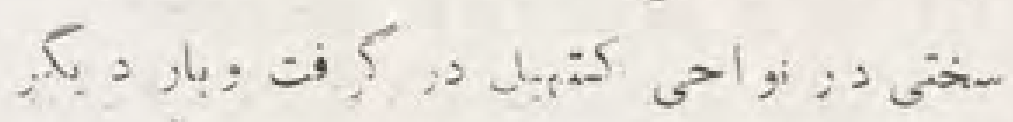

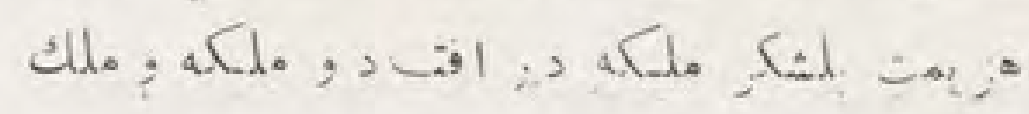

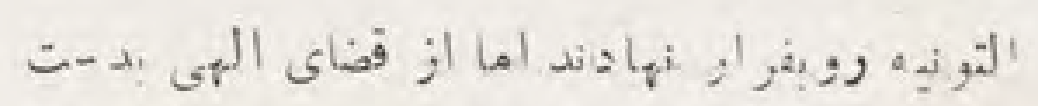

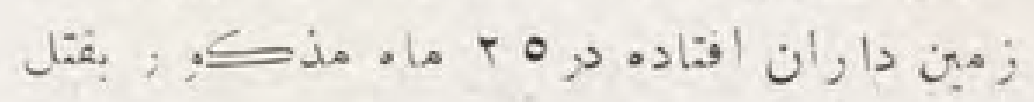

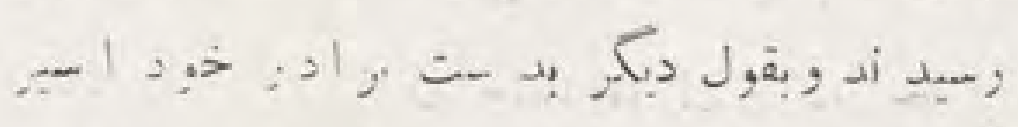

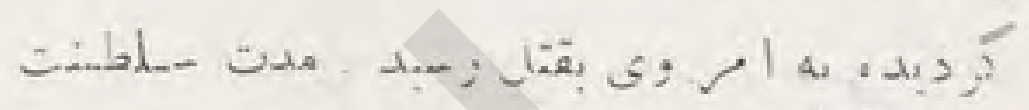
إئ ملـ

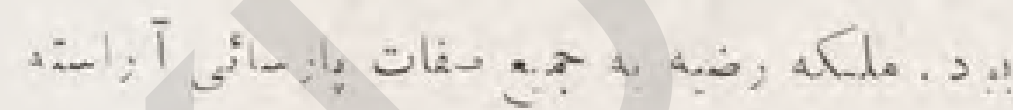
$\because=1$ ب :

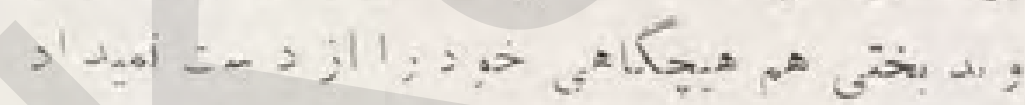

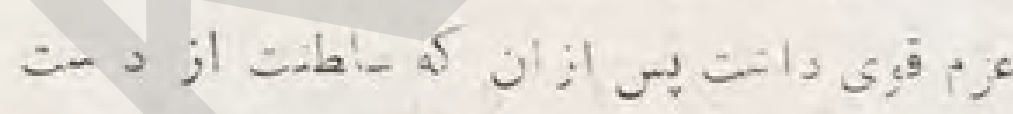

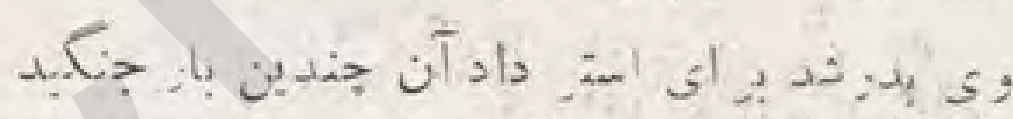

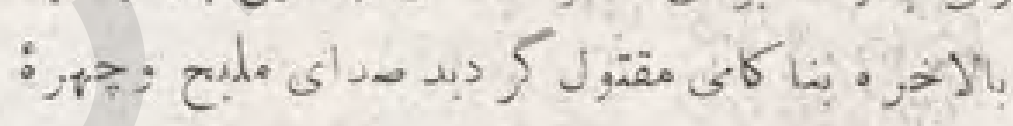
ق.

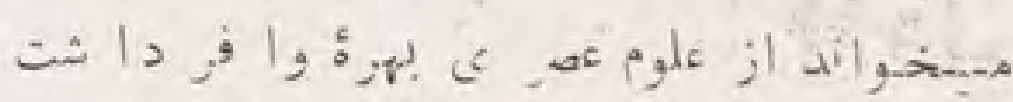

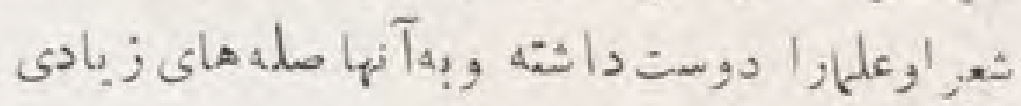

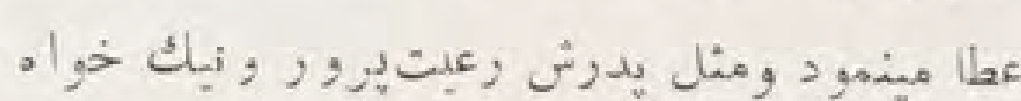

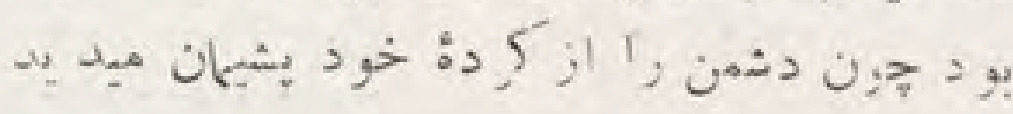

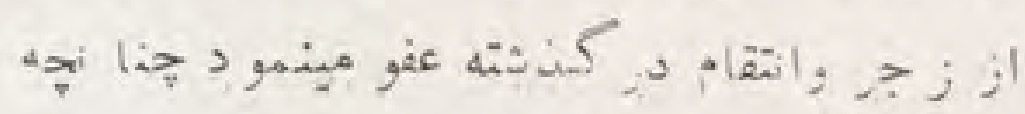

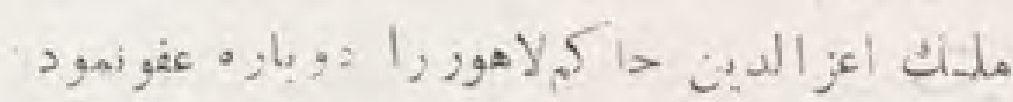
درموق كارز حهت : خستكى راقطعاً حس نمبنمود

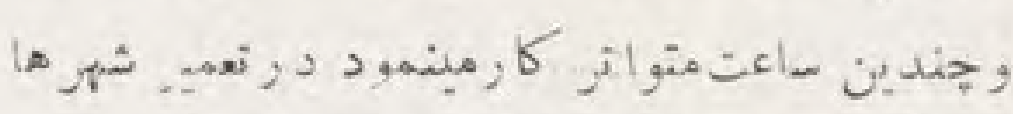

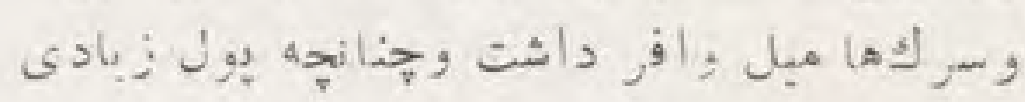

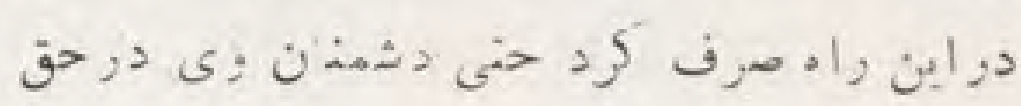

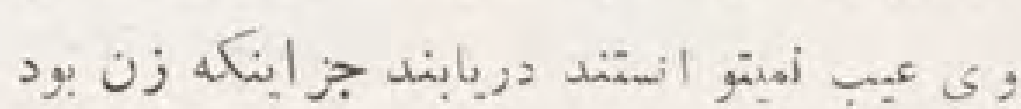




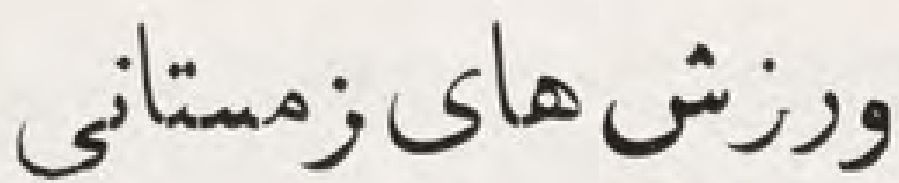

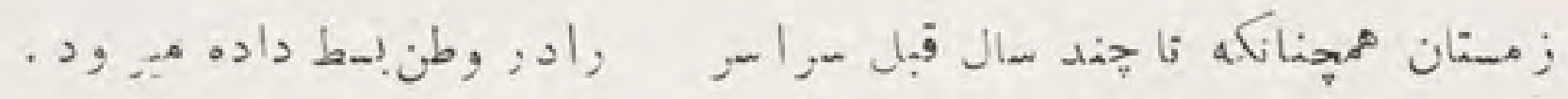

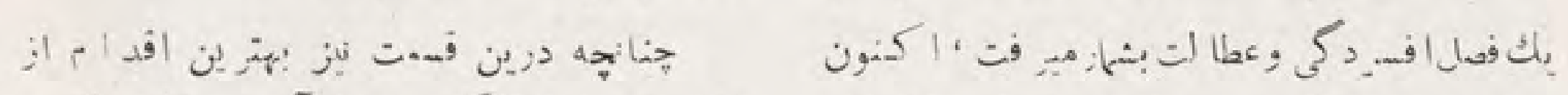

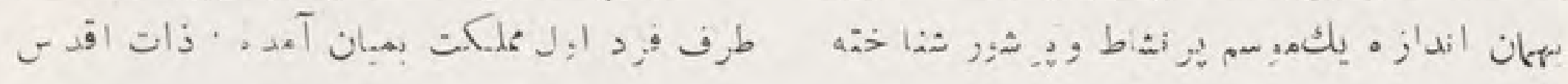

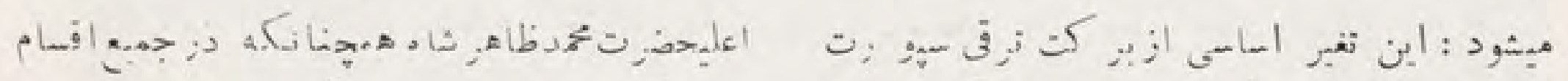

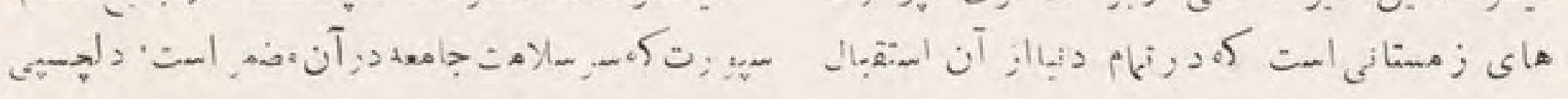

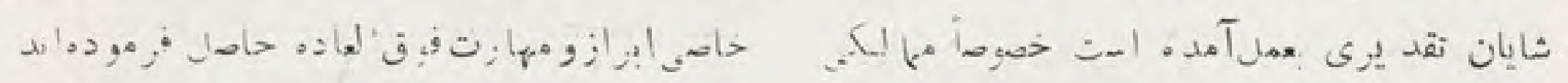

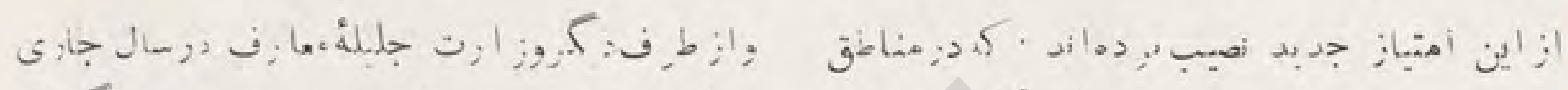

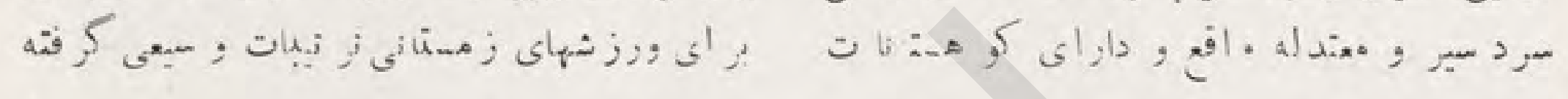

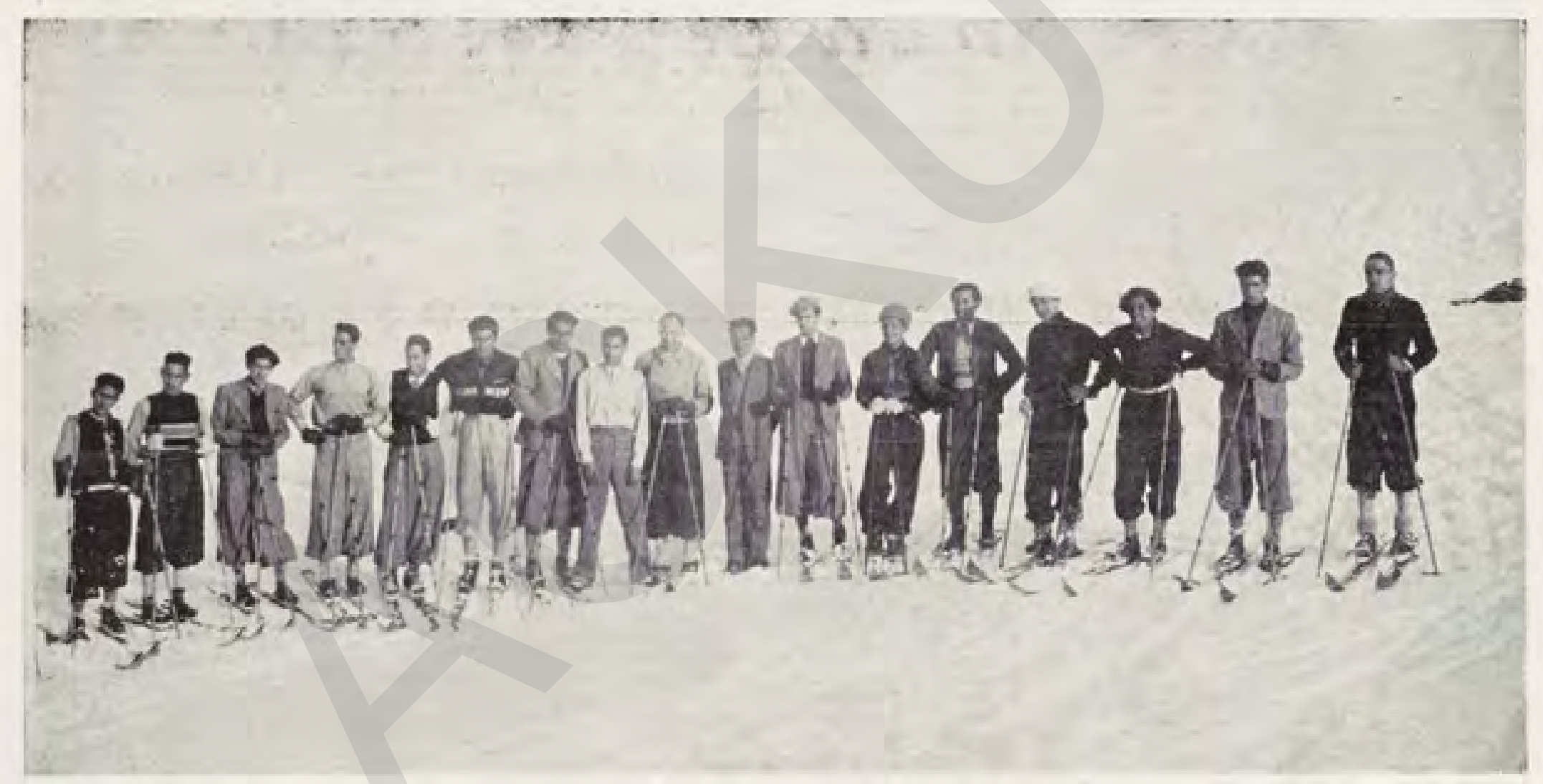

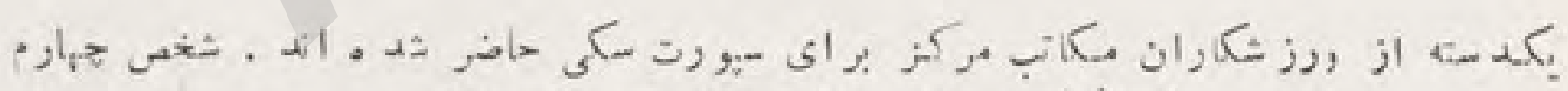

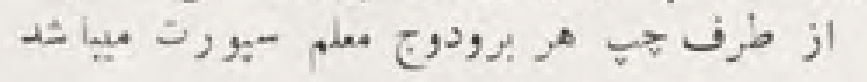

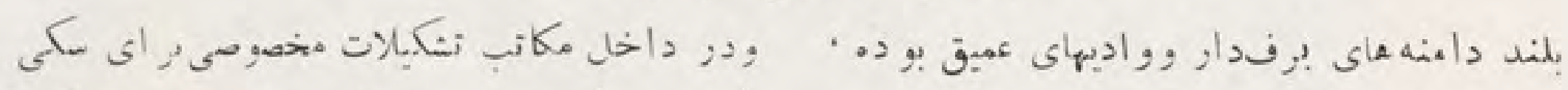

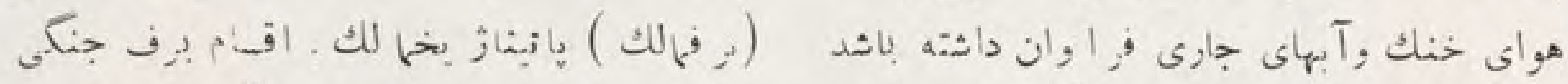

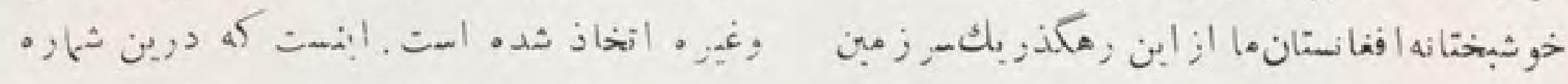

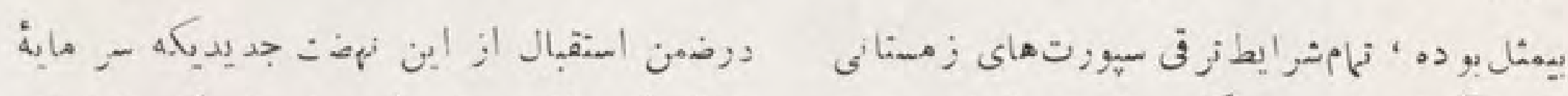

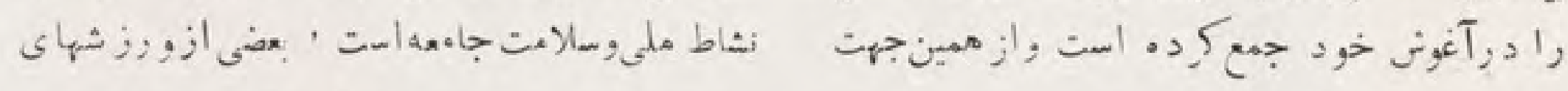

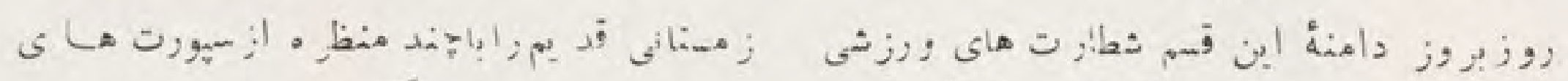

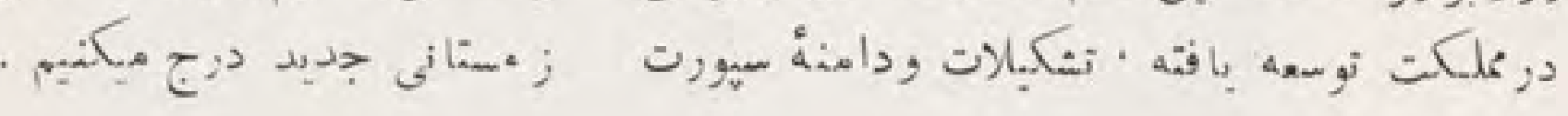



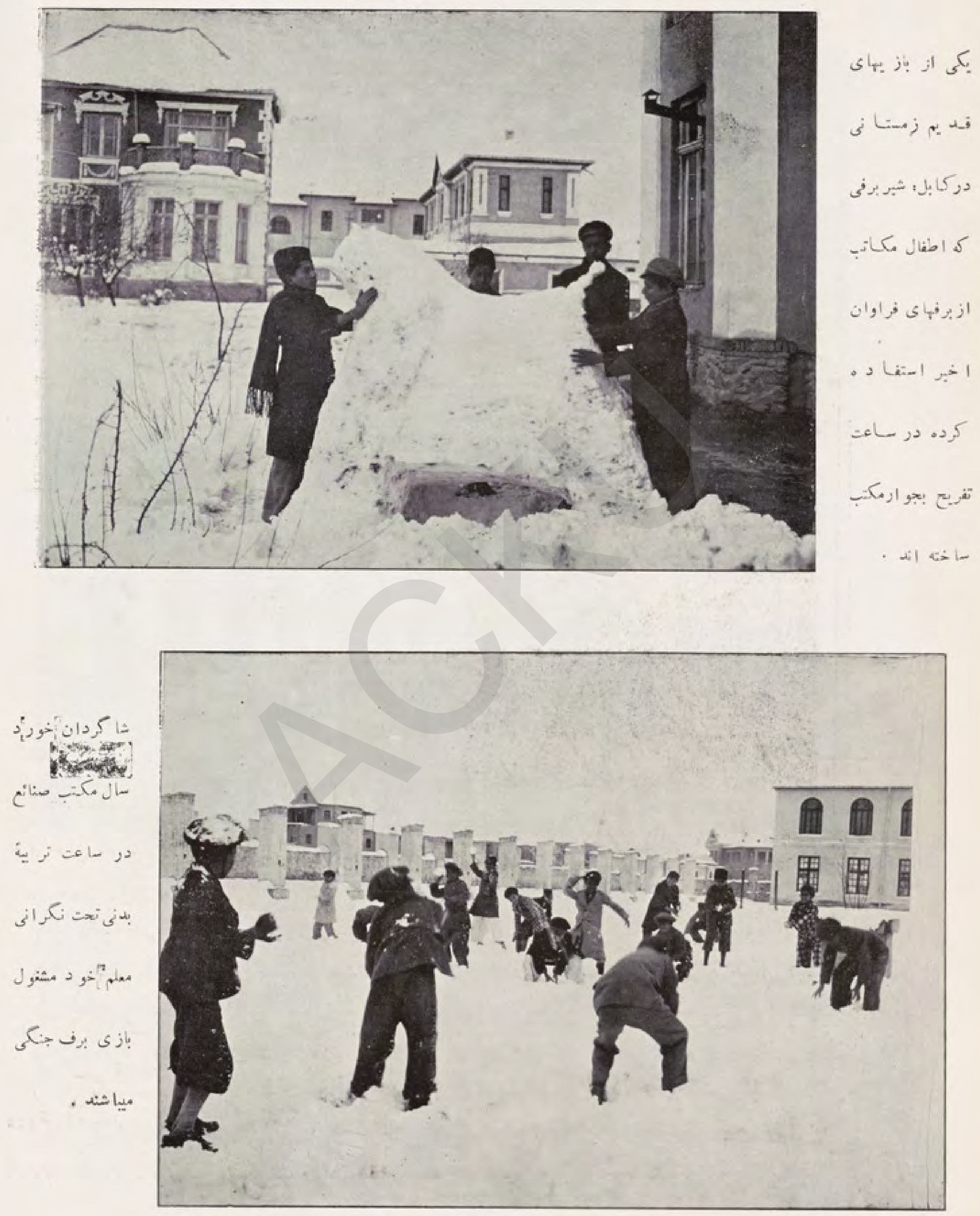


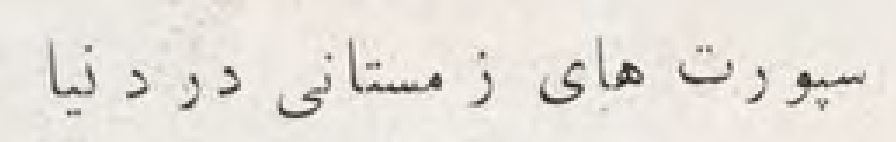

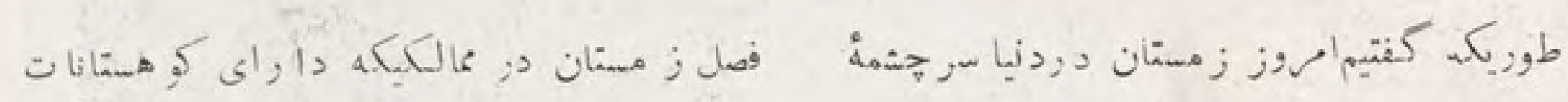

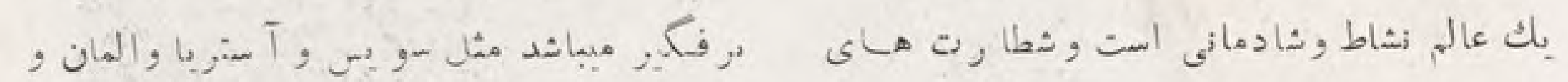

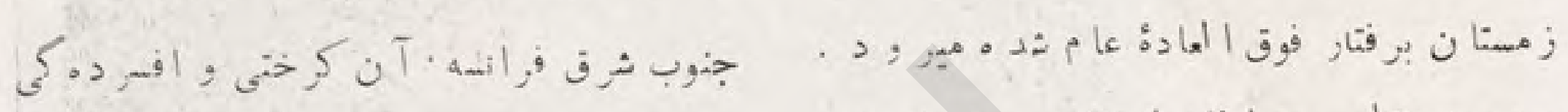

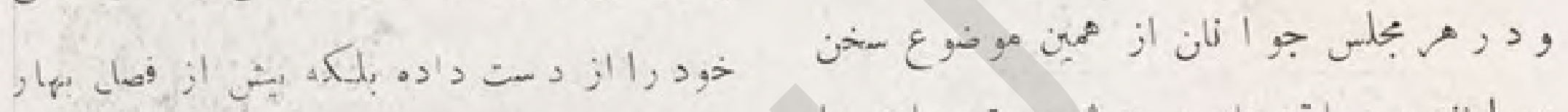

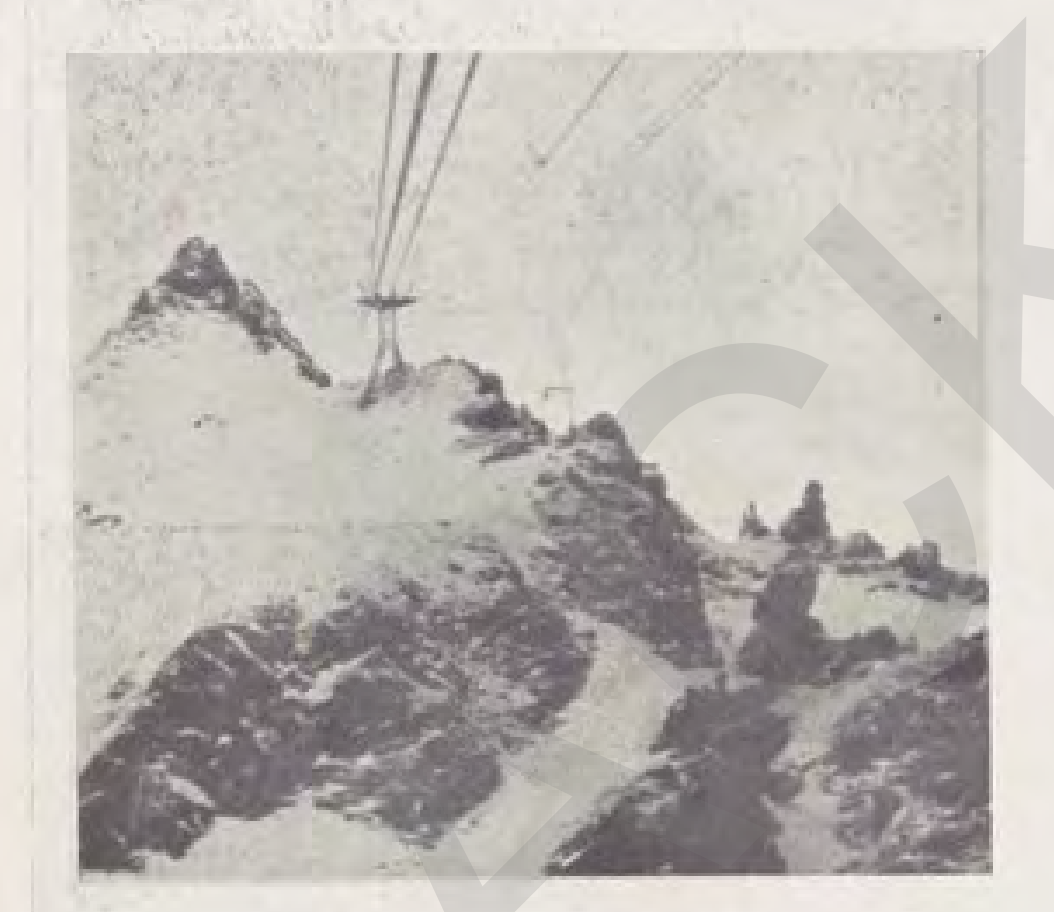

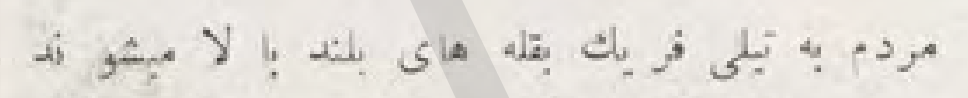
كأرا

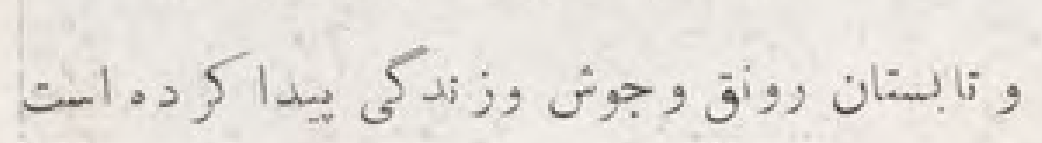

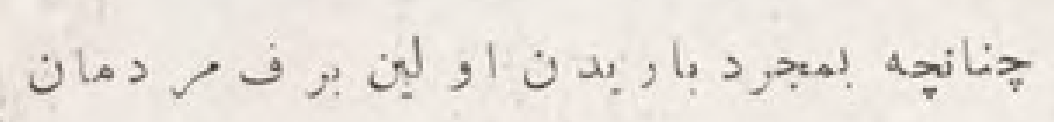

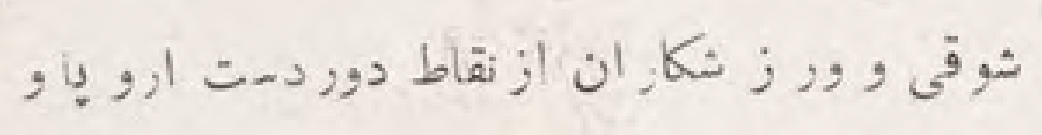

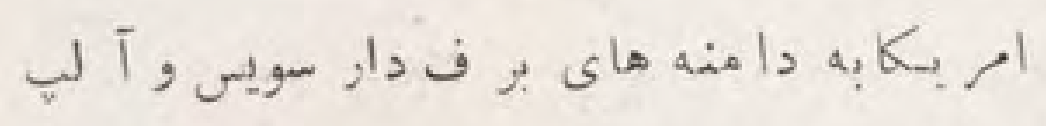

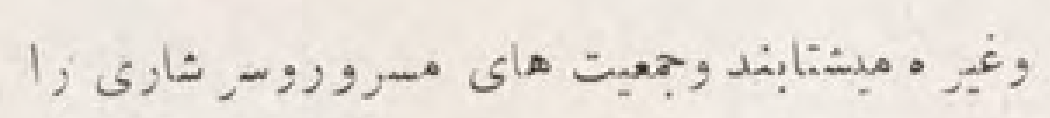

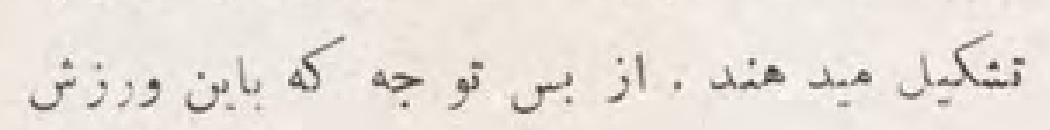

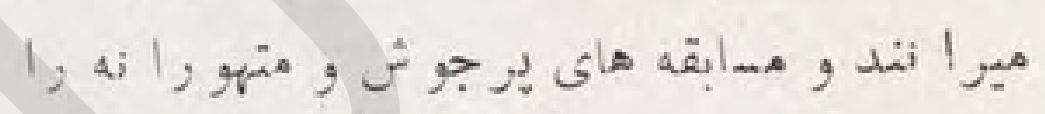

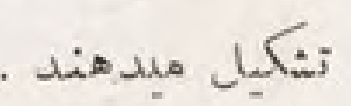

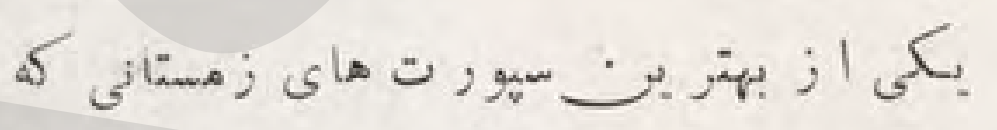

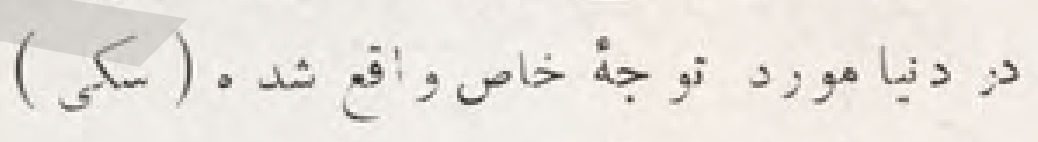
وِا بر فمالك است كه ابقداء دواوقات خيلى قديم

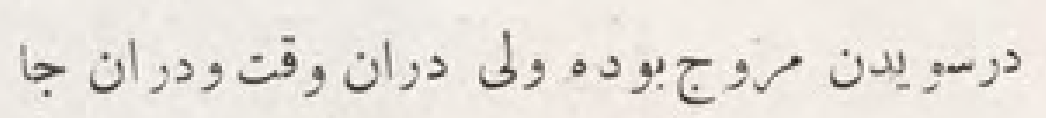

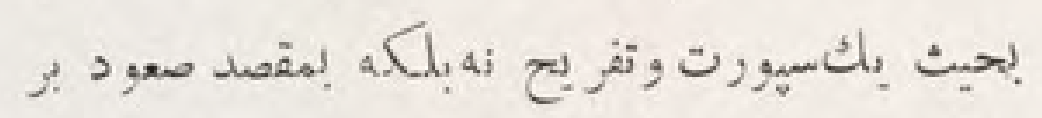
قله هاى بلند ور فت ر آمد در دين قربه هاى دور

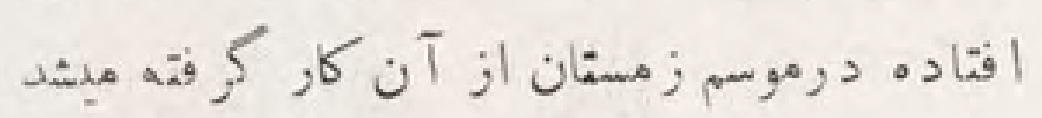

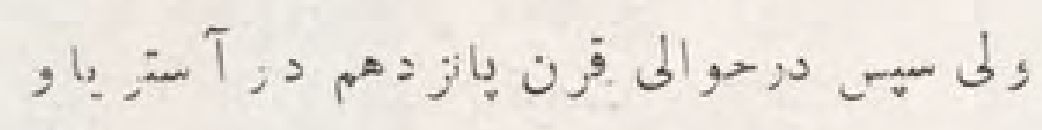
(عضى حصع اللمان و سو يس نيز بهمان مقصد رائج

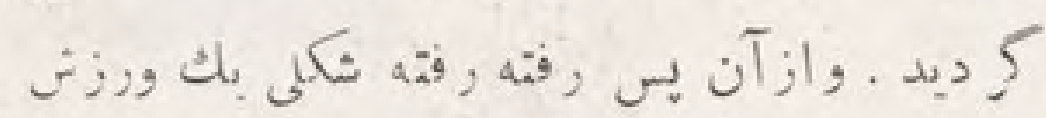

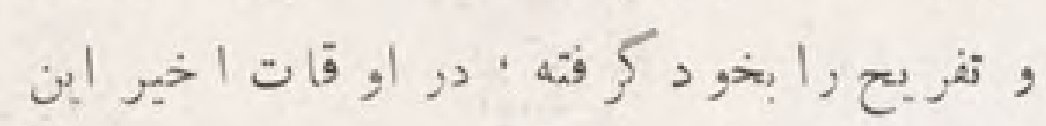
جنبه آن خيلى كسب قوت ,عموميت نهود و خصوصاً

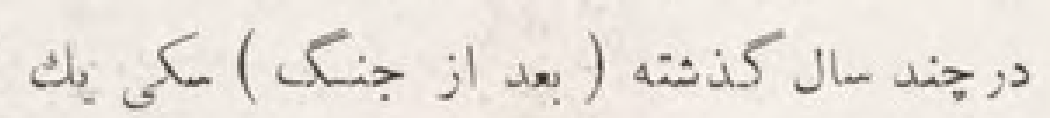
ورزش زمستا نى معروف وطرف توجه عموم كرديد

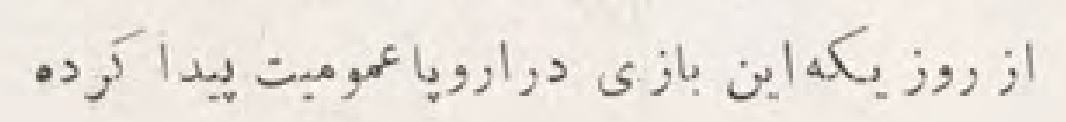




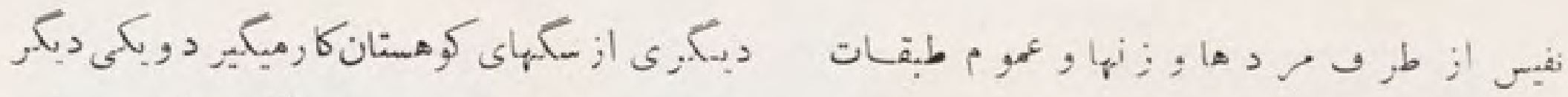

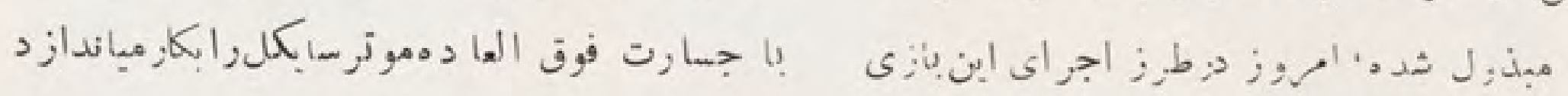
وعدة هم براى صعو د به
(a) ماط مرتفع از تيلى فريك

كاز ميكيرد

قلل مر تفعه بـا لا ثده

ا آن آن جا بو سيلة سكى

سرازير ثده مدمانى 1ز

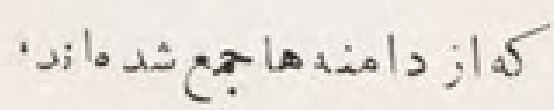

از مها, ت خود متعجب

ساز ند. مسا بقها هاى بزركى

كم جنبه خطر آنهم جندان

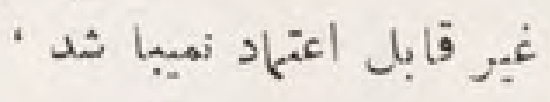

دز مراكز سبوت هانى

كوهنسا نى ترتيب مى با بد

ازطرف ديكربرخى ديكر

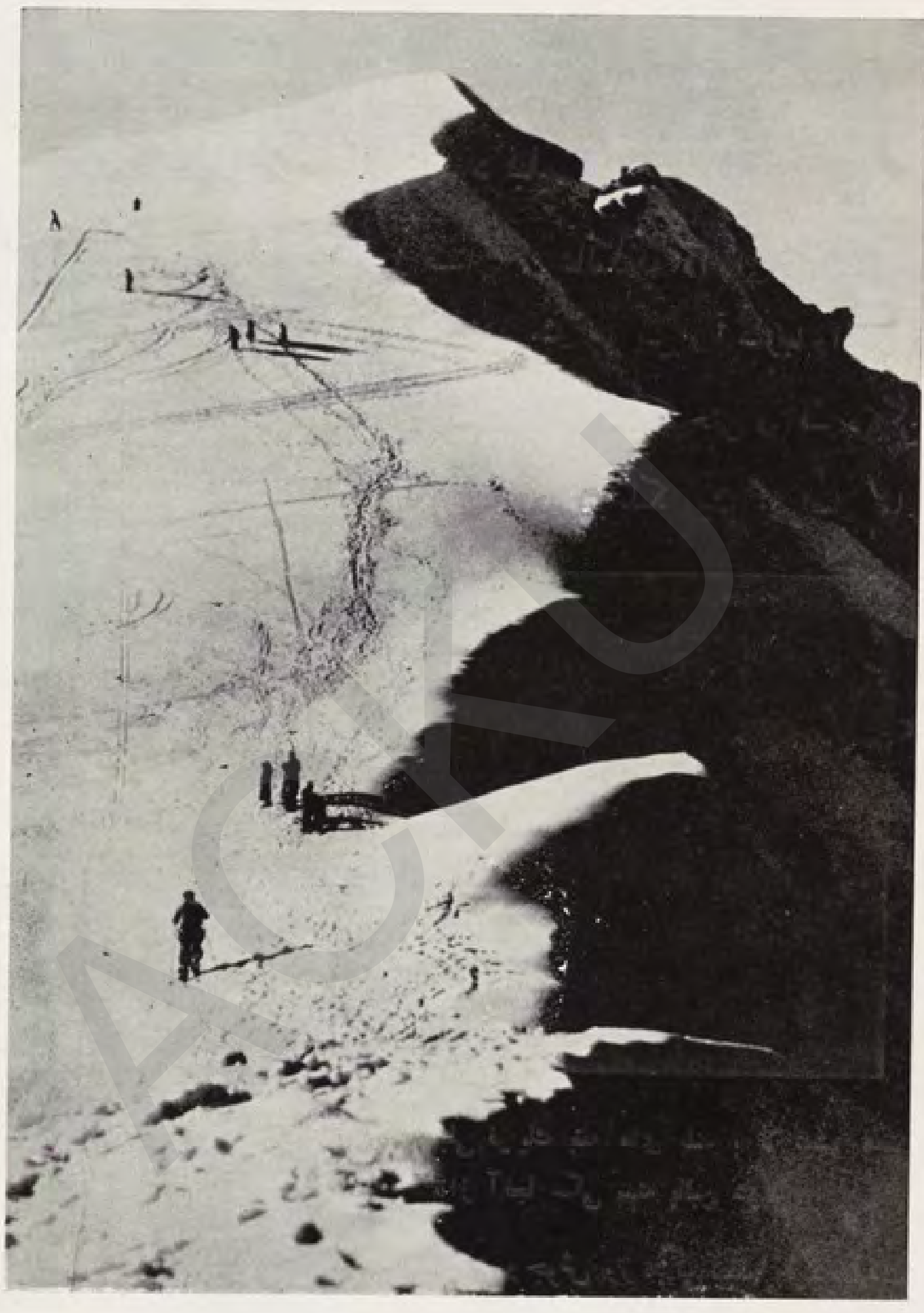

$$
\text { إكى از دامنه هاى سكى در فرانس. }
$$

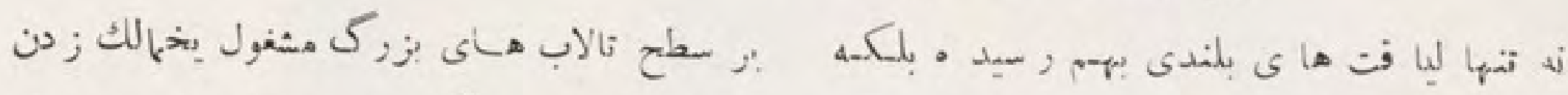

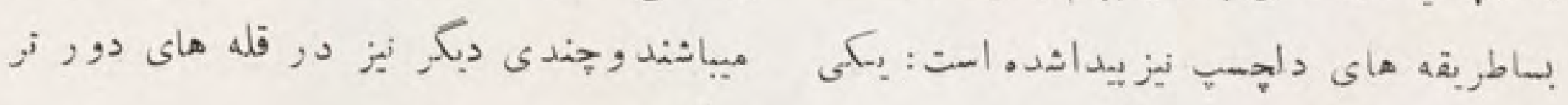

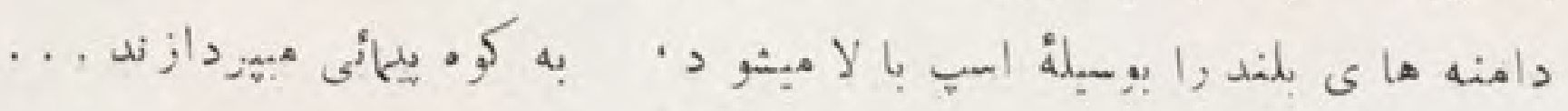




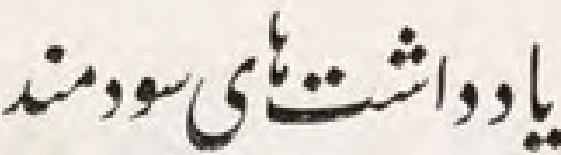

ابر يشم خام

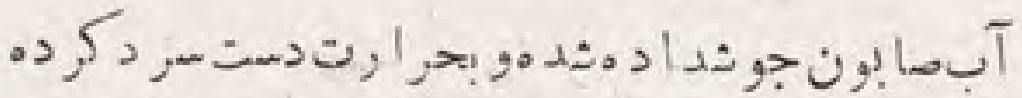

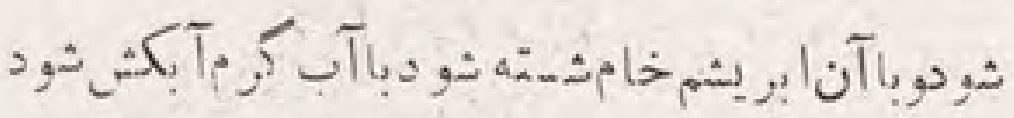

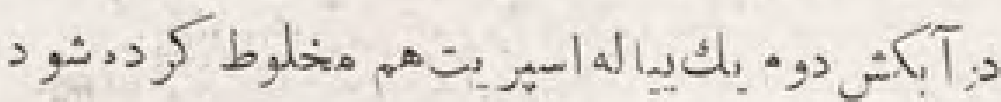

$$
\text { ابو يشم شَسته }
$$

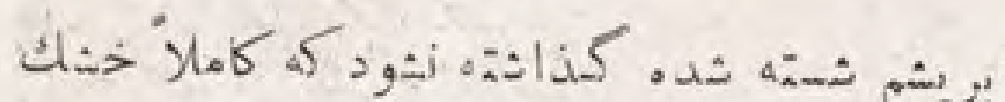

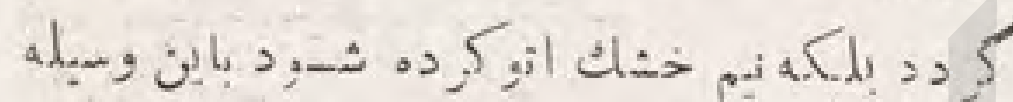

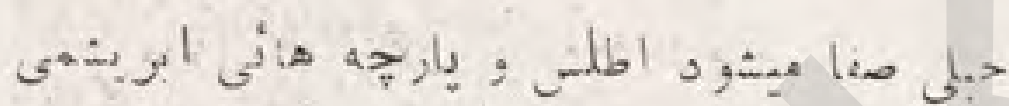

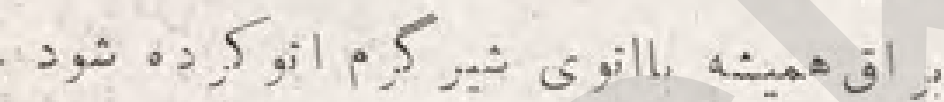

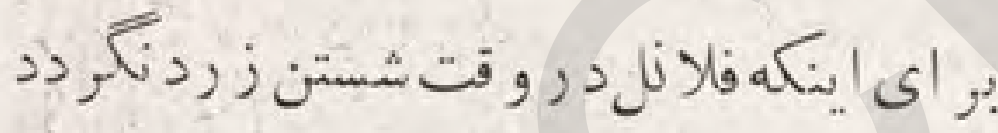

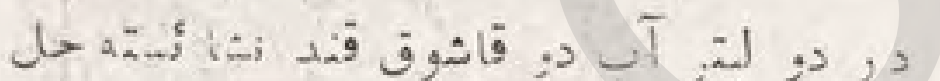

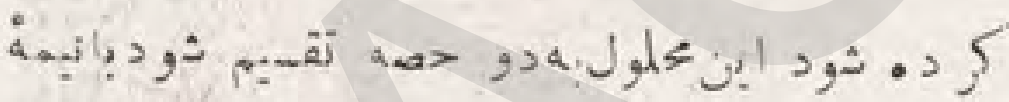

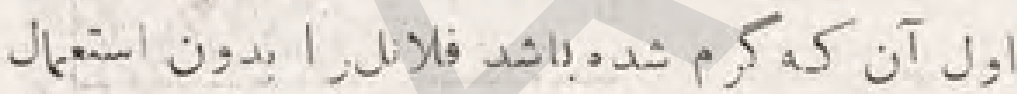

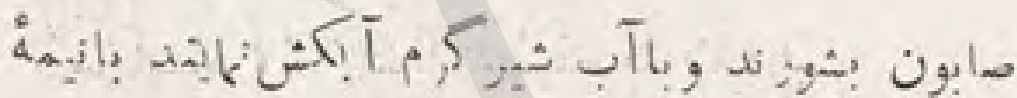

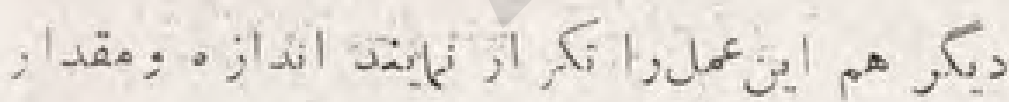

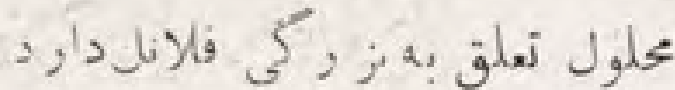

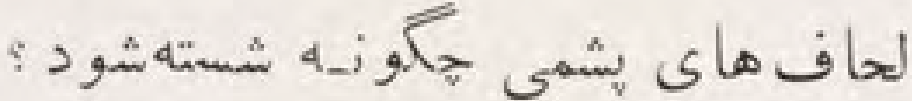

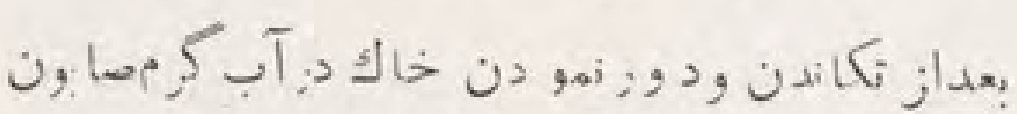

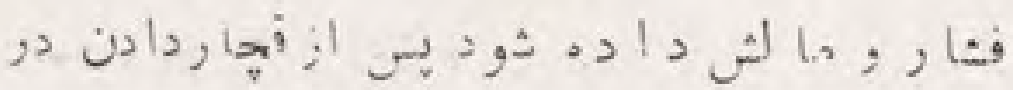

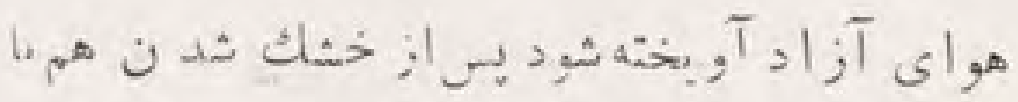

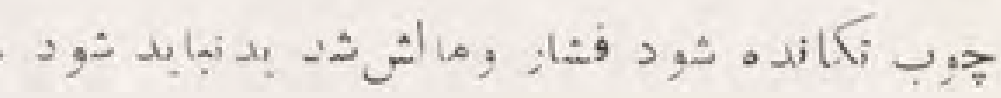

محافظت دسكشهاى حرى ازعرق

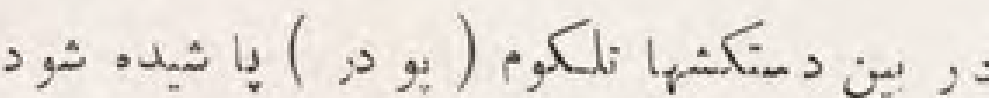

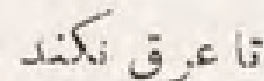

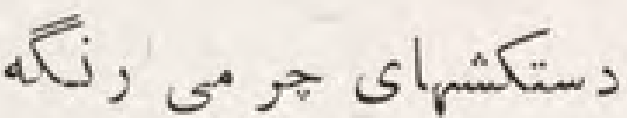

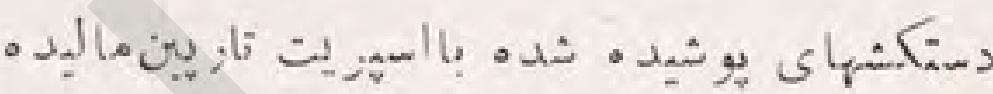

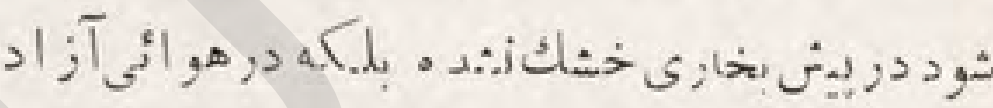
خشك كرد م. شو

يا لك نمودن كال كاى يو ستى

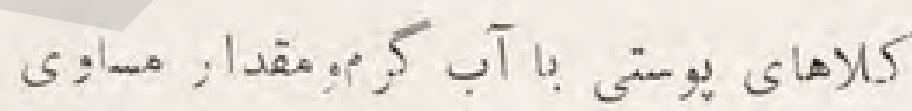
ز لهياك بالك كرده شود بك صا في يالك در محلول

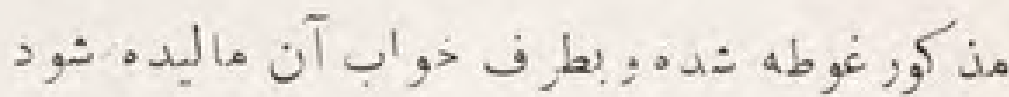

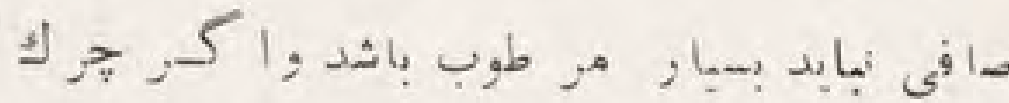

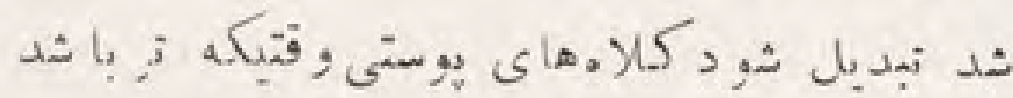

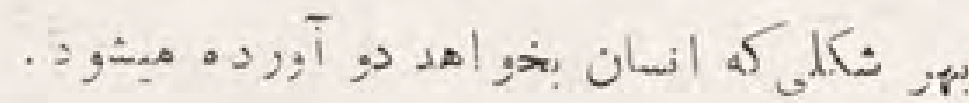
كالاه هاى إو ستى سفيد

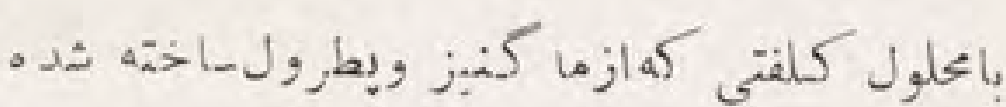

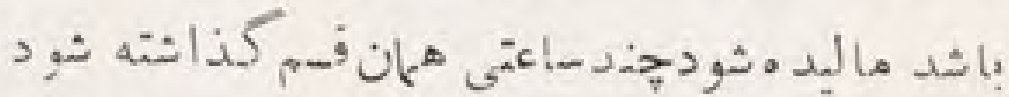

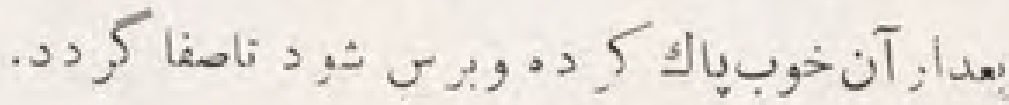
سفيد نمو دن فلازل كه، ز رد شدهباشد ام V V V مخلوط شو د وبا آن فلانل شسته شود م. 


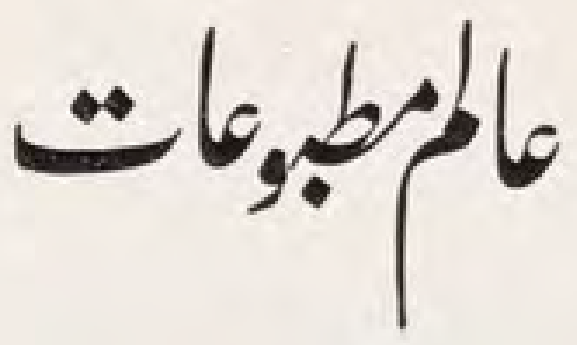

\section{?}

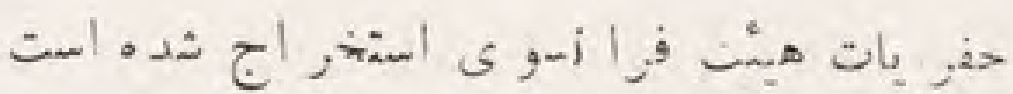

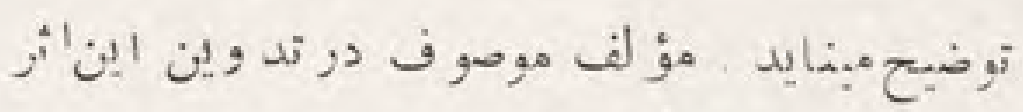

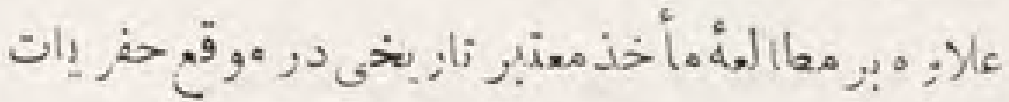

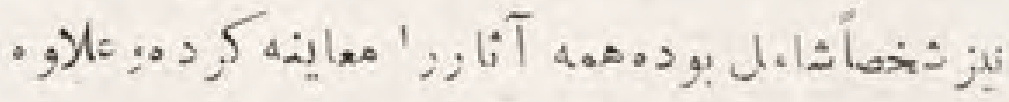

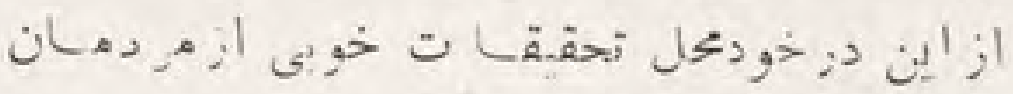

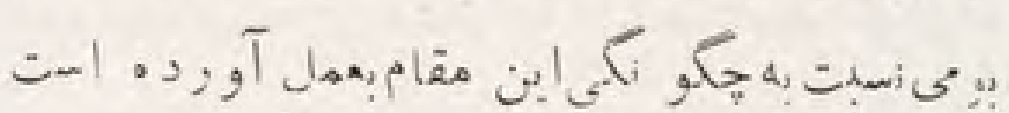

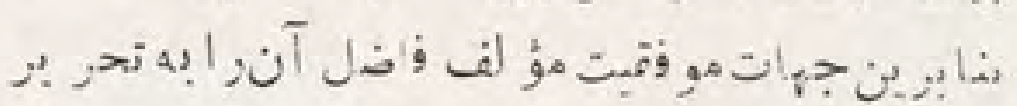

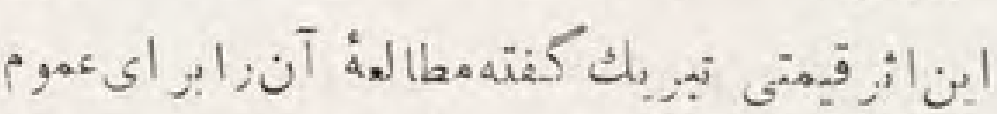

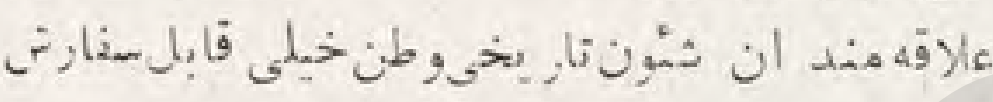

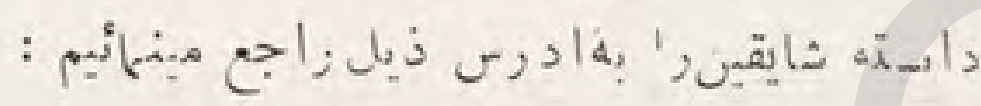

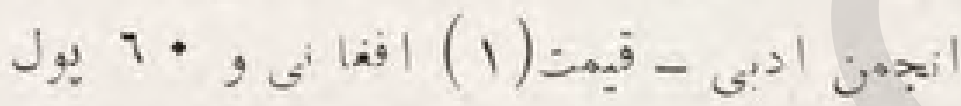

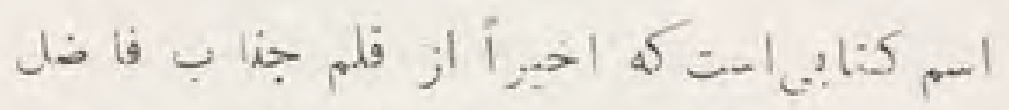

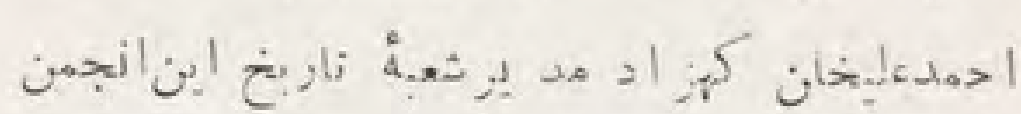

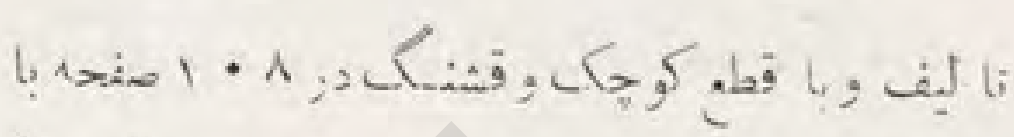

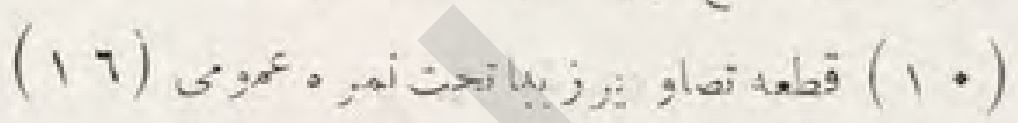

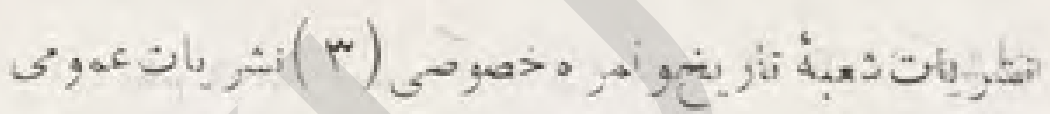

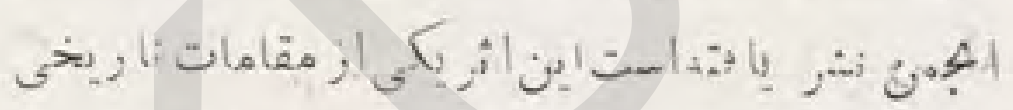

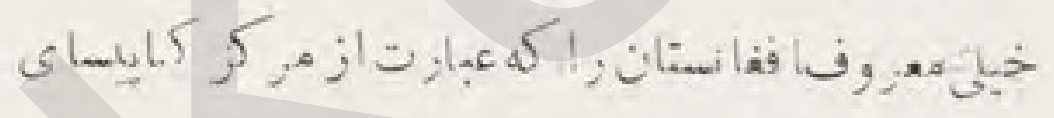

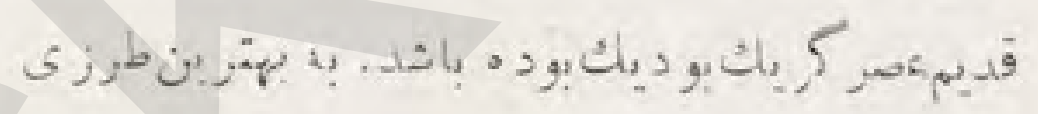

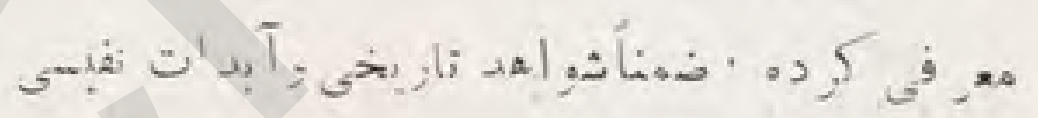
iا

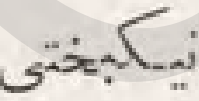

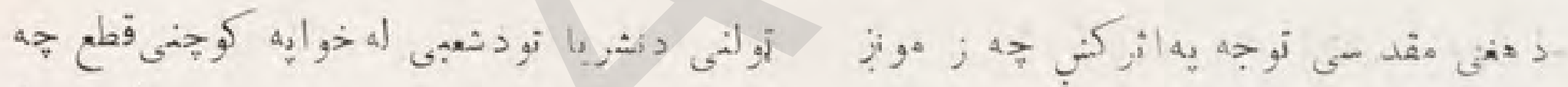

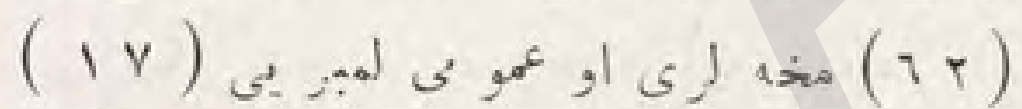

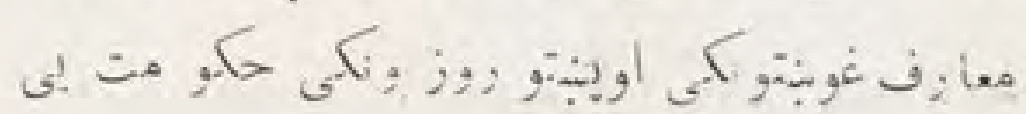

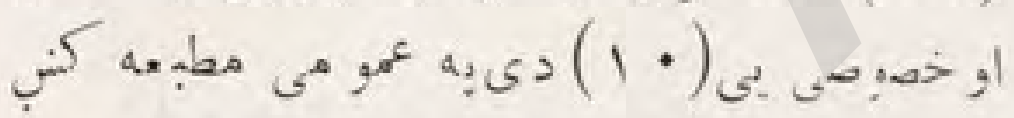
a: ¿

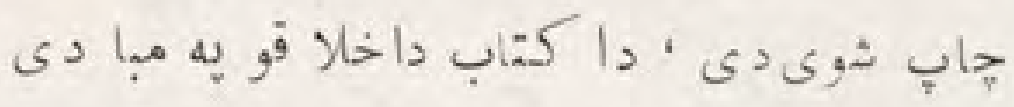

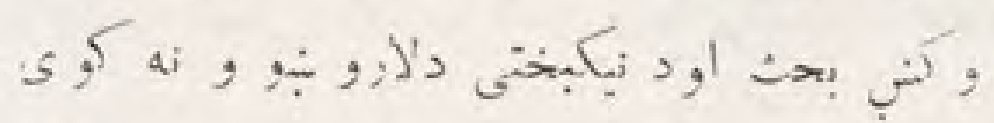

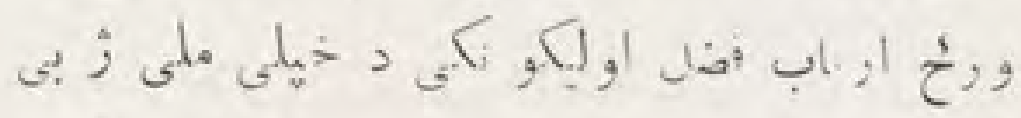

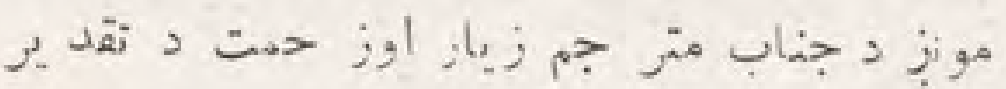

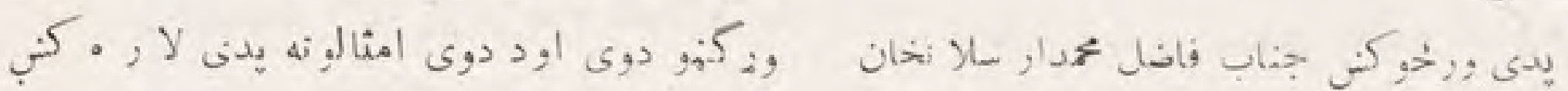

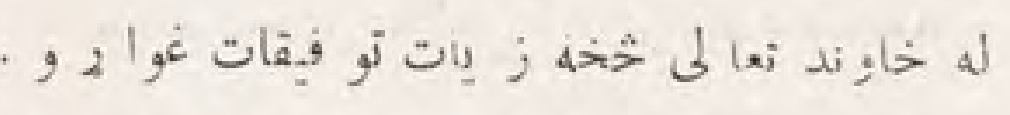

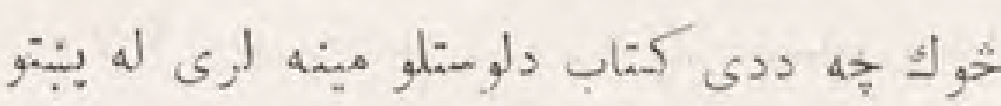

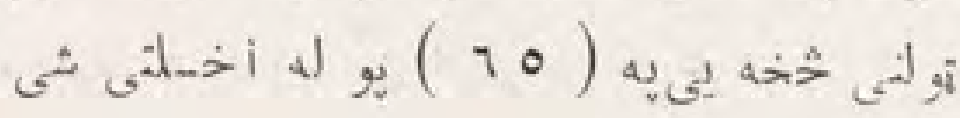

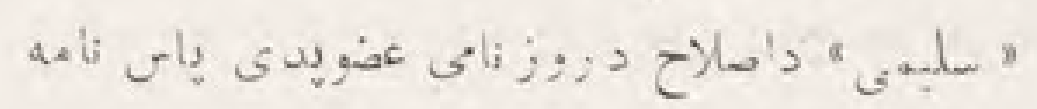

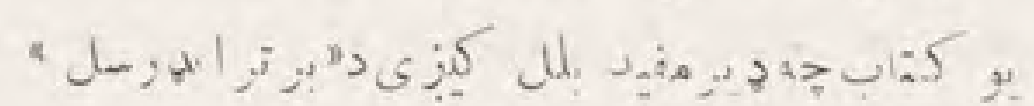

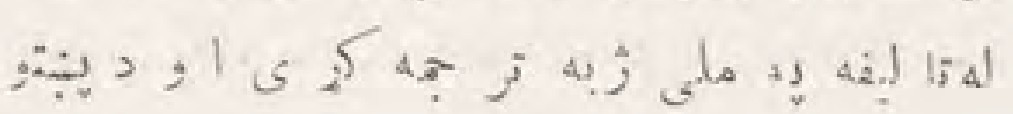
كن

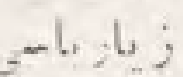




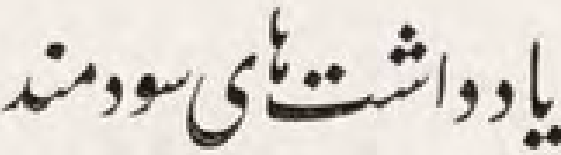

ابر يشم خام

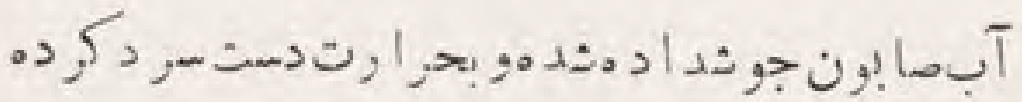

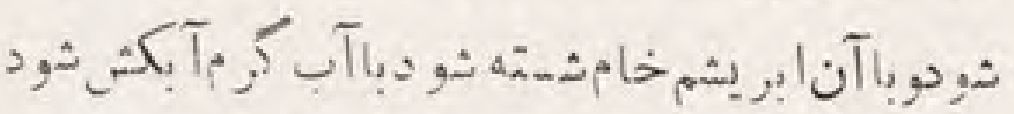

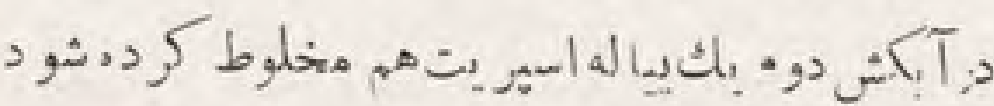

$$
\text { ابر يشم شسته }
$$

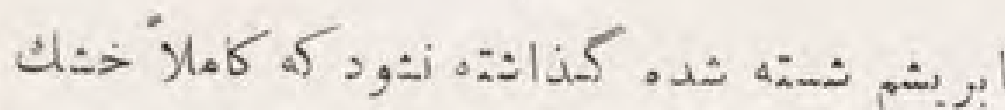

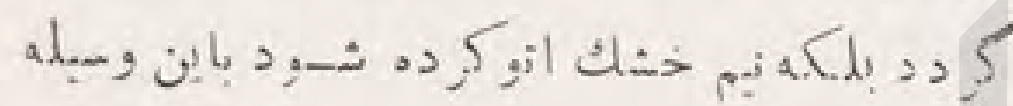

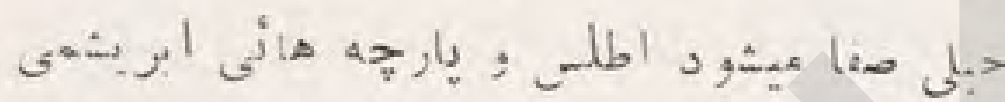

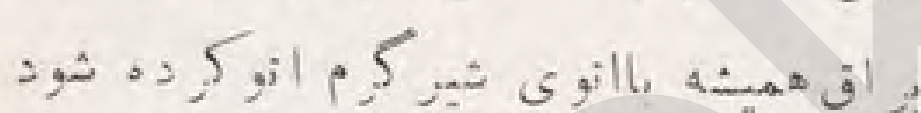

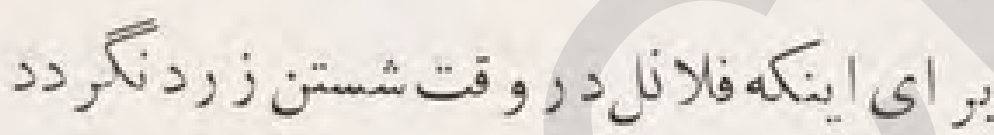

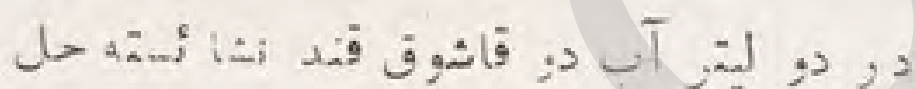

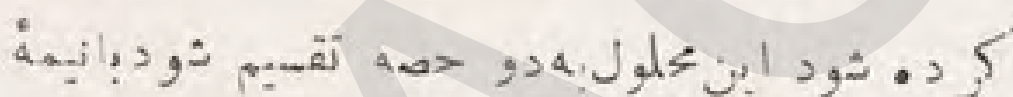

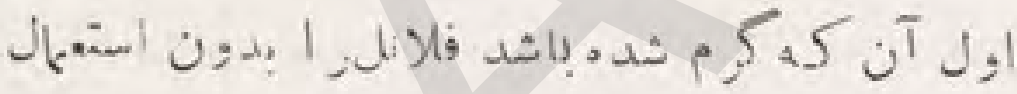

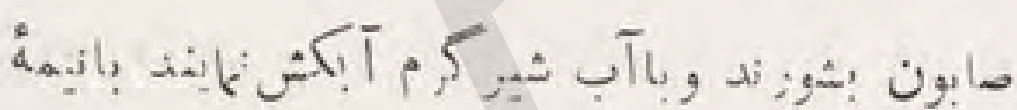

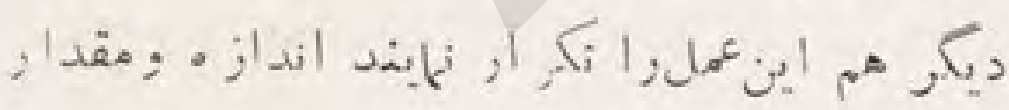

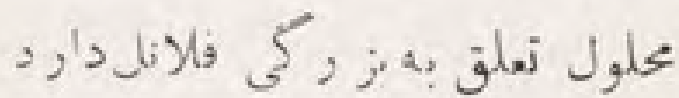

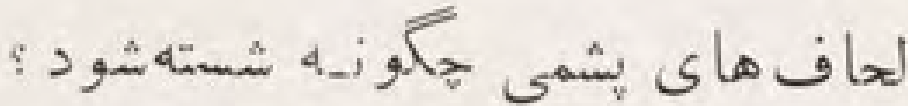

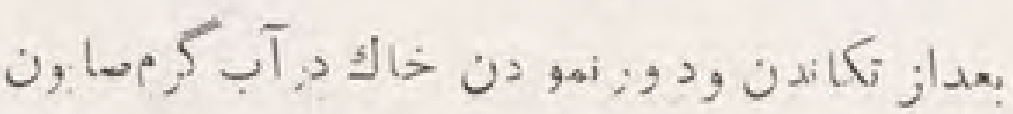

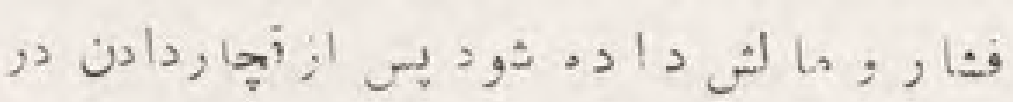

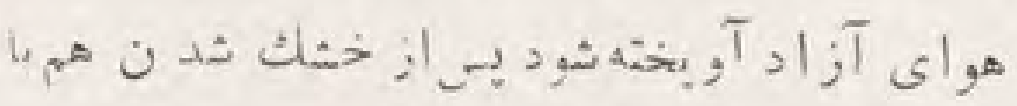

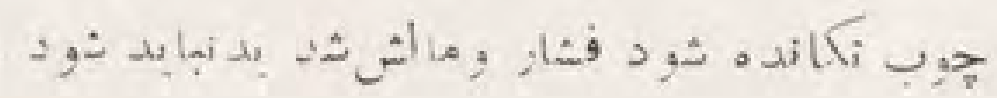

محافظت دسكشهاى جرى ازعرق

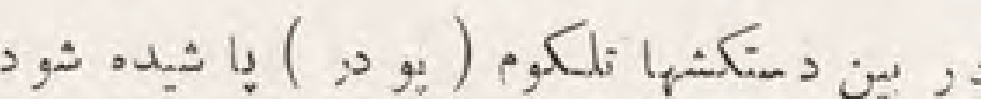

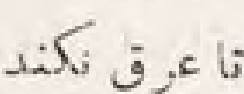

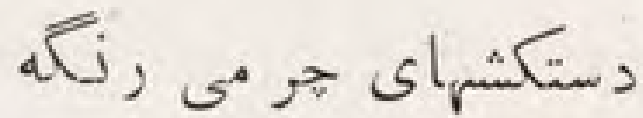

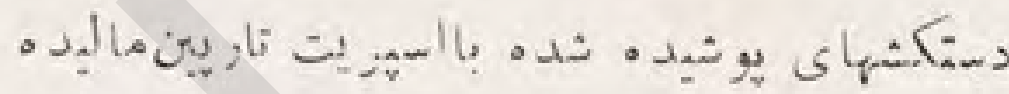

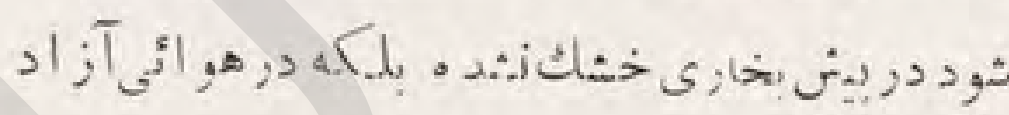

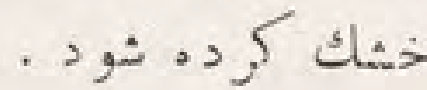

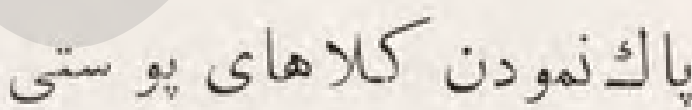

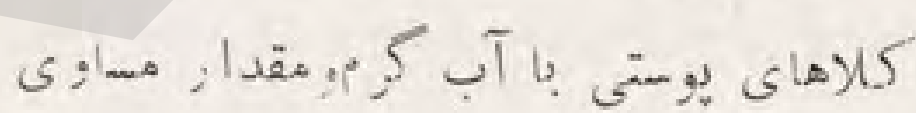

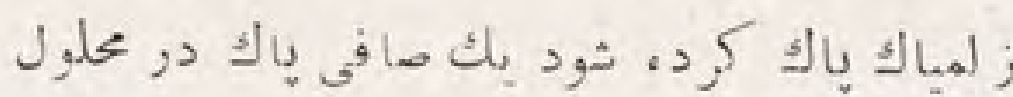

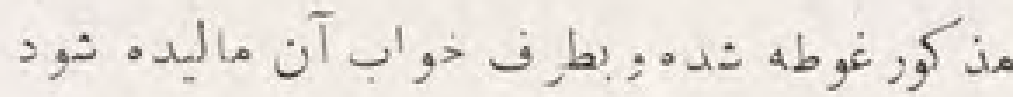

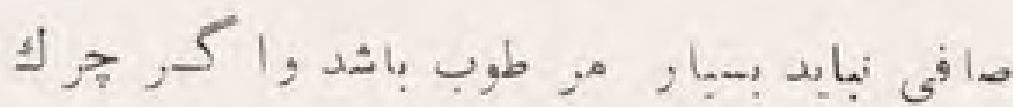

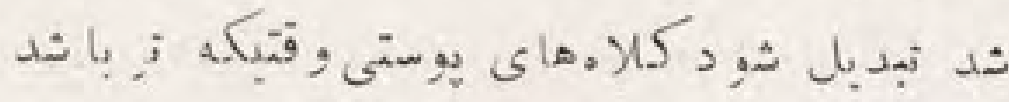

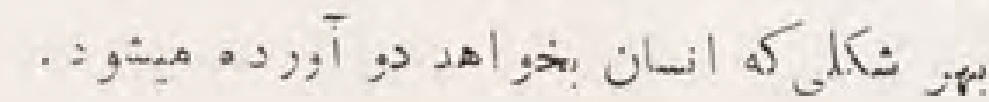
كلاه هاى إو ستى سفيد

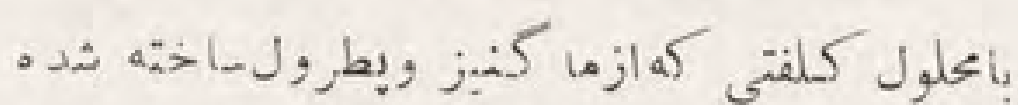

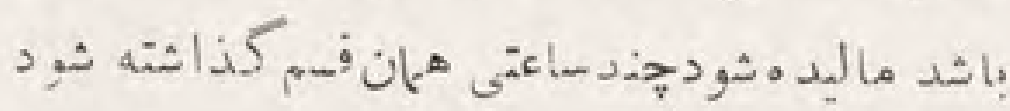

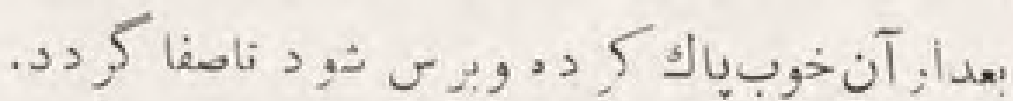
سفيد نمودن فالازلك كهز رد شدهد وباشيد

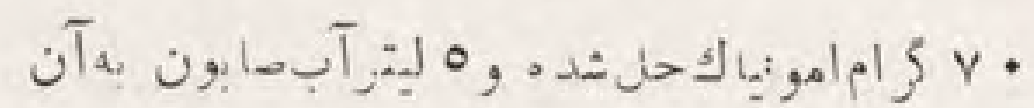
مخلوط شود وبا آن فلانال شيتهه ثود. 


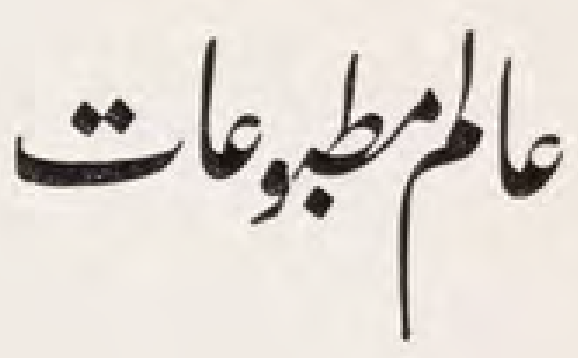

\section{?}

حفز يات هينت فوأ زموى استخر اج شده إست

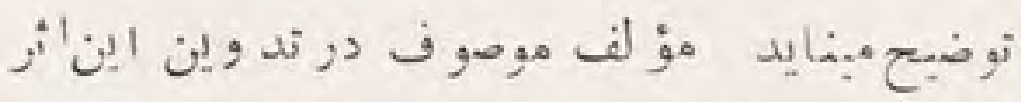

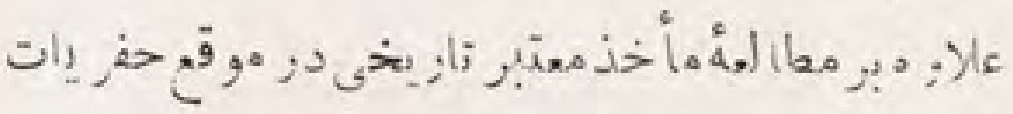

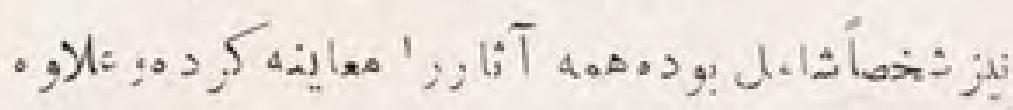

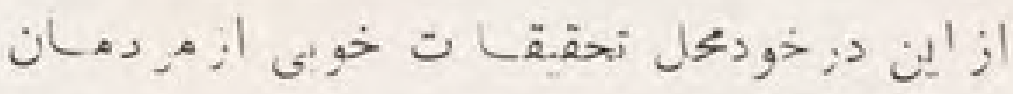

ب.

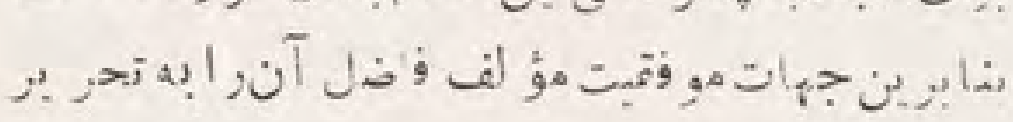

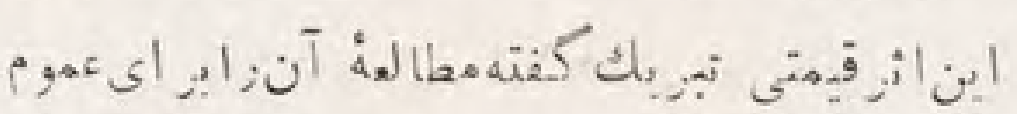

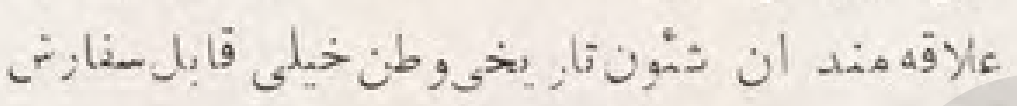

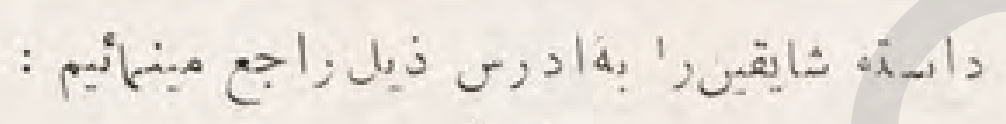

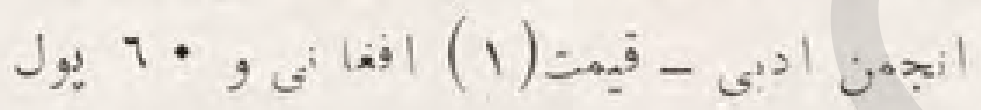

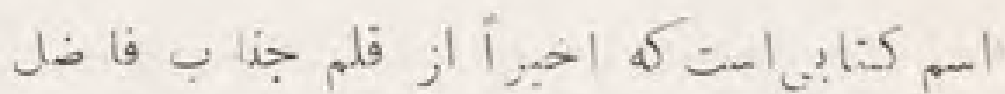

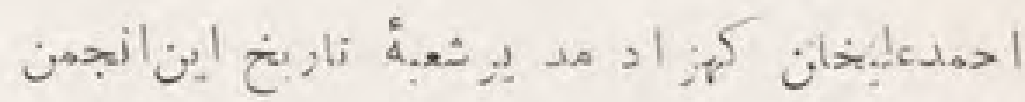

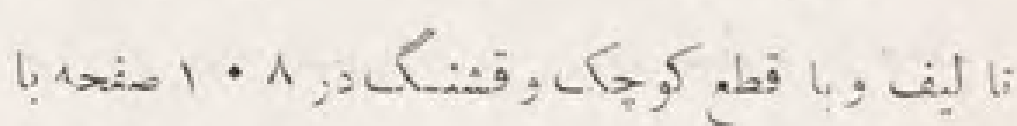

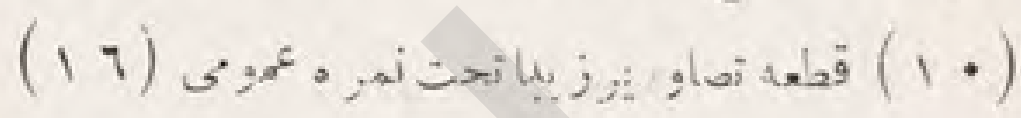

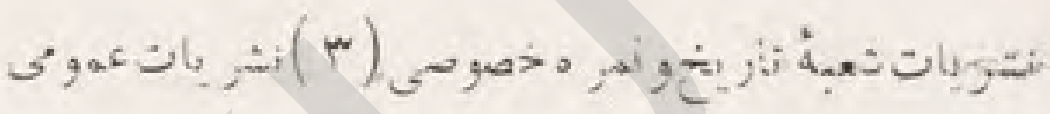

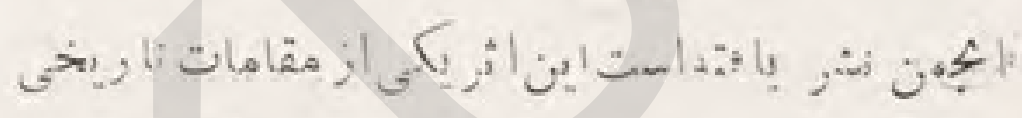

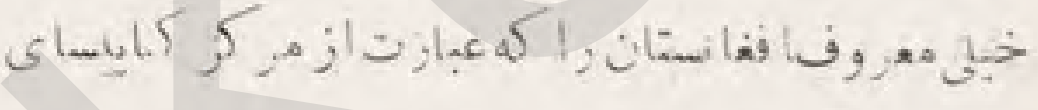

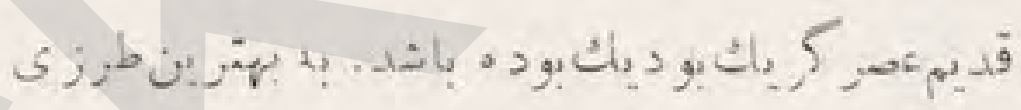

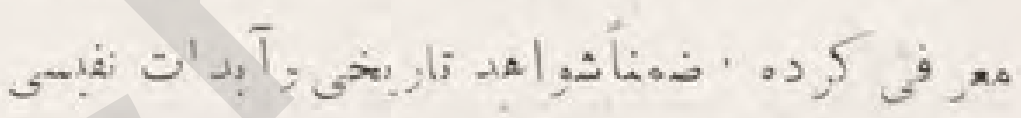

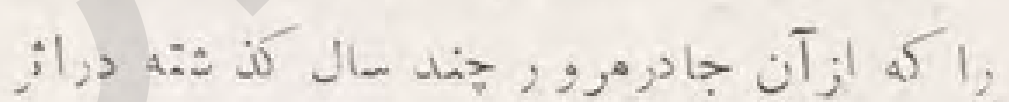
ज:

آزولن ( IV ) (

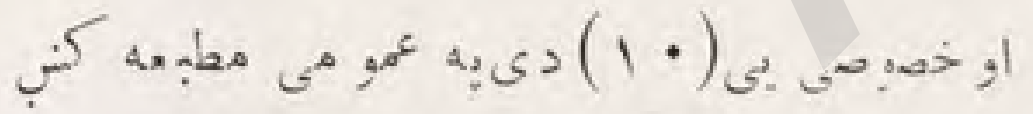

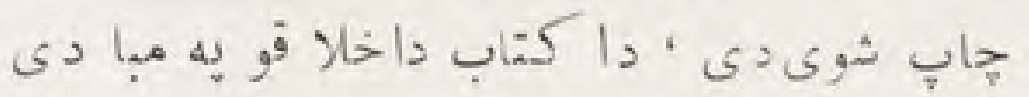

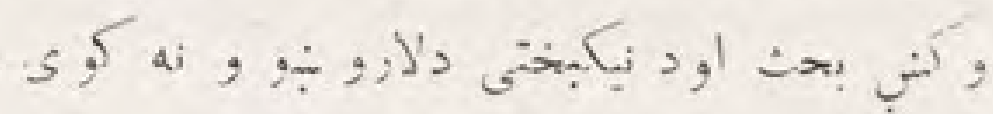

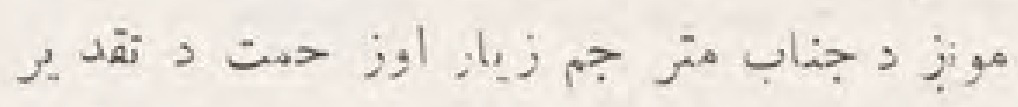

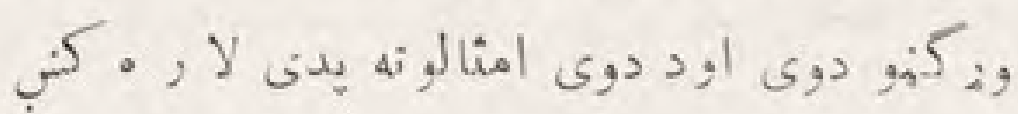

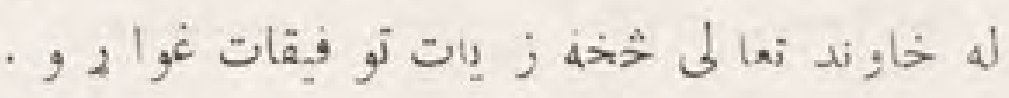

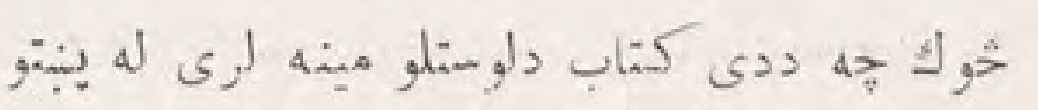

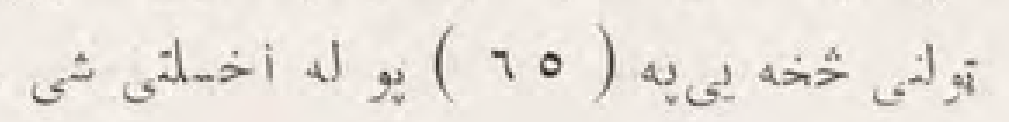

نو ز

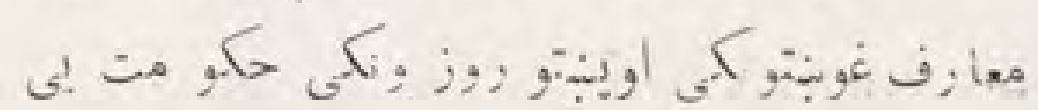

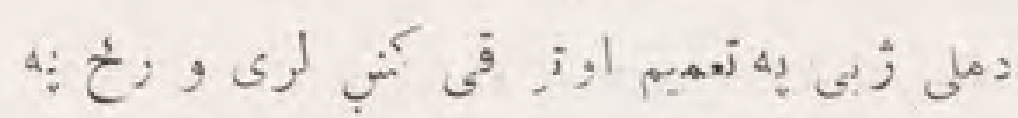

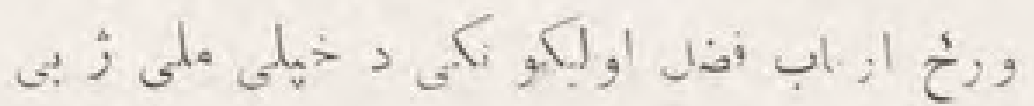

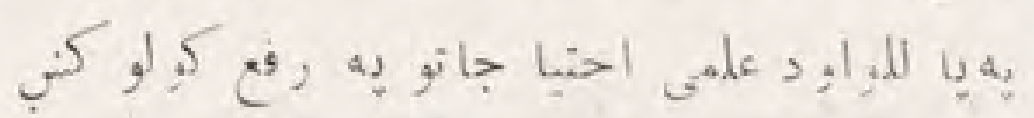
. - - l.

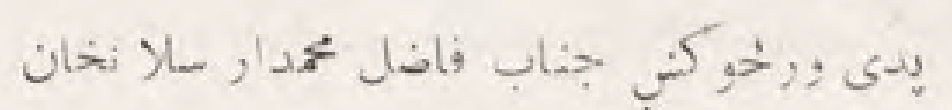

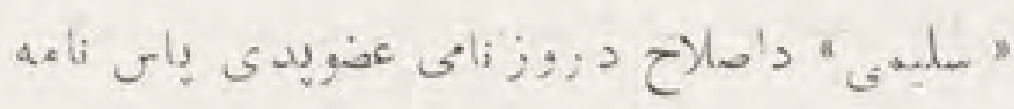

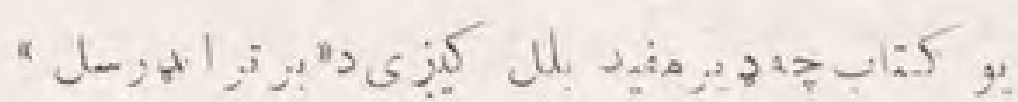

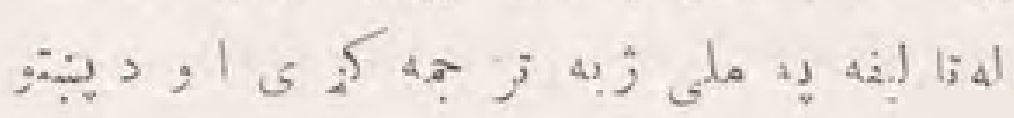




\section{بإواشثت}

$$
\text { ابر يشمخام }
$$

آبصابون جوشداد مثدهو بحرار تدستسر دكرده.

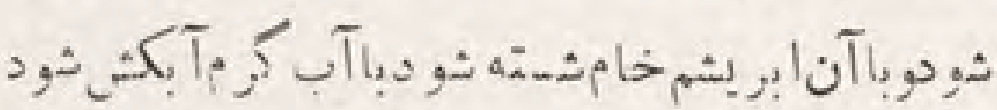

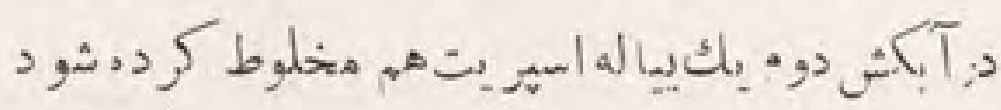

$$
\text { ابو يشم شسته }
$$

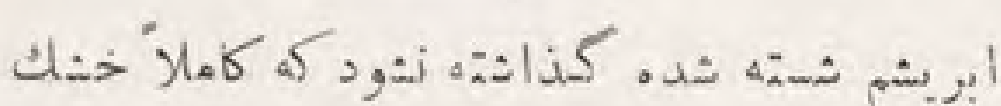

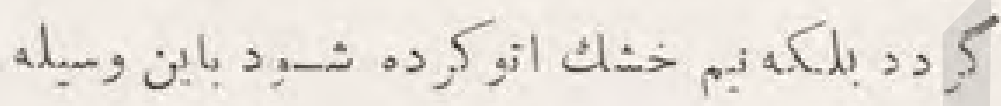

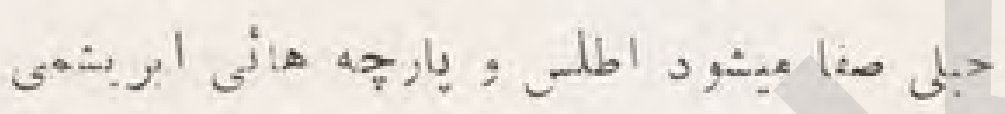

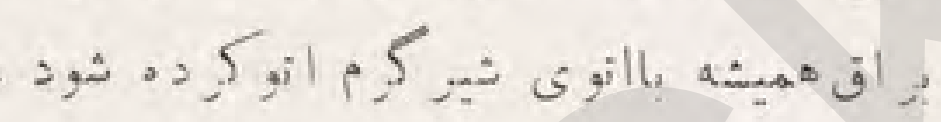
بر اي ائكه فلانل د, و وقتشستن ز ردنكر دد

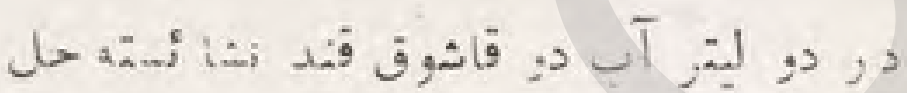

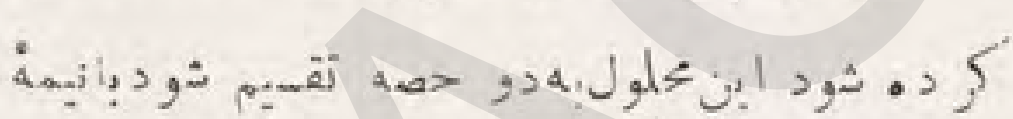

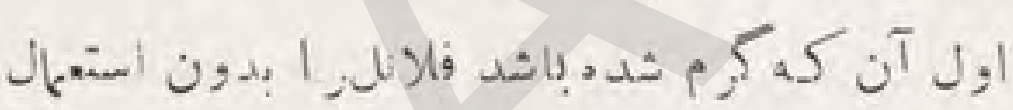

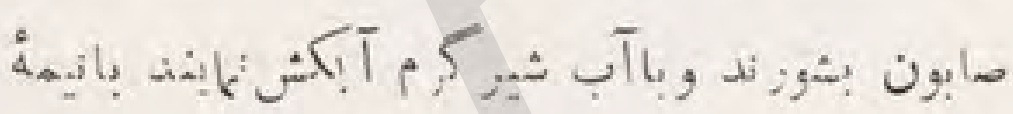

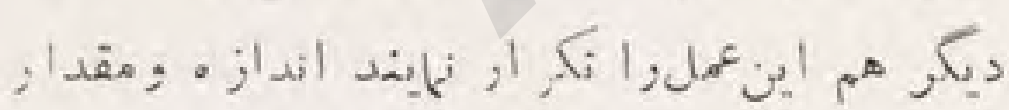

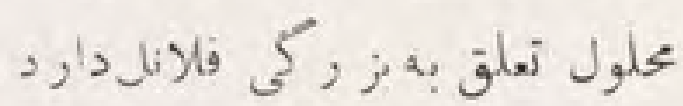

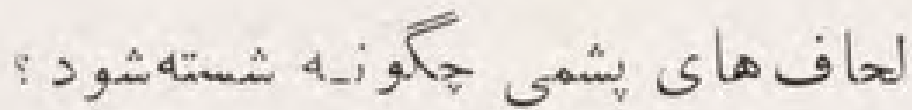

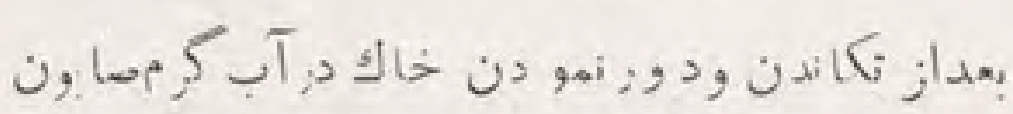

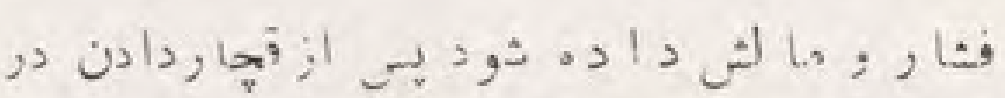

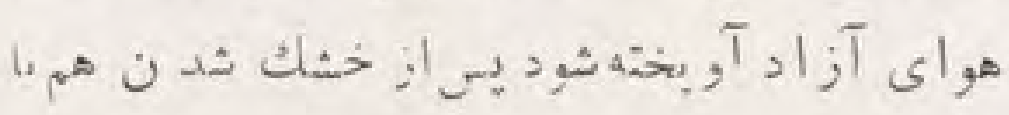

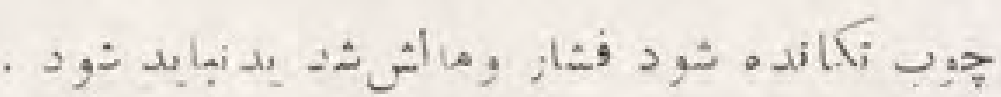

محافظت دسكشهاى جرى ازعرق

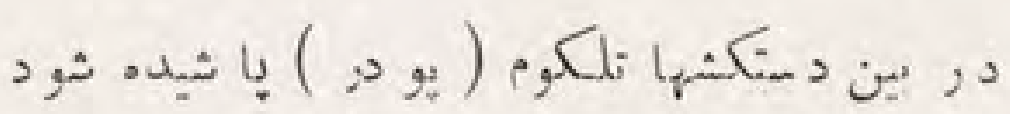

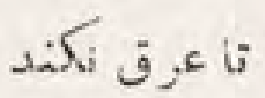

دستشهاى حهر مى رانمه

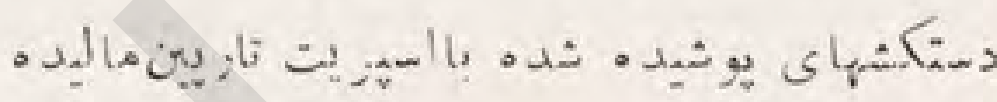

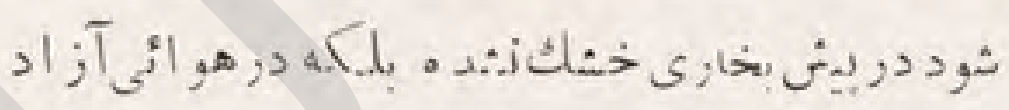

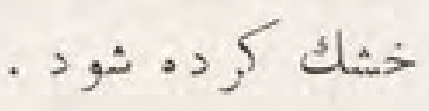

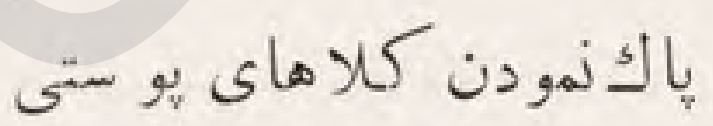

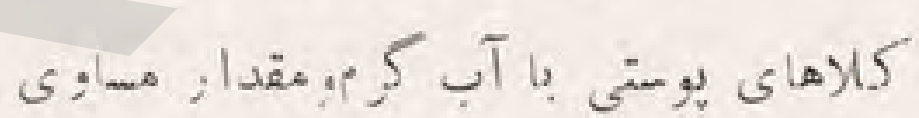

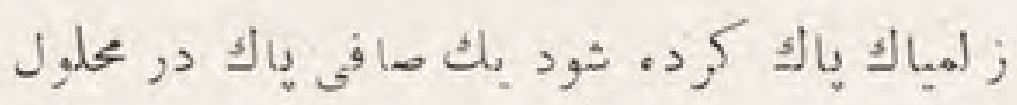

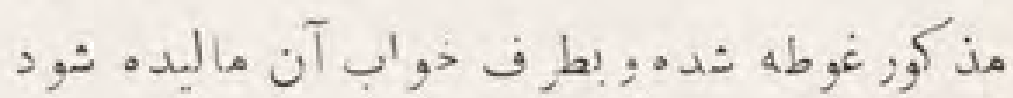

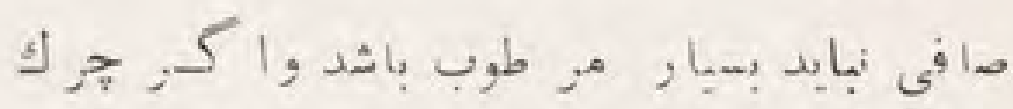

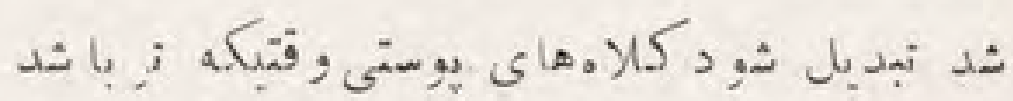

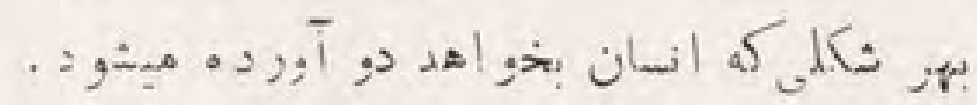
كالاه هاى ليو ستى سفيد

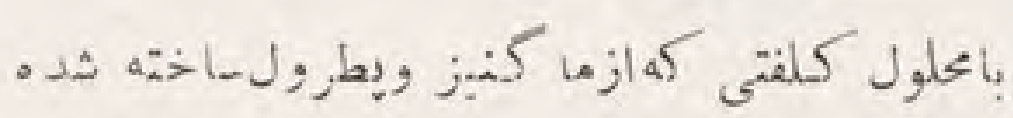

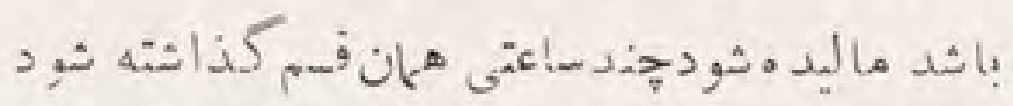

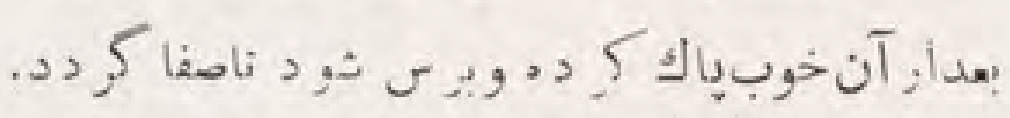

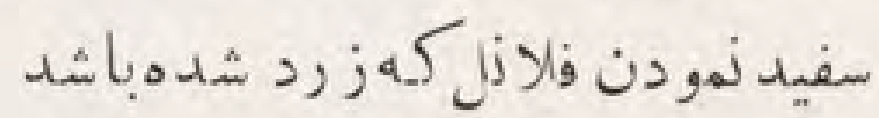

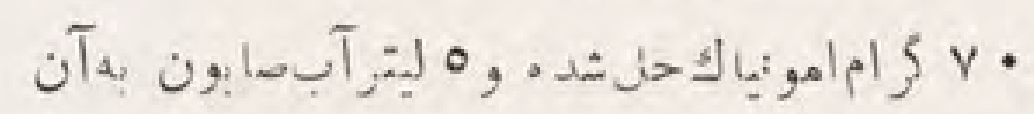

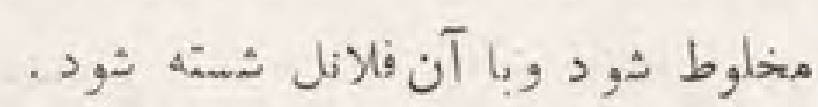




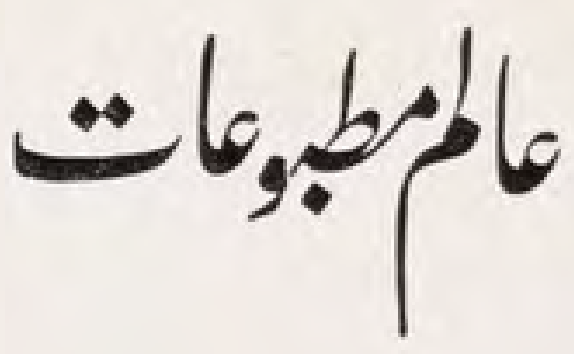

\section{?}

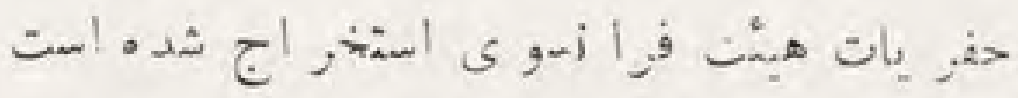

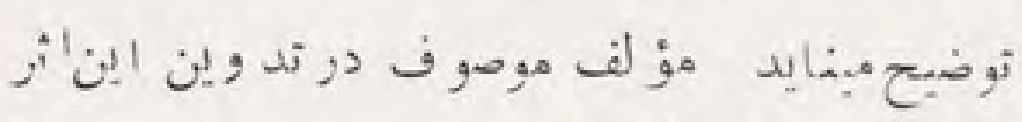

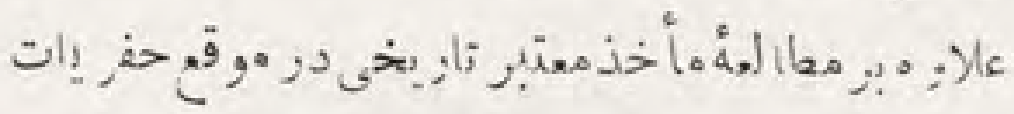

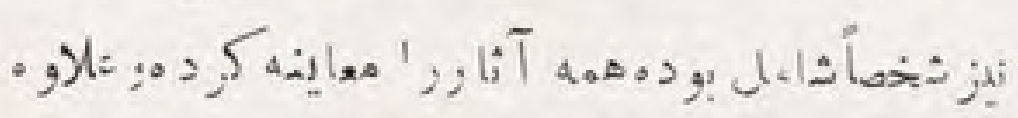

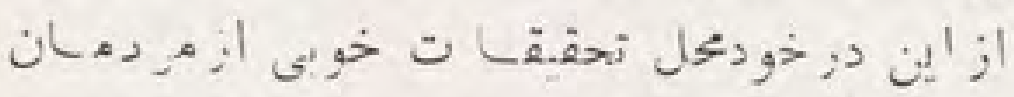

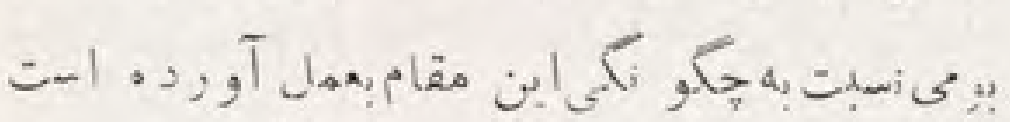

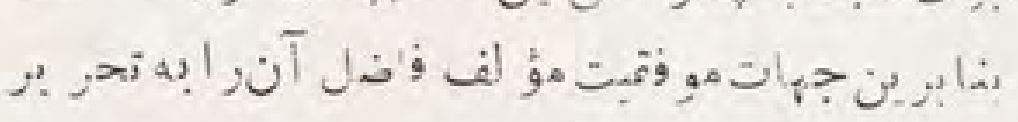

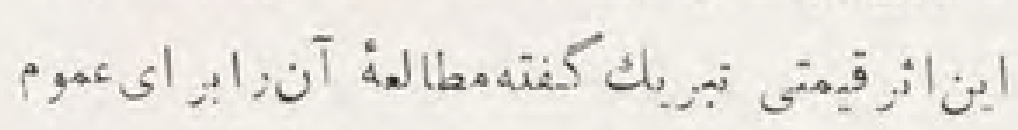

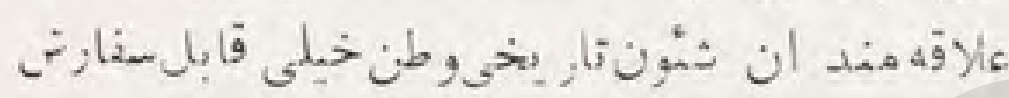

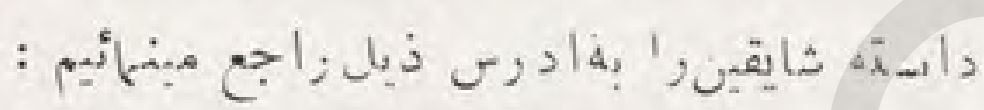

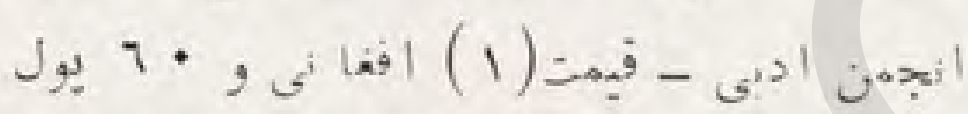

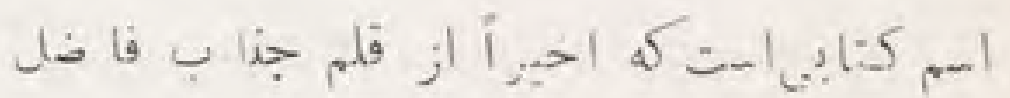

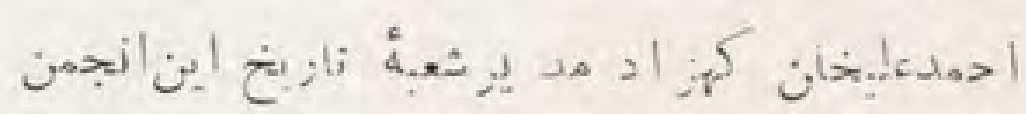
أ إلف , إ

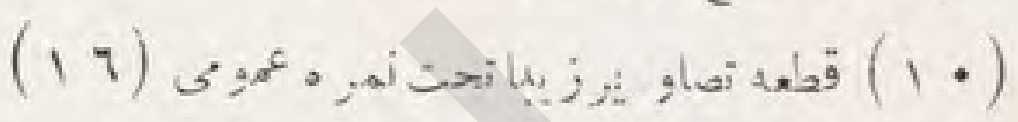

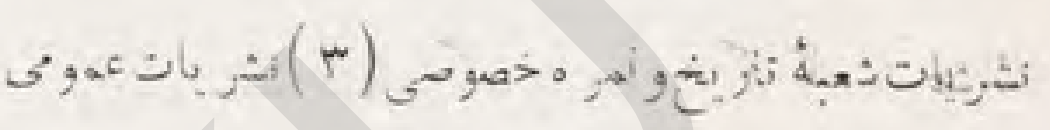

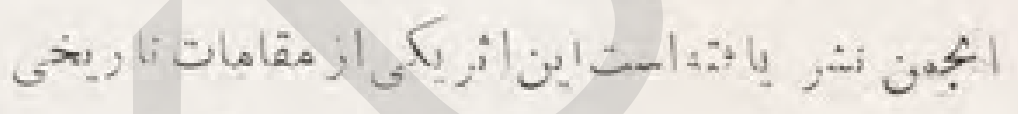

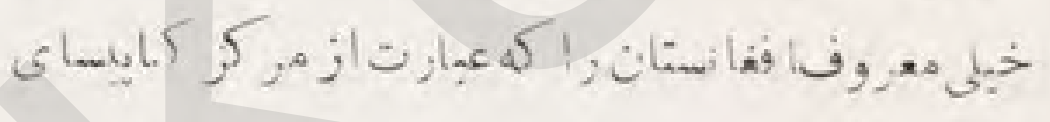

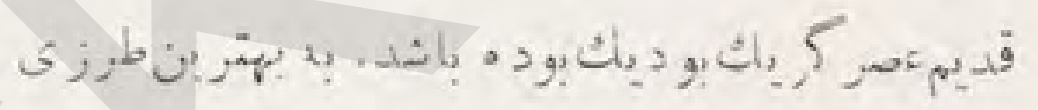

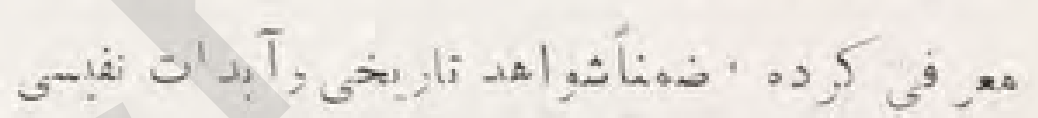

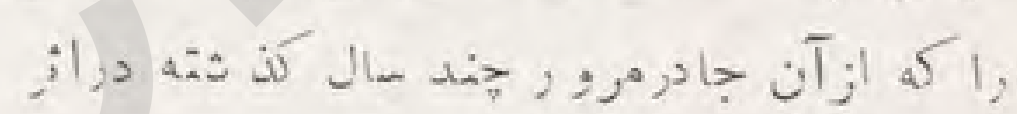

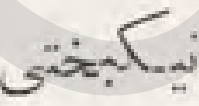

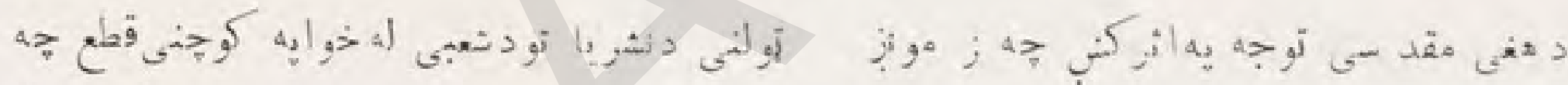

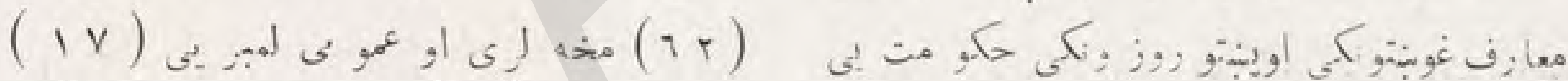

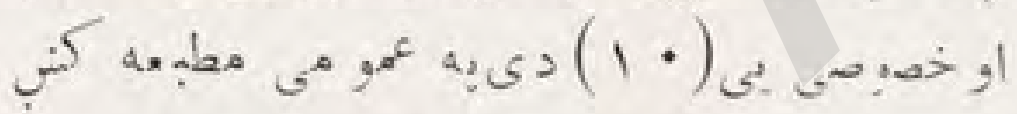

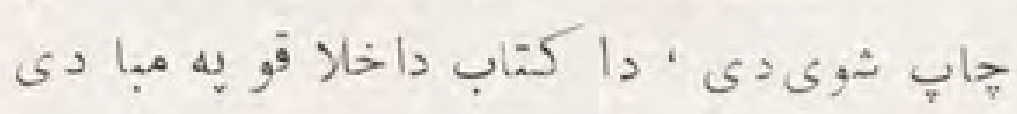

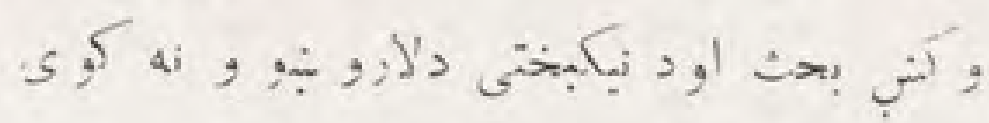

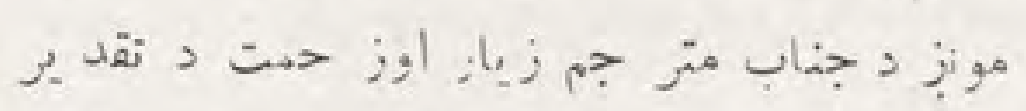

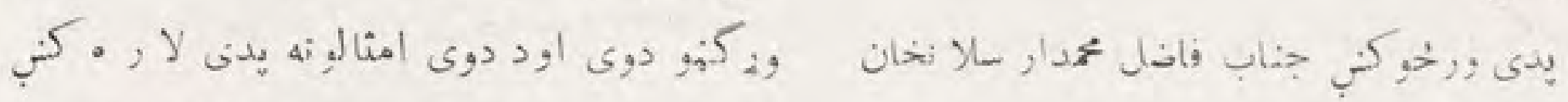

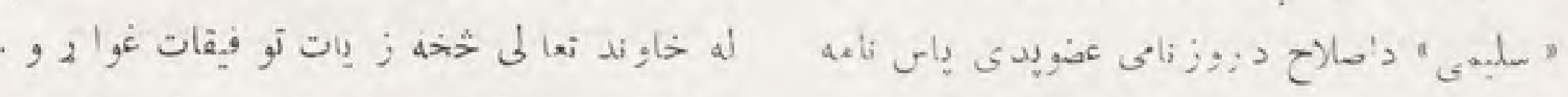

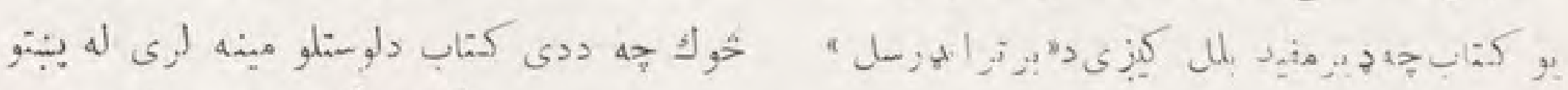

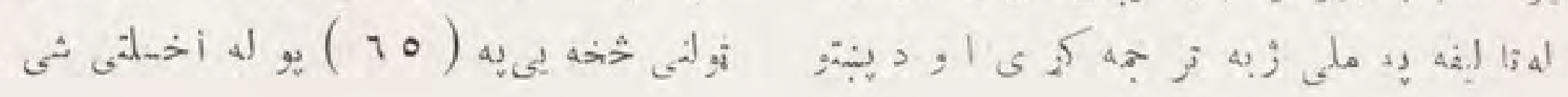




\section{!إوراثن}

$$
\text { إبر يشم خام }
$$

آب بصابون جوشداد مثدهو بجرا ارتدستسر دكرده

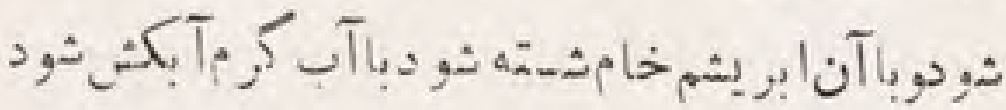

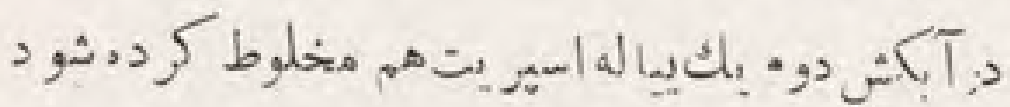

$$
\text { ابر يشم شتسته }
$$

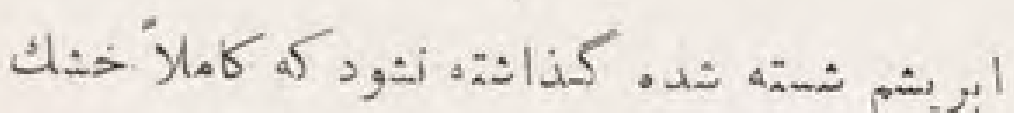

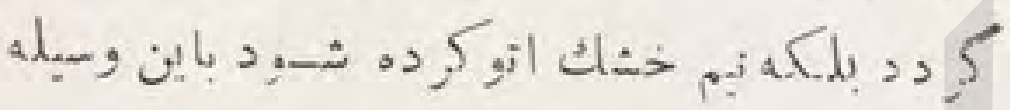

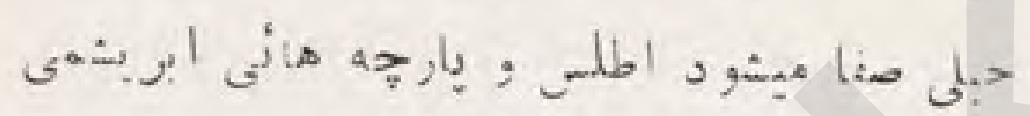

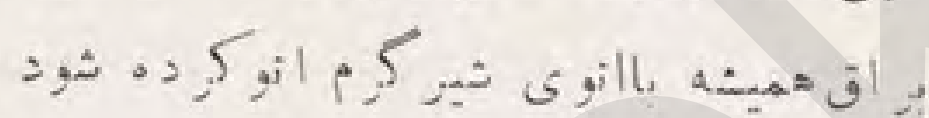

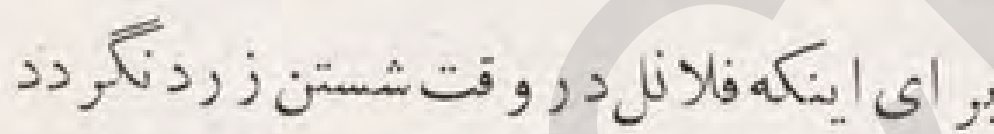

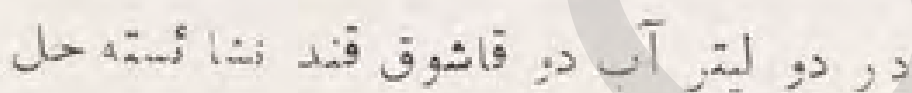

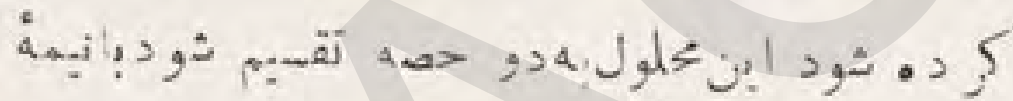
اول آن كه كرم شندمباشد فلانلز ا بدون استيمال

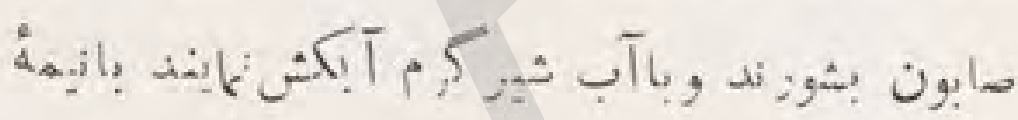

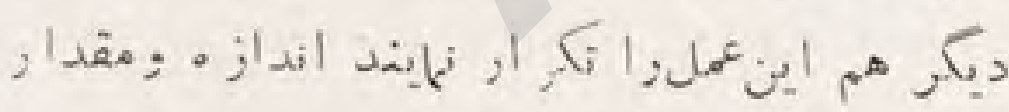

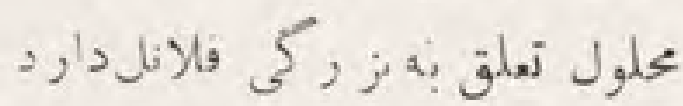

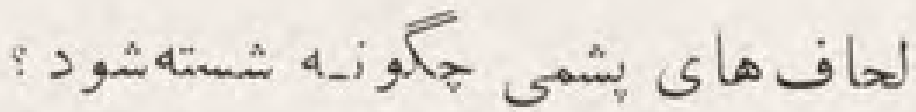

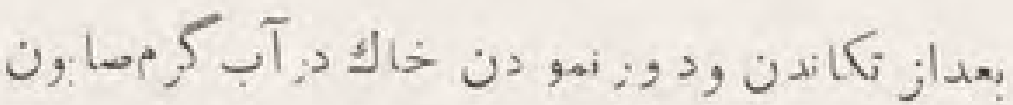

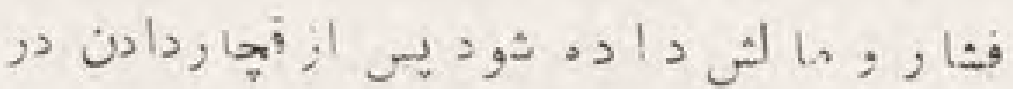

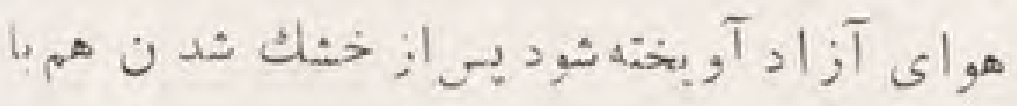

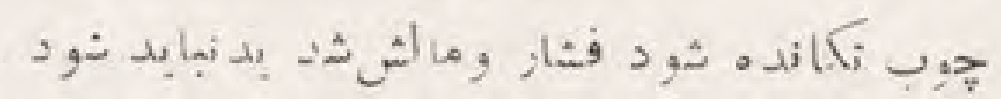

محافظت دسكشهاى حجرى ازعرق

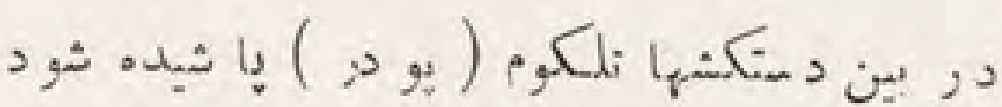

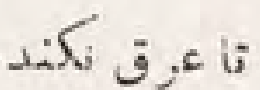
دستشهاى حهر مى ر)

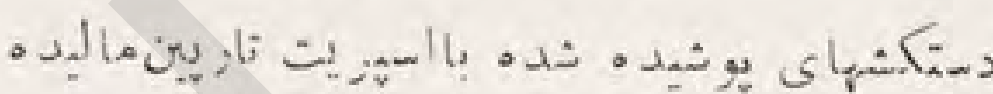

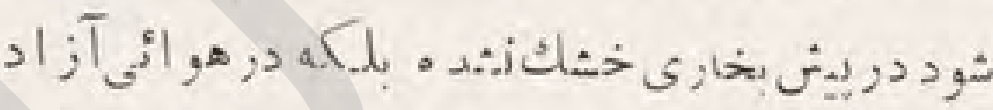
خثك كردم شود . لم

$$
\text { يإك نهودن كلانهاى يو ستى }
$$

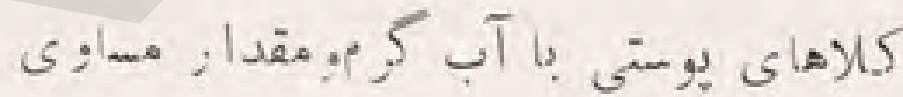
ز لمياك بالك كرد، شود بك صافي ياكك در محلول مذكور غوطه خده:: إطرف خواب آن ماليده شو

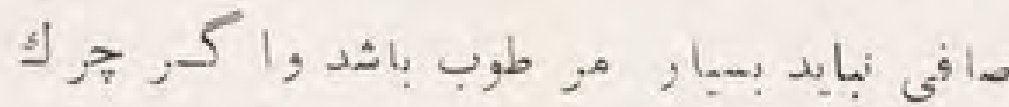

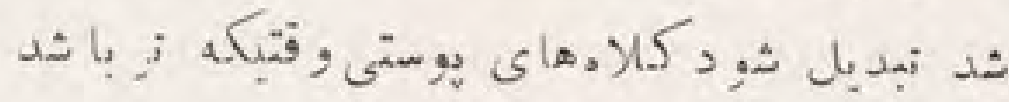

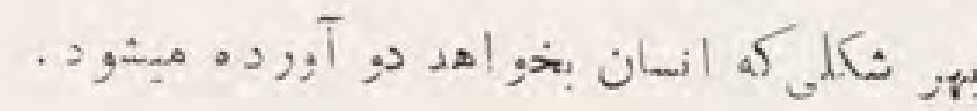
كلاه هاى لو ستى سفيد بأحلول كلفتى كهازما كث:ز وبطرول كساخته شده

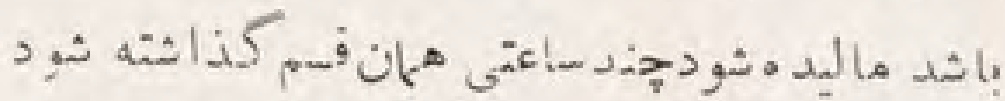

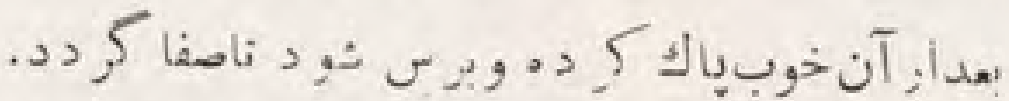

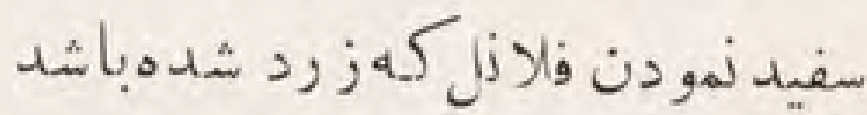

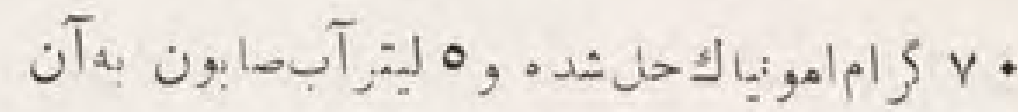
مخلوط شو د وبا آن فالانل شسمه شود . 


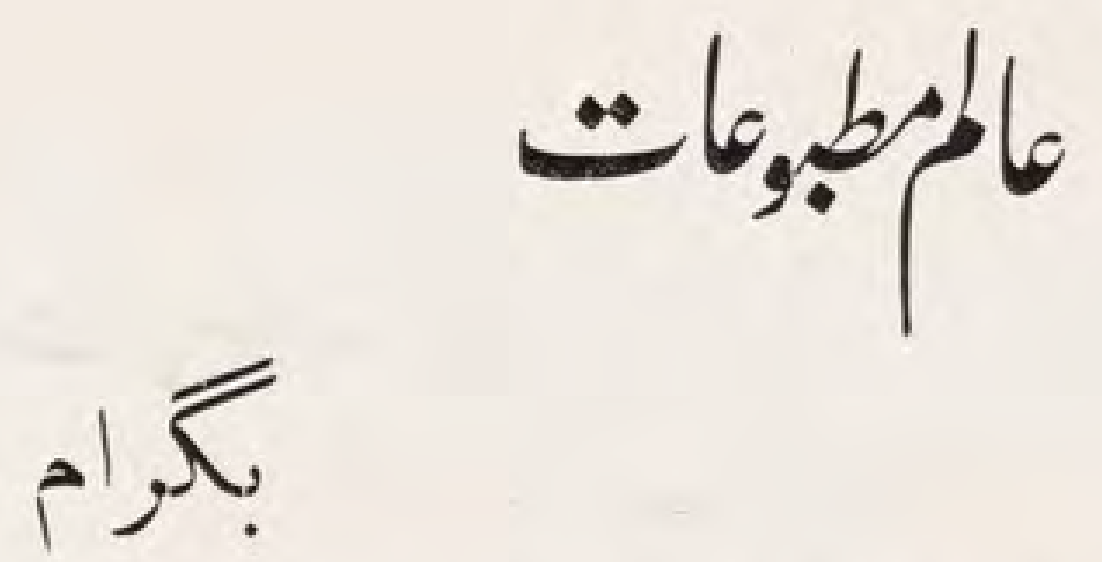

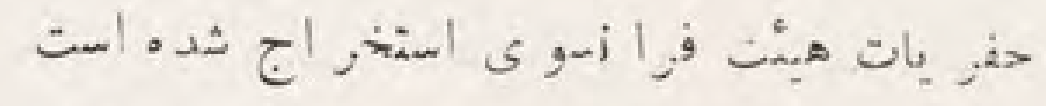

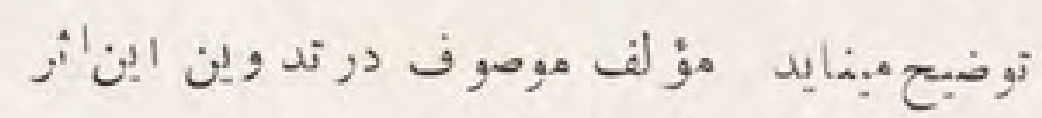

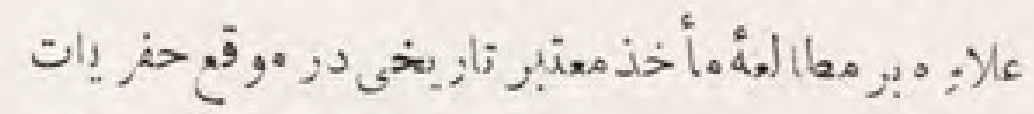

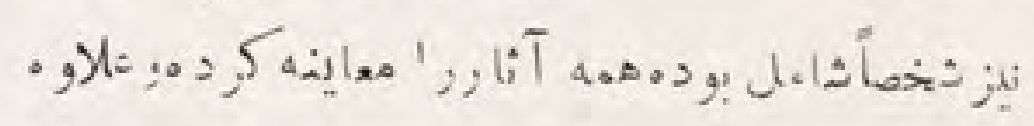

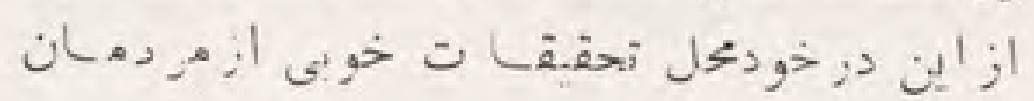

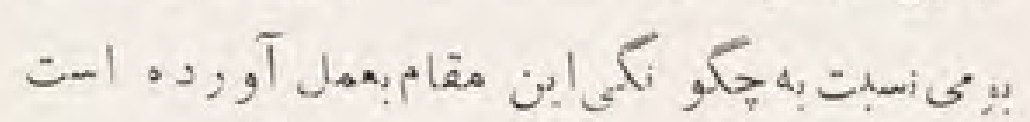

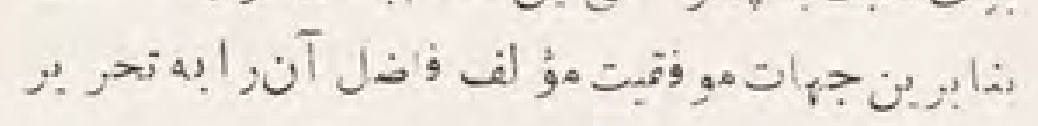

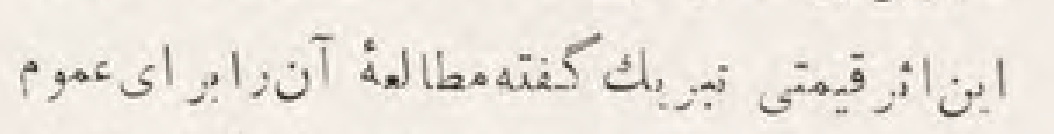

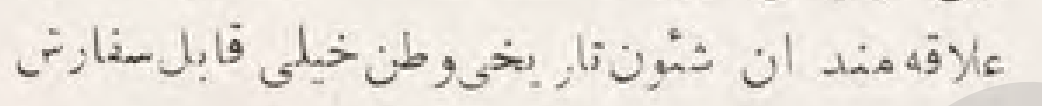

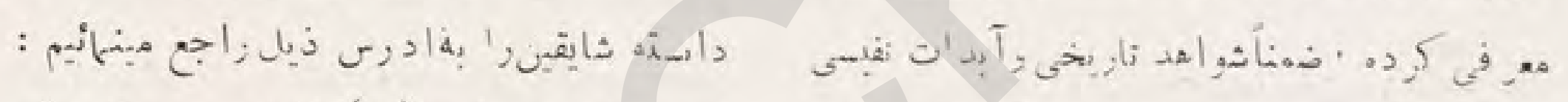

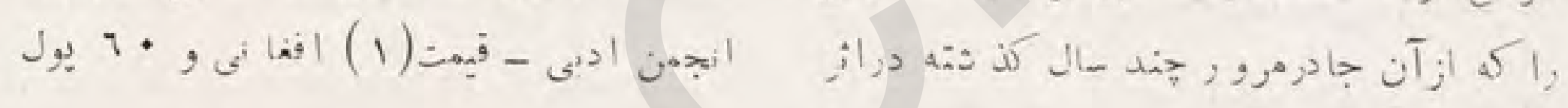

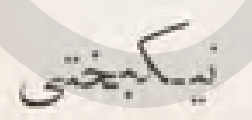

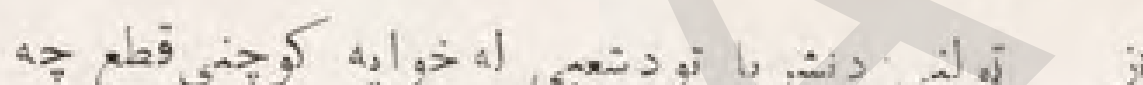

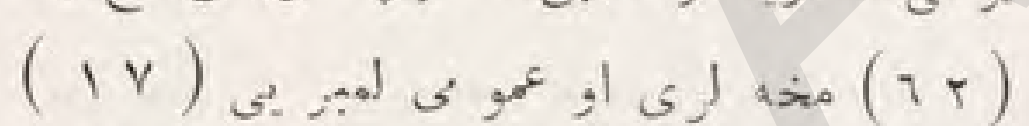

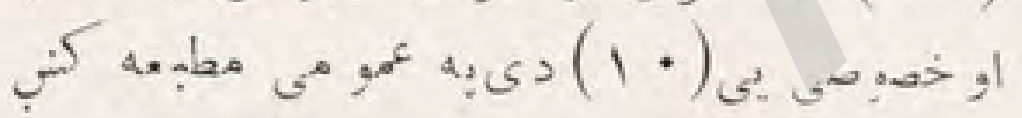

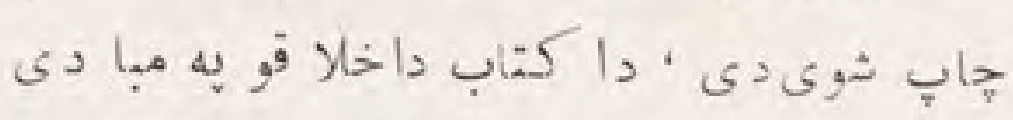

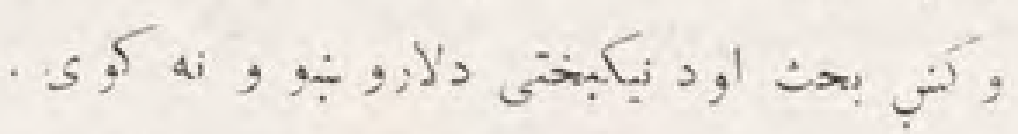

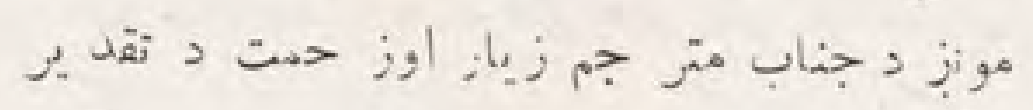

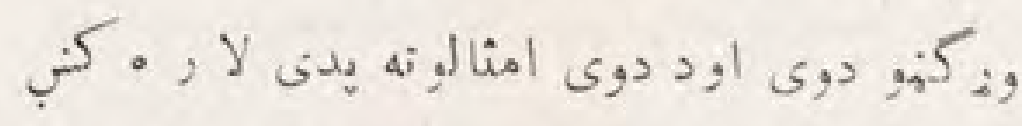

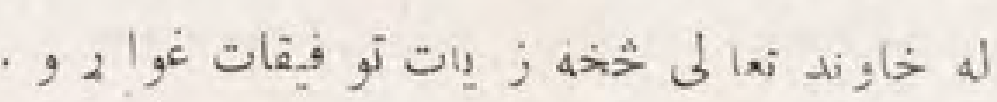

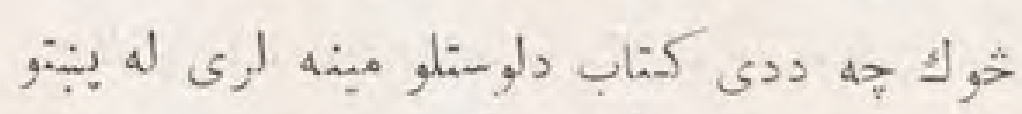

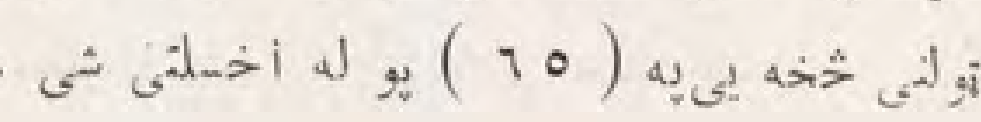

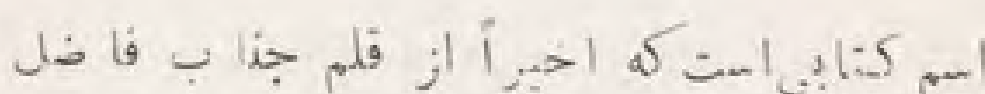

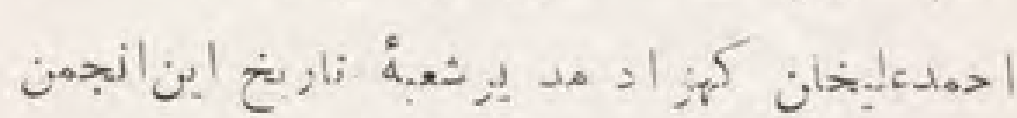

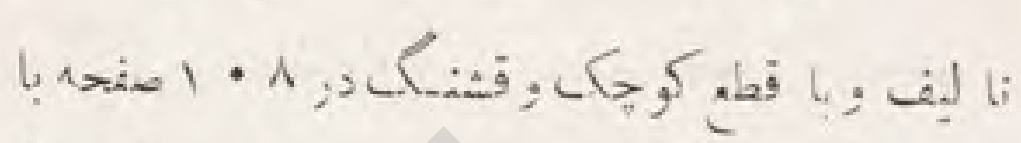

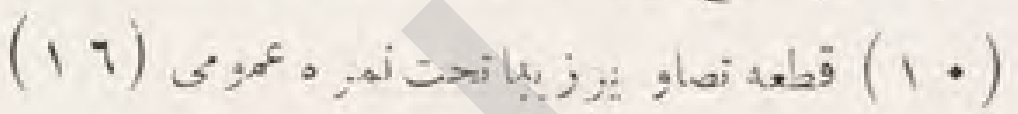

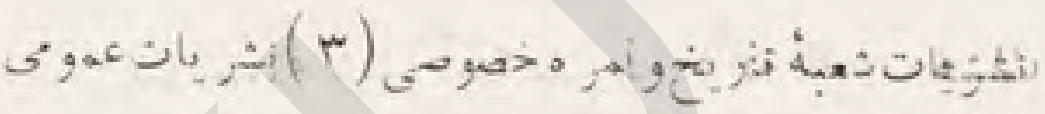

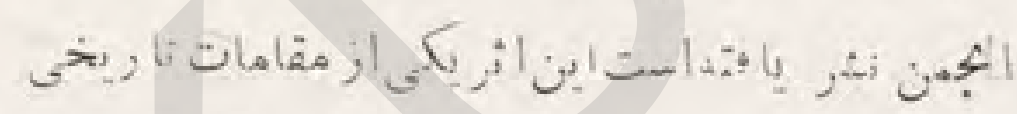

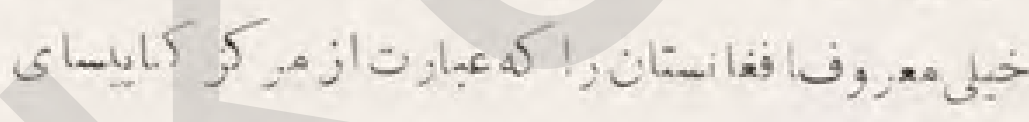

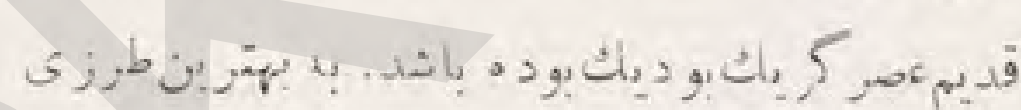

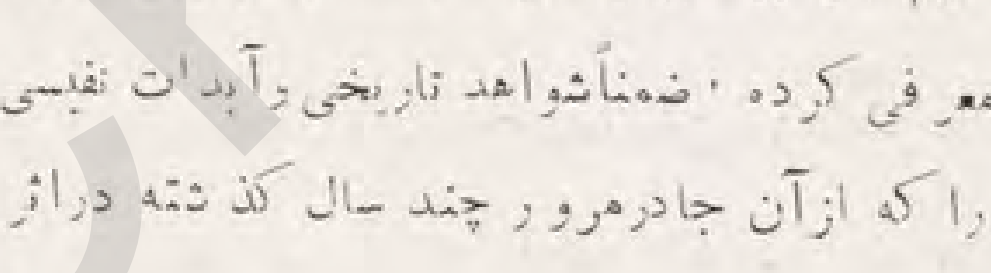

د د

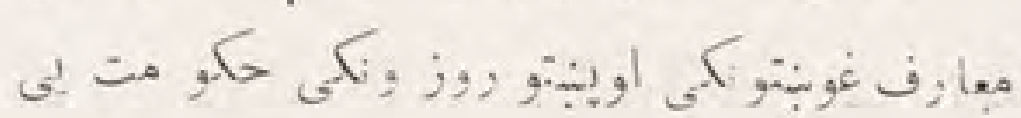

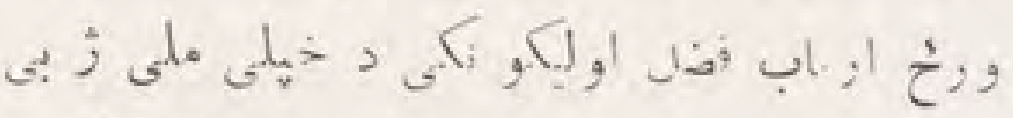

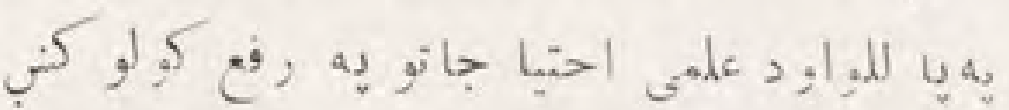

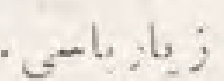

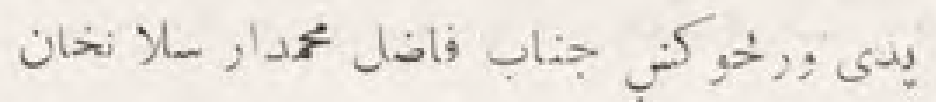

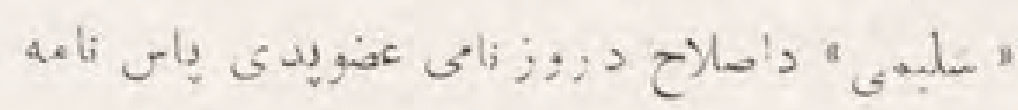

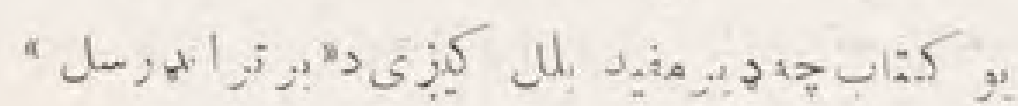

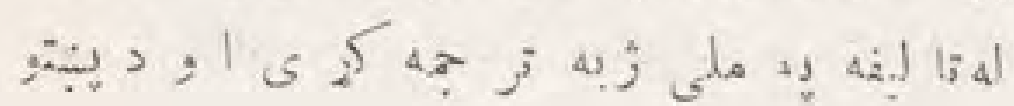

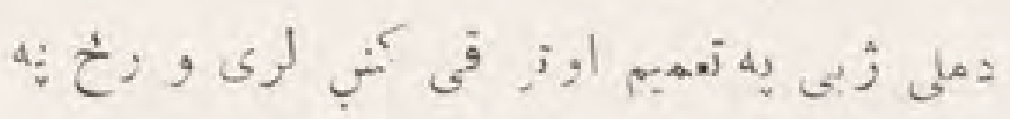




\section{بإواثثن}

$$
\text { ابو يشم خام }
$$

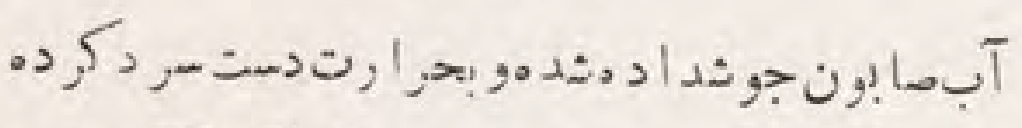

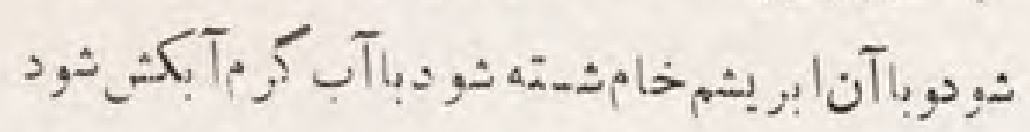

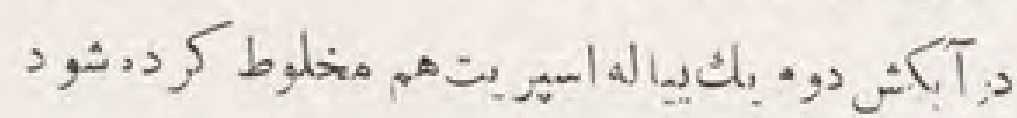

$$
\text { ابر يشم شتسنه }
$$

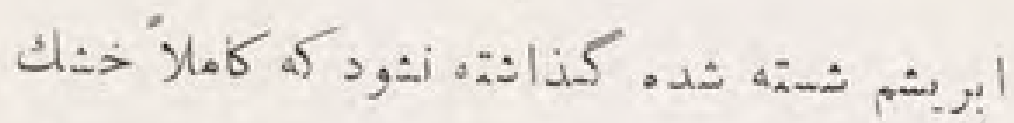

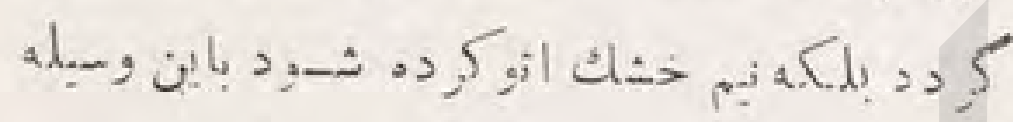

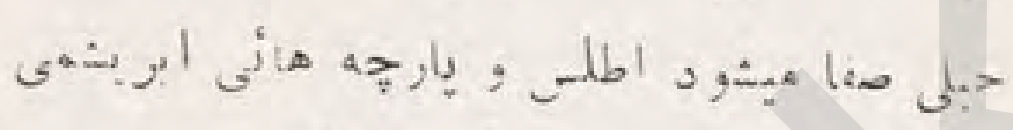

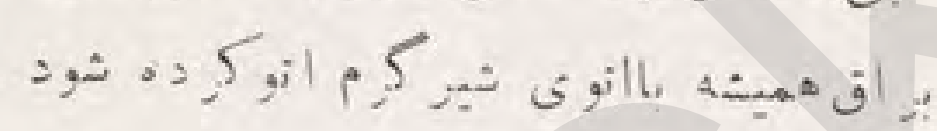

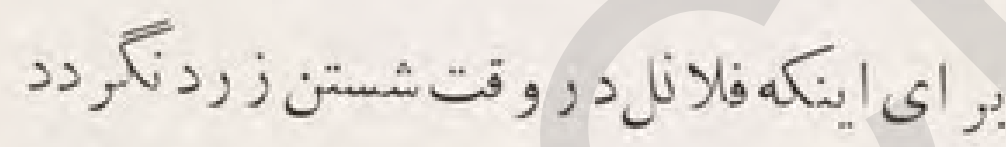

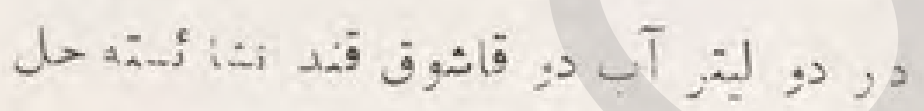

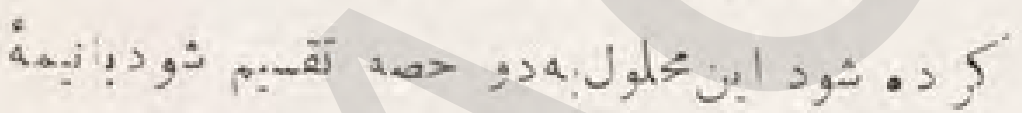

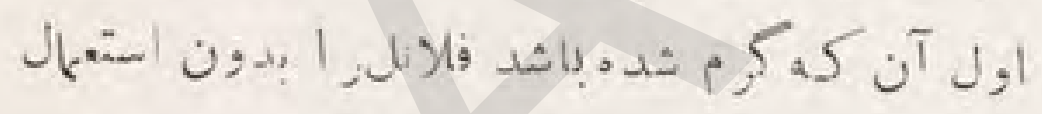

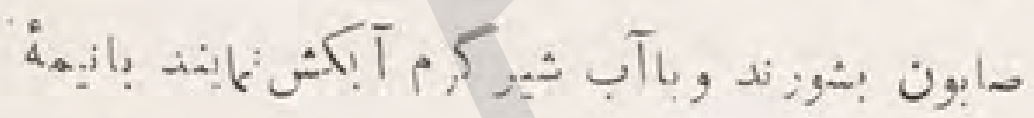

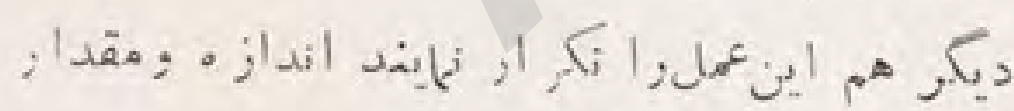

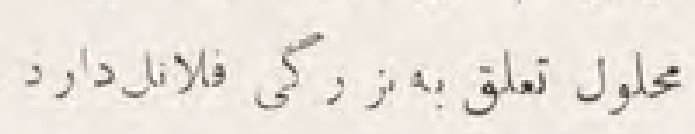

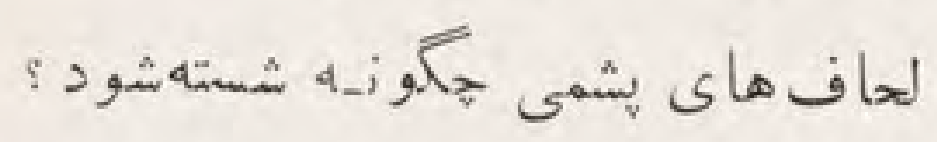

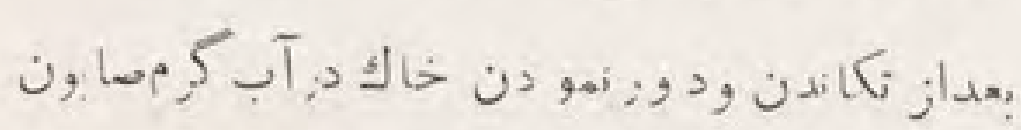

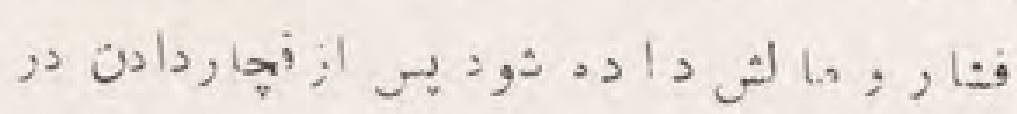

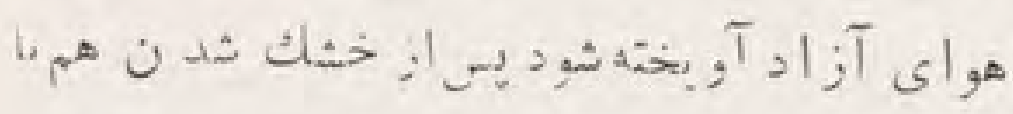

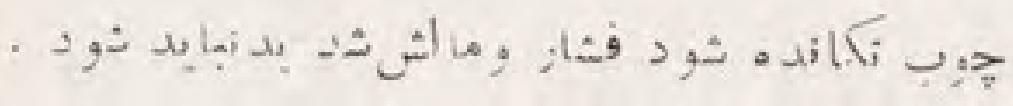

محافظت دسكشهاى ثرى ازعرق

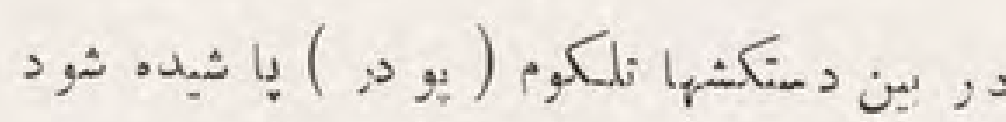

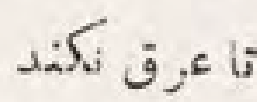

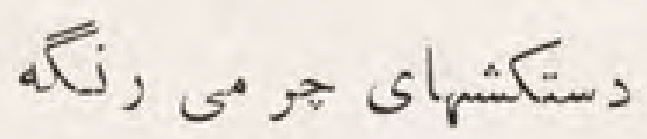

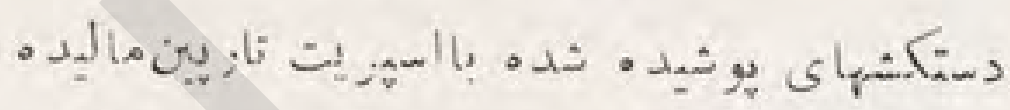

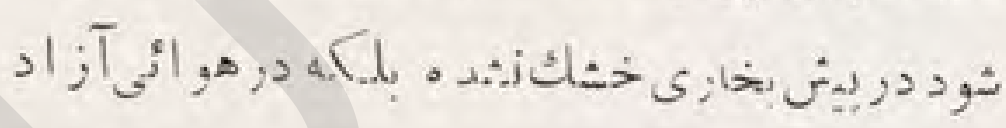

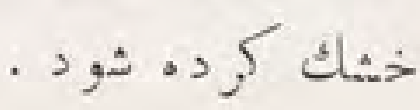

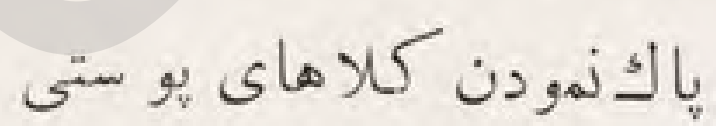

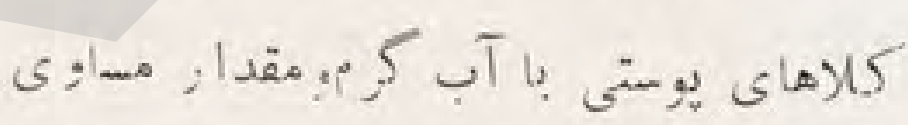

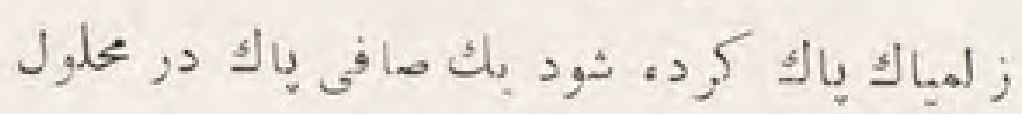

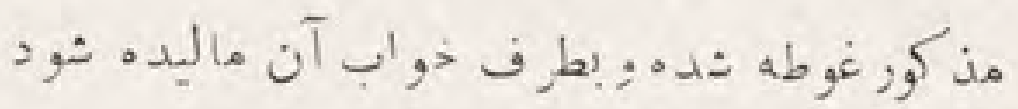

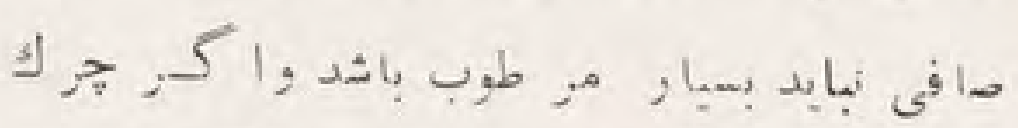

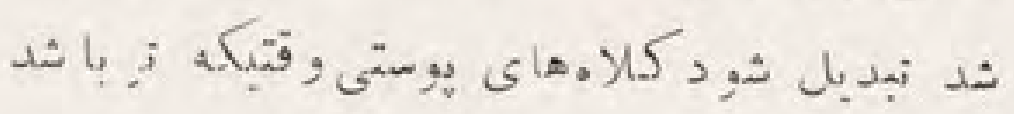

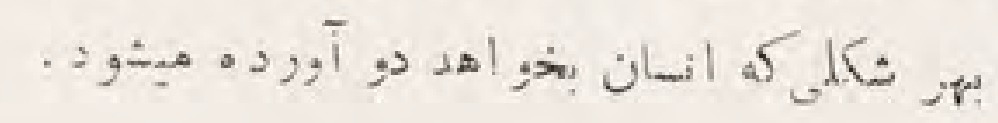
كلاه هاى ليو ستى سفيد

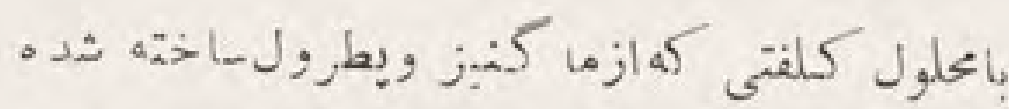

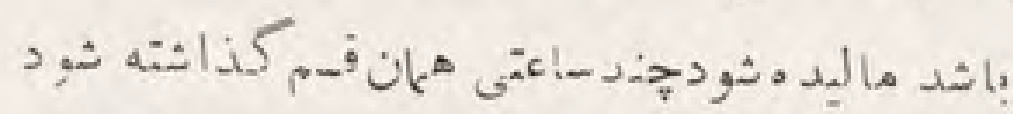

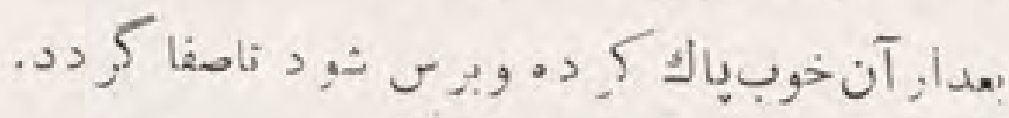
سفيد نمو دن فلازل كمه ز رد شدهباشد

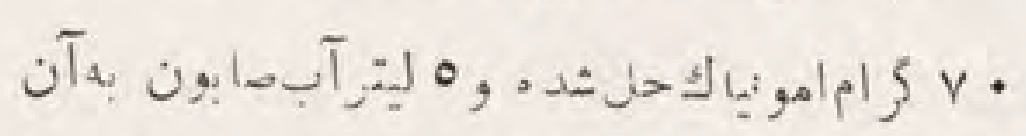

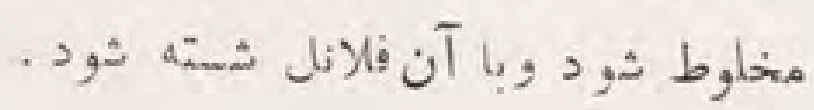




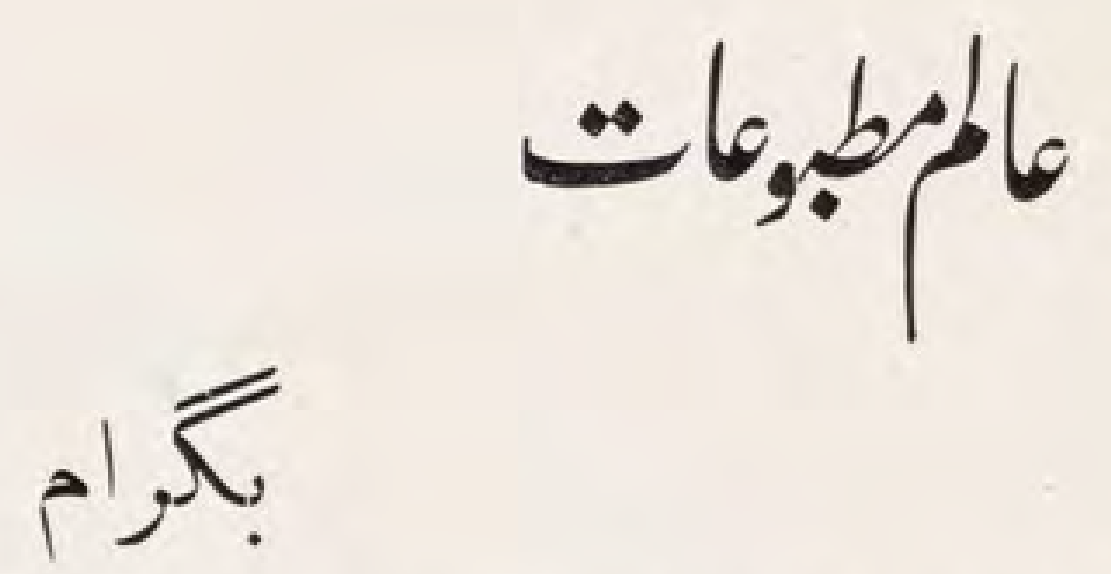

حفز يات هينت فرا أسوى الفخر اج شده أست

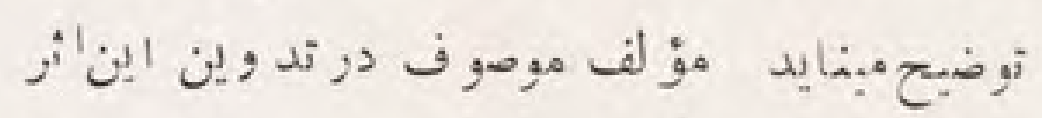

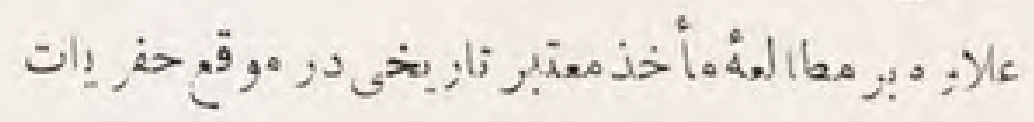

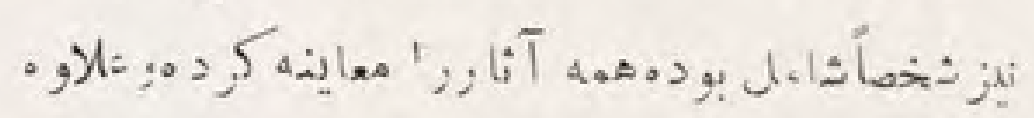

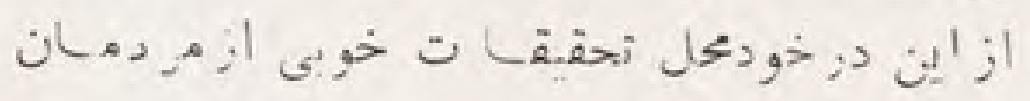

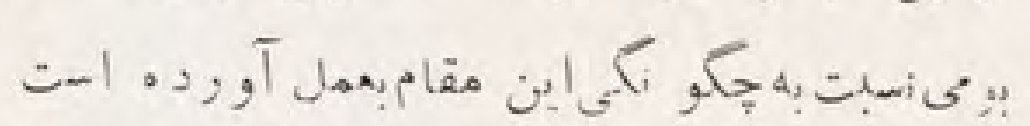

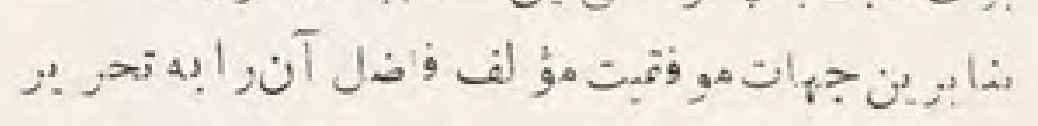

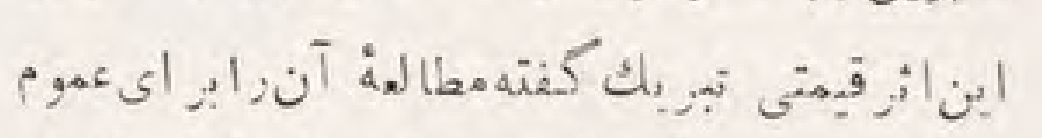

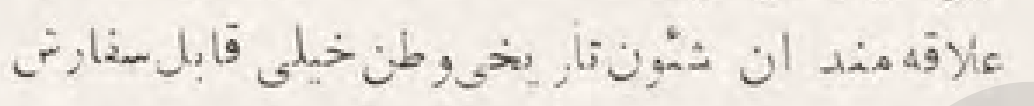
:

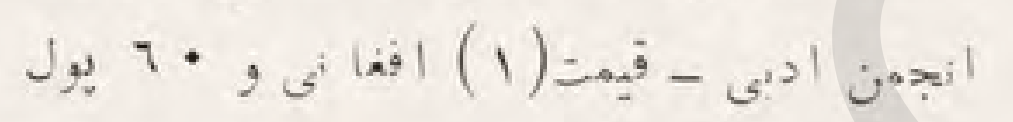

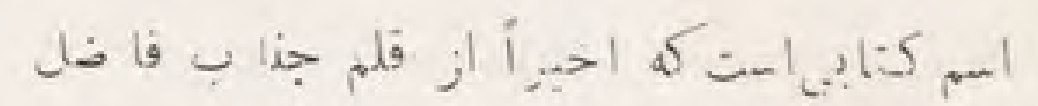

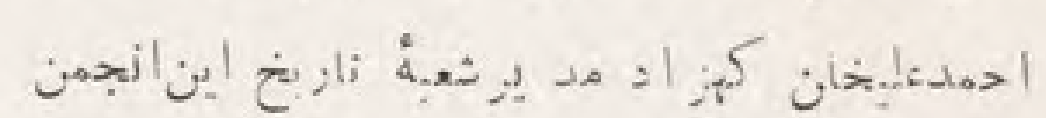

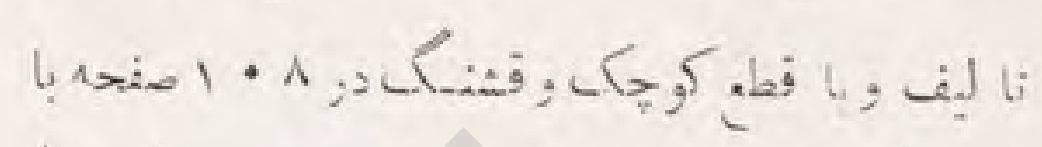

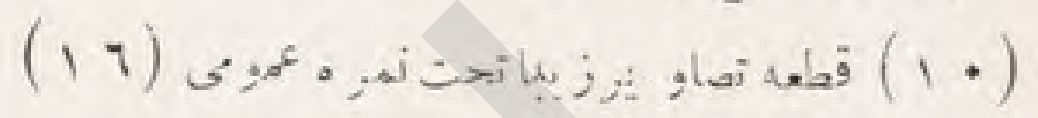

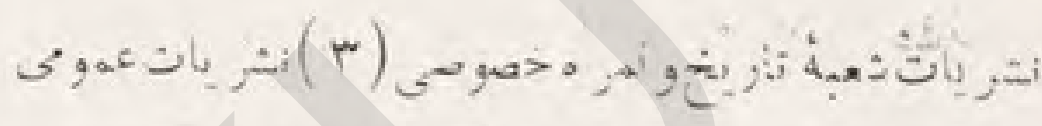

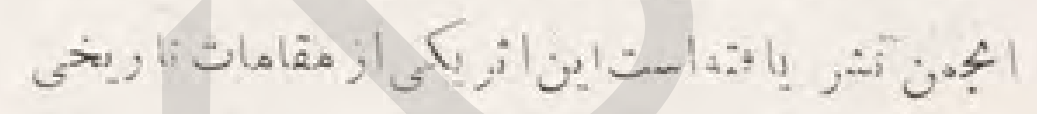

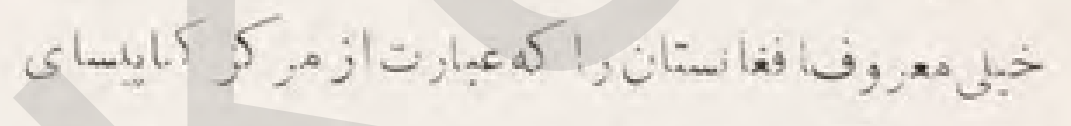

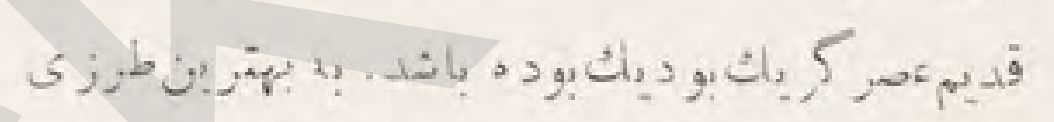

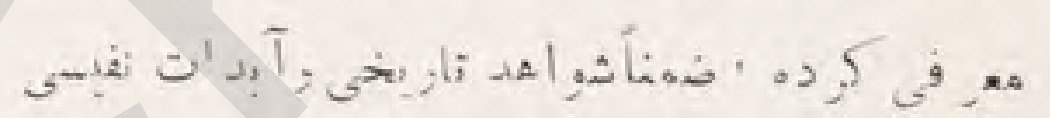

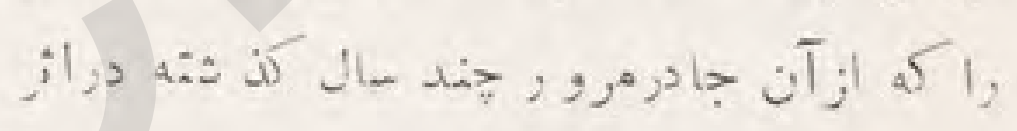

\section{ن}

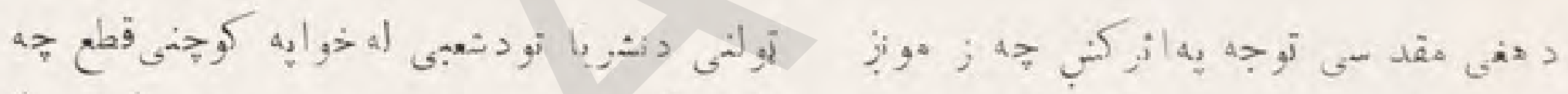

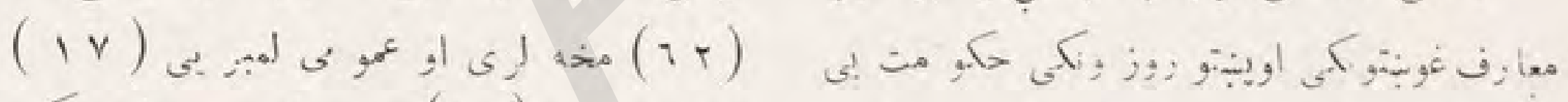

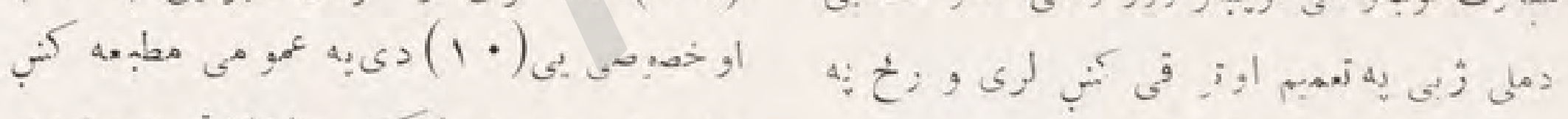

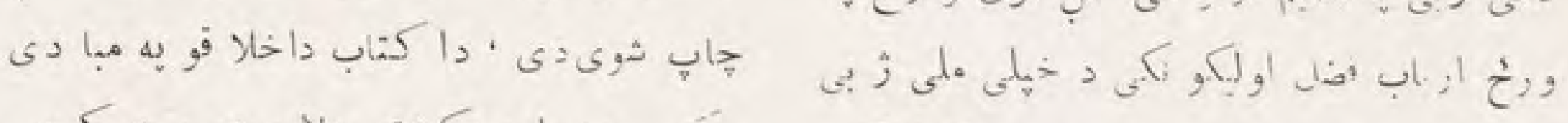

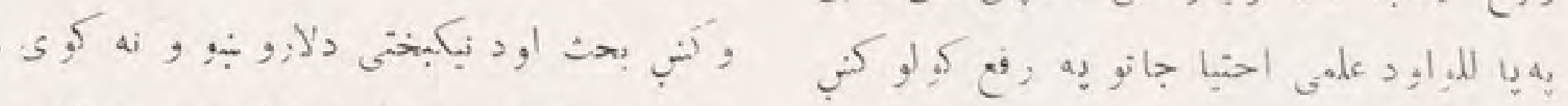

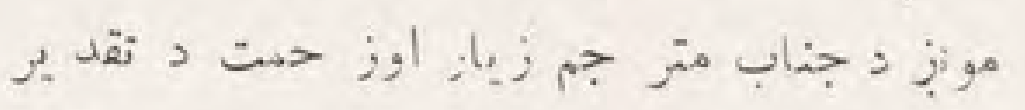

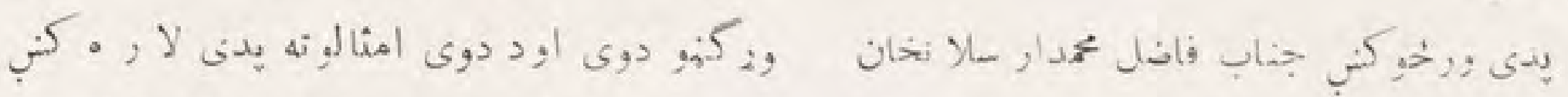

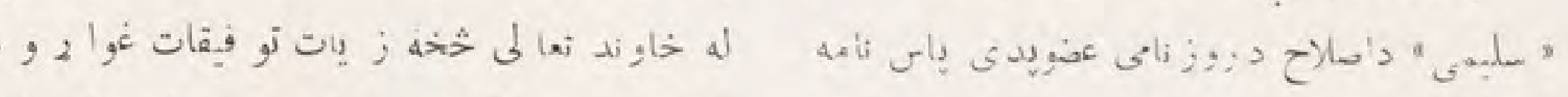

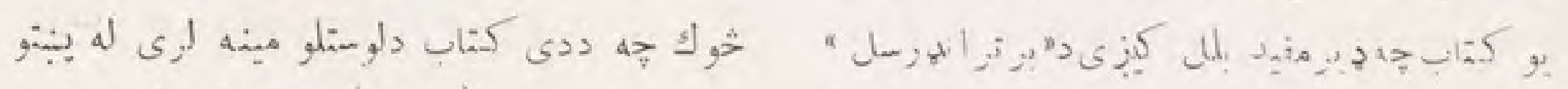

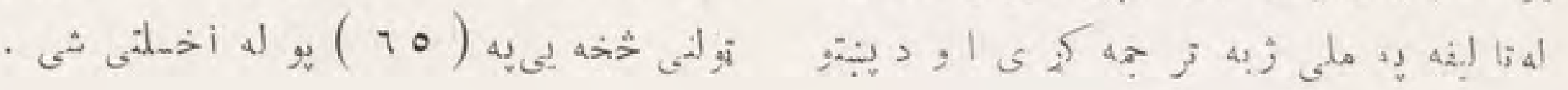




\section{i, axil,}

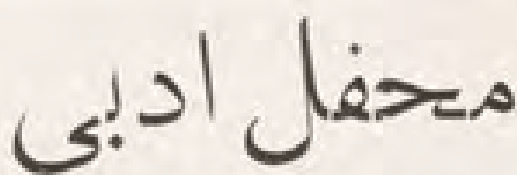

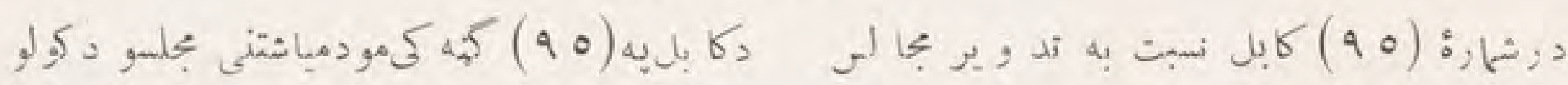

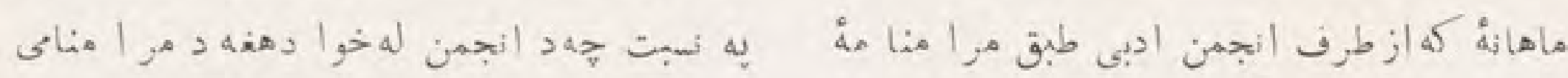

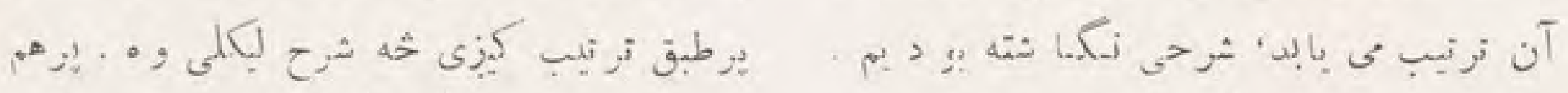

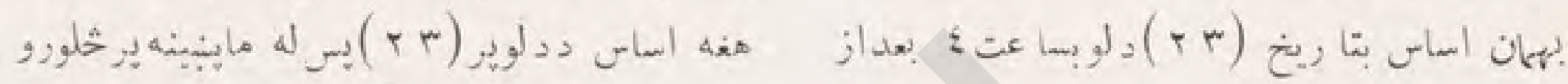

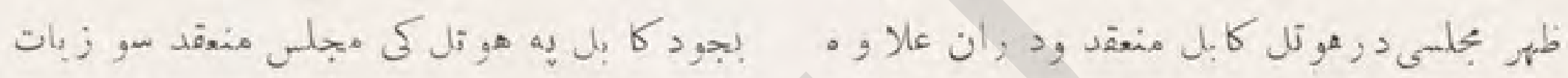

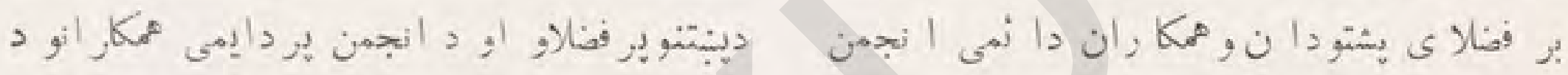

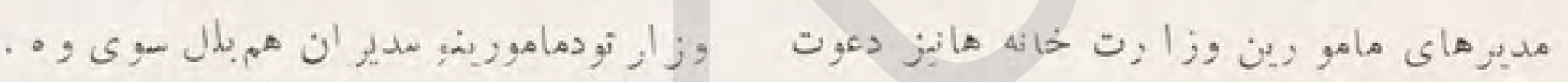

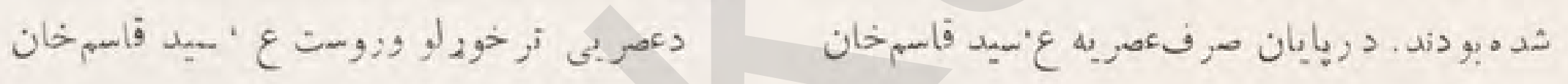

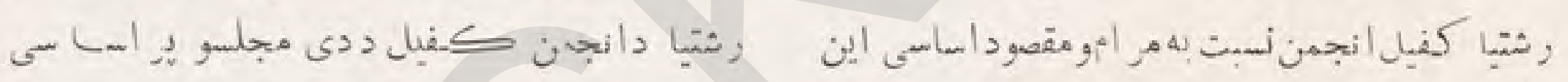

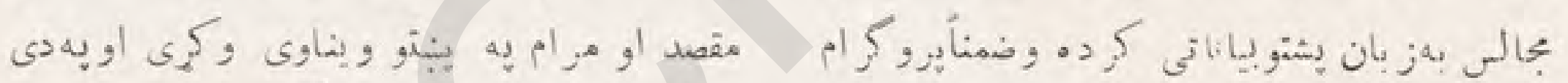

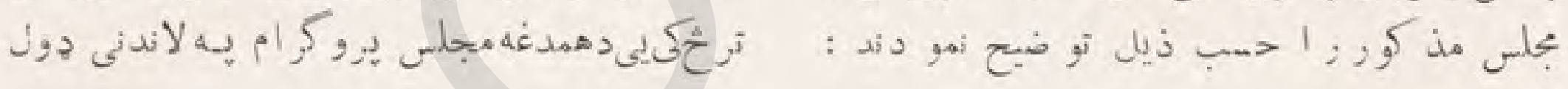

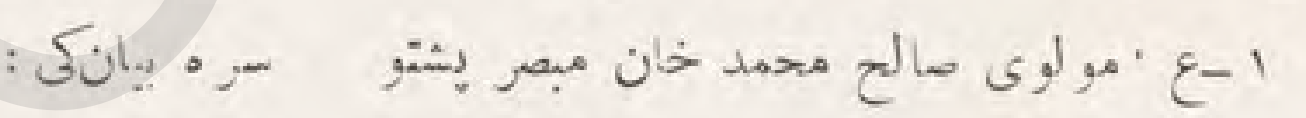

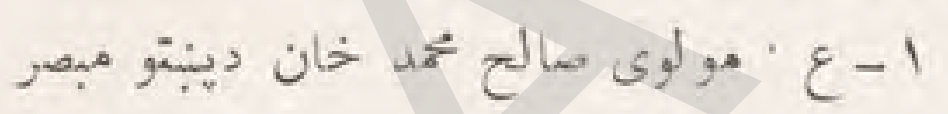

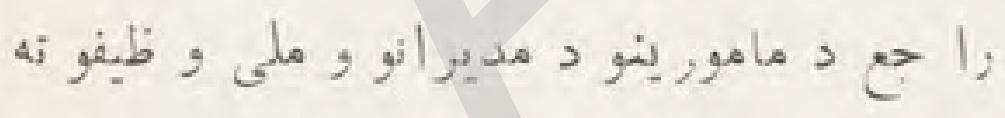

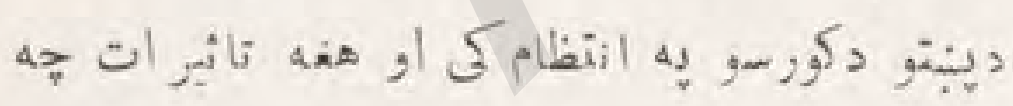

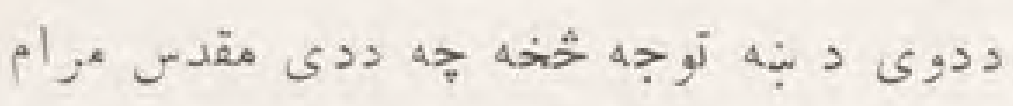

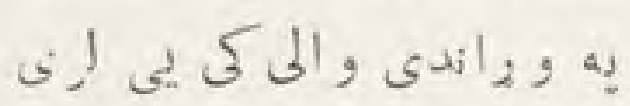

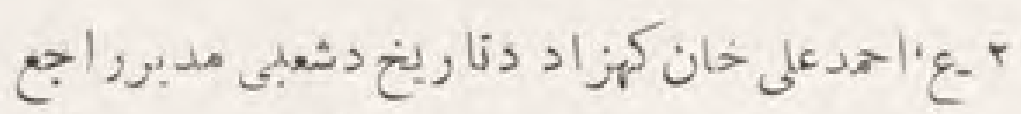

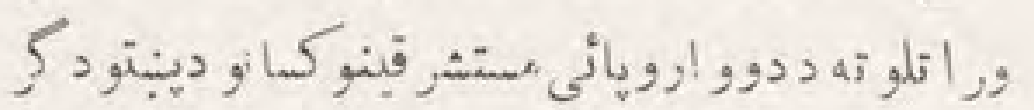

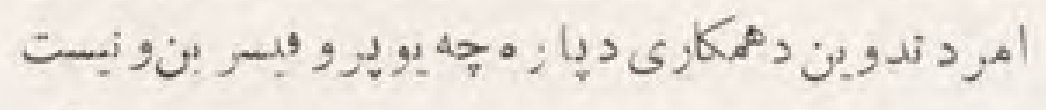
فر انسوى كوليزدو فر انس - او بلديرو فيسرماركن

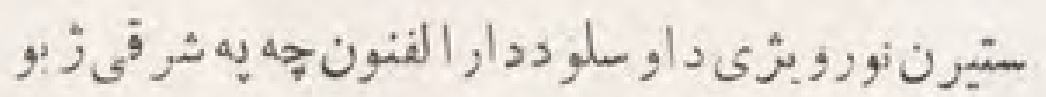

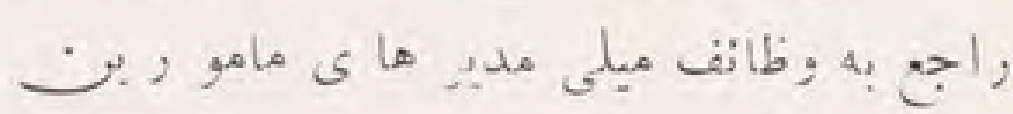

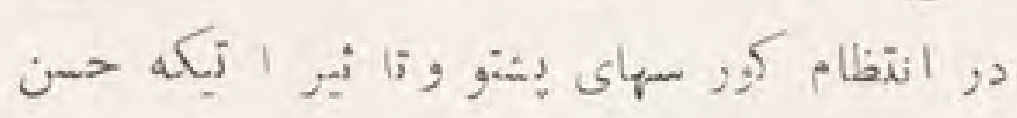

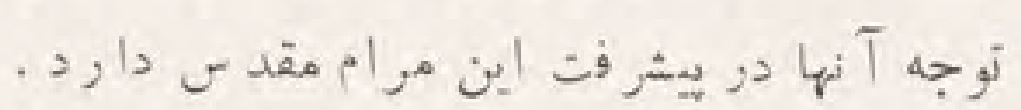

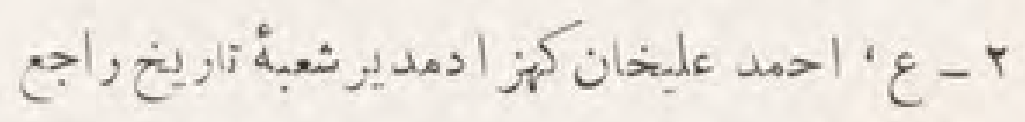

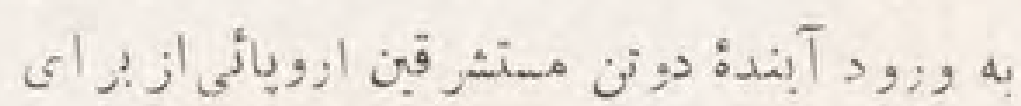

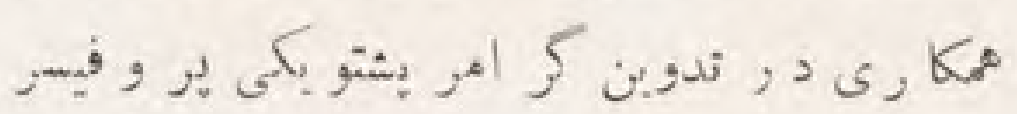

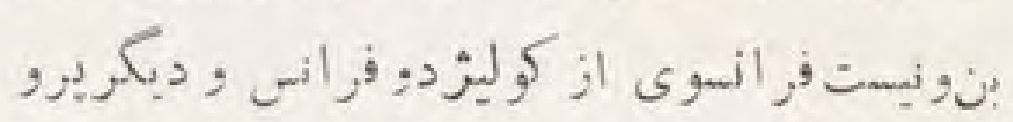

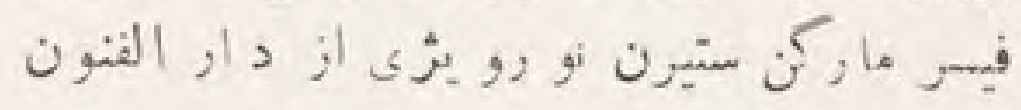

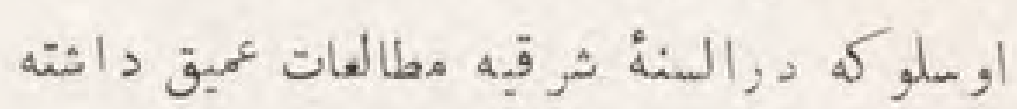
اززبان شناسان معروف بشهار مى آيند ودر بهات 
كى زورب مطالهات لرى اودمعرو فوزب يوهـانو

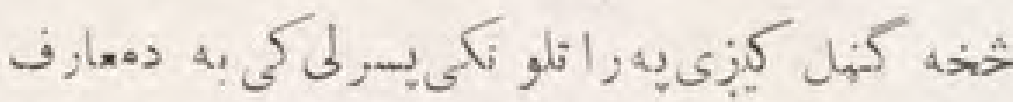
دوزارت دغر بنتلو ب-هه حسب كـا بل نه راسى

$$
\text { (4) }
$$

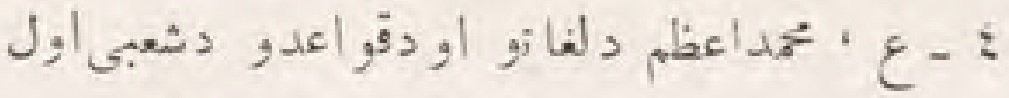

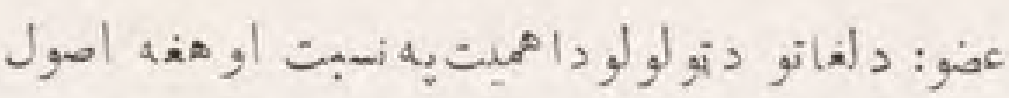

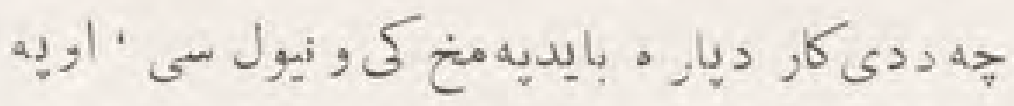

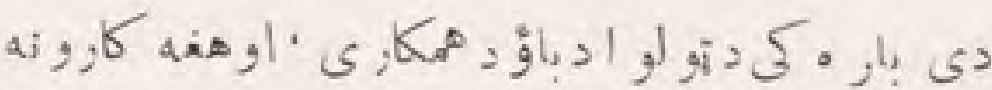

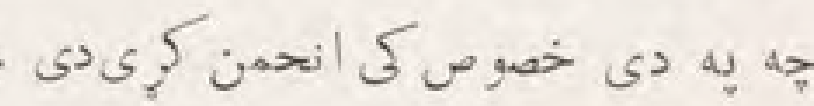

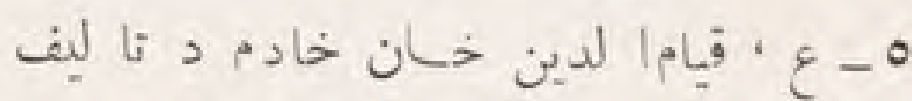

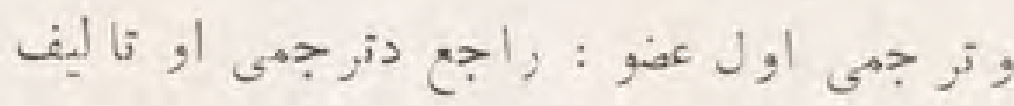

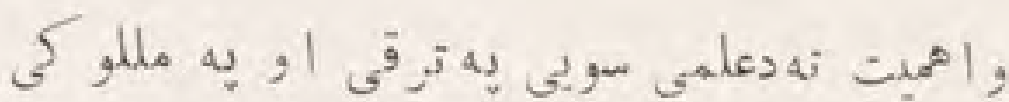

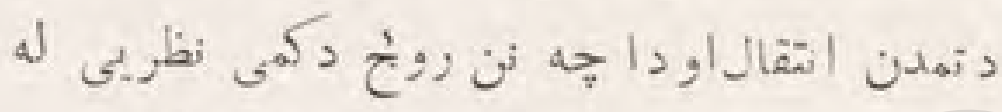
روبه ادبى انجهن ودى موضوع زه اقدام كربدى . 1, و, دز5 سوى ادبى هجلى , و بداد

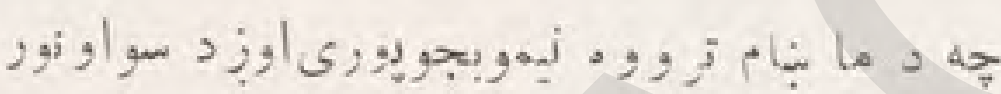

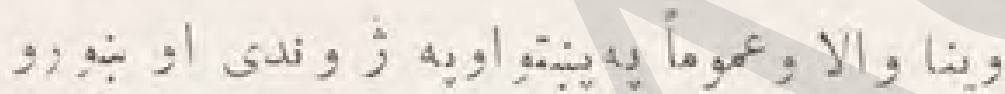

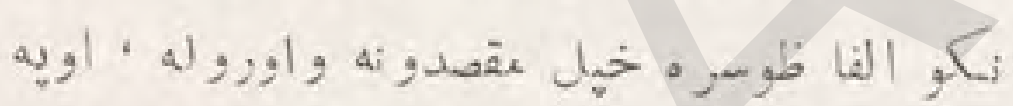
دى

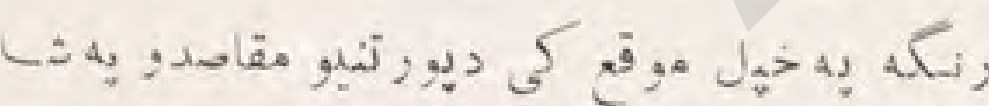

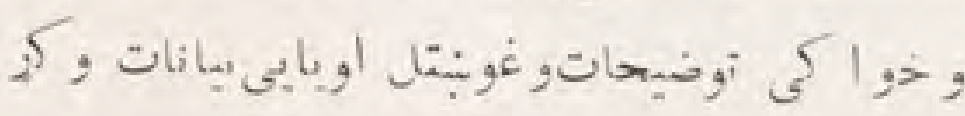

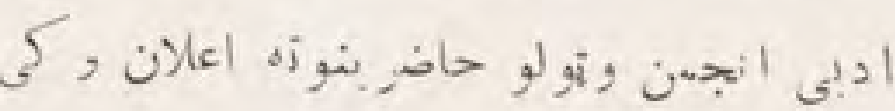

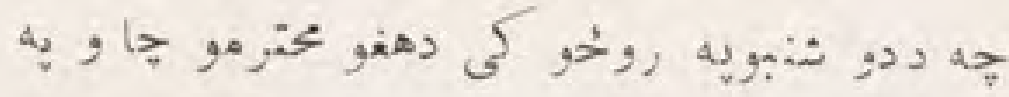

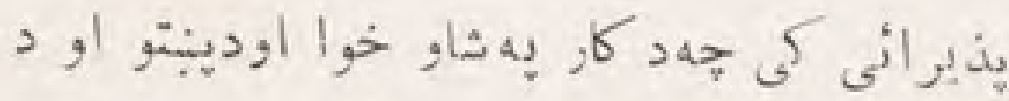

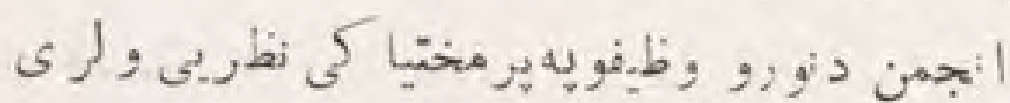

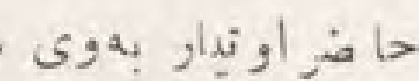

آينده حسب خو إهث وزا, اتمعارف بكابال وارد

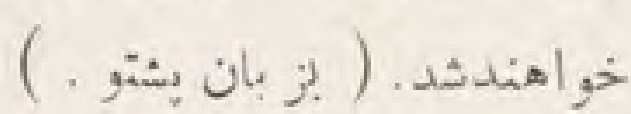
" - ع' امين اله خان زمريالى را جع ده مفهوم

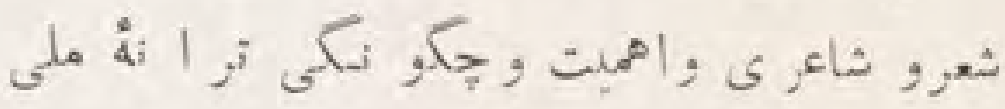

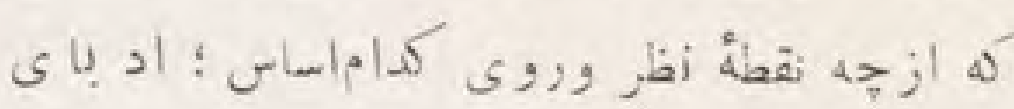
افغان درين خصوص عمف توجه بفرمابند

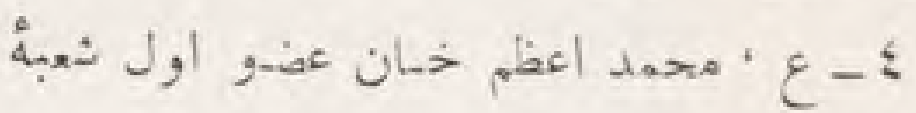
الغات ,وقواعد : نسبت بهاههيت جمع آهورى الغات

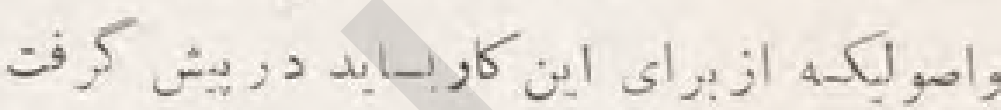

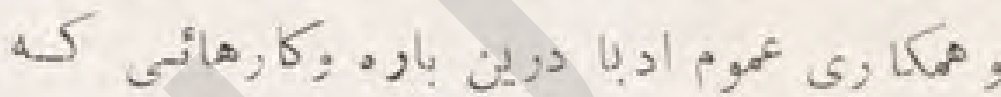
انجمن دربن خصوص نهودم است

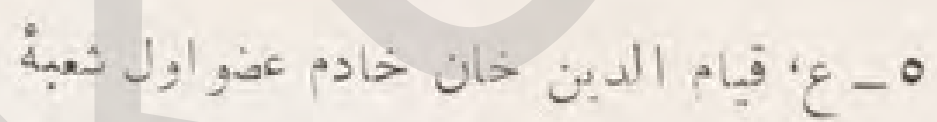

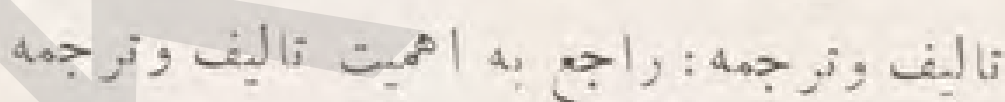

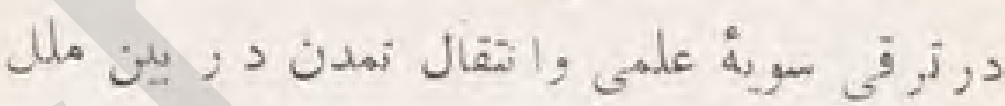

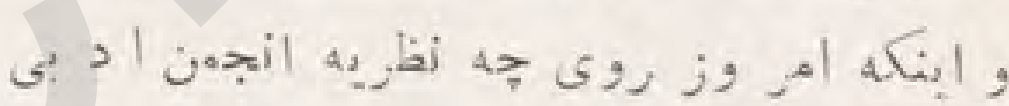

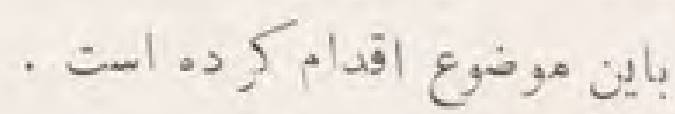

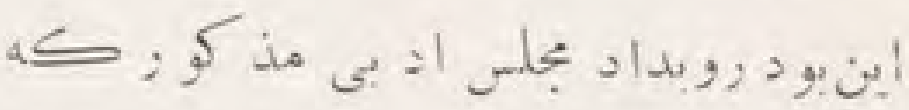
•

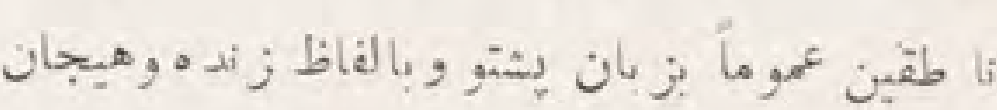

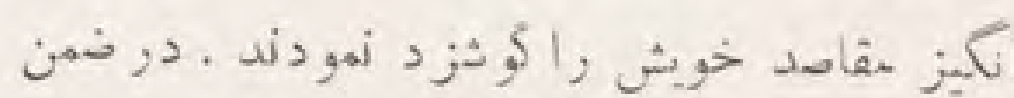

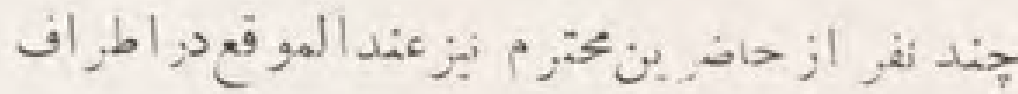

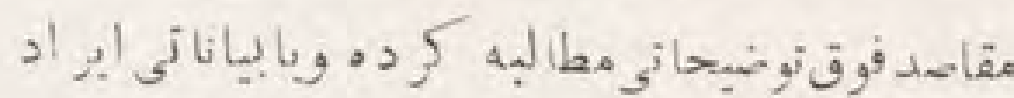

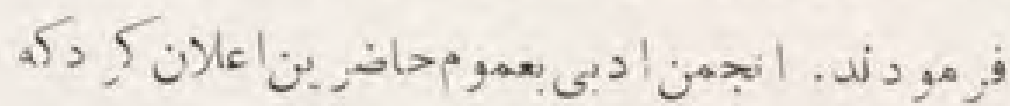

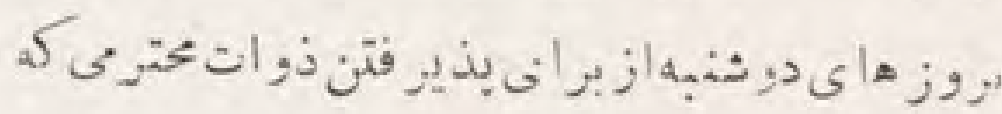
دزاطراف كار ويلثر فت بشتو وغير هوخائفانجهن

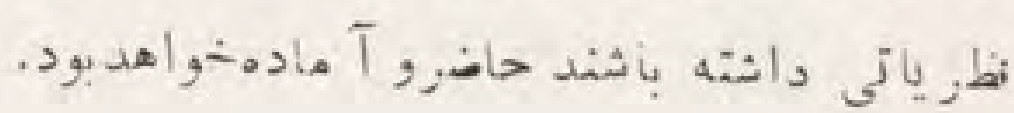




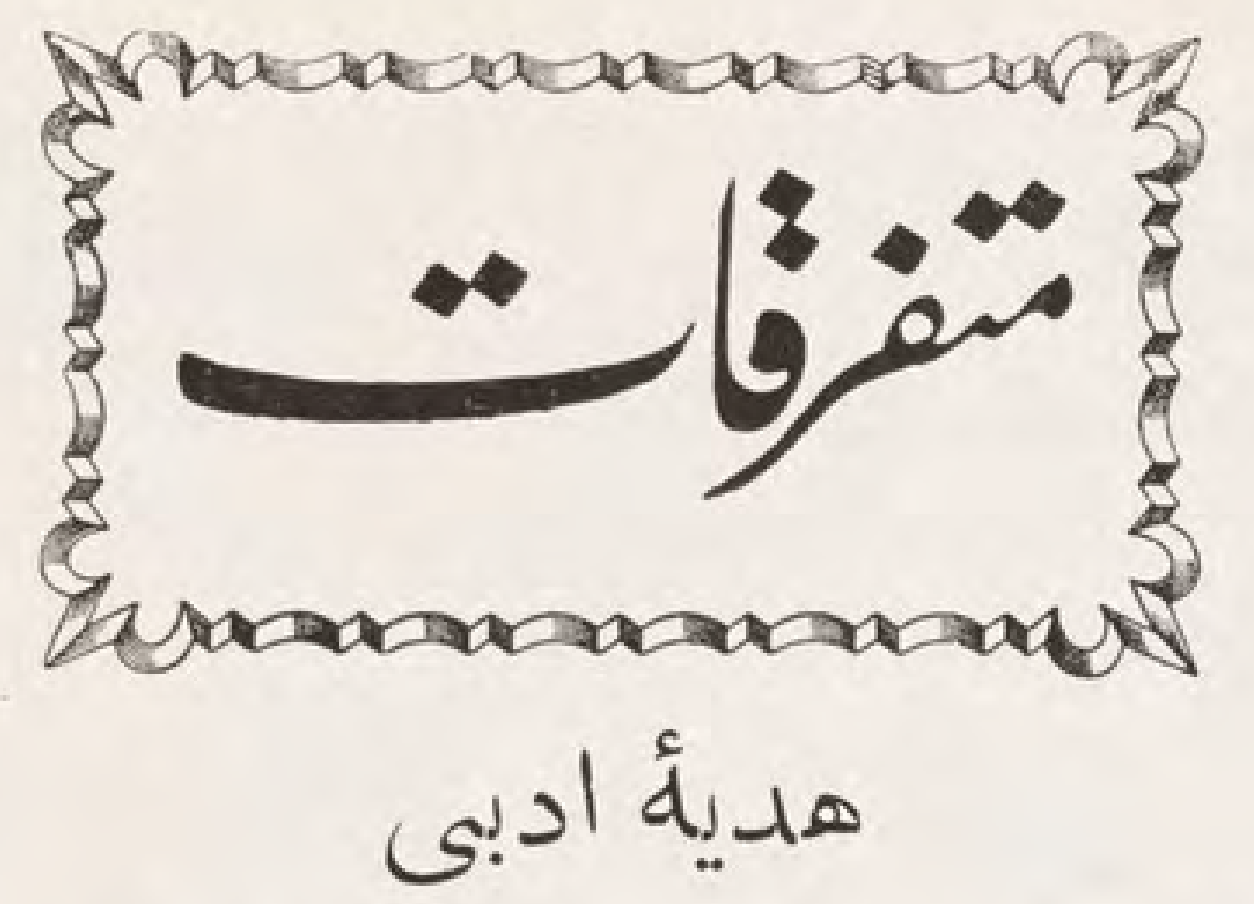

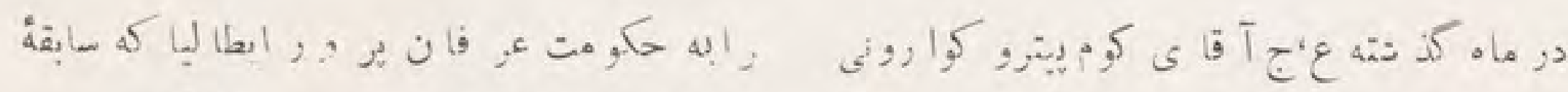

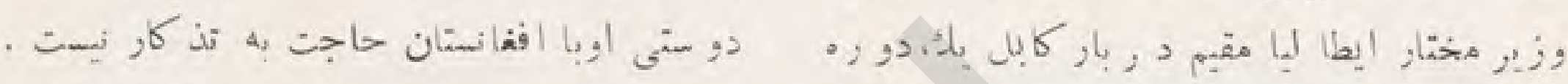

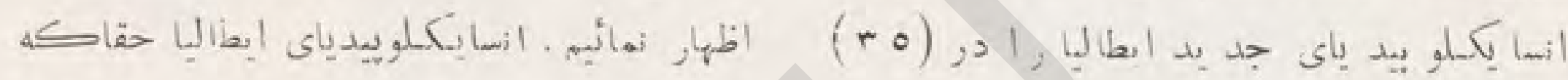

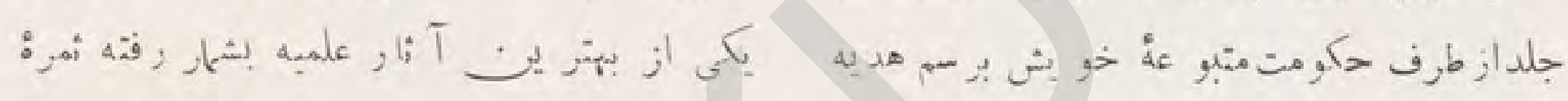

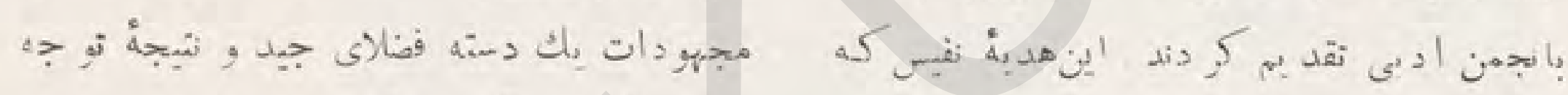

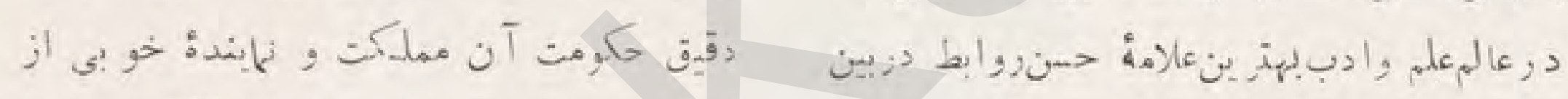

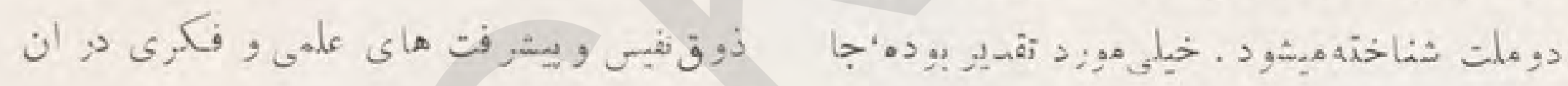

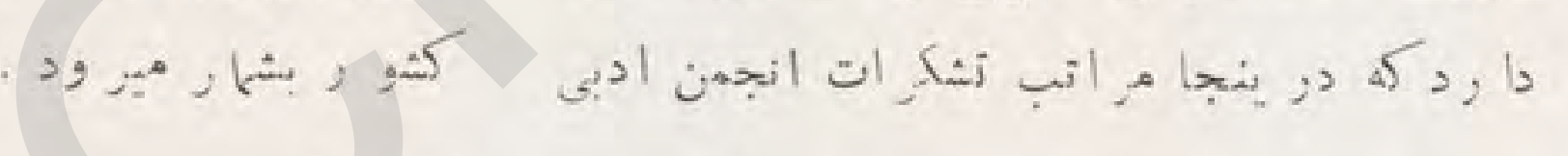

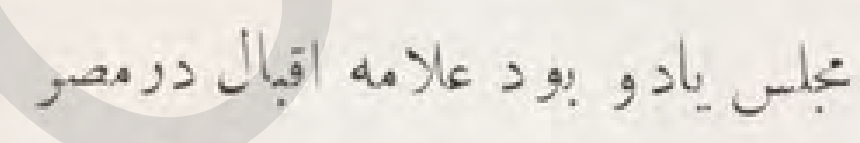

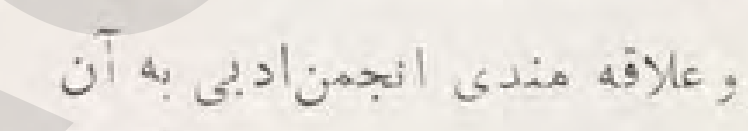

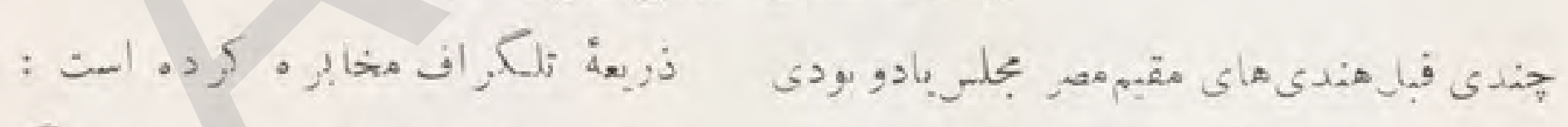

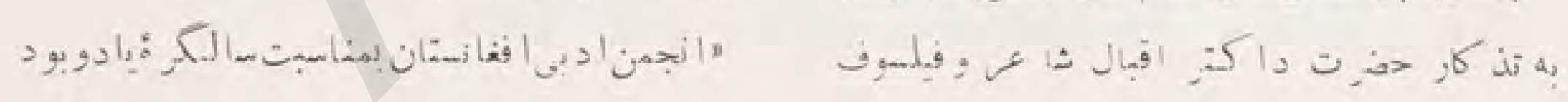

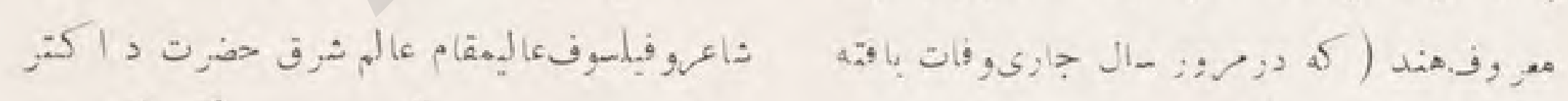

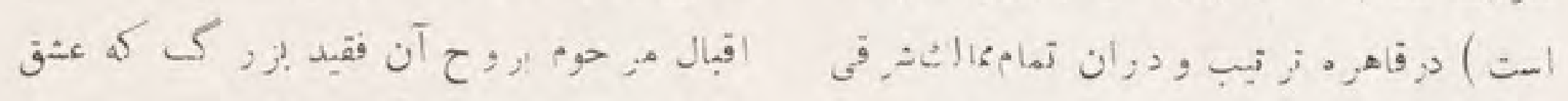

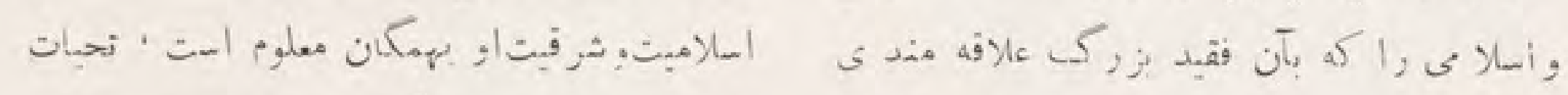

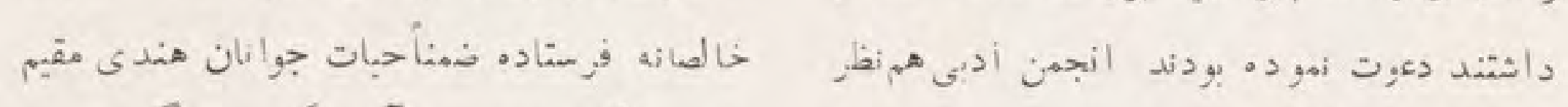

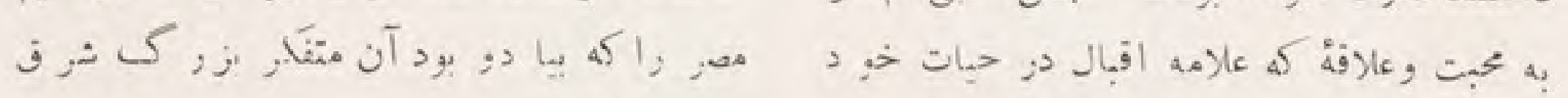

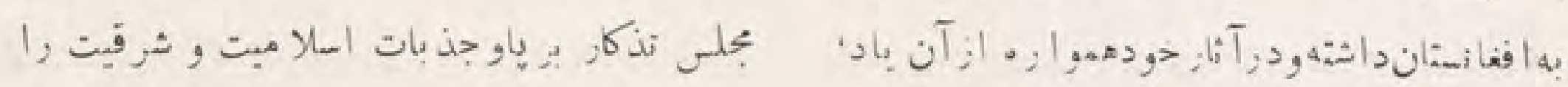

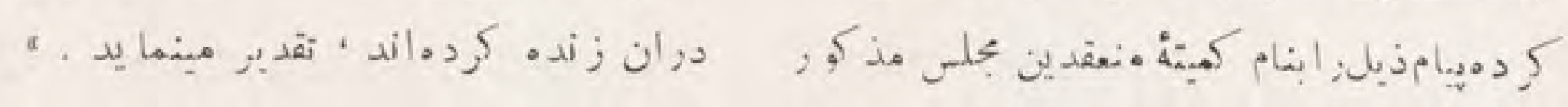




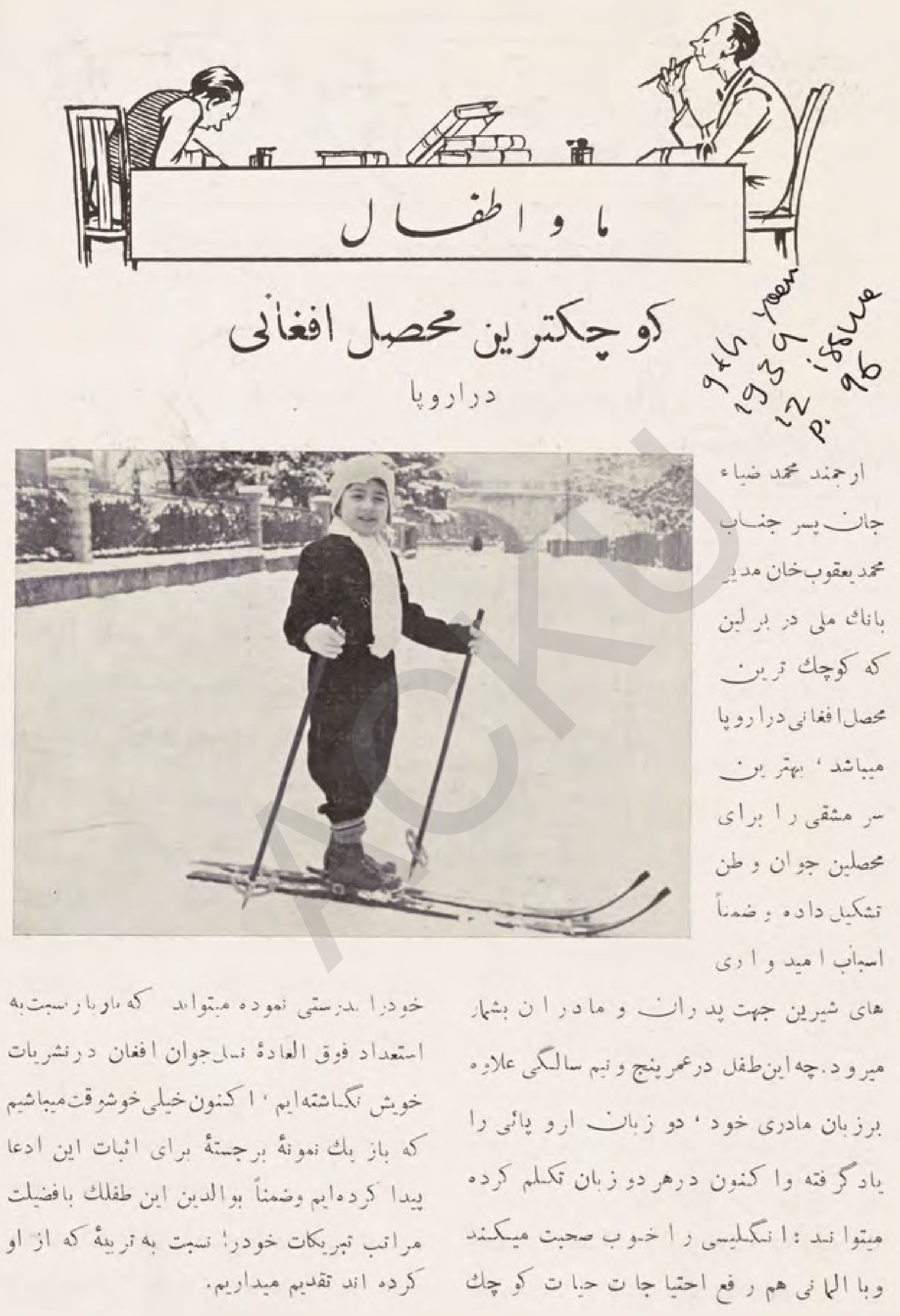




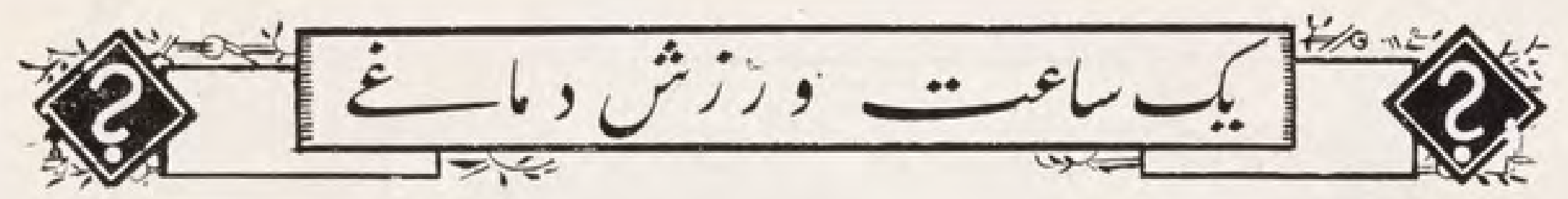

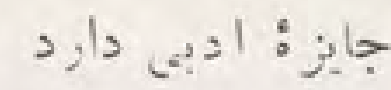

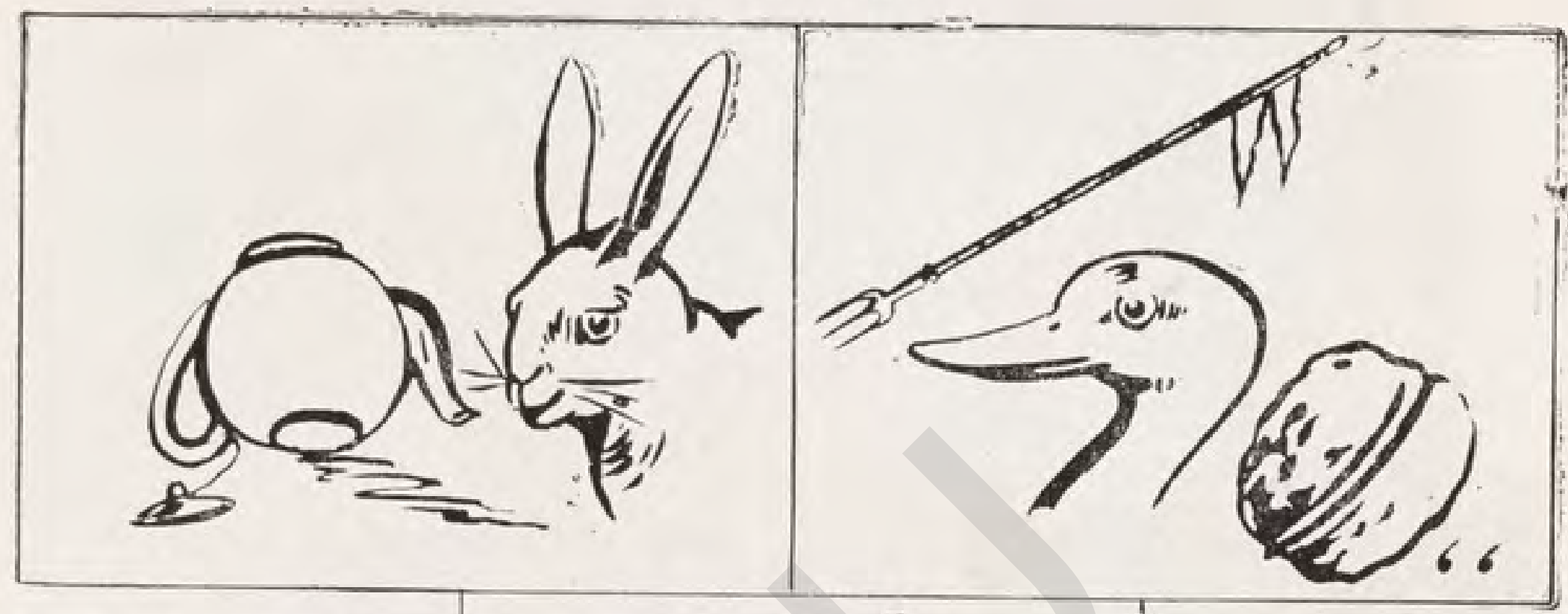

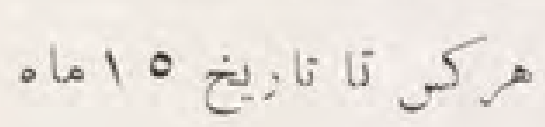

حوت بحل اين معما مو فق

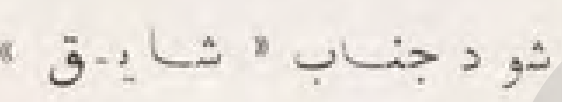

دمغزن تأز ماز طبه خويش

باو إهداء خواهد كر

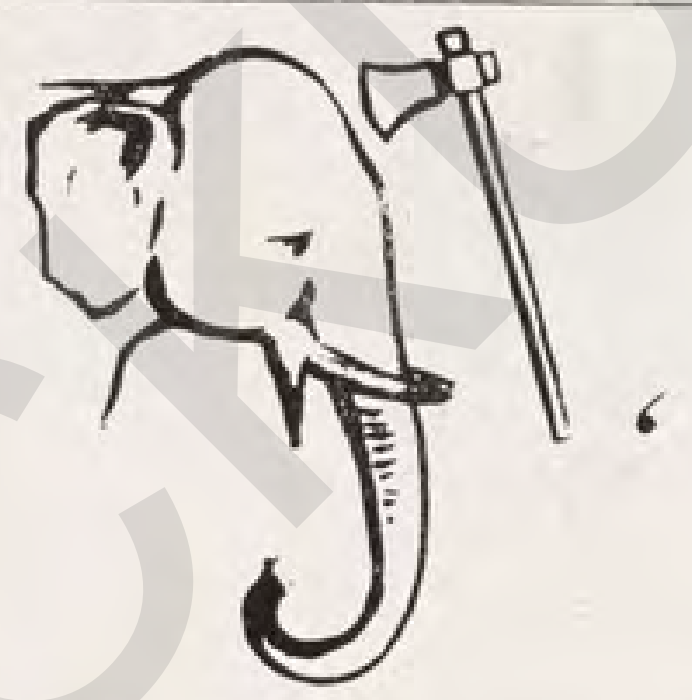

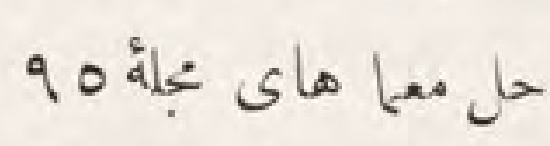

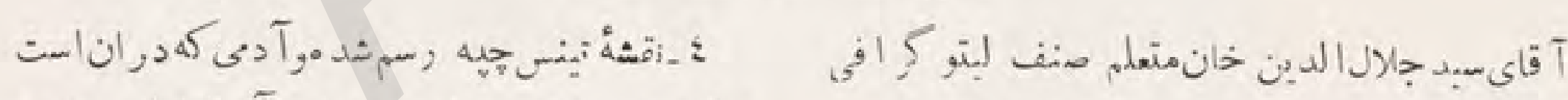

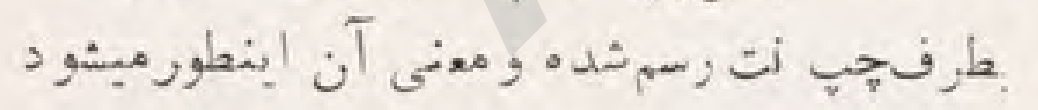

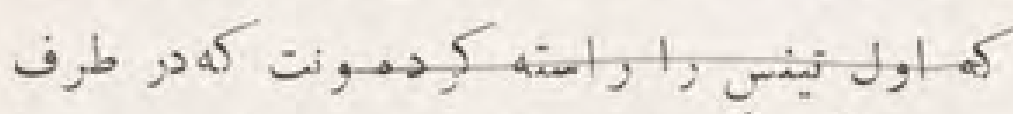

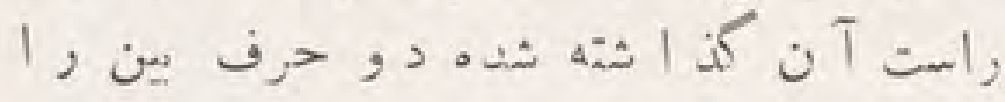

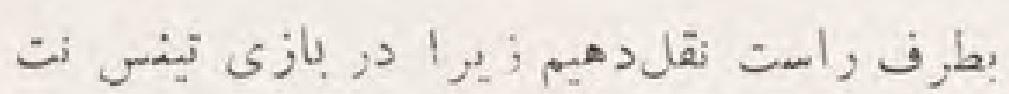

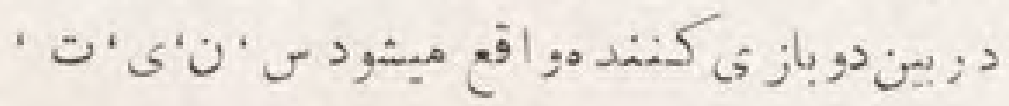

ميسوبدت

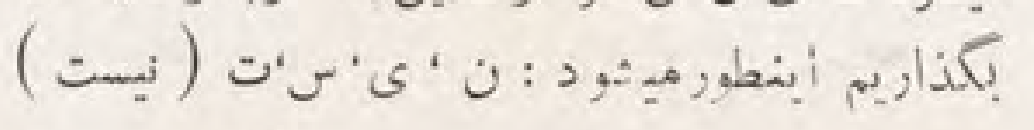

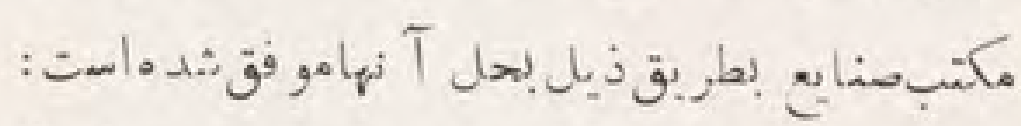

1

ب.

( ) ( $)$

تبديل كردبده : خيز

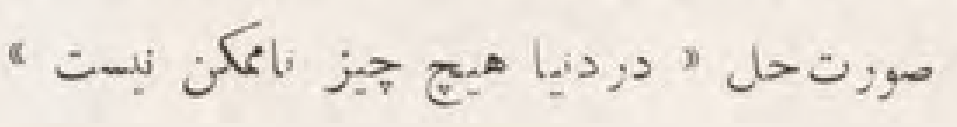

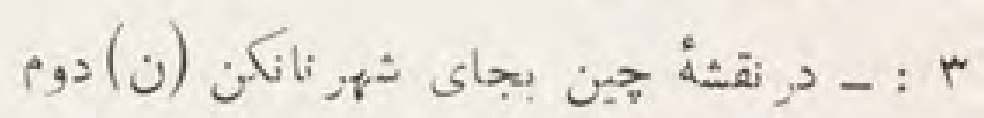

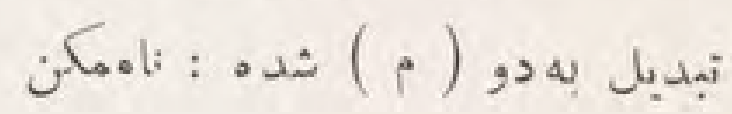



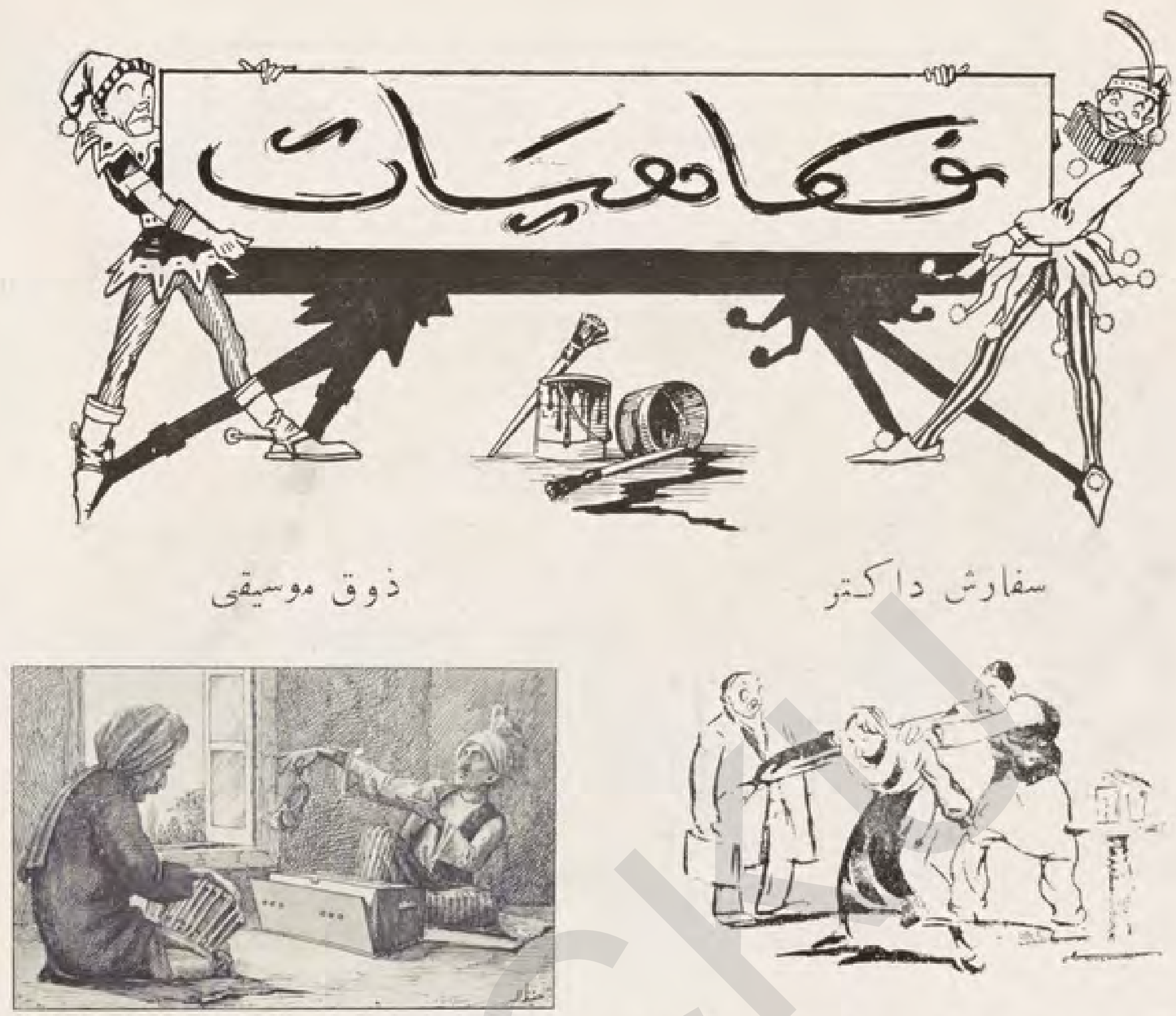

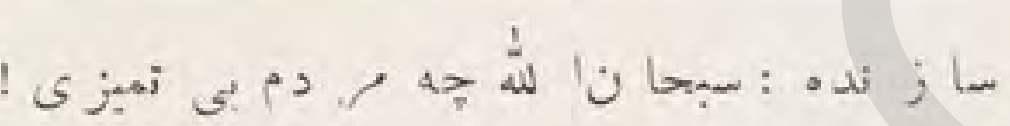

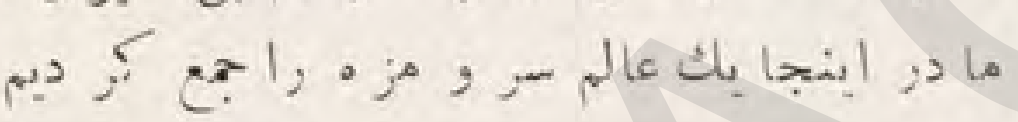

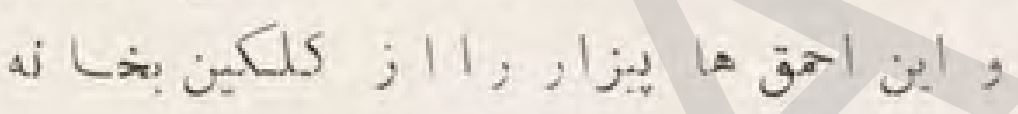

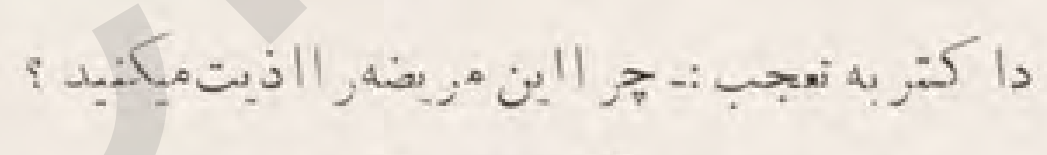

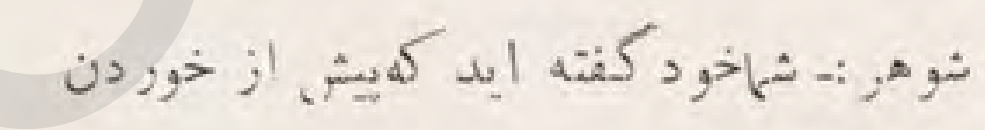

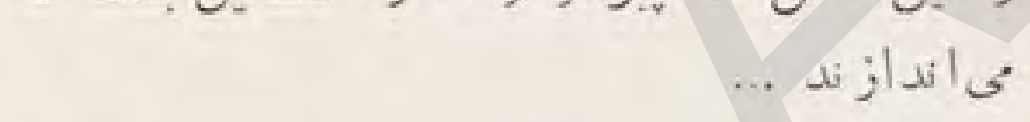

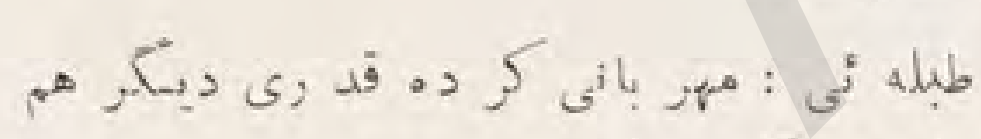

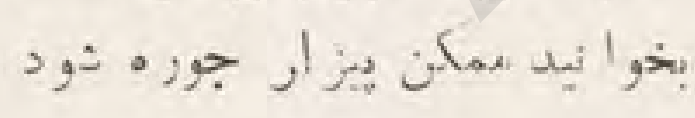

$$
\begin{aligned}
& \text { تشخيص مرض }
\end{aligned}
$$

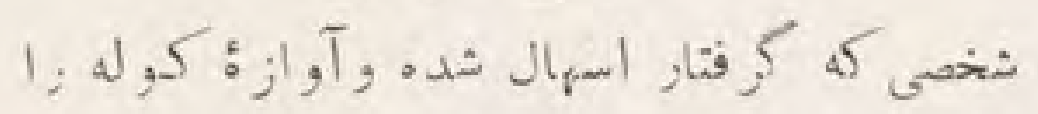

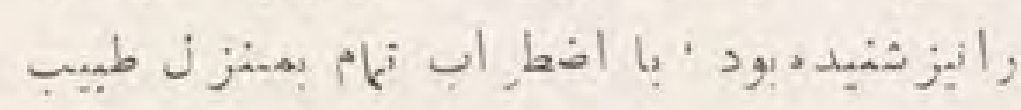

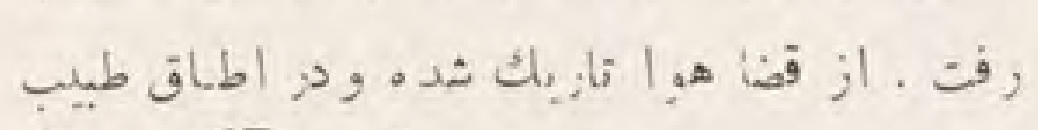

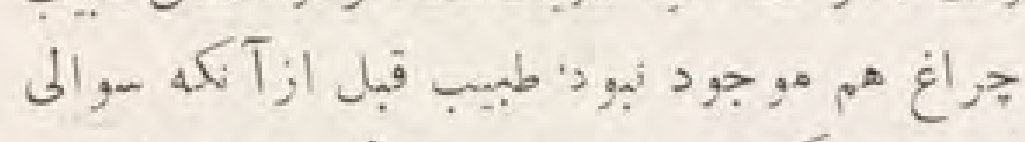

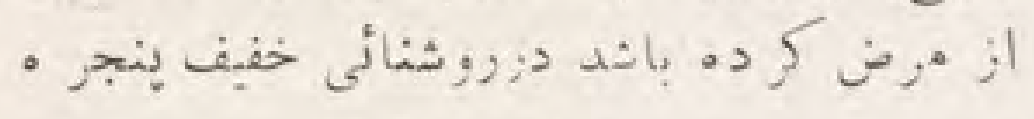

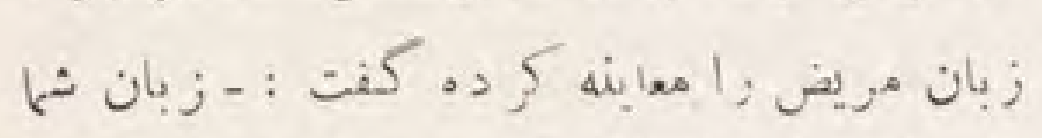
دواشور داده ثنو

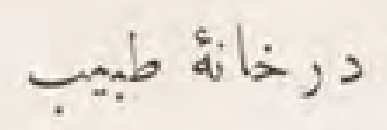
طبيب - ز بان خود رانشان بد هيد. مريض - ز بانم دزد دميكند · قبضيت دارم. مر إص وطبي؟

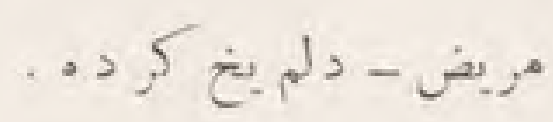

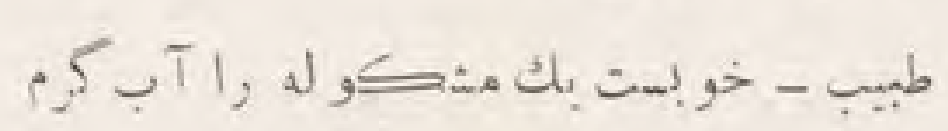

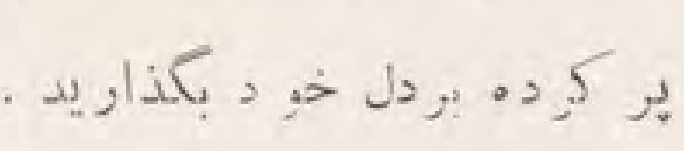

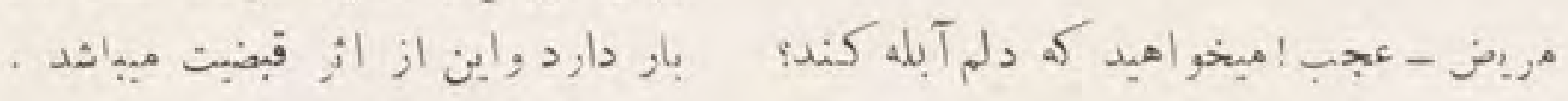




$$
\text { الا تزظار وواشد من القتل }
$$

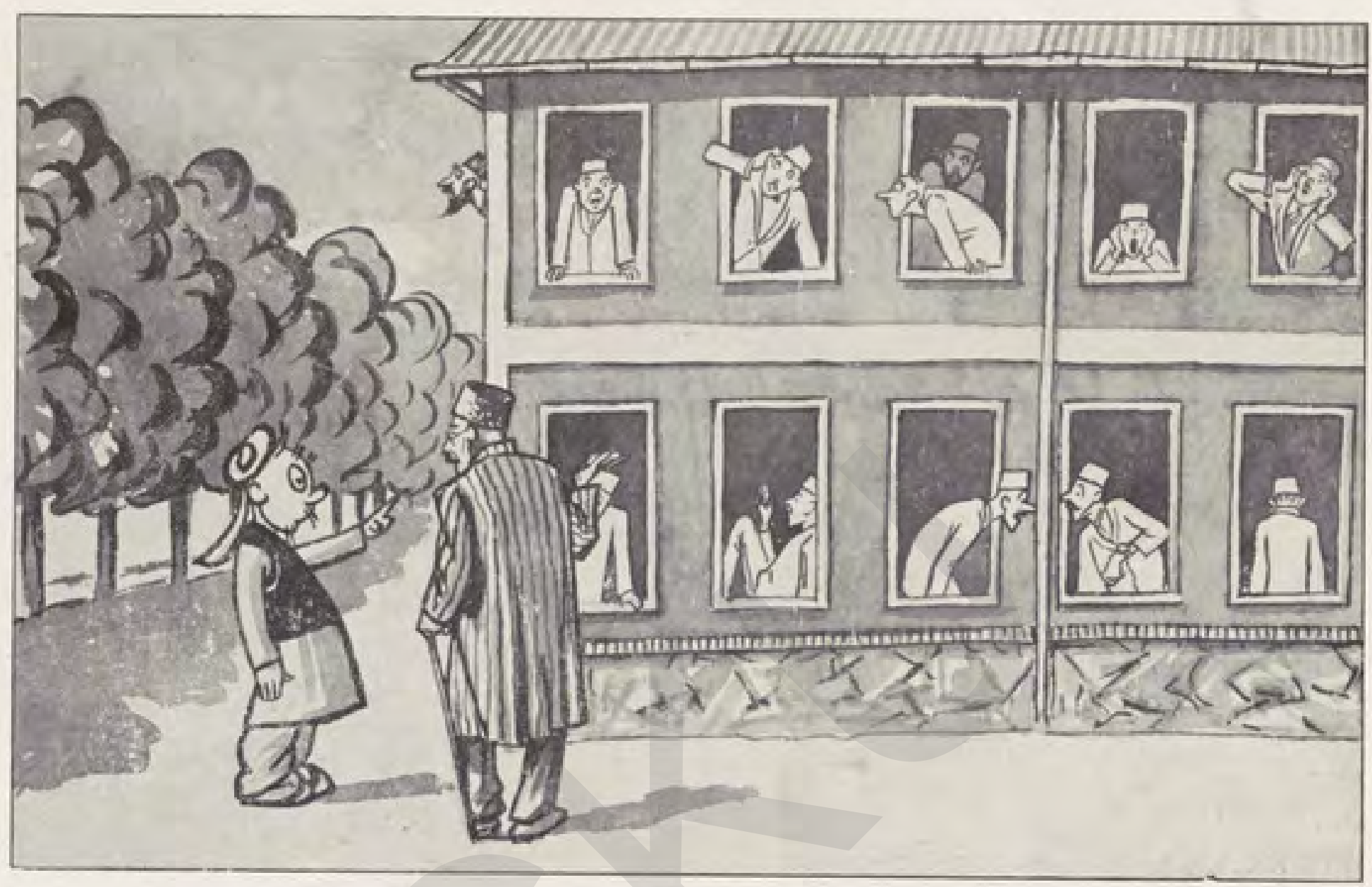

ههر كن كي شخص ظر بف وزكته دانى بود

$$
\begin{aligned}
& \text { فروا مهرى :اين هضمون باو تقديم كر د : }
\end{aligned}
$$

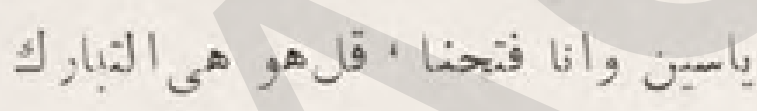

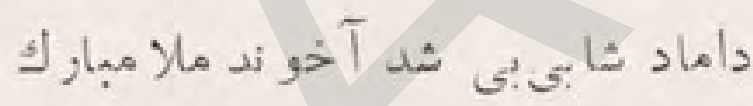

$$
\begin{aligned}
& \text { رشته صحمبت }
\end{aligned}
$$

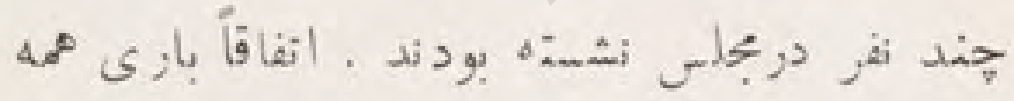

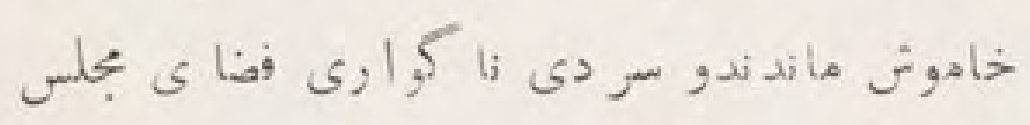

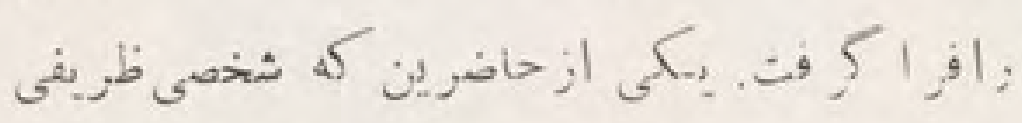$$
\text { بود ' بصد اى بلمند از بهلو نشين خوح برسيد : }
$$

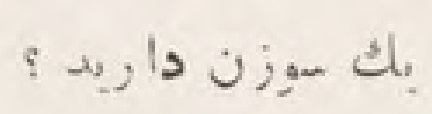$$
\text { سوزن , آحه ميـكنيد }
$$

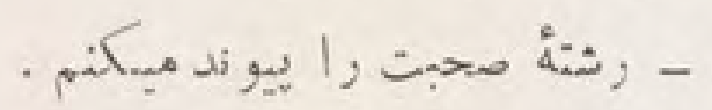

$$
\text { , }
$$

رهكذر :- , قت قو له عصر است , آنها منتظراند .

$$
\text { קecen. }
$$

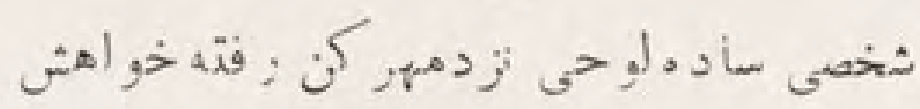

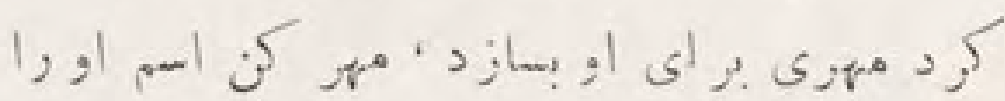

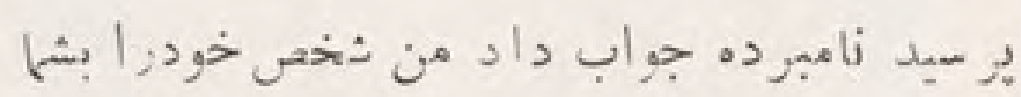

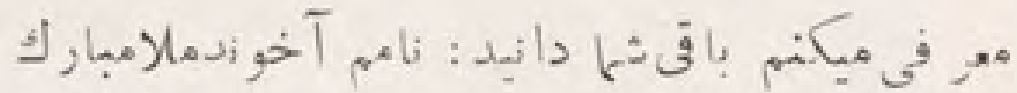

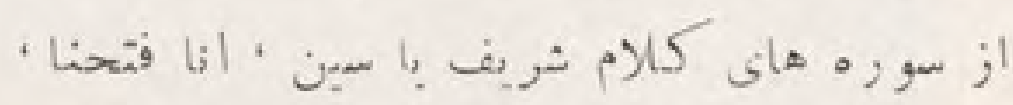

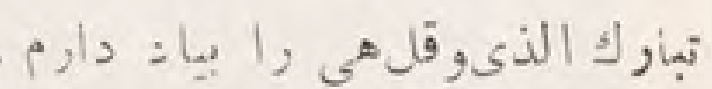

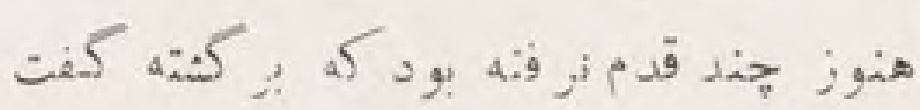

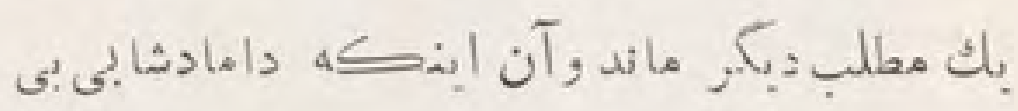
هـ 


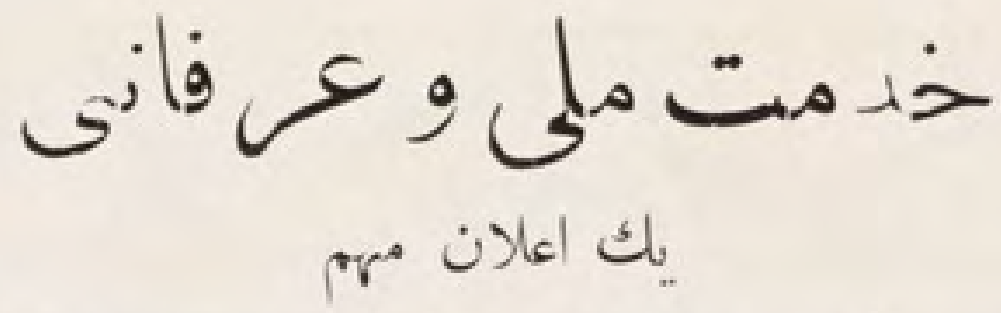

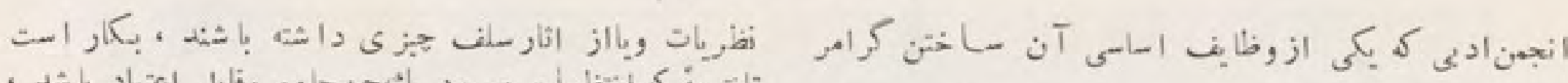

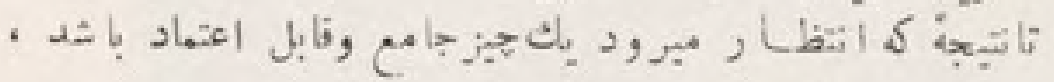

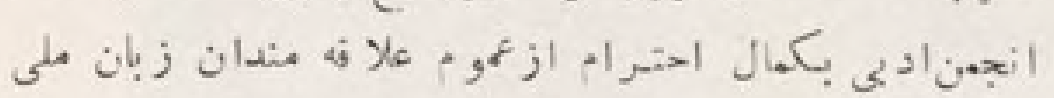

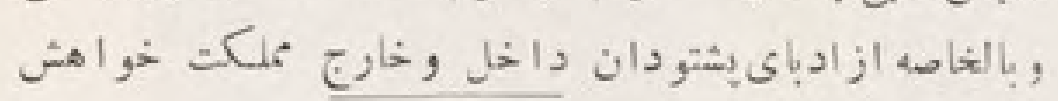

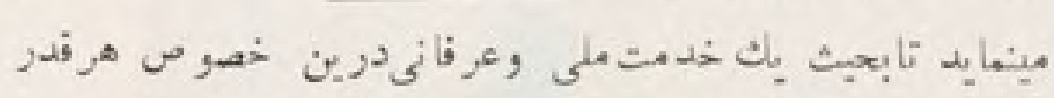

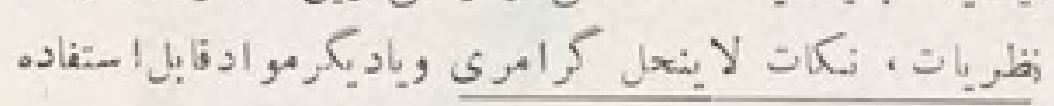

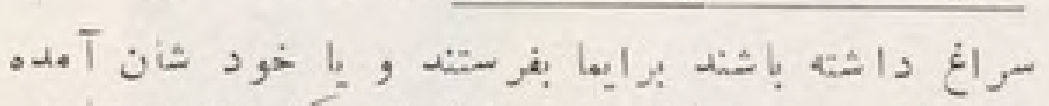

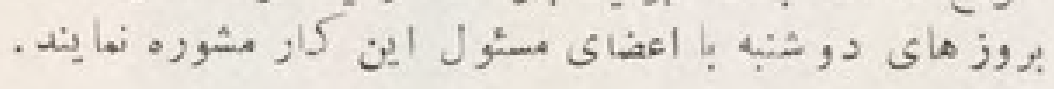

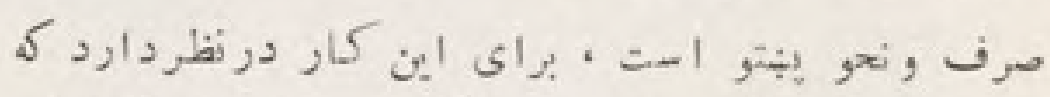

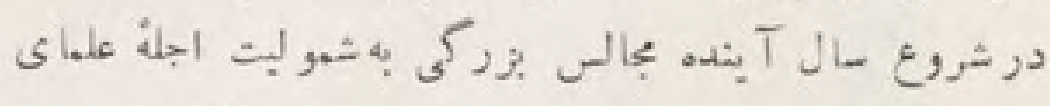

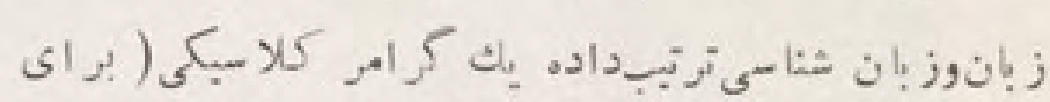

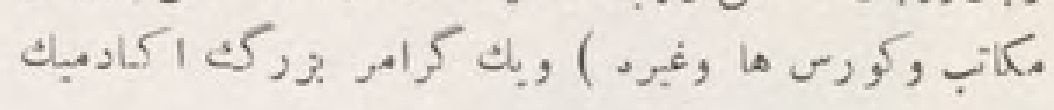

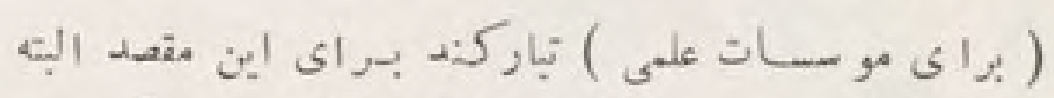

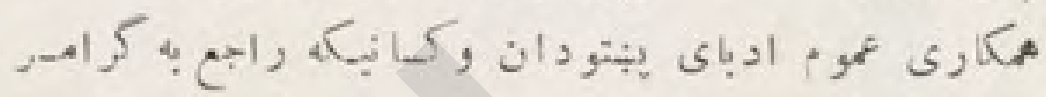
(4) (9)

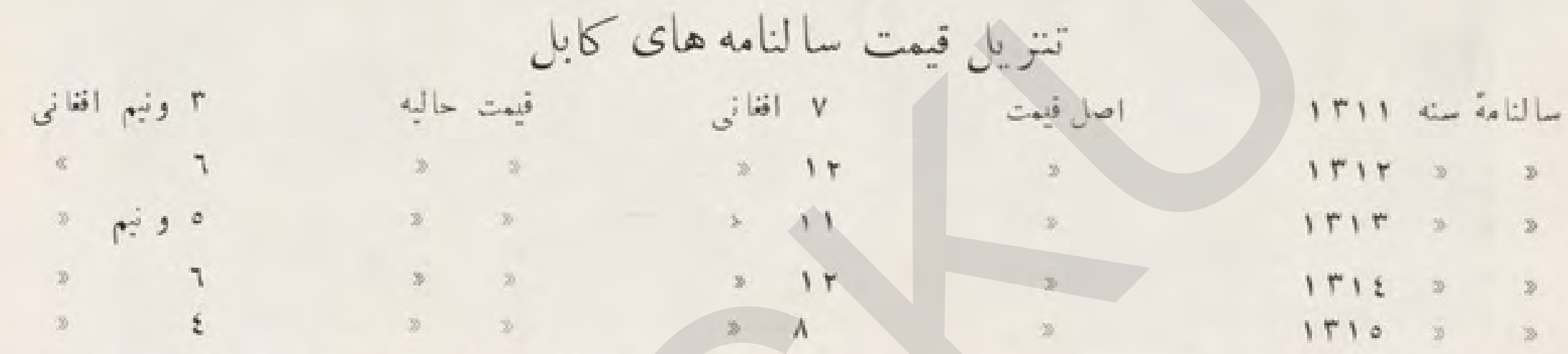

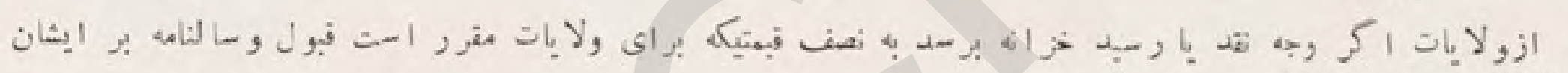

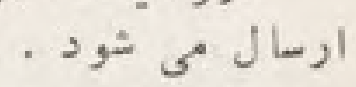

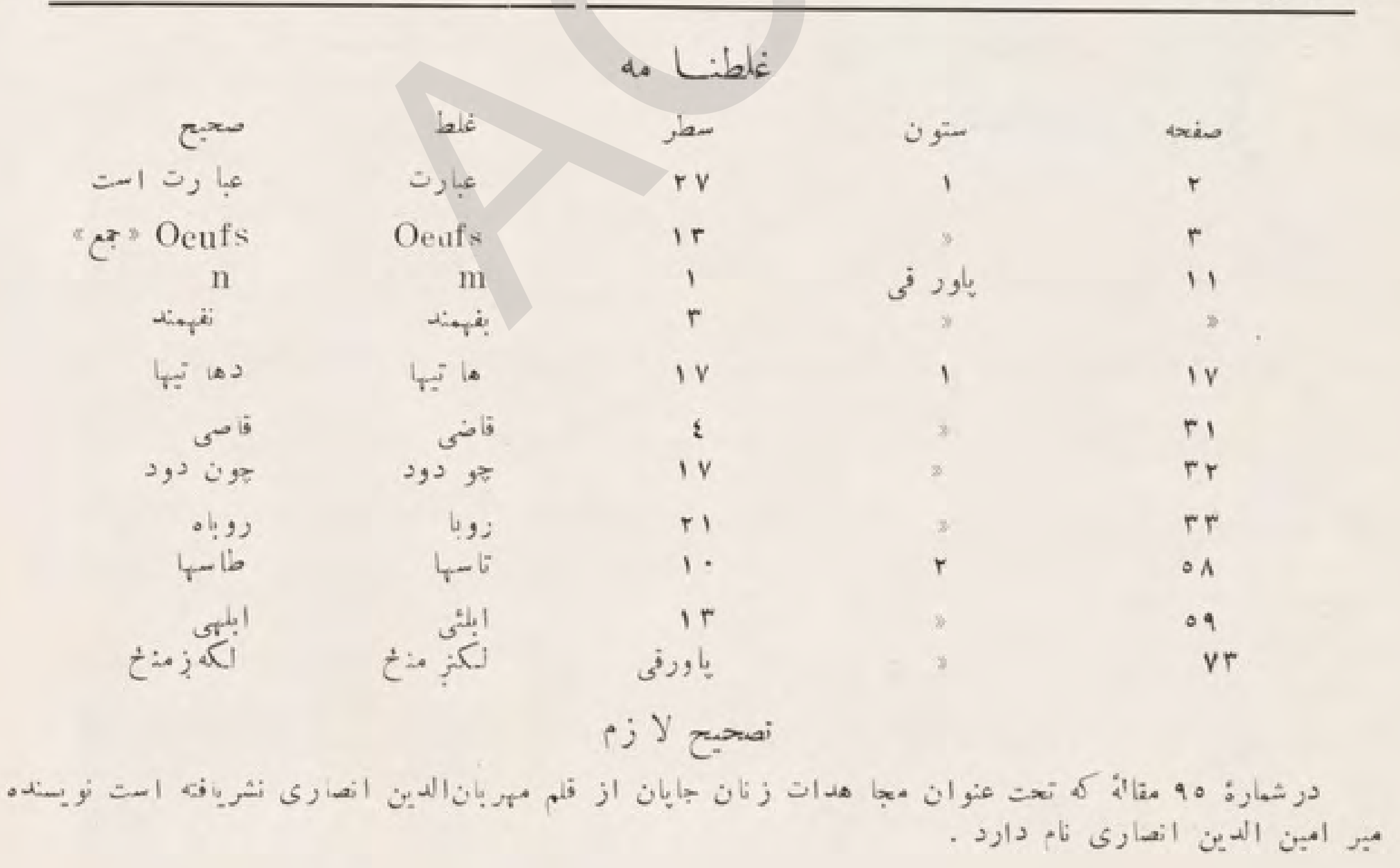




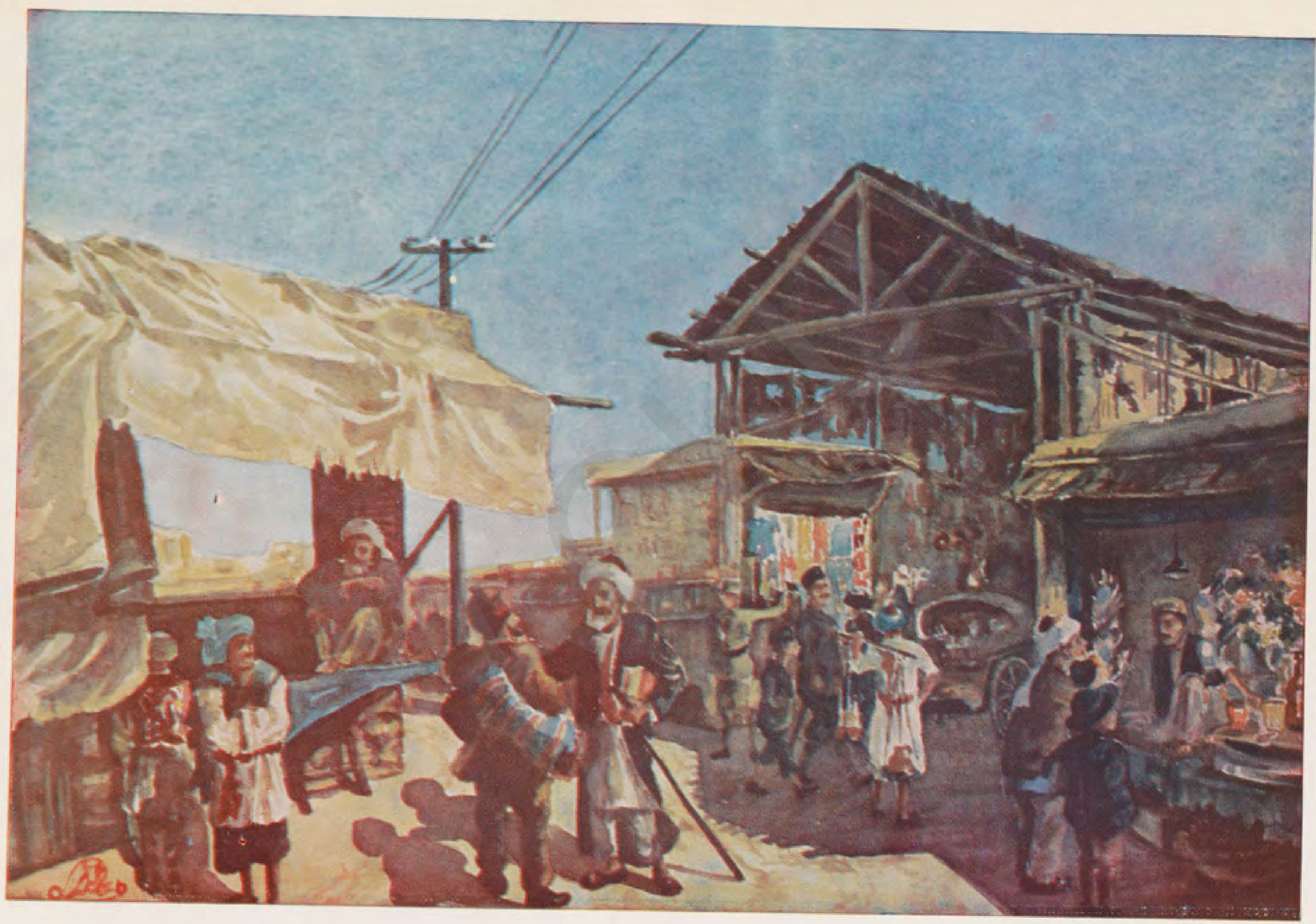

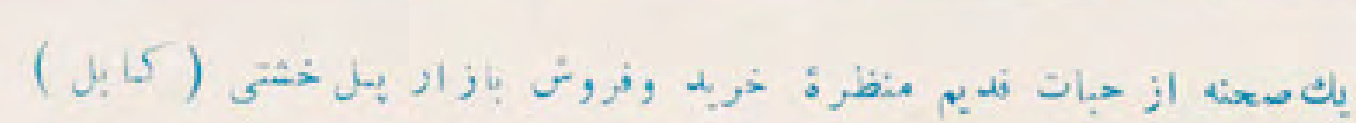





\section{KABOUL}

Revue mensuelle scientifique, historique, littéraire, publiée par la section des publications et de la presse de l'Acalémie Afyhaue.

Monnements : ville de Kaboul 1 :n 12 afos.

Provinces d'Afglamistan

Etranger

\section{إعلان}

\section{lo slowil}

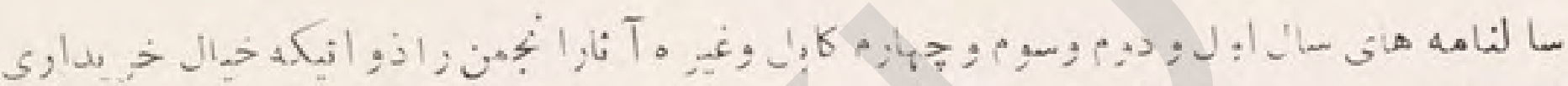

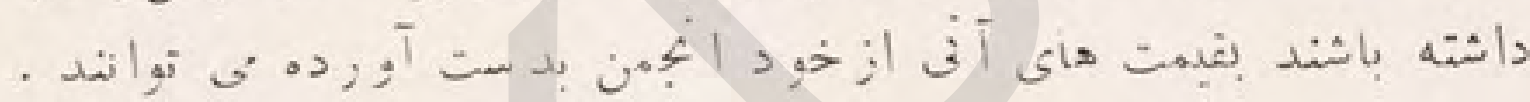

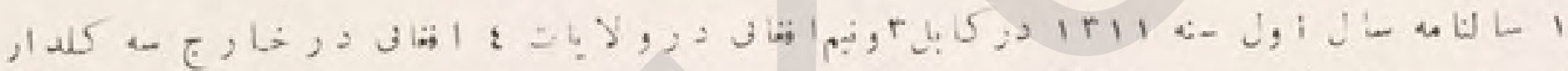

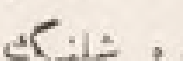

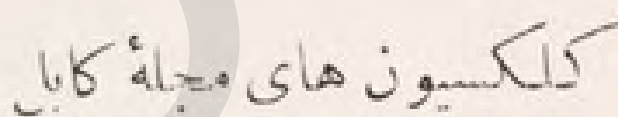

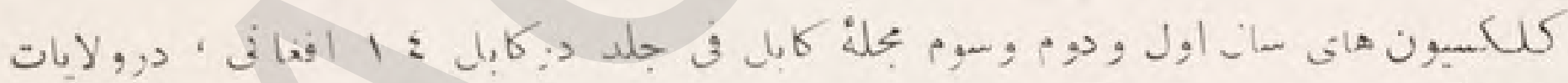

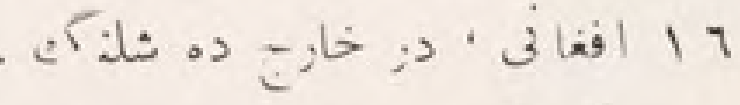

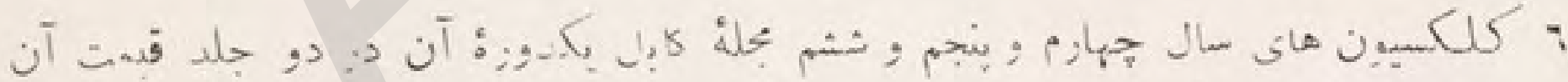

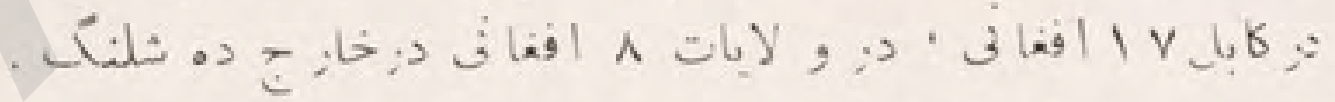

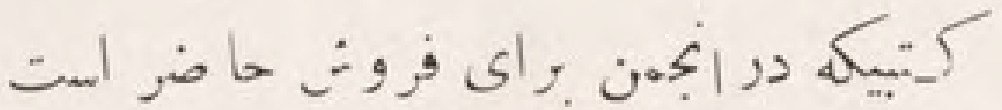

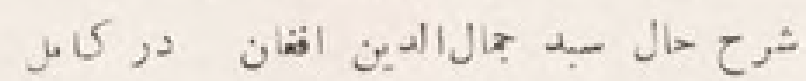

$$
\begin{aligned}
& \text { vون }
\end{aligned}
$$

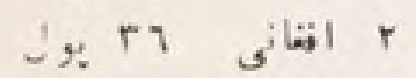

$$
\begin{aligned}
& \text { ig.ro, } \quad r \\
& \text { I g. V. } \\
& \begin{array}{l}
\$ 1 . \\
\$ 70
\end{array}
\end{aligned}
$$

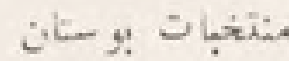

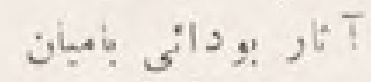

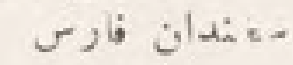

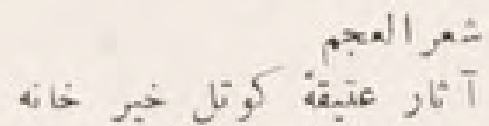$$
\text { صنعت باختر ( بفارسى , فرانسه ) }
$$$$
\text { نضئت }
$$$$
\text { ثـكوكات فديم انفانستان }
$$

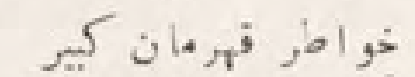

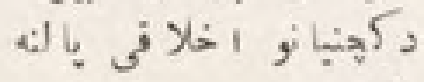

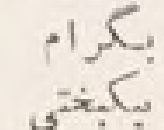




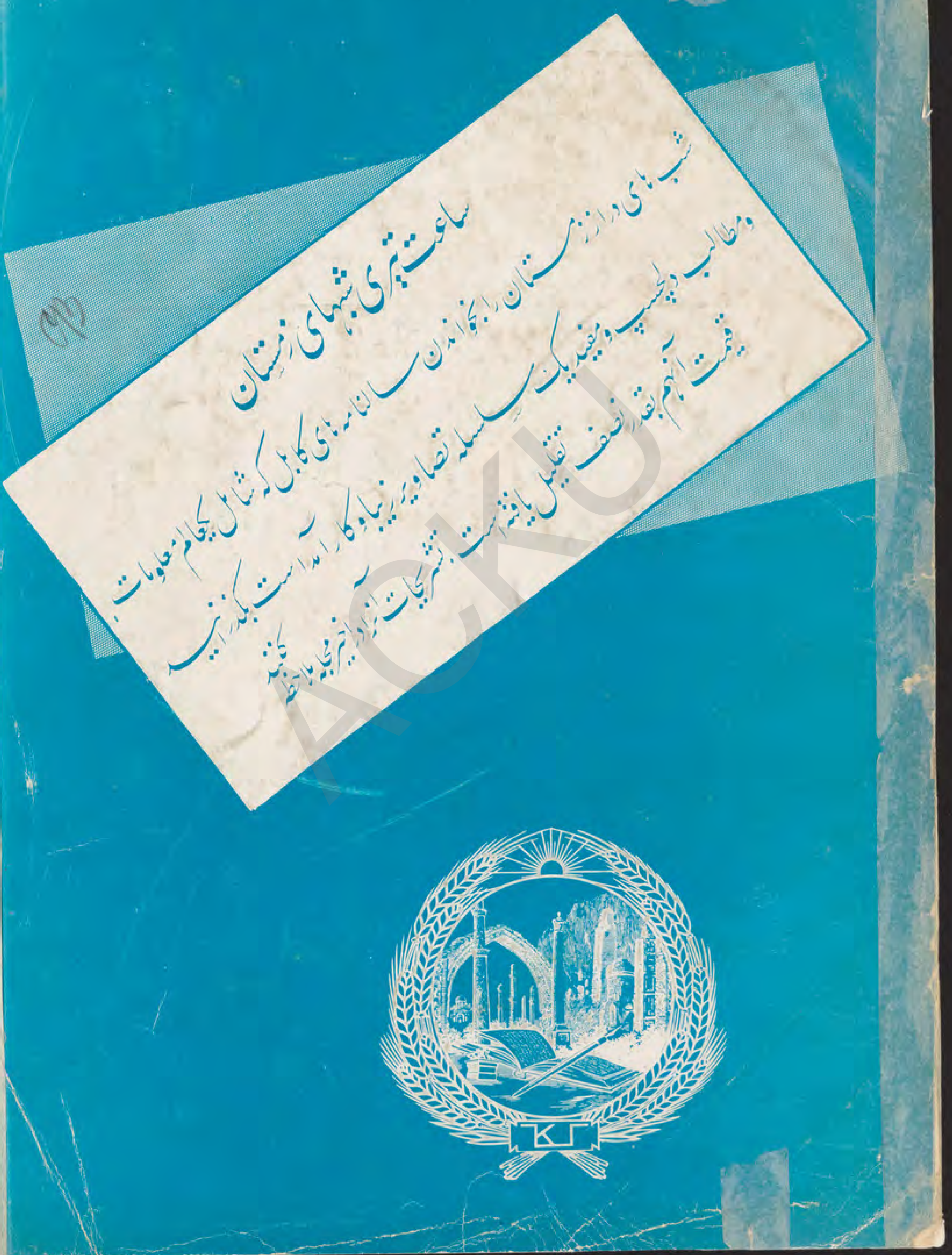

